\author{
UNIVERSIDADE DE SÃO PAULO \\ ESCOLA DE ENGENHARIA DE SÃO CARLOS \\ DEPARTAMENTO DE GEOTECNIA
}

JACQUELINE ZANIN LIMA

CARACTERIZAÇÃO GEOLÓGICA-GEOTÉCNICA E ESTUDO DA ADSORÇÃO DE Pb, Zn E Cd POR TURFA E COMPOSTOS ORGÂNICOS

São Carlos

2017 



\title{
CARACTERIZAÇÃO GEOLÓGICA-GEOTÉCNICA E ESTUDO DA ADSORÇÃO DE Pb, Zn E Cd POR TURFA E COMPOSTOS ORGÂNICOS
}

\author{
Dissertação apresentada à Escola de \\ Engenharia de São Carlos da Universidade \\ de São Paulo, como parte dos requisitos \\ para a obtenção do título de Mestre em \\ Ciências, Programa de Pós-Graduação em \\ Geotecnia.
}

Orientadora: Prof ${ }^{\mathrm{a}}$. Dr ${ }^{\mathrm{a}}$. Valéria Guimarães Silvestre Rodrigues

\section{Versão corrigida}

Original se encontra disponível na Unidade que aloja o Programa

São Carlos, SP 
AUTORIZO A REPRODUCÃO TOTAL OU PARCIAL DESTE TRABALHO, POR QUALQUER MEIO CONVENCIONAL OU ELETRÔNICO, PARA FINS DE ESTUDO E PESQUISA, DESDE QUE CITADA A FONTE.

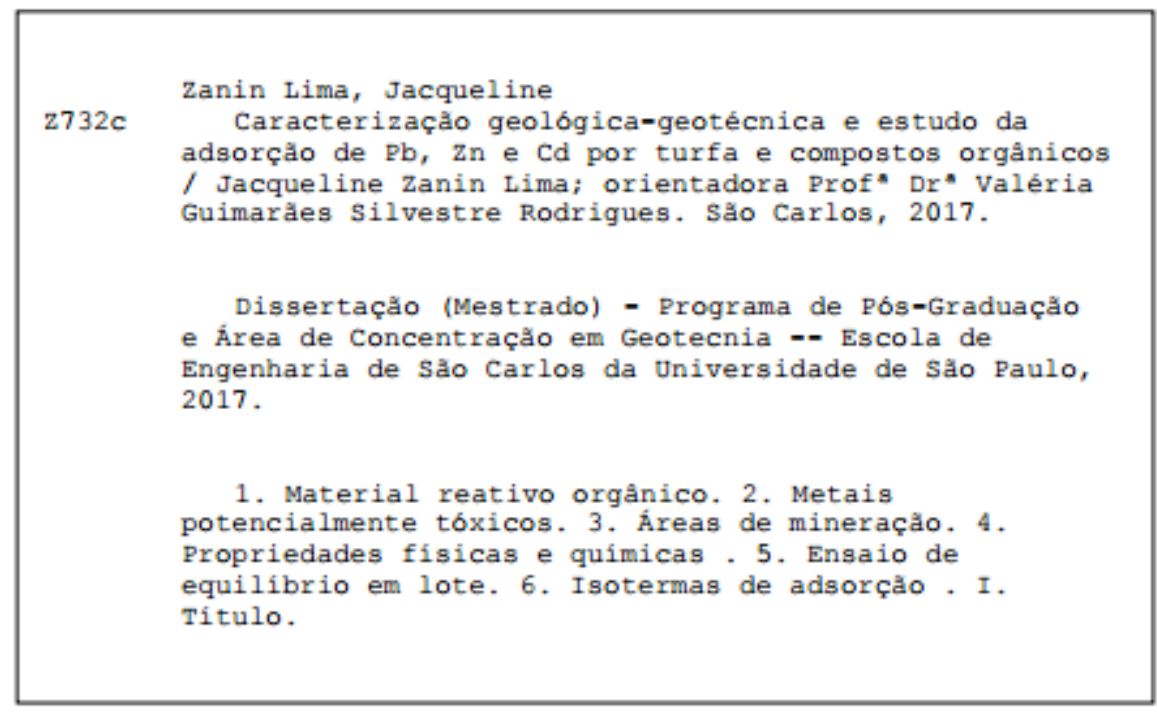

FORAM UTILIZADAS AS DIRETRIZES PARA APRESENTAÇÃO DE DISSERTAÇÕES E TESES DA USP: PARTE I (ABNT) - $3^{a}$ EDIÇÃO REVISADA, AMPLIADA E MODIFICADA DE 2016. 


\section{FOLHA DE JULGAMENTO}

Candidata: JACQUELINE ZANIN LIMA

Título da dissertação: "Caracterização geológica-geotécnica e estudo da adsorção de $\mathrm{Pb}$, Zn e Cd por turfa e compostos orgânicos"

Data da defesa: 25.07.2017

\section{Comissão Julgadora:}

Prof ${ }^{0}$. Dr ${ }^{a}$. Valéria Guimarães Silvestre Rodrigues

(Orientadora)

(Escola de Engenharia de São Carlos/EESC)

$\operatorname{Prof}^{a}$. Dr ${ }^{a}$. Eny Maria Vieira

(Instituto de Química de São Carlos/IQSC-USP)

$\mathrm{Dr}^{\mathrm{a}}$. Cleide Aparecida de Abreu

(Instituto Agronômico de Campinas/IAC)
Resultado:
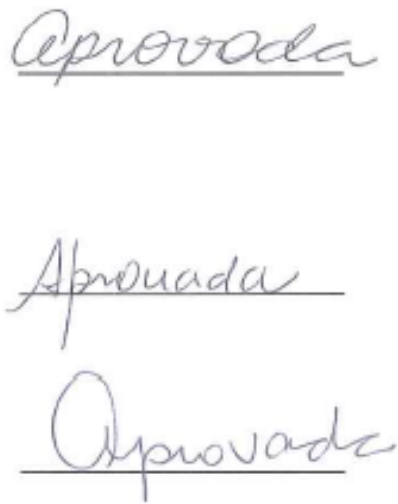

Coordenador do Programa de Pós-Graduação em Geotecnia:

Prof. Dr. Edmundo Rogério Esquivel

Presidente da Comissão de Pós-Graduação:

Prof. Associado Luis Fernando Costa Alberto 

Dedico este trabalho aos meus pais, Luis e Regina, e a minha irmã Laura por terem sido sempre em minha vida sinônimo de amor, amizade e compreensão.

À toda minha família, em especial aos meus avós, de laços sanguíneos e sentimentais, por serem a base da minha vida. 



\section{AGRADECIMENTOS}

Primeiramente agradeço a Deus por sempre ter me dado força e proteção em minha jornada profissional e pessoal.

À Prof ${ }^{a}$ Dr $^{a}$ Valéria Guimarães Silvestre Rodrigues pelo zelo, atenção, paciência e dedicação como professora e orientadora. Agradeço também pela compreensão, conselhos e sincera amizade.

À Coordenação de Aperfeiçoamento de Pessoal de Nível Superior (CAPES) pela concessão dos primeiros meses da bolsa de estudo (vigência: 06/2015 a 10/2015) e à Fundação de Amparo à Pesquisa do Estado de São Paulo (FAPESP) pela bolsa de estudo - $\mathrm{n}^{\circ}$ processo 2015/02529-4 (vigência: 11/2015 a 05/2017) e pelo auxílio à pesquisa (2014/07180-7).

Ao Luiz Augusto Artimonte Vaz e a empresa Axihum Fertilizantes pelo fornecimento da turfa estudada. À Prof ${ }^{a}$ Dr $^{a}$ Eny Maria Vieira pelo apoio e colaboração.

Ao Grupo de Estudos e Intervenções Sócio Ambientais (GEISA) por intermédio do Prof Dr Valdir Schalch e do aluno Renan Marques Lupion pelo fornecimento dos compostos orgânicos.

Aos profissionais que trabalham no Departamento de Geotecnia (EESC-USP) que sempre se mostraram solícitos em ajudar e ensinar. Em especial, ao Sr Antônio que me acompanhou nas análises iniciais, sempre com paciência e atenção.

Aos técnicos dos laboratórios de Solos e de Técnicas Nucleares da Empresa Brasileira de Pesquisa Agropecuária (EMBRAPA - Instrumentação - São Carlos), de Saneamento e Hidráulica do Departamento de Hidráulica (EESC - USP), de Caracterização Tecnológica da Escola Politécnica (POLI - USP), de Difração de Raios-X do Instituto de Física de São Carlos (IFSC USP), da Central de Análises Químicas Instrumentais do Instituto de Química de São Carlos (IQSC - USP) e de Corretivos, Fertilizantes e Resíduos Orgânicos do Departamento de Ciência do Solo da Escola Superior de Agricultura Luiz de Queiroz (ESALQ - USP).

A todos meus professores ao longo destes mais de 19 anos de vida escolar, em especial, aqueles com os quais convivi durante o Mestrado. Sem eles esta dissertação não seria possível.

Aos meus pais, Luis e Regina, e a minha irmã Laura, por me ensinarem o que é o amor, a amizade e a família. Ao meu namorado e melhor amigo, Raul, pela compreensão, amor e companheirismo.

Aos amigos da pós-graduação, em especial a minhas colegas de sala, Isabela, Jéssica e Mariana, pelo carinho e amizade. As minhas amigas, em especial, Aline, Gabriela, Jéssica, Laura e Michelle, pelo apoio, ajuda e muitos momentos felizes.

A todos que indiretamente contribuíram para a realização desta pesquisa. 



\section{RESUMO}

LIMA, J. Z. Caracterização geológica-geotécnica e estudo da adsorção de $\mathbf{P b}, \mathbf{Z n}$ e Cd por turfa e compostos orgânicos. 2017. 360 p. Dissertação (Mestrado) - Escola de Engenharia de São Carlos, Universidade de São Paulo, São Carlos, 2017.

Os materiais reativos orgânicos, como turfas e compostos, apresentam um considerável potencial efetivo de utilização na remediação de áreas contaminadas por metais potencialmente tóxicos, haja vista sua elevada capacidade de adsorção, comumente associada a altos teores de matéria orgânica. O emprego do composto orgânico se torna vantajoso por ser uma possibilidade de destinação final correta dos resíduos sólidos urbanos compostáveis, conforme as políticas públicas, podendo agregar valor econômico e ambiental ao resíduo. Nessa perspectiva, na seleção dos materiais reativos mais viáveis para serem empregados na retenção de metais é imprescindível sua caracterização (geológica e geotécnica) e o estudo de sua real capacidade adsortiva, através de ensaios de adsorção. Assim, o objetivo desta pesquisa foi a caracterização geológica e geotécnica de uma turfa (proveniente da bacia hidrográfica do rio Mogi Guaçu, município de Cravinhos) e de quatro compostos (compostos total, indiano, estático e alambrado, advindos de composteiras localizadas na Universidade de São Paulo - São Carlos), bem como ensaios de adsorção (equilíbrio em lote) com chumbo $(\mathrm{Pb})$, zinco $(\mathrm{Zn})$ e cádmio $(\mathrm{Cd})$. Para tanto foram realizados os seguintes ensaios de caracterização: granulometria, massa específica dos sólidos, densidade, teor de umidade, parâmetros físico-químicos (potencial hidrogeniônico $(\mathrm{pH}), \Delta \mathrm{pH}$, potencial de oxi-redução (Eh) e condutividade elétrica (CE), ponto de efeito salino nulo (PESN), matéria orgânica (MO), teor de cinzas $(\mathrm{Cz})$, capacidade de troca catiônica (CTC), capacidade de retenção de água (CRA), composição elementar $(\mathrm{C}, \mathrm{H}$ e N), carbono orgânico, Difratometria de Raios-X (DRX), Fluorescência de Raios-X (FRX), Microscopia Eletrônica de Varredura/Espectroscopia de Energia Dispersiva por Raios-X (MEV/EDS) e Análise Térmica Diferencial (ATD). A partir do conhecimento minucioso dos parâmetros físicos e químicos dos materiais foi possível proceder o ensaio de equilíbrio em lote com soluções monoelementares de $\mathrm{Pb}, \mathrm{Zn}$ e $\mathrm{Cd}$ com oito concentrações distintas e inferiores a $220 \mathrm{mg} \mathrm{L}^{-1}$ e razão material reativo/solução de 1/50 (conforme definido em etapa preliminar). Quanto aos resultados de caracterização, turfa e compostos apresentaram características promissoras para a adsorção. A turfa revelou um $\mathrm{pH}$ moderadamente ácido $(5,1)$, um $\Delta \mathrm{pH}$ negativo $(-1,0)$ atestando para a presença majoritária de cargas negativas na superfície das partículas, o que foi confirmado pelo PESN $(3,6)<\mathrm{pH}(5,1)$, um considerável teor de MO $\left(520,43 \mathrm{mg} \mathrm{kg}^{-1}\right)$ e uma CTC elevada $(91,00$ $\left.\mathrm{cmol}_{\mathrm{c}} \mathrm{kg}^{-1}\right)$. Já os compostos exibiram valores de $\mathrm{pH}$ ligeiramente ácidos a ligeiramente básicos $(6,4$ a 7,7$), \Delta \mathrm{pH}$ negativo $\left(-0,4\right.$ a -1,0), MO promissora (193,92 a 418,70 $\left.\mathrm{mg} \mathrm{kg}^{-1}\right)$ e CTC variável $\left(29,00\right.$ a $\left.75,00 \mathrm{cmol}_{\mathrm{c}} \mathrm{kg}^{-1}\right)$. Em termos gerais, os compostos total e indiano apresentaram características mais favoráveis para a retenção metálica o que foi confirmado por etapa preliminar do ensaio de adsorção. Como o composto indiano sobressaiu levemente na imobilização de $\mathrm{Cd}$ e $\mathrm{Zn}$ e por ele apresentar maior controle no processo de compostagem ele foi o escolhido para a realização do ensaio de equilíbrio em lote com variadas concentrações de $\mathrm{Pb}, \mathrm{Zn}$ e $\mathrm{Cd}$, assim como a turfa. Os resultados finais de adsorção atestaram que a turfa e o composto indiano apresentaram a mesma ordem de afinidade metálica: $\mathrm{Pb}>\mathrm{Cd}>\mathrm{Zn}$, sendo que o composto revelou uma tendência superior de adsorção. A turfa revelou uma porcentagem de remoção metálica (A\%) superior a $90 \%$ para concentrações de $\mathrm{Pb}$ de até $137 \mathrm{mg} \mathrm{L}^{-1}$, enquanto o composto adsorveu mais de $98 \%$ do $\mathrm{Pb}$ em todas as concentrações estudadas $\left(26\right.$ a $\left.214 \mathrm{mg} \mathrm{L}^{-1}\right)$, não atingindo o estado de saturação. Dessa forma, turfa e compostos, caracterizados por um baixo custo e uma significativa disponibilidade, podem ser enquadrados como potenciais materiais reativos orgânicos para a imobilização de cátions metálicos, principalmente $\mathrm{Pb}^{2+} \mathrm{e} \mathrm{Cd}^{2+}$.

Palavras-chave: Material reativo orgânico. Metais potencialmente tóxicos. Áreas de mineração. Propriedades físicas e químicas. Ensaio de equilíbrio em lote. Isotermas de adsorção. 



\begin{abstract}
LIMA, J. Z. Geological-geotechnical characterization and adsorption study of $\mathbf{P b}$, Zn and Cd by peat and organic compounds. 2017. 360 p. Dissertação (Mestrado) Escola de Engenharia de São Carlos, Universidade de São Paulo, São Carlos, 2017.
\end{abstract}

Organic reactive materials, such as peat and compounds, have a considerable potential for use in the remediation of contaminated areas by potentially toxic metals, due to their high adsorption capacity, commonly associated with high organic matter content. The use of organic compound becomes advantageous because it is a possibility of final destination for the compostable municipal solid waste, according to the public policies, being able to add economic and environmental value to the waste. In this perspective, the selection of the most viable reactive materials to be used in the retention of metals is needful, its characterization (geological and geotechnical) and the study of its real adsorptive capacity through adsorption tests are essential. Thus, the objective of this research was to characterize the geological and geotechnical characteristics of a peat (from Mogi Guaçu's basin in the city Cravinhos) and four compounds (total, indian, static and wired, from composters located at the University of São Paulo), besides batch tests with lead $(\mathrm{Pb})$, zinc $(\mathrm{Zn})$ and cadmium $(\mathrm{Cd})$. To achieve the objectives, the following tests were done: particle size analysis, solids specific mass' determination, density, moisture content, physico-chemical parameters (potential hydrogenion - $\mathrm{pH}, \Delta \mathrm{pH}$, oxy-reduction potential - Eh and electrical conductivity - EC), point of zero salt effect (PZSE), organic matter (OM), ash content, cation exchange capacity (CEC), water retention capacity (WRC), elemental composition (C, H and N), organic carbon, X-Ray Diffraction (XRD), X-Ray Fluorescence (XRF), Scanning Electron Microscopy/X-Ray Dispersive Energy Spectroscopy (SEM/DES) and Differential Thermal Analysis (DTA). From the detailed knowledge of the physical and chemical parameters of the materials was possible to perform the batch equilibrium test with monoelemental solutions of $\mathrm{Pb}, \mathrm{Zn}$ and $\mathrm{Cd}$ with different concentrations below $220 \mathrm{mg} \mathrm{L}^{-1}$ and reactive material / solution ratio of $1 / 50$ (as defined in the preliminary stage). Regarding the characterization results, peat and compounds presented promising characteristics for adsorption. The peat showed moderately acidic $\mathrm{pH}(5.1)$, negative $\Delta \mathrm{pH}(-1.0)$ attesting to a majority presence of negative charges on the surface of the particles, which was confirmed by the PZSE (3.6) $<\mathrm{pH}(5.1)$, a considerably high OM content (520.43 mg kg${ }^{-1}$ ) and a high CEC $\left(91.00 \mathrm{cmol}_{\mathrm{c}} \mathrm{kg}^{-1}\right)$. The compounds exhibited from slightly acidic to slightly basic $\mathrm{pH}$ values (6.4 to 7.7$)$, negative $\Delta \mathrm{pH}(-0.4$ to -1.0$)$, promising $\mathrm{OM}$ (193.92 to $418.70 \mathrm{mg} \mathrm{kg}^{-1}$ ) and variable CEC (29.00 to $75.00 \mathrm{cmol}_{\mathrm{c}} \mathrm{kg}^{-1}$ ). In general, terms, the total and indian compounds presented more favorable characteristics for metal retention, what was confirmed by the preliminary step of the adsorption test. As the indian compound had a small enhancement on the immobilization of $\mathrm{Cd}$ and $\mathrm{Zn}$ and due, it showed greater control in the composition process, it was chosen for a batch equilibrium test with varying concentrations of $\mathrm{Pb}, \mathrm{Zn}$ and $\mathrm{Cd}$, as well as a peat. The final adsorption results showed that the peat and the indian compound had the same order of metal affinity: $\mathrm{Pb}>\mathrm{Cd}>\mathrm{Zn}$, whereby the compound showed a higher adsorption tendency. The peat showed a metal removal percentage (A\%) higher than $90 \%$ for $\mathrm{Pb}$ concentrations up to $137 \mathrm{mg} \mathrm{L}^{-1}$, while the compound adsorbed more than $98 \%$ at all concentrations studied ( 26 to $214 \mathrm{mg} \mathrm{L}^{-1}$ ) not reaching the saturation state. Thus, peat and organic compounds, characterized by a low cost and a significant availability, can be classified as potential organic low-cost reactive materials for metal cations immobilization, mainly $\mathrm{Pb}^{2+}$ and $\mathrm{Cd}^{2+}$.

Keywords: Organic reactive material. Potentially toxic metals. Mining areas. Physical and chemical properties. Batch test. Adsorption isotherms. 



\section{Lista de Figuras}

Figura 1 - Representação esquemática da dispersão dos metais potencialmente tóxicos a partir das áreas mineralizadas até seu destino final, atuando como poluentes difusos em locais de deposição, solos e sedimentos 41

Figura 2 - Especiação geoquímica de metais potencialmente tóxicos 44

Figura 3 - Tendências de solubilidade de metais potencialmente tóxicos em relação ao $\mathrm{pH}$ e ao Eh, em condições de ausência de matéria orgânica sólida e dissolvida. A) Principais minerais que controlam solubilidade dos metais; B) Tendência do aumento da solubilidade 45

Figura 4 - Representação de órgãos e sistemas que são alvo de alguns metais potencialmente tóxicos em seres humanos. Destaque dado aos metais de interesse nessa pesquisa..................... 46

Figura 5 - Distribuição de espécies iônicas de $\mathrm{Cd}$ em função do $\mathrm{pH}$........................................... 50

Figura 6 - Distribuição de espécies iônicas de $\mathrm{Pb}$ em função do $\mathrm{pH}$.......................................... 54

Figura 7 - Espécies iônicas e compostos de Zn que comumente ocorrem em solos .................... 57

Figura 8 - Distribuição de espécies iônicas de $\mathrm{Zn}$ em função do $\mathrm{pH}$............................................5 59

Figura 9 - Configurações básicas de barreira reativa. A) Parede contínua; B) Funnel-and-gate 63

Figura 10 - Representação esquemática da retenção de um cátion metálico por um ácido fúlvico

Figura 11 - Representação esquemática do processo de compostagem ...................................... 75

Figura 12 - Padrão de temperatura observado durante a compostagem...................................... 77

Figura 13 - Relação entre o conteúdo de água e diferentes condições de sucção para turfas com

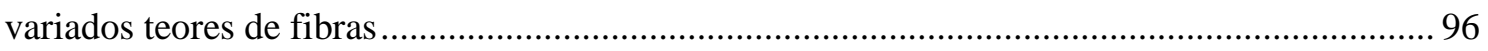

Figura 14 - Curvas de retenção de água para diversas turfas do norte de Minesota ................... 97

Figura 15 - Exemplo de mecanismo associado com a adsorção de metais em turfa................. 100

Figura 16 - Caracterização esquemática dos processos de absorção e adsorção........................ 106

Figura 17 - Tipos de sorção: I) Adsorção favorável; II) Adsorção linear e absorção; III) Adsorção

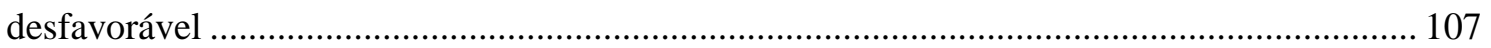

Figura 18 - Representação esquemática da nomenclatura usual dos componentes................... 108

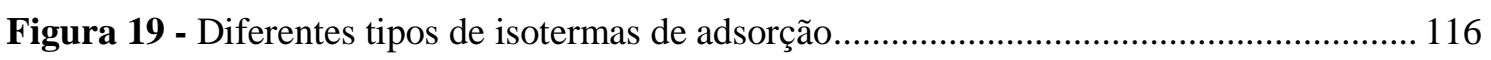

Figura 20 - Representação da isoterma linear. À esquerda, modelo tradicional. À direita, método

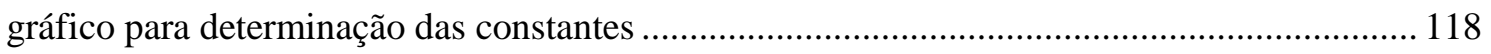

Figura 21 - Representação da isoterma de Freundlich. À esquerda, modelo tradicional. À direita, método gráfico para determinação das constantes ............................................................. 120

Figura 22 - Esquema básico para o desenvolvimento do Modelo de Langmuir ....................... 121

Figura 23 - Representação da isoterma de Langmuir. À esquerda, modelo tradicional. À direita, método gráfico para determinação das constantes ................................................................... 123

Figura 24 - Efeito do pH sobre a adsorção de $\mathrm{Pb}, \mathrm{Cu}$ e $\mathrm{Cd}$........................................................ 125

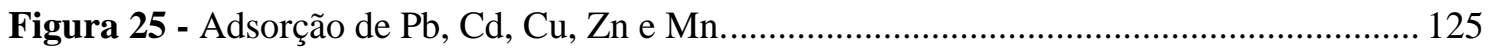


Figura 26 - Efeito da adsorção de Cu por turfa herbácea a uma concentração de $3.10^{-4} \mathrm{M}$ e pH de 5,5. O gráfico representa a variação da quantidade de íons metálicos adsorvidos por unidade de massa do adsorvente $(\mathrm{x} / \mathrm{m})$ em função do tempo 127

Figura 27 - Comparação da remoção percentual de $\mathrm{Pb}$ em relação ao tempo de contato, sendo empregado carvão ativado, argila do Vale do Ribeira (Argila VP), argila de Ajapí (Argila A) e turfa. A) Efluente industrial; B) Efluente sintético

Figura 28 - Remoção percentual de $\mathrm{Cu}^{2+}$ após $12 \mathrm{~h}$ de tempo de contato, com tamanho das partículas dos adsorventes: 250 - $800 \mu \mathrm{m}$; massa de adsorvente: $0,5 \mathrm{~g}$; temperatura: $20 \pm 1{ }^{\circ} \mathrm{C}$; $\mathrm{pH}$ : 4,2; concentração inicial de $\mathrm{Cu}^{2+}: 100 \mathrm{mg} \mathrm{L}^{-1}$

Figura 29 - Cinética de adsorção de $\mathrm{Cd}, \mathrm{Cu}$ e Ni pela turfa. 130

Figura 30 - Esquema comparativo simplificado entre os limites das frações de acordo com EMBRAPA (2011) e com ABNT NBR 6502 - 95

Figura 31 - Figura esquemática das relações entre o PESN e as cargas de superfície positivas e negativas 142

Figura 32 - Bacia hidrográfica do rio Mogi Guaçu, com destaque para a região da sub-bacia do Ribeirão da Onça (município de Cravinhos), local da turfeira.

Figura 33 - Principais turfeiras fluviais localizadas no estado de São Paulo que apresentam potencial de exploração comercial. Destaque para o Setor Mogi Guaçu/Pardo. 146

Figura 34 - Turfeira às margens do rio Mogi Guaçu.

Figura 35 - Método de composteira indiana. A) Vista interior durante o acréscimo de resíduos orgânicos; B) Vista lateral superficial 148

Figura 36 - Método de composteira alambrado. A) Colocação das coroas de abacaxi, iniciando o procedimento; B) Vista interior durante o acréscimo de resíduos orgânicos; C) Vista superficial

Figura 37 - Método da composteira estática. A) Vista interior durante o acréscimo de resíduos

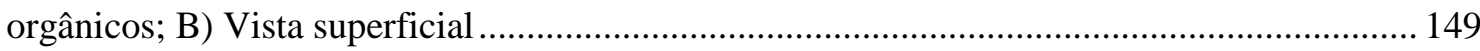

Figura 38 - Peneiramento e armazenamento dos compostos ................................................... 150

Figura 39 - Quarteamento pelo método de pilhas alongadas. A) Composto indiano; B) Composto total.

Figura 40 - Cubetas para medida do coeficiente de atenuação em massa - Ensaio granulométrico 154

Figura 41 - Da esquerda para à direita: amostras da porção mineral com $\mathrm{NaOH}$ e água, amostras da turfa total com $\mathrm{NaOH}$ e água e amostras da turfa total apenas com água destilada 154

Figura 42 - Agitação do conjunto de amostras no agitador tipo Wagner. 155

Figura 43 - Cubetas já preparadas para serem encaminhadas para análise. Da esquerda para à direita: amostras da porção mineral com $\mathrm{NaOH}$ e água, amostras da turfa total com $\mathrm{NaOH}$ e água e amostras da turfa total apenas com água destilada 155

Figura 44 - Analisador granulométrico da EMBRAPA. Atentar para a presença, na parte superior do equipamento, de um agitador, pois cada leitura se inicia após agitação, e de um termômetro, já que a viscosidade da água é dependente da temperatura e é um dos parâmetros usados no cálculo 
Figura 45 - Cubetas após sedimentação. Da esquerda para à direita: amostra da porção mineral apenas com água, amostra da porção mineral com hexametafosfato de sódio e água e amostra da turfa total com hexametafosfato de sódio e água 156

Figura 46 - Peneiramento em água corrente e transferência da amostra para o recipiente de evaporação.

Figura 47 - Partículas retidas em cada peneira. Em A e B, amostra de turfa total, respectivamente, antes e após secagem. Em C e D, porção mineral da turfa, respectivamente, antes e após secagem 157

Figura 48 - Agitador mecânico com conjunto de peneiras - Ensaio granulométrico com o composto

Figura 49 - Compostos fracionados após o peneiramento. A) Composto indiano; B) Composto total; C) Composto alambrado; D) Composto estático

Figura 50 - Amostras com água destilada, em repouso (ensaio de massa específica dos sólidos). A) Triplicata de turfa; B) Amostra do composto total, indiano, estático e alambrado, respectivamente. 161

Figura 51 - Ensaio de massa específica dos sólidos. A) Deaeração da amostra de turfa; B) Balões volumétricos contendo as amostras de compostos para posterior determinação da temperatura e massa

Figura 52 - Etapa final do ensaio de massa específica. A) Transferência da amostra de turfa após ensaio para um recipiente de evaporação; B) Recipiente de evaporação com amostra de turfa após secagem final.

Figura 53 - Recipientes de evaporação com compostos após secagem final. A) Composto indiano; B) Composto total; C) Composto alambrado; D) Composto estático ....................................... 163

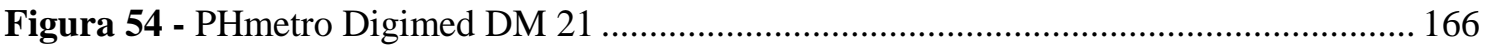

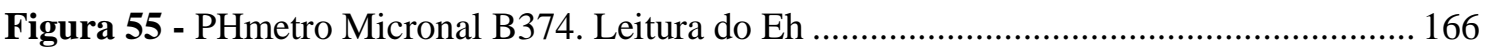

Figura 56 - Leitura da CE em condutivímetro Analyser 650 ................................................... 167

Figura 57 - Soluções eletrolíticas e material reativo durante o ensaio de ponto de efeito salino nulo. 168

Figura 58 - Soluções de turfa preparadas em $\mathrm{KCl}(0,001 \mathrm{M})$................................................ 169

Figura 59 - Ensaio para determinação do teor de matéria orgânica da turfa.............................. 170

Figura 60 - Ensaio para determinação do teor de matéria orgânica dos compostos................... 170

Figura 61 - Ensaio de adsorção com azul de metileno .............................................................. 173

Figura 62 - Preparação das lâminas com a amostra de turfa - ensaio de DRX. A) Dispersão da suspensão; B) Lâminas após secagem.

Figura 63 - Preparação das lâminas com a parte mineral dos compostos para execução do DRX. A) Recipientes contendo a suspensão durante sua deposição sobre as lâminas; B) Lâminas após secagem; C) Lâminas secas e prontas para serem enviadas para a análise em DRX ................. 175

Figura 64 - Pastilhador e esquema simplificado de operação da obtenção das pastilhas.......... 177

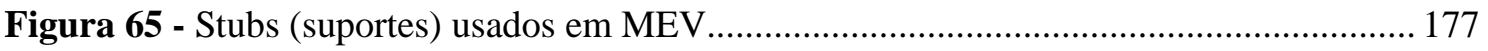

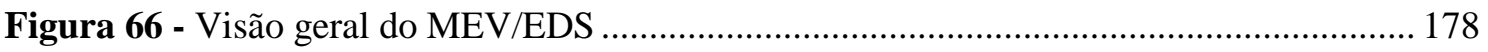


Figura 67 - Ensaio de ATD. A) Visão geral do equipamento de ATD; B) Dois porta amostras preenchidos por alumina calcinada (branca) e um terceiro repleto de amostra

Figura 68 - Solução mãe com concentração de $240 \mathrm{mg} \mathrm{L}^{-1}$ de cádmio (à esquerda) e solução diluída com concentração de $30 \mathrm{mg} \mathrm{L}^{-1}$ de cádmio (à direita)

Figura 69 - Centrifugação de amostras de turfa em solução contendo $\mathrm{Cd}$.

Figura 70 - Filtração de amostras de composto indiano após contato com solução contendo $\mathrm{Pb}$

Figura 71 - Espectrofotômetro de Absorção Atômica da PerkinElmer 186

Figura 72 - Padrões de calibração PerkinElmer Pure com certificação de análise 186

Figura 73 - Presença de turfa nas amostras do ensaio prévio de equilíbrio em lote. 189

Figura 74 - Teste melhor composto em relação à adsorção de Cd.

Figura 75 - Ensaio de equilíbrio em lote. A) Determinação da massa de turfa; B) Agitação do conjunto de amostras da turfa em contato com soluções contendo $\mathrm{Pb}$.

Figura 76 - Amostras do ensaios de equilíbrio em lote. À esquerda, parte líquida e soluções branco e à direita, parte sólida. A) Amostras de turfa e $\mathrm{Pb}$; B) Conjunto de amostras de composto indiano e $\mathrm{Pb}$. 191

Figura 77 - Distribuição granulométrica da turfa total (com $\mathrm{NaOH}$, com hexametafosfato e sem defloculante) 196

Figura 78 - Distribuição granulométrica da porção mineral da turfa (com $\mathrm{NaOH}$, com hexametafosfato e sem defloculante) 198

Figura 79 - Distribuição granulométrica comparativa da turfa total e da porção mineral (com $\mathrm{NaOH}$, com hexametafosfato e sem defloculante) 199

Figura 80 - Ponto de efeito salino nulo (PESN) da turfa 210

Figura 81 - DRX da turfa. A) Amostra total; B) Porção mineral 220

Figura 82 - Fotomicrografia em Microscopia Eletrônica de Varredura da porção mineral da turfa. 224

Figura 83 - Fotomicrografia em MEV da porção mineral da turfa com os respectivos espectros EDS . 225

Figura 84 - Fotomicrografia em MEV da porção mineral da turfa com os respectivos espectros EDS 226

Figura 85 - Fotomicrografia em Microscopia Eletrônica de Varredura da amostra total da turfa.

Figura 86 - Fotomicrografia em MEV, destacando um grão da turfa 228

Figura 87 - Fotomicrografia em MEV da turfa (total) com os respectivos espectros EDS...... 229

Figura 88 - Fotomicrografia em MEV da turfa (total) com os respectivos espectros EDS...... 230

Figura 89 - Distribuição granulométrica dos compostos: total, indiano, alambrado e estático 232

Figura 90 - Água perdida acumulada para os compostos: total, indiano, alambrado e estático236

Figura 91 - DRX da porção mineral dos compostos. 257 
Figura 92 - Fotomicrografia em MEV da porção mineral do composto total com os respectivos espectros EDS

Figura 93 - Fotomicrografia em MEV da porção mineral do composto total com os respectivos espectros EDS

Figura 94 - Fotomicrografia em MEV da porção mineral do composto indiano com os respectivos espectros EDS

Figura 95 - Fotomicrografia em MEV da porção mineral do composto alambrado com os respectivos espectros EDS 264

Figura 96 - Fotomicrografia em MEV da porção mineral do composto estático com os respectivos espectros EDS

Figura 97 - Fotomicrografia em MEV do composto total com os respectivos espectros EDS 266

Figura 98 - Fotomicrografia em MEV do composto indiano com os respectivos espectros EDS

Figura 99 - Fotomicrografia em MEV do composto alambrado com os respectivos espectros EDS 268

Figura 100 - Fotomicrografia em MEV do composto estático com os respectivos espectros EDS

Figura 101 - Fotomicrografia em MEV do composto estático com os respectivos espectros EDS. Destaque para os microrganismos

Figura 102 - Curva da análise térmica diferencial para os compostos com matéria orgânica (MO) 271

Figura 103 - Curva da análise térmica diferencial para a porção mineral dos compostos (sem MO)

Figura 104 - Valores de pH iniciais e finais para as diversas razões turfa/solução empregadas no ensaio de equilíbrio em lote preliminar. 274

Figura 105 - Valores de pH iniciais e finais para os brancos da solução e para os brancos da turfa empregados no ensaio de equilíbrio em lote preliminar. 275

Figura 106 - Valores de Eh iniciais e finais para as diversas razões turfa/solução empregadas no ensaio de equilíbrio em lote preliminar.

Figura 107 - Valores de Eh iniciais e finais para os brancos da solução e para os brancos da turfa empregados no ensaio de equilíbrio em lote preliminar. 276

Figura 108 - Valores de condutividade elétrica (CE) iniciais e finais para as diversas razões turfa/solução empregadas no ensaio de equilíbrio em lote preliminar..... 277

Figura 109 - Valores de condutividade elétrica (CE) iniciais e finais para os brancos da solução e para os brancos da turfa empregados no ensaio de equilíbrio em lote preliminar.

Figura 110 - Comparação entre os dados obtidos experimentalmente e as isotermas trabalhadas 279

Figura 111 - Análise comparativa da porcentagem de remoção de $\mathrm{Pb}(\mathrm{A} \%)$ e da capacidade de remoção de $\mathrm{Pb}$ pela turfa $\left(\mathrm{q}_{\mathrm{e}}\right)$ em função da razão turfa/solução 280

Figura 112 - Valores de $\mathrm{pH}$ iniciais e finais para os quatro compostos:total, indiano, alambrado e estático, com $\mathrm{Pb}, \mathrm{Zn}, \mathrm{Cd}$ e água deionizada 
Figura 113 - Valores de Eh iniciais e finais para os quatro compostos:total, indiano, alambrado e estático, com $\mathrm{Pb}, \mathrm{Zn}, \mathrm{Cd}$ e água deionizada. 283

Figura 114 - Valores de condutividade elétrica (CE) iniciais e finais para os quatro compostos:total, indiano, alambrado e estático, com $\mathrm{Pb}, \mathrm{Zn}, \mathrm{Cd}$ e água deionizada . 284

Figura 115 - Análise comparativa da porcentagem de remoção de $\mathrm{Pb}, \mathrm{Zn}$ e Cd (A\%) para os compostos estudados (total, indiano, alambrado e estático)

Figura 116 - Análise comparativa da capacidade de remoção de $\mathrm{Pb}, \mathrm{Zn}$ e $\mathrm{Cd}\left(\mathrm{q}_{\mathrm{e}}\right)$ pelos compostos estudados (total, indiano, alambrado e estático). 285

Figura 117 - Variação de pH ao longo do ensaio de equilíbrio em lote com $\mathrm{Pb}$ para a turfa e para o composto indiano 288

Figura 118 - Variação de Eh ao longo do ensaio de equilíbrio em lote com $\mathrm{Pb}$ para a turfa e para o composto indiano

Figura 119 - Variação de condutividade elétrica (CE) ao longo do ensaio de equilíbrio em lote com $\mathrm{Pb}$ para a turfa e para o composto indiano 291

Figura 120 - Análise comparativa das concentrações adsorvida e em equilíbrio ao longo do ensaio de equilíbrio em lote com $\mathrm{Pb}$ para a turfa e para o composto indiano 292

Figura 121 - Comparação entre os dados obtidos experimentalmente e as isotermas que apresentaram $\mathrm{R}^{2} \geq 0,8$ na forma linearizada em relação à adsorção de $\mathrm{Pb}$ 294

Figura 122 - Variação de pH ao longo do ensaio de equilíbrio em lote com Zn para a turfa e para o composto indiano 297

Figura 123 - Variação de Eh ao longo do ensaio de equilíbrio em lote com Zn para a turfa e para o composto indiano 298

Figura 124 - Variação de condutividade elétrica (CE) ao longo do ensaio de equilíbrio em lote com Zn para a turfa e para o composto indiano 300

Figura 125 - Análise comparativa das concentrações adsorvida e em equilíbrio ao longo do ensaio de equilíbrio em lote com $\mathrm{Zn}$ para a turfa e para o composto indiano 301

Figura 126 - Comparação entre os dados obtidos experimentalmente e as isotermas que apresentaram $\mathrm{R}^{2} \geq 0,6$ na forma linearizada em relação à adsorção de $\mathrm{Zn}$. 304

Figura 127 - Variação de pH ao longo do ensaio de equilíbrio em lote com Cd para a turfa e para o composto indiano 306

Figura 128 - Variação de Eh ao longo do ensaio de equilíbrio em lote com Cd para a turfa e para o composto indiano 307

Figura 129 - Variação de condutividade elétrica (CE) ao longo do ensaio de equilíbrio em lote com Cd para a turfa e para o composto indiano. 309

Figura 130 - Análise comparativa das concentrações adsorvida e em equilíbrio ao longo do ensaio de equilíbrio em lote com Cd para a turfa e para o composto indiano 310

Figura 131 - Comparação entre os dados obtidos experimentalmente e as isotermas que apresentaram $\mathrm{R}^{2} \geq 0,9$ na forma linearizada em relação à adsorção de $\mathrm{Cd}$..... 313 


\section{Lista de Quadros}

Quadro 1 - Valores orientadores para alguns metais potencialmente tóxicos............................. 43

Quadro 2 - Principais vantagens e desvantagens da utilização das barreiras reativas ................ 65

Quadro 3 - Classificação visual de turfas de acordo com o grau de humificação - Escala de von

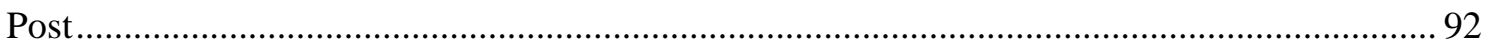

Quadro 4 - Classificação de turfas em função do seu teor de fibras ........................................... 93

Quadro 5 - Classificação de turfas segundo a ASTM D4427 - 13 levando em consideração

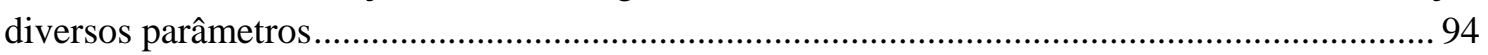

Quadro 6 - Modelos de equilíbrio de sorção (Linear, Freundlich, Freundlich linearizada,

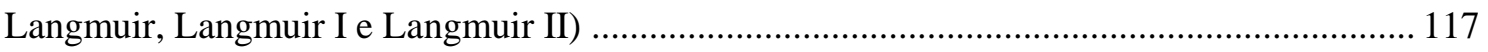

Quadro 7 - Denominação e respectivo diâmetro das frações de partículas (ABNT) ................ 131

Quadro 8 - Denominação e respectivo diâmetro das frações de partículas (EMBRAPA)........ 132

Quadro 9 - Características gerais das cargas permanentes e variáveis nos diferentes

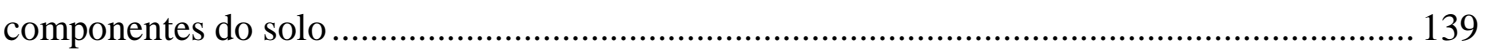

Quadro 10 - Síntese dos parâmetros estudados e suas respectivas metodologias ..................... 152

Quadro 11 - Metodologias empregadas pela ESALQ na caracterização dos materiais reativos

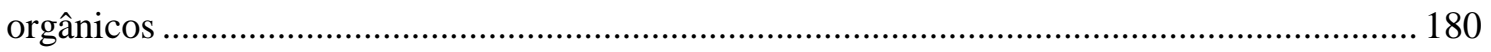

Quadro 12 - Massa molar referente ao cloreto de chumbo $\left(\mathrm{PbCl}_{2}\right)$........................................ 182

Quadro 13 - Massa molar referente ao cloreto de zinco $\left(\mathrm{ZnCl}_{2}\right)$........................................... 182

Quadro 14 - Massa molar referente ao cloreto de cádmio hidratado $\left(\mathrm{CdCl}_{2} \cdot \mathrm{H}_{2} \mathrm{O}\right)$,................. 183

Quadro 15 - Análise comparativa de razões adsorvente/solução empregadas por diversos autores

Quadro 16 - Classificação da turfa segundo o pH, apresentada por Lucas, Riecke e Farnham205

Quadro 17 - Classificação da turfa segundo o pH, apresentada pela ASTM ............................. 205

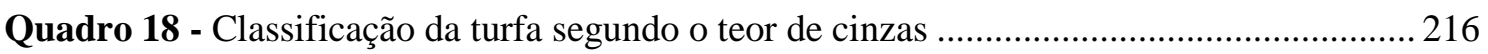

Quadro 19 - Intervalo de variação média para concentrações de Pb e Zn em diferentes solos 217

Quadro 20 - Escala de valores $\left(\mathrm{g} \mathrm{kg}^{-1}\right)$ para fertilizantes orgânicos com umidade natural...... 247

Quadro 21 - Limites máximos de alguns metais admitidos em fertilizantes orgânicos ............ 252 



\section{Lista de Tabelas}

Tabela 1 - Constituição das amostras empregadas na etapa prévia do ensaio de equilíbrio em lote 188

Tabela 2 - Distribuição granulométrica das amostras de turfa total, segundo limites de frações estabelecidos por EMBRAPA (2011)

Tabela 3 - Distribuição granulométrica das amostras de turfa total, segundo limites de frações estabelecidos por ABNT NBR 6502 - 95

Tabela 4 - Distribuição granulométrica das amostras da porção mineral da turfa, segundo limites de frações estabelecidos por EMBRAPA (2011) 197

Tabela 5 - Distribuição granulométrica das amostras da porção mineral da turfa, segundo limites de frações estabelecidos por ABNT NBR 6502. 197

Tabela 6 - Massa específica dos sólidos para a turfa. 201

Tabela 7 - Teor de umidade obtido para a turfa, resultante de secagem entre 40 e $50^{\circ} \mathrm{C}$ e 105 e $110^{\circ} \mathrm{C}$

Tabela 8 - Teor de umidade obtido para a turfa resultante do ensaio com temperaturas combinadas 202

Tabela 9 - Valores de $\mathrm{pH}$ em $\mathrm{H}_{2} \mathrm{O}$ para a turfa. 204

Tabela 10 - Valores de $\mathrm{pH}$ em $\mathrm{H}_{2} \mathrm{O}$ para turfas de diversas localidades nacionais e internacionais 206

Tabela 11 - Parâmetros físico-químicos ( $\mathrm{pH}$ em KCl, pH em $\mathrm{H}_{2} \mathrm{O}$ e $\Delta \mathrm{pH}$ ) da turfa................. 207

Tabela 12 - Valores de $\mathrm{pH}$ em $\mathrm{KCl}$ para uma turfa nacional e outra internacional................... 208

Tabela 13 - Valores de potencial de oxi-redução (Eh) para a turfa............................................ 209

Tabela 14 - Valores de condutividade elétrica (CE) para a turfa ............................................. 209

Tabela 15 - Composição elementar das amostras de turfa, relacionando a presença de C, H e N 211

Tabela 16 - Relações e razões atômicas $\mathrm{C} / \mathrm{N}$ e H/C para a turfa 212

Tabela 17 - Composição elementar adicional das amostras de turfa estudadas, secas a $65^{\circ} \mathrm{C}$, e valores esperados para turfas (FAO, 2016), relacionando a presença de P, K, Ca, Mg e S ...... 213

Tabela 18 - Valores de carbono orgânico para turfas nacionais ................................................... 214

Tabela 19 - Teor de matéria orgânica (MO) obtido na amostra de turfa. 215

Tabela 20 - Valores de matéria orgânica (MO) para turfas de localidades nacionais e internacionais .....

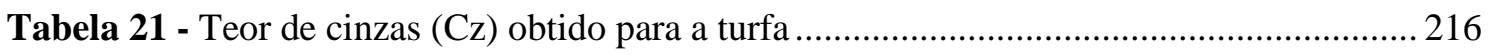

Tabela 22 - Valores de teor de cinzas $(\mathrm{Cz})$ para turfas nacionais............................................. 217

Tabela 23 - Concentrações naturais de $\mathrm{Pb}$ e $\mathrm{Zn}$ obtidas na turfa empregada na presente pesquisa

Tabela 24 - Capacidade de troca catiônica e superfície específica para as amostras de turfa .. 218 
Tabela 25 - Valores de CTC para turfas de diversas localidades nacionais e internacionais ... 219

Tabela 26 - Análise química da turfa por Fluorescência de Raios-X.

Tabela 27 - Composição elementar da porção mineral e da amostra total da turfa estudada... 223

Tabela 28 - Distribuição granulométrica das amostras de compostos: total, indiano, alambrado e estático

Tabela 29 - Diâmetros característicos $\left(D_{10}, D_{30}\right.$ e $\left.D_{60}\right)$ e coeficientes de uniformidade $\left(C_{U}\right)$ e curvatura $\left(\mathrm{C}_{\mathrm{C}}\right)$ para os compostos: total, indiano, alambrado e estático

Tabela 30 - Massa específica dos sólidos $\left(\mathrm{g} \mathrm{cm}^{-3}\right)$ para os compostos: total, indiano, alambrado e estático. 234

Tabela 31 - Densidade $\left(\mathrm{g} \mathrm{cm}^{-3}\right)$ dos compostos: total, indiano, alambrado e estático 235

Tabela 32 - Teor de umidade dos compostos: total, indiano, alambrado e estático, resultante de secagem em estufa entre 40 e $50^{\circ} \mathrm{C}$.

Tabela 33 - Teor de umidade dos compostos: total, indiano, alambrado e estático, resultante de secagem em estufa entre 105 e $110^{\circ} \mathrm{C}$ 236

Tabela 34 - Teor de umidade dos compostos: total, indiano, alambrado e estático, resultante do ensaio com temperaturas combinadas $\left(60-65^{\circ} \mathrm{C}\right.$ e $\left.105-110^{\circ} \mathrm{C}\right)$

Tabela 35 - Capacidade de retenção de água para os compostos: total, indiano, alambrado e estático, em \% (massa/massa)

Tabela 36 - Valores de $\mathrm{pH}$ em $\mathrm{H}_{2} \mathrm{O}$ para os compostos: total, indiano, alambrado e estático . 239

Tabela 37 - Valores de $\mathrm{pH}$ em $\mathrm{H}_{2} \mathrm{O}$ para compostos nacionais e internacionais.....

Tabela 38 - Valores de $\Delta \mathrm{pH}$ para os compostos: total, indiano, alambrado e estático

Tabela 39 - Valores de potencial de oxi-redução - Eh (mV) para os compostos: total, indiano, alambrado e estático

Tabela 40 - Valores de condutividade elétrica - CE $\left(\mu \mathrm{S} \mathrm{cm}^{-1}\right)$ para os compostos: total, indiano, alambrado e estático

Tabela 41 - Composição elementar dos compostos total e indiano relacionando a presença de C, $\mathrm{He} \mathrm{N}$

Tabela 42 - Composição elementar dos compostos alambrado e estático relacionando a presença de $\mathrm{C}, \mathrm{H}$ e $\mathrm{N}$. 243

Tabela 43 - Relações C/N e H/C para os compostos: total, indiano, alambrado e estático

Tabela 44 - Razões atômicas C/N e H/C para os compostos: total, indiano, alambrado e estático

Tabela 45 - Valores de carbono, nitrogênio e relação $\mathrm{C} / \mathrm{N}$ para compostos nacionais e internacionais

Tabela 46 - Composição elementar adicional das amostras dos compostos: total, indiano, alambrado e estático, secos a $65^{\circ} \mathrm{C}$, relacionando a presença de $\mathrm{P}, \mathrm{K}, \mathrm{Ca}, \mathrm{Mg}$ e S $\left(\mathrm{g} \mathrm{kg}^{-1}\right)$..... 246

Tabela 47 - Concentrações de alguns elementos $\left(\mathrm{g} \mathrm{kg}^{-1}\right)$ para compostos nacionais e internacionais

Tabela 48 - Teor de carbono orgânico obtido nos compostos: total, indiano, alambrado e estático, secos a $65^{\circ} \mathrm{C}$ 
Tabela 49 - Teor de matéria orgânica - MO $\left(\mathrm{g} \mathrm{kg}^{-1}\right)$ para os compostos: total, indiano, alambrado e estático

Tabela 50 - Teores de matéria orgânica (MO) para compostos de localidades nacionais e internacionais

Tabela 51 - Teor de cinzas - $\mathrm{Cz}\left(\mathrm{g} \mathrm{kg}^{-1}\right)$ para os compostos: total, indiano, alambrado e estático 250

Tabela 52 - Concentrações de metais $\left(\mathrm{mg} \mathrm{kg}^{-1}\right)$ para os compostos: total, indiano, alambrado e estático. 252

Tabela 53 - Concentrações de metais $\left(\mathrm{mg} \mathrm{kg}^{-1}\right)$ para compostos nacionais e internacionais ... 253

Tabela 54 - Capacidade de troca catiônica $\left(\mathrm{cmol}_{\mathrm{c}} \mathrm{kg}^{-1}\right)$ para os compostos: total, indiano, alambrado e estático (Ensaio do azul de metileno) ..... 254

Tabela 55 - Superfície específica $\left(\mathrm{m}^{2} \mathrm{~g}^{-1}\right)$ para os compostos: total, indiano, alambrado e estático 254

Tabela 56 - Capacidade de troca catiônica $\left(\mathrm{cmol}_{\mathrm{c}} \mathrm{kg}^{-1}\right)$ para os compostos: total, indiano, alambrado e estático (Titulometria) 255

Tabela 57 - Valores de CTC para compostos de diversas localidades nacionais e internacionais 256

Tabela 58 - Valores médios para a análise química dos compostos por Fluorescência de Raios-X . .258

Tabela 59 - Composição elementar das porções minerais e amostras totais dos compostos ... 260

Tabela 60 - Parâmetros de adsorção estimados a partir das isotermas Linear e de Freundlich 278

Tabela 61 - Parâmetros de adsorção estimados a partir das isotermas de Langmuir (I e II) .... 278

Tabela 62 - Concentração de $\mathrm{Pb}, \mathrm{Zn}$ e $\mathrm{Cd}$ nos brancos dos compostos (composto + água deionizada)

Tabela 63 - Parâmetros de adsorção para o $\mathrm{Pb}$ estimados a partir das isotermas Linear e de Freundlich 293

Tabela 64 - Parâmetros de adsorção para o Pb estimados a partir das isotermas de Langmuir (I e II) 293

Tabela 65 - Parâmetros de adsorção para o Zn estimados a partir das isotermas Linear e de Freundlich 302

Tabela 66 - Parâmetros de adsorção para o Zn estimados a partir das isotermas de Langmuir (I e II). 303

Tabela 67 - Parâmetros de adsorção para o Cd estimados a partir das isotermas Linear e de Freundlich

Tabela 68 - Parâmetros de adsorção para o Cd estimados a partir das isotermas de Langmuir (I e II)

Tabela 69 - Valores de pH inicial (imediatamente após o contato material reativo e solução contendo o contaminante) e no equilíbrio para $\mathrm{Pb}, \mathrm{Zn}$ e $\mathrm{Cd}$....................................................... 316

Tabela 70 - Valores de pH ótimo para turfas temperadas e tropicais 316 
Tabela 71 - Dados comparativos quanto aos parâmetros de adsorção de $\mathrm{Pb}, \mathrm{Zn}$ e Cd pela turfa

Tabela 72 - Condições dos ensaios de adsorção com turfa 320

Tabela 73 - Dados comparativos quanto aos parâmetros de adsorção de $\mathrm{Pb}, \mathrm{Zn}$ e $\mathrm{Cd}$ pelo composto 321

Tabela 74 - Condições dos ensaios de adsorção com composto orgânico 322

Tabela 75 - Ordem de afinidade de adsorção de $\mathrm{Pb}, \mathrm{Zn}$ e Cd por turfas e compostos orgânicos 324

Tabela 76 - Propriedades em relação aos íons divalentes $\mathrm{Pb}^{2+}, \mathrm{Zn}^{2+} \mathrm{e} \mathrm{Cd}^{2+}$ 325

Tabela 77 - Dados comparativos quanto aos parâmetros de adsorção de $\mathrm{Pb}, \mathrm{Zn}$ e $\mathrm{Cd}$ por materiais reativos orgânicos de baixo custo... 327

Tabela 78 - Ordem de afinidade de adsorção de $\mathrm{Pb}, \mathrm{Zn}$ e Cd por materiais reativos orgânicos de baixo custo 328

Tabela 79 - Matriz de correlação de Pearson relacionando a caracterização geológica e geológica da turfa e dos compostos 331

Tabela 80 - Matriz de correlação de Pearson relacionando a caracterização geológica e geológica dos compostos e parâmetros do teste melhor composto.

Tabela 81 - Matriz de correlação de Pearson relacionando as porcentagens de metais adsorvidos (A\%) para turfa e composto indiano,

Tabela 82 - Matriz de correlação de Pearson relacionando as capacidades de remoção $\left(\mathrm{q}_{\mathrm{e}}\right)$ para turfa e composto indiano, 


\begin{tabular}{|c|c|c|}
\hline $\mathrm{ABNT}$ & - & Associação Brasileira de Normas Técnicas \\
\hline ASTM & - & American Society for Testing and Materials \\
\hline AA & - & Absorção Atômica \\
\hline ATD & - & Análise Térmica Diferencial \\
\hline ATSDR & - & Agency for Toxic Substances and Disease Registry \\
\hline CAQI & - & Central de Análises Químicas Instrumentais \\
\hline $\mathrm{CE}$ & - & Condutividade elétrica \\
\hline CETESB & - & Companhia Ambiental do Estado de São Paulo \\
\hline CRA & - & Capacidade de retenção de água \\
\hline CTC & - & Capacidade de troca catiônica \\
\hline DRX & - & Difratometria de Raios-X \\
\hline EDS & - & Espectroscopia de Energia Dispersiva por Raios-X \\
\hline EESC & - & Escola de Engenharia de São Carlos \\
\hline Eh & - & Potencial de oxi-redução \\
\hline EMBRAPA & - & Empresa Brasileira de Pesquisa Agropecuária \\
\hline EPA & - & Environmental Protection Agency \\
\hline ESALQ & - & Escola Superior de Agricultura Luiz de Queiroz \\
\hline FAPESP & - & Fundação de Apoio à Pesquisa do Estado de São Paulo \\
\hline FRX & - & Fluorescência de Raios-X \\
\hline GEISA & - & Grupo de Estudos e Intervenções Sócio Ambientais \\
\hline IFSC & - & Instituto de Física de São Carlos \\
\hline IHSS & - & International Humic Substances Society \\
\hline IPEA & - & Instituto de Pesquisa Econômica Aplicada \\
\hline IPS & - & International Peatland Society \\
\hline IPT & - & Instituto de Pesquisas Tecnológicas do Estado de São Paulo \\
\hline IQSC & - & Instituto de Química de São Carlos \\
\hline ITRC & - & Interstate Technology \& Regulatory Council \\
\hline LCT & - & Laboratório de Caracterização Tecnológica \\
\hline MAPA & - & Ministério da Agricultura, Pecuária e Abastecimento \\
\hline MEV & - & Microscopia Eletrônica de Varredura \\
\hline MMA & - & Ministério do Meio Ambiente \\
\hline MO & - & Matéria orgânica \\
\hline
\end{tabular}


OECD - $\quad$ Organization for Economic Co-Operation and Development

PCZ _ - Ponto de carga zero

PEAD _ - Polietileno de Alta Densidade

PERH _ - Plano Estadual dos Recursos Hídricos

PESN $\quad-\quad$ Ponto de efeito salino nulo

$\mathrm{pH} \quad-\quad$ Potencial hidrogeniônico

POLI - Escola Politécnica

PZSE $\quad-\quad$ Point of zero salt effect

SE $\quad-\quad$ Superfície específica

UNEP _ - United Nations Environmental Programme

USP _ - Universidade de São Paulo

VI $\quad-\quad$ Valor de Intervenção

VP $\quad-\quad$ Valor de Prevenção

VRQ _ - $\quad$ Valor de Referência de Qualidade

WER _ - World Energy Resources

WHO _ _ World Health Organization 


\section{Lista de Símbolos}

$\AA$ Angstrom

As Arsênio

Ba Bário

C Carbono

C/N Relação carbono/nitrogênio

$\mathrm{C}_{1} \quad$ Concentração desejada

$\mathrm{C}_{2}$ Concentração da solução estoque

$\mathrm{Ca} \quad$ Cálcio

Cd Cádmio

$\mathrm{C}_{\mathrm{e}} \quad$ Concentração de soluto na solução em equilíbrio

$\mathrm{Cl}$ Cloro

Co Cobalto

$\mathrm{Cr}$ Cromo

$\mathrm{Cu} \quad$ Cobre

$\mathrm{C}_{\mathrm{z}} \quad$ Teor de cinza

D Distância interplanar

$\mathrm{D}_{10}$ Diâmetro do grão que apresenta $10 \%$ de grãos com diâmetros menores que ele

$\mathrm{D}_{30}$ Diâmetro do grão que apresenta $30 \%$ de grãos com diâmetros menores que ele

D60 Diâmetro do grão que apresenta $60 \%$ de grãos com diâmetros menores que ele

g Grama

H Hidrogênio

h Teor de umidade

H/C Relação hidrogênio/carbono

$\mathrm{Hg} \quad$ Mercúrio

K Potássio

$\mathrm{K}_{\mathrm{d}} \quad$ Coeficiente de distribuição de equilíbrio

$\mathrm{K}_{\mathrm{f}} \quad$ Constante de equilíbrio de Freundlich

$\mathrm{K}_{\mathrm{L}} \quad$ Constante de adsorção de Langmuir relacionada à energia de ligação

L Litro

m Metro

$M_{1} \quad$ Massa da amostra úmida mais a massa do recipiente

$M_{2} \quad$ Massa da amostra seca mais a massa do recipiente

$M_{3} \quad$ Massa do recipiente 
$M_{I} \quad$ Massa do balão volumétrico, água e sólidos

$M_{I I} \quad$ Massa do balão volumétrico e água

$M_{S} \quad$ Massa de sólidos que ocupa o volume $\mathrm{V}_{\mathrm{s}}$

$M_{a} \quad$ Massa total da amostra (sólidos e água)

$M_{f} \quad$ Massa da amostra após a mufla

$M_{i} \quad$ Massa da amostra antes da mufla

$M_{\text {rec }} \quad$ Massa do recipiente

$M_{\text {rec }+m s}$ Massa do recipiente e material seco

$M_{S} \quad$ Massa de sólidos na amostra

$M_{w} \quad$ Massa de água na amostra

Mn Manganês

n Coeficiente exponencial de Freundlich

$\mathrm{n}^{\circ} \quad$ Ordem de difração

$\mathrm{N}$ Nitrogênio

$\mathrm{Na}$ Sódio

$\mathrm{NaOH}$ Hidróxido de sódio

$\left(\mathrm{NaPO}_{3}\right)_{6}$ Hexametafosfato de sódio

${ }^{\circ} \mathrm{C} \quad$ Graus Celsius

P Fósforo

$\rho_{s} \quad$ Massa específica dos sólidos

$\rho_{w} \quad$ Massa específica da água

$\mathrm{Pb}$ Chumbo

qe Concentração de soluto adsorvida pelo adsorvente

$\mathrm{q}_{\mathrm{m}} \quad$ Capacidade de adsorção ou número total de locais de adsorção disponíveis

R Radical

S Enxofre

S Segundo

Se Selênio

$\mathrm{Sr} \quad$ Estrôncio

v Volume

$\mathrm{V}_{1} \quad$ Volume desejado

$\mathrm{V}_{2} \quad$ Volume da solução estoque

Zn Zinco

$\Theta \quad$ Ângulo de incidência do feixe sobre determinados planos do cristal

$\lambda \quad$ Comprimento de onda dos raios- $\mathrm{X}$ incidentes 


\section{Sumário}

2 OBJETIVOS

2.1 Objetivos específicos.

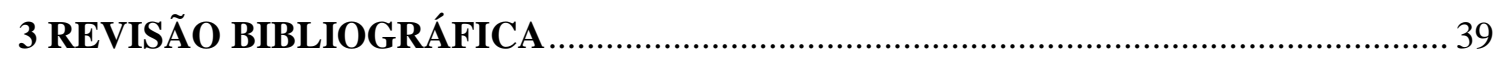

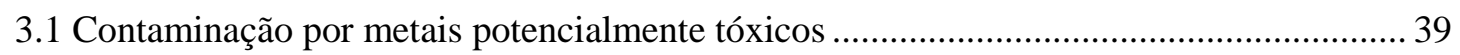

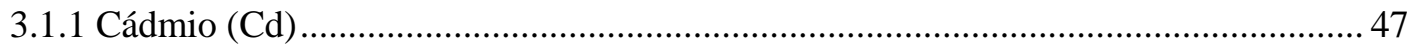

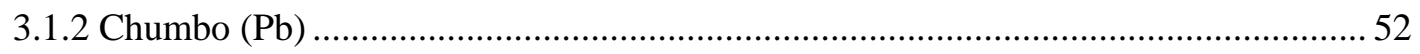

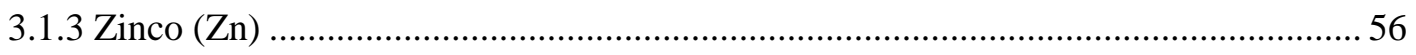

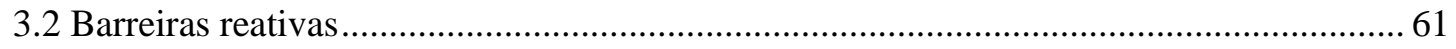

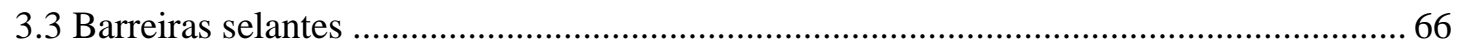

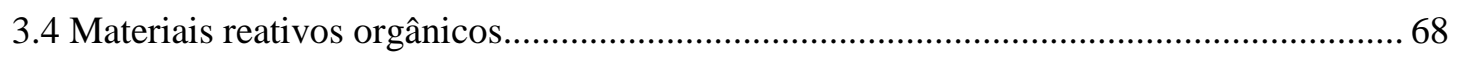

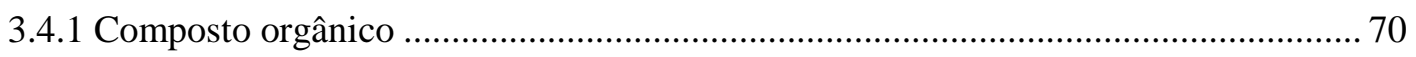

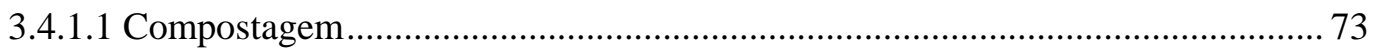

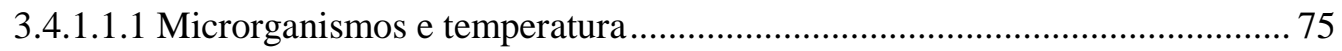

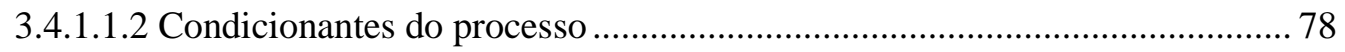

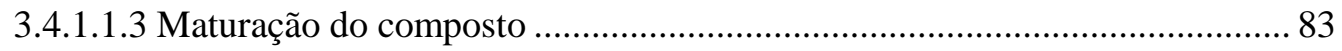

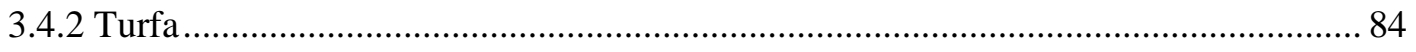

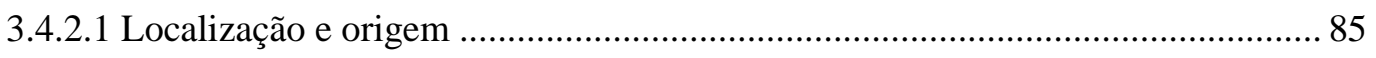

3.4.2.2 Composição e processo de formação ………………………………………..... 86

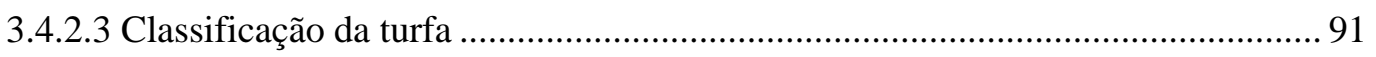

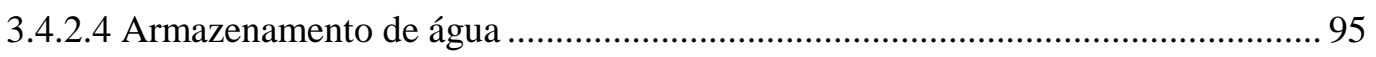

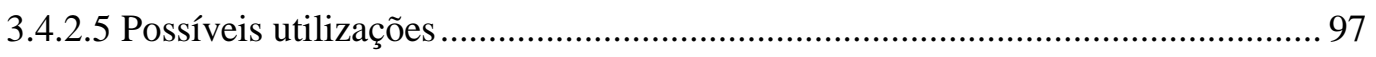

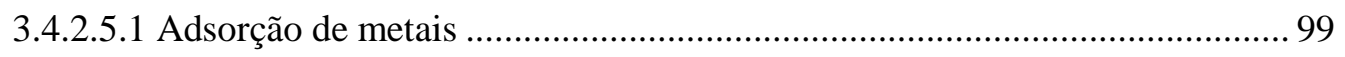

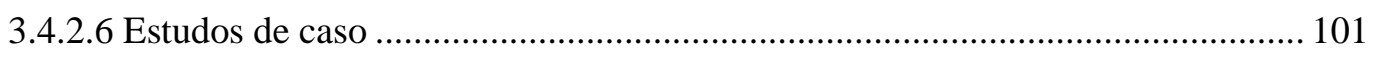

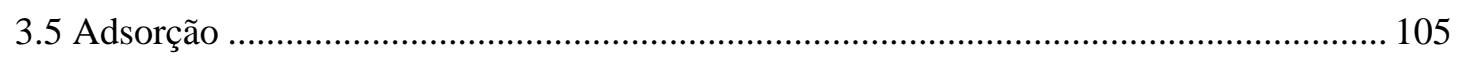

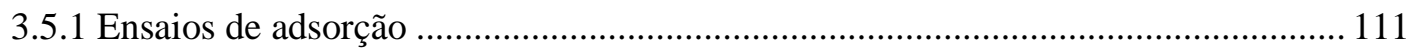

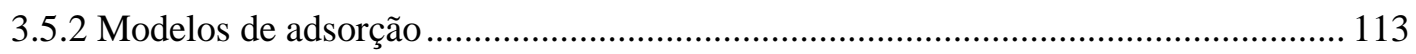




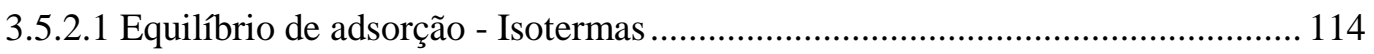

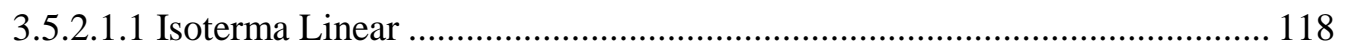

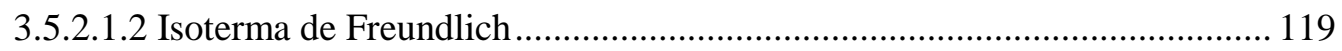

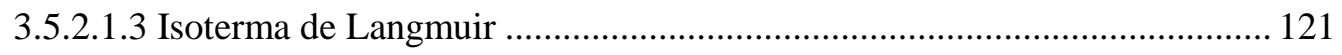

3.5.3 Fatores que influenciam na adsorção de metais por materiais reativos.................... 123

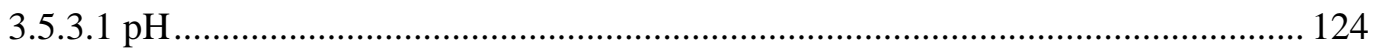

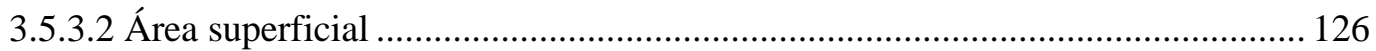

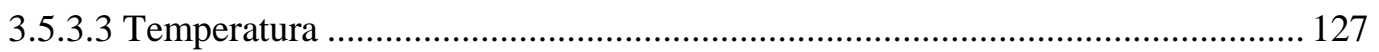

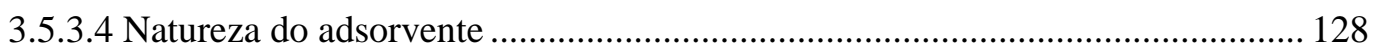

3.5.3.5 Natureza e concentração das espécies adsorvíveis ............................................ 130

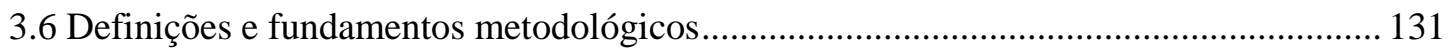

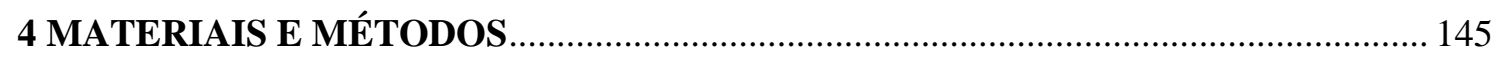

4.1 Origem e pré-preparo dos materiais reativos orgânicos .................................................. 145

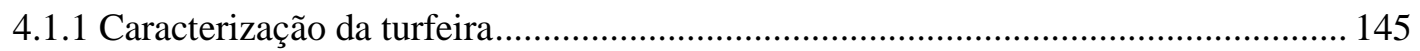

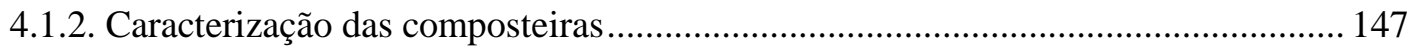

4.2 Caracterização geológica e geotécnica dos materiais reativos orgânicos ........................ 151

4.3 Ensaio de adsorção dos materiais reativos orgânicos - Equilíbrio em lote ....................... 180

4.3.1 Etapa preliminar - Teste da melhor razão turfa/solução........................................... 187

4.3.2 Etapa preliminar - Teste do composto com maior capacidade adsortiva .................. 189

4.3.3 Ensaio de equilíbrio em lote para turfa e composto indiano ..................................... 190

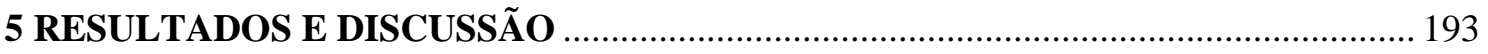

5.1 Caracterização geológica e geotécnica dos materiais reativos orgânicos ........................ 193

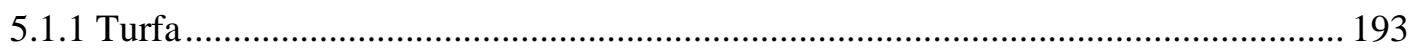

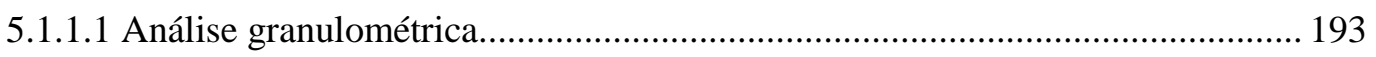

5.1.1.2 Massa específica dos sólidos e densidade aparente.......................................... 201

5.1.1.3 Teor de umidade e capacidade de retenção de água (CRA) ............................... 201

5.1.1.4 Parâmetros físico-químicos (pH, $\Delta \mathrm{pH}$, Eh e CE) ............................................. 204

5.1.1.5 Ponto de carga zero (PCZ) e ponto de efeito salino nulo (PESN) ...................... 209

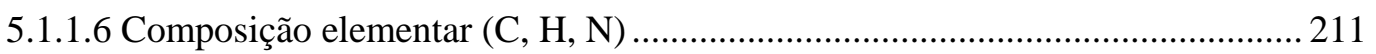

5.1.1.7 Composição elementar complementar (P, K, Ca, Mg e S)................................ 213

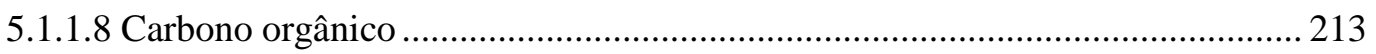




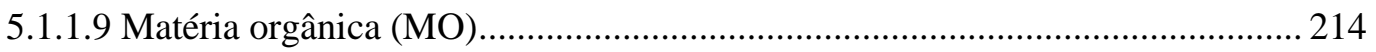

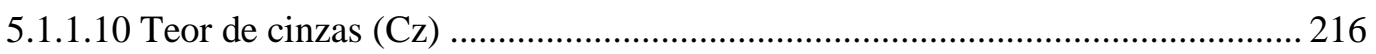

5.1.1.11 Absorção Atômica (AA) ........................................................................... 217

5.1.1.12 Capacidade de troca catiônica (CTC) e superfície específica (SE) ................. 218

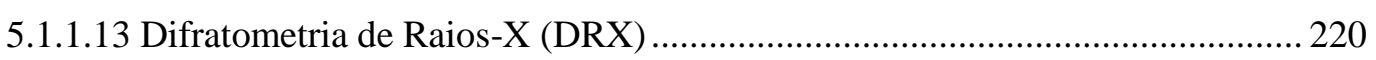

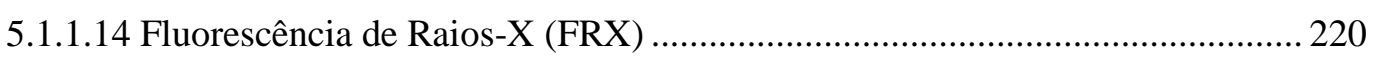

5.1.1.15 Microscopia Eletrônica de Varredura/Espectroscopia de Energia Dispersiva por

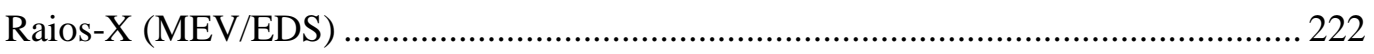

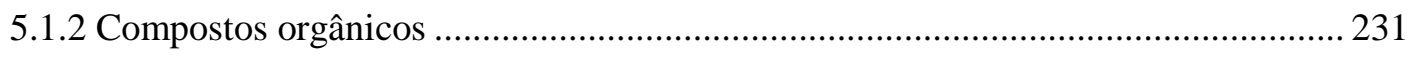

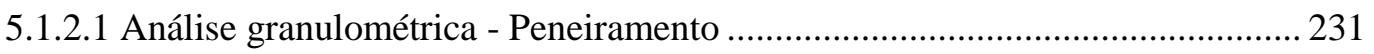

5.1.2.2 Massa específica dos sólidos e densidade aparente.......................................... 234

5.1.2.3 Teor de umidade e capacidade de retenção de água (CRA) ............................... 235

5.1.2.4. Parâmetros físico-químicos ( $\mathrm{pH}, \Delta \mathrm{pH}$, Eh e CE) ............................................. 238

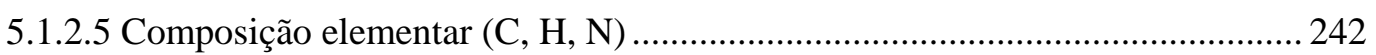

5.1.2.6 Composição elementar complementar (P, K, Ca, Mg e S)............................... 245

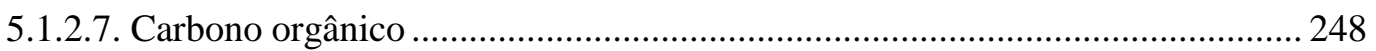

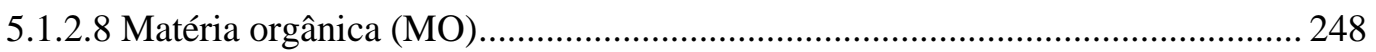

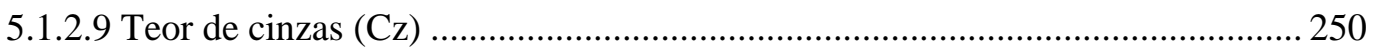

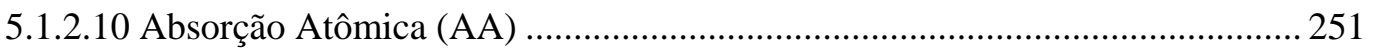

5.1.2.11 Capacidade de troca catiônica (CTC) e superfície específica (SE) .................. 254

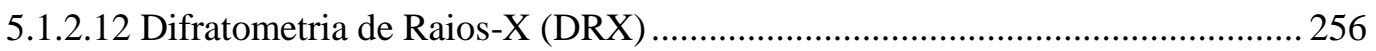

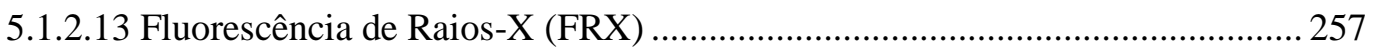

5.1.2.14 Microscopia Eletrônica de Varredura/Espectroscopia de Energia Dispersiva por

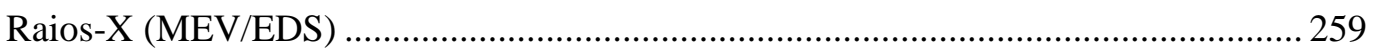

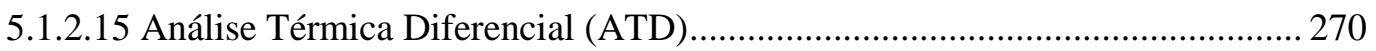

5.1.3 Considerações referentes à caracterização geológica-geotécnica de turfa e compostos

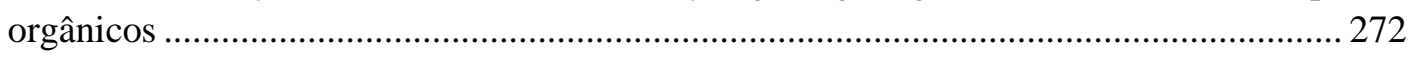

5.2 Ensaio de adsorção de equilíbrio em lote com materiais reativos orgânicos (turfa e

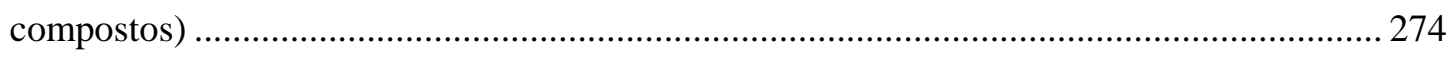

5.2.1 Etapa preliminar - Determinação da melhor razão turfa/solução ............................. 274

5.2.2 Etapa preliminar - Teste do composto com maior capacidade adsortiva .................. 281

5.2.3 Ensaio de equilíbrio em lote para turfa e composto indiano .................................... 287

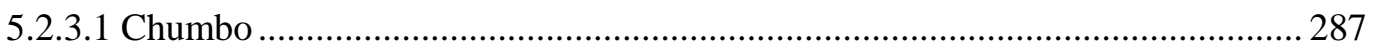

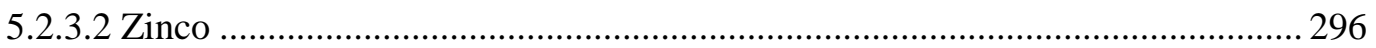

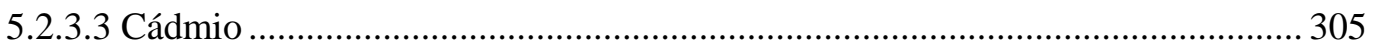

5.2.4 Considerações referentes aos resultados de adsorção ............................................... 315 
5.2.4.1 pH

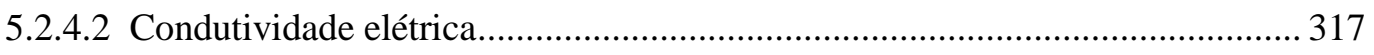

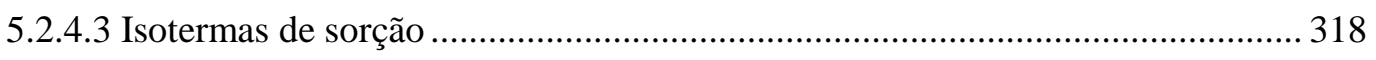

5.2.4.4 Porcentagens adsorvidas e capacidades de remoção de metais em função da afinidade metal - material reativo

5.2.4.5 Comparação da adsorção de $\mathrm{Pb}, \mathrm{Zn}$ e $\mathrm{Cd}$ em outros materiais reativos orgânicos

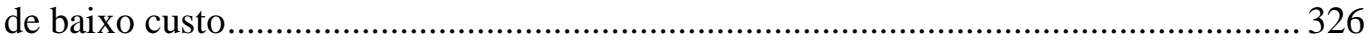

5.2.4.6 Matriz de correlação de Pearson ....................................................................... 328

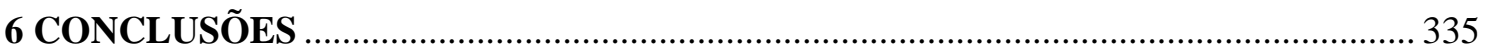

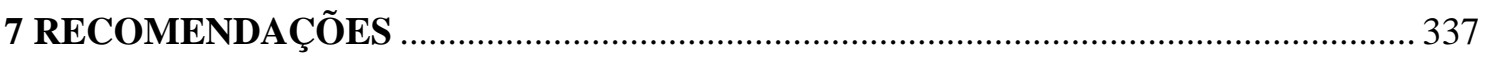

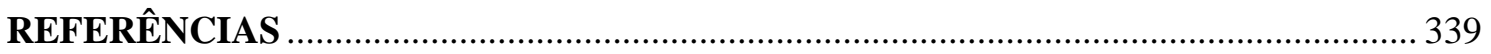




\section{INTRODUÇÃO}

Diversas atividades antrópicas resultam em impactos ambientais negativos que, por sua vez, culminam na degradação dos solos e na perda de sua capacidade de suporte dos processos naturais. Tais degradações estão diretamente associadas à contaminação química, à erosão acelerada, à compactação excessiva, à impermeabilização e à redução da biodiversidade (PEJON; RODRIGUES; ZUQUETTE, 2013).

A mineração é uma das atividades antrópicas que pode vir a causar sérios problemas de degradação ambiental (impacto ambiental negativo). A mineração de minerais metálicos pode contaminar o solo e/ou as águas superficiais e subterrâneas, através do lançamento inadequado de efluentes ou da disposição descontrolada de resíduos (estéreis, rejeitos e escórias), os quais, geralmente ainda contêm elevadas concentrações dos metais de interesse. Além disso, comumente esses resíduos são alocados na forma de pilhas, ficando expostos aos agentes intempéricos, o que acelera as reações de oxidação e dissolução, aumentando a mobilidade dos metais nas soluções aquosas que permeiam pela pilha (GABAS, 2005).

Segundo Hashim et al. (2011), os metais potencialmente tóxicos são conhecidos por sua toxicidade, acumulação nos tecidos vivos e biomagnificação e podem tornar-se móveis e biodisponíveis aos organismos no solo e na água, dependendo das condições de $\mathrm{pH}$ existentes no meio e de sua forma química. Conforme Salomons (1995), após a contaminação da água subterrânea, os metais potencialmente tóxicos podem migrar por diversos quilômetros, ocasionando danos ao ecossistema e comprometendo os sistemas de abastecimento.

Diante disso, pode-se dizer que a mineração é uma atividade potencialmente geradora de passivos ambientais, necessitando de total controle desde sua abertura até o seu fechamento. De acordo com Sánchez (2001), o termo passivo ambiental se referia, em um primeiro momento, ao valor monetário atribuído a recuperação de áreas acometidas por danos ambientais. Todavia, frequentemente, esta expressão é empregada sem conotação monetária, como uma alusão a danos ambientais que não podem ser taxados economicamente. Em um sentido figurado, está associado a uma espécie de "dívida” para com as gerações futuras.

Portanto, é necessário o desenvolvimento de técnicas de baixo custo que visem à prevenção e/ou remediação da contaminação do subsolo e das águas subterrâneas de forma a garantir tais bens públicos, que se constituem em reservas estratégicas para o abastecimento populacional e para o desenvolvimento sustentável.

Nessa perspectiva, os materiais reativos orgânicos de baixo custo são considerados como possíveis alternativas na retenção de contaminantes, se destacando pela acentuada 
presença de substâncias húmicas, as quais apresentam elevado potencial de adsorção de diversos elementos e substâncias, como os cátions metálicos. Nas últimas décadas diversos trabalhos estudaram a possibilidade de utilização de turfas e compostos orgânicos na recuperação de áreas contaminadas por metais (RASHID, 1974; QIN et al., 2006; KALMYKOVA; STRÖMVALL; STEENARI, 2008; LOURIE; GJENGEDAL, 2011; BARTCZAK et al., 2015; SIMANTIRAKI; GIDARAKOS, 2015; VENEGAS; RIGOL; VIDAL, 2015). O principal enfoque inicial destas pesquisas era o tratamento de águas residuais. Contudo, sua utilização, de forma isolada e combinada, na construção de barreiras reativas e, mais recentemente, em barreiras selantes também passou a ser avaliado (CRESCÊNCIO JÚNIOR, 2008; KOIVULA et al., 2009; OBIRI-NYARLO; GRAJALES-MESA; MALINA, 2014).

A efetiva atuação de turfas e compostos orgânicos como adsorvente, semelhante aos outros materiais de caráter similar, depende diretamente de suas propriedades físicas e químicas. Como estas propriedades não são uniformes e variam consideravelmente, principalmente em função dos materiais de origem e do tempo de decomposição/humificação, a continuidade das pesquisas se faz necessário, a fim de encontrar padrões de caracterização e sua influência na sorção de contaminantes.

Neste contexto, a presente pesquisa buscou caracterizar duas tipologias de materiais reativos orgânicos: turfa e compostos, bem como analisar a capacidade de adsorção de metais potencialmente tóxicos (chumbo - $\mathrm{Pb}$, zinco - $\mathrm{Zn}$ e cádmio - $\mathrm{Cd}$; comumente associados à contaminação por resíduos de mineração de minérios metálicos) por esses materiais reativos.

Esse estudo apresenta como justificativa a contribuição científica que poderá ser dada, tendo como foco a minimização da contaminação em áreas de mineração de minérios metálicos, a partir da utilização de materiais dotados, simultaneamente, de um baixo custo e uma considerável disponibilidade. No caso da turfa, mesmo demandando um longo período de tempo para sua humificação, existem extensas turfeiras pelo país e pesquisas consolidadas quanto a sua capacidade de retenção de cátions metálicos. Já quanto aos compostos, o processo de compostagem pode ser considerado rápido (da ordem de meses), simples (em termos tecnológicos) e eficiente (destinação correta para a fração orgânica dos resíduos sólidos urbanos). Com a Política Nacional de Resíduos Sólidos de 2010 espera-se que o volume de compostos orgânicos aumente nos próximos anos. Assim, a escolha deste material visa avaliar sua possibilidade de uso na imobilização de metais, alternativa ainda menos estudada, agregando valor ao resíduo e, ao mesmo tempo, se tornando uma forma de destinação para este material. 


\section{OBJETIVOS}

O objetivo principal desta pesquisa foi caracterizar detalhadamente os materiais reativos, turfa e compostos orgânicos (provenientes do processo de compostagem), bem como avaliar a capacidade desses materiais em reter metais potencialmente tóxicos $(\mathrm{Pb}, \mathrm{Zn}$ e $\mathrm{Cd})$.

\subsection{Objetivos específicos}

A) Caracterizar geológica e geotecnicamente uma amostra de turfa proveniente de Cravinhos e quatro compostos orgânicos (composto total, composto indiano, composto alambrado e composto estático);

B) Determinar a razão turfa/solução contaminante mais eficiente;

C) Encontrar o composto dotado da maior capacidade adsortiva para ser empregado no ensaio de equilíbrio em lote;

D) Avaliar a capacidade de retenção da turfa, a partir do ensaio de equilíbrio em lote (para soluções monoelementares de $\mathrm{Pb}, \mathrm{Zn}$ e $\mathrm{Cd}$ );

E) Avaliar a capacidade de retenção do composto indiano, a partir do ensaio de equilíbrio em lote (para soluções monoelementares de $\mathrm{Pb}, \mathrm{Zn}$ e $\mathrm{Cd}$ );

F) Determinar a ordem de afinidade de adsorção dos metais para a turfa e o composto orgânico;

G) Avaliar se a turfa e o composto indiano eram adequados para serem empregados em barreiras selantes e permeáveis, no que se refere a caracterização e a adsorção. 


\section{REVISÃO BIBLIOGRÁFICA}

\subsection{Contaminação por metais potencialmente tóxicos}

Desde a revolução industrial, os esforços visando à remoção de poluentes e/ou contaminantes, de origem antrópica, lançados em ambientes naturais têm sido incapazes de acompanhar o ritmo elevado de produção de resíduos e o crescimento populacional, o que acaba agravando ainda mais essa situação. Tal fato muitas vezes culmina na transformação de lagos, rios e águas costeiras, com a consequente perturbação do equilíbrio ecológico natural e, em alguns casos, total rompimento (FÖRSTNER; WITTMANN, 1983). De forma similar, o solo também vem sendo afetado, tanto em extensão como em profundidade, propiciando, em alguns casos, a contaminação das águas subterrâneas. Ademais, o ar e os organismos vivos são impactados, tanto de forma direta como indireta. As emissões para a atmosfera são inclusive uma via para o transporte desses elementos, principalmente devido à estreita ligação com a hidrosfera que, através das precipitações transporta esses elementos para o solo e corpos hídricos.

Nessa perspectiva, uma área contaminada ou poluída pode ser definida como sendo um local ou terreno onde há comprovadamente contaminação ou poluição advinda da introdução de quaisquer substâncias ou resíduos que ali foram depositados, acumulados, armazenados, enterrados ou infiltrados de modo planejado, acidental ou, até mesmo, natural (COMPANHIA AMBIENTAL DO ESTADO DE SÃO PAULO - CETESB, 2001a).

A maioria dos textos científicos não fazem distinção entre os termos contaminação e poluição. Entretanto, de acordo com Boscov (2008), algumas diferenças podem ser salientadas no tocante a esses dois termos. A contaminação, de fato, pode ser vista como de menor gravidade, uma vez comparada à poluição, já que não ocorre o rompimento do equilíbrio ecológico do ecossistema em questão. Nass (2002) complementa esta afirmação dizendo que a poluição está associada a uma modificação ecológica, isto é, uma alteração entre os seres vivos, advinda de ações humanas que afetam negativamente, de forma direta ou indireta, a vida e o bem-estar do homem, bem como provoca danos aos recursos naturais. Já a contaminação se refere à presença de seres patogênicos que causem doenças ou substâncias que estejam no ambiente em concentrações acima dos valores de referência estabelecidos por órgãos ambientais ou acima dos valores de background. Contudo, se estas substâncias não afetarem as relações ecológicas existentes no meio, esta contaminação não pode ser considerada como uma forma de poluição. 
De acordo com Boscov (2008), a contaminação do solo acontece de maneira lenta e, na maioria dos casos, sem consequências imediatas trágicas. Todavia, em longo prazo pode ocasionar sérios impactos ambientais negativos. Ainda segundo a mesma autora, a contaminação do solo é a principal responsável pela deterioração das águas subterrâneas. Ao atingirem o solo, os contaminantes e/ou poluentes podem penetrar pelas camadas superficiais não saturadas e atingir as águas subterrâneas. Ao entrarem em contato com o fluxo subterrâneo, os contaminantes e/ou poluentes vão se espalhando, devido à dispersão hidrodinâmica, alcançando regiões cada vez mais distantes. Esse espalhamento, correspondente à porção contaminada a partir da própria fonte, e é chamado pluma de contaminação.

Segundo Pejon, Rodrigues e Zuquette (2013), os contaminantes podem ser categorizados em três grandes grupos: orgânicos, inorgânicos e patogênicos. Os orgânicos englobam hidrocarbonetos, orgânicos sintéticos, orgânicos nitrogenados, sulfonados e fosforados. Os inorgânicos, por sua vez, incluem, principalmente, os metais potencialmente tóxicos. Nesta pesquisa, especial atenção foi dada aos metais potencialmente tóxicos, principalmente aqueles advindos da mineração (como $\mathrm{Pb}, \mathrm{Zn}$ e $\mathrm{Cd}$ ). As principais fontes de contaminação e/ou poluição do solo por metais potencialmente tóxicos, são os depósitos de resíduos industriais ou domésticos e de rejeitos ou estéreis de mineração (resíduos de mineração).

Conforme Salomons (1995), em condições naturais, os metais potencialmente tóxicos podem ser liberados dos minérios a partir do intemperismo e/ou por processos erosivos. Entretanto, a mineração potencializa muito esta liberação, já que desloca grandes massas de material rico em metais que estavam, até então, em equilíbrio geoquímico natural. Zonas mineralizadas, quando economicamente viável, são exploradas visando à retirada e o processamento do minério presente (FÖRSTNER; WITTMANN, 1983). Durante todas as etapas da atividade de mineração são produzidos os chamados resíduos de mineração que ainda contém concentrações consideráveis dos minérios de interesse que não são mais viáveis de serem extraídos, economicamente e/ou tecnicamente.

Os minérios de interesse, conforme Förstner e Wittmann (1983) podem ser compostos por metais potencialmente tóxicos, como é o caso da galena (sulfeto de $\mathrm{Pb}$ ). Sendo assim, se esses resíduos não forem destinados de forma planejada e controlada podem vir a contaminar o meio, afetando ecossistemas terrestres e aquáticos. De forma análoga, mesmo após seu uso, os produtos fabricados com metais potencialmente tóxicos também devem ser devidamente descartados. A Figura 1 exibe a dispersão dos metais potencialmente tóxicos a partir das áreas mineralizadas até seu destino final. 
Figura 1 - Representação esquemática da dispersão dos metais potencialmente tóxicos a partir das áreas mineralizadas até seu destino final, atuando como poluentes difusos em locais de deposição, solos e sedimentos

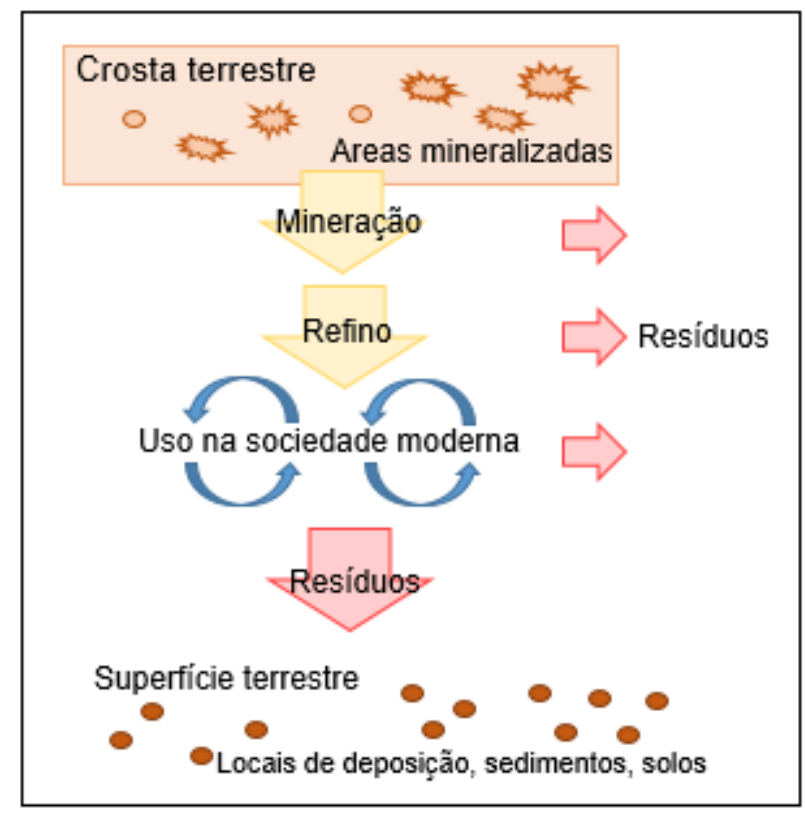

Fonte: Adaptado de Salomons (1995).

Para a avaliação da contaminação por metais potencialmente tóxicos provenientes de uma área de mineração, deve-se ter o conhecimento da concentração natural dos metais de interesse no meio em questão. Uma razão importante para se conhecer as concentrações naturais dos metais potencialmente tóxicos, segundo Fergusson (1990), é que essas fornecem um verdadeiro ponto de referência para a estimativa do nível de contaminação e/ou poluição. De fato, isto apresenta particular importância quando se avalia os efeitos tóxicos dos elementos no ambiente. Assim, uma alternativa é a utilização do chamado background ou amostra controle, que corresponde à amostra que foi coletada a montante da contaminação, sendo essa representativa das condições naturais do meio. Sua utilização é de indubitável relevância, pois mediante sua comparação com os resultados referentes a possível área contaminada, pode-se promover a confirmação da contaminação e, caso ela de fato exista, a determinação de seu grau e extensão.

Além disso, como um indicativo da periculosidade de uma possível contaminação por metais potencialmente tóxicos, com o intuito de proteger a qualidade dos solos e das águas, bem como gerenciar áreas contaminadas, pode-se utilizar os chamados valores orientadores. No caso do estado de São Paulo, têm-se os Valores Orientadores para Solos e Águas Subterrâneas elaborado pela CETESB. Esses valores apresentam vantagens como a rapidez e facilidade de utilização; a capacidade de indicar o grau de contaminação e/ou poluição; o caráter 
de fonte de informação, associado à facilidade e democratização quanto ao planejamento de ações; a coerência com os padrões ambientais; a redução de influências de políticas locais; a uniformização de ações de controle e a possibilidade comparativa em monitoramentos, permitindo avaliar a eficiência da remediação. Contudo, também existem limitações. O uso de valores numéricos preestabelecidos no tocante à avaliação de áreas suspeitas de contaminação apresenta a dificuldade da influência de condições específicas, como o tipo e propriedades do contaminante, o uso do solo e a situação hidrogeológica. Por conseguinte, contaminações aparentemente similares não conduzem, necessariamente, a riscos similares. Assim, os critérios numéricos não devem ser empregados para fornecer respostas universais (CETESB, 2001b). De acordo com CETESB (2005), esses valores orientadores podem ser categorizados em:

Valor de Referência de Qualidade (VRQ): corresponde a concentração de uma substância presente no solo ou na água subterrânea que permite declarar um solo como limpo ou a água subterrânea em sua condição de qualidade natural;

Valor de Prevenção (VP): corresponde a concentração de uma substância presente no solo ou na água subterrânea acima da qual podem ser acarretadas modificações nocivas para o meio em questão;

Valor de Intervenção (VI): corresponde a concentração de uma substância presente no solo ou na água subterrânea acima da qual são induzidos riscos potenciais, tanto de ordem direta como indireta, para à saúde humana.

A lista vigente dos valores orientadores da CETESB foi publicada no Diário Oficial do Estado, em 21/02/2014 e os dados relacionados ao $\mathrm{Cd}$, $\mathrm{Pb}$ e $\mathrm{Zn}$ (metais de interesse para essa pesquisa) se encontram apresentados no Quadro 1. 
Quadro 1 - Valores orientadores para alguns metais potencialmente tóxicos

\begin{tabular}{|c|c|c|c|c|c|c|}
\hline \multirow{3}{*}{ Substância } & \multicolumn{5}{|c|}{ Solo } & \multirow{3}{*}{$\begin{array}{c}\begin{array}{c}\text { Água } \\
\text { Subterrânea }\end{array} \\
\text { VI }\left(\mu \mathrm{g} \mathrm{L}^{-1}\right)\end{array}$} \\
\hline & \multirow{2}{*}{$\begin{array}{c}\mathrm{VRQ} \\
\left(\mathrm{mg} \mathrm{kg}^{-1}\right)\end{array}$} & \multirow{2}{*}{$\begin{array}{c}\text { VP } \\
\left(\mathrm{mg} \mathrm{kg}^{-1}\right)\end{array}$} & \multicolumn{3}{|c|}{ VI (mg kg $\left.{ }^{-1}\right)$} & \\
\hline & & & Agrícola & Residencial & Industrial & \\
\hline Cd & $<0,5$ & 1,3 & 3,6 & 14 & 160 & 5 \\
\hline $\mathbf{P b}$ & 17 & 72 & 150 & 240 & 4.400 & 10 \\
\hline Zn & 60 & 86 & 1.900 & 7.000 & 10.000 & 1.800 \\
\hline
\end{tabular}

Fonte: Adaptado de CETESB (2014).

A análise do Quadro 1 permite observar a diferenciação de metas de remediação em função do uso do solo. Esta alternativa pode ser atrativa, com vistas nos elevados custos associados aos processos de remediação, uma vez que permite concentrações residuais maiores de contaminantes para locais com um uso menos nobre ou com uma menor exposição (CETESB, 2001b).

Ademais, segundo Förstner e Wittmann (1983), em relação aos metais potencialmente tóxicos, nos últimos anos, ficou claro que a importância da concentração total de um dado elemento na produção de um efeito positivo ou negativo sobre um organismo é inferior à sua forma química, a qual influencia decisivamente o efeito tóxico. Assim, além da concentração total dos metais potencialmente tóxicos, é extremamente importante determinar a forma química de tais metais no meio (LIMA, 2014). Os metais potencialmente tóxicos podem estar na forma solúvel, trocável, ligado aos carbonatos, ligado aos óxidos/hidróxidos, ligado aos sulfetos/matéria orgânica e na forma residual. Os metais nas frações solúvel, trocáveis e carbonáticas são mais móveis e biodisponíveis que nas frações ligadas aos sulfetos/matéria orgânica e residual (KASEMODEL et al., 2016).

Portanto, pode-se dizer que não é a quantidade total ou a concentração de um determinado metal potencialmente tóxico que é mais importante para a compreensão do seu comportamento no meio ambiente, mas sim sua especiação geoquímica. O termo especiação está relacionado justamente à distribuição entre as formas químicas ou espécies de um elemento metálico (BOURG, 1995). A Figura 2 ilustra a especiação geoquímica de metais potencialmente tóxicos. Os complexos dissolvidos inorgânicos e orgânicos são mais disponíveis para a biota. Já os metais precipitados/co-precipitados e adsorvidos, quando comparados com os dissolvidos, são menos disponíveis para a biota. 
Figura 2 - Especiação geoquímica de metais potencialmente tóxicos

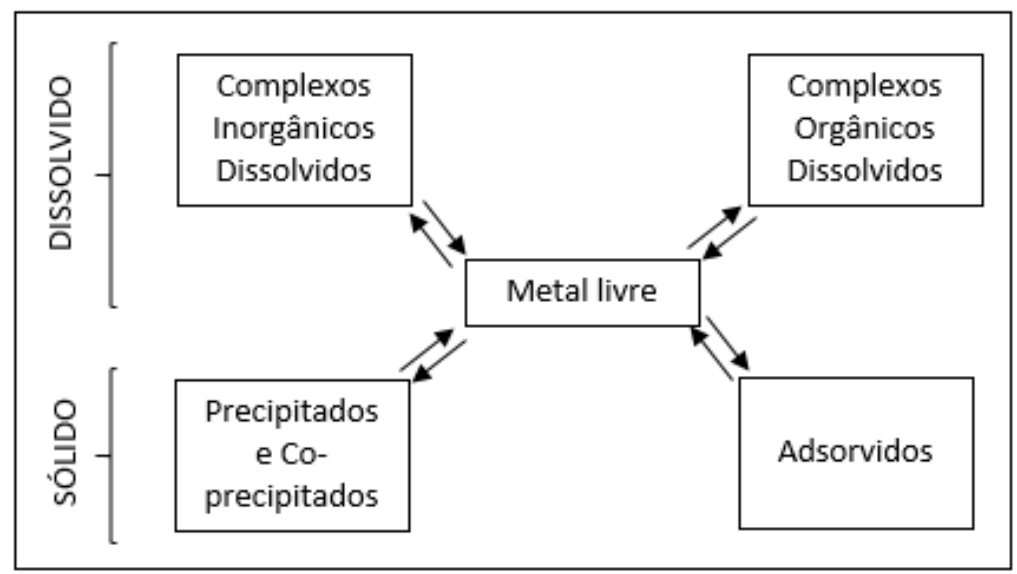

Fonte: Adaptado de Bourg (1995).

De modo geral, a mobilidade dos metais potencialmente tóxicos depende diretamente de interações existentes entre as reações químicas heterogêneas aquosas e dos fenômenos de coagulação e floculação. Assim, a distribuição de um metal entre as suas várias espécies possíveis pode ser considerada como o resultado de diversas reações químicas heterogêneas. Por exemplo, a hidrólise tende a aumentar a solubilidade dos metais enquanto que a precipitação e a adsorção tendem a diminuir a disponibilidade do metal e, como consequência, o seu transporte (BOURG, 1995).

Ademais, os mecanismos de retenção de metais potencialmente tóxicos em solos são diferentes para valores de $\mathrm{pH}$ distintos. Assim, a capacidade do solo de reter esses metais depende de sua resistência para alterações no pH, ou seja, de sua capacidade tampão (YONG; MOHAMED; WARKENTIN, 1992). A química de metais potencialmente tóxicos no solo e materiais reativos está intimamente relacionada também com a formação de complexos com a matéria orgânica. Em se tratando de cátions monovalentes, como $\mathrm{Na}^{+}$e $\mathrm{K}^{+}$, ocorre principalmente troca catiônica simples através da formação de sais com os grupos $\mathrm{COOH}$ (RCOONa, RCOOK). Já os cátions multivalentes, como $\mathrm{Cu}^{2+}, \mathrm{Zn}^{2+}, \mathrm{Mn}^{2+} \mathrm{e} \mathrm{Co}^{2+}$, apresentam a capacidade de formar ligações coordenadas com as moléculas orgânicas (STEVENSON, 1982).

Segundo BOURG (1995), o comportamento de metais potencialmente tóxicos no solo está ainda associado à degradação da matéria orgânica e as reações envolvendo óxidos, hidróxidos e sulfetos de ferro (Fe) e manganês $(\mathrm{Mn})$, diretamente dependentes do pH e Eh. Em condições de $\mathrm{pH}$ neutro a alcalino e ambientes oxidantes, os sólidos amorfos ou cristalinos de $\mathrm{Fe}$ e Mn funcionam como adsorventes fortes ou matrizes co-precipitantes. Enquanto isso, em 
meios redutores, os metais são removidos da solução principalmente pela ação dos sulfetos. A Figura 3 exibe a predisposição da solubilidade de metais em função do pH e Eh.

Figura 3 - Tendências de solubilidade de metais potencialmente tóxicos em relação ao pH e ao Eh, em condições de ausência de matéria orgânica sólida e dissolvida. A) Principais minerais que controlam solubilidade dos metais; B) Tendência do aumento da solubilidade

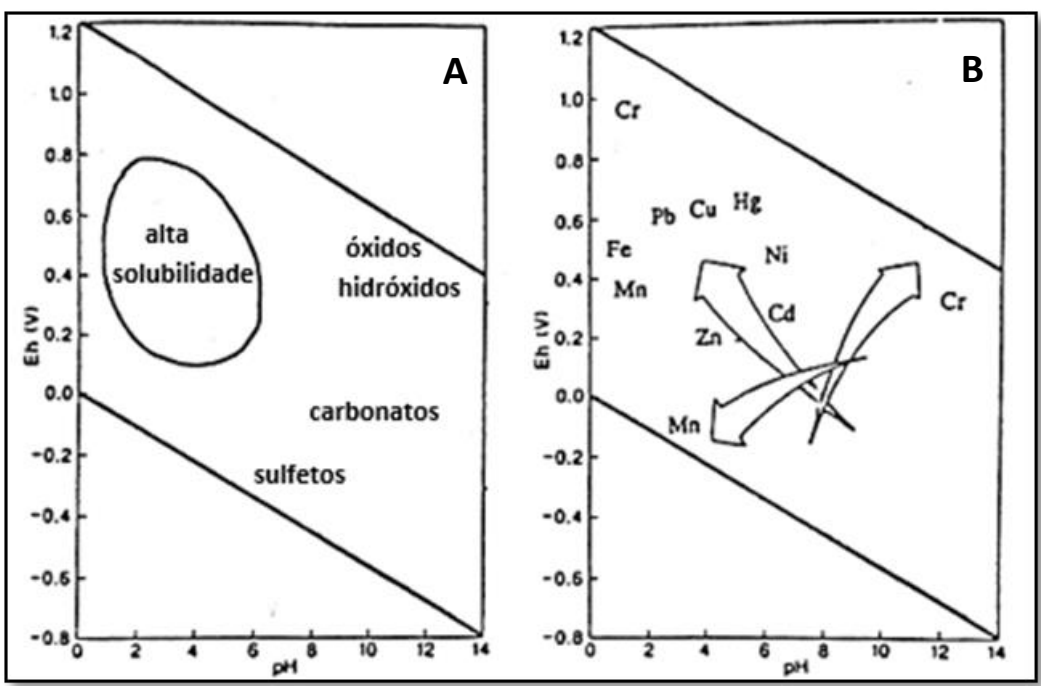

Fonte: Adaptado de Förstner (1987) ${ }^{1}$ apud Bourg (1995).

Assim, de acordo com Kabata-Pendias e Pendias (1984), os solos se sobressaem por apresentarem características intrínsecas quando comparados aos outros componentes do meio físico, já que exercem a função não apenas de "dreno" para os contaminantes, mas também de tampão natural que regula o transporte dos elementos químicos para a atmosfera, hidrosfera e biota. Os lixiviados contendo contaminantes inorgânicos e orgânicos podem interagir com os constituintes sólidos presentes no solo, através de processos de fisiossorção, quimissorção, precipitação e/ou complexação, promovendo uma consequente acumulação dessas espécies contaminantes no solo. Quando um lixiviado responsável pela contaminação de um solo contém mais de uma espécie de metal potencialmente tóxico, por exemplo, ocorrerá a concorrência desses íons metálicos pelos sítios de adsorção presentes, além da competição de outros ligantes contidos no sistema (YONG; MOHAMED; WARKENTIN, 1992).

Intuitivamente, é plausível considerar que o solo apresenta uma capacidade limitada para reter esses contaminantes. Desse modo, se existe uma carga contaminante contínua é possível que a capacidade de retenção do solo vá diminuindo ou até mesmo cesse. Portanto, é necessário conhecer o risco associado a uma quantidade particular do contaminante. Além

\footnotetext{
${ }^{1}$ FÖRSTNER, U.; Changes in metal mobilities in aquatic and terrestrial cycles. In: PATTERSON, J. W.; PASSINO, R. (eds); Metals Speciation, Separation, and Recovery; Lewis Public, Chlesea, Michigan, p.3-26, 1987.
} 
disso, conforme relatado anteriormente, é também importante entender quão forte são as ligações dos contaminantes com as partículas sólidas, ou seja, quão imóveis esses contaminantes podem ser considerados (YONG; MOHAMED; WARKENTIN, 1992).

Nessa perspectiva, é de indubitável importância a análise da capacidade de adsorção de solos e materiais reativos orgânicos, para contaminantes específicos, como os metais potencialmente tóxicos. Assim, é possível estimar a quantidade máxima de contaminantes que pode ser retida por um adsorvente garantindo a imobilização da contaminação.

Casos de contaminação por metais potencialmente tóxicos são tão preocupantes já que, ao atingirem os seres vivos, esses metais reagem com ligantes difusores e macromoléculas, o que implica, muitas vezes, nos processos de bioacumulação e de biomagnificação na cadeia alimentar, causando distúrbios no metabolismo da biota em diferentes níveis tróficos. A contaminação é capaz, inclusive, de provocar sérios problemas de saúde pública (KUMMER, 2008). A Figura 4 ilustra, de modo esquemático, os órgãos e sistemas que são alvo de alguns dos metais potencialmente tóxicos, em casos de contaminação humana.

Figura 4 - Representação de órgãos e sistemas que são alvo de alguns metais potencialmente tóxicos em seres humanos. Destaque dado aos metais de interesse nessa pesquisa

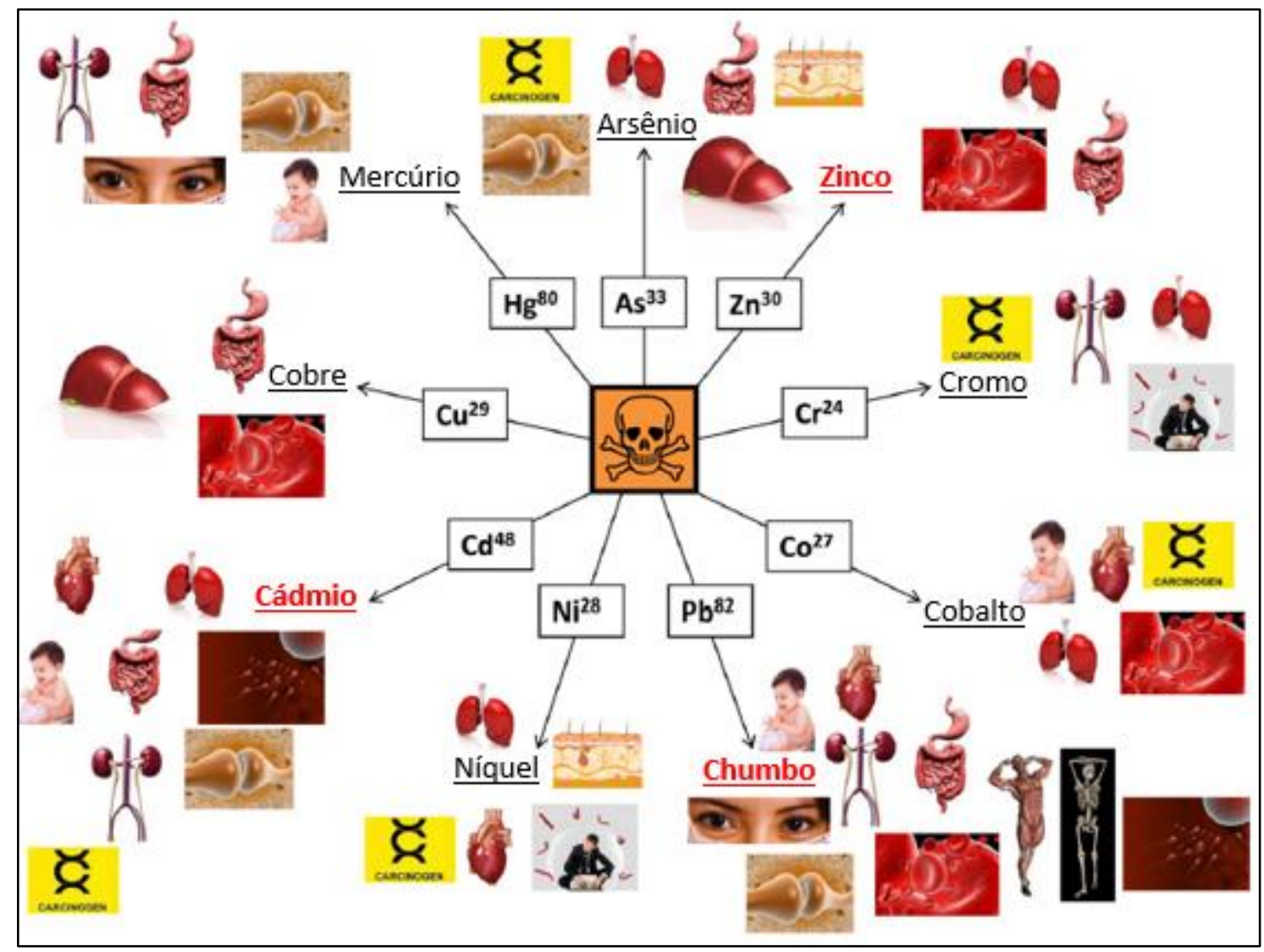

Fonte: Adaptado de Namor et al. (2012). 
Portanto, é fundamental o desenvolvimento de técnicas que visem à contenção e minimização da ação dos metais potencialmente tóxicos, seja nos solos ou nas águas subterrâneas e/ou superficiais. Neste contexto, as barreiras reativas, verticais ou horizontais, atuam na contenção destes metais, principalmente devido aos processos de adsorção.

Kasemodel et al. (2016) e Lima (2014) estudaram o solo de cobertura e o solo que se encontra associado com os resíduos de mineração de $\mathrm{Pb}$ da empresa Plumbum Mineração e Metalurgia Ltda, no município de Adrianópolis, localizado no Vale do Ribeira. Após a realização de diversos ensaios de caracterização geológica, geoquímica e geotécnica, os autores concluíram que três metais mereciam destaque: $\mathrm{Zn}, \mathrm{Pb}$ e $\mathrm{Cd}$. Os dois primeiros por apresentarem elevadas concentrações, em algumas situações, até mesmo milhares de vezes superiores ao background. No entanto, por se encontrarem predominantemente associados aos óxidos e hidróxidos, revelaram uma mobilidade reduzida o que é responsável por minimizar seu impacto ambiental. Já o Cd mesmo exibindo uma baixa concentração total, é altamente tóxico para os organismos vivos, representando um elevado potencial contaminador. Ademais, mesmo estando associado, principalmente, também a fração ligada aos óxidos e hidróxidos, na maioria das amostras estudadas, houve também uma concentração similar associada aos carbonatos, a qual expõe uma maior mobilidade e implica na necessidade de especial atenção, haja vista sua elevada toxicidade.

Diante disso e como a presença de $\mathrm{Zn}, \mathrm{Pb}$ e $\mathrm{Cd}$ é comum nas demais minerações de minerais metálicos, estes três metais potencialmente tóxicos foram selecionados para serem os principais alvos desta pesquisa.

\subsubsection{Cádmio $(C d)$}

O Cd é, similar a outros elementos como o Zn e o mercúrio $(\mathrm{Hg})$, um metal de transição pertencente ao grupo IIB da Tabela Periódica. Apresenta uma massa atômica igual a 112,41 e um número atômico igual a 48. Assim como o Zn, o Cd é encontrado, quase sempre, em estado divalente em todas suas formas estáveis. Seu composto mais comum é CdS (ADRIANO, 1986). Dentre os minerais mais raros, a maioria de origem secundária, estão o seleneto de cádmio (CdSe), a monteponita (CdO) e a otavita $\left(\mathrm{CaCO}_{3}\right)$ (FERGUSSON, 1990).

Em ambientes naturais, seu principal estado de valência é +2 , embora ele também possa formar íons complexos como: $\mathrm{CdCl}^{+}, \mathrm{CdOH}^{+}, \mathrm{CdHCO}_{3}{ }^{+}, \mathrm{CdCl}_{3}{ }^{-}, \mathrm{CdCl}_{4}{ }^{2-}, \mathrm{Cd}(\mathrm{OH})_{3}{ }^{-}, \mathrm{Cd}(\mathrm{OH})_{4}{ }^{2-}$ e, até mesmo, como quelatos orgânicos (KABATA-PENDIAS; PENDIAS, 1984). 
O Cd apresenta oito isótopos estáveis na natureza, com respectivas abundâncias relativas: ${ }^{106} \mathrm{Cd}(1,22 \%) ;{ }^{108} \mathrm{Cd}(0,88 \%) ;{ }^{110} \mathrm{Cd}(12,39 \%) ;{ }^{111} \mathrm{Cd}(12,75 \%) ;{ }^{112} \mathrm{Cd}(24,07 \%)$; ${ }^{113} \mathrm{Cd}(12,26 \%) ;{ }^{114} \mathrm{Cd}(28,86 \%)$ e ${ }^{116} \mathrm{Cd}(12,39 \%)$ (ADRIANO, 1986).

O Cd é um elemento relativamente raro (WORLD HEALTH ORGANIZATION WHO, 1992) que pode ser encontrado na natureza em pequenas concentrações e, comumente, associado a outros minérios de Zn, como a esfarelita, onde aparece na proporção de 0,1 a $0,5 \%$. De modo geral, o Cd é majoritariamente um subproduto de minérios de $\mathrm{Zn}$, cobre $(\mathrm{Cu})$ e $\mathrm{Pb}$, obtido por destilação em colunas de fracionamento (CHASIN; CARDOSO, 2003). Esse metal forma hidróxidos e íons complexos juntamente com a amônia e o cianeto, tais como $\mathrm{Cd}\left(\mathrm{NH}_{3}\right)_{6}{ }^{4-}$ e $\mathrm{Cd}(\mathrm{CN})_{4}{ }^{2-}$. Constitui também um dos elementos de uma variedade de aminas orgânicas complexas, complexos de enxofre e quetalos. Ademais, íons de $\mathrm{Cd}$ podem ainda formar compostos insolúveis brancos, normalmente hidratados, com carbonatos, fosfatos, oxalatos e ferrocianetos (ADRIANO, 1986).

O Cd apresenta a tendência de ser mais móvel em solos e, por conseguinte, mais disponível para as plantas que muitos outros metais, como o Pb e o $\mathrm{Cu}$ (ALLOWAY, 1995a). Ele se destaca por ser tóxico para os organismos vegetais em concentrações muito mais reduzidas do que outros metais, como o $\mathrm{Zn}, \mathrm{Pb}$ e $\mathrm{Cu}$. É válido destacar que a fitotoxicidade varia em função da espécie da planta, bem como da concentração de Cd presente no substrato (ADRIANO, 1986). Apesar do Cd ser considerado um elemento não essencial para as plantas, ele é eficazmente adsorvido pelas raízes e folhas. Em quase todos os casos, é relatada uma relação linear entre o Cd no material vegetal versus o Cd no meio de crescimento. No entanto, vários fatores referentes ao solo e a planta afetam a absorção de $\mathrm{Cd}$. $\mathrm{O}$ pH do solo, por exemplo, é listado por muitos pesquisadores como sendo o principal fator controlador da absorção de $\mathrm{Cd}$ pelas plantas, sendo que ela sempre se eleva com a diminuição do pH. Assim, a absorção de Cd pelas plantas é comumente mais elevada em solos ácidos em comparação com solos alcalinos. Contudo, embora as raízes de diversas espécies possam reter grandes quantidades de $\mathrm{Cd}$ a partir do meio de crescimento, o deslocamento desse elemento através da planta pode ser restringido, já que o Cd é facilmente mantido principalmente em locais de troca de compostos localizados nas paredes celulares das plantas (KABATA-PENDIAS; PENDIAS, 1984).

Em geral, os sintomas evidentes induzidos pelas elevadas concentrações de $\mathrm{Cd}$ em plantas incluem o retardo de crescimento, dano à raiz, clorose e coloração vermelhoacastanhada de folhas. A fitotoxicidade de $\mathrm{Cd}$, além de interferir no metabolismo normal de alguns micronutrientes, pode inibir a fotossíntese, perturbar a transpiração e a fixação de $\mathrm{CO}_{2}$ e alterar a permeabilidade das membranas das células. Este elemento também é conhecido por 
interferir na simbiose entre microrganismos e plantas, bem como por aumentar a predisposição da planta a invasão de fungos (KABATA-PENDIAS; PENDIAS, 1984).

O principal fator determinante da concentração de Cd no solo é a composição química da rocha de origem. As concentrações médias de Cd em solos situam-se entre 0,07 e 1,1 mg kg1. No entanto, aparentemente, as concentrações deste elemento não deveriam exceder $0,5 \mathrm{mg}$ $\mathrm{kg}^{-1}$. Portanto, todos os valores mais elevados refletem o impacto antropogênico na concentração de $\mathrm{Cd}$ em horizontes superficiais do solo. Em especial, em solos formados sob a influência de climas úmidos, a migração de Cd pelo perfil é mais provável de ocorrer do que a sua acumulação no horizonte superficial. Dessa forma, o enriquecimento da concentração de Cd quando observado em camadas superficiais comumente deverá estar relacionado com efeitos de contaminação (KABATA-PENDIAS; PENDIAS, 1984). Em baixas concentrações de $\mathrm{Cd}$, a solução de equilíbrio encontra-se subsaturada na forma de $\mathrm{Cd}_{3}\left(\mathrm{PO}_{4}\right)_{2}$ e $\mathrm{CdCO}_{3}$. No entanto, em altas concentrações, a precipitação de $\mathrm{Cd}_{3}\left(\mathrm{PO}_{4}\right)_{2}$ e e/ou $\mathrm{CdCO}_{3}$ controlam a solubilidade do Cd (ADRIANO, 1986).

O Cd geralmente se liga fortemente com a matéria orgânica, sendo imobilizado, em sua grande maioria. Todavia, o comportamento do $\mathrm{Cd}$ no solo depende das condições ambientais locais (AGENCY FOR TOXIC SUBSTANCES AND DISEASES REGISTRY - ATSDR, 2012).

Segundo Kabata-Pendias e Pendias (1984), com o intemperismo, o Cd passa prontamente para a solução do solo e os fatores mais importantes que controlam a mobilidade de seus íons são o pH e o potencial de oxi-redução. Alloway (1995a) destaca que o pH do solo é o fator determinante da disponibilidade de Cd, já que ele afeta os mecanismos de adsorção e a especiação de metais em solução.

Assim, o Cd é mais móvel em solos ácidos, principalmente no intervalo de pH de 4,5 a 5,5 , enquanto que em solos alcalinos o Cd é praticamente imóvel. Contudo, como o pH aumenta na gama alcalina, espécies iônicas monovalentes de hidroxila são susceptíveis de ocorrer, como na forma de $\mathrm{CdOH}^{+}$, as quais não ocupam facilmente os locais de troca catiônica (KABATAPENDIAS; PENDIAS, 1984). Dessa forma, é recomendado que o pH do solo que recebe resíduos sólidos contendo Cd seja mantido em um valor de 6,5 ou superior (ADRIANO, 1986).

A Figura 5 retrata a dependência do $\mathrm{pH}$ em função das espécies $\mathrm{Cd}^{2+}, \mathrm{Cd}(\mathrm{OH})^{+}$, $\mathrm{Cd}(\mathrm{OH})_{2}, \mathrm{HCdO}_{2}^{-}$e $\mathrm{CdO}_{2}^{-2}$ (FERGUSSON, 1990). 
Figura 5 - Distribuição de espécies iônicas de Cd em função do pH

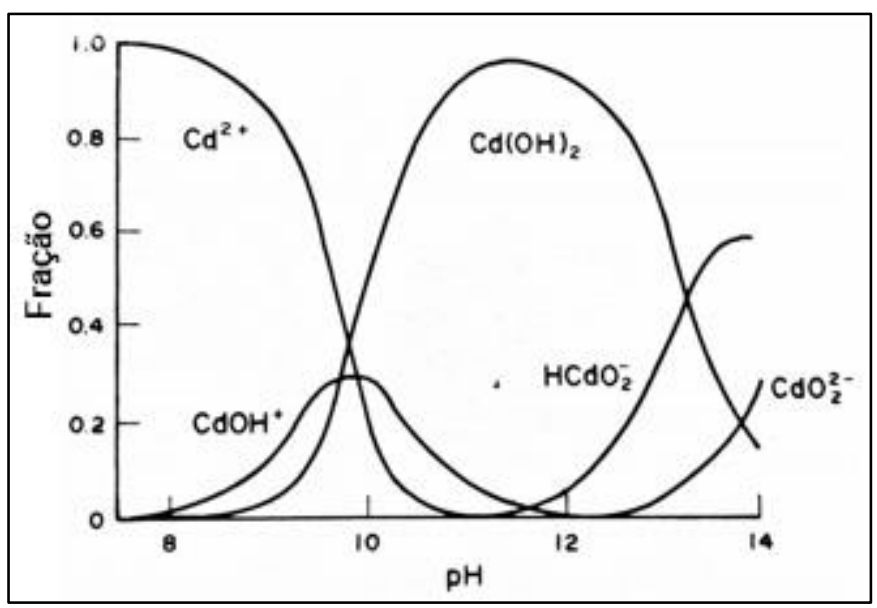

Fonte: Adaptado de Fergusson (1990).

De acordo com Adriano (1986), a mobilidade e a fitodisponibilidade do Cd é dependente, em grande parte, de sua forma química e especiação em solos. A distribuição das formas em que o $\mathrm{Cd}$ se encontra no solo é extremamente variável, já que é diretamente influenciada por um conjunto de fatores. Nos solos, o Cd pode estar presente associado a uma das seguintes formas:

a) fase trocável - adsorção de Cd em função da atração eletrostática responsável por carregar negativamente locais de troca em argilas, partículas orgânicas e óxidos hídricos;

b) fase redutível - adsorção ou coprecipitação com óxidos, hidróxidos e óxidos hidratados de $\mathrm{Fe}, \mathrm{Mn}$ e, possivelmente, Al presente como revestimento sobre os minerais de argila ou como partículas discretas;

c) fase de carbonato - precipitação com o carbonato presente em solos com elevadas concentrações de $\mathrm{CaCO}_{3}$ ou bicarbonato, em reações alcalinas;

d) fase orgânica - complexação com a fração orgânica ou quelatos, sendo que os complexos podem variar em termos de estabilidade em imediatamente móvel, facilmente decomposto, moderadamente resistente e resistentes à decomposição;

e) fase residual - fixação dentro das redes cristalinas de partículas minerais, às vezes conhecida como fase de rede;

f) fase de sulfeto - compostos muito insolúveis e estáveis com sulfetos de Cd ocorrem em solos mal aerados;

g) fase de solução - ocorre na solução dos solos, seja na forma iônica ou complexada. 
O Cd apresenta produção comercial sendo um subproduto da indústria de Zn. Nessa perspectiva, suas formas de utilização mais importante estão associadas às ligas, em galvanoplastia, como estabilizadores para plásticos de polivinil, em pigmentos e em baterias (baterias Ni-Cd). Além disso, por figurar como uma impureza do Zn, quantidades significativas de $\mathrm{Cd}$ podem também estar presentes em metais galvanizados. Consequentemente, o Cd pode estar presente em diversos bens consumidos, sendo que praticamente todos os lares e indústrias contêm algum produto com Cd (ADRIANO, 1986).

Como fontes de emissões naturais de Cd para o ambiente estão as erupções vulcânicas e os incêndios florestais naturais (ATSDR, 2012). Já a contaminação dos solos por Cd associada a fontes antrópicas pode ocorrer devido a disposição de resíduos sólidos. Dentre os resíduos com elevado potencial contaminador estão os resíduos sólidos associados a produção de metais não ferrosos, a manufatura de artigos contendo $\mathrm{Cd}$ e as cinzas de incineradores. Já dentre os resíduos que também contém $\mathrm{Cd}$, mas em pequenas proporções estão as cinzas produzidas pela queima de combustíveis sólidos, os resíduos de cimento, os resíduos sólidos urbanos e os resíduos de esgoto (WHO, 1992; CHASIN; CARDOSO, 2003).

Ademais, podem ser citadas ainda como fontes de contaminação do solo a aplicação de fertilizantes fosfatados e lodo resultante do tratamento de esgotos, utilizado também como fertilizante. Altas concentrações de Cd podem ainda ser constatadas em minerações de minerais metálicos, sobretudo por estar comumente associado a minérios de Zn (ATSDR, 2012).

Numerosos estudos têm demonstrado que a exposição aguda de $\mathrm{Cd}$ pode causar a morte de seres humanos e animais. No ser humano, os alvos sensíveis da toxicidade do Cd são, principalmente, o rim e os ossos, quando resultantes da exposição oral, e o rim e o pulmão, após exposição por inalação. Organismos em desenvolvimento podem também ser considerados um alvo sensível. Ademais, existem evidências que sugerem que o Cd é um elemento carcinógeno. Outros efeitos que foram observados em seres humanos e animais incluem toxicidade reprodutiva e efeitos hepáticos, hematológicos e imunológicos (ATSDR, 2012). WHO (1992) complementa ainda que a alta exposição, provavelmente combinada com outros fatores, tais como deficiências nutricionais, pode levar ao desenvolvimento de osteoporose e/ou osteomalacia.

O tabaco é uma fonte importante de Cd para fumantes. Já para a população não-fumante, de modo geral, a principal via de exposição ao Cd é através dos alimentos contaminados, mas para trabalhadores expostos, a contaminação se dá principalmente pela absorção de Cd após a inalação de ar do local de trabalho (WHO, 1992). 


\subsubsection{Chumbo $(\mathrm{Pb})$}

$\mathrm{O} \mathrm{Pb}$ pertence ao grupo IVA da tabela periódica, apresenta uma massa atômica igual a 207,19 e um número atômico igual a 82. Esse elemento exibe estados de oxidação II ou IV, quatro isótopos estáveis, com respectivas abundâncias relativas: ${ }^{204} \mathrm{~Pb}(1,48 \%)$; ${ }^{206} \mathrm{~Pb}(23,6 \%)$; ${ }^{207} \mathrm{~Pb}(22,6 \%)$ e ${ }^{208} \mathrm{~Pb}(52,3 \%)$, e dois isótopos radioativos que são usados como traçadores em experimentos: ${ }^{210} \mathrm{~Pb}$ (meia vida de 22 anos) e ${ }^{212} \mathrm{~Pb}$ (meia vida de 10 horas) (ADRIANO, 1986).

A forma primária do $\mathrm{Pb}$ no estado natural é a galena $(\mathrm{PbS})$ e sua mobilidade é baixa, se comparada com os outros metais potencialmente tóxicos (KABATA-PENDIAS; PENDIAS, 1984). Normalmente, encontra-se associado com dois ou mais elementos para formar compostos de $\mathrm{Pb}$ (ATSDR, 2007).

$\mathrm{O} \mathrm{Pb}$ ocorre principalmente como $\mathrm{Pb}^{2+} \mathrm{e}$ as características geoquímicas dessa forma bivalente se assemelham ao grupo dos metais alcalino terrosos divalentes. Por conseguinte, o $\mathrm{Pb}$ apresenta a capacidade de substituir potássio $(\mathrm{K})$, bário $(\mathrm{Ba})$, estrôncio $(\mathrm{Sr})$ e, até mesmo, cálcio $(\mathrm{Ca})$, tanto em minerais como em sítios de sorção. O seu estado de oxidação +4 também é conhecido, já que forma vários outros minerais que são muito insolúveis em águas naturais. Os principais poluentes de $\mathrm{Pb}$ emitidos em fundições apresentam formas minerais, como $\mathrm{PbS}$, $\mathrm{PbO}, \mathrm{PbSO}_{4}, \mathrm{PbO}^{-\mathrm{PbSO}_{4}}$ (KABATA-PENDIAS; PENDIAS, 1984).

A abundância terrestre de $\mathrm{Pb}$ indica sua tendência em concentrar-se na série ácida de rochas magmáticas e sedimentos argilosos, com concentrações comuns na faixa de 10 a $40 \mathrm{mg}$ $\mathrm{kg}^{-1}$, enquanto em rochas ultramáficas e depósitos calcários sua gama é de 0,1 a $10 \mathrm{mg} \mathrm{kg} \mathrm{kg}^{-1}$ (KABATA-PENDIAS; PENDIAS, 1984). Quando o Pb está presente em formas solúveis na solução nutritiva, as raízes das plantas são capazes de assimilar grandes quantidades deste metal, a uma taxa crescente com o aumento da concentração nas soluções e com o tempo (KABATA-PENDIAS; PENDIAS, 1984).

Embora o $\mathrm{Pb}$ ocorra naturalmente em plantas, ele não desempenha qualquer papel essencial no seu metabolismo (KABATA-PENDIAS; PENDIAS, 1984). Inclusive, não é incomum que as concentrações de $\mathrm{Pb}$ sejam diferentes entre as várias partes das plantas. $\mathrm{O} \mathrm{Pb}$ é adsorvido pelas raízes, concentra-se principalmente nessa região e é geralmente mal deslocado para as partes vegetativas e, particularmente, para os órgãos reprodutores. Isso se deve, em parte, as características de movimentação únicas de Pb (ADRIANO, 1986).

Vários fatores, como os processos pedogênicos, efeitos climáticos, condições topográficas e atividades microbianas, influenciam diretamente na distribuição de $\mathrm{Pb}$ ao longo do perfil de solo. Em geral, apresenta a tendência natural de se acumular na superfície do solo, principalmente nos primeiros poucos centímetros superficiais, e diminui com o aumento da 
profundidade (ADRIANO, 1986; DAVIES, 1995). Nota-se que o Pb de origem antrópica comumente revela o mesmo padrão de acumulação nas camadas superficiais, mas também, em alguns casos, pode vir a migrar para as camadas mais profundas (ADRIANO, 1986). Esse fato é importante no tocante à contaminação de plantas, já que suas raízes se encontram justamente na camada superficial. Ademais, a localização característica do $\mathrm{Pb}$ nas proximidades da superfície do solo, na maioria dos perfis, está relacionada, principalmente, ao acúmulo superficial de matéria orgânica (KABATA-PENDIAS; PENDIAS, 1984). A matéria orgânica pode contribuir para a retenção dos óxidos hidratados de Fe, Mn e alumínio (Al), que são componentes importantes do solo para a absorção de elementos químicos (KABATAPENDIAS; PENDIAS, 1984; ADRIANO, 1986).

A fixação de $\mathrm{Pb}$ pela matéria orgânica é mais importante do que a precipitação por carbonato ou a sorção por óxidos hidratados. Nesse sentido, a maioria do Pb imobilizado pelo solo está diretamente ligado com a matéria orgânica. Possivelmente, um mecanismo de fixação de cátions metálicos pela matéria orgânica é através da troca iônica (ADRIANO, 1986).

A textura do solo, principalmente seu teor de argila, influencia a absorção de $\mathrm{Pb}$ pelas plantas, assim como a sorção de $\mathrm{Pb}$ pelos materiais presentes no solo. Desse modo, solos que apresentam teores de argila mais elevados, geralmente exibem maiores valores de capacidade de troca catiônica (CTC) e, portanto, revelam uma maior capacidade de retenção de cátions (KABATA-PENDIAS; PENDIAS, 1984; ADRIANO, 1986).

Similar ao que acontece com outros elementos, a química do $\mathrm{Pb}$ no solo pode ser qualitativamente descrita como sendo afetada pela adsorção específica com uma dada matriz mineral; precipitação de compostos fracamente solúveis, dos quais o $\mathrm{Pb}$ é um de seus componentes; formação de íons complexos relativamente estáveis e quelatos resultantes da interação ocorrida com a matéria orgânica (ADRIANO, 1986).

$\mathrm{O} \mathrm{pH}$ do solo, provavelmente, é o fator mais importante que afeta a solubilidade, mobilidade e fitodisponibilidade de $\mathrm{Pb}$ (ADRIANO, 1986). Assim, a solubilidade do $\mathrm{Pb} \mathrm{em}$ solo pode ser consideravelmente diminuída pela adição de calcário. Um solo com pH elevado pode precipitar o $\mathrm{Pb}$ como hidróxido, fosfato ou carbonato, assim como promover a formação de complexos orgânicos (KABATA-PENDIAS; PENDIAS, 1984).

Conforme retratado na Figura 6, a estabilidade das espécies iônicas é influenciada pelo pH. Simulações computacionais indicam que na faixa de $\mathrm{pH}$ de 6 a 7 (valor típico de $\mathrm{pH}$ da maior parte das terras agrícolas produtivas) a distribuição de $\mathrm{Pb}^{2+}$ será determinada pela solubilidade de $\mathrm{PbOH}^{+}$, com este composto predominando com o aumento do pH (ADRIANO, 1986). 
Figura 6 - Distribuição de espécies iônicas de $\mathrm{Pb}$ em função do pH

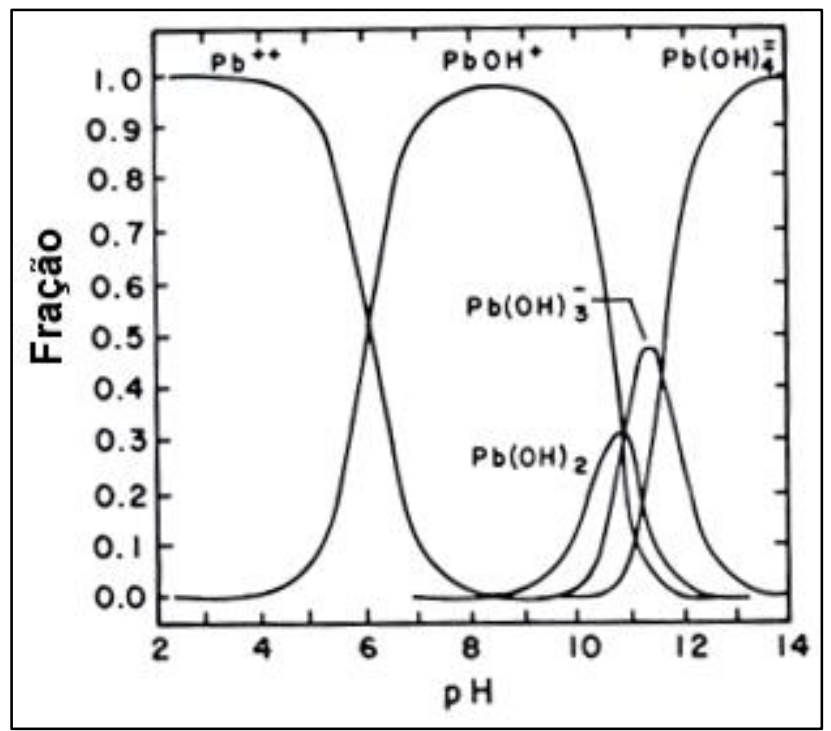

Fonte: Adaptado de Hahne e Kroontje (1973) apud Adriano (1986).

$\mathrm{O} \mathrm{Pb}$ não é um elemento particularmente abundante na crosta terrestre, porém os seus depósitos de minério são facilmente acessíveis e estão amplamente distribuídos em todo o mundo. $\mathrm{O} \mathrm{Pb}$ metálico é resistente à corrosão e é facilmente moldado. Dessa forma, um de seus empregos é na fabricação de materiais resistentes à corrosão. $\mathrm{O} \mathrm{Pb}$ ainda pode ser combinado com outros metais para formar ligas. Assim, outra utilização do $\mathrm{Pb}$ é a produção de ligas, comumente encontradas em tubos e munições.

Todavia, o maior uso industrial de $\mathrm{Pb}$ hoje é na produção de baterias de $\mathrm{Pb}$, largamente utilizadas na indústria automobilística (ATSDR, 2007). Uma bateria é um aparelho eletroquímico que gera energia através do controle de reações químicas. No caso das baterias de $\mathrm{Pb}$ são empregadas reações reversíveis, possibilitando que elas sejam recarregadas. Suas placas são compostas de $\mathrm{Pb}$ metálico, cobertas por uma pasta de dióxido de $\mathrm{Pb}$, para as placas positivas, ou uma pasta de $\mathrm{Pb}$ metálico poroso, para as placas negativas. Em ambas as formas de $\mathrm{Pb}$ estão associados outros elementos como antimônio ( $\mathrm{Sb}$ ), arsênio (As), bismuto (Bi), $\mathrm{Cd}$, $\mathrm{Cu}, \mathrm{Ca}$, prata (Ag) e estanho (Sn) (PAOLIELLO; CAPITANI, 2003).

De acordo com ATSDR (2007), os compostos de Pb são empregados ainda como pigmento em tintas, corantes e esmaltes cerâmicos. Nota-se que a quantidade de $\mathrm{Pb}$ contida nestes produtos foi reduzida nos últimos anos, a fim de minimizar o efeito prejudicial deste elemento em pessoas e animais. Conforme a Organization for Economic Co-operation and

\footnotetext{
${ }^{2}$ HAHNE, H.; KROONTJE, W.; Significance of pH and Chloride Concentration on Behavior of Heavy Metal Pollutants: Mercury (II), Cadmium (II), Zinc (II), and Lead (1l). Journal of Environmental Quality 2, 1973.
} 
Development - OECD e United Nations Environmental Programme - UNEP (1999), outra utilização do $\mathrm{Pb}$, até cerca de 1970, era sua adição na gasolina, na forma de $\mathrm{Pb}$ tetraetila, usada em quase todos os países. Em muitos casos, as concentrações de $\mathrm{Pb}$ eram superiores a $0,4 \mathrm{~g} \mathrm{~L}$

1. Então, desde o início dos anos 1970, houve um movimento constante pela redução dessa utilização, impulsionado por preocupações sobre os efeitos na saúde e devido ao fato dos catalisadores usados em veículos modernos para reduzir as emissões de monóxido de carbono, hidrocarbonetos e óxido de nitrogênio serem inoperáveis na presença do $\mathrm{Pb}$. O Brasil foi um dos primeiros países a remover o $\mathrm{Pb}$ de suas gasolinas automotivas.

A contaminação dos solos por $\mathrm{Pb}$ de origem antrópica requer muita atenção, porque este metal é perigoso para o homem e para os animais de duas formas: pela cadeia alimentar e pela inalação de poeira oriunda do solo (KABATA-PENDIAS; PENDIAS, 1984). Dessa forma, em humanos e animais, o Pb é absorvido após ingestão ou inalação, já que a absorção cutânea é mínima. Ademais, os efeitos decorrentes da exposição ao Pb são os mesmos se ele entra no corpo através da respiração ou de forma oral.

A absorção humana de $\mathrm{Pb}$ advindo de fontes ambientais é diretamente dependente da quantidade assimilada do metal e dos estados físico e químico nos quais ele se encontra. Ela também é influenciada por características relacionadas com o hospedeiro, como idade, estado fisiológico, condição nutricional e, até mesmo, fatores genéticos (PAOLIELLO; CAPITANI, 2003).

$\mathrm{O} \mathrm{Pb}$ é um elemento tóxico, que pode ser considerado como não essencial e apresenta a capacidade de se acumular no organismo humano acarretando em sérias consequências. Quando em interação com a matéria viva, ele apresenta tanto características similares a outros metais quanto algumas peculiaridades. Esse metal afeta adversamente diversos órgãos e sistemas, sendo que as modificações subcelulares e os efeitos neurológicos sobre o desenvolvimento podem ser considerados como os mais críticos. Ademais, seus mecanismos de toxicidade estão associados a processos bioquímicos fundamentais, como a habilidade do $\mathrm{Pb}$ de inibir ou imitar a ação do Ca e de interagir com proteínas (MOREIRA; MOREIRA, 2004).

A forma mais comum de se avaliar sua dose absorvida é através da concentração no sangue $(\mathrm{PbB})$, embora outros índices, como o $\mathrm{Pb}$ presente nos ossos, cabelo ou dentes também estão disponíveis. A concentração de $\mathrm{Pb}$ no sangue reflete principalmente a história de exposição dos meses anteriores, enquanto a concentração nos ossos pode ser considerada como um biomarcador acumulativo e a longo prazo, já que o $\mathrm{Pb}$ apresenta uma tendência de se acumular nos ossos ao longo da vida e a maior parte da carga corporal de $\mathrm{Pb}$ reside justamente nos ossos (ATSDR, 2007). 
Estudos envolvendo trabalhadores que lidam com o $\mathrm{Pb}$ sugerem que a exposição a longo prazo, pode ser associada a um aumento da mortalidade devido a doença vascular cerebral. Ademais, os alvos mais sensíveis para intoxicação são os sistemas nervoso, hematológico, cardiovascular e renal. Em homens, uma exposição de alto nível pode danificar os órgãos responsáveis pela produção de esperma. Já em mulheres grávidas, os altos níveis de exposição podem induzir ao aborto. No entanto, devido aos múltiplos modos de ação do $\mathrm{Pb}$ nos sistemas biológicos, ele pode potencialmente afetar qualquer sistema ou órgão do corpo (WHO, 1995; ATSDR, 2007). Ademais, devido a razões neurológicas, metabólicas e comportamentais, as crianças são mais vulneráveis aos efeitos do Pb do que os adultos (WHO, 1995).

\subsubsection{Zinco (Zn)}

O Zn pertence ao grupo IIB da tabela periódica, apresenta uma massa atômica igual a 65,37 e número atômico igual a 30. Exibe cinco isótopos estáveis, com respectivas abundâncias relativas: ${ }^{64} \mathrm{Zn}(48,89 \%) ;{ }^{66} \mathrm{Zn}(27,81 \%) ;{ }^{67} \mathrm{Zn}(4,11 \%) ;{ }^{68} \mathrm{Zn}(18,56 \%)$ e ${ }^{70} \mathrm{Zn}(0,62 \%)$, e seis isótopos radioativos: ${ }^{62} \mathrm{Zn},{ }^{63} \mathrm{Zn},{ }^{65} \mathrm{Zn},{ }^{69} \mathrm{Zn},{ }^{72} \mathrm{Zn}$ e ${ }^{73} \mathrm{Zn}$ (ADRIANO, 1986). Inúmeros sais de Zn podem ser encontrados na natureza, tais como acetato de zinco, cloreto de zinco, óxido de zinco, estearato de zinco e sulfato de zinco (SILVA, 2003).

O estado de oxidação exibido pelo $\mathrm{Zn}$ em ambientes naturais, como os solos, é exclusivamente II. A maior parcela do $\mathrm{Zn}$ produzido mundialmente apresenta como origem os minérios que contêm sulfetos de Zn. Embora mais de 80 minerais sejam conhecidos, apenas alguns deles apresentam importância comercial. Os principais minérios de $\mathrm{Zn}$ são os sulfetos, como esfalerita e wurtzita e seus produtos, principalmente smithsonita $\left(\mathrm{ZnCO}_{3}\right)$ e hemimorphita $\left[\mathrm{Zn}_{4} \mathrm{Si}_{2} \mathrm{O}_{7}(\mathrm{OH})_{2}\right.$. $\left.\mathrm{H}_{2} \mathrm{O}\right]($ ADRIANO, 1986).

As concentrações de $\mathrm{Zn}$ presentes no solo, sedimentos e água são fortemente influenciadas pela geologia local e influências antrópicas. Portanto, seus valores variam substancialmente. Contudo, de modo geral, de acordo com Kabata-Pendias e Pendias (1984), o Zn se encontra distribuído de modo relativamente uniforme nas rochas magmáticas, com um ligeiro aumento em rochas máficas (80 a $120 \mathrm{mg} \mathrm{kg}^{-1}$ ) e uma ligeira diminuição em rochas ácidas (40 a $60 \mathrm{mg} \mathrm{kg}^{-1}$ ). A concentração de $\mathrm{Zn}$ presente em sedimentos argilosos e xistos apresenta uma variação de 80 a $120 \mathrm{mg} \mathrm{kg}^{-1}$, enquanto em arenitos e rochas carboníferas esses valores diminuem para o intervalo de 10 a $30 \mathrm{mg} \mathrm{kg}^{-1}$. O $\mathrm{Zn}$ ocorre principalmente como sulfuretos simples $(\mathrm{ZnS})$, mas também se destaca por substituir $\mathrm{Mg}^{2+}$ nos silicatos.

O Zn é um dos nutrientes essenciais para o crescimento vegetal. Segundo KabataPendias e Pendias (1984), ele desempenha papéis essenciais no metabolismo das plantas, sendo 
que o mais importante deles é a sua atividade como um componente de uma variedade de enzimas, tais como as peptidases, desidrogenases, proteinases e fosfohidrolases. As formas solúveis de Zn estão prontamente disponíveis para a absorção pelas plantas que tem sido relatada como sendo linear com sua concentração na solução nutriente e nos solos. A taxa de absorção de Zn apresenta consideráveis diferenças em função das espécies de plantas e dos meios de crescimento.

Várias espécies de plantas e de genótipos são conhecidas por apresentarem uma grande tolerância ao Zn e uma grande seletividade na sua absorção através dos solos. Entretanto, as plantas usualmente refletem as mudanças na concentração de Zn de seu meio de crescimento e, portanto, são bons indicadores em investigações biogeoquímicas (KABATA-PENDIAS; PENDIAS, 1984). Ainda segundo esses autores, durante o intemperismo, a solubilização de minerais contendo $\mathrm{Zn}$ produz a espécie iônica móvel $\mathrm{Zn}^{2+}$, especialmente em ambientes ácidos e oxidantes. Acredita-se que esta forma é a mais comum e móvel no solo, mas diversas outras espécies iônicas também podem ocorrer (Figura 7). No entanto, o Zn também é facilmente absorvido por minerais e componentes orgânicos e, portanto, na maioria dos tipos de solo, é observada a sua acumulação nos horizontes superficiais.

Figura 7 - Espécies iônicas e compostos de Zn que comumente ocorrem em solos

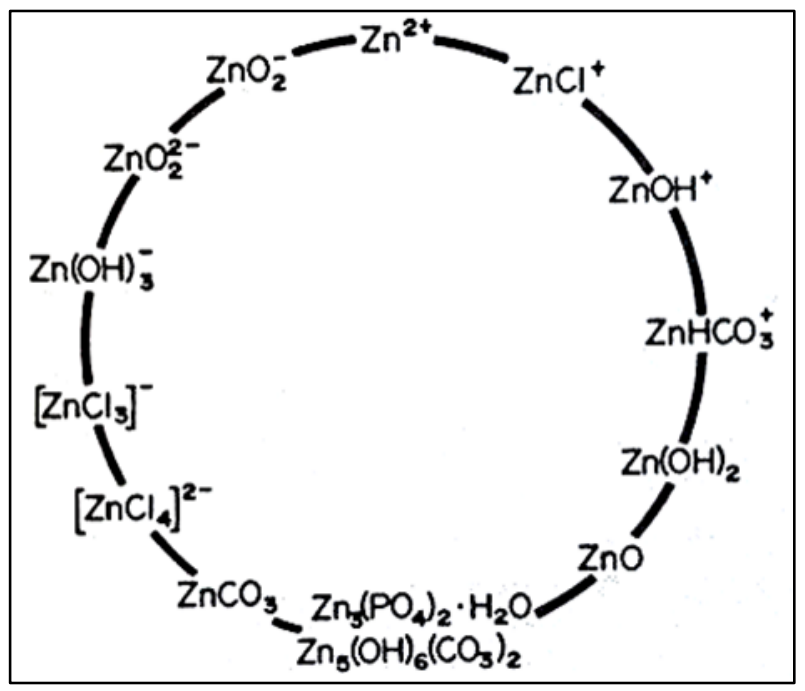

Fonte: Kabata-Pendias e Pendias (1984).

O conteúdo e a distribuição de Zn ao longo do perfil de solo podem ser associados a vários processos e fatores, tais como a formação do solo, o intemperismo, o conteúdo de matéria orgânica, a capacidade de troca catiônica, o teor de argila e o pH (ADRIANO, 1986). Kiekens (1995) acrescenta ainda como fatores interferentes, a concentração de Zn e outros íons na 
solução, o tipo e a quantidade de sítios de adsorção, o potencial de oxi-redução do solo e a atividade microbiana. Assim, mesmo solos que exibem propriedades semelhantes, podem apresentar variações amplas no tocante aos conteúdos de Zn total e extraível, devido às alterações nos fatores de formação do solo, principalmente em termos pedológicos e biológicos. A acumulação de Zn na superfície é resultado de sua assimilação pelas raízes das plantas de horizontes mais profundos e da decomposição da matéria orgânica com consequente imobilização superficial. Casos de aumento na concentração de Zn extraível em horizontes mais profundos são indicativos de materiais de origem que exibem uma elevada concentração de $\mathrm{Zn}$ ou de horizontes superficiais se esgotando devido à remoção de Zn pelas plantas (ADRIANO, 1986).

Caso ocorra uma modificação em algum destes parâmetros provavelmente haverá um deslocamento do equilíbrio global e uma transferência de $\mathrm{Zn}$ de uma forma para outra, até que um novo equilíbrio seja atingido. Esses deslocamentos de equilíbrio podem ser provocados pela absorção das plantas, perdas por lixiviação, entrada adicional de Zn, alteração do teor de umidade do solo, modificação de $\mathrm{pH}$, mineralização da matéria orgânica e mudança do estado de oxi-redução do solo (KIEKENS, 1995).

A distribuição e o transporte de Zn em água, sedimentos e solo são dependentes das espécies químicas de $\mathrm{Zn}$ presentes e das características do próprio meio ambiente, sendo que a solubilidade do $\mathrm{Zn}$ é determinada principalmente pelo $\mathrm{pH}$ (WHO, 2001). Assim, a disponibilidade de Zn é reduzida em função do aumento dos valores de pH (KIEKENS, 1995). Em ambientes nos quais se observa valores de $\mathrm{pH}$ ácidos, o $\mathrm{Zn}$ pode estar presente na fase aquosa em sua forma iônica. Já em condições de $\mathrm{pH}$ superiores a 8,0, o $\mathrm{Zn}$ pode se encontrar precipitado. Este elemento pode ainda formar complexos orgânicos estáveis, por exemplo, com ácidos húmicos e ácidos fúlvicos. Além disso, o Zn é dificilmente lixiviado a partir do solo em virtude de sua adsorção com partículas de argila e matéria orgânica. Contudo, solos ácidos e solos arenosos com um baixo teor de matéria orgânica apresentam uma capacidade reduzida de adsorção de Zn (WHO, 2001).

Segundo Adriano (1986), em solos que apresentam pH acima de 7,0, a disponibilidade de Zn torna-se muito baixa. Assim, casos de deficiência grave de Zn para as plantas estão frequentemente associados com altos valores de $\mathrm{pH}$ do solo. Em contrapartida, o Zn é mais solúvel e, consequentemente, mais biodisponível, sob condições ácidas. Ademais, em solos calcários, caracterizados pela presença de $\mathrm{CaCO}_{3}$ livre, a deficiência deste elemento pode também ser predominante. A importância do pH sobre a previsão das espécies iônicas do Zn que podem estar presentes no ambiente está representada na Figura 8. 
Figura 8 - Distribuição de espécies iônicas de $\mathrm{Zn}$ em função do pH

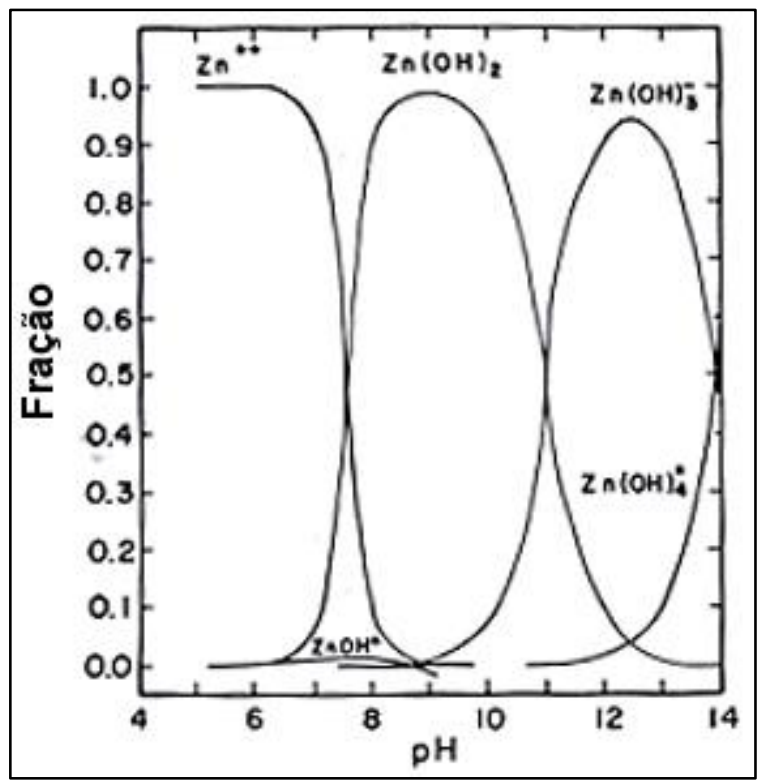

Fonte: Adaptado de Hahne e Kroontje (1973) ${ }^{3}$ apud Adriano (1986).

De modo geral, a superfície da fase coloidal do solo é carregada negativamente, consequentemente, esses sítios de adsorção com carga negativa são compensados atraindo quantidades equivalentes de elementos dotados de cargas positivas, tais como cátions, por exemplo, $\mathrm{Zn}^{2+}$. Desse modo, a adsorção de $\mathrm{Zn}^{2+}$ presente na solução pelas partículas sólidas do solo é geralmente acompanhada por uma dessorção simultânea de quantidades equivalentes de outros cátions, que migram da fase sólida para a solução do solo. Este processo é comumente denominado de troca iônica (KIEKENS, 1995).

A solubilidade e a disponibilidade de $\mathrm{Zn}$ estão negativamente correlacionadas com compostos de $\mathrm{Ca}$ e $\mathrm{P}$ presentes nos solos. Esta relação pode refletir diretamente nos processos de adsorção e precipitação, assim como sobre as interações entre estes elementos. No entanto, complexos orgânicos e solúveis de Zn e formas aniônicas de Zn podem ser responsáveis pela solubilidade relativa e disponibilidade de $\mathrm{Zn}$ em solos com uma gama de pH elevado (KABATA-PENDIAS; PENDIAS, 1984).

Além disso, a matéria orgânica do solo é conhecida por sua elevada capacidade de promover a ligação com o $\mathrm{Zn}$, constituindo formas estáveis. Por conseguinte, é observada a acumulação de $\mathrm{Zn}$ em horizontes orgânicos do solo e em alguns tipos de turfa. No entanto,

\footnotetext{
${ }^{3}$ HAHNE, H.; KROONTJE, W.; Significance of $\mathrm{pH}$ and Chloride Concentration on Behavior of Heavy Metal Pollutants: Mercury (II), Cadmium (II), Zinc (II), and Lead (11). Journal of Environmental Quality 2, 1973.
} 
constantes de estabilidade de complexos entre matéria orgânica e Zn em solos são relativamente baixas (KABATA-PENDIAS; PENDIAS, 1984).

Os fatores que controlam a distribuição de elementos, como o $\mathrm{Zn}$, entre a matriz e a solução do solo também influenciam diretamente na sua dissolução e no seu destino no tocante aos sistemas biológicos. Consequentemente, a disponibilidade de $\mathrm{Zn}$ para a planta é dependente da diferente fração do solo com a qual esse elemento se encontra ligado. Quando presente em formas solúveis e trocáveis é prontamente disponível para as plantas. Contudo, o Zn nas outras formas, comumente, ou não se encontra tão prontamente disponível, ou mesmo não se encontra disponível para as plantas. O Zn em sua fração trocável é adsorvido como um cátion por sólidos minerais coloidais e materiais orgânicos carregados negativamente, devido a atração eletrostática. Destaca-se que o Zn que é fixado dentro da rede cristalina torna-se disponível apenas através do intemperismo mineral (ADRIANO, 1986).

O Zn é amplamente utilizado como um revestimento que propicia a proteção de outros metais, em tintura de fundição e na indústria de construção, e é também empregado na fabricação das ligas. Compostos inorgânicos de Zn revelam ainda aplicações de caráter odontológico, médico e doméstico. Enquanto os compostos orgânicos são usados como fungicidas, antibióticos e lubrificantes (WHO, 2001).

O Zn é um dos elementos terrestres mais comuns que pode ser encontrado, naturalmente, no solo, no ar e na água, como resultado de processos naturais e/ou antrópicos. Segundo WHO (2001), as maiores fontes de emissão natural de Zn são a erosão, as emissões ígneas e os incêndios florestais. Já no tocante as fontes antropogênicas Kabata-Pendias e Pendias (1984) diz que elas estão relacionadas, em primeiro lugar, com a indústria de metais não férricos e, em seguida, com a prática agrícola. WHO (2001) e ATSDR (2005) completam ainda ao citar como fontes antrópicas, além da mineração e do uso de fertilizantes e pesticidas que contêm Zn, a corrosão de estruturas galvanizadas, a combustão de carvão e combustíveis e a eliminação e incineração de resíduos.

Contudo, de acordo com ATSDR (2005), as emissões de fontes antrópicas são superiores aquelas de fontes naturais. Ademais, em termos mundiais, as emissões para o solo são provavelmente a maior fonte de $\mathrm{Zn}$ no meio ambiente. Apesar deste elemento geralmente permanecer adsorvido às partículas do solo, a lixiviação tem sido relatada em locais de eliminação de resíduos. Quando atinge a água, o Zn não volatiliza, contudo é depositado principalmente em sedimentos através de adsorção e precipitação. No meio aquático, a atividade biológica pode influenciar na mobilidade de $\mathrm{Zn}$, embora a biota contenha relativamente pouco $\mathrm{Zn}$ em comparação com os sedimentos. 
As concentrações de Zn em seres vivos, sobretudo plantas e animais, são mais elevadas nas proximidades de fontes pontuais de contaminação de origem antropogênica. Ademais, são comuns variações no teor de Zn em níveis consideráveis entre diferentes espécies. Já para uma mesma espécie essas divergências podem também ser observadas em função do estágio de vida, sexo, estação, dieta e idade do organismo (WHO, 2001).

O Zn é um elemento essencial também para a nutrição animal. De acordo com WHO (2001), ele não é biomagnificado. Inclusive a absorção de $\mathrm{Zn}$ por animais aquáticos tende a ocorrer principalmente a partir de água e não através do alimento. Destaca-se que o Zn apenas em suas formas dissolvidas tende a estar biodisponível e essa biodisponibilidade depende fortemente das características físicas e químicas do ambiente e dos processos biológicos presentes.

Segundo ATSDR (2005) e WHO (2001), o Zn é fundamental para o correto funcionamento de um grande número de metaloenzimas. A deficiência de $\mathrm{Zn}$ tem sido associada a efeitos numerosos sobre a saúde humana, incluindo alterações neurossensoriais, dermatite, anorexia, atraso no crescimento, comprometimento da função imune, danificação de funções neuropsicológicas, doenças imunológicas, má cicatrização e hipogonadismo com capacidade de reprodução prejudicada. Por outro lado, sua ingestão acentuada pode provocar uma variedade de efeitos negativos nos sistemas gastrointestinais e hematológicos, incluindo alterações no sangue.

\subsection{Barreiras reativas}

Segundo Environmental Protection Agency - EPA (1998), o conceito de barreira reativa é relativamente simples, sendo que o material reativo é colocado no subsolo de modo que uma pluma d'água subterrânea contaminada passe por esse material e que a água tratada saia pelo outro lado, sob a inclinação natural do fluxo do lençol subterrâneo.

Desta forma, à medida que o contaminante se move através da barreira, reações ocorrem imobilizando as espécies contaminantes prejudiciais ou transformando os contaminantes em espécies menos tóxicas. Portanto, trata-se não de uma barreira para a água subterrânea, mas sim, uma barreira para os contaminantes (THIRUVENKATACHARI; VIGNESWARAN; NAIDU, 2008), sendo que uma vez instalada, a barreira reativa opera de forma passiva (INTERSTATE TECHNOLOGY \& REGULATORY COUNCIL - ITRC, 2005).

Ainda conforme ITRC (2005), a barreira reativa é uma tecnologia de reparação que pode ser instalada em qualquer ponto ao longo da pluma de contaminação, permitindo o tratamento 
de contaminantes através de processos biológicos, físicos e/ou químicos. Todavia, trata-se de uma tecnologia relativamente nova e futuros desenvolvimentos são promissores para se aumentar a gama de contaminantes tratados e de meios reativos, além da eficácia do processo (CAREY et al., 2002).

Ademais, um profundo conhecimento da hidrogeologia da região e os limites da pluma são necessários antes de se implementar uma barreira reativa, devido à necessidade do fluxo passivo da pluma através da zona reativa da barreira. A caracterização hidrogeológica também deve produzir informações capazes da determinação da taxa de fluxo de água subterrânea através da zona reativa. Isso é necessário para estabelecer o tempo de residência da água subterrânea e seus contaminantes por unidade de espessura do meio reativo que, quando combinado com a taxa de transformação de contaminantes à medida que passam através do meio, determina a espessura total do meio reativo que é necessária (EPA, 1998).

De acordo com Blowes et al. (2000), os custos associados com a implementação de um sistema de tratamento de barreira reativa incluem os gastos iniciais relacionados ao design, instalação e reabilitação do local contaminado, e os custos contínuos de monitoramento do desempenho da barreira. Podem gerar despesas também a recuperação e a eliminação do material reativo, após a conclusão do programa de tratamento.

Segundo EPA (1998), uma vez instalada, a barreira reativa deve ser monitorada para avaliação de sua eficiência e desempenho, determinando se as metas de remediação almejadas estão sendo alcançadas e se estão sendo cumpridos os seus critérios de projeto e as expectativas de longevidade.

Atualmente, as barreiras reativas comerciais mais comuns são construídas em duas configurações básicas (embora outros tipos estejam sendo avaliados): parede contínua (Figura 9A) e funnel-and-gate (Figura 9B) (EPA, 1998; CAREY et al., 2002). Ambos os designs têm exigido algum grau de escavação e limitam-se bastante para profundidades rasas, em torno de 50 a 70 metros ou menos (EPA, 1998). 
Figura 9 - Configurações básicas de barreira reativa. A) Parede contínua; B) Funnel-and-gate
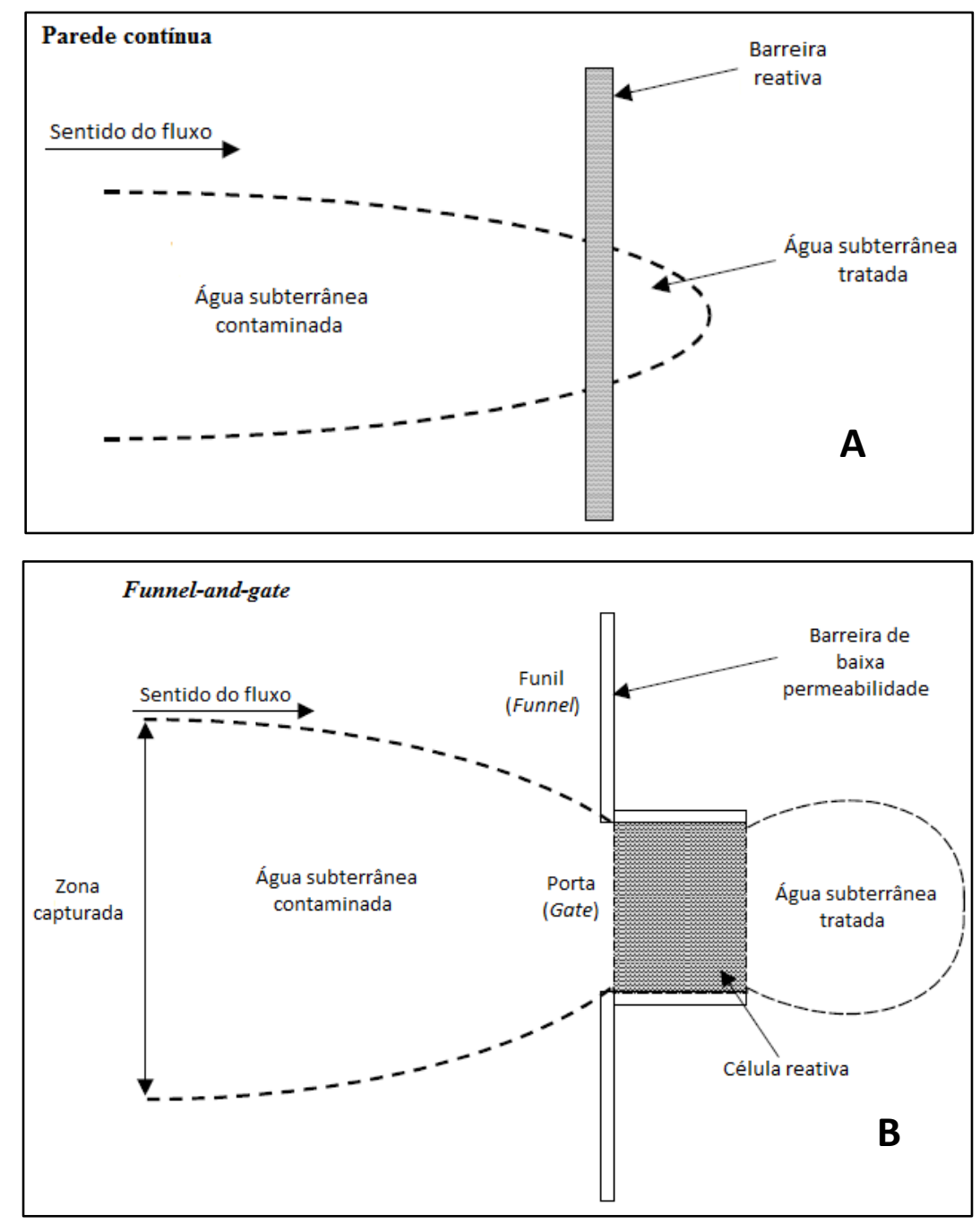

Fonte: Adaptado de Carey et al., 2002.

$\mathrm{O}$ design funnel-and-gate compreende paredes impermeáveis que funcionam como um "funil" (funnel) para dirigir a pluma de contaminação para uma "porta" (gate) que contém o material reativo, enquanto a barreira reativa contínua intercepta completamente o caminho do fluxo da pluma com meios reativos. Devido à construção dos funis, a concepção funnel-andgate tem um impacto maior, pois altera o fluxo da água subterrânea. Em ambos os modelos, é necessário manter a permeabilidade da zona reativa igual ou maior do que a permeabilidade do aquífero para evitar o desvio do curso das águas em torno da zona reativa (EPA, 1998).

As barreiras reativas vêm sendo utilizadas para tratar uma variedade de contaminantes nas águas subterrâneas, tais como os compostos orgânicos halogenados, metais, nitrato e radionuclídeos. No tratamento destes contaminantes é empregada uma variedade de processos, tais como, manipulação do potencial redox, degradação química, precipitação, sorção e 
biodegradação. Estes processos de tratamento podem ser classificados como destrutivos (como no caso da biodegradação, oxidação, redução e hidrólise, em que os contaminantes são permanentemente transformados em substâncias menos nocivas) ou não destrutivos (como na sorção, precipitação ou mudança de estado químico, onde os contaminantes são imobilizados ou fixados aos meios reativos, sendo estes processos reversíveis) (CAREY et al., 2002).

Os materiais utilizados em barreiras reativas não devem permitir a geração de produtos intermediários tóxicos ou produtos com efeitos prejudiciais que possam vir a reagir com os contaminantes. Da mesma forma, o material não deve interromper o fluxo das águas subterrâneas, deve ser de baixo custo e deve ter uma longa vida útil (NAVARRO et al., 2006). Podem ainda constituir um meio reativo de caráter permanente, semipermanente ou substituível (THIRUVENKATACHARI; VIGNESWARAN; NAIDU, 2008). Idealmente, estes materiais são suficientemente reativos para o tratamento de água por décadas. Os materiais empregados na barreira devem fornecer tratamento a custos competitivos com outros programas de remediação (BLOWES et al., 2000).

Nos estágios iniciais desta tecnologia, eram empregados apenas materiais simples e de forma individual. No entanto, atualmente, são aplicadas também combinações de materiais visando, principalmente, eliminar os inconvenientes dos materiais individuais, aumentando assim, o desempenho a longo prazo das barreiras, melhorando sua permeabilidade, reduzindo os custos de utilização de materiais puros, oferecendo múltiplos mecanismos para a remoção de contaminantes e acelerando as taxas de remoção. Outra vantagem da utilização de materiais reativos de forma combinada é permitir o tratamento de plumas com múltiplos contaminantes. A combinação de materiais pode incluir meios biótico-biótico, abiótico-biótico ou abióticoabiótico (OBIRI-NYARLO; GRAJALES-MESA; MALINA, 2014). Ainda de acordo com esses autores, o efeito desta combinação de materiais sobre o desempenho global das barreiras reativas é diretamente dependente de diversos fatores, incluindo a relação entre materiais presentes na mistura. Assim, o tipo e a proporção de cada material, dependerá do objetivo a ser conseguido, mas devem ser determinados considerando os contaminantes a serem tratados, os mecanismos de remoção necessários, a geologia e a geoquímica do aquífero, a disponibilidade e os custos dos materiais e a reatividade e os efeitos interativos dos materiais a longo prazo.

As principais vantagens e desvantagens da utilização das barreiras reativas estão listadas no Quadro 2. 
Quadro 2 - Principais vantagens e desvantagens da utilização das barreiras reativas

\begin{tabular}{|c|c|}
\hline Vantagens & Desvantagens \\
\hline $\begin{array}{l}\text { O material reativo utilizado na barreira pode } \\
\text { degradar ou imobilizar contaminantes in situ } \\
\text { sem qualquer necessidade de trazê-los até a } \\
\text { superfície. Isso implica na não necessidade de } \\
\text { gastos associados a instalações acima do solo } \\
\text { para armazenamento, tratamento, transporte ou } \\
\text { disposição dos contaminantes } \\
\text { (THIRUVENKATACHARI; } \\
\text { VIGNESWARAN; NAIDU, 2008). }\end{array}$ & $\begin{array}{l}\text { Longos períodos de tempo (décadas) } \\
\text { podem ser necessários para gerir os riscos } \\
\text { associados com uma longa duração do } \\
\text { processo ou fonte persistente de } \\
\text { contaminantes, implicando na } \\
\text { necessidade de monitoramento a longo } \\
\text { prazo (CAREY et al., 2002; } \\
\text { BRONSTEIN, 2005). }\end{array}$ \\
\hline $\begin{array}{l}\text { Após a instalação da barreira reativa, o solo } \\
\text { acima pode ser reutilizado para outros fins, } \\
\text { representando menos restrições ao } \\
\text { desenvolvimento na superfície em comparação } \\
\text { com outras abordagens de remediação } \\
\text { (CAREY et al., 2002; BRONSTEIN, 2005; } \\
\text { THIRUVENKATACHARI; } \\
\text { VIGNESWARAN; NAIDU, 2008). }\end{array}$ & $\begin{array}{l}\text { Ocasionalmente, quando chuvas } \\
\text { incomuns ocorrerem ou quando a } \\
\text { reatividade e/ou porosidade da barreira } \\
\text { for significativamente reduzida, a água } \\
\text { subterrânea pode escolher caminhos } \\
\text { alternativos ao redor da barreira } \\
\text { (BRONSTEIN, 2005). }\end{array}$ \\
\hline $\begin{array}{l}\text { As barreiras reativas não necessitam de entrada } \\
\text { contínua de energia, porque um gradiente } \\
\text { natural de fluxo de águas subterrâneas é } \\
\text { utilizado para transportar contaminantes } \\
\text { através das zonas reativas } \\
\text { (THIRUVENKATACHARI; } \\
\text { VIGNESWARAN; NAIDU, 2008). }\end{array}$ & $\begin{array}{l}\text { Há necessidade de caracterização do } \\
\text { local, o que irá, normalmente, ser mais } \\
\text { complexo e caro, especialmente em } \\
\text { relação ao regime hidráulico (CAREY et } \\
\text { al., 2002; BRONSTEIN, 2005). }\end{array}$ \\
\hline $\begin{array}{l}\text { Não ocorre perda de recursos hídricos } \\
\text { subterrâneos e é minimizado o volume de solos } \\
\text { e águas subterrâneas que necessitam } \\
\text { manipulação física, reduzindo a exposição aos } \\
\text { contaminantes (CAREY et al., 2002; } \\
\text { BRONSTEIN, 2005). }\end{array}$ & $\begin{array}{l}\text { Possível necessidade de remoção do } \\
\text { material reativo no fim da remediação ou } \\
\text { mesmo substituição durante a operação } \\
\text { (CAREY et al., 2002). }\end{array}$ \\
\hline $\begin{array}{l}\text { As barreiras reativas têm vidas operacionais } \\
\text { potenciais, como décadas (CAREY et al., } \\
\text { 2002; BRONSTEIN, 2005). }\end{array}$ & $\begin{array}{l}\text { Plumas mais profundas podem apresentar } \\
\text { problemas de construção e } \\
\text { monitoramento (CAREY et al., 2002). }\end{array}$ \\
\hline $\begin{array}{c}\text { As barreiras reativas são capazes de tratar uma } \\
\text { vasta gama de contaminantes (orgânicos, } \\
\text { inorgânicos e radionuclídeos) (BRONSTEIN, } \\
\text { 2005). }\end{array}$ & $\begin{array}{l}\text { O uso das barreiras reativas pode ser } \\
\text { limitado pelas condições geológicas, } \\
\text { incluindo rochas fraturadas } \\
\text { (CAREY et al., 2002). }\end{array}$ \\
\hline
\end{tabular}


O emprego de barreiras reativas percorreu um longo caminho desde que foi inventado. Claramente, trata-se de uma tecnologia ainda relativamente nova, porém com uma substancial quantidade de investigação, permitindo modificações de design, a descoberta de novos materiais reativos, a melhoria de seu desempenho e uma lenta transição de uma tecnologia inovadora para uma tecnologia desenvolvida e comprovada. Além disso, com as pesquisas, temse aumentado a gama de contaminantes que podem ser tratados, devido à descoberta de materiais mais adequados e uma melhor compreensão dos mecanismos de remoção. No entanto, mais pesquisas ainda são necessárias visando a compreensão destes mecanismos, principalmente em relação aos materiais recém-descobertos (OBIRI-NYARLO; GRAJALESMESA; MALINA, 2014). Justamente sob esta perspectiva está embasada esta pesquisa, visando avaliar o potencial de materiais reativos orgânicos, como turfas e compostos orgânicos, e sua possível aplicação como meio reativo em barreiras reativas, seja de forma individual ou combinada.

\subsection{Barreiras selantes}

As barreiras selantes (também denominadas de barreiras impermeáveis ou liners) são sistemas que apresentam como principais funções a impermeabilização, a coleta e a retenção de líquidos em diferentes tipos de obras de engenharia, principalmente aquelas destinadas à disposição de resíduos, como aterros sanitários urbanos e industriais e lagoas de tratamento. Desta forma, as barreiras selantes podem ser consideradas como imprescindíveis nessas obras, já que diminuem a infiltração de líquidos, minimizando a migração de contaminantes (LEITE, 2001).

Segundo Christensent, Cossu e Stegmann (1994), o revestimento é a função principal de um sistema de barreira selante. Esse baseia-se na utilização de elementos dotados de baixa permeabilidade incluindo diferentes tipos de materiais, sejam eles de origem natural ou sintética, empregados individualmente ou de forma combinada, variando de acordo com as diferentes funções necessárias.

Dentre os materiais naturais, o solo argiloso, compactado ou in situ, é o material de revestimento de base (barreira selante) mais comum. Sua qualidade como revestimento é afetada pela condutividade hidráulica, teor de umidade, mineralogia, espessura da camada, grau e método de compactação, sendo que, de modo geral, para uma argila compactada, sua condutividade hidráulica irá diminuir com o aumento do esforço de compactação (CHRISTENSENT; COSSU; STEGMANN, 1994; SHARMA; LEWIS, 1994). 
De acordo com Rowe, Quigley e Booker (1995), embora alguns detalhes possam variar de uma jurisdição a outra, alguns critérios gerais podem ser citados a fim de se garantir o bom funcionamento de barreiras selantes construídas com solos argilosos compactados:

a) a condutividade hidráulica deve ser de, no máximo, $10^{-9} \mathrm{~m} \mathrm{~s}^{-1} \mathrm{e}$ as barreiras não devem possuir fraturas naturais ou induzidas por compactação. Ressaltando-se que para um fluxo químico, é preferível o valor de $10^{-10} \mathrm{~m} \mathrm{~s}^{-1}$, visto que muitas vezes a difusão se torna o mecanismo dominante de migração da contaminação;

b) a baixa condutividade hidráulica comumente está associada com a presença de minerais de argila. Assim, pode ser especificada a necessidade de um mínimo de 15 a $20 \%$ de partículas inferiores a $2 \mu \mathrm{m}$, um índice de plasticidade superior a 7\% e uma atividade coloidal de, pelo menos, 0,3 ou ainda uma capacidade mínima de troca catiônica de $10 \mathrm{cmol}_{\mathrm{c}} \mathrm{kg}^{-1}$;

c) a barreira argilosa deve ser compatível com os lixiviados, permitindo que a condutividade hidráulica não aumente de forma significativa quando exposta aos líquidos percolantes, garantindo sua retenção;

d) A espessura mínima de uma barreira compactada para a colocação de resíduos domésticos é de, aproximadamente, 90 a $100 \mathrm{~cm}$. Contudo, este valor é altamente variável e, inclusive, é reduzido para $60 \mathrm{~cm}$, se houver uma combinação da camada argilosa com uma geomembrana. Já para uma instalação com resíduos industriais e/ou tóxicos, a espessura mínima deve ser de 3 a 4 m, embora algumas jurisdições solicitam até $15 \mathrm{~m}$ ou vários sistemas de revestimento composto.

Para Sharma e Lewis (1994) uma barreira de solo argiloso compactado deve possuir uma condutividade hidráulica igual ou inferior a $10^{-7} \mathrm{~cm} \mathrm{~s}^{-1}$ sendo construída a partir de uma série de camadas finas, permitindo uma compactação adequada e homogênea. É importante que cada camada seja devidamente ligada aos níveis subjacente e sobreposto. Para isso, findada a compactação de um estrato, sua superfície deve se tornar áspera antes do início da nova camada, fazendo com que no final todo o material se encontre misturado, sem o desenvolvimento de interfaces distintas com possíveis variações de condutividade hidráulica.

No tocante aos materiais sintéticos, usualmente chamados de geossintéticos, eles têm sido cada vez mais empregados a fim de melhorar o comportamento dos materiais naturais, já que são capazes de realizar muitas das funções necessárias para a eficiência de um sistema de barreiras. As principais categorias de geossintéticos que podem ser aplicados em uma área de aterro são: geomembranas, geotêxteis, georredes, geogrelhas e geocompostos. Ademais, o material mais empregado na fabricação de geomembranas é o polietileno de alta densidade 
(PEAD), em função de sua resistência química e biológica e de sua capacidade de ser “costurado" (CHRISTENSENT; COSSU; STEGMANN, 1994).

No entanto, existem muitas situações práticas nas quais nem uma argila de baixa permeabilidade e nem a utilização de apenas uma geomembrana é suficiente para evitar um impacto ambiental, a longo prazo. Nestas circunstâncias, a barreira é concebida como sendo um sistema que pode englobar vários componentes que trabalham em conjunto a fim de proporcionar uma proteção efetiva do ambiente (ROWE; QUIGLEY; BOOKER, 1995). A bentonita está associada aos minerais de argila que apresentam a capacidade de inchar quando em contato com líquidos, atingindo até uma faixa de 15 a 18 vezes o seu volume quando seco. Uma combinação de geotêxtil e bentonita (GCL bentonítico), por exemplo, é muitas vezes proposta (CHRISTENSENT; COSSU; STEGMANN, 1994).

De acordo com Rowe, Quigley e Booker (1995), a concepção atual de barreiras se devidamente construídas, pode promover um retardo significativo da migração de contaminantes. Contudo, se não forem cuidadosamente concebidas, pode haver uma contaminação significativa, principalmente das águas subterrâneas, a longo prazo. Diante disso, devem ser estabelecidas medidas de acompanhamento e de contingência com o intuito de detectar e corrigir quaisquer possíveis falhas imprevisíveis que possam vir a ocorrer.

Ademais, Koivula et al. (2009) partiram do princípio que muitos materiais utilizados nas barreiras selantes também apresentam propriedades de sorção que podem ser aproveitadas para reduzir os riscos ambientais. Assim, barreiras construídas com materiais que apresentam considerável potencial de adsorção, são especialmente úteis em situações onde há uma grande quantidade de lixiviados, bem como em destinos onde o lixiviado contém apenas algumas substâncias nocivas, como áreas de colocação final de solo poluído. Ao utilizar materiais adsorventes, é possível projetar estruturas de fundo ainda mais seguras e, ao mesmo tempo, poupar recursos em materiais de construção. Justamente sob esta perspectiva está inserida a avaliação do potencial de materiais reativos orgânicos, como turfas e compostos orgânicos, e sua possível aplicação na construção de barreiras selantes, seja de forma individual, seja de forma combinada com outros materiais.

\subsection{Materiais reativos orgânicos}

O uso de diversos tipos de materiais reativos orgânicos para o tratamento de águas subterrâneas afetadas por diferentes tipos de contaminantes, como os metais, foram investigados para a aplicação em barreiras reativas (CAREY et al., 2002; BABEL; 
KURNIAWAN, 2003; SILVA, 2009; BARBOSA et al., 2013). Entre esses materiais estão a turfa, o composto (proveniente da compostagem), o carvão ativado, a casca de arroz, as lascas de madeira, a vinhaça de cana, entre outros. O principal conceito que subsidia o emprego de materiais reativos consiste no conhecimento dos mecanismos de retenção, principalmente os processos de adsorção.

Similar a outras espécies químicas, os íons de metais potencialmente tóxicos são adsorvidos frequentemente sobre as superfícies de materiais particulados, principalmente de caráter orgânico (BAIRD, 2002). Os materiais reativos orgânicos se destacam justamente pelas suas elevadas concentrações de substâncias húmicas. Os materiais húmicos apresentam uma elevada afinidade pelos cátions dos metais potencialmente tóxicos, de forma que os imobiliza especialmente através dos processos de troca iônica. Sendo assim, a retenção de cátions metálicos se dá, principalmente, através da formação de complexos entre os íons metálicos e os grupos $-\mathrm{COOH}$ dos ácidos húmicos e fúlvicos. No caso dos ácidos fúlvicos, as interações principais envolvem, provavelmente, um grupo $-\mathrm{COOH}$ e um grupo $-\mathrm{OH}$ associados aos carbonos adjacentes a um anel benzênico presente na estrutura polimérica, de forma que o metal $\mathrm{M}^{2+}$ substitui dois íons $\mathrm{H}^{+}$, conforme esquematizado na Figura 10.

Figura 10 - Representação esquemática da retenção de um cátion metálico por um ácido fúlvico

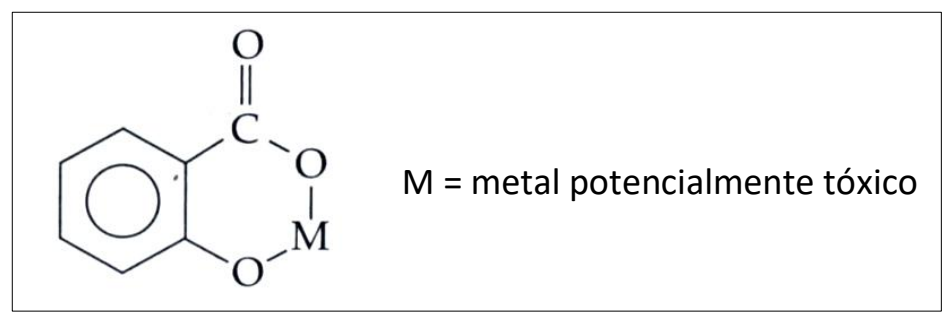

Fonte: Adaptado de Baird (2002).

Nessa pesquisa foram caracterizados dois materiais reativos, composto orgânico e turfa, para se avaliar sua potencial utilização em barreiras reativas e selantes destinadas à remediação de áreas contaminadas por metais potencialmente tóxicos, sobretudo, por $\mathrm{Pb}, \mathrm{Cd}$ e $\mathrm{Zn}$. Esses materiais reativos foram escolhidos devido à facilidade de obtenção, o baixo custo e a descomplicada utilização, já que eles apresentam simples manuseio e não são tóxicos. No caso do composto, também há a necessidade de um estudo, visando identificar sua efetiva empregabilidade na retenção de metais. 


\subsubsection{Composto orgânico}

O processo de compostagem permite reproduzir, de forma controlada, a formação natural de húmus sobre o solo a partir da decomposição de folhas e galhos. Esse processo transforma a matéria orgânica, presente, por exemplo, na fração orgânica dos resíduos sólidos urbanos, em um produto final que é justamente o composto orgânico (MINISTÉRIO DO MEIO AMBIENTE - MMA, 2010).

De acordo com Sposito (1989), os processos bioquímicos envolvidos na formação de húmus e, de maneira análoga na compostagem, não são totalmente compreendidos. Entretanto, é sabido que quatro estágios de desenvolvimento estão presentes na transformação de biomassa do solo em húmus:

a) decomposição dos componentes da biomassa, incluindo lignina, em compostos orgânicos simples;

b) metabolismo microbiano dos compostos simples;

c) ciclagem de C, H, N e S entre a matéria orgânica do solo e a biomassa microbiana;

d) polimerização mediada microbiologicamente nos ciclos dos compostos orgânicos.

Ainda segundo o mesmo autor, os principais compostos associados à formação de húmus resultantes dos estágios 3 e 4 são polímeros fenólicos, derivados dos estágios 1 e 2, que são convertidos a elementos reativos que contêm anéis de benzeno oxigenados (quinonas), facilmente polimerizados.

Na compostagem, a decomposição da matéria orgânica pode ocorrer através de processos aeróbios e anaeróbios. Todavia, na compostagem é estimulado apenas a digestão aeróbia. Assim, a matéria orgânica, em presença de água e ar, passa pela digestão microbiológica (MMA, 2010).

O composto produzido pelo processo final da compostagem consiste em uma matéria orgânica humificada biologicamente estável (BEESLEY et al., 2014) que pode ser empregada em diversos usos. Muitos autores (como: LELIS; PEREIRA NETO, 1999; KIEHL, 2004; GOYAL; DHUL; KAPOOR, 2005; OLIVEIRA; SARTORI; GARCEZ, 2008; BRITO, 2008; MASSUKADO, 2008; VALENTE et al., 2009; MMA, 2010) atestam os benefícios para as plantas advindos da aplicação de compostos orgânicos e destacam justamente essa assimilação de nutrientes como sendo o principal uso do composto.

Ademais, em termos agrícolas, Mehta et al. (2014) inclusive afirmam que a aplicação de composto em campos agrícolas é uma excelente abordagem natural, que pode ser empregada na luta contra patógenos que atacam as plantas. Assim, pode ser vista como uma alternativa 
ambientalmente amigável para o uso de produtos químicos que, infelizmente, ainda é a abordagem mais comum na agricultura atual.

Entretanto, os resíduos compostáveis, como a matéria orgânica presente nos resíduos sólidos urbanos, apresenta certo número de agentes químicos e biológicos, que podem expor a riscos a saúde de diferentes populações, desde trabalhadores das usinas de compostagem até os consumidores de produtos vegetais cultivados em solos tratados com o composto (DOMINGO; NADAL, 2009). Portanto, é importante que a qualidade do produto final da compostagem seja normatizada por legislação específica de cada país, já que o composto não é um produto único, podendo variar suas características em função dos resíduos orgânicos e dos processos empregados (VALENTE et al., 2009).

Os compostos orgânicos, além de serem empregados na melhoria da qualidade do solo, também estão sendo utilizados como materiais reativos na retenção de contaminantes (KOCASOY; GÜVENER, 2009). Assim como a turfa, o composto apresenta alta capacidade de adsorção devido à presença de substâncias húmicas. Apesar da grande capacidade adsortiva, conforme Obiri-Nyarlo, Grajales-Mesa e Malina (2014), os compostos, semelhante às turfas, são amplamente utilizados nas barreiras reativas em misturas com outros meios reativos, com a finalidade de aumentar a eficiência de remoção e a longevidade das barreiras. A combinação de materiais bióticos com abióticos também vem ganhando destaque, ainda segundo esses autores.

Segundo o ITRC (2011), o composto como material construtivo para uma barreira reativa deve ser obtido, de preferência, de uma comunidade local, sendo, desta forma, considerado uma tecnologia específica altamente sustentável. Considerando o fato da Lei Federal nº 12.305 (Política Nacional de Resíduos Sólidos - PNRS), de 2 de agosto de 2010, que institui a necessidade de gestão municipal para os resíduos orgânicos, e que a compostagem pode ser considerada um método eficiente, rápido e de baixo custo para este fim; pode-se inferir que a quantidade de composto disponível no Brasil irá aumentar consideravelmente nos próximos anos. Assim, a utilização destes compostos em barreiras reativas e barreiras selantes pode ser uma alternativa, viável e econômica, para remediação da contaminação por metais potencialmente tóxicos.

Segundo Kocasoy e Güvener (2009), os compostos orgânicos podem ser empregados na remoção de metais potencialmente tóxicos, especialmente, $\mathrm{Cu}, \mathrm{Zn}$ e níquel (Ni). No estudo realizado por esses autores, o $\mathrm{Cu}$ foi o metal que apresentou maior remoção pelo composto orgânico, seguido do Zn e Ni. O cromo (Cr) foi o metal com menor remoção. 
Farrell e Jones (2010b) comprovaram o efeito benéfico de vários compostos, sendo um deles derivado de resíduos municipais, em um solo contaminado por $\mathrm{As}, \mathrm{Cu}, \mathrm{Pb}$ e $\mathrm{Zn}$, em condições altamente ácidas. De modo geral, com exceção do As, todos os compostos reduziram as concentrações dos elementos potencialmente tóxicos da solução do solo e também elevaram os níveis de $\mathrm{pH}$ e de nutrientes, sendo, portanto, bem adequados para a revegetação de áreas contaminadas. Contudo, é necessária uma análise cuidadosa do $\mathrm{pH}$ do solo a fim de assegurar a imobilização ótima dos metais, além de um controle das concentrações de metais já presentes nos compostos. O composto de resíduos sólidos urbanos, apresentava níveis muito mais elevados de $\mathrm{As}, \mathrm{Cu}, \mathrm{Pb}$ e $\mathrm{Zn}$, comparado aos compostos, produzidos a partir de combinações entre resíduos verdes, resíduos de refeições e papeis. No entanto, isto teve pouco efeito, a curto prazo, sobre a absorção desses elementos pelas plantas, com a exceção de Zn. Assim, isto sugere que as concentrações totais desses metais potencialmente tóxicos nos compostos não podem fornecer um indicador confiável de sua fitodisponibilidade.

Venegas, Rigol e Vidal (2015) avaliaram a viabilidade da utilização de oito diferentes materiais derivados de resíduos orgânicos na remediação de solos contaminados por metais potencialmente tóxicos. Para isso foi realizada a caracterização físico-química completa, incluindo a análise da capacidade de sorção de $\mathrm{Cd}, \mathrm{Cu}, \mathrm{Ni}, \mathrm{Pb}$ e $\mathrm{Zn}$, envolvendo soluções monoelementares. Os referidos autores concluíram que o composto, produzido a partir da compostagem de resíduos orgânicos municipais, exibiu juntamente com os resíduos verdes um $\mathrm{pH}$ alcalino. O composto se destacou ainda por apresentar um dos maiores valores de $\mathrm{Kd}$. Assim, ele se mostrou como sendo um dos materiais mais adequados para a recuperação ambiental de solos contaminados por metais, podendo ser usado sozinho ou em misturas, visando aumentar o pH do solo e a capacidade de sorção. No entanto, ele deve ainda ser testado com solos contaminados em maior escala e considerando uma contaminação contendo vários metais a fim de avaliar plenamente o seu desempenho e possíveis alterações no meio. Além disso, a estabilidade a longo prazo também deve ser investigada, especialmente em termos de garantir a manutenção ao longo do tempo do deslocamento de um pH ácido inicial dos solos para valores de $\mathrm{pH}$ mais básicos.

Farrell et al. (2010) estudaram as consequências da adição de materiais orgânicos e inorgânicos em um solo ácido ( $\mathrm{pH}$ de 2,27 £ 0,03) contaminado com metais tóxicos. Para isso, os autores construíram colunas contendo o solo e o respectivo tratamento: solo acrescido de composto derivado de resíduos verdes, solo mais composto de resíduos sólidos municipais, solo e fertilizante inorgânico e apenas solo. Sob condições controladas de temperatura e umidade, foram plantadas sementes de Agrotis capillaris L. e seu crescimento foi acompanhado, assim 
como o lixiviado produzido, por 112 dias. No caso dos compostos, eles foram adicionados na proporção de $40 \%$ (v/v) no topo das colunas. Os compostos, a curto prazo, aumentaram o rendimento e a profundidade de enraizamento, promoveram a diminuição da captação de metal pelos vegetais e elevaram o $\mathrm{pH}$ e o estado nutricional do solo. Contudo, os autores destacaram a possibilidade de uma futura reemissão de poluentes em virtude da degradação da matéria orgânica. De fato, uma reaplicação de resíduos orgânicos poderia solucionar esse problema. Porém, ao longo do tempo, poderia haver um aumento das cargas de elementos presentes nos compostos. Portanto, é necessário acompanhar a biodisponibilidade também a longo prazo.

A possibilidade de utilização do composto orgânico como material adsortivo de outros tipos de contaminantes, podendo assim ser empregado em outras finalidades, além da remediação de áreas contaminadas por metais, também vem sendo estudada. Simantiraki et al. (2013) estudaram a eficiência da aplicação de materiais orgânicos, mais especificamente, composto de resíduos sólidos urbanos (fresco e maduro) e lodo de tratamento de águas residuais (não tratado e digerido), na remediação de hidrocarbonetos de petróleo presentes em águas subterrâneas. O composto maduro se mostrou como o material menos fitotóxico e as amostras do composto apresentaram um teor maior de bactérias se comparado ao lodo, favorecendo a biodegradação. Ademais, o composto maduro se revelou como o melhor adsorvente para benzeno, tolueno, etilbenzeno e xileno (BTEX), atingindo uma remoção máxima de até $90 \%$.

\subsubsection{Compostagem}

Os resíduos sólidos urbanos, de modo geral, são compostos por uma fração orgânica que é constituída pela matéria orgânica oriunda dos resíduos domiciliares e restos de poda e capina dos resíduos de limpeza urbana. Há também a fração não orgânica que se refere aos resíduos recicláveis que, teoricamente, são recolhidos pela coleta seletiva, compactados e vendidos através de cooperativas de catadores. Por fim, existem ainda os rejeitos que correspondem a fraldas, papel higiênico e outros materiais não recicláveis que não apresentam qualquer tipo de tratamento viável e são encaminhados para o aterro sanitário (GUERMANDI, 2015).

De acordo com o Instituto de Pesquisa Econômica Aplicada - IPEA (2012), 51,4\% dos resíduos sólidos urbanos produzidos e coletados no Brasil, em termos gravimétricos, corresponde à matéria orgânica, o que equivale a um total estimado de 94.309,5 t dia ${ }^{-1}$. Desse montante, estima-se que apenas 1,6\% seja encaminhado para unidades de compostagem. Frésca (2007) avaliou a participação mássica dos resíduos sólidos domiciliares encaminhados ao aterro 
sanitário do município de São Carlos, sendo que destaque deve ser dado justamente para os materiais orgânicos que perfizeram um total de 59,08\%.

$\mathrm{Na}$ compostagem não devem estar presentes vidros, plásticos, tintas, óleos, metais e pedregulhos. Não deve haver um excesso de gorduras, visto que elas podem propiciar a liberação de ácidos graxos de cadeia curta, como o acético, o propiônico e o butírico, os quais retardam a compostagem e prejudicam o composto. Já quanto à carne ela deve ser evitada, pois pode atrair animais. O papel pode ser empregado, mas não deve exceder $10 \%$ do total (OLIVEIRA; SARTORI; GARCEZ, 2008). Desse modo, a compostagem não pode ser considerada como uma forma de destinação para a totalidade dos resíduos orgânicos urbanos. Contudo, ela pode ser uma opção para uma porção significativa deles. Sobretudo, levando em consideração o grande volume total de resíduos produzidos ela, de fato, deve ser devidamente analisada e possivelmente utilizada, amenizando substancialmente a questão de disposição final.

A compostagem é praticada desde a História Antiga. Gregos, romanos e povos orientais já tinham conhecimento de que os resíduos orgânicos poderiam ser retornados ao solo, favorecendo sua fertilidade. Entretanto, somente a partir de 1920, com Albert Howard, esse processo começou a ser pesquisado cientificamente e realizado de maneira racional (FERNANDES; SILVA, 1999). Nessa perspectiva, a reciclagem de materiais orgânicos através da compostagem pode contribuir significativamente para a gestão eficiente de resíduos e, consequentemente, para a diminuição do impacto sobre o meio ambiente, uma vez que se pode prolongar a vida útil dos aterros sanitários e minimizar as emissões de gases do efeito estufa, mediante a produção de compostos (SENG et al., 2013).

Contudo, para se obter um composto de alta qualidade, é necessário compreender o processo envolvido (SÁNCHEZ-MONEDERO et al., 2001). Assim, é de indubitável importância um conhecimento holístico sobre todos os parâmetros que afetam o processo de compostagem. Afinal, a otimização desses fatores tem influência direta sobre o processo e a consequente estabilidade dos produtos, maximizando a reciclagem e a recuperação de componentes dos resíduos compostáveis.

A Figura 11 ilustra, de modo esquemático, as principais entradas e saídas do processo de compostagem, bem como os fatores diretamente interferentes. 
Figura 11 - Representação esquemática do processo de compostagem

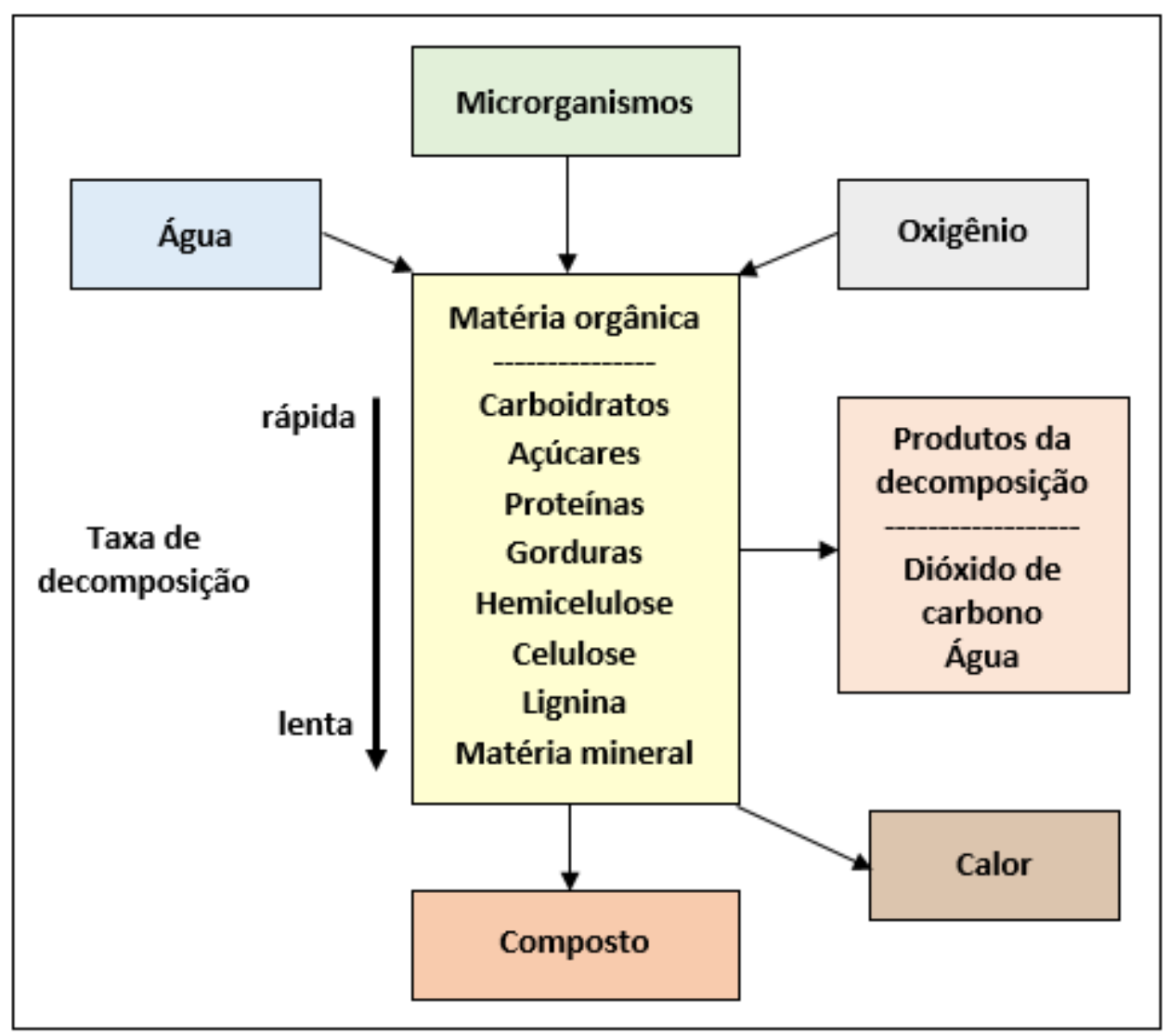

Fonte: Adaptado de Epstein (1997).

\subsection{Microrganismos e temperatura}

A eficiência da compostagem é totalmente dependente da atividade microbiana, que possibilita as alterações químicas e físicas no material compostável, estabilizando a matéria orgânica, ao mesmo tempo em que propicia a elevação da temperatura, reduzindo os microrganismos patogênicos, um dos grandes objetivos dessa tecnologia. Resultando assim, em um produto final estável, sanitizado, rico em compostos húmicos e cujo uso no solo, não implica em riscos ao meio ambiente (VALENTE et al., 2009).

A temperatura desempenha um papel importante na compostagem. Provavelmente, o aspecto mais importante da temperatura é o seu impacto direto sobre a comunidade microbiológica e sobre a umidade, que, por sua vez, altera a atividade microbiológica. A interação da temperatura com vários parâmetros, frequentemente, faz com que seja difícil separar as causas e efeitos a ela associados (EPSTEIN, 1997).

$\mathrm{Na}$ compostagem, bactérias, fungos e actinomicetos são os responsáveis primordiais pela ocorrência da decomposição da matéria orgânica. Ademais, participam também outros organismos, como algas, protozoários, nematoides, vermes, insetos e suas possíveis larvas. 
Assim, quando estes microrganismos se encontram em condições favoráveis, eles se multiplicam exponencialmente e se distribuem por toda a massa de resíduos orgânicos. Notase que esta elevação da comunidade microbiana é afetada pela constituição física e química favorável da matéria orgânica e pela presença de umidade e boa aeração, garantindo o oxigênio, indispensável para o desenvolvimento do metabolismo microbiano (KIEHL, 2004).

Os microrganismos decompositores apresentam metabolismo exotérmico, gerando, dessa forma, calor e elevando a temperatura da massa de resíduos orgânicos. De modo geral, a faixa ótima de temperatura varia de $45^{\circ} \mathrm{C}$ a $65^{\circ} \mathrm{C}$. Temperaturas superiores a $65^{\circ} \mathrm{C}$ diminuem a eficiência do processo, sendo que temperaturas acima de $70^{\circ} \mathrm{C}$, por um longo período, podem restringir a atuação dos microrganismos mais sensíveis, insolubilizar proteínas hidrossolúveis e acarretar em modificações químicas indesejáveis e desprendimento de amônia, caso o material apresente reduzida relação carbono/nitrogênio (C/N) (KIEHL, 2004).

Goyal, Dhul e Kapoor (2005), estudaram a compostagem de diferentes resíduos orgânicos e observaram que alterações químicas e biológicas durante o processo indicaram que há sucessão da população microbiana, dependendo da temperatura atingida durante a compostagem. De fato, muitos fatores determinam a comunidade microbiana durante a compostagem. Em condições aeróbias, a temperatura é o fator principal que determina os tipos de microrganismos, a diversidade de espécies e a taxa de atividades metabólicas (HASSEN et al., 2001).

De modo geral, no início do processo de compostagem há um acelerado desenvolvimento dos microrganismos mesófilos. Na sequência, com a elevação gradativa da temperatura, advinda da biodegradação, a população de mesófilos diminui, enquanto proliferam mais intensamente os microrganismos termófilos. Nota-se que a população termófila é altamente ativa, produzindo uma degradação da matéria orgânica de modo intenso e rápido, elevando a temperatura e eliminando os microrganismos patogênicos, ao mesmo tempo em que se reduz os fatores fitotóxicos. Então, no momento em que a maior parcela do substrato orgânico for transformada, a temperatura diminui, restringindo a população termófila e reduzindo significativamente a atividade biológica global. Ocorre também a instalação novamente dos microrganismos mesófilos. Nesta etapa, a maioria das moléculas facilmente biodegradáveis já foram alteradas e já se deu início ao processo de humificação, denominado maturação (FERNANDES; SILVA, 1999; VALENTE et al., 2009). De acordo com Polprasert (1989), o calor residual produzido biologicamente durante a compostagem pode atingir uma temperatura de cerca de $60^{\circ} \mathrm{C}$, o que é suficiente para inativar organismos patogênicos como 
bactérias, vírus e ovos de helminto, desde que esta temperatura seja mantida durante pelo menos 1 dia.

Segundo Epstein (1997), a curva de temperatura observada na compostagem pode ser dividida em duas zonas: mesófila, quando as temperaturas são inferiores aos $45^{\circ} \mathrm{C}$, e termófila, quando as temperaturas ultrapassam os $45^{\circ} \mathrm{C}$. Polprasert (1989) já faz essa distinção de fase aos $40^{\circ} \mathrm{C}$. Esse autor, cita ainda a existência da fase latente, período inicial da compostagem, correspondendo ao tempo necessário para que os microrganismos possam se aclimatar e colonizar o novo ambiente da pilha de compostagem. A Figura 12 ilustra essa composição de fases observadas no processo de compostagem.

Figura 12 - Padrão de temperatura observado durante a compostagem

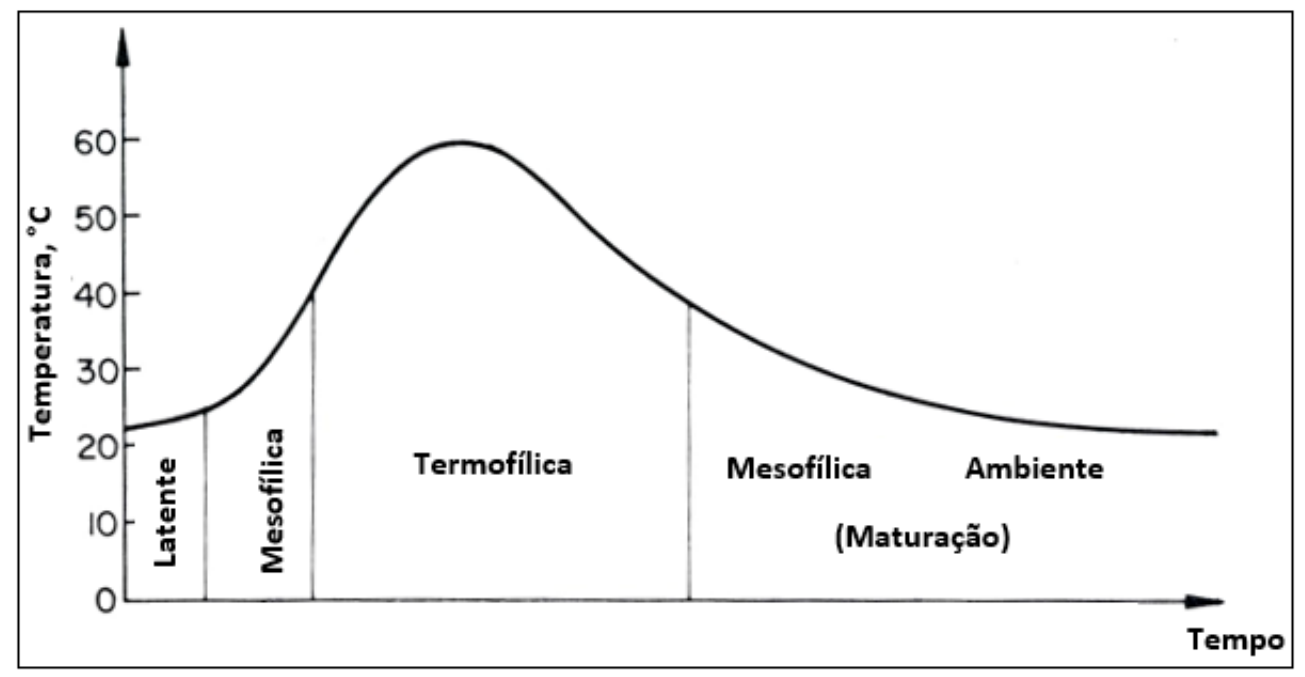

Fonte: Adaptado de Polprasert (1989).

Hassen et al. (2001) estudaram a compostagem a partir da matéria orgânica oriunda de resíduos sólidos urbanos e observaram que no início do ciclo de compostagem aeróbia, o número de bactérias mesófilas tendeu a aumentar durante os primeiros 25 dias do ciclo de compostagem, degradando predominantemente os resíduos frescos e oscilando entre 8,5 x $10^{8}$ e 5,8 $\times 10^{9}$ bactérias $\mathrm{g}^{-1}$ de resíduo seco nas diferentes configurações de leiras estudadas. As bactérias mesófilas foram mortas parcialmente ou inativadas durante a fase termofílica (temperaturas de $40-60^{\circ} \mathrm{C}$ ), onde ao contrário, a diversidade de espécies de bactérias termofílicas, actinomicetos e fungos emergiu. Durante a fase de esfriamento, houve um ressurgimento e crescimento de bactérias mesófilas que atingiu aproximadamente $1,8 \times 10^{8}$ células $\mathrm{g}^{-1}$ de resíduo seco para uma temperatura entre 30 e $40^{\circ} \mathrm{C}$. 


\subsection{Condicionantes do processo}

A compostagem pode ser definida como um processo controlado, devido a necessidade de se verificar vários parâmetros, como temperatura, aeração e umidade, que envolve a decomposição microbiana, a oxidação e a oxigenação de um montante heterogêneo de matéria orgânica que se encontra, inicialmente no estado sólido e úmido. Ao longo de todo este processo ocorre produção de calor e desprendimento considerável de vapor de água e de gás carbônico (KIEHL, 2004).

$\mathrm{O}$ conjunto de fatores considerados como condicionantes para $\mathrm{o}$ eficiente desenvolvimento de um sistema biologicamente complexo, assim como a compostagem, deve ser regido por vários parâmetros. Desse modo, cada tipologia de material a ser compostado implica em uma combinação ótima de umidade, aeração, relação $\mathrm{C} / \mathrm{N}, \mathrm{pH}$, granulometria e altura de leira (VALENTE et al., 2009). Soma-se também a esses fatores o tempo do processo.

Epstein (1997), destaca como principais propriedades que afetam a decomposição da matéria orgânica por microrganismos, o oxigênio e a umidade. A temperatura também é um fator importante no processo de compostagem. No entanto, ela é o resultado da atividade microbiana.

A seguir, são descritos com maior riqueza de detalhes os fatores principais que afetam diretamente o sucesso da compostagem.

\section{a) Umidade}

Ao longo do processo de compostagem, o teor de umidade é modificado como um resultado da atividade microbiana e da oxidação biológica de matéria orgânica e, simultaneamente, a água é perdida por evaporação (EPSTEIN, 1997).

Nota-se que a presença de água é de fundamental importância para as necessidades fisiológicas dos organismos. Quando a umidade do substrato se encontra abaixo de 40\%, haverá decomposição aeróbia, mas de forma lenta, já que se manifestará a predominância da ação de fungos, uma vez que as bactérias, possivelmente, estarão pouco ativas. Já quando a umidade é superior a $60 \%$, o material estará molhado ou encharcado, permitindo que a água ocupe os espaços vazios onde deveria haver ar. Por conseguinte, parte da decomposição será anaeróbia, podendo acarretar em maus odores. Portanto, a umidade deve estar situada na faixa entre 40 a 60\%, sendo 55\% seu valor ótimo (FERNANDES; SILVA, 1999; KIEHL, 2004).

Lelis e Pereira Neto (1999) em seus estudos envolvendo a compostagem de resíduos sólidos domiciliares restringiram essa faixa de umidade ótima para o intervalo compreendido entre 45 a 55\%, objetivando uma maximização da velocidade de degradação. Segundo os 
referidos autores, a umidade quando elevada pode absorver o calor produzido na massa de resíduos, no momento em que já estiverem esgotadas as fontes de carbono mais facilmente assimiláveis, responsáveis justamente pelas reações exotérmicas mais intensas. Já baixos teores de umidade podem reduzir a atividade microbiológica, responsável pela efetiva degradação, elevando o período de compostagem sem, contudo, "paralisar" a compostagem.

\section{b) Aeração}

A decomposição da matéria orgânica pode ocorrer de forma aeróbia ou anaeróbia. $O$ caso aeróbio é caracterizado por elevadas temperaturas, ausência de maus odores, menor tempo de degradação e reações de oxidação e oxigenação. Já no caso anaeróbio, há predomínio de bactérias que decompõem a matéria orgânica por fermentação, estando presentes, comumente, reduzidas temperaturas, produção de maus odores, reações de redução química, maior tempo de cura e tendência do composto vir a se tornar ácido (KIEHL, 2004). Na compostagem aeróbia os produtos finais do metabolismo biológico são o dióxido de carbono, $\mathrm{NH}_{3}$, água e calor. Já no caso anaeróbio se formam metano, $\mathrm{CO}_{2}, \mathrm{NH}_{3}$, pequenas quantidades de outros gases e outros ácidos orgânicos de baixa massa molecular (POLPRASERT, 1989).

Na compostagem, a afirmação de que o processo é inteiramente aeróbio não é verdadeira (KIEHL, 2004). No entanto, no tratamento de resíduos orgânicos através da compostagem se busca oferecer aos microrganismos um ambiente aeróbio, favorecendo seu desenvolvimento (VALENTE et al., 2009). Assim, os três principais métodos de aeração que fornecem oxigênio durante este processo são: revolvimento, fluxo de ar por convecção e aeração mecânica (EPSTEIN, 1997).

\section{c) Relação carbono/nitrogênio $(\mathrm{C} / \mathrm{N})$}

A quantidade de nitrogênio presente em resíduos varia de acordo com sua tipologia. Por exemplo, os resíduos alimentares e biossólidos, tem maiores teores de $\mathrm{N}$ que os resíduos de jardim (EPSTEIN, 1997). Por conseguinte, os materiais empregados na compostagem podem ser classificados em dois grupos: materiais ricos em carbono e materiais ricos em nitrogênio. Entre os elementos ricos em carbono estão os materiais lenhosos, como cascas de árvores, aparas de madeira, podas de jardins, folhas e galhos das árvores, papel, palhas e fenos. Já no tocante aos materiais nitrogenados incluem-se as folhas verdes, estrumes de animais, urinas, solos, restos de vegetais e frutas, entre outros (OLIVEIRA; SARTORI; GARCEZ, 2008).

Assim, de modo geral, os dois nutrientes mais importantes são, justamente, o carbono e o nitrogênio, sendo que a relação $\mathrm{C} / \mathrm{N}$ afeta o processo e o produto da compostagem (EPSTEIN, 
1997). O carbono é a principal fonte de energia e o nitrogênio é necessário para a ocorrência da síntese celular. Além disso, fósforo (P) e enxofre (S) também são fundamentais, mas sua função no processo é menos conhecida. Ademais, os microrganismos apresentam ainda como necessidade micronutrientes similares aos requeridos pelas plantas: $\mathrm{Cu}, \mathrm{Ni}$, molibdênio (Mo), $\mathrm{Fe}$, magnésio $(\mathrm{Mg})$, Zn e sódio $(\mathrm{Na})$, que são empregados nas reações enzimáticas (FERNANDES; SILVA, 1999).

Em se tratando do carbono, durante a atividade microbiana, $\mathrm{CO}_{2}$ é emitido para a atmosfera e o $\mathrm{C}$ prontamente disponível é utilizado inicialmente. Como o processo da compostagem continua, a taxa de evolução de $\mathrm{CO}_{2}$ diminui como resultado da redução da atividade metabólica e da diminuição de carbono disponível (EPSTEIN, 1997).

Especificamente para o nitrogênio, aproximadamente $98 \%$ desse elemento presente na matéria orgânica se encontra na forma orgânica. Com a compostagem, esse nitrogênio orgânico se transforma em nitrogênio amídico e, em seguida, em nitrogênio amoniacal, elevando o pH devido a reação alcalina, típica da amônia. Então, nitrosomonas e nitrobactérias transformam esse nitrogênio amoniacal para a forma de nitrato, produto final da degradação do nitrogênio orgânico. Desse modo, no final da compostagem todo o nitrogênio orgânico deve se encontrar mineralizado na forma de nitrato (KIEHL, 2004).

Segundo Sánchez-Monedero et al. (2001), a evolução das diferentes formas de nitrogênio durante a compostagem é dependente do material orgânico fornecido e da taxa de degradação da matéria orgânica durante a compostagem. Os autores observaram uma maior concentração de amônia durante as primeiras semanas de compostagem, coincidindo com o período mais intenso de degradação da matéria orgânica. Em seguida, essa concentração tendeu a diminuir gradualmente até atingir os valores finais abaixo de $0,04 \%$.

A falta de nitrogênio assim como a falta de carbono limita a atividade microbiológica. Quando a relação $\mathrm{C} / \mathrm{N}$ for muito baixa pode haver uma elevada perda de nitrogênio pela volatização da amônia. Já nos casos em que a relação $\mathrm{C} / \mathrm{N}$ for muito elevada os microrganismos podem não encontrar nitrogênio suficiente para a ocorrência da síntese de proteínas, limitando seu desenvolvimento. Como consequência, a compostagem se desenvolverá de maneira mais lenta (FERNANDES; SILVA, 1999).

De modo geral, os microrganismos utilizam C e $\mathrm{N}$ a uma razão de 30:1 (EPSTEIN, 1997; VALENTE et al., 2009). Mais especificamente, dois terços do carbono presente são liberados na forma de dióxido de carbono que é empregado pelos microrganismos para a obtenção de energia. Quanto ao outro terço do carbono, ele é utilizado em conjunto com o nitrogênio para a constituição das células microbianas. Assim, na síntese efetiva da constituição 
de seu protoplasma, os microrganismos utilizam 10 carbonos e 1 nitrogênio, mas eles requerem ainda cerca de 20 carbonos para obtenção de energia fundamental para a realização desse processo (OLIVEIRA; SARTORI; GARCEZ, 2008).

Todavia, já foram realizados estudos empregando diversas fontes de dejetos e resíduos, tanto da produção animal como vegetal, apresentando, por conseguinte, uma diversidade bem grande na relação C/N inicial, indo desde 5/1 até 513/1. De fato, nos casos onde parte do C disponível apresenta uma difícil degradação, como na celulose, na lignina e na hemicelulose, é recomendável que haja, entre os resíduos compostáveis, uma relação $\mathrm{C} / \mathrm{N}$ inicial maior, visto que o $\mathrm{C}$ biodisponível é inferior ao $\mathrm{C}$ total. Assim, mesmo muitos autores sugerindo valores para a relação $\mathrm{C} / \mathrm{N}$ ótima na compostagem, não há um valor absoluto, mas sim, um valor que deve variar em função das características dos resíduos orgânicos (VALENTE et al., 2009).

\section{d) Potencial hidrogeniônico (pH)}

A reação da matéria orgânica, tanto de origem animal como vegetal, comumente apresenta natureza ácida. Sendo assim, a decomposição da matéria orgânica na compostagem tem inicialmente caráter ácido, com a formação de ácidos orgânicos que tornam o meio mais ácido se comparado com a própria matéria prima original (KIEHL, 2004). Epstein (1997), afirma segundo seus estudos que, inicialmente, um $\mathrm{pH}$ de aproximadamente 5,5 pode decair para perto de 5,1. Esta diminuição é curta e, em seguida, quando a temperatura aumenta, o pH aumenta. Justamente porque, de acordo com Kiehl (2004), na sequência esses ácidos orgânicos e traços de ácidos minerais reagem com bases liberadas da matéria orgânica, produzindo compostos de reação alcalina. São formados também ácidos húmicos que reagem com os elementos químicos básicos, produzindo humatos alcalinos. Assim, ocorre a elevação do $\mathrm{pH}$ do composto, atingindo, até mesmo, valores superiores a 8,0.

Nessa perspectiva, Valente et al. (2009) afirmam que não existem problemas em se empregar substratos caracterizados por baixos valores de $\mathrm{pH}$, visto que ao longo do processo da compostagem haverão inúmeras reações químicas, do tipo ácido-base e de óxido-redução, com potencial para regular esta condição ácida, acarretando na geração de um produto final com $\mathrm{pH}$ na faixa de 7,0 a 8,5 .

Lelis e Pereira Neto (1999) em suas pesquisas observaram na compostagem valores de $\mathrm{pH}$ inicialmente ácido, na faixa de 4,6 a 5,8, mas que mantiveram uma contínua e gradual elevação durante a primeira fase, sendo a partir de então detectados valores da ordem de 8,8 a 9,5. Ademais, em seus experimentos foi constatado um tempo médio de 7 a 8 dias para que o $\mathrm{pH}$ alcançasse valores alcalinos. 


\section{e) Granulometria}

A granulometria da matéria-prima é outro fator fortemente interferente na compostagem. De forma geral, quanto menor a partícula, maior é a superfície exposta ao ataque dos microrganismos. No entanto, partículas minúsculas, que teoricamente apresentam uma intensa e rápida decomposição, na prática da compostagem podem apresentar sérios problemas de aeração, compactação e encharcamento (KIEHL, 2004).

A determinação da granulometria ótima é altamente difícil, já que cada material a ser compostado apresenta suas particularidades. Dessa forma, pode ser interessante associar vários tipos de resíduos orgânicos, a fim de tentar corrigir o tamanho das partículas, propiciando a homogeneização do meio em compostagem, favorecendo uma melhor porosidade (VALENTE et al., 2009). Fernandes e Silva (1999) afirmam que alguns pesquisadores alcançaram ótimas condições de compostagem utilizando substratos com porosidade entre 30 e $36 \%$.

\section{f) Altura de leira}

A altura das leiras deve ser determinada em função do material a ser compostado. Todavia, é recomendável que haja uma altura mínima de $0,80 \mathrm{~m}$, já que em leiras com altura inferior podem não haver condições adequadas que favoreçam a formação e a manutenção da temperatura (VALENTE et al., 2009), relacionadas, por exemplo, a aeração e a umidade.

\section{g) Tempo}

O tempo é ainda um importante parâmetro que influencia diretamente a degradação dos materiais orgânicos durante a compostagem, afetando a estabilidade dos produtos. Segundo Oliveira, Sartori e Garcez (2008), para que todo o ciclo seja completado são requeridos, aproximadamente, de 90 a 120 dias após a mistura dos materiais orgânicos e o início do processo, resultando em um composto normalmente de coloração escura e de textura similar à turfa.

Guermandi (2015) estudou a compostagem de resíduos orgânicos associados a serragem e grama, como materiais estruturantes. A autora avaliou os seguintes tratamentos: leira com resíduos triturados e com revolvimento quinzenal, leira com resíduos não triturados e com revolvimento quinzenal, leira controle (sem revolvimento e sem trituração) e leira composta por tubos de PVC (sem revolvimento e sem trituração). Para os dois primeiros casos a compostagem foi considerada encerrada após cerca de 4 meses, já para as duas últimas configurações, o período de compostagem foi de, aproximadamente, 5 meses. 


\subsection{Maturação do composto}

Não há nenhum parâmetro único que pode ser usado como um indicador apropriado de maturidade de uma vasta gama de compostos preparados a partir de materiais diferentes (KIEHL, 2004; GOYAL; DHUL; KAPOOR, 2005; VALENTE et al., 2009). Diversos parâmetros podem informar, de modo generalizado, a evolução da matéria orgânica, indicando a qualidade de um composto. No entanto, podem existir problemas, visto que um parâmetro pode ser um bom indicador do grau de maturação sob o ponto de vista teórico, contudo, sendo inadequado por perda de significância ao não considerar a origem da amostra ou por não ser funcional em análises de rotina (VALENTE et al., 2009).

Um dos parâmetros que pode ser analisado é a presença das substâncias húmicas, já que a maturação do composto está diretamente associada com a proporção de humina, ácidos húmicos e ácidos fúlvicos (VALENTE et al., 2009). Stevenson (1982) corrobora com esta afirmação ao dizer que na etapa de maturação, a matéria orgânica é complexada e as substâncias húmicas são sintetizadas, podendo ser consideradas como o estágio final da evolução dos compostos de carbono. De modo geral, quando o composto está imaturo ele apresenta alta concentração de ácido fúlvico e menor concentração de ácido húmico (TUOMELA; VIKMAN; HATAKKA, 2000). Então, durante a compostagem, a diminuição da fração de ácido fúlvico é um indicativo da geração de estruturas mais complexas e polimerizadas, correspondentes às substâncias húmicas (GARCIA-GOMEZ; BERNAL; ROIG, 2005).

Além disso, em geral, a diminuição da proporção de $\mathrm{C} / \mathrm{N}$ pode ser considerada como um índice de confiança de maturidade do composto quando combinado com outros parâmetros, tais como a evolução de $\mathrm{CO}_{2}$ a partir dos diferentes compostos, $\mathrm{C}$ solúvel em água e o conteúdo de substâncias húmicas (GOYAL; DHUL; KAPOOR, 2005).

Todavia, o comportamento da relação $\mathrm{C} / \mathrm{N}$ é fortemente dependente da tipologia de resíduo orgânico empregada e das condições da decomposição, conforme mostrado nos experimentos de Goyal, Dhul e Kapoor (2005). Esses autores estudaram a compostagem de diferentes resíduos orgânicos, podendo ser observado que, comumente, à medida em que a decomposição progrediu, devido às perdas de carbono, principalmente como dióxido de carbono, o teor de carbono dos materiais compostáveis diminuiu com o tempo, enquanto o conteúdo de nitrogênio aumentou, resultando na redução da razão C/N. No entanto, houve um aumento da proporção de $\mathrm{C} / \mathrm{N}$ de resíduos de aves, em virtude das perdas de $\mathrm{N}$, principalmente, devido à volatilização da amônia.

Outro parâmetro que pode ser empregado é a CTC, que se origina e aumenta em função da decomposição da matéria orgânica. Conforme o húmus é formado, componente relacionado 
com a adsorção de nutrientes catiônicos, é elevada a CTC do resíduo orgânico. Afinal, o húmus é um coloide eletronegativo com elevada superfície específica, apresentando cargas negativas que passarão por um balanceamento com cátions de cargas positivas (KIEHL, 2004; VALENTE et al., 2009).

Além disso, a elevação da temperatura pode ser utilizada como um indicativo do equilíbrio microbiológico. Entretanto, não deve ser empregada como parâmetro para se determinar a maturidade do composto (VALENTE et al., 2009).

O rendimento final do processo de compostagem é da ordem de $1 / 3$ a $1 / 2$ do volume inicial de resíduos compostáveis, dependendo diretamente do material de origem e do teor de umidade (OLIVEIRA; SARTORI; GARCEZ, 2008).

\subsubsection{Turfa}

\section{Segundo a ASTM D2487 (AMERICAN SOCIETY FOR TESTING AND} MATERIALS, 2006) a turfa é um solo constituído por tecido vegetal que se encontra em diferentes estágios de decomposição, apresentando comumente um odor orgânico, uma coloração marrom escura a preta, uma consistência esponjosa e uma textura variando de fibrosa a amorfa.

Ademais, a turfa corresponde a uma substância fóssil, organo-mineral, advinda da decomposição de restos vegetais que crescem e se desenvolvem em regiões alagadiças, como várzeas de rios, planícies costeiras e áreas lacustres. Portanto, a formação da turfeira fica restrita a locais com a presença de água estagnada (KIEHL, 1985; FRANCHI, 2004) sendo que ela geralmente se apresenta na forma de depósitos superficiais não consolidadas com conteúdo elevado de coloides não cristalinos, chamados húmus (HUAT et al., 2014). A continuação da transformação da matéria vegetal em turfa, através de alterações diagenéticas ou metamórficas, culmina na formação de linhito, carvão, antracito e grafite. Pode ser categorizada como um biólito, ou seja, um depósito sedimentar com o desenvolvimento através de processos biológicos. Além disso, como é passível de utilização como combustível, pode ser subclassificada como caustobiólitos (FRANCHI, 2004).

Para um engenheiro geotécnico, solos orgânicos são todos aqueles que apresentam um teor orgânico superior a $20 \%$, sendo que quando a base orgânica é de mais do que $75 \%$, esses solos são ditos turfas. Esta definição de engenharia é essencialmente baseada nas propriedades mecânicas do solo, já que quando um solo possui conteúdo orgânico superior a 20\%, os critérios mecânicos de um solo mineral convencional já não podem ser satisfeitos (HUAT et al., 2014). Corroborando com esta definição, segundo a ASTM D653 - 14, a turfa pode ser definida como 
sendo uma substância natural altamente orgânica que se distingue dos materiais orgânicos dos solos pelo reduzido teor de cinzas (inferior a $25 \%$ por massa seca) e dos materiais fitogênicos de maior espessura, como o carvão, pelo menor poder calorífico.

\subsubsection{Localização e origem}

As turfeiras estão presentes em todos os continentes, desde áreas tropicais até zonas árticas, do nível do mar até elevadas altitudes (JOOSTEN; CLARKE, 2002). As turfeiras cobrem uma área estimada de 400 milhões de hectares, o equivalente a, aproximadamente, 3\% da superfície terrestre do planeta. Dessa porção, sua maior parte, cerca de 350 milhões de hectares, estão localizados no hemisfério norte, cobrindo grandes áreas, principalmente, da América do Norte, Rússia e Europa. Existem também turfeiras de clima tropical no leste e sudeste da Ásia, Caribe, América Central, América do Sul e no sul da África (INTERNATIONAL PEATLAND SOCIETY - IPS, 2008).

As turfeiras no Brasil são estimadas em cerca de $24.000 \mathrm{~km}^{2}$, correspondendo ao segundo maior depósito na América do Sul, sendo superado apenas pelo Peru. Existem grandes reservas de turfa na Amazônia e no Pantanal, perto da fronteira com a Bolívia. Turfeiras menores estão localizadas em áreas costeiras. Além disso, turfeiras do sudeste do Brasil, nos estados do Espírito Santo, Rio de Janeiro e São Paulo, e mais ao norte no estado da Bahia, têm atraído recentemente interesse como locais potenciais para a produção de turfa para as utilizações energéticas (WORLD ENERGY RESOURCES - WER, 2013).

A maior parte das turfeiras localizadas no hemisfério norte são originadas a partir de lagos rasos resultantes do recuo de gelo ocorrido no último período glacial do Quaternário. Diferentemente, os depósitos brasileiros se formaram em depressões advindas de processos fluviais e costeiros. Assim, em termos geológicos, os depósitos brasileiros podem ser divididos em litorâneos e interiores. No tocante aos depósitos litorâneos, pode-se constatar que a Planície Costeira é caracterizada por grandes áreas contendo tratos morfológicos propícios a acumulação sedimentar de origem fluvial, como meandros abandonados, planícies de inundação e terraços aluviais, e de origem marinha, como cordões litorâneos, lagunas, mangues e restingas, sendo todas essas feições importantes para a geração de turfas. Ademais, o perfil típico das turfeiras litorâneas tem início com um substrato arenoso, originado nos cordões litorâneos, seguido por sedimentos argilosos advindos do ambiente lagunar e, por fim, a turfa, comumente sem qualquer cobertura e apresentando espessura média entre 1,5 a 2,0 m. Já os depósitos interiores estão localizados nas extensas planícies de inundação associados, frequentemente, ao ambiente fluvial. Apresentam caráter alongado e teores variáveis de cinzas. São originados, 
preponderantemente, de remanescentes de gramíneas e, subsidiariamente, de plantas lenhosas. Estão ligados a sistemas meandrantes, de forma que se encontram vinculados a cursos fluviais com baixo gradiente e traçado sinuoso e que percorrem planícies aluviais amplas. Podem existir também turfeiras com grau mais elevado de pureza em braços abandonados ou lagos protegidos, situados mais distantes ao canal principal (FRANCHI, 2004).

\subsubsection{Composição e processo de formação}

A turfa é constituída por uma mistura complexa de compostos orgânicos, incluindo os ácidos orgânicos (húmicos e fúlvicos) e seus sais, bem como a celulose, a lignina e as proteínas, juntamente com componentes minerais ( $\mathrm{Mg}, \mathrm{K}, \mathrm{Ca}, \mathrm{Na}, \mathrm{Al}$, silício ( $\mathrm{Si}$ ) e Fe). Esta composição leva a ótimas propriedades de sorção, associadas, principalmente, à presença na superfície de grupos funcionais ácidos (carboxílico, fenólico e sulfônico), que permitem a troca de íons $\mathrm{H}^{+}$ por outros cátions (BARTCZAK et al., 2015).

A turfa é um material poroso, e seus litotipos parcialmente decompostos (fibrosos) revelam uma porosidade de, aproximadamente, 95\% e uma área específica de até $200 \mathrm{~m}^{2} \mathrm{~g}^{-1}$, apresentando melhores propriedades hidráulicas. Já os litotipos hêmicos e sápricos, por apresentarem uma decomposição mais pronunciada, são mais efetivos como adsorventes, em virtude de sua natureza amorfa (COUILLARD, 1994).

Ao longo da evolução das turfeiras vão sendo formados estratos referentes ao desenvolvimento dos vegetais e as contribuições de argila, silte, areia e sais minerais presentes na água. Dessa maneira, no fundo das turfeiras existem massas de plantas que se depositaram juntamente com esqueletos, dejeções, partes quitinosas dos insetos e demais animais. Esta estratificação é variável de um depósito para outro e, até mesmo, em uma única turfeira. Isso ocorre como consequência dos diversos restos vegetais, estado de decomposição da matéria orgânica e concentrações de argila, silte e areia presentes. Assim, turfeiras com predominância de silte e argila apresentam uma consistência mais viscosa e mais elástica, enquanto isso, naquelas com predomínio de areia, a turfa pode ser dita mais friável (KIEHL, 1985).

De modo geral, a formação das turfeiras está associada a três fatores primordiais: a sedimentação da areia, silte e argila advindos dos terrenos à montante; a deposição de restos vegetais que se desenvolvem emergindo ou sobrenadando a água, como também a participação das plantas presentes ao redor da área alagada que, posteriormente, poderão inclusive integrar a turfeira; e o tempo necessário para a formação da turfa, sendo dependente do tipo de planta e das condições ambientais. Estima-se que são necessários de 100 a 500 anos para a efetiva produção de uma camada com 30 centímetros de turfa (KIEHL, 1985). 
Dessa forma, a composição da turfa varia com a localização e também com a profundidade dentro de uma mesma turfeira. No entanto, variações de um depósito para outro apresentam a tendência de serem muito superiores. É necessário, portanto, no planejamento da produção de produtos associados a turfa, uma seleção do tipo apropriado, a fim de garantir alto rendimento e qualidade. Assim, inicialmente, devem ser realizadas observações de campo objetivando o levantamento de algumas características básicas geológicas, botânicas e físicoquímicas da turfa. Em seguida, amostras promissoras e representativas devem ser sujeitas a análises laboratoriais mais detalhadas (FUCHSMAN, 1980).

O curso da decomposição da turfa é variado. Embora a turfa se desenvolva somente em ambientes úmidos, nos quais o ar é amplamente excluído, os primeiros estágios da decomposição das plantas mortas podem ocorrer em condições pelo menos parcialmente aeróbias. Então, somente quando o oxigênio disponível na água de cobertura se esgotar, prevalecerão as condições anaeróbias. Em estações secas algumas das camadas superficiais da decomposição da vegetação podem ser novamente expostas ao ar, afetando consideravelmente o curso da decomposição (FUCHSMAN, 1980). A redução no fornecimento de oxigênio propicia a diminuição da atividade microbiana aeróbica, encorajando, por sua vez, a decomposição anaeróbica, que é muito menos rápida (HUAT et al., 2014). Nota-se que como consequência da ausência de oxigênio suficiente, devido à saturação da massa vegetal, nas turfeiras não ocorre a oxidação completa da matéria orgânica (KIEHL, 1985).

As turfeiras hospedam uma ampla diversidade de espécies e formas de vida. Embora a maioria das informações disponíveis sobre as formas de vida associadas com a turfa estejam relacionadas às plantas superiores que habitam a região, já que elas fornecem a base estrutural e são fonte de compostos orgânicos derivados da fotossíntese para o sustento dos animais e microrganismos, a natureza e a dimensão das populações microbianas subsuperficiais são também elementos importantes da comunidade biológica presente na turfeira (FUCHSMAN, 1980; RYDIN; JEGLUM, 2013). A transformação gradual das plantas é causada por microrganismos heterotróficos, principalmente bactérias e fungos que obtêm energia a partir da degradação. Dessa maneira, um fator-chave na taxa de decomposição e na diversidade de microrganismos é a natureza da turfa, especialmente sua composição botânica e sua qualidade, ou seja, a quantidade de matéria orgânica que pode ser considerada como facilmente decomposta (RYDIN; JEGLUM, 2013).

Assim, existe uma relação não-linear dessas populações com a profundidade, sendo que bactérias aeróbias e facultativas-aeróbias, actinomicetos e fungos, diminuem em número rapidamente com a profundidade. Enquanto isso, as bactérias anaeróbias aumentam com a 
profundidade e tornam-se particularmente numerosas em níveis em que as espécies tolerantes ao oxigênio estão completamente ausentes (FUCHSMAN, 1980).

A diversidade bacteriana é enorme sendo que as bactérias típicas de turfeiras são: Bacillus, Pseudomonas, Achromobacter, Cytophaga, Micrococus, Chromobacterium, Clostridium, Streptomyces, Actinomyces, Mycobacterium, Micromonospora e Nocardia (WILLIAMS; CRAWFORD, 1983). Ademais, dois grupos ecologicamente importantes de microrganismos são o metanogênico e a Archae, que vivem em turfa anóxica, e um grupo diversificado de bactérias consumidoras de metano, as metanotróficas, que são capazes de oxidar $\mathrm{CH}_{4}$ em $\mathrm{CO}_{2}$, uma transformação de indubitável importância no ciclo do carbono de turfeiras. Existem ainda protozoários, sendo que os grupos mais presentes em turfeiras são os ciliados, como o Paramecium, e rizópodes, como o Testate amoebae. As turfeiras são também ricas em algas microscópicas, sendo que algumas delas podem se agregar ou formar cadeias. A turfa pode hospedar centenas de espécies de microalgas, com presença comum das algas verdes, incluindo as desmídias e as diatomáceas (RYDIN; JEGLUM, 2013).

Em termos de composição, as propriedades físicas e químicas da turfa são altamente influenciadas pelas plantas de origem. Desse modo, as turfas de superfície, excetuando-se as chamadas turfas sedimentares, presentes nas camadas mais profundas, podem ser classificadas, em função de seu material de origem, em duas categorias: turfas fibrosas, quando associadas a plantas das famílias das ciperáceas (Carex), dos musgos (Sphagnum, Hyppnum) e das tifas (Typha); e turfas lenhosas, advindas de árvores de folhas caducas, de coníferas e arbustos variados (KIEHL, 1985).

Para se entender as diferenças relacionadas à composição química da turfa, pode-se analisar os processos vinculados com a morte e a decomposição das plantas de regiões alagadiças. As plantas vivas, a partir das quais é derivada a turfa, são constituídas, principalmente, por proteínas, carboidratos, lipídios e polifenois, tais como a lignina. Podem estar presentes também pequenas quantidades de ácidos nucleicos, pigmentos, alcaloides, vitaminas e outras substâncias orgânicas, juntamente com materiais inorgânicos. Todas estas substâncias podem ser encontradas distribuídas ao longo da planta viva em padrões característicos para cada tecido, cada órgão e cada espécie. Alguns componentes, inclusive, são insolúveis em água e são resquícios relativamente permanentes da planta (FUCHSMAN, 1980).

A celulose, que compreende uma grande fração do conteúdo de carboidratos das plantas, constitui a maior parte da estrutura das paredes celulares e dá forma as partes lenhosas e fibrosas das plantas. Outros carboidratos, tais como os açúcares simples, são solúveis em água e, portanto, componentes transitórios das plantas. Eles podem ser consumidos durante a 
fabricação da celulose e de outros elementos essenciais das células vivas, oxidados visando fornecer energia ou armazenados, na forma de amido, que pode ser convertido em açúcares, conforme necessário (FUCHSMAN, 1980).

As plantas lenhosas, ervas, juncos e ciperáceas apresentam quantidades variáveis de lignina, um material fenólico com elevada massa molecular que atua como uma substância cimentante das paredes celulares e das fibras celulósicas que constituem os principais elementos estruturais destas plantas. Enquanto isso, musgos, hepáticas e vegetais relacionados não possuem lignina, porém exibem substâncias quimicamente semelhantes que exercem funções análogas. Durante a decomposição das plantas, a lignina revela relativa estabilidade (FUCHSMAN, 1980). Na lignina está presente uma quantidade significativa de carbono em forma de anéis de benzeno aromático contendo seis membros conectados através de cadeias de átomos de carbono e oxigênio. Então, como resultado da oxidação parcial de uma parcela de lignina, várias fibras poliméricas resultantes apresentam grupos ácido carboxílico (BAIRD, 2002).

Os ácidos húmicos que compreendem a maior fração da composição da turfa não ocorrem em plantas vivas, sendo que sua origem é uma questão controversa. Alguns consideram os ácidos húmicos como originários diretamente da lignina. Outros acreditam que eles são um produto microbiano derivado em grande parte de outros componentes da planta em decomposição. Similar a lignina, os ácidos húmicos apresentam elementos fenólicos na sua estrutura, mas ao contrário da lignina, eles exibem um alto teor de ácido carboxílico e contêm quantidades significativas de nitrogênio (FUCHSMAN, 1980).

Então, quando uma planta morre seus açúcares são rapidamente liberados para o ambiente, sendo ligeiramente metabolizados pelos microrganismos. Quanto aos amidos, eles também, embora insolúveis, são rapidamente digeridos por enzimas ou por microrganismos, sendo assim, convertidos em açúcares consumíveis. Já a hemicelulose e as pectinas são atacadas mais lentamente, apresentando uma tendência de sobreviverem em quantidades variáveis juntamente com a celulose, como componentes da turfa.

No tocante as proteínas vegetais, elas são largamente consumidas pelos microrganismos decompositores. Embora muito do nitrogênio contido nas proteínas vegetais seja perdido, provavelmente como sais de amônio que são lixiviados a partir do resíduo insolúvel, alguns dos compostos de nitrogênio, como aminoácidos ou como seus derivados, parecem estar envolvidos na formação de ácidos húmicos da turfa (FUCHSMAN, 1980). Nas turfeiras, o nitrogênio, na forma de amônia, está presente em reduzidas quantidades, já que é originado da decomposição da matéria orgânica, mas não se acumula, pois é consumido pelas plantas e também pelos 
próprios microrganismos que decompõem os carboidratos dos vegetais. Ademais, em turfeiras drenadas, a amônia pode se oxidar a nitrato, que é uma forma química mais estável. Todo o nitrogênio presente na turfeira é oriundo das plantas e sua quase totalidade encontra-se na forma orgânica como proteínas e derivados (KIEHL, 1985).

Os vários lipídeos de organismos vegetais vivos apresentam características distintivas e comuns, como a insolubilidade em água e a solubilidade em solventes orgânicos. Este grupo quimicamente heterogêneo engloba as gorduras, os óleos vegetais, os ácidos graxos livres, as ceras vegetais, os esteroides e os terpenos (FUCHSMAN, 1980).

Durante a decomposição, triglicerídeos são prontamente hidrolisados, produzindo ácidos graxos e glicerol. Em condições anaeróbias, o glicerol é rapidamente consumido como uma fonte de carbono e de oxigênio para os microrganismos. Os ácidos graxos, ceras inalteradas e esteroides persistem se tornando componentes relativamente estáveis na turfa. Coletivamente, estas substâncias e quaisquer outras extraíveis com solventes orgânicos não aquosos, são chamadas de betumes (FUCHSMAN, 1980).

As bactérias e os fungos decompositores também morrem, contribuindo com seus próprios resíduos, principalmente carboidratos. Inclusive monossacarídeos que são únicos em bactérias e fungos constituem uma pequena porção dos carboidratos totais da turfa. Além disso, substâncias derivadas da vida animal das turfeiras, juntamente com poeiras levadas pelo vento de outras regiões e o conteúdo de água subterrânea que escoa através da turfa, oriunda de solos menos orgânicos, adicionam seus componentes na grande mistura (FUCHSMAN, 1980).

Em adição a estes variados componentes orgânicos, a turfa é constituída ainda, invariavelmente, por um componente inorgânico, que é vulgarmente denominado de "cinza". No entanto, o maior componente da turfa é a água, sendo que turfas frescas normalmente contém de 80 a $90 \%$ de água (FUCHSMAN, 1980). Nessa perspectiva, a turfa, quando bem decomposta, pode reter de 400 a $800 \%$ de água, correspondendo de 4 a 8 vezes sua própria massa (KIEHL, 1985). Essa elevada capacidade de retenção pode ser interessante para diversas utilizações da turfa, inclusive no tocante a construção de barreiras selantes.

Com efeito, quando a turfa é removida de seu estado natural e é drenada, seja ao ar livre ou mecanicamente, e depois moída ou triturada, embora sua composição seja essencialmente inalterada, uma grande mudança ocorre em algumas de suas propriedades. Há uma perda da capacidade de retenção de umidade, em graus variados, de acordo com o tipo de turfa, e outras propriedades são também alteradas, como porosidade e permeabilidade (COUILLARD, 1994).

Quando seca ao ar, a umidade da turfa é reduzida para valores entre 30 a $40 \%$ e, em condições favoráveis, pode atingir cerca de $15 \%$. No entanto, em condições de umidade baixa, 
ela resulta em um produto resistente à reidratação, em virtude dos filmes de ar que envolvem as partículas, podendo assim, ser considerada um material aerófilo. Ademais, a secagem provoca ainda uma alteração em sua natureza coloidal, que dificulta o reumedecimento. Em laboratório, é possível promover um rápido reumedecimento da turfa com agente umectante, como o álcool, ou aplicando vácuo para retirar o ar retido nos coloides (KIEHL, 1985).

Uma importante característica da turfa é sua capacidade de contração e expansão. Essa variação de seu volume ocorre em função do seu conteúdo de água e presença de matéria orgânica humificada. Justamente essa tendência que a turfa manifesta para se contrair intensamente ao secar e se expandir ao reabsorver água, dificulta o estabelecimento de sua densidade aparente. Assim, a densidade da turfa deve vir sempre acompanhada do teor de umidade. Como exemplo, um metro cúbico de turfa, em estado molhado, apresenta uma massa de, aproximadamente, uma tonelada. Já quando completamente seca, esse mesmo volume, passa a ter uma massa de, cerca de, 100 quilogramas (KIEHL, 1985).

\subsubsection{Classificação da turfa}

O grau de decomposição tem se mostrado uma propriedade chave em estudos de solos orgânicos, porém não está claramente definido e apresenta uma difícil quantificação. Afinal, trata-se de uma quantidade relativa que é comumente aproximada através do emprego da medida de uma característica química ou física da turfa (BOELTER, 1968).

A decomposição ou humificação envolve a perda de matéria orgânica, quer como gás ou em solução, o desaparecimento da estrutura física e a mudança de estado químico. Os produtos da humificação são, basicamente, dióxido de carbono e água, sendo o processo de oxidação essencialmente bioquímico (HUAT el al., 2014). A taxa segundo a qual os materiais vegetais presentes nas turfeiras são decompostos depende de variados fatores, tais como acidez, temperatura, umidade, fornecimento de oxigênio, composição bioquímica e organismos presentes em termos de composição e número (BRANDYK et al., 2003).

Dessa forma, mesmo existindo diversas classificações considerando variados parâmetros, se destaca a classificação das turfas no tocante ao grau de humificação. O grau de humificação pode ser medido através do método de von Post, uma metodologia amplamente utilizada, simples e eficiente para a caracterização de campo da turfa. Este teste se baseia em apertar uma amostra de material orgânico na mão e observar a cor da solução que flui entre os dedos, a distinção das estruturas da planta que permanecem na mão, a proporção entre a quantidade de material amorfo e a amostra original (RYDIN; JEGLUM, 2013). Este sistema de classificação visual é composto por dez graus de decomposição que variam de H1 (muito 
fibroso) a H10 (pouco fibroso), que representam o estado de decomposição/decaimento da parcela orgânica. Assim, números superiores estão associados a um maior grau de decomposição (HUAT et al., 2011), conforme pode ser observado no Quadro 3.

Quadro 3 - Classificação visual de turfas de acordo com o grau de humificação - Escala de von Post

\begin{tabular}{|c|c|c|c|}
\hline $\begin{array}{c}\text { Grau de } \\
\text { humificação }\end{array}$ & $\begin{array}{l}\text { Característica } \\
\text { geral }\end{array}$ & $\begin{array}{c}\text { Qualidade da água } \\
\text { que flui entre os } \\
\text { dedos }\end{array}$ & $\begin{array}{l}\text { Natureza do resíduo deixado na } \\
\text { mão }\end{array}$ \\
\hline $\mathrm{H} 1$ & $\begin{array}{l}\text { Completamente } \\
\text { não humificada }\end{array}$ & $\begin{array}{l}\text { Água transparente e } \\
\text { incolor }\end{array}$ & $\begin{array}{l}\text { Presença de estruturas } \\
\text { características das plantas, que } \\
\text { permanecem quase inalteradas }\end{array}$ \\
\hline $\mathrm{H} 2$ & $\begin{array}{c}\text { Quase } \\
\text { completamente } \\
\text { não humificada }\end{array}$ & $\begin{array}{l}\text { Água amarelo- } \\
\text { marrom }\end{array}$ & $\begin{array}{c}\text { Resíduos vegetais facilmente } \\
\text { identificáveis }\end{array}$ \\
\hline $\mathrm{H} 3$ & $\begin{array}{c}\text { Pouco } \\
\text { humificada }\end{array}$ & $\begin{array}{l}\text { Água marrom turva, } \\
\text { mas nenhum sólido } \\
\text { passa entre os dedos }\end{array}$ & $\begin{array}{l}\text { Resíduos de plantas identificáveis, } \\
\text { sendo que o resíduo na mão não é } \\
\text { lamacento }\end{array}$ \\
\hline $\mathrm{H} 4$ & $\begin{array}{l}\text { Fracamente } \\
\text { humificada }\end{array}$ & $\begin{array}{l}\text { Água muito turva, } \\
\text { água marrom }\end{array}$ & $\begin{array}{c}\text { Resíduos vegetais dificilmente } \\
\text { identificáveis e porções } \\
\text { lamacentas visíveis. }\end{array}$ \\
\hline $\mathrm{H} 5$ & $\begin{array}{l}\text { Parcialmente } \\
\text { humificada }\end{array}$ & $\begin{array}{l}\text { Água muito turva } \\
\text { com a presença de } \\
\text { alguns sólidos mais } \\
\text { grosseiros de turfa }\end{array}$ & $\begin{array}{l}\text { Resíduos vegetais enlameados } \\
\text { ainda identificáveis, mas um tanto } \\
\text { obscuros. }\end{array}$ \\
\hline H6 & $\begin{array}{l}\text { Com algum } \\
\text { grau de } \\
\text { humificação }\end{array}$ & $\begin{array}{l}\text { Um terço de turfa se } \\
\text { perde na água }\end{array}$ & $\begin{array}{c}\text { Resíduos vegetais muito } \\
\text { enlameados e de identificação } \\
\text { vaga. São pastosos, mas mostram } \\
\text { as estruturas da planta mais } \\
\text { claramente do que a turfa bruta }\end{array}$ \\
\hline $\mathrm{H} 7$ & $\begin{array}{l}\text { Bastante } \\
\text { humificada }\end{array}$ & $\begin{array}{l}\text { Metade de turfa é } \\
\text { perdida em água }\end{array}$ & $\begin{array}{c}\text { Resíduos vegetais muito } \\
\text { enlameados, porém, ainda } \\
\text { discerníveis }\end{array}$ \\
\hline $\mathrm{H} 8$ & $\begin{array}{c}\text { Bem } \\
\text { humificada }\end{array}$ & $\begin{array}{l}\text { Dois terços de turfa } \\
\text { são perdidos na água }\end{array}$ & $\begin{array}{c}\text { Permanecem apenas resíduos } \\
\text { mais resistentes, como raízes, } \\
\text { madeira e fibras grossas }\end{array}$ \\
\hline H9 & $\begin{array}{l}\text { Quase } \\
\text { completamente } \\
\text { humificada }\end{array}$ & $\begin{array}{l}\text { Nove décimos de } \\
\text { turfa perdidos na } \\
\text { água, similar a uma } \\
\text { lama homogênea }\end{array}$ & $\begin{array}{c}\text { Restam apenas alguns resíduos } \\
\text { vegetais isolados }\end{array}$ \\
\hline $\mathrm{H} 10$ & $\begin{array}{c}\text { Completamente } \\
\text { humificada }\end{array}$ & $\begin{array}{c}\text { Massa inteira desliza } \\
\text { por entre os dedos }\end{array}$ & Nenhum resíduo \\
\hline
\end{tabular}

Fonte: Modificado de von Post (1925) apud Fuchsman (1980) e von Post e Granlund (1926) ${ }^{5}$ apud

Stanek e Silc (1977).

\footnotetext{
${ }^{4}$ VON POST, L.; Gotlands-agen (Cladium Mariscus R.Br.) i Sveriges postarktikum. 1925.

${ }^{5}$ VON POST, L.; GRANLUND, E.; Södra Sveriges Torvtillgânger. Sveriges Geologiska Undersökning, Ârsbok, v.335, n.19.2, p.1-127, 1926.
} 
O emprego desta escala de classificação mesmo sendo internacional requer algumas ressalvas. De acordo com Fuchsman (1980) este sistema, na prática, tende a ser consideravelmente subjetivo e de difícil utilização em um sentido quantitativo. Ademais, Lenz $(1984)^{6}$ citado por Franchi (2004) destaca que esta classificação foi desenvolvida para as turfeiras localizadas no hemisfério norte, em clima moderado a boreal. Assim, seu emprego para turfeiras tropicais requer alguns cuidados, já que normalmente as turfeiras tropicais que já atingiram um grau avançado de humificação, podem ainda apresentar fibras resistentes em sua composição. Assim, pelo sistema usual de von Post elas podem ser categorizadas falsamente como turfas fibrosas em estágio inicial de decomposição.

Outra classificação tradicional da turfa é em função de seu teor de fibras, que é o critério principal desta classificação, sendo necessário definí-lo. Podem ser consideradas fibras os fragmentos de tecido de planta, com exceção das raízes vivas, com dimensão suficientemente grande para serem retidas em uma peneira de malha 100\# (abertura de 0,15 mm de diâmetro). Os fragmentos maiores que $2 \mathrm{~cm}$ são chamados de fibras somente se eles são decompostos o suficiente para serem esmagados e triturados com os dedos. Por conseguinte, esta regra culmina na exclusão de pedaços de madeira maiores do que $2 \mathrm{~cm}$, que são considerados grosseiros e podem ser comparáveis aos cascalhos presentes em solos minerais (SOIL SURVEY STAFF, 2014). O Quadro 4 apresenta esta classificação em termos qualitativos.

Quadro 4 - Classificação de turfas em função do seu teor de fibras

\begin{tabular}{|c|c|c|}
\hline \hline Tipologia & Cor típica & Características principais \\
\hline \hline Fibrosa & $\begin{array}{c}\text { Marrom } \\
\text { avermelhado } \\
\text { claro }\end{array}$ & $\begin{array}{c}\text { Elevado conteúdo de matéria orgânica, resultando em um baixo } \\
\text { grau de humificação. É composta por materiais orgânicos } \\
\text { fibrosos não decompostos e facilmente identificáveis. Se } \\
\text { caracteriza por ser extremamente ácida }\end{array}$ \\
\hline Sâmica & $\begin{array}{c}\text { Marrom } \\
\text { avermelhado } \\
\text { escuro }\end{array}$ & $\begin{array}{c}\text { Contém grau de decomposição ou humificação, matéria orgânica } \\
\text { e densidade intermediários entre as turfas fibrosa e sáprica }\end{array}$ \\
\hline Cinza escuro & $\begin{array}{c}\text { Apresenta grande quantidade de materiais decompostos, sendo } \\
\text { que a maioria das fibras vegetais já desapareceram. Se } \\
\text { caracteriza por ser altamente estável em relação às suas } \\
\text { propriedades físicas, com menor índices de vazios, menor ângulo } \\
\text { de atrito, menor permeabilidade, menor compressibilidade, } \\
\text { menor capacidade de retenção de água, maior teor de matéria } \\
\text { orgânica e maior densidade mássica dentre os três tipos de turfa }\end{array}$ \\
\hline \hline
\end{tabular}

Fonte: Modificado de Huat et al. (2011) e Huat et al. (2014).

\footnotetext{
${ }^{6}$ LENZ, G. R.; Turfa - métodos de lavra e opções para uso no Nordeste brasileiro. Revista Brasileira de Geociências, v.14, n.2, p.111-119, 1984.
} 
Estas categorias envolvendo o conteúdo de fibras podem ser relacionadas com a avaliação do grau de humificação, desenvolvida por von Post. No entanto, não existe um consenso quanto a esta relação, sendo que podem ser vistas variações mesmo que pequenas entre diversos autores e instituições. De acordo com a ASTM D4427 - 13 a classe fibrosa corresponde aproximadamente ao intervalo de classificação de $\mathrm{H} 1$ a H3, as turfas hêmicas, de H4 a H6 e as sápricas, de H7 a H10. Já para Huat e colaboradores (2011) os grupos H1 a H4 são chamados fibrosos, os grupos $\mathrm{H} 5$ a H7, hêmicos e os grupos H8 a H10 são ditos sápricos.

O Quadro 5 exibe diversas classificações para as turfas sendo que segundo a ASTM D4427 - 13, para turfas com teor de fibras inferior a 33\% (turfas sápricas) é aconselhável se abster da designação botânica. Este quadro apresenta novamente a classificação quanto ao conteúdo de fibras, no entanto, neste caso, a variação entre as classes é feita em função do percentual de fibras.

Quadro 5 - Classificação de turfas segundo a ASTM D4427 - 13 levando em consideração diversos parâmetros

\begin{tabular}{|c|c|}
\hline $\begin{array}{c}\text { Bases para } \\
\text { classificação }\end{array}$ & Categorias \\
\hline \multirow{3}{*}{ Conteúdo de fibras } & Fibrosa: conteúdo de fibras superior a $67 \%(2 / 3)$ \\
\hline & Hêmica: conteúdo de fibras entre $33 \%$ e $67 \%$ (1/3 e $2 / 3)$ \\
\hline & Sáprica: conteúdo de fibras inferior a $33 \%(1 / 3)$ \\
\hline \multirow{3}{*}{$\begin{array}{l}\text { Conteúdo de cinza } \\
\text { (ASTM D2974) }\end{array}$} & Baixo teor de cinza: cinzas inferiores a $5 \%$ \\
\hline & Médio teor de cinza: cinzas entre 5 a $15 \%$ \\
\hline & Alto teor de cinzas: cinzas superiores a $15 \%$ \\
\hline \multirow{4}{*}{$\begin{array}{c}\text { Acidez } \\
(\text { ASTM D2976) }\end{array}$} & Altamente ácida: $\mathrm{pH}$ inferior a 4,5 \\
\hline & Moderadamente ácida: $\mathrm{pH}$ entre 4,5 e 5,4 \\
\hline & Ligeiramente ácida: $\mathrm{pH}$ entre 5,4, e 7,0 \\
\hline & Básica: $\mathrm{pH}$ acima de 7,0 \\
\hline \multirow{4}{*}{$\begin{array}{l}\text { Capacidade de } \\
\text { absorção } \\
\text { (ASTM D2980) }\end{array}$} & $\begin{array}{l}\text { Extremamente absorvente: capacidade de retenção de água } \\
\text { superior a } 1500 \%\end{array}$ \\
\hline & $\begin{array}{l}\text { Altamente absorvente: capacidade de retenção de água entre } \\
\qquad 800 \text { e } 1500 \%\end{array}$ \\
\hline & $\begin{array}{l}\text { Moderadamente absorvente: capacidade de retenção de água } \\
\text { entre } 300 \text { e } 800 \%\end{array}$ \\
\hline & $\begin{array}{c}\text { Ligeiramente absorvente: capacidade de retenção de água } \\
\text { inferior ou igual a } 300 \%\end{array}$ \\
\hline
\end{tabular}




\begin{tabular}{|c|c|}
\hline \hline $\begin{array}{c}\text { Bases para } \\
\text { classificação }\end{array}$ & Categorias \\
\hline \hline \multirow{5}{*}{ Composição botânica } & $\begin{array}{c}\text { Se for utilizado um único nome botânico, como Turfa } \\
\text { Sphagnum ou Turfa Moss, é necessário que no mínimo 75\% } \\
\text { do teor de fibra presente na turfa seja derivado deste tipo de } \\
\text { material vegetal }\end{array}$ \\
\cline { 2 - 3 } & $\begin{array}{c}\text { Se duas ou mais designações botânicas forem utilizadas, como } \\
\text { Turfa Reed-Sedge ou Turfa Spruce-Moss-Sedge, é necessário } \\
\text { que no mínimo 75\% do teor de fibra presente na turfa seja } \\
\text { composto por este grupo de plantas. Além disso, o nome pode } \\
\text { indicar a quantidade relativa das plantas com as tipologias } \\
\text { dominantes aparecendo primeiro }\end{array}$ \\
\hline \hline
\end{tabular}

Fonte: Modificado de ASTM D4427 - 13.

\subsubsection{Armazenamento de água}

As propriedades físicas características de qualquer tipologia de solo são diretamente dependentes da porosidade e da distribuição de tamanho destes poros, que, por sua vez, estão relacionadas com a distribuição de tamanho das partículas. Em turfas, tanto o tamanho das partículas como a estrutura e porosidade resultantes são consequência principalmente do grau de decomposição (BOELTER, 1968). Brandyk et al. (2003) complementam que em solos orgânicos, a retenção de água e a condutividade hidráulica são dependentes do grau da decomposição da turfa e também de sua origem botânica, sendo que em alguns depósitos de turfa, a hidráulica da condutividade é anisotrópica.

Segundo Ostwald (1921) ${ }^{7}$ apud Feustel e Byers (1930), a capacidade de uma turfa de absorver ou reter água pode ser atribuída basicamente a cinco diferentes fenômenos: (i) água de obstrução, retida em poros com 1 milímetro ou mais de diâmetro; (ii) água mantida por capilaridade; (iii) água adsorvida; (iv) água ligada por osmose; e (v) água quimicamente combinada. Assim, a capacidade máxima de retenção de umidade da turfa corresponde ao total de todas estas formas.

Com a acentuação da decomposição, o tamanho das partículas orgânicas é reduzido, implicando, por conseguinte, em poros menores e em mais material seco por unidade de volume. Contudo, o volume de poros, mesmo sofrendo uma redução gradual em função do aumento da decomposição, é elevado para todos os tipos de turfa (BOELTER, 1968).

\footnotetext{
${ }^{7}$ OSTWALD, W.; Beiträge zur dispersoidchemie des torfes I. Ueber die natur der wasserbinduno im torfe. Kolloid Ztschr. 29:316-329. 1921.
} 
De modo geral, a distribuição do tamanho dos poros é mais significativa do que a porosidade total, sendo que as turfas não decompostas normalmente apresentam baixa densidade e alto teor de fibras, condicionando a existência de grandes poros que permitem uma rápida circulação de água, por serem facilmente drenados. Por outro lado, com a decomposição, o conteúdo de fibras é reduzido, acarretando no aumento da densidade e em uma maior presença proporcional de poros pequenos, implicando em lentas taxas de movimentação de água (BOELTER, 1968), conforme mostrado na Figura 13.

Figura 13 - Relação entre o conteúdo de água e diferentes condições de sucção para turfas com variados teores de fibras

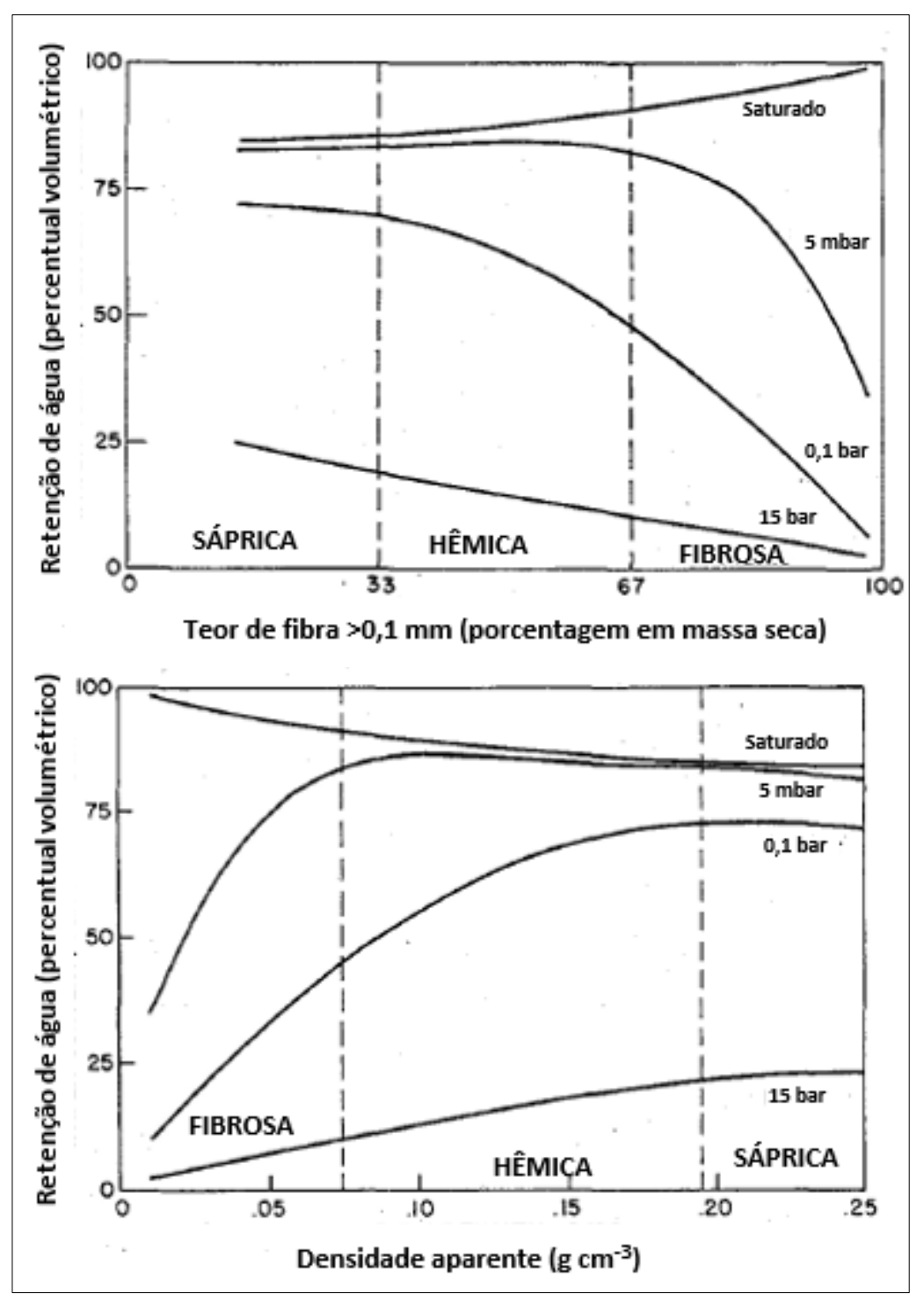

Fonte: Adaptado de Boelter (1969).

Exemplificando esta constatação, a Figura 14 mostra os resultados obtidos para extração de água, utilizando um equipamento apropriado e diferentes tipologias de turfa. As curvas de 
retenção de água revelam que a turfa pouco decomposta Sphagnum retém mais água em condição de saturação do que as turfas mais decompostas. No entanto, essa situação é revertida facilmente já que ela perde uma grande quantidade de água com uma sucção de apenas 5 mbar. Em contrapartida, os poros finos presentes nas turfas mais decompostas não são facilmente drenados e em sucções superiores a 5 mbar os conteúdos de água presentes nessas turfas são muito mais elevados se comparados às turfas menos decompostas (BOELTER, 1968).

Figura 14 - Curvas de retenção de água para diversas turfas do norte de Minesota

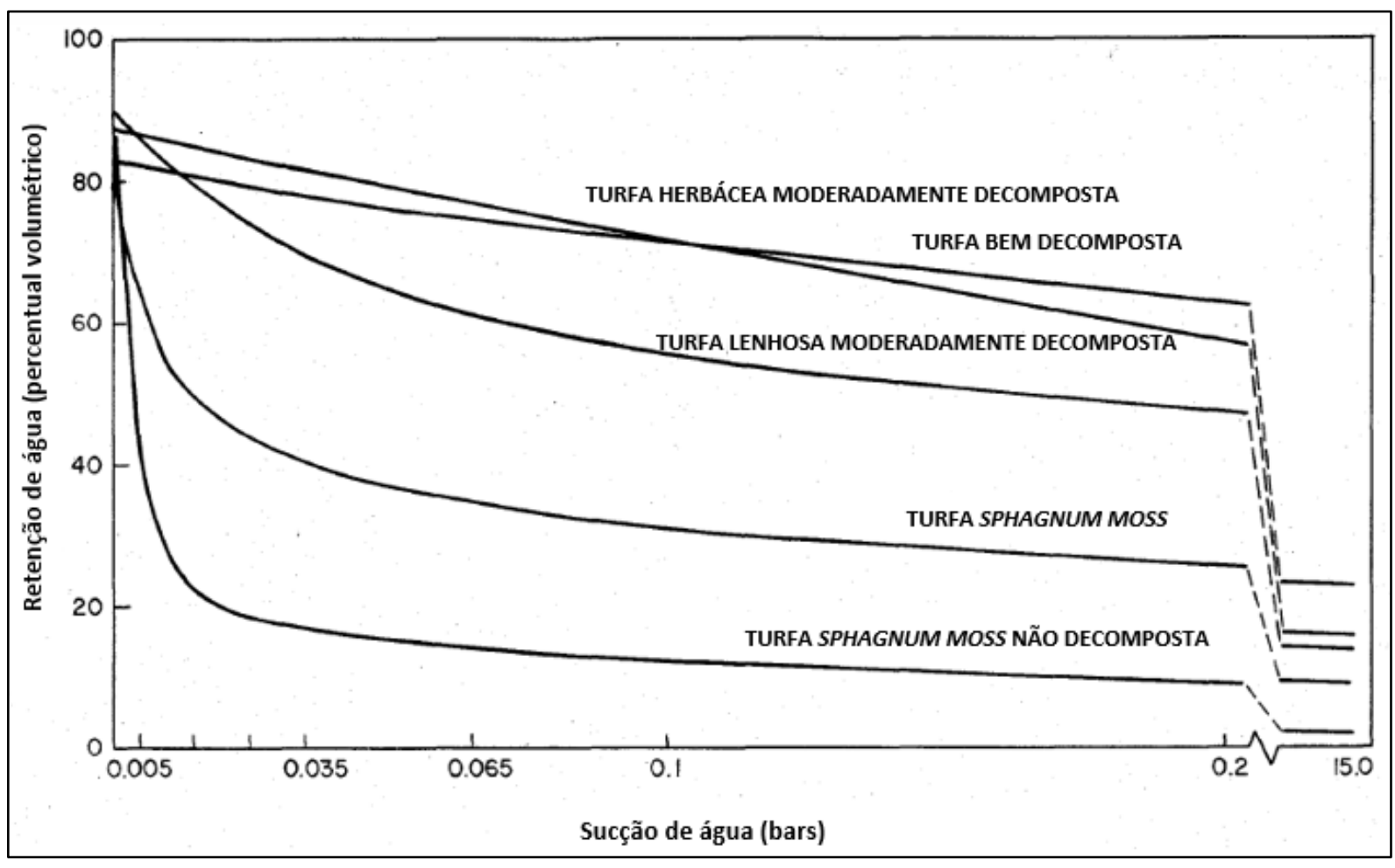

Fonte: Adaptado de Boelter (1968).

\subsubsection{Possíveis utilizações}

Tradicionalmente, a turfa é utilizada como combustível e na agricultura. Na agricultura, seus principais usos estão associados à sua aplicação como fertilizante e condicionador do solo, podendo ser empregada também como substrato de variadas culturas. Em geral, para essa finalidade, é necessário pouco processamento da turfa, sendo assim considerada como um material de baixo valor comercial e de elevado volume (SPEDDING, 1988).

Os Estados Unidos e o Canadá são os países que mais extensivamente empregam a turfa na agricultura como condicionador de solos (FRANCHI; SÍGOLO; DE LIMA, 2003). No entanto, o aproveitamento da turfa para outras finalidades tem sido objeto de estudo extensivo. Fuchsman (1980) salienta que, inclusive, a associação complexa de diversas substâncias 
orgânicas presentes na turfa possibilita uma variedade de oportunidades para o desenvolvimento de produtos promissores para a indústria farmacêutica e também para outras indústrias com caráter bioquímico.

Ademais, as propriedades de adsorção da turfa se mostraram extremamente úteis no controle da poluição/contaminação da água (SPEDDING, 1988). A elevada capacidade de quelação da turfa pode permitir o desenvolvimento de métodos para a remoção de $\mathrm{Cd}, \mathrm{Cr}, \mathrm{Cu}$, $\mathrm{Fe}, \mathrm{Pb}, \mathrm{Hg}, \mathrm{Ni}, \mathrm{Ag}, \mathrm{Zn}$ e fosfatos, bem como para os compostos orgânicos, tais como óleos, detergentes e corantes (COUILLARD, 1994).

Usos mais alternativos também já são observados, como a utilização dessa potencial capacidade de adsorção associada aos próprios depósitos de turfa para quantificar os efeitos de poluição atmosférica (SMIEJA-KRÓL et al., 2010).

No tocante ao tratamento de águas residuais, a turfa é empregada para remover impurezas diversas, tais como sólidos em suspensão, matéria orgânica e metais potencialmente tóxicos. Os sólidos que são maiores do que os canais intersticiais da turfa são filtrados. É importante considerar o modo de colocar em contato o adsorvente sólido e as soluções aquosas na aplicação do processo de adsorção para tratamento em grande escala. Existem essencialmente quatro fases do processo de adsorção usando turfa porosa: i) transporte de impurezas da solução para a superfície exterior da turfa; ii) movimento de poluentes através da interface e locais de adsorção de superfície externa; iii) migração de moléculas de poluentes no interior dos poros da turfa; e iv) interação de moléculas poluentes com os locais disponíveis para adsorção localizados nas superfícies internas, delimitadas pelos poros e capilares da turfa. Desse modo, um ou mais dos passos anteriores podem controlar a taxa em que os poluentes são adsorvidos e a quantidade de poluentes adsorvidos sobre as partículas sólidas. Em baixos níveis de fluxos, quando a turbulência ou a agitação é baixa, a resistência da camada limite será significativa e o passo ii) irá ser um importante controlador desse processo (COIULLARD, 1994).

Contudo, a extração da turfa, independentemente de sua finalidade, deve se dar de forma planejada, a fim de minimizar os impactos ambientais associados. Segundo Fuchsman (1980), a perturbação e eventual destruição de ecossistemas naturais podem resultar em consequências profundamente trágicas atingindo a região da perturbação inicial e, até mesmo, além dela. Turfeiras podem propiciar um habitat temporário ou sazonal para vários pássaros e mamíferos, se tornando essenciais para a sua alimentação, nidificação, ou descanso, ou ainda para o abrigo de humanos e outros predadores. Além disso, a água contida no interior das turfeiras pode controlar os níveis e moderar os movimentos das águas subterrâneas e superficiais em grandes 
sistemas de drenagem. Assim, a intervenção nas turfeiras pode afetar esse equilíbrio, comprometendo essas funções e ainda acarretar na retenção ou na liberação de substâncias orgânicas e inorgânicas que apresentam considerável potencial de afetar a qualidade da água em rios que atravessam ou são originários nas zonas úmidas. Ainda segundo Fuchsman (1980), estas relações são conhecidas, de modo geral, apenas qualitativamente. No entanto, turfeiras variam substancialmente em termos de fauna, flora, geografia e hidrologia, sendo necessário estudar cada área separadamente, a fim de avaliar os efeitos físicos e biológicos intrínsecos associados a qualquer perturbação em grande escala.

\subsection{Adsorção de metais}

Os mecanismos de sorção presentes na turfa, bem como nas plantas, estão associados a quantidades significativas de ligantes orgânicos, tais como proteínas, carboidratos e ácidos carboxílicos, bem como ácidos nucleicos, lipídeos e esteróides. Desse modo, sempre que íons metálicos e ligantes estão presentes, será estabelecido equilíbrio entre eles (KOIVULA et al., 2009).

Os constituintes da turfa apresentam grupos funcionais polares na sua estrutura molecular, tais como aldeídos, cetonas, ácido carboxílico, hidroxílico e fenólico, os quais estão envolvidos na adsorção de metais. Devido ao caráter polar da turfa, esse material apresenta um bom potencial de adsorção de metais e moléculas orgânicas polares (COUILLARD, 1994; QIN et al., 2006).

Ademais, a matéria orgânica da turfa apresenta como principais constituintes as substâncias húmicas (subdivididas em ácidos húmicos e fúlvicos) e a humina (PETRONI, 1999). Nesse sentido, as substâncias húmicas e os metais podem formar desde fracas forças de atração até ligações altamente estáveis.

Dessa forma, o mecanismo pelo qual os íons metálicos são adsorvidos pela turfa tem sido assunto de grande destaque. Diferentes estudos atingiram distintas conclusões sobre esse processo, já que variações no tipo de turfa, preparação, metodologia e metais estudados torna difícil a comparação de resultados. No entanto, de modo geral, a sorção de metais pela turfa permite a atuação, isolada ou em conjunto, de vários mecanismos, incluindo troca iônica, adsorção de superfície, adsorção química, complexação e adsorção-complexação (BROWN; GILL; ALLEN, 2000; FRANCHI, 2004). Destes mecanismos, a troca iônica é o principal, haja vista, a elevada capacidade de troca catiônica da turfa (FRANCHI, 2004).

Bartczak et al. (2015) corroboram com esta ideia, ao sugerirem a troca iônica para explicar o mecanismo de adsorção. Segundo os referidos autores, esta troca iônica estaria 
baseada na permutação de íons, carregados positivamente, com os seguintes grupos funcionais orgânicos: carboxílico, fenólico, hidroxílico e éter. Esses grupos promovem a ligação de íons de metais nocivos para o ambiente através da dissociação de um cátion hidrogênio, fazendo com que a turfa normalmente apresente uma carga de superfície negativa, conforme esquematizado na Figura 15.

Figura 15 - Exemplo de mecanismo associado com a adsorção de metais em turfa

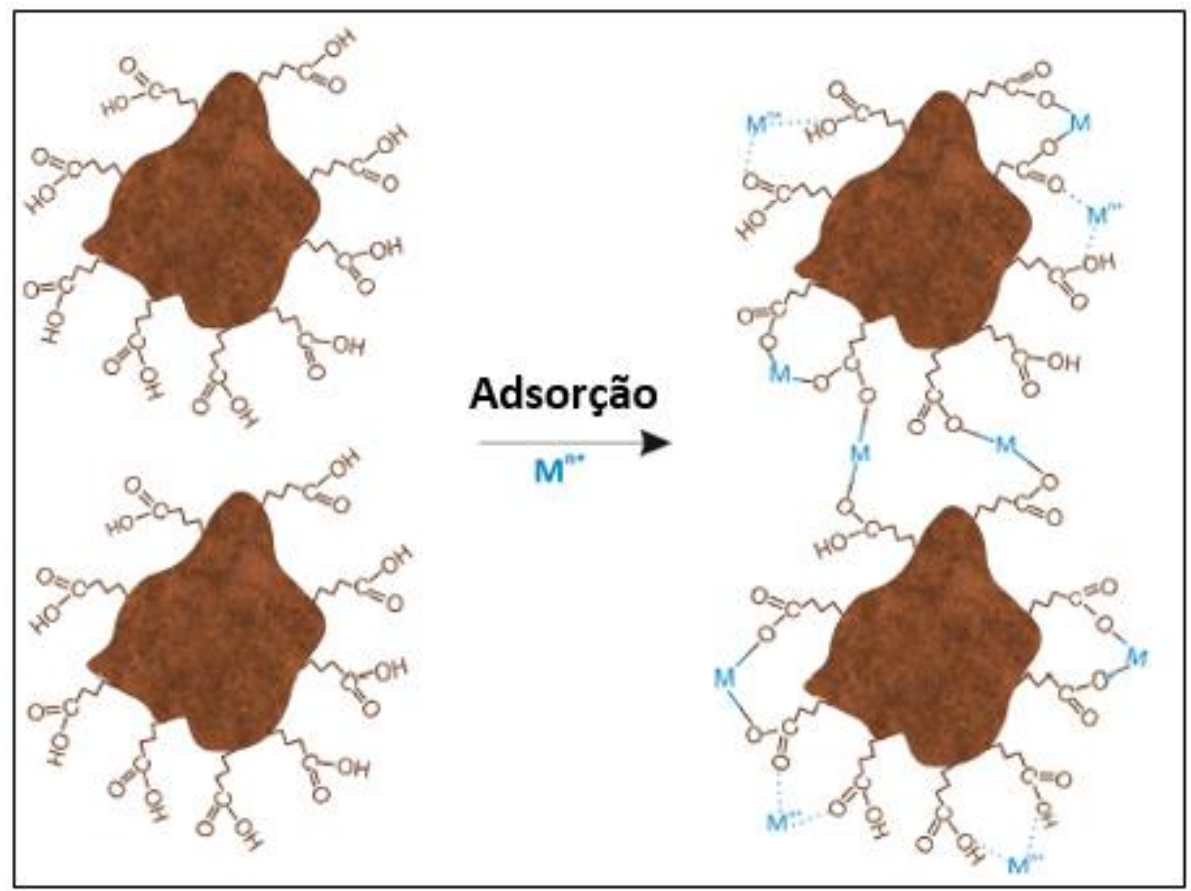

Fonte: Adaptado de Bartczak et al. (2015).

Couillard (1994) complementa essa perspectiva ao afirmar que o mecanismo de sorção de metais pela turfa pode ser explicado como uma reação de permuta de cátions, devido à elevada capacidade de troca catiônica da turfa ou também uma reação química na qual os grupos funcionais da turfa formam complexos, incluindo a quelação, com os metais. Para ambos os processos, é necessário que haja a difusão dos íons positivos considerados do meio aquoso até as partículas de turfa. Assim, o processo global é governado por difusão, porque ambas as reações são consideradas instantâneas.

Vários fatores influenciam mutuamente na eficiência e no tempo necessário de remoção dos contaminantes, tais como: superfície específica da turfa; $\mathrm{pH}$; temperatura; presença de elementos interferentes e natureza; e concentrações iniciais dos metais presentes. Nota-se que em efluentes líquidos, geralmente, há uma mistura de substâncias, acarretando na competição pelos sítios de adsorção da turfa (FRANCHI, 2004). 
Além disso, a decomposição da turfa aumenta sua natureza amorfa, elevando a sua eficácia como sorvente. Contudo, a decomposição também reduz a capacidade de drenagem. Portanto, turfas parcialmente decompostas são mais fibrosas e apresentam melhores características hidráulicas (COUILLARD, 1994).

De modo geral, a turfa, em condições naturais, já apresenta elevada capacidade de adsorção, podendo ser utilizada para a remoção de contaminantes, como metais, sem que haja um pré-tratamento, sendo que bons resultados podem ser obtidos. Contudo, segundo Couillard (1994), a eficiência de remoção pode ser adversamente afetada pelas características da turfa natural, como baixa resistência mecânica, uma elevada afinidade pela água, fraca estabilidade química e uma tendência para encolher e/ou inchar. Dessa forma, para superar estes problemas, pode ser empregado um pré-tratamento térmico ou químico. Brown, Gill e Allen (2000), complementam que o pré-tratamento físico e químico da turfa antes do contato com os metais, tem buscado o desenvolvimento da turfa, como um adsorvente de metais, até o alcance de seu potencial máximo através do reforço da troca iônica.

Ademais, devido à sua ampla disponibilidade e reduzidos gastos associados à sua extração, pode ser considerada um adsorvente de baixo custo, o que é favorável para seu uso no desenvolvimento de tecnologias de neutralização acessíveis economicamente para os resíduos e impurezas (BROWN; GILL; ALLEN, 2000; BARTCZAK et al., 2015).

\subsubsection{Estudos de caso}

A adequabilidade do emprego da turfa como um adsorvente natural é comprovada por uma série de estudos que têm demonstrado a capacidade de adsorção de metais por esse material reativo orgânico. Rashid (1974) conduziu experimentos de laboratório para investigar a adsorção de metais pela turfa, concluindo que cada quilograma da turfa estudada revelou a capacidade de adsorver um total de cerca de 1.500 miligramas de metais potencialmente tóxicos. A ordem de absorção foi $\mathrm{Cu}>\mathrm{Ni}>$ cobalto $(\mathrm{Co})>\mathrm{Zn}>\mathrm{Mn}$. Na presença de iguais concentrações desses íons metálicos, o $\mathrm{Cu}$ foi preferencialmente adsorvido, aproveitando, aproximadamente, $50 \%$ da capacidade total de adsorção de metais pela turfa.

Petroni (1999) realizou estudos envolvendo a adsorção de $\mathrm{Zn}$ e Cd em colunas de turfa sob condições de pH variando de 2 a 6,5 (condições iniciais). Esse autor concluiu que a eficiência de remoção dos íons metálicos atingiu valores superiores a 98\%, em uma faixa de $\mathrm{pH}$ de 3,5 a 6,5, sendo observada uma maior afinidade da turfa pelo $\mathrm{Cd}$ em relação ao $\mathrm{Zn}$. Foi

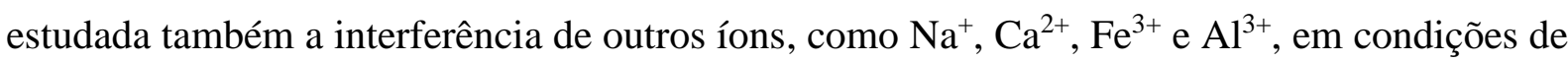
pH 4, sendo verificada uma diminuição nas porcentagens de retenção dos metais. 
Crescêncio Júnior (2008) estudou a potencialidade do emprego de turfa in natura em barreiras reativas permeáveis visando a remediação de aquíferos contaminados por compostos inorgânicos, como $\mathrm{Cu}$ e Cd, e orgânicos, como BTEX. O autor trabalhou com duas tipologias de turfa: uma classificada como fibrosa, originada de Mogi Guaçu, e outra, sáprica, advinda de Resende. A primeira se destacou por apresentar maior teor de matéria orgânica e a segunda, uma textura mais argilosa. Os ensaios de permeabilidade demonstraram que as turfas estudadas puras não apresentaram uma permeabilidade adequada para uma barreira reativa. Ademais, o ensaio de equilíbrio em lote mostrou que as turfas exibiram afinidades semelhantes para o $\mathrm{Cu}$, evidenciando que não há uma relação direta entre a adsorção de $\mathrm{Cu}$ e os teores de matéria orgânica e argila. Já quanto ao Cd, houve uma maior afinidade de adsorção para a turfa de Resende, o que demonstrou que o teor de argila é mais importante que a matéria orgânica, nesse caso. No ensaio de coluna, houve uma acidificação do meio aquoso acompanhando a saturação da turfa. Além disso, como consequência da maior concentração de íons dissolvidos no percolado, a condutividade elétrica também aumentou. Quanto à adsorção, a capacidade de remoção de $\mathrm{Cu}$ foi semelhante para ambas as turfas, enquanto para o $\mathrm{Cd}$, a adsorção foi superior para a turfa de Mogi Guaçu, diferentemente do ensaio de equilíbrio em lote, provavelmente devido ao fato do ensaio de coluna ser dinâmico e impedir a imobilização mais acentuada do Cd pela turfa de Resende que ocorreu através de ligações eletrostáticas, ditas fracas. Por fim, o ensaio de dessorção lixiviou cerca de $90 \%$ da massa dos contaminantes em 2 horas, revelando um intenso processo de dessorção que inviabiliza a inertização da turfa in situ, requerendo a necessidade de substituição periódica da célula em caso de utilização em barreira reativa. Diante disso, de modo geral, o autor concluiu que mesmo apresentando diferenças físicas e químicas, ambas as turfas mostraram boa capacidade de adsorção física de metais. Contudo, seu uso em barreiras reativas se encontra limitado em virtude da dessorção.

Kalmykova, Strömvall e Steenari (2008) estudaram a adsorção de Cd, Cu, Ni, Pb e Zn em turfa da tipologia Sphagnum. Os resultados mostraram que as constantes de Freundlich e a adsorção de metais potencialmente tóxicos aumentaram com a elevação do pH. Em pH 4,0, os íons metálicos foram adsorvidos na ordem decrescente: $\mathrm{Pb} \geq \mathrm{Cu}>\mathrm{Ni}>\mathrm{Cd}>\mathrm{Zn}$, que está de acordo com outros resultados obtidos por estes autores. Já a ordem da capacidade de adsorção a $\mathrm{pH}$ 5,6 foi: $\mathrm{Pb}>\mathrm{Cd}>\mathrm{Zn}>\mathrm{Ni}>\mathrm{Cu}$. Estas diferenças de afinidade do adsorvente podem ser devido a diferentes mecanismos de adsorção. A maioria das ligações entre o $\mathrm{Cu}$ e a turfa foram atribuídas a grupos fenólicos, enquanto os grupos carboxílicos foram predominantes nas ligações de $\mathrm{Pb}$, Ni e $\mathrm{Zn}$. 
Koivula et al. (2009) avaliaram a adsorção de $\mathrm{Pb}, \mathrm{Cr}, \mathrm{Cu}$ e As em turfa compactada, através do ensaio de equilíbrio em lote e do ensaio de coluna, ambos sem ajuste de pH e em condições ácidas, com pretensão de uso em barreira hidráulica à base de turfa para aterro de resíduos industriais. Os pesquisadores observaram que a quantidade adsorvida dos metais na realização do ensaio em equilíbrio em lote variou dependendo das concentrações iniciais dos metais. A presença de múltiplos metais criou uma competição pelos locais adsorvíveis na superfície do adsorvente. Os resultados indicaram que o $\mathrm{Pb}$ e o $\mathrm{Cu}$ têm uma maior afinidade para sorção que o $\mathrm{Cr}$ e o As. As quantidades de $\mathrm{Pb}$ e $\mathrm{Cu}$ adsorvidas aumentaram de forma constante conforme as concentrações foram elevadas até $489 \mathrm{mg} \mathrm{kg}^{-1}$ para o $\mathrm{Pb}$ e $308 \mathrm{mg} \mathrm{kg}^{-1}$ para o $\mathrm{Cu}$, enquanto a adsorção de As foi quase constante em todas as concentrações (até 60 $\mathrm{mg} \mathrm{kg}^{-1}$ ) e a de $\mathrm{Cr}$ aumentou, no início, atingindo $210 \mathrm{mg} \mathrm{kg}^{-1}$, mas depois começou a diminuir à medida que as concentrações de outros metais aumentavam. Neste ensaio, o pH era inferior a 3,5 em todas as amostras e o $\mathrm{pH}$ de equilíbrio das amostras diminuiu na medida em que a concentração inicial dos metais aumentou. Isto é consistente com o princípio da troca iônica, segundo o qual uma vez que mais metais são adsorvidos pela turfa, mais íons de hidrogênio são liberados, diminuindo, assim, o $\mathrm{pH}$.

Posteriormente, o ensaio de adsorção em coluna foi utilizado para estudar a adsorção em uma amostra de solo compactado (KOIVULA et al., 2009). Este ensaio representa melhor as condições de adsorção reais em uma situação de aterro do que o ensaio de equilíbrio em lote, porque o fluxo de água e a proporção líquido/sólido são muito mais realistas. A proporção líquido/sólido da coluna representava um período de tempo de cerca de 40 anos em um aterro, sob clima finlandês. $\mathrm{O}$ pH do lixiviado das colunas estava entre 4 e 4,3 durante todo o ensaio. Os metais $\mathrm{Pb}, \mathrm{Cr}$ e $\mathrm{Cu}$ foram adsorvidos muito fortemente na camada superior da turfa (primeiros $2 \mathrm{~cm}$ ) e as quantidades de metais adsorvidas, em geral, foram mais elevadas do que no ensaio de equilíbrio em lote: $40.000 \mathrm{mg}$ de $\mathrm{Pb}$ por $\mathrm{kg}$ de turfa seca, $13.000 \mathrm{mg}$ de $\mathrm{Cr}$ por $\mathrm{kg}$ de turfa seca e $8.400 \mathrm{mg}$ de $\mathrm{Cu}$ por $\mathrm{kg}$ de turfa seca. As concentrações de metais no lixiviado foram bem menores que as concentrações de alimentação, de modo que mais de $99 \%$ de todos os metais foram adsorvidos à turfa.

Diante disso, Koivula et al. (2009) corroboraram que a capacidade de adsorção do material tem efeito significativo sobre a migração de contaminantes em uma estrutura de aterro. Para uma camada com $1 \mathrm{~m}$ de espessura e em condições meteorológicas finlandesas, conforme aproximação realizada durante o ensaio, o teste de coluna representou um período de aproximadamente 40 anos. Nessas condições apenas cerca de 1/5 da capacidade de adsorção da coluna foi utilizada. Portanto, segundo esses autores a turfa deve ser considerada na concepção 
de barreira de fundo de aterros de resíduos industriais e em áreas de deposição final para solos contaminados, de modo que a estrutura possa ser otimizada.

Lourie e Gjengedal (2011) partiram do princípio que muitos métodos físico-químicos utilizados no tratamento de águas residuais podem levar à contaminação da água por produtos químicos e/ou são consideravelmente dispendiosos economicamente, já que a água comumente apresenta uma baixa concentração de metal. Dessa forma, essa foi a razão dos pesquisadores se concentrarem em tecnologias alternativas, com base no uso de materiais naturais como casca, palha, turfa e algas, visando o tratamento de águas residuais. Foi avaliado ainda o tratamento de turfa com microalgas, o qual se mostrou ser uma forma eficaz de aumentar a sorção do metal, na medida em que resultou em menos tempo para se atingir um equilíbrio na adsorção. A afinidade de metais exibida pela turfa granulada apresentou a seguinte ordem: $\mathrm{Pb}>\mathrm{Cu}>\mathrm{Ni}>$ $\mathrm{Cd}>\mathrm{Zn}>\mathrm{Co}$. Já com o tratamento da turfa granulada com microalgas ocorreu ligeiras mudanças para: $\mathrm{Pb}>\mathrm{Cu}>\mathrm{Ni}>\mathrm{Cd} \approx \mathrm{Co} \approx \mathrm{Zn}$.

Abat et al. (2012) estudaram três turfas tropicais da Malásia no tocante a adsorção de $\mathrm{Cu}$ e $\mathrm{Zn}$, com vistas para a agricultura. Os pesquisadores trabalharam com a turfa em condições naturais com pH variando de 3,3 a 3,4, portanto, em condições ácidas, e essa mesma turfa tratada com carbonato de cálcio, elevando o $\mathrm{pH}$ para 5,5, já que muitas culturas requerem um pH superior a 4,5 para seu crescimento ótimo. Nas três turfas estudadas, a adsorção de ambos os metais, $\mathrm{Cu}$ e $\mathrm{Zn}$, aumentaram com a elevação do $\mathrm{pH}$. Os autores ajustaram ainda a equação de Freundlich aos dados de adsorção, encontrando valores de $\mathrm{K}_{\mathrm{f}}$ maiores para o $\mathrm{Cu}$ do que para o Zn, tanto no controle como nas turfas que sofreram adição de carbonato de cálcio, indicando que o $\mathrm{Cu}$ é muito mais fortemente adsorvido pelos solos que o $\mathrm{Zn}$. Assim, o íon $\mathrm{Cu}$ provavelmente é menos móvel nesses solos. Por conseguinte, a aplicação de fertilizantes contendo $\mathrm{Cu}$ e $\mathrm{Zn}$ nesses solos com turfa, principalmente se combinado com a aplicação de carbonato de cálcio, poderiam resultar em uma quantidade significativa do $\mathrm{Cu}$ e $\mathrm{Zn}$ fortemente adsorvida na matéria orgânica, perdendo a sua eficácia para o crescimento das culturas.

Lee et al. (2013) pesquisaram a eficiência da turfa na imobilização de Pb presente no solo. O solo contaminado com $\mathrm{Pb}\left(2.000 \mathrm{mg} \mathrm{kg}^{-1}\right)$ foi alterado com $1 \%, 5 \%$ e $10 \%$ de turfa e a imobilização de $\mathrm{Pb}$ foi avaliada através de um ensaio de lixiviação em coluna, um teste de microcosmos e um teste de incubação em lote. Os resultados mostraram que a turfa reduziu, significativamente, a lixiviação de $\mathrm{Pb}$ em todos os experimentos, podendo ser utilizada de forma eficaz para a recuperação de solos contaminados com $\mathrm{Pb}$. De forma mais precisa, o $\mathrm{Pb}$ imobilizado dos solos tratados com 1\%, 5\% e 10\% de turfa foi de, respectivamente, 37,9\%, 
$87,1 \%$, e $95,4 \%$ para o teste de lixiviação em coluna, $18,5 \%, 90,9 \%$, e $96,4 \%$ para o teste de microcosmos e 2,0\%, 36,9\%, e 57,9\% para o teste de incubação em lote.

\subsection{Adsorção}

O solo é um sistema complexo e diversas reações podem ocorrer simultaneamente. Baird (2002) afirma que os metais potencialmente tóxicos podem ser retidos no solo e nos materiais reativos orgânicos através de três maneiras: por adsorção (sobre as superfícies das partículas); por complexação (pelas substâncias húmicas associadas as partículas orgânicas) e por reações de precipitação.

Contudo, a partição dos contaminantes, ou seja, a transferência química e física de sua massa a partir da solução para as superfícies dos sólidos do solo e de materiais reativos, apresenta, geralmente, a sorção como mecanismo primário e principal (YONG; MULLIGAN, 2004). O termo sorção trata-se de uma expressão geral associada a um processo no qual um componente se movimenta a partir de uma fase para ser acumulado em outra fase, particularmente para os casos em que a segunda fase é sólida. Ele envolve tanto a adsorção (em uma superfície bidimensional) como a absorção (em uma matriz tridimensional), sendo que a distinção entre estes fenômenos não é clara para muitos sistemas ambientais (WEBER, 1972; WEBER; DIGIANO, 1996; STUMM; MORGAN, 1996).

A absorção pode ser considerada como um processo no qual as moléculas, íons ou átomos de uma fase interpenetram-se ou introduzem-se na outra fase, ficando assim, absorvidas. Segundo Weber e DiGiano (1996), a absorção pode ocorrer em um sistema gás-gás, líquidolíquido, gás-líquido, gás-sólido e líquido-sólido. A condição de equilíbrio de absorção está associada a uma distribuição intrafásica uniforme das espécies químicas, sendo que esta distribuição provavelmente será diferente entre as fases, mas será uniforme dentro de cada fase. Ademais, o particionamento de uma espécie química entre diferentes fases depende da sua compatibilidade termodinâmica relativa ou solubilidade nessas fases.

Já a adsorção corresponde ao processo através do qual uma substância química se acumula no limite comum de duas fases, tais como, líquido-líquido, líquido-gás, gás-sólido ou líquido-sólido, sendo a base dos processos químicos superficiais (WEBER, 1972; STUMM; MORGAN, 1996; SPOSITO, 2004). A maioria dos fenômenos de adsorção é composta por alguma combinação de forças relacionadas ao solvente e ao adsorvente (WEBER; DIGIANO, 1996). Se a reação produz aumento da substância em uma camada interfacial, o processo é dito 
adsorção positiva. Se, em vez disso, é produzido um esgotamento da substância, o processo é denominado adsorção negativa (SPOSITO, 2004).

A adsorção ocorre em solos quando se acumulam solutos aquosos nas superfícies minerais ou na matéria orgânica particulada (ZACHARA; WESTALL, 1998), influenciando a distribuição dessas substâncias entre as fases aquosa e sólida, afetando seu transporte e produzindo um efeito pronunciado sobre sua especiação. Este mecanismo influencia a reatividade das superfícies e afeta as propriedades eletrostáticas de partículas suspensas e coloides, o que, por sua vez, influencia sua tendência de agregação e ligação (STUMM; MORGAN, 1996). Assim, trata-se de um mecanismo fundamental no solo que, na prática, do ponto de vista agronômico, interfere diretamente nas conexões de nutrientes e, por outro lado, do ponto de vista ambiental, exibe a capacidade do solo de proporcionar a atenuação da mobilidade de contaminantes, minimizando a introdução desses elementos na cadeia alimentar (ZACHARA; WESTALL, 1998; SOARES; CASAGRANDE, 2000).

A Figura 16 ilustra esquematicamente os processos de adsorção e absorção. É válido destacar que o caráter energético da adsorção pode ser muito mais complexo em relação à absorção, particularmente se as interfaces em que a adsorção ocorre são heterogêneas (WEBER; DIGIANO, 1996).

Figura 16 - Caracterização esquemática dos processos de absorção e adsorção

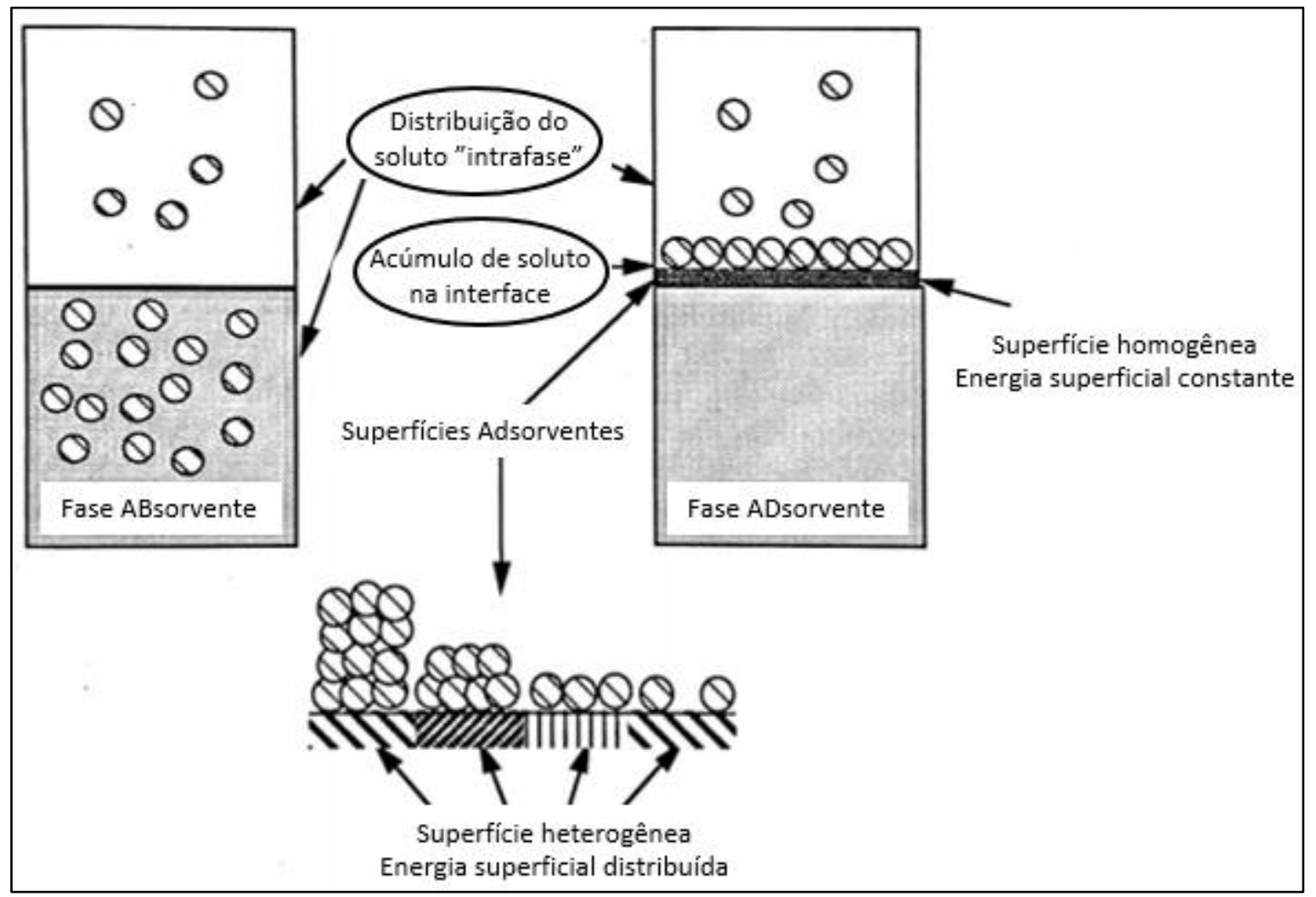

Fonte: Adaptado de Weber e DiGiano (1996). 
Os processos de absorção e adsorção revelam diferenças em termos termodinâmicos e fenomenológicos (WEBER; DIGIANO, 1996). Em termos fenomenológicos, as diferenças entre eles são ilustradas esquematicamente no gráfico apresentado na Figura 17, considerando uma substância que se desloca a partir da fase líquida para a fase sólida. No eixo das abcissas está representada a concentração das substâncias que migram pela fase líquida que se encontra em contato com a fase sólida (letra C). Já o eixo das ordenadas indica a quantidade da substância que se encontra aderida à interface líquido-sólido (termo qe) (WEBER, 1972).

Figura 17 - Tipos de sorção: I) Adsorção favorável; II) Adsorção linear e absorção; III) Adsorção desfavorável

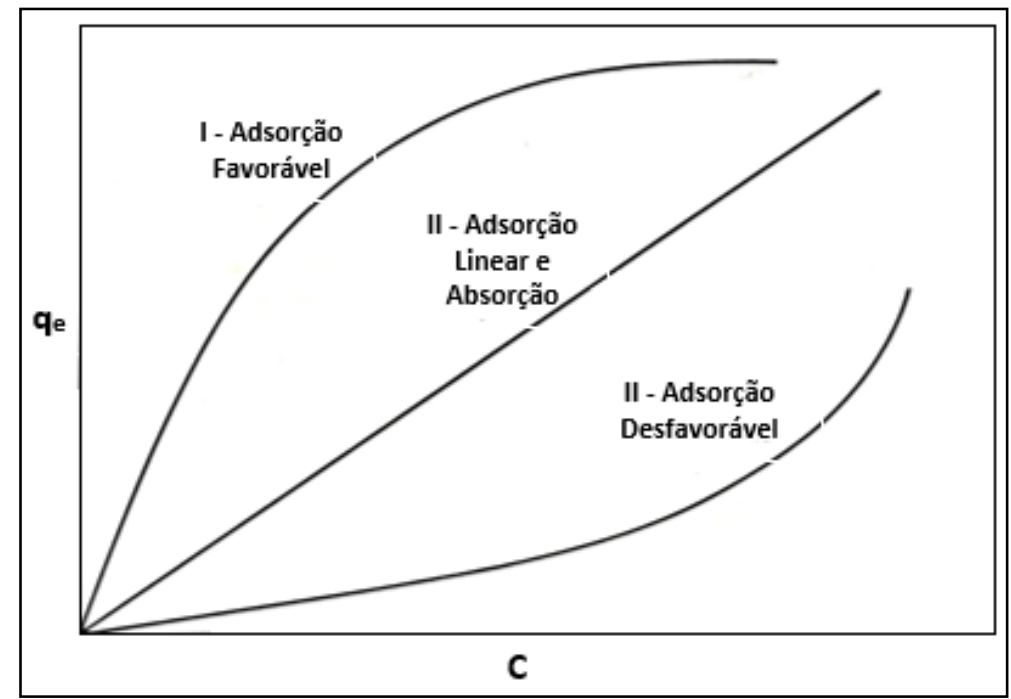

Fonte: Adaptado de Weber (1972).

Em relação à adsorção, as curvas I e III revelam a dependência, existente em formato curvilíneo, da quantidade de substância concentrada na superfície sólida com a quantidade remanescente dessa substância na fase de solução para padrões de separação favoráveis e desfavoráveis, respectivamente. Já a curva II mostra um exemplo de adsorção linear, como também um caso de absorção, que se manifesta segundo um modelo de proporção direta com a concentração (WEBER, 1972). O termo favorável refere-se a sorções nas quais a capacidade de retenção da fase sólida aumenta com a elevação da concentração em solução, gerando uma isoterma convexa. Nesses casos, a quantidade adsorvida por unidade de massa de adsorvente diminui apenas gradualmente à medida que a concentração de um contaminante diminui. Em contrapartida, as isotermas côncavas são consideradas desfavoráveis porque a sorção diminui acentuadamente com concentrações mais baixas. Assim o adsorvente perde eficiência rapidamente (WEBER; DIGIANO, 1996). 
A adsorção, por ser considerado como o principal processo de sorção (FREEZE; CHERRY, 1979), será mais detalhada nesta pesquisa. Para contaminação, de acordo com Yong (2001), as reações de adsorção são processos pelos quais os solutos (contaminantes) em solução se ligam às superfícies das partículas que compõem o solo e/ou materiais reativos. A matéria que se acumula em arranjos moleculares numa interface é denominada adsorvato; a superfície sólida sobre a qual se acumula esta substância é o adsorvente e uma molécula ou um íon passível de ser adsorvido é chamado adsorvível (SPOSITO, 1989). A Figura 18 ilustra, de modo esquemático, estas relações.

Figura 18 - Representação esquemática da nomenclatura usual dos componentes típicos do processo de adsorção

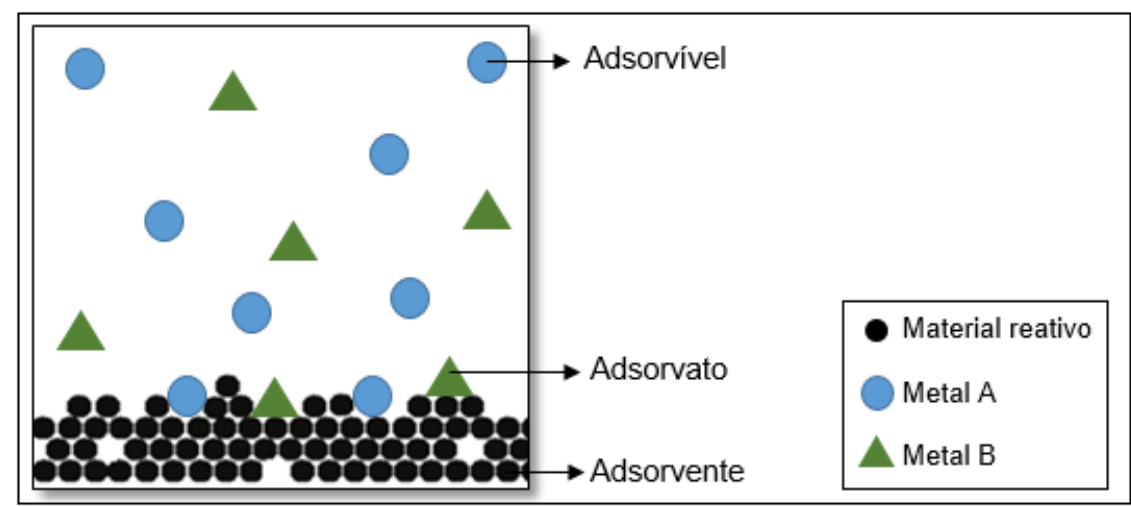

Fonte: A autora.

De acordo com Sposito (1989), as superfícies sólidas das partículas do solo e/ou de materiais reativos desenvolvem carga elétrica através de duas formas principais: substituições isomórficas entre íons de diferentes valências em minerais, ou a partir de reações de grupos funcionais de superfície com íons presentes na solução. Kabata-Pendias e Pendias (1984) complementa que em solos, as cargas superficiais são resultantes principalmente de substituições iônicas e estão relacionadas especialmente aos coloides.

Estas cargas podem ser positivas, nulas ou negativas, dependendo das condições químicas em que ocorre a adsorção. Nessa perspectiva, Langmuir (1997) afirma que uma fase sorvente dotada de uma carga superficial negativa líquida exibe uma capacidade de troca catiônica, enquanto uma fase contendo uma carga superficial positiva líquida revela uma capacidade de troca aniônica. Constata-se que a um pH baixo é prevalecida uma superfície carregada positivamente, enquanto que a um $\mathrm{pH}$ elevado se desenvolve uma superfície carregada negativamente. Assim, os coloides da maioria dos solos apresentam cargas negativas que podem ser eletroneutralizadas em virtude da associação com cátions presentes nas soluções 
circundantes. Consequentemente, quando está presente no sistema um excesso de cátions, esse processo de troca catiônica mantém sua eletroneutralidade (KABATA-PENDIAS; PENDIAS, 1984).

Ademais, a carga superficial pode ser permanente e independente da composição da solução contendo as partículas adsorvíveis, ou variável e dependente da composição da solução. Por exemplo, a capacidade de troca catiônica de esmectitas, vermiculitas e zeólitas é permanente e independente da química da solução. Em contraste, os oxi-hidróxidos metálicos e a caulinita apresentam uma carga superficial fortemente dependente do pH (LANGMUIR, 1997). De modo semelhante, a matéria orgânica apresenta carga fortemente dependente das condições do meio, principalmente do $\mathrm{pH}$, sendo um componente importante, por contribuir com cargas negativas em grande quantidade, geralmente superiores àquelas associadas a caulinita e aos óxidos de Fe e Al (ALLEONI; MELLO; ROCHA, 2016; LANGMUIR, 1997).

Portanto, os processos envolvidos na adsorção são governados pelas propriedades de superfície dos sólidos (orgânicos e inorgânicos) e a físico-química do lixiviado contaminante e dos seus componentes, tais como cátions, ânions e moléculas não iônicas. Entre os vários fenômenos que contribuem para a sorção, as interações químicas apresentam o principal objeto de interesse em casos de contaminação do solo (YONG; MOHAMED; WARKENTIN, 1992; YONG, 2001). Complementando esta afirmação, Yong (2001) ressalta que os vários mecanismos de sorção podem envolver tanto as forças químicas de curto alcance (como a ligação covalente), como as forças de longo alcance (como as forças eletrostáticas).

Assim, a ocorrência da adsorção se deve a existência de forças que atraem o adsorvato da solução para a superfície do adsorvente, sendo que essas forças de atração podem ter natureza física ou química. A adsorção física envolve apenas forças intermoleculares relativamente fracas (baixa afinidade de adsorção específica), incluindo tanto as forças de Van der Waals (dispersão-repulsão) como interações eletrostáticas que compreendem polarização e interações dipolo e quadrupolo. Já a adsorção química é uma ligação química, normalmente covalente, que ocorre entre uma molécula de adsorvato e átomos superficiais (superfície do adsorvente) (RUTHVEN, 1984; BOSCOV, 2008; SINGH; UEHARA, 1998). Ela exibe altas energias de adsorção, visto que o adsorvato constitui fortes laços com centros ativos do adsorvente (WEBER, 1972). Com esta adsorção específica de alta afinidade, o íon adsorvido torna-se parte da superfície e traduz sua carga para o sólido (SINGH; UEHARA, 1998). A interação química entre o adsorvente e o adsorvato é favorecida pela temperatura mais elevada, já que as reações químicas se processam mais rapidamente em maiores temperaturas do que em temperaturas mais baixas (WEBER, 1972). A adsorção é um processo reversível, o que possibilita que o 
contaminante venha a ser dessorvido, em função da passagem de água ou de uma solução salina (YONG; MOHAMED; WARKENTIN, 1992), sendo que a adsorção física é mais facilmente reversível que a adsorção química, devido às suas energias de ligação serem mais fracas (RUTHVEN, 1984; BOSCOV, 2008).

É importante destacar que a maioria dos casos de adsorção resultam de combinações envolvendo todas as formas de adsorção, já que diversas forças que influenciam os diferentes tipos de adsorção muitas vezes interagem, de forma conjunta, para promover a concentração de um soluto particular em uma interface. Assim, geralmente não é fácil distinguir entre adsorção física e química (WEBER, 1972).

No processo de adsorção, merecem destaque, os argilominerais e a matéria orgânica, os quais são dotados de um alto potencial de adsorção associado às suas forças de atração que são consequência de cargas desequilibradas presentes nas paredes dessas partículas (FREEZE; CHERRY, 1979). Neste contexto, a turfa e o composto, apresentam alta capacidade de adsorção, devido, principalmente, à presença de substâncias húmicas.

Conforme Petroni, Pires e Munita (2000), a forte atração da turfa pela maioria dos cátions metálicos em solução deve-se, principalmente, ao elevado teor de substâncias húmicas (ácidos húmico e fúlvico) na sua matéria orgânica. Estas substâncias são conhecidas como polímeros naturais, sendo ricas em grupos funcionais com cargas negativas, tais como ácidos carboxílicos e hidroxilas fenólicas e alcóolicas, que são justamente os sítios de adsorção dos metais em solução.

A adsorção de um contaminante não segue uma função, segundo a qual todos os contaminantes são adsorvidos até que se atinja uma capacidade máxima, com qualquer quantidade adicional permanecendo em solução. Há a existência de um equilíbrio entre a parcela do contaminante presente em solução e a parcela que é adsorvida. Desse modo, quando se trata de uma solução contendo pequenas quantidades de contaminantes, provavelmente apenas uma porção vestigial deles permanecerá em solução (YONG; MOHAMED; WARKENTIN, 1992).

Várias pesquisas, nacionais e internacionais, estudaram os mecanismos envolvidos na adsorção de metais potencialmente tóxicos pelos mais variados materiais reativos orgânicos, além da turfa e do composto, como nanotubos de carbono (IHSANULLAH et al., 2016), grânulos de celulose e quitina (ZHOU et al., 2004), pó de tabaco (QI; ALDRICH, 2008), esterco de vaca (OJEDOKUN; BELLO, 2016), serragem de madeira (RODRIGUES et al., 2006; BOŽIĆ et al., 2009), carvão de cascas de amendoim (RICORDEL et al., 2001), carvão ativado preparado a partir de semente de goiaba, fruto de palmeira e cascas de amêndoas tropicais 
(LARGITTE et al., 2016), carvão ativado preparado a partir de coco (KADIRVELU; THAMARAISELVI; NAMASIVAYAM, 2001), casca de coco verde (SOUSA et al., 2007), casca de laranja (FENG et al., 2011), casca de arroz (MIMURA et al., 2010; LATTUADA et al., 2014), resíduos de cascas de amendoim incineradas (TAHA; RICORDEL; CISSE, 2011), bagaço de caju (MOREIRA et al., 2009), resíduos de chá (AMARASINGHE; WILLIAMS, 2007), biomassa de macrófitas aquáticas (SCHNEIDER, 1995), e materiais reativos inorgânicos, como argila (GHORBEL-ABID; TRABELSI-AYADI, 2015), aluminossilicatos (AGUIAR; NOVAES; GUARINO, 2002), vermiculita (MALANDRINO et al., 2006), zeólita natural escolecita (BOSSO; ENZWEILER, 2002; DAL BOSCO; JIMENEZ; CARVALHO, 2004), diatomita (NAMOR et al., 2012), caulinita e bentonita (LIU et al., 2016).

Nota-se que dentre estas pesquisas citadas, indubitavelmente, a maioria delas avalia a adsorção com enfoque principalmente para o emprego dos materiais reativos no tratamento de águas residuais. No entanto, podem ser observadas algumas exceções, como BOŽIĆ et al. (2009), que optaram pela escolha de $\mathrm{Cu}, \mathrm{Zn}, \mathrm{Mn}, \mathrm{Cd}, \mathrm{Fe}$ e Ni, justamente por serem metais que aparecem com mais frequência na drenagem ácida de minas de $\mathrm{Cu}$.

\subsubsection{Ensaios de adsorção}

Segundo Yong, Mohamed e Warkentin (1992), não existe qualquer processo teórico, simples e fácil, que proporcione previsões quantitativas precisas, exatas ou próximas, dos constituintes que serão adsorvidos e como este processo ocorrerá, por qualquer tipo de solo e/ou material reativo, ao longo de um período de tempo. Também, não se pode especificar quantitativamente a relação entre o tempo de adsorção e o destino dos contaminantes como um resultado de seu transporte através do meio. No entanto, é necessário obter algum identificador físico sobre a capacidade de um solo e/ou material reativo para adsorver contaminantes. Então, reconhecendo a natureza variada da composição química de um lixiviado contaminante e uma natureza semelhantemente variada relacionada ao adsorvente, segue-se que a teoria ideal tem de ser apoiada com provas físicas.

De modo geral, os ensaios de adsorção são tipicamente compostos por uma sequência de três etapas essenciais: i) reação das espécies adsorvíveis com o adsorvente em contato com uma fase fluida de composição conhecida, sob temperatura e pressão controladas durante um período de tempo prescrito; ii) separação do adsorvente da fase fluida após a reação; e iii) quantificação da substância química adsorvida (SPOSITO, 2004). Assim, para o estudo das características da adsorção, duas técnicas experimentais são comumente empregadas em 
laboratório: o teste de equilíbrio em lote e o ensaio de adsorção em coluna (YONG; MOHAMED; WARKENTIN, 1992).

Os testes de equilíbrio em lote (também denominados de batch test) possibilitam a obtenção das constantes para as isotermas de adsorção e são aplicados a suspensões de solo e/ou material reativo. O modelo físico que se assume com esta situação é de um sistema contendo partículas adsorventes completamente dispersas onde todas as superfícies dessas partículas estão expostas e disponíveis para interação com os contaminantes. Para isso, é preparada uma suspensão com o material reativo previamente seco, em quantidade conhecida, para posterior mistura com os contaminantes, também presentes em quantidade conhecida (YONG; MOHAMED; WARKENTIN, 1992; LANGMUIR, 1997). Sistematicamente, podem ser variadas as concentrações de adsorvente e adsorvato e o pH do sistema (LANGMUIR, 1997).

O tempo de contato do ensaio deve ser predeterminado e ao seu término se admite que o sistema atingiu o estado de equilíbrio da reação (SOARES, CASAGRANDE, 2000). Segundo Zuquette, Silva Jr. e Garcia (2008), o tempo é um fator determinante neste tipo de ensaio, devendo ser suficiente para que ocorra o máximo de sorção. Entretanto, ele deve ser limitado, pois em tempos muito extensos podem ocorrer reações químicas, que não sejam a sorção.

O ensaio de equilíbrio em lote é uma metodologia simples, rápida e replicável, portanto, altamente empregada em estudos de adsorção/dessorção. De acordo com Soares e Casagrande (2000), este método apresenta algumas limitações, tais como: i) a quantidade adsorvida é estimada a partir da variação entre as concentrações inicial e de equilíbrio, sendo assim, caso esta diferença seja pequena em relação ao erro analítico, a medição da adsorção apresentará uma falsa exatidão; ii) a proporção solo/solução empregada, comumente se encontra entre 1/5 e 1/100, não reproduzindo as condições de campo e, por conseguinte, apresentando uma aplicação prática questionável; iii) a agitação e a dispersão da suspensão possibilita que as partículas adsorventes exibam uma superfície de contato superior àquela evidenciada em condições reais; e iv) o equilíbrio físico não é considerado.

Os ensaios de coluna são realizados com amostras de solo e/ou material reativo com uma estrutura definida (material indeformado). Assim, as características da adsorção obtidas são o resultado da interação dos contaminantes com um sistema de estrutura em que nem todas as superfícies das partículas do material reativo estão expostas ou disponíveis para interação com contaminantes químicos presentes (YONG; MOHAMED; WARKENTIN, 1992).

Comparando estas duas metodologias, os testes de equilíbrio em lote apresentam como condição estável o estado de equilíbrio e a concentração de adsorvato diminui enquanto os íons 
dessorvidos aumentam. Já as colunas, com uma concentração de metal em solução constante, manifestam como estado estável a saturação dos sítios de adsorção e os íons adsorvidos são periodicamente substituídos sendo que os íons dessorvidos são lixiviados. Portanto, no ensaio de equilíbrio em lote a condição de estabilidade é alcançada no momento em que a energia da reação de adsorção é igual à energia da reação de dessorção e, por outro lado, no método de coluna a reação reversa é eliminada possibilitando que a reação de adsorção seja concluída antes que o estado de equilíbrio seja atingido (HARTER; NAIDU, 2001).

Diante disso, os resultados gerados nos ensaios de equilíbrio em lote e nos ensaios de coluna, por envolverem sistemas totalmente diferentes, não são diretamente comparáveis. Enquanto os ensaios de equilíbrio em lote avaliam a adsorção de um metal por suspensões de solo, em um sistema fechado, os ensaios de coluna estudam a adsorção e a difusão de íons, em um sistema aberto. Assim, o ensaio de equilíbrio em lote apresenta resultados que se aproximam mais do comportamento dos íons de interesse e as colunas reproduzem melhor o movimento do adsorvato em condições reais (HARTER; NAIDU, 2001).

Após a realização de ensaio de equilíbrio em lote e ensaio de coluna, visando avaliar a adsorção de metais pela turfa, Koivula et al. (2009) observaram que o ensaio de equilíbrio em lote não descreveu muito bem a adsorção em turfa compactada, porque ele subestimou a adsorção devido, principalmente, ao efeito do $\mathrm{pH}$ e uma razão líquido/sólido irreal. O efeito do pH do líquido é grande no ensaio de equilíbrio em lote, sendo maior do que em um ambiente real. Em geral, metais e outros íons inorgânicos tendem a adsorver prontamente a pH mais elevado. Além disso, os metais foram adsorvidos fortemente à superfície da amostra no teste de coluna e foram adsorvidos em camadas mais profundas apenas quando quase todos os locais de adsorção na superfície estavam ocupados. Este fenômeno não poderia ser estudado no ensaio de equilíbrio em lote. No entanto, de acordo com Yong, Mohamed e Warkentin (1992), os testes de equilíbrio em lote podem fornecer informações valiosas no tocante às características de sorção de um solo ou material reativo.

\subsubsection{Modelos de adsorção}

As reações de sorção de metais em solos têm sido descritas usando uma matriz de ordem empírica, semi-empírica e modelos de complexação de superfície. Em alguns casos, estes modelos descrevem bem os dados de adsorção e são, muitas vezes, úteis para descrever a sorção dos metais ao longo de um intervalo de valores de $\mathrm{pH}$ e força iônica. De fato, muitos desses modelos têm inúmeros parâmetros reguláveis e, portanto, seus dados de adsorção resultantes são bem descritos. A maioria dos modelos de sorção requerem, muitas vezes, ajustes de curvas. 
No entanto, alguns destes modelos podem descrever vários mecanismos diferentes de sorção. Assim, a conformidade dos dados para um determinado modelo não prova que um mecanismo específico está ocorrendo (SPARKS, 1995b).

\subsubsection{Equilíbrio de adsorção - Isotermas}

A adsorção positiva em um sistema envolvendo uma fase sólida e outra líquida resulta na remoção de solutos que estavam presentes na solução e na sua consequente concentração na superfície do sólido. Com o avanço desse processo, em um dado momento, a concentração de soluto que permaneceu em solução entra em equilíbrio dinâmico com a concentração presente na superfície. Justamente durante este equilíbrio, existe uma distribuição definida de soluto entre as fases líquida e sólida. Essa taxa de distribuição é uma medida da posição de equilíbrio no processo de adsorção, podendo ser uma função de diversos fatores, como da concentração de soluto, da concentração e da natureza dos solutos concorrentes e da natureza da solução. A maneira usualmente preferida para descrever esta distribuição é expressando graficamente a quantidade de soluto adsorvido por unidade de massa do adsorvente sólido em função da concentração de soluto que permaneceu em solução no equilíbrio. Uma expressão deste tipo é denominada isoterma de adsorção (WEBER, 1972), recebendo esta denominação por envolver dados coletados sob efeito de uma temperatura constante (BOSCOV, 2008).

As chamadas isotermas de adsorção devem ser empregadas como uma ferramenta de previsão do comportamento da adsorção (ZUQUETTE; SILVA Jr; GARCIA, 2008), já que os resultados experimentais podem fornecer, de forma direta, alguns parâmetros quantitativos da reação de adsorção, como a porcentagem de remoção do contaminante (A\%) e a concentração de soluto adsorvida pelo adsorvente $\left(\mathrm{q}_{\mathrm{e}}\right)$. Estes parâmetros diretos podem ser obtidos a partir das Equações 1 e 2, respectivamente (SOARES, CASAGRANDE, 2000):

$$
\begin{gathered}
A \%=\left(\frac{C_{0}-C_{e}}{C_{0}}\right) 100 \\
q_{e}=\frac{V_{\text {solução }}\left(C_{0}-C_{e}\right)}{M_{\text {adsorvente }}}
\end{gathered}
$$

Onde:

A\%: porcentagem de adsorção do contaminante (\%);

$\mathrm{C}_{0}$ : concentração de soluto na solução inicialmente adicionada $\left(\mathrm{mg} \mathrm{L}^{-1}\right)$;

$\mathrm{C}_{\mathrm{e}}$ : concentração de soluto na solução em equilíbrio $\left(\mathrm{mg} \mathrm{L}^{-1}\right)$; 
$\mathrm{q}_{\mathrm{e}}$ : concentração de soluto adsorvida pelo adsorvente $\left(\mathrm{mg} \mathrm{g}^{-1}\right)$;

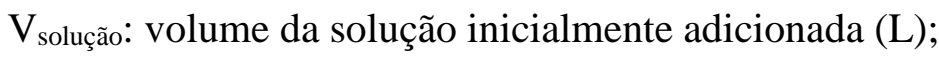

$\mathrm{M}_{\text {adsorvente: }}$ massa de adsorvente $(\mathrm{g})$.

No entanto, outros indicadores numéricos podem ser conseguidos a partir da utilização de artifícios matemáticos simples, geralmente embasados na conversão da representação gráfica dos resultados experimentais em parâmetros numéricos dotados de fácil interpretação (SOARES, CASAGRANDE, 2000).

Geralmente, a quantidade de material adsorvido por unidade de massa de adsorvente aumenta com o incremento da concentração, mas isso comumente não ocorre de forma proporcionalmente direta (WEBER, 1972; LANGMUIR, 1997). Uma isoterma típica indica que a fração mais elevada da espécie adsorvida é observada nas concentrações mais baixas de adsorvato, correspondendo à parte mais íngreme da isoterma. Dito de forma diferente, menor a concentração de uma substância dissolvida, maior a fração dela que será adsorvida (LANGMUIR, 1997). Harter e Naidu (2001) complementam que, geralmente, o rápido aumento da sorção é resultado de variações na carga superficial e de mudanças nas espécies iônicas presentes na solução. Uma isoterma pode ser considerada completa quando o soluto atingiu seu valor de saturação no solvente (GILES; SMITH; HUITSON, 1974).

Um modelo particular pode ser definido com o intuito de descrever dados experimentais com precisão sob um conjunto específico de condições, porém não em condições diferentes. Nenhum modelo único foi encontrado como sendo aplicável, o que pode ser dito como plausível, haja vista as suposições restritivas associadas com os desenvolvimentos de tais modelos e a complexidade e variabilidade de sistemas e superfícies ambientais (WEBER; DIGIANO, 1996).

Assim, pode-se considerar a associação dos dados experimentais a um modelo de adsorção isotérmica apropriado como um elemento importante da implementação de um processo de adsorção de íons metálicos (BARTCZAK et al., 2015).

Existem vários modelos para representar o equilíbrio de adsorção. Em se tratando de solução monocomponente, as isotermas mais empregadas são a linear, a de Freundlich e a de Langmuir. A Figura 19 mostra as formas típicas dessas isotermas de adsorção ditas mais populares. É importante destacar que tanto a isoterma linear como a de Freundlich preveem adsorção ilimitada e devem ser usadas com base em limites definidos a partir de informação experimental. 
Figura 19 - Diferentes tipos de isotermas de adsorção

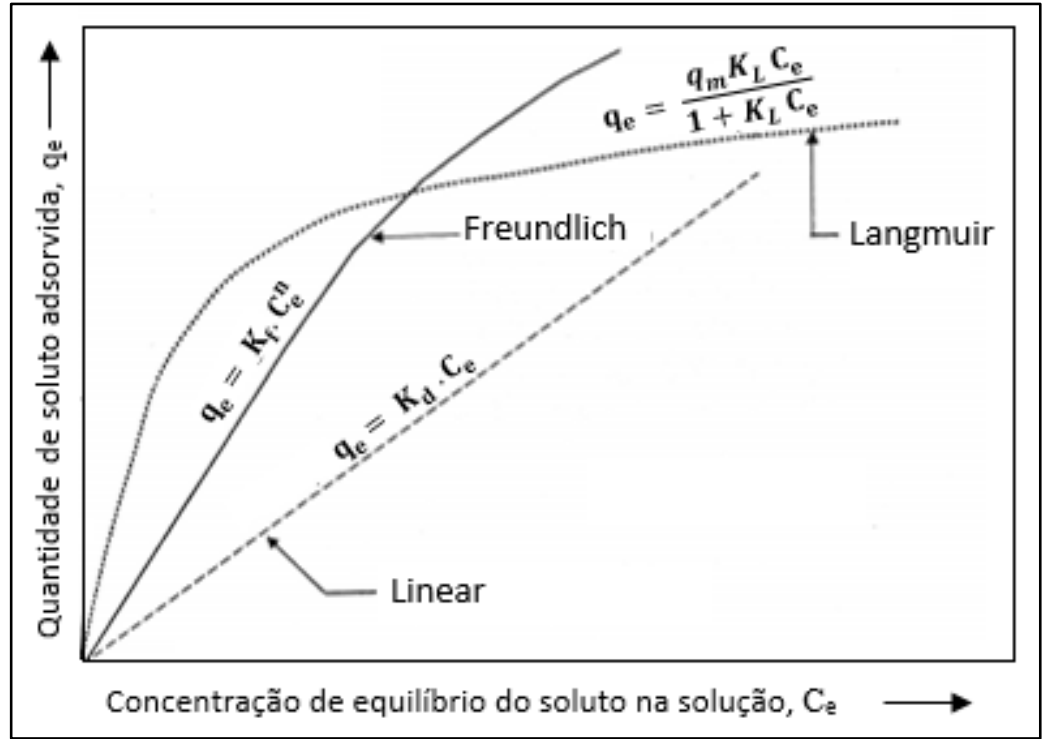

Fonte: Adaptado de Yong e Mulligan (2004).

Diversos autores utilizam diferentes símbolos para representar os parâmetros envolvidos nessas isotermas, conforme mostrado nas formulações exibidas no Quadro 6. 
Quadro 6 - Modelos de equilíbrio de sorção (Linear, Freundlich, Freundlich linearizada, Langmuir, Langmuir I e Langmuir II)

\begin{tabular}{|c|c|c|c|c|c|c|}
\hline Linear & Freundlich & Freundlich linearizada & Langmuir & Langmuir I & Langmuir II & Autor \\
\hline- & $\frac{x}{m}=K_{f} C^{1 / n}$ & $\log \left(\frac{x}{m}\right)=\log K_{f}+\frac{1}{n} \log C$ & $\frac{x}{m}=\frac{K_{L} M C}{1+K_{L} C}$ & $\frac{C}{x / m}=\frac{1}{K_{L} M}+\frac{C}{M}$ & $\frac{1}{x / m}=\frac{1}{K_{L} M C}+\frac{1}{M}$ & $\begin{array}{l}\text { Roy et al. } \\
\text { (1992) }\end{array}$ \\
\hline$q=K_{p} C$ & $q=K_{d} C^{1 / n}$ & - & $q=\frac{k C b}{1+k C}$ & $\frac{C}{q}=\frac{1}{k b}+\frac{C}{b}$ & - & $\begin{array}{l}\text { Sparks } \\
(1995 a)\end{array}$ \\
\hline$K_{d}=\frac{C_{s}}{C_{w}}$ & $\begin{array}{c}\Gamma=m[A]^{n} \\
\quad \text { ou } \\
C_{s}=m C_{w}^{n}\end{array}$ & - & $\Gamma=\Gamma_{\max } \frac{K_{a d s}[A]}{1+K_{a d s}[A]}$ & - & - & $\begin{array}{l}\text { Stumm e } \\
\text { Morgan } \\
(1996)\end{array}$ \\
\hline$\frac{x / m}{C}=K_{d}$ & $\frac{x}{m}=K C^{n}$ & $\log \frac{x}{m}=\log K+\mathrm{n} \log C$ & $\frac{x}{m}=\frac{a C}{1+b C}=\frac{b C N_{\max }}{1+b C}$ & $\frac{C}{x / m}=\frac{1}{b N_{\max }}+\frac{C}{N_{\max }}$ & $\frac{1}{x / m}=\frac{1}{b C N_{\max }}+\frac{1}{N_{\max }}$ & $\begin{array}{l}\text { Langmuir } \\
\text { (1997) }\end{array}$ \\
\hline- & $q_{e}=a C_{e}^{b}$ & $\ln q_{e}=\mathrm{b} \ln C_{e}+\ln a$ & $q_{e}=\frac{K_{L} C_{e}}{1+a_{L} C_{e}}$ & $\frac{C_{e}}{q_{e}}=\frac{1}{K_{L}}+\frac{a_{L}}{K_{L}} C_{e}$ & - & $\begin{array}{c}\text { McKay e Porter } \\
\text { (1997) }\end{array}$ \\
\hline$S=K_{d} C_{e}$ & $S=K_{f} C_{e}^{N}$ & $\log S=\mathrm{N} \log C_{e}+\log K_{f}$ & $S=\frac{S_{m} b C_{e}}{1+b C_{e}}$ & $\frac{C_{e}}{S}=\frac{1}{S_{m} b}+\frac{C_{e}}{S_{m}}$ & $\frac{1}{S}=\frac{1}{b S_{m} C_{e}}+\frac{1}{S_{m}}$ & $\begin{array}{c}\text { Fagundes e } \\
\text { Zuquette (2009) }\end{array}$ \\
\hline$S_{e}=K_{f} C_{l}$ & $S_{e}=K_{f} C_{l}^{N}$ & $\log S_{e}=\log K_{f}+\mathrm{N} \log C_{e}$ & $S_{e}=\frac{a Q C_{l}}{1+a C_{l}}$ & $\frac{C_{l}}{S_{e}}=\frac{1}{a Q}+\frac{C_{l}}{Q}$ & $\frac{1}{S_{e}}=\frac{1}{a Q C_{l}}+\frac{1}{Q}$ & $\begin{array}{l}\text { Don Scott } \\
(2000)\end{array}$ \\
\hline[]$_{a d s}=K_{f} C_{e}$ & {[]$_{a d s}=K_{f} C_{e}^{n}$} & $\log []_{a d s}=\log K_{f}+\mathrm{n} \log C_{e}$ & {[]$_{a d s}=\frac{A d s_{\text {máx }} K_{L} C_{e}}{1+K_{L} C_{e}}$} & $\frac{C_{e}}{[]_{a d s}}=\frac{1}{K_{L} A d s_{\text {máx }}}+\frac{1 C_{e}}{A d s_{m a ́ x}}$ & - & $\begin{array}{c}\text { Soares e } \\
\text { Casagrande } \\
(2000)\end{array}$ \\
\hline$c^{*}=k_{1} c+k_{2}$ & $c^{*}=k_{1} c^{k_{2}}$ & $\log c^{*}=\log k_{1}+k_{2} \log c$ & $c^{*}=\frac{k_{1} c}{1+k_{2} c}$ & - & - & Yong (2001) \\
\hline
\end{tabular}




\subsection{Isoterma Linear}

A isoterma linear corresponde ao modelo mais simples de adsorção, ao admitir proporcionalidade direta. De acordo com Fagundes e Zuquette (2009) esta isoterma estima à sorção de soluto em concentrações infinitamente crescentes.

$\mathrm{Na}$ literatura relacionada à ciência do solo, muitas vezes, esse modelo de equilíbrio é representado pela Equação 3:

$$
q_{e}=K_{d} \cdot C_{e} \quad \text { (Equação 3) }
$$

Onde:

qe: concentração de soluto adsorvida pelo adsorvente (mg de soluto/g de adsorvente);

$\mathrm{K}_{\mathrm{d}}$ : coeficiente de distribuição de equilíbrio ( $\mathrm{L}$ de solução/g de adsorvente);

$\mathrm{C}_{\mathrm{e}}$ : concentração de soluto na solução em equilíbrio (mg de soluto/L de solução).

Segundo Anderson e Christensen (1988), a mobilidade de metais potencialmente tóxicos é frequentemente caracterizada pelo coeficiente de distribuição $\left(K_{d}\right)$, definido como a razão entre as concentrações do metal na fase sólida e na solução em equilíbrio. Nessa perspectiva, valores reduzidos de $\mathrm{K}_{\mathrm{d}}$ revelam que a maior parte do metal permanece em solução, estando disponível para o transporte e para reações biológicas ou geoquímicas. Enquanto isso, valores elevados de $\mathrm{K}_{\mathrm{d}}$ refletem que o metal foi retido pelo sólido através de reações de sorção, ou seja, o sólido adsorvente apresenta grande afinidade pelo contaminante.

Conforme Don Scott (2000), graficando-se qe versus $\mathrm{C}_{\mathrm{e}}$ obtém-se uma linha cuja inclinação é igual ao valor de $\mathrm{K}_{\mathrm{d}}$ (Figura 20). Portanto, a sorção de um determinado soluto pode ser comparada para uma série de adsorventes, ou diferentes solutos podem ser comparados para um dado tipo de adsorvente.

Figura 20 - Representação da isoterma linear. À esquerda, modelo tradicional. À direita, método gráfico para determinação das constantes

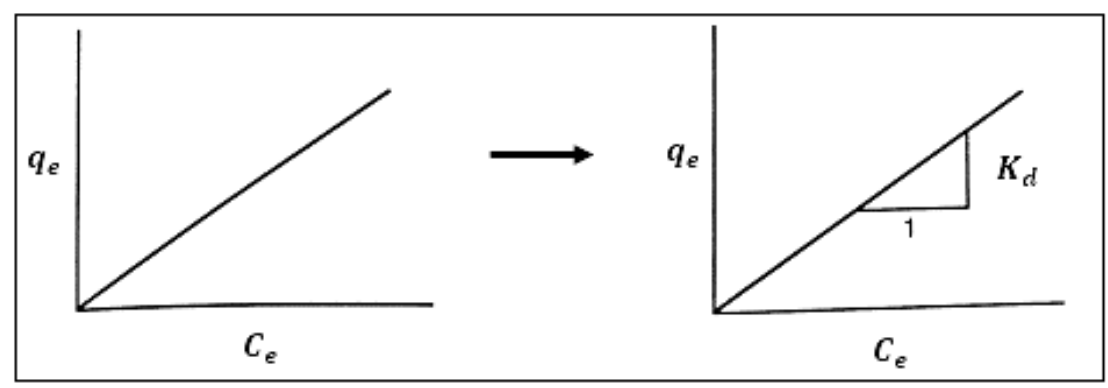

Fonte: Adaptado de Weber e DiGiano (1996). 
A obtenção de valores de $K_{d}$ para metais é mais complexa do que para compostos orgânicos, haja vista que para grande parte dos contaminantes inorgânicos, esse coeficiente revela uma grande variação de valores, como resultado de alterações em virtude das condições do adsorvente aliadas às diferenças entre os métodos experimentais (SOARES; CASAGRANDE, 2000).

A relação de equilíbrio exibida pela isoterma linear de adsorção implica em uma taxa constante de adsorção, o que, comumente, não é válido fisicamente. Na prática, ocorre exatamente o contrário das expectativas do modelo linear, uma vez que a capacidade das partículas para adsorver íons do soluto diminui à medida em que a quantidade adsorvida dos íons aumenta (YONG; MOHAMED; WARKENTIN, 1992).

\subsection{Isoterma de Freundlich}

Outro modelo de equilíbrio de adsorção empírica é a equação de Freundlich. Segundo Fagundes e Zuquette (2009), este modelo é uma evolução da isoterma linear e surgiu para melhor representar os processos de sorção que se apresentam através de curvas.

Este modelo pode expressar matematicamente a relação entre a concentração adsorvida e a concentração de equilíbrio, conforme descrito pela Equação 4:

$$
q_{e}=K_{f} \cdot C_{e}^{n} \quad \text { (Equação 4) }
$$

Onde:

$\mathrm{K}_{\mathrm{f}}$ : constante de equilíbrio de Freundlich (L de solução/g de adsorvente);

n: coeficiente exponencial de Freundlich (adimensional).

O coeficiente $n$ está relacionado ao tipo de sorção. Quando $n>1$ a sorção é dita favorável; quando $\mathrm{n}<1$, desfavorável e quando $\mathrm{n}=1$ a sorção se iguala ao modelo linear (FAGUNDES; ZUQUETTE, 2009).

O modelo de Freundlich assume que não existe uma concentração limitante do adsorvato já que a concentração da solução é aumentada sem limite. Isto é razoável, visto que qualquer adsorvente deve ter uma quantidade limitada de superfície disponível para adsorção e, portanto, uma quantidade máxima de adsorção (DON SCOTT, 2000).

Soares e Casagrande (2000) complementam que a isoterma de Freundlich apresenta uma capacidade prognóstica limitada a soluções muito diluídas e considera que a superfície de 
adsorção é heterogênea e a energia de adsorção diminui logaritmicamente em função da cobertura da superfície do adsorvente pelo adsorvato.

Para simplificação da modelagem, Fagundes e Zuquette (2009) sugeriram o uso da forma logarítmica que possibilita a obtenção dos parâmetros através de regressão.

A forma logarítmica é linear e é representada pela Equação 5:

$$
\log q_{e}=\log K_{f}+n \log C_{e} \quad \text { (Equação 5) }
$$

A partir desta formulação, $n$ corresponde ao coeficiente angular da reta, enquanto log $\mathrm{K}_{\mathrm{f}}$ é a interceptação da reta no eixo das ordenadas de um diagrama $\log \mathrm{q}_{\mathrm{e}}$ versus $\log \mathrm{C}_{\mathrm{e}}$ (FAGUNDES; ZUQUETTE, 2009) (Figura 21).

Figura 21 - Representação da isoterma de Freundlich. À esquerda, modelo tradicional. À direita, método gráfico para determinação das constantes

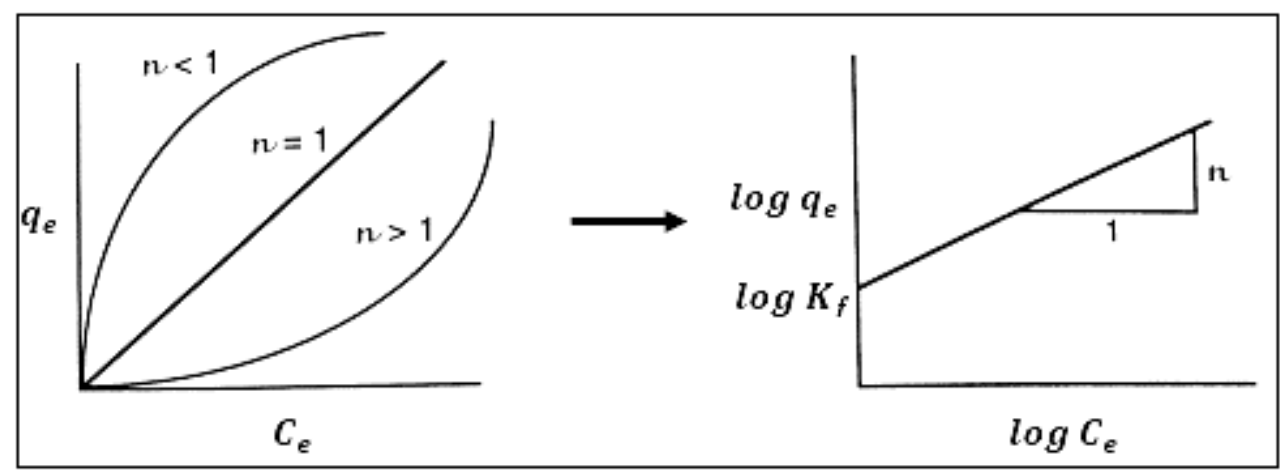

Fonte: Adaptado de Weber e DiGiano (1996).

Um aumento no pH dos sistemas naturais tende a favorecer a remoção da maioria dos elementos traços da solução, especialmente cátions. Sua remoção ocorre, geralmente, por adsorção e/ou por precipitação em sólidos que se tornam insolúveis com o aumento do $\mathrm{pH}$. Os sólidos adsorventes já podem estar presentes no sistema ou podem ser sólidos que precipitaram, tais como carbonatos metálicos. Os elementos traços podem precipitar em seus próprios sólidos puros, entretanto, na maioria das vezes, eles são co-precipitados. Nessa perspectiva, os valores resultantes de $\mathrm{K}_{\mathrm{f}}$ descrevem a remoção de elementos traços (metais potencialmente tóxicos) da solução por todos esses mecanismos combinados. Assim, esses valores apenas descrevem o comportamento do sistema no qual foram medidos. Consequentemente, supondo que um único valor de $\mathrm{K}_{\mathrm{f}}$ seja utilizado para predizer a remoção de uma espécie dissolvida em córregos, solos ou águas subterrâneas, geralmente, ocorrerão erros graves para espécies que formam complexos 
fortes, precipitam em sólidos insolúveis ou estão sujeitas a oxidação ou redução (LANGMUIR, 1997). Ainda segundo o referido autor, quando os valores de $K_{f}$ estão relacionados predominantemente a um processo de sorção, verificou-se que $\log \mathrm{K}_{\mathrm{f}}$ frequentemente varia linearmente em função do $\mathrm{pH}$, pelo menos para uma faixa de valores de $\mathrm{pH}$.

\subsection{Isoterma de Langmuir}

O último modelo de sorção de equilíbrio considerado é representado pela isoterma de Langmuir. Ele apresenta uma boa base conceitual, uma vez que foi desenvolvido a partir da cinética de adsorção de gases em superfícies sólidas (DON SCOTT, 2000). Proposto pelo químico Irving Langmuir, este modelo apresenta como pressupostos básicos: i) as moléculas são adsorvidas por um número fixo de sítios com localização definida, com adsorção em monocamada; ii) cada sítio pode conter apenas uma molécula de adsorvato; e iii) todos os sítios são energicamente equivalentes e não há interação entre as moléculas adsorvidas em sítios vizinhos (RUTHVEN, 1984). Essas considerações estão esquematizadas na Figura 22.

Figura 22 - Esquema básico para o desenvolvimento do Modelo de Langmuir

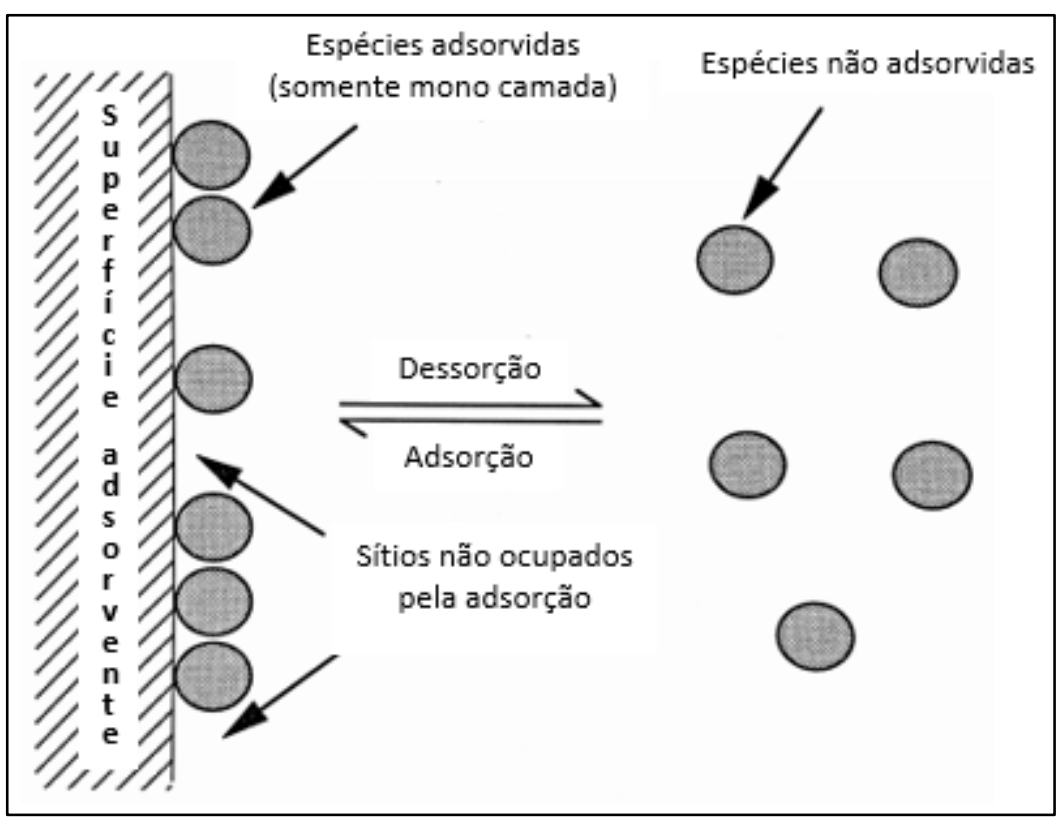

Fonte: Adaptado de Weber e DiGiano (1996). 
O modelo proposto por Langmuir pode ser expresso pela Equação 6:

$$
q_{e}=\frac{q_{m} K_{L} C_{e}}{1+K_{L} C_{e}} \quad \text { (Equação 6) }
$$

Onde:

qm: capacidade de adsorção ou número total de locais de adsorção disponíveis, isto é, a quantidade máxima de íons ou molécula que irão ser absorvidos (mg de soluto/g de adsorvente);

$\mathrm{K}_{\mathrm{L}}$ : constante de adsorção de Langmuir relacionada à energia de ligação (L de solução/mg de soluto).

Com o intuito de simplificar a obtenção dos parâmetros de Langmuir ( $\left.\mathrm{q}_{\mathrm{m}} \mathrm{e} \mathrm{K}_{\mathrm{L}}\right)$, Fagundes e Zuquette (2009) explicam que duas linearizações podem ser utilizadas, denominadas Langmuir I (expressa na Equação 7) e Langmuir II (apresentada na Equação 8). Essas linearizações, segundo Don Scott (2000), são expressas matematicamente como:

$$
\begin{array}{ll}
\frac{C_{e}}{q_{e}}=\frac{1}{K_{L} q_{m}}+\frac{C_{e}}{q_{m}} & (\text { Equação 7) } \\
\frac{1}{q_{e}}=\frac{1}{K_{L} q_{m} C_{e}}+\frac{1}{q_{m}} & \text { (Equação 8) }
\end{array}
$$

Os dados devem então ser graficados, para o primeiro caso, na forma de $\mathrm{C}_{\mathrm{e}} / \mathrm{q}_{\mathrm{e}}$ versus $\mathrm{C}_{\mathrm{e}}$, e para o segundo, em formato $1 / \mathrm{q}_{\mathrm{e}}$ versus $1 / \mathrm{C}_{\mathrm{e}}$. Se os dados se aproximarem de uma reta, então é válido considerar que o modelo de Langmuir pode ser usado para descrever os dados de sorção (DON SCOTT, 2000). A partir desses gráficos, o coeficiente angular representa os parâmetros 1/q (para Langmuir I) e 1/( $\mathrm{K}_{\mathrm{L}} \mathrm{q}_{\mathrm{m}}$ ) (para Langmuir II), enquanto a interceptação da reta no eixo das ordenadas, dos respectivos gráficos, fornece o valor para obtenção de $1 /\left(\mathrm{K}_{\mathrm{L}}\right.$ $\mathrm{q}_{\mathrm{m}}$ ) (para Langmuir I) e 1/q (para Langmuir II) (FAGUNDES; ZUQUETTE, 2009). A Figura 23 ilustra esquematicamente as linearizações de Langmuir. 
Figura 23 - Representação da isoterma de Langmuir. À esquerda, modelo tradicional. À direita, método gráfico para determinação das constantes

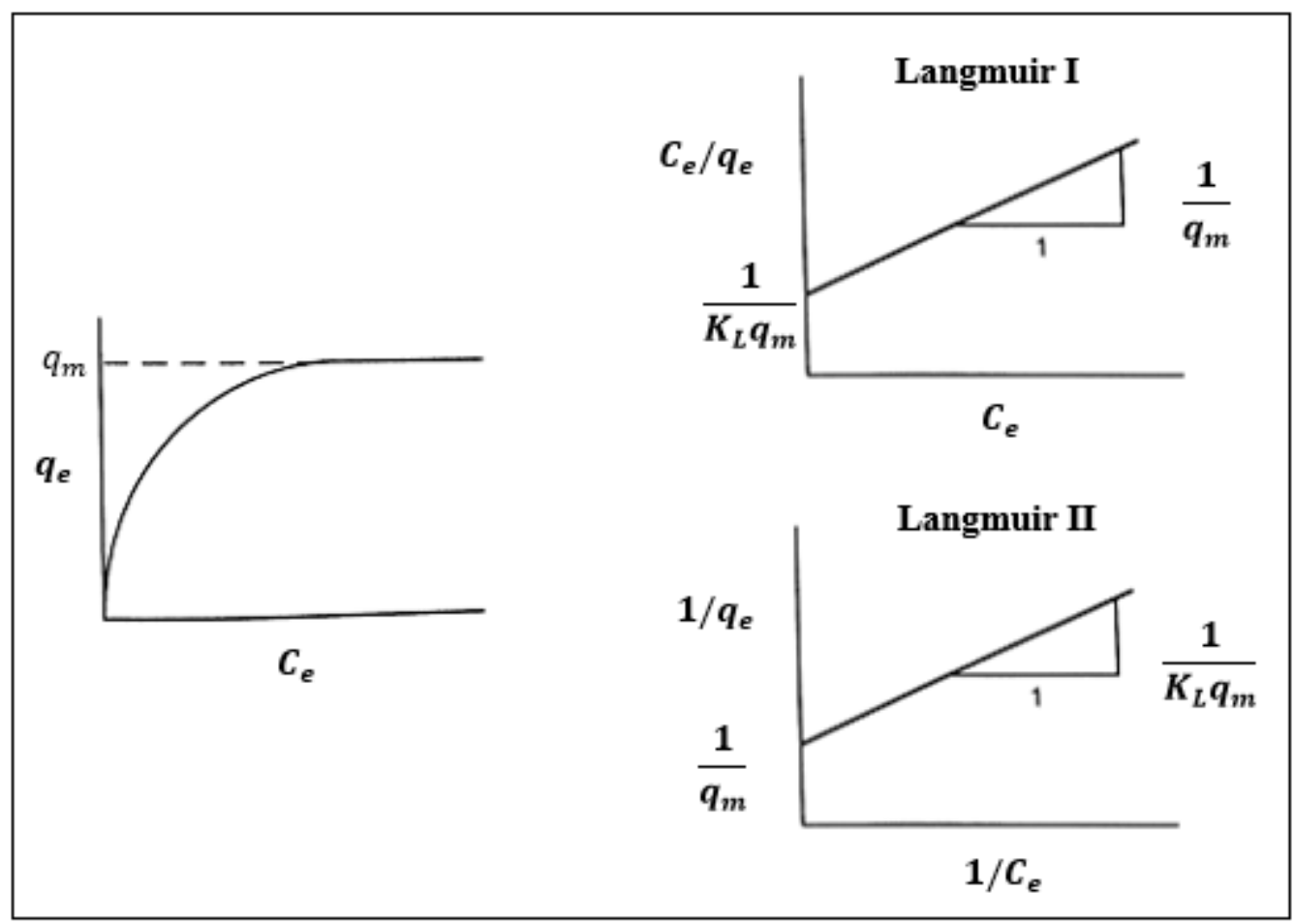

Fonte: Adaptado de Weber e DiGiano (1996).

De acordo com Don Scott (2000), as desvantagens dos modelos de equilíbrio de sorção de Freundlich e de Langmuir são: i) fornecem poucas informações sobre os mecanismos de sorção; ii) assumem sítios de sorção uniformes; iii) assumem não interação lateral entre as moléculas adsorvidas; iv) não se adequam bem em concentrações muito baixas ou muito elevadas, provavelmente porque diferentes tipos de sítios de sorção e mecanismos operam nesses casos; e v) muitos processos de adsorção são dependentes do tempo.

Aasim, os estudos cinéticos são importantes por fornecerem informações valiosas a respeito dos caminhos e dos mecanismos envolvidos nas reações químicas. No entanto, infelizmente, devido à dificuldades teóricas e experimentais, muitas vezes, é árdua a tarefa de aplicar a cinética química pura até mesmo para soluções homogêneas simples (FROST; PEARSON, $1961^{8}$ apud SPARKS, 1986).

\subsubsection{Fatores que influenciam na adsorção de metais por materiais reativos}

Diversos fatores interferem diretamente na adsorção de metais potencialmente tóxicos por materiais reativos. A seguir, serão descritos alguns fatores principais.

\footnotetext{
${ }^{8}$ FROST, A. A.; PEARSON, R. G.; Kinetics and Mechanism. John Wiley \& Sons, New York, 1961.
} 


\subsubsection{1 pH}

O pH de uma solução a partir da qual ocorre a adsorção, de modo geral, influencia diretamente no grau e extensão em que ocorre esse processo. Haja vista que os íons $\mathrm{H}^{+}$e $\mathrm{OH}^{-}$ são adsorvidos muito fortemente, por conseguinte, a adsorção de outros íons é grandemente influenciada pelo pH da solução. Ademais, como a ionização de um determinado elemento afeta a sua adsorção, o pH também afetará a adsorção, na medida em que regula o grau de ionização (WEBER, 1972).

Alguns minerais sorventes específicos podem revelar dependências variadas entre suas capacidades de troca catiônica e os respectivos pHs. Quando estas dependências forem caracterizadas como insignificantes (por exemplo, para a vermiculita) ou ligeiras (ilita e clorita) há um indicativo de que o sorvente obtém sua CTC principalmente devido a desequilíbrios manifestados no interior de sua estrutura. Enquanto isso, algumas frações do solo apresentam cargas de superfície dependentes do $\mathrm{pH}$, implicando que os valores de CTC variem também em função do $\mathrm{pH}$ do sistema. Dependências fortes (como observado para a caulinita, solos orgânicos naturais, materiais húmicos e vários óxidos ou materiais amorfos) indicam que a carga de superfície resulta de reações que ocorrem na interface sorvente-solução (LANGMUIR, 1997; YONG; MULLIGAN, 2004).

Assim, em se tratando da utilização da turfa como material reativo orgânico, a manipulação do $\mathrm{pH}$ do sistema pode provocar a dissociação dos grupos funcionais, trazendo uma melhoria significativa ou uma diminuição da eficácia da remoção dos metais (BARTCZAK et al., 2015). Em termos numéricos, a estrutura da turfa degrada a um pH superior a 9,0; abaixo de pH 3,0, a sua capacidade de remoção da maioria dos metais, não será eficiente (COUILLARD, 1994). Entre estes valores, sabe-se que a turfa pode adsorver a maioria dos metais de um modo muito eficiente, atingindo até $4 \%$ da massa de turfa seca (COUPAL; LALANCETTE, 1976).

Qin et al. (2006) observaram, conforme representado na Figura 24, que a adsorção de cátios de metais aumentou com a elevação do pH do meio de 2,0 até 8,0, sendo que o pH ótimo para a adsorção de $\mathrm{Pb}, \mathrm{Cu}$ e $\mathrm{Cd}$ em turfa foi determinado graficamente como 4,0; 4,0 e 6,0, respectivamente. Além disso, não foi observada nenhuma diferença marcante na adsorção de metais pelas duas turfas estudadas, uma dinamarquesa e outra chinesa. Assim, o fato do $\mathrm{pH}$ máximo de adsorção ser diferente para $\mathrm{Pb}, \mathrm{Cu}$ e Cd, salienta a importância do pH no tratamento de efluentes contendo metais diferentes. 
Figura 24 - Efeito do pH sobre a adsorção de $\mathrm{Pb}, \mathrm{Cu}$ e $\mathrm{Cd}$.

Em A, turfa dinamarquesa e em B, turfa chinesa (Heilongjiang)

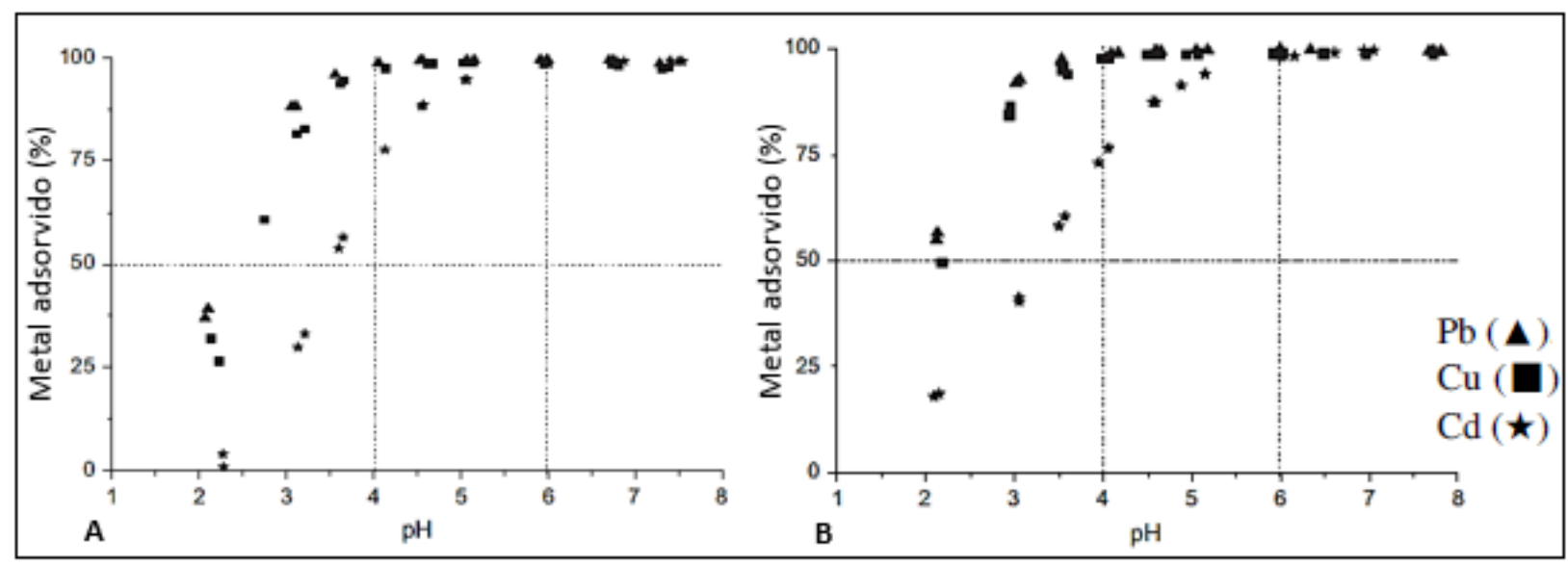

Fonte: Adaptado de Qin et al. (2006).

Franchi (2004) trabalhou com lixívias produzidas em laboratório a partir de resíduos de mineração do Vale do Ribeira (contendo metais potencialmente tóxicos), mais precisamente, da Mina do Rocha e Mina de Panelas. O referido pesquisador estudou duas variedades de turfa: in natura e ativada no tocante a variação na retenção de metais ( $\mathrm{Pb}, \mathrm{Cd}, \mathrm{Cu}, \mathrm{Zn}$ e $\mathrm{Mn})$ mediante a variação de pH de 2,0 até 6,5 (Figura 25). Em ambos os casos, nota-se que o Zn foi o elemento que apresentou menor afinidade pela turfa e o melhor valor de $\mathrm{pH}$ para a ocorrência da adsorção foi 6,5. Comparando os resultados obtidos referentes às duas modalidades de turfa, foi possível observar que na faixa de $\mathrm{pH}$, entre 2,0 e 3,0 a turfa ativada apresentou melhor capacidade adsortiva para todos os metais, com destaque para o $\mathrm{Pb}$ e exceto para o Mn. Já a turfa in natura revelou uma maior eficiência na adsorção com pH entre 4,0 e 6,5 para Cd, $\mathrm{Zn}$ e $\mathrm{Mn}$. De modo geral, para as duas tipologias de turfa, o acréscimo do pH implicou na elevação da retenção de todos os metais.

Figura 25 - Adsorção de $\mathrm{Pb}, \mathrm{Cd}, \mathrm{Cu}, \mathrm{Zn}$ e $\mathrm{Mn}$.

A) Turfa in natura ; B) Turfa ativada, em função do $\mathrm{pH}$

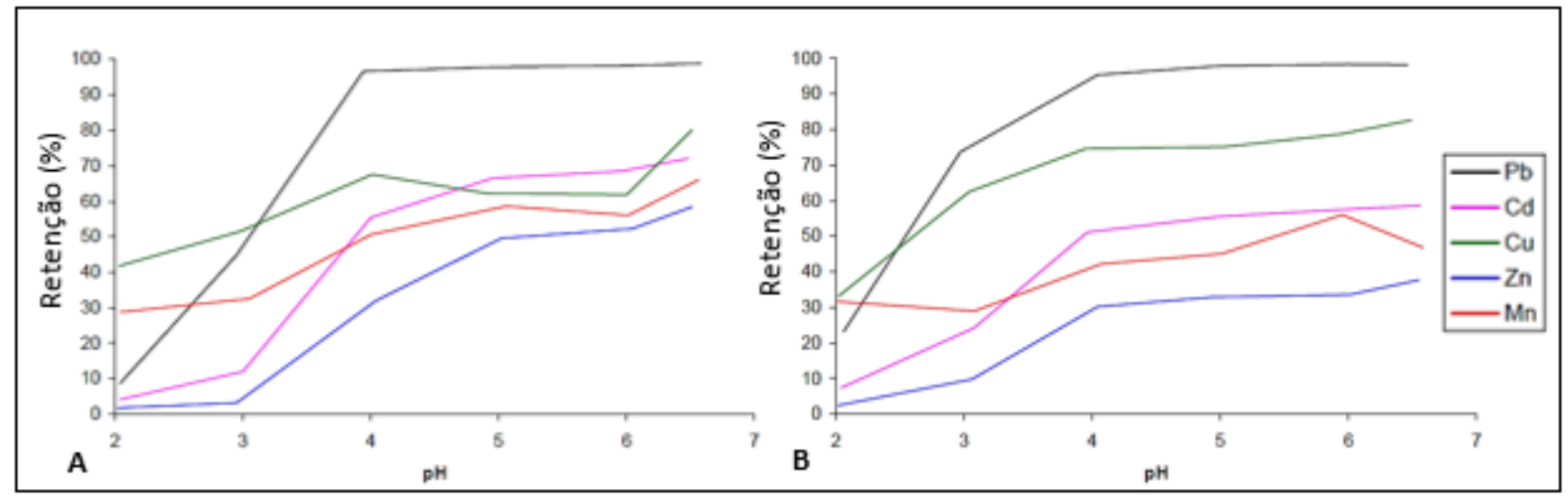

Fonte: Franchi (2004). 


\subsubsection{2 Área superficial}

Partículas que apresentam diâmetros inferiores a $1 \mu \mathrm{m}$ tem uma porcentagem significativa de seus átomos localizados justamente em sua porção superficial. Consequentemente, essas partículas, enquadradas na gama de tamanhos coloidais, revelam propriedades de superfície importantes, diferente do que ocorre, geralmente, com as partículas maiores (LANGMUIR, 1997).

Conforme comentado anteriormente, a adsorção é um fenômeno de superfície, estando, portanto, diretamente associada às propriedades de superfície de uma dada massa de material exposto a uma solução (WEBER, 1972; LANGMUIR, 1997). Nessa perspectiva, a superfície específica pode ser definida como sendo a parcela da área superficial total que se encontra disponível para a ocorrência do fenômeno da adsorção (WEBER, 1972). Sendo assim, a extensão da adsorção pode ser considerada como proporcional à superfície específica, ou seja, ela aumenta proporcionalmente em função da área superficial do material e de sua densidade de carga superficial ou número de locais carregados por unidade de área ou massa (WEBER, 1972; LANGMUIR, 1997). Desse modo, a adsorção de fato ocorrida por unidade de massa de um adsorvente sólido será proporcionalmente maior quanto mais finamente dividido e mais poroso estiver o adsorvente (WEBER, 1972). Por conseguinte, o equilíbrio nas reações de troca é mais rápido quando materiais de tamanho argiloso estão envolvidos, permitindo que os íons sorbatos entrem em contato diretamente com os locais de superfície (LANGMUIR, 1997).

Similar aos materiais reativos, Bertoni e Lombardi Neto (1985) afirmaram que em se tratando do solo, as reações físicas e químicas ocorrem principalmente na superfície das partículas, justificando um grande interesse nas frações menores, que apresentam proporcionalmente, uma superfície maior. Por exemplo, cinco quilogramas de argila seca, contendo partículas de $0,001 \mathrm{~mm}$ de diâmetro, exibem aproximadamente uma superfície equivalente a área de um hectare.

Como exemplo do efeito da área superficial, uma partícula de um material sólido com superfícies perfeitamente lisas, em forma cúbica e com um volume de $1 \mathrm{~cm}^{3}$ apresenta uma área superficial total de $6 \mathrm{~cm}^{2}$. Se esse cubo for dividido em partículas cúbicas menores, com 0,01 $\mathrm{cm}$ de lado, sua área superficial total passa a ser de $600 \mathrm{~cm}^{2}$. Já se essa subdivisão originar partículas cúbicas ainda menores, contendo $0,001 \mathrm{~cm}$ de lado, a área superficial total seria de $6.000 \mathrm{~cm}^{2}$ (WEBER, 1972). 


\subsubsection{Temperatura}

As reações de adsorção são geralmente exotérmicas. Desse modo, a extensão da adsorção aumenta comumente em função da diminuição da temperatura. Ademais, as modificações ocorridas na entalpia de adsorção são frequentemente da mesma ordem daquelas presentes nas reações de condensação e de cristalização. Contudo, pequenas variações de temperatura manifestam uma tendência de não alterar o processo de adsorção, de forma significativa (WEBER, 1972).

As diferenças de temperatura podem afetar, substancialmente, a cinética de adsorção, a concentração do metal presente na solução em equilíbrio e o próprio tempo necessário para que o sistema atinja o estado de equilíbrio. No entanto, em trabalhos de campo, a temperatura não pode ser controlada; já em ensaios laboratoriais esse controle pode ser realizado (HARTER; NAIDU, 2001).

Franchi (2004) constatou que a eficiência da adsorção aumentou com o decréscimo da temperatura, na medida em que comparou os resultados obtidos para amostras contendo as mesmas concentrações de metais, nas quais a unida modificação ocorrida nas condições operacionais foi justamente a temperatura. Com o decaimento da temperatura de $26^{\circ} \mathrm{C}$ para $14^{\circ} \mathrm{C}$ houve um aumento na adsorção pela turfa ativada de $3,48 \%$ em relação ao $\mathrm{Pb}$ e de $154,17 \%$ em termos de Zn. Contudo, Gündoğan, Acemioğlu e Alma (2004) em seus experimentos de adsorção de $\mathrm{Cu}$ em turfa, observaram que a remoção do metal passou de $96,95 \%$ para $97,13 \%$ com o aumento da temperatura de 12 para $30^{\circ} \mathrm{C}$ (Figura 26), demonstrando um pequeno efeito da temperatura sobre a adsorção.

Figura 26 - Efeito da adsorção de Cu por turfa herbácea a uma concentração de $3.10^{-4} \mathrm{M}$ e pH de 5,5. O gráfico representa a variação da quantidade de íons metálicos adsorvidos por unidade de massa do adsorvente $(\mathrm{x} / \mathrm{m})$ em função do tempo

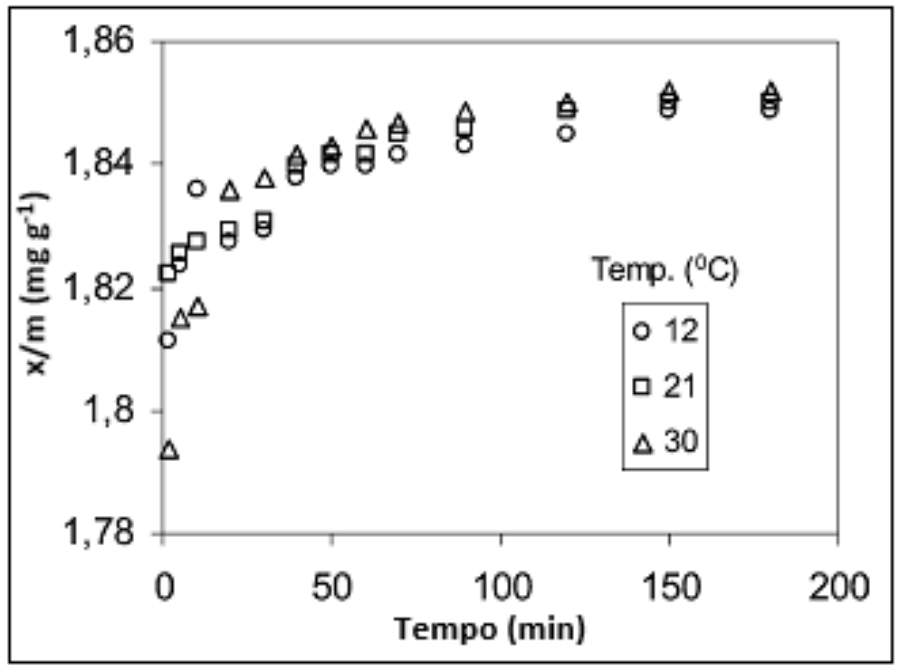

Fonte: Adaptado de Gündoğan, Acemioğlu e Alma (2004). 
Contudo, Franchi (2004) constatou que a eficiência da adsorção aumentou com o decréscimo da temperatura, na medida em que comparou os resultados obtidos para amostras contendo as mesmas concentrações de metais, nas quais a única modificação ocorrida nas condições operacionais foi justamente a temperatura. Com o decaimento da temperatura de $26^{\circ} \mathrm{C}$ para $14^{\circ} \mathrm{C}$ houve um aumento na adsorção pela turfa ativada de $3,48 \%$ em relação ao $\mathrm{Pb}$ e $154,17 \%$ em termos de $\mathrm{Zn}$.

\subsubsection{Natureza do adsorvente}

A natureza físico-química do adsorvente pode implicar em efeitos profundos sobre a taxa e a sua capacidade de adsorção. Dessa forma, partindo do princípio de que cada sólido é um adsorvente potencial, deve-se considerar que, no entanto, o caráter de superfície de cada um deles apresenta características intrínsecas (WEBER, 1972). Assim, em virtude das especificidades de cada caso, levando em consideração os demais fatores levantados nesse tópico, um ou outro adsorvente pode ser mais apropriado. É válido destacar que na escolha do adsorvente deve-se levar também em consideração o objetivo da adsorção (remover total ou parcialmente os elementos do meio em questão), os custos financeiros associados, a necessidade tecnológica e a facilidade de manuseio.

Tomasella (2013) avaliou a capacidade adsortiva de diferentes materiais (argilas de duas localidades, turfa e carvão ativado) na remoção de $\mathrm{Pb}$ de um efluente sintético padronizado no qual está presente apenas $\mathrm{Pb}$ e um efluente industrial oriundo de uma indústria química que fabrica óxido de $\mathrm{Pb}$, contendo, portanto, baixa concentração de $\mathrm{Pb}$, graxas e detergentes. Foi utilizado ensaio de batelada, a $25^{\circ} \mathrm{C}$ e com agitação de $200 \mathrm{rpm}$. Para o efluente industrial notouse a grande eficiência do carvão ativado, sendo que houve um equilíbrio adsortivo já no início do ensaio que se manteve até o final do experimento. Já quanto aos outros compostos, esse equilíbrio não foi observado dentro do período analisado (24 horas). Em seguida, o autor promoveu uma análise similar, porém, com o efluente sintético, visando avaliar possíveis interferências de outros elementos do efluente industrial. Comparando os gráficos da Figura 27, foi possível perceber uma melhor eficiência de remoção para o efluente sintético, provavelmente em função da complexidade de outros elementos, orgânicos ou inorgânicos, que além do $\mathrm{Pb}$ estão presentes no efluente industrial. Especificamente para a turfa, sua capacidade de adsorção se mostrou inferior em relação aos demais adsoventes estudados. 
Figura 27 - Comparação da remoção percentual de $\mathrm{Pb}$ em relação ao tempo de contato, sendo empregado carvão ativado, argila do Vale do Ribeira (Argila VP), argila de Ajapí (Argila A) e turfa.

A) Efluente industrial; B) Efluente sintético

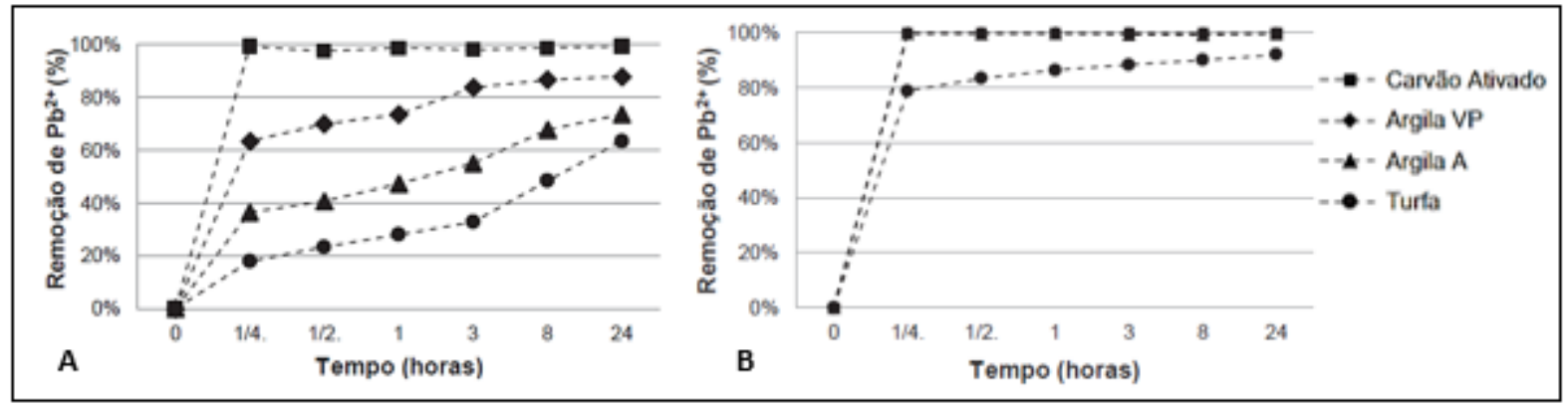

Fonte: Adaptado de Tomasella (2013).

Cochrane et al. (2006) estudaram comparativamente três biossorventes (carapaça de caranguejo, macroalgas Fucus vesiculosus e turfa) e dois materiais comerciais (carvão ativado e resina de troca iônica) para a remoção de $\mathrm{Cu}$ a partir de um meio aquoso. A Figura 28 exibe a porcentagem de remoção de $\mathrm{Cu}^{2+}$ em função do tempo de contato. Ambos os adsorventes comerciais exibiram uma excelente remoção do metal, com destaque para a resina de troca iônica, que removeu quase $99 \%$ de $\mathrm{Cu}^{2+}$ após apenas 1 hora de contato. A carapaça de caranguejo e as macroalgas mostraram resultados comparáveis nos estágios iniciais da adsorção. Já a turfa exibiu uma pequena remoção de apenas 45\% após 12 horas de contato.

Figura 28 - Remoção percentual de $\mathrm{Cu}^{2+}$ após $12 \mathrm{~h}$ de tempo de contato, com tamanho das partículas dos adsorventes: 250 - $800 \mu \mathrm{m}$; massa de adsorvente: $0,5 \mathrm{~g}$; temperatura: $20 \pm 1{ }^{\circ} \mathrm{C} ; \mathrm{pH}: 4,2$; concentração inicial de $\mathrm{Cu}^{2+}: 100 \mathrm{mg} \mathrm{L}^{-1}$

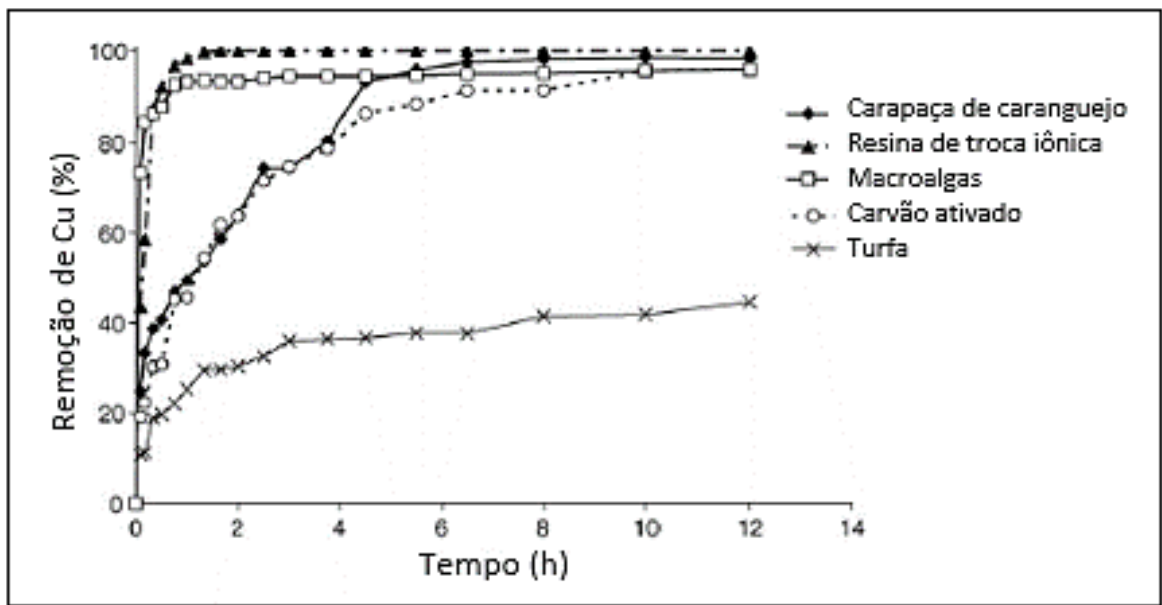

Fonte: Adaptado de Cochrane et al. (2006). 


\subsubsection{Natureza e concentração das espécies adsorvíveis}

Em qualquer consideração de adsorção, a solubilidade do soluto é de indubitável importância, na medida em que, trata-se de um fator controlador do equilíbrio da adsorção. De um modo geral, uma relação inversa pode ser estabelecida envolvendo a taxa de adsorção de um soluto e a sua solubilidade no solvente, regra esta conhecida como Lei de Lundelius. Nesse contexto, quanto maior for a solubilidade, mais fortes serão as ligações entre o soluto e o solvente e, portanto, menor será a extensão da adsorção. Assim, pode ser necessário romper algumas das ligações entre o soluto e o solvente antes que ocorra a adsorção (WEBER, 1972).

Ademais, a concentração do adsorvato é um parâmetro decisivo na taxa de adsorção. Langmuir (1997) afirma que uma isoterma simples sugere que em concentrações mais elevadas de espécies adsorvíveis, uma fração menor de material é adsorvida.

Além disso, a concentração inicial dos metais potencialmente tóxicos em solução interfere decisivamente na adsorção e, por conseguinte, no tempo de equilíbrio. Petroni (2004) avaliou as cinéticas de adsorção do $\mathrm{Cd}, \mathrm{Cu}$ e $\mathrm{Ni}$ frente a diferentes valores de concentração inicial para estes metais. A Figura 29 apresenta a relação dos metais adsorvidos à turfa $\left(\mathrm{q}_{\mathrm{t}}\right)$ em relação ao tempo (t). Pode-se observar que o aumento nas concentrações iniciais implicou em um aumento dos tempos requeridos para se atingir o equilíbrio.

Figura 29 - Cinética de adsorção de $\mathrm{Cd}, \mathrm{Cu}$ e Ni pela turfa
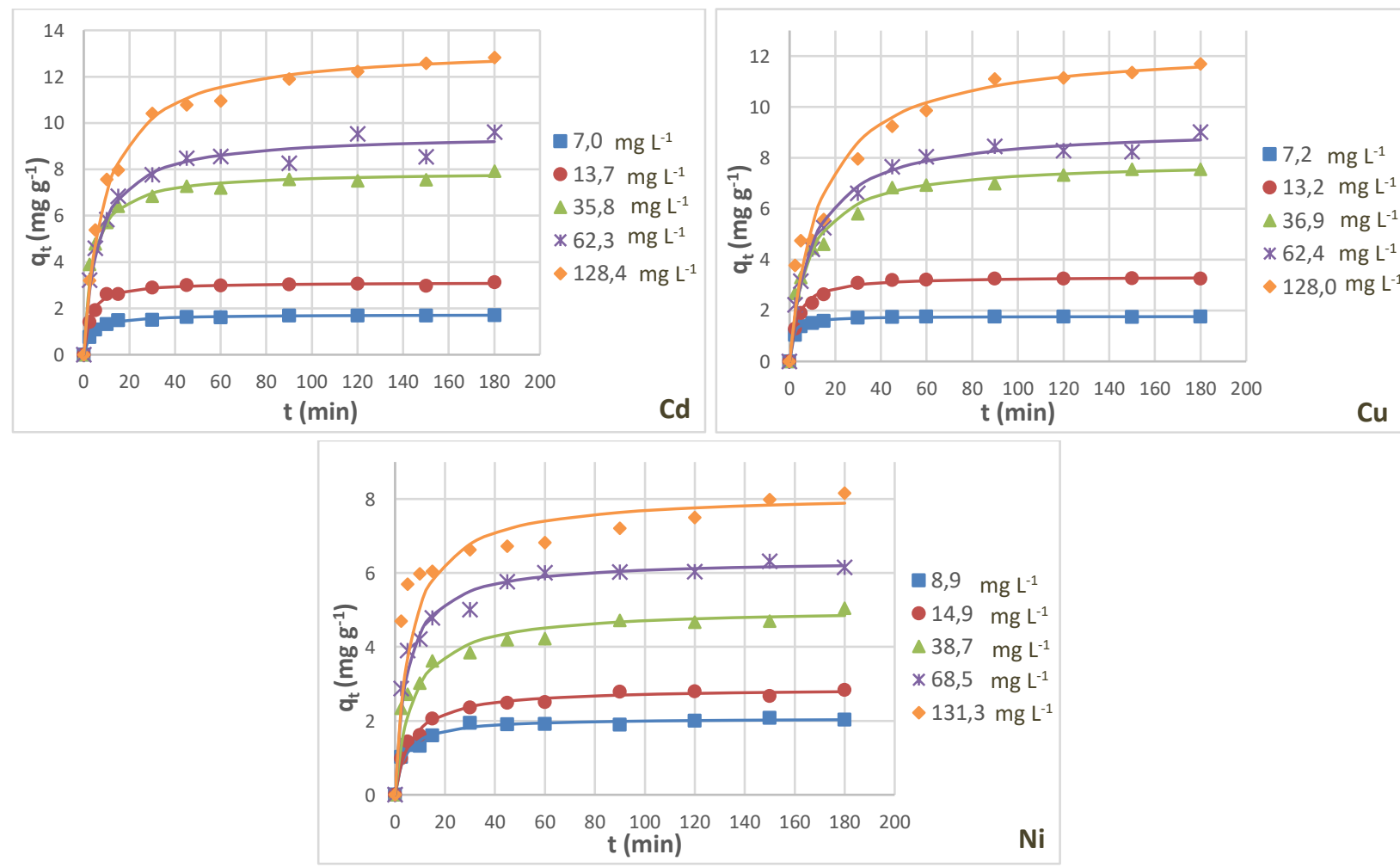

Fonte: Adaptado de Petroni (2004). 


\subsection{Definições e fundamentos metodológicos}

A seguir é apresentada uma sucinta explicação teórica das principais definições e fundamentos metodológicos que envolvem os ensaios realizados nesta pesquisa.

\section{A) Análise granulométrica}

A partir das curvas granulométricas é possível determinar as porcentagens das frações contidas nas amostras de interesse. É importante salientar que existem variações entre diferentes classificações no tocante aos limites de diâmetro das partículas que separam cada classe. $\mathrm{O}$ Quadro 7 exibe os limites das frações de acordo com a ABNT NBR 6502 (ASSOCIAÇÃO BRASILEIRA DE NORMAS TÉCNICAS, 1995) e o Quadro 8 apresenta a classificação segundo a Empresa Brasileira de Pesquisa Agropecuária - EMBRAPA (2011) que foram justamente as classsificações utilizadas nesta pesquisa.

Quadro 7 - Denominação e respectivo diâmetro das frações de partículas (ABNT)

\begin{tabular}{|c|c|c|}
\hline \multicolumn{2}{|c|}{ Denominação } & Diâmetro (mm) \\
\hline \multicolumn{2}{|c|}{ Argila } & Inferior a 0,002 \\
\hline \multicolumn{2}{|c|}{ Silte } & 0,002 a 0,06 \\
\hline \multirow{3}{*}{ Areia } & Fina & 0,06 a 0,2 \\
\hline & Média & 0,2 a 0,6 \\
\hline & Grossa & 0,6 a 2,0 \\
\hline \multirow{3}{*}{ Pedregulho } & Fino & 2,0 a 6,0 \\
\hline & Médio & 6,0 a 20,0 \\
\hline & Grosso & 20,0 a 60,0 \\
\hline \multicolumn{2}{|c|}{ Pedra-de-mão } & 60 a 200 \\
\hline \multicolumn{2}{|c|}{ Matacão } & 200 a 1000 \\
\hline
\end{tabular}

Fonte: ABNT NBR 6502 - 95. 
Quadro 8 - Denominação e respectivo diâmetro das frações de partículas (EMBRAPA)

\begin{tabular}{|c|c|c|}
\hline \multicolumn{2}{|c|}{ Denominação } & Diâmetro (mm) \\
\hline \hline \multicolumn{2}{|c|}{ Argila } & Inferior a 0,002 \\
\hline \multicolumn{2}{|c|}{ Silte } & 0,002 a 0,05 \\
\hline \multirow{2}{*}{ Areia } & Fina & 0,05 a 0,2 \\
\cline { 2 - 4 } & Grossa & 0,2 a 2,0 \\
\hline \hline
\end{tabular}

Fonte: EMBRAPA (2011).

A Figura 30 possibilita uma análise comparativa simplificada entre estas duas classificações, no tocante ao intervalo de diâmetros que engloba as frações argila, silte e areia.

Figura 30 - Esquema comparativo simplificado entre os limites das frações de acordo com EMBRAPA (2011) e com ABNT NBR 6502 - 95

\begin{tabular}{|c|c|c|c|c|c|}
\hline argila & silte & areia fina & \multicolumn{2}{|c|}{ areiagrossa } & \multirow[b]{2}{*}{$\Rightarrow$ NBR 6502} \\
\hline argila & silte & areia fina & areia média & areia grossa & \\
\hline \multicolumn{2}{|c|}{0,002} & 0,06 & & 6 & $(\mathrm{~mm})$ \\
\hline
\end{tabular}

Fonte: A autora.

\section{B) Massa específica dos sólidos}

A massa específica dos sólidos, por definição, está diretamente relacionada à relação entre a massa e o volume dos sólidos, ocupados por um mesmo volume de material. A massa pode ser facilmente aferida em balança convencional, porém o volume deve ser determinado indiretamente, sendo igual ao volume de água deslocada devido à introdução dos sólidos no balão volumétrico (NOGUEIRA, 1995).

\section{C) Teor de umidade e capacidade de retenção de água (CRA)}

Os materiais reativos orgânicos se caracterizam por apresentarem uma elevada capacidade de retenção de água (CRA). Sendo assim, a determinação do teor de umidade é um indicativo da presença de água nas amostras (MINISTÉRIO DA AGRICULTURA, PECUÁRIA E ABASTECIMENTO - MAPA, 2013). 


\section{D) Parâmetros físico-químicos (pH, $\Delta \mathrm{pH}$, Eh e CE)}

O potencial hidrogeniônico $(\mathrm{pH})$ está relacionado com a concentração do íon $\mathrm{H}^{+}$ presente nos poros do solo ou material reativo que se encontra em equilíbrio dinâmico com as superfícies carregadas negativamente predominantemente localizadas nas partículas sólidas. É importante destacar que esses íons de hidrogênio são fortemente atraídos pelas cargas negativas de superfície e eles apresentam o potencial de substituir a maioria dos outros cátions (ALLOWAY, 1995b).

O potencial de oxi-redução (Eh), avalia a transferência, ou seja, a doação ou o recebimento de elétrons. O doador é aquele que perde elétrons, sofrendo oxidação e aumentando seu número de oxidação, enquanto o receptor é aquele que recebe elétrons, sofrendo redução e diminuindo seu número de oxidação. De acordo com Fageria e Stone (2006), os fatores principais que controlam o Eh de um solo ou material reativo são a aeração e as reações biológicas, sendo que a fonte primordial de elétrons é a matéria orgânica. Segundo Canellas et al. (2008), os processos oxidativos estão intimamente associados ao controle do balanço de carbono, sendo que os principais elementos ligados a essas reações são C, N, O, S, Mn e Fe.

A condutividade elétrica (CE), segundo Lima (2014), é uma propriedade que mede a capacidade de condução da corrente elétrica em uma solução aquosa, estando diretamente associada a quantidade de sais que se encontram dissolvidos no solo ou material reativo. Portanto, quanto mais sais estiverem presentes, consequentemente, maior será sua condutividade elétrica. Ademais, este parâmetro é influenciado pela temperatura, concentração total e valência dos íons.

\section{E) Matéria orgânica (MO) e teor de cinzas (Cz)}

A matéria orgânica apresenta um interesse especial, uma vez que se destaca devido a sua capacidade de adsorver quantidades consideráveis de cátions inorgânicos, incluindo íons de metais potencialmente tóxicos, através do mecanismo de troca iônica (ADRIANO, 1986). Na turfa, a matéria orgânica pode estar presente em várias formas: a humificada (correspondendo à parcela decomposta completamente e que já se encontra estabilizada ou, até mesmo, carbonizada), a parcialmente humificada e a matéria orgânica crua (referente à porção recentemente incorporada, sendo representada, principalmente, pelas raízes) (KIEHL, 1985).

Os principais grupos presentes na matéria orgânica são as ligninas e as proteínas, que aparecem frequentemente associadas com outros grupos, em ordem decrescente de quantidades: hemicelulose, celulose e compostos solúveis de éter e álcool. Nota-se que embora a maior parte 
desses componentes não sejam solúveis em água, eles são solúveis na presença de bases fortes (SPARKS, 1995a).

Com a retirada da matéria orgânica da amostra, o resíduo mineral restante é comumente denominado cinza, cinza bruta, materiais não voláteis ou resíduo mineral total. O termo resíduo mineral total indica que este material pode ser desdobrado em duas porções: resíduo mineral insolúvel (constituído principalmente por sílica) e resíduo mineral solúvel ou cinza útil (onde podem estar contidos $\mathrm{P}, \mathrm{K}, \mathrm{Ca}, \mathrm{Mg}, \mathrm{S}$ e mais micronutrientes) (KIEHL, 1985).

\section{F) Capacidade de troca catiônica (CTC) e superfície específica (SE)}

A troca iônica pode ocorrer entre os íons que se encontram em difusão e os íons presentes nas superfícies das partículas reativas do solo e dos materiais orgânicos em função do desequilíbrio de carga. A troca de cátions ocorre quando íons carregados positivamente presentes na água são atraídos para as superfícies dos sólidos, devido à necessidade de satisfazer a eletroneutralidade. Este processo é estequiométrico e almeja atingir a eletroneutralidade do sistema. Nessa perspectiva, a quantidade de cátions trocáveis que pode ser retida é chamada de capacidade de troca catiônica (CTC) que, geralmente, corresponde à quantidade de cargas negativas presentes nas partículas sólidas do solo (YONG; MULLIGAN, 2004) ou material reativo.

A capacidade de troca catiônica é altamente dependente da quantidade e do tipo de argila, matéria orgânica, ferro, manganês e óxidos de alumínio (ADRIANO, 1986; LANGMUIR, 1997). Estes componentes apresentam diversificadas propriedades de troca de cátions. Em geral, quanto maior for a CTC, maior será a quantidade de metal que um solo ou material reativo pode reter sem riscos potenciais para o ambiente (ADRIANO, 1986).

Praticamente toda a CTC de solos altamente orgânicos, como a turfa, é originada da matéria orgânica presente (STEVENSON, 1982; SPARKS, 1995a), sendo que quanto maior for o grau de humificação da matéria orgânica, maior será a CTC. Isso se deve ao fato de que a fração orgânica apresenta partículas com superfícies que são carregadas negativamente atraindo os cátions, carregados positivamente. Essa carga negativa surge consideravelmente da ionização de grupos $\mathrm{COOH}$, embora haja também alguma contribuição de grupos $\mathrm{OH}$ e $\mathrm{NH}$ fenólicos (STEVENSON, 1982). Ainda de acordo com o mesmo autor, diferentemente dos argilominerais, a matéria orgânica não exibe uma capacidade fixa para a ligação de cátions trocáveis. Esta constatação é justificada pela ampla variação do grau de acidez das substâncias húmicas, bem como pelo fato da capacidade de troca catiônica aumentar rigorosamente em virtude de uma elevação do $\mathrm{pH}$. Este último fator pode ser atribuído a uma maior ionização de 
grupos ácidos, sobretudo $\mathrm{COOH}$, que ocorre quando o meio é caracterizado por valores de $\mathrm{pH}$ mais elevados.

Já a superfície específica corresponde à área potencial para a manifestação da adsorção. Portanto, quanto mais poroso for o meio e menores forem as partículas do solo ou material reativo, maior será sua superfície específica, e, por conseguinte, mais elevada será sua capacidade de adsorção (WEBER, 1972), já que maior será seu potencial de desenvolver cargas em superfície.

\section{G) Composição elementar}

Os principais constituintes da matéria orgânica são carbono (C), oxigênio (O), hidrogênio $(\mathrm{H})$ e nitrogênio $(\mathrm{N})$. Aparecem ainda, fósforo (P) e enxofre (S) (SPARKS, 1995a). Assim, a composição química da turfa, em nível básico, pode ser dividida em $\mathrm{C}, \mathrm{H}, \mathrm{N}, \mathrm{O}, \mathrm{S}$ e cinzas (INSTITUTO DE PESQUISAS TECNOLÓGICAS DO ESTADO DE SÃO PAULO - IPT, 1979).

De acordo com Nelson e Sommers (1982), o carbono total presente nos solos se refere à soma entre carbono orgânico e carbono inorgânico. A parcela inorgânica está fortemente ligada à presença de minerais carbonatados. Dessa forma, não são todos os solos que contém carbono inorgânico já que pode ter havido a dissociação durante o processo de formação dos minerais carbonatados que estavam originalmente presentes no material parental. Contudo, em solos formados a partir de material rico em calcário e sob condições áridas, pode ocorrer que a concentração de carbono inorgânico exceda a quantidade de carbono orgânico presente. Já a maioria da fração orgânica está diretamente ligada à matéria orgânica. Assim, o carbono orgânico está contido na fração orgânica do solo, que consiste em células de microrganismos, resíduos vegetais e animais que se encontram em variados estágios de decomposição, húmus estável sintetizado a partir dos resíduos e compostos altamente carbonizados, como carvão e grafite. $\mathrm{O}$ carbono orgânico no solo pode ser estimado pela diferença entre o carbono total e o carbono inorgânico, por procedimentos diretos após a remoção do carbono inorgânico ou por oxidação com dicromato seguida da titulação.

$\mathrm{Na}$ análise elementar é estabelecida a presença de carbono total, não sendo realizada nenhuma distinção entre carbono orgânico e inorgânico. Assim, nessa pesquisa optou-se também por determinar o carbono orgânico através da oxidação com dicromato e posterior titulação. Em termos ambientais, esta metodologia apresenta a desvantagem de se produzir um resíduo tóxico contendo cromo em um meio fortemente ácido. De acordo com MAPA (2013) o $\mathrm{Cr}$ na forma hexavalente apresenta elevada toxicidade. Assim, o dicromato residual deve ser 
tratado antes do seu descarte. Uma maneira de tratamento é a agregação de matéria orgânica ao dicromato que reagiu com a amostra para que se consuma o oxidante residual. Desse modo, ocorre a conversão do cromo hexavalente para a forma trivalente que é menos tóxica. Nessa perspectiva, uma alternativa é a adição de álcool etílico como fonte de carbono orgânico. Recomenda-se adicionar $3 \mathrm{~mL}$ de álcool etílico $96 \%$ para cada litro de dicromato residual. Deve-se também, ao término deste processo, promover o ajuste do $\mathrm{pH}$ com a introdução de uma solução concentrada de hidróxido de sódio até que ele atinja o valor 8. Então, a solução sobrenadante pode ser descartada e o precipitado deve ser seco e encaminhado para descarte de resíduos sólidos. Outras possibilidades para redução do Cr são o uso de açúcar, metabissulfito de sódio, bissulfito de sódio ou outro produto orgânico.

\section{H) Difratometria de Raios-X (DRX)}

A Difratometria de Raios-X é uma análise não destrutiva que permite uma investigação mineralógica dos materiais de interesse através da avaliação do espaçamento entre as bases das unidades cristalinas presentes. Segundo Gobbo (2009), esta técnica está baseada na incidência de um feixe de radiação sobre uma amostra e na consequente detecção do feixe difratado, constituído por fótons difratados. Como as estruturas cristalinas contém átomos que se encontram arranjados periodicamente no espaço, a difração satisfaz a Lei de Bragg, dada pela Equação 9:

$$
n^{\circ} \lambda=2 d \operatorname{sen} \theta \quad \text { (Equação 9) }
$$

Onde $\lambda$ corresponde ao comprimento de onda dos raios-X incidentes $(\AA)$; $\Theta$ é o ângulo de incidência do feixe sobre determinados planos do cristal $\left({ }^{\circ}\right)$; "d" revela a distância interplanar ( $)$ e " $\mathrm{n}$ " mostra a ordem de difração, sendo um número inteiro.

O feixe difratado é comumente apresentado em um gráfico chamado padrão difratométrico ou difratograma, na forma de picos registrados em um espectro que relaciona a intensidade versus o ângulo $2 \Theta$ (GOBBO, 2009). Assim, na prática, em difração, é conhecido o comprimento de onda dos raios-X, determina-se experimentalmente o ângulo de incidência e calcula-se a distância interplanar. Com estes dados, obtém-se um conjunto de distâncias entre planos cristalinos. Na medida em que cada composto revela um padrão difratométrico intrínseco é possível, através da comparação dessas características com dados tabelados, identificar a substância cristalina de origem. 


\section{I) Fluorescência de Raios-X (FRX)}

A Fluorescência de Raios-X é uma técnica não destrutiva que além de possibilitar a detecção dos elementos químicos presentes na amostra total estudada, permite também estabelecer em que proporção cada elemento se encontra, sendo válido destacar que se trata de uma análise semiquantitativa. Essa metodologia está baseada no princípio de que átomos, ao serem incididos por um feixe de raios-X, são excitados devido a absorção de energia. Contudo, visando a estabilidade, esses átomos, no processo de desexcitação, emitem energia na forma de um fóton de raio-X (fluorescência) sendo que essas linhas espectrais de energia são características para cada elemento e suas intensidades são proporcionais com a concentração do elemento presente na amostra (SIMABUCO, 1993).

\section{J) Microscopia Eletrônica de Varredura/Espectroscopia de Energia Dispersiva por Raios- X (MEV/EDS)}

O método da Microscopia Eletrônica de Varredura (MEV) com o Espectrômetro de Dispersão de Energia de Raios-X (EDS) apresenta a finalidade de estudar a morfologia das partículas e permitir uma determinação dos constituintes das amostras por uma análise química pontual. Nesta técnica, incide-se um feixe de elétrons sobre a amostra e os elétrons retroespalhados pela superfície das partículas são captados. Esse feixe eletrônico é capaz de produzir uma imagem de alta magnificação e ainda gerar raios-X fluorescentes, os quais são emitidos pelos elementos químicos presentes na amostra. Assim, é possível analisar em termos qualitativo e semiquantitativo a distribuição destes elementos, através do emprego do método de energia dispersiva que utiliza detectores de estado sólido (PORPHÍRIO, BARBOSA, BERTOLINO, 2010).

\section{K) Análise Térmica Diferencial (ATD)}

De acordo com Petroni (1999), as reações endotérmicas ou exotérmicas que acontecem com a elevação da temperatura de determinado material, relacionadas às respectivas temperaturas de ocorrência, ou seja, seu comportamento térmico, podem auxiliar na determinação de seus constituintes minerais. Diante disso, a Análise Térmica Diferencial (ATD) está baseada justamente neste princípio, envolvendo uma medição precisa da temperatura por termopares, durante o aquecimento da amostra e do material inerte de referência, submetidos a mesma programação de elevação térmica. 


\section{L) Carga superficial - ponto de carga zero (PCZ) e ponto de efeito salino nulo (PESN)}

O solo apresenta cargas eletroquímicas que são responsáveis pela ocorrência de diversos processos, como a dispersão e a floculação dos coloides e a capacidade de troca catiônica e aniônica. Essas cargas apresentam sua origem na fração mineral, estando principalmente associadas a argila e a matéria orgânica (BENITES; MENDONÇA, 1998).

Ademais, as cargas elétricas geram campos elétricos que apresentam o potencial de atrair os íons da solução. Campos associados a cargas negativas atraem cátions, enquanto as cargas positivas atraem ânions. Considerando uma partícula argilosa carregada negativamente, é possível observar que os cátions serão atraídos para o entorno da argila. Assim, haverá nas proximidades desta partícula uma concentração máxima de cátions e outra mínima de ânions. Com o aumento da distância em relação à argila, a presença de cátions diminui e a de ânions aumenta até que, ao se atingir uma distância fora da ação do campo elétrico, estas concentrações equilibram-se. Desse modo, é possível distinguir duas regiões distintas: a solução interna ou miscelar, correspondendo à área sob a ação do campo elétrico, e a solução externa ou intermiscelar, referente à porção fora da atuação do campo elétrico (ALLEONI; MELLO; ROCHA, 2016).

Ainda conforme Alleoni, Mello e Rocha (2016), o comportamento descrito anteriormente origina a formação de uma dupla camada elétrica, em virtude do aparecimento de duas camadas contendo cargas opostas: uma camada carregada negativamente, referente à superfície coloidal, e outra camada carregada positivamente, contendo os cátions adsorvidos. Esta estrutura é mais especificamente chamada de dupla camada difusa, uma vez que os íons adsorvidos se encontram distribuídos difusamente.

Segundo Fontes, Camargo e Sposito (2001), em função da distribuição destas cargas é formado um potencial elétrico máximo localizado na superfície das partículas, sendo decrescente com o aumento da distância. Assim, o potencial elétrico de superfície será variável e a densidade de cargas será constante, no caso desta dupla camada ser advinda de imperfeições internas em conjunto com substituições isomórficas estruturais. Por outro lado, o potencial elétrico de superfície será constante e a densidade de cargas será variável, quando esta dupla camada estiver associada à adsorção de íons determinantes do potencial elétrico.

Nessa perspectiva, existem dois tipos básicos de duplas camadas eletroquímicas, dependendo do mecanismo pelo qual as cargas livres se encontram distribuídas em uma interface sólido-líquido: (i) a dupla camada completamente polarizável ou de carga superficial constante, nas quais as cargas permanentes se manifestam independentemente do $\mathrm{pH}$ e são inerentes ao mineral, podendo ser também chamadas de cargas estruturais. Nessa situação, as 
cargas livres estão situadas apenas na fase líquida; (ii) a dupla camada completamente reversível ou de cargas variáveis, nas quais a carga líquida está associada ao íon que é adsorvido em excesso, sendo que os íons presentes podem cruzar a interface sólido-líquido, promovendo um deslocamento de cargas de uma fase para a outra (PARKS; BRUYN, 1962; RAIJ, 1973; FONTES; CAMARGO; SPOSITO, 2001).

O Quadro 9 contém uma síntese das características e formas de ocorrência das cargas permanentes e variáveis nos diferentes componentes do solo.

Quadro 9 - Características gerais das cargas permanentes e variáveis nos diferentes componentes do solo

\begin{tabular}{|c|c|}
\hline $\begin{array}{c}\text { Cargas permanentes } \\
\text { (negativas) }\end{array}$ & $\begin{array}{c}\text { Cargas variáveis } \\
\text { (negativas e positivas) }\end{array}$ \\
\hline \hline $\begin{array}{c}\text { Resultam de substituições iônicas } \\
\text { (isomórficas) de } \mathrm{Si} \text { por } \mathrm{Al} \text { ou de } \mathrm{Al} \text { por } \mathrm{Mg} \\
\text { ou Fe } \mathrm{Fe}^{(\mathrm{II})} \text { na rede cristalina }\end{array}$ & $\begin{array}{c}\text { Resultam de reações entre íons } \mathrm{H}^{+} \text {e átomos } \\
\text { de oxigênio existentes na superfície da } \\
\text { partícula }\end{array}$ \\
\hline $\begin{array}{c}\text { Ocorrem somente nos minerais de argila } 2: 1 \\
\text { e } 1: 1\end{array}$ & $\begin{array}{c}\text { Ocorrem nos óxidos de Fe e de } \mathrm{Al} \text {, nos } \\
\text { minerais silicatados e no húmus }\end{array}$ \\
\hline $\begin{array}{c}\text { Não são influenciadas pelas condições do } \\
\text { meio como pH e força iônica da solução }\end{array}$ & $\begin{array}{c}\text { São influenciadas pelas condições do meio } \\
\text { como pH e força iônica da solução }\end{array}$ \\
\hline Têm origem interna & Têm origem externa \\
\hline São sempre negativas & Podem ser positivas ou negativas \\
\hline \hline
\end{tabular}

Fonte: Alleoni, Mello e Rocha (2016).

Nos componentes orgânicos, as cargas variáveis apresentam como origem a dissociação de variados grupamentos funcionais e se desenvolvem em valores de $\mathrm{pH}$ inferiores em comparação aos óxidos. Sendo assim, é menos provável a ocorrência de cargas positivas nesses materiais em condições de pH típicos de solo (FONTES; CAMARGO; SPOSITO, 2001). Alleoni, Mello e Rocha (2016) complementam que dentre estes grupos funcionais se destacam os grupos carboxílicos (Equação 10) e os grupos fenólicos (Equação 11). Em menor importância, os grupamentos alcoólicos dos coloides orgânicos podem também sofrer dissociação, dando origem a cargas negativas (Equação 12). Estas equações são apresentadas pelos autores, para um radical qualquer $(\mathrm{R})$. 

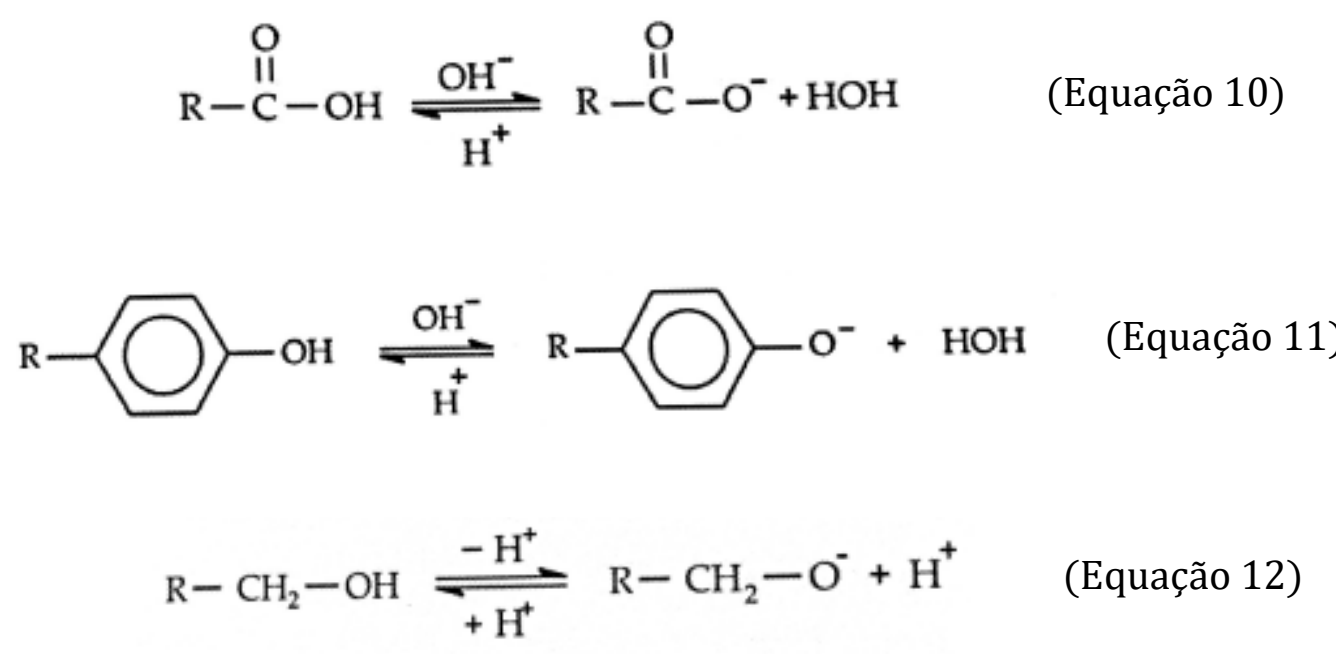

Ainda segundo Alleoni, Mello e Rocha (2016), a carga variável está diretamente associada à atividade do íon $\mathrm{H}^{+}$, responsável pela regulação do grau de protonação ou desprotonação dos grupamentos funcionais. Em condições ácidas, comumente, os grupos estão protonados. Entretanto, com a elevação do $\mathrm{pH}$, ocorre a desprotonação e o consequente surgimento de cargas negativas livres. Já as cargas positivas dificilmente se manifestam nos coloides orgânicos associados à protonação de grupos amídicos da matéria orgânica, em estado de elevada atividade dos íons hidrogênio, conforme demostrado pela Equação 13:

$$
\mathrm{R}-\mathrm{CH}_{2}-\mathrm{NH}_{2} \underset{-\mathrm{H}^{+}}{\stackrel{+\mathrm{H}^{+}}{\rightleftharpoons}} \mathrm{R}-\mathrm{CH}_{2}-\mathrm{NH}_{3}^{+}
$$

Para descrever as propriedades resultantes de uma dupla camada de cargas livres, o parâmetro mais importante é seu ponto de carga zero (PCZ) (PARKS; BRUYN, 1962; RAIJ, 1973). De acordo com Raij (1973) e Sposito (1989), o PCZ pode ser definido como sendo o pH da solução que apresenta uma carga elétrica líquida total da superfície nula, em condição de equilíbrio com o solo. Segundo Hendershot e Lavkulich (1978) esta carga líquida nula é aquela oriunda de cargas permanentes, devido à substituições isomórficas, e também de cargas variáveis, relacionadas com superfícies hidroxiladas. Por conseguinte, quando se atinge este valor de pH, não há nenhuma carga líquida contribuindo para a adsorção de íons difusos, seja devido à ausência de cargas, seja em virtude da presença de quantidades iguais de cargas positivas e negativas (FONTES; CAMARGO; SPOSITO, 2001).

Diante disso, em condições experimentais esta situação pode ser determinada através do estabelecimento do valor de $\mathrm{pH}$ no qual as partículas do solo não se movem em um campo 
elétrico aplicado (medida da mobilidade eletroforética) ou quando ocorre a sedimentação em uma suspensão de partículas de solo (medida da floculação). Portanto, o ponto de carga zero sinaliza a ausência de uma livre movimentação de íons adsorvidos e o fortalecimento das forças interparticulares, desempenhando uma função importante em se tratando da formação de agregados do solo e da retenção de íons adsorvidos, especialmente em relação às cargas variáveis (SPOSITO, 1989).

Já o ponto de efeito salino nulo (PESN) está relacionado ao valor de $\mathrm{pH}$ no qual a carga líquida do protón, dada pela diferença entre os mols de $\mathrm{H}^{+}$e de $\mathrm{OH}^{-}$adsorvidos, não se modifica em virtude da variação da concentração salina (SPOSITO, 1989). Alleoni e Camargo (1993) propõem a utilização da terminologia "ponto de efeito salino nulo" para se referir ao $\mathrm{pH}$ no ponto de intersecção de curvas de titulação potenciométrica. Segundo os autores, é mais adequada a utilização do adjetivo "nulo", já que ele expressa uma qualidade do efeito salino, do que do numeral "zero", amplamente utilizado na literatura para definir este ponto, do inglês point of zero salt effect (PZSE).

Existem diversos métodos laboratoriais empregados com a finalidade de se analisar o comportamento das cargas superficiais de partículas do solo, como a titulação potenciométrica, a retenção iônica, as técnicas eletrocinéticas, a titulação salina e a técnica de adição mineral. Entretanto, se destacam as duas primeiras técnicas, devido à facilidade operacional e por medirem atributos importantes para a avaliação eletroquímica (CAMARGO; ALLEONI, 2006; ALLEONI; MELLO; ROCHA, 2016). Assim, o PCZ pode apresentar valores diferentes, em função do método empregado. Consequentemente, seria mais coerente a adoção de nomes diversos para cada valor obtido por métodos diferentes (ALLEONI; MELLO; ROCHA, 2016).

Nesta pesquisa foi determinado o PESN através do método de titulação potenciométrica. Este método envolve a repetição da titulação de uma suspensão de solo, contendo volumes conhecidos de ácido ou de base, para diferentes forças iônicas, devido à presença de um eletrólito indiferente atuando como soluto de suporte. Construindo-se um gráfico colocando de um lado do zero as cargas negativas e do outro, as cargas positivas em função dos valores do pH de equilíbrio, o ponto de cruzamento das curvas de titulação corresponde ao PESN (ALLEONI; MELLO; ROCHA, 2016).

Ademais, o PESN revela ainda um importante impacto nas propriedades advindas das cargas do solo, já que a variação entre o PESN e o pH estabelece o sinal e a magnitude da carga variável em questão. Nos casos em que o pH é menor que o PESN, a carga superficial é predominantemente positiva, favorecendo a retenção aniônica. Esta situação ocorre mais frequentemente no subsolo. Em contrapartida, quando o pH é maior que o PESN, a carga 
variável é majoritariamente negativa, facilitando a troca catiônica. Esta é a situação que se manifesta para a maioria dos solos superficiais (KENG, UEHARA, 1973). A Figura 31 esquematiza estas circunstâncias.

Figura 31 - Figura esquemática das relações entre o PESN e as cargas de superfície positivas e negativas

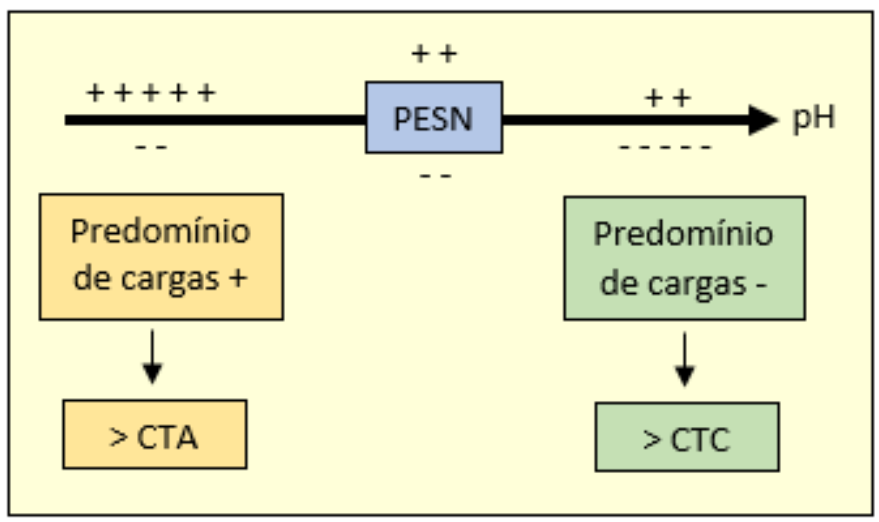

Fonte: A autora.

\section{M) Testes de equilíbrio em lote (batch test)}

Não existe uma metodologia universalmente adotada por todos os laboratórios para a realização dos testes de equilíbrio em lote. Diversas pesquisas apresentam suas particularidades, sobretudo quanto à massa de adsorvente, relação adsorvente/solução, concentração dos contaminantes, $\mathrm{pH}$ e tempo de equilíbrio. No tópico "3.5.1. Ensaios de adsorção" foi apresentado o conceito geral deste tipo de experimento. Neste tópico, contudo, será abordado, com base na literatura, algumas minuciosidades de determinados parâmetros que interferem diretamente nos resultados deste ensaio e que, desse modo, deverão ser conhecidas intimamente para possibilitar a melhor escolha durante a prática deste experimento.

As variações na relação solo-material reativo/solução podem influenciar a química da fase aquosa de íons e, assim, afetar tanto o processo de sorção quanto o processo de dessorção. A reação de sorção é dependente principalmente de três fatores: (i) o número de locais disponíveis para reter o sorvato, ou seja, a capacidade de sorção; (ii) o total de elementos sorvíveis em solução e (iii) a probabilidade deles entrarem em contato com os locais de sorção. Ademais, o sorvato precisará deslocar íons que já ocupam locais de sorção e íons diferentes apresentarão resistência variável à ocorrência desse deslocamento, afetando substancialmente o número de locais disponíveis. Tomando como base uma determinada quantidade de soluto, quando a capacidade de sorção do solo ou material reativo é alta em relação à quantidade de soluto presente, é possível constatar que a maior parte ou todo o soluto pode ser removido da 
solução empregando-se uma pequena quantidade do solo ou material reativo em questão. Assim, se for adicionado mais solo ou material reativo à suspensão, diminuindo a relação solomaterial reativo/solução, pode ser que isso não acarrete no aumento da quantidade de sorção observada, pois o número de sítios de sorção disponíveis pode exceder amplamente o número de íons ou moléculas presentes. Consequentemente, se a taxa de sorção for calculada em função da massa de sorvente, com esse acréscimo de material, na verdade, a taxa de sorção vai diminuir. Se por outro lado, a capacidade de sorção de um sorvente for baixa, a quantidade de soluto presente pode ser muito superior aos locais de sorção, de modo que a remoção do soluto da solução passa a depender diretamente da quantidade de solo ou material reativo presente. Sendo assim, a taxa de sorção, em relação à massa de sorvente, aumentará conforme a relação solo-material reativo/solução for diminuída, já que a probabilidade de interação entre sorvato e sorvente aumenta à medida em que a disponibilidade de locais aumenta (HARTER; NAIDU, 2001).

Outro fator de indubitável importância é o tempo de contato. As taxas de reação obtidas nos ensaios de equilíbrio em lote realizados por Gosset, Trancart e Thévenot (1986) evidenciaram que existe um tempo de residência necessário para que ocorra um tratamento completo das soluções contaminadas com cátions metálicos. Desse modo, camadas de turfa muito finas parecem apresentar utilização improvável quando se almeja conseguir uma completa remoção de metal por complexação, adsorção ou troca iônica.

Além disso, para garantia da confiabilidade dos resultados obtidos através do ensaio de equilíbrio em lote, é de indubitável importância que o sistema solo-material reativo/solução seja colocado em agitação, mantendo-se a temperatura e a pressão em condições constantes. Decorrido o período considerado ideal para o equilíbrio da reação de adsorção, é importante que haja a separação das fases líquida e sólida. Com este intuito, podem ser utilizados os processos de centrifugação e filtração, sendo empregadas uma das técnicas ou o uso combinado delas (SOARES; CASAGRANDE, 2000).

Em relação à filtração, nota-se que as membranas de celulose contendo abertura de poro de 0,45 mm vêm sendo consideradas as mais adequadas. No entanto, algumas partículas coloidais, sobretudo aquelas representadas por óxidos de Fe e por ácidos húmicos dissolvidos, em função de suas reduzidas dimensões (variando de 0,001 a 0,1 mm) podem ultrapassar a membrana. Além disso, a principal fonte de erro na filtração é a adsorção do elemento de interesse pelos filtros e membranas (SOARES; CASAGRANDE, 2000).

Já no tocante à centrifugação, esta operação geralmente expõe o sobrenadante ao efeito tamponante das partículas em suspensão. Assim, sua utilização visando à separação das fases 
sólida e líquida pode provocar a formação de uma zona muito fina na superfície do líquido, na qual a tensão superficial acaba aprisionando as partículas finas. Por conseguinte, deve ser evitada a coleta de alíquotas na porção superficial da solução clarificada. Desse modo, quando a solução sobrenadante for coletada por sucção, é importante que a pipeta seja inserida a uma distância suficientemente abaixo da superfície, com o intuito de se evitar o recolhimento de partículas em suspensão. Por outro lado, é crucial ainda que a ponta da pipeta seja colocada e mantida acima da interface sólido-líquido, a fim de se proteger da sucção de partículas que por ventura estejam acomodadas no fundo do recipiente devido à centrifugação. Diante disso, o uso da filtração elimina estas potencialidades de erro, devendo ser considerado como um procedimento alternativo após a operação de centrifugação (SOARES; CASAGRANDE, 2000).

Com a obtenção de um extrato límpido, a concentração do soluto presente na solução de equilíbrio deve ser analisada a partir da utilização de uma instrumentação analítica viável e condizente com as condições experimentais, princípios, limite de detecção e exatidão dos resultados propostos no estudo. Para concentrações mais baixas, por exemplo, é recomendado o emprego da espectrometria de absorção atômica com forno de grafite (SOARES; CASAGRANDE, 2000). 


\section{MATERIAIS E MÉTODOS}

\subsection{Origem e pré-preparo dos materiais reativos orgânicos}

\subsubsection{Caracterização da turfeira}

A turfa analisada nesta pesquisa foi coletada em uma turfeira no município de Cravinhos (estado de São Paulo), pertencente à bacia hidrográfica do rio Mogi Guaçu (Figura 32).

Figura 32 - Bacia hidrográfica do rio Mogi Guaçu, com destaque para a região da sub-bacia do Ribeirão da Onça (município de Cravinhos), local da turfeira

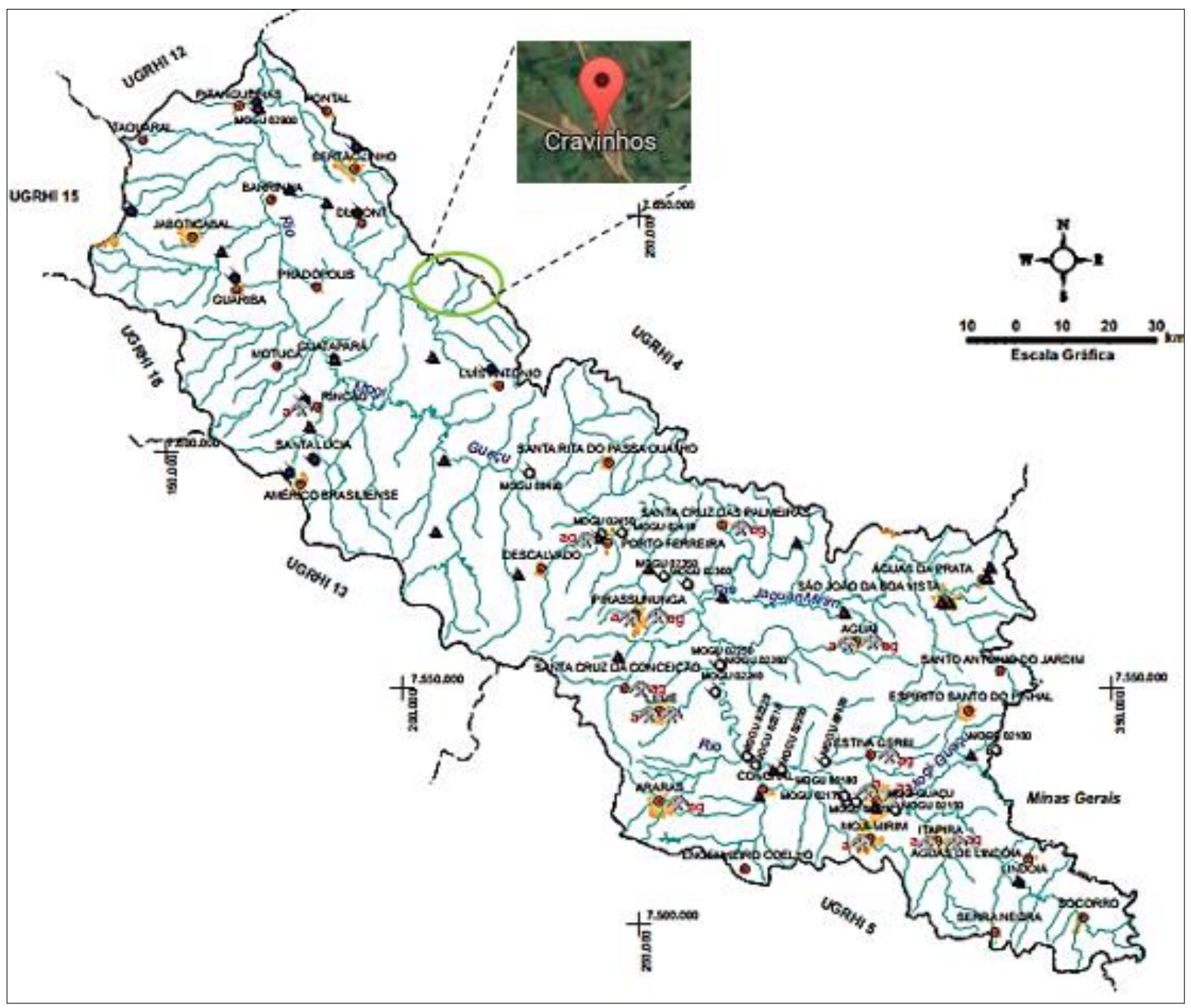

Fonte: Adaptado de Plano Estadual dos Recursos Hídricos - PERH (2004).

No estado de São Paulo, os principais depósitos de turfa se localizam nas bacias dos rios Paraíba do Sul, Mogi Guaçu, Pardo, Itapetininga, Jacaré-Pepira, Jacaré-Guaçu, baixo Vale do Ribeira de Iguape e em Colônia (SAAD et al., 1996). Esses depósitos apresentam idade holocênica e estão intimamente associados à áreas paludais costeiras e várzeas de planícies de 
inundação (CABRAL JUNIOR et al., 2001). A Figura 33 exibe as principais turfeiras fluviais paulistas com potencial comercial. A área de coleta da turfa estudada se encontra destacada no mapa.

Figura 33 - Principais turfeiras fluviais localizadas no estado de São Paulo que apresentam potencial de exploração comercial. Destaque para o Setor Mogi Guaçu/Pardo

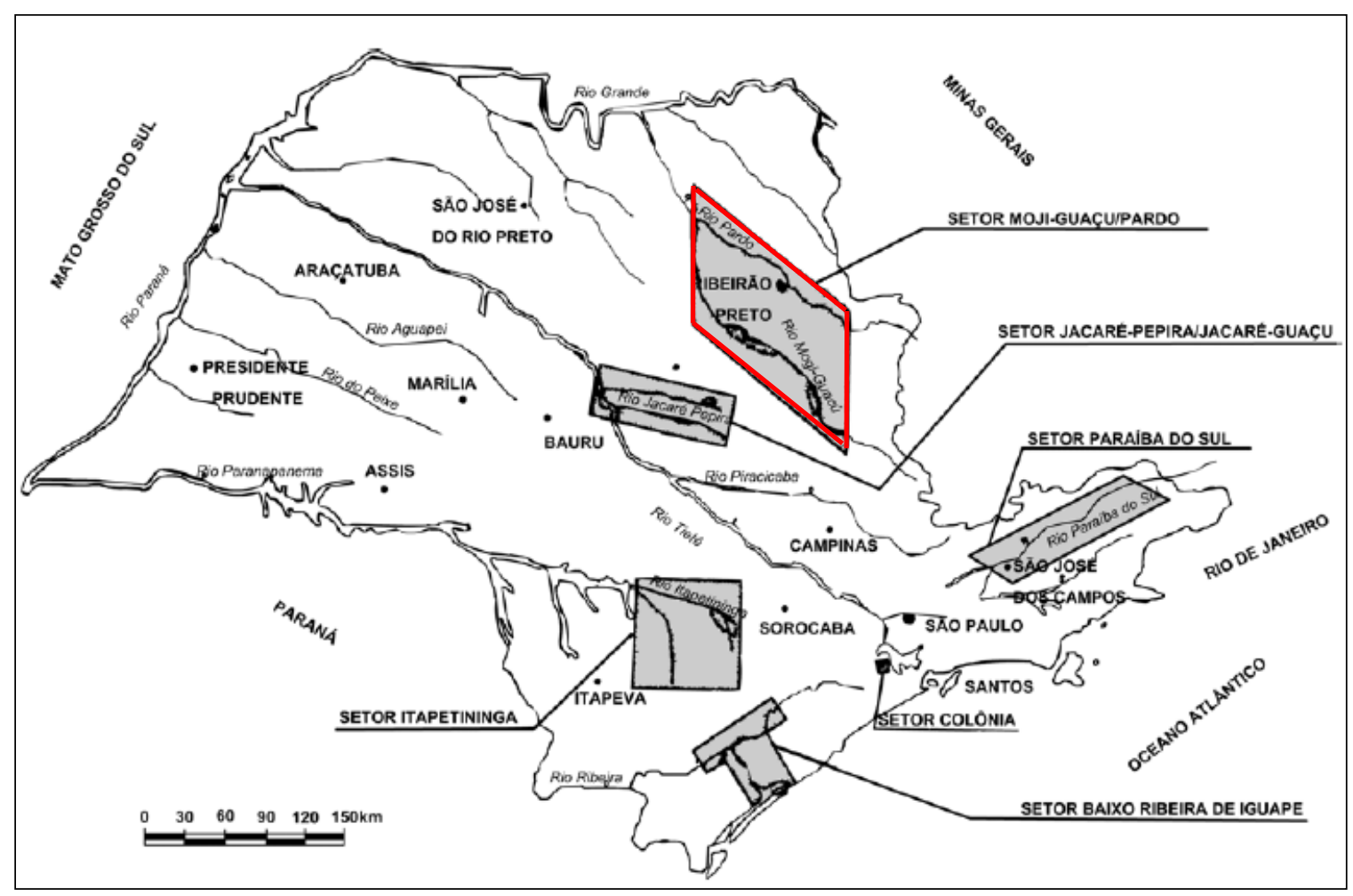

Fonte: Adaptado de Shimada et al. (1981) ${ }^{9}$ apud Franchi (2004).

As turfeiras localizadas às margens do rio Mogi Guaçu (Figura 34), similar àquelas próximas aos rios Paraíba do Sul e Jacaré-Pepira, estão diretamente correlacionadas aos seus respectivos sistemas fluviais, formados por rios meandrantes que percorrem planícies de inundação. Apresentam porte variável, com espessura variando, comumente, de 1 a 3 metros. Trata-se de uma turfa predominantemente fibrosa a hêmica, com elevado teor de cinzas, geralmente superior a 20\%, como consequência de inundações periódicas (CABRAL JUNIOR et al., 2001).

\footnotetext{
${ }^{9}$ SHIMADA, H.; MOTTA, J. F. M.; CABRAL Jr, M.; NAKANO, S.; Prospecção de turfa no Estado de São Paulo. In: Simpósio Regional de Geologia, 3., 1981. Curitiba. Atas... Curitiba: SBG, 1981. p. 259-273.
} 
Figura 34 - Turfeira às margens do rio Mogi Guaçu

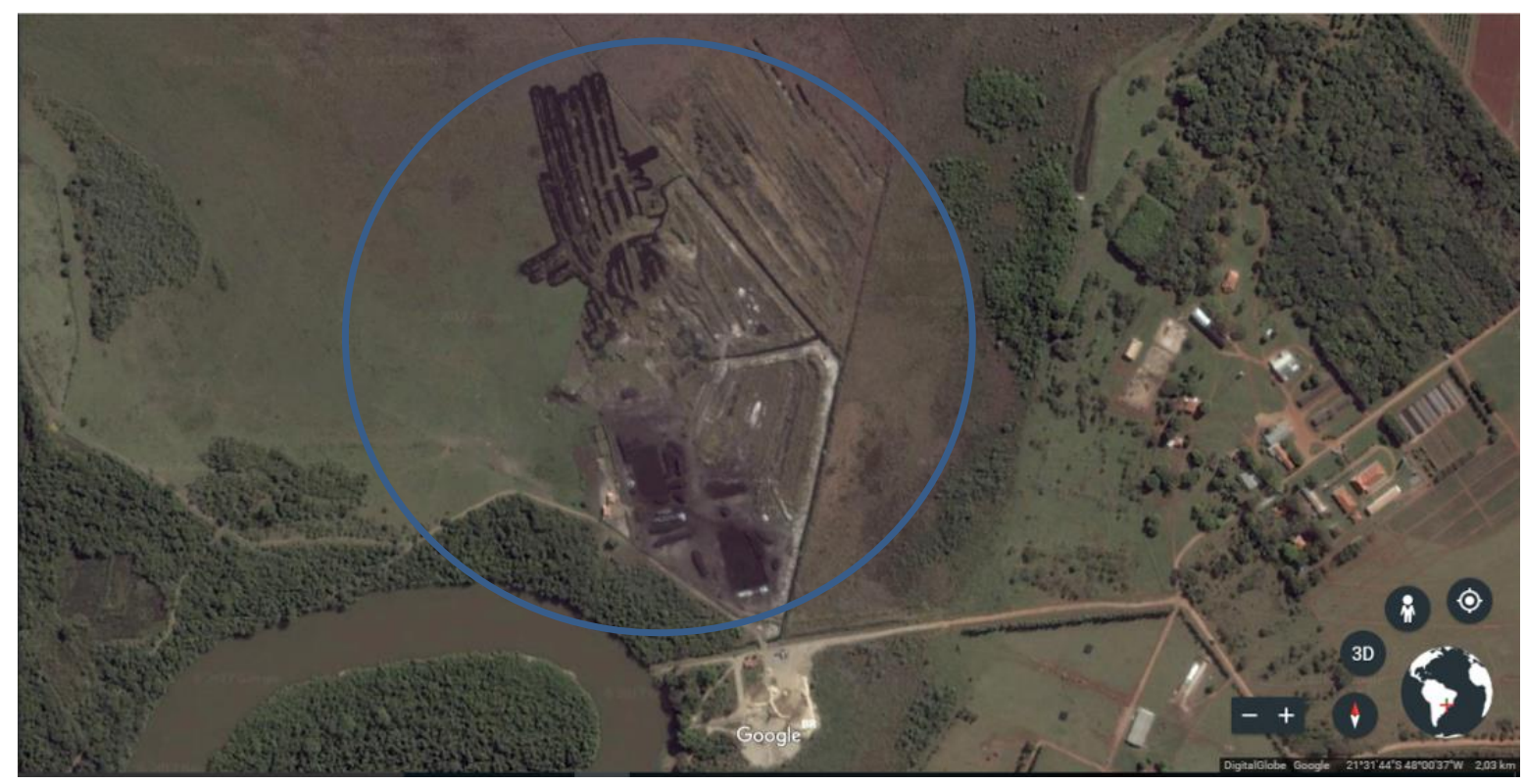

Fonte: Google Earth (2017).

A turfa analisada nesta pesquisa foi fornecida pela Empresa Axihum Fertilizantes (antiga Agrolatina). As amostras cedidas foram secas ao ar, destorroadas e peneiradas (peneira 2,0 mm). No laboratório, a turfa foi quarteada pelo método de pilhas alongadas e as alíquotas menores foram armazenadas em sacos de polietileno para as posteriores análises.

\subsubsection{Caracterização das composteiras}

Os compostos orgânicos utilizados nesta pesquisa foram fornecidos pelo aluno Renan Marques Lupion e pelo prof. Dr. Valdir Schalch (EESC/USP). O aluno Renan Marques Lupion desenvolveu, em meso-escala e em condições ambientais, diferentes métodos de compostagem no pátio gerido pelo Grupo de Estudos e Intervenções Sócio Ambientais (GEISA), no Campus II da Universidade de São Paulo (USP), Escola de Engenharia de São Carlos (EESC). Os compostos orgânicos foram gerados a partir de resíduos alimentares provenientes do restaurante universitário da EESC-USP São Carlos.

A seguir são apresentados os procedimentos adotados em cada método de compostagem:

A) Método da composteira indiana ou windrow: procedimento alicerçado na sobreposição de camadas em formato quadrangular sobre uma espécie de cama formada por galhos, folhas, serragem ou até mesmo composto já maturado (servindo nesse caso como inóculo de decompositores). Os resíduos orgânicos foram depositados na região central com a colocação 
de matéria seca nas superfícies laterais e superior. Para o acréscimo de resíduo orgânico a matéria seca superficial foi deslocada para as laterais, aumentando a altura das paredes e possibilitando comportar o novo volume de material disposto sobre a massa de resíduos orgânicos parcialmente decompostos. O composto proveniente deste método (Figura 35) recebeu a denominação de composto indiano.

Figura 35 - Método de composteira indiana. A) Vista interior durante o acréscimo de resíduos orgânicos; B) Vista lateral superficial
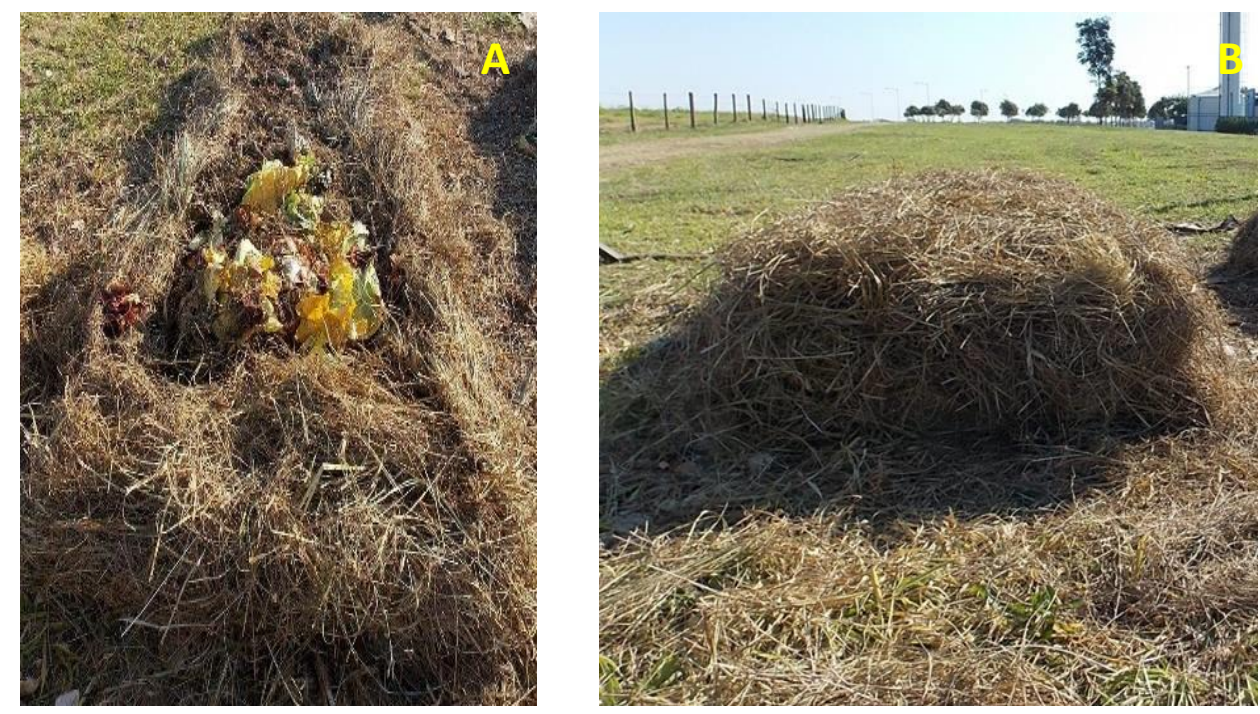

Fonte: Cedida por Lupion, R. M. (2016).

B) Método da composteira alambrado: envolveu o preenchimento de uma estrutura cilíndrica vertical de alambrado, utilizando como base uma espécie de cama de galhos, a fim de evitar o contato direto com o solo, sendo que, neste caso, foram empregadas coroas de abacaxi. Nesta leira, o resíduo orgânico foi depositado na parte interior da estrutura em alambrado e a lateral interna foi recoberta com a palhagem, impedindo o contato do resíduo com o exterior. Devido à constituição vertical, este método possibilita uma melhor aeração, devido a maior facilidade de circulação de ar pela massa de composto (Figura 36). O composto resultante foi denominado de composto alambrado. 
Figura 36 - Método de composteira alambrado. A) Colocação das coroas de abacaxi, iniciando o procedimento; B) Vista interior durante o acréscimo de resíduos orgânicos; C) Vista superficial
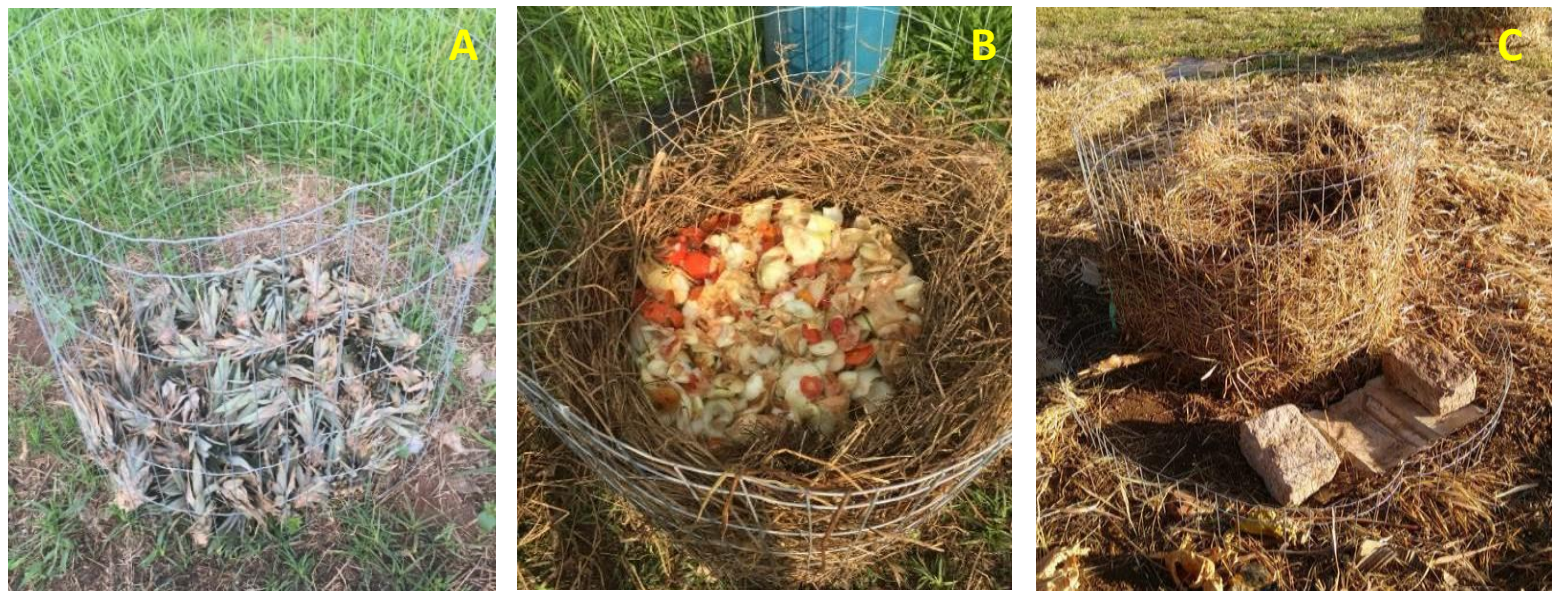

Fonte: Cedida por Lupion, R. M. (2016).

C) Método da composteira estática: este procedimento se baseiou em um sistema de sobrecamadas, com o resíduo orgânico sendo colocado na base, diretamente sobre o solo. Cada camada de resíduo foi coberta com matéria seca e a adição de uma nova massa de resíduo se deu sobre a camada de palha anterior e foi coberta com uma nova palhagem (Figura 37). Este composto recebeu a denominação de composto estático.

Figura 37 - Método da composteira estática. A) Vista interior durante o acréscimo de resíduos orgânicos; B) Vista superficial
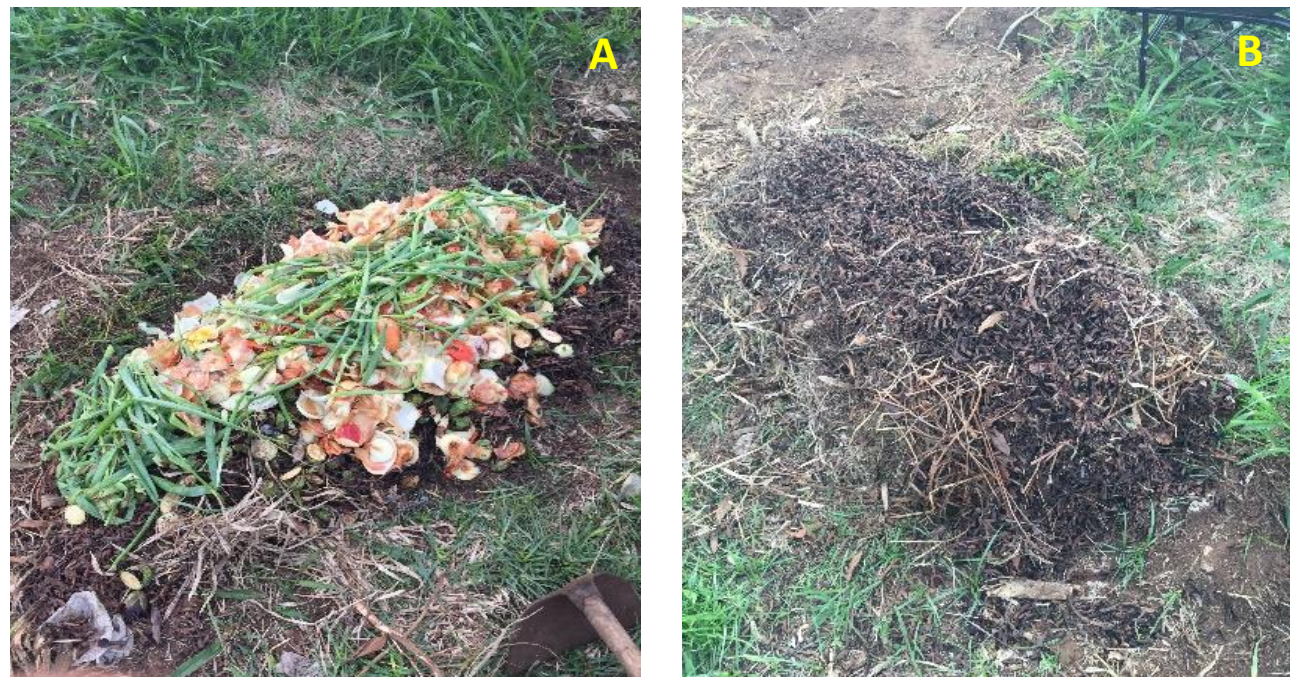

Fonte: Cedida por Lupion, R. M. (2016).

O processo de compostagem ocorreu no período referente à última semana de março até a segunda semana de junho de 2016. Foram manejadas três leiras contendo apenas resíduos orgânicos de pré-preparo (provenientes do restaurante universitário), como cascas, talos e 
legumes crus, seguindo cada um dos métodos descritos anteriormente. Além destes três compostos, foi gerida ainda uma quarta leira constituída por resíduos orgânicos de pré-preparo e sobras de alimentos cozidos, como arroz, feijão e, em raros momentos, carnes. Este composto seguiu também o método da composteira indiana e foi denominado de composto total.

Findado o processo de compostagem, todos os compostos foram peneirados, a fim de se retirar o excesso de matéria seca e resíduos grosseiros não decompostos, e foram armazenados em recipientes plásticos (Figura 38).

Figura 38 - Peneiramento e armazenamento dos compostos

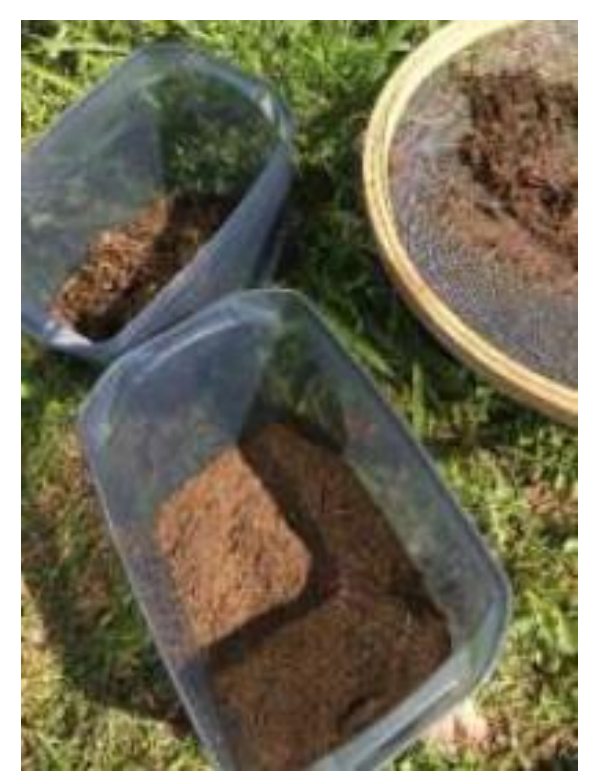

Fonte: Cedida por Lupion, R. M. (2016).

Posteriormente, os compostos foram quarteados, pelo método de pilhas alongadas (Figura 39), objetivando a obtenção de alíquotas homogêneas para as posteriores análises. As amostras foram armazenadas em sacos de polietileno.

Figura 39 - Quarteamento pelo método de pilhas alongadas. A) Composto indiano; B) Composto total
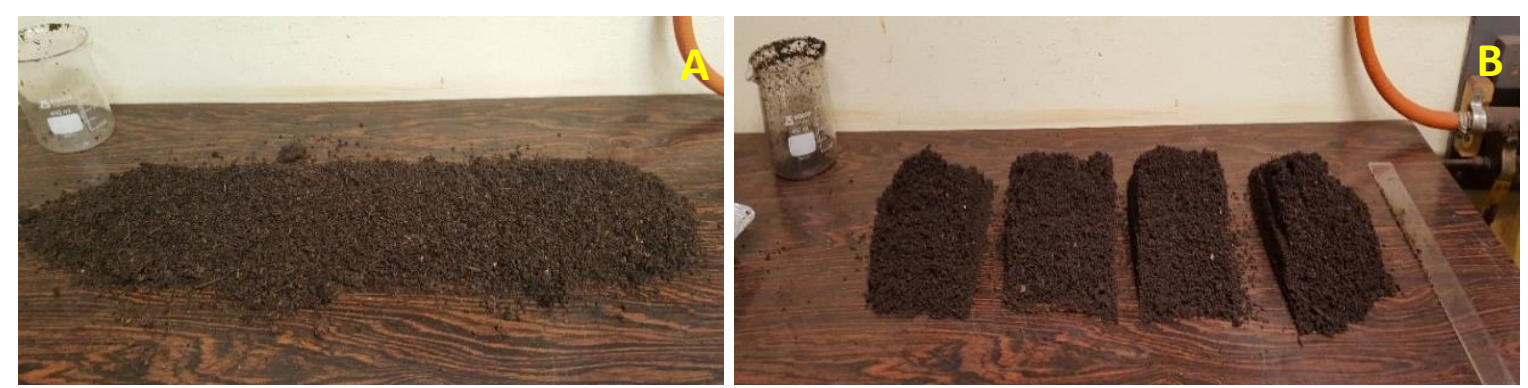

Fonte: A autora. 


\subsection{Caracterização geológica e geotécnica dos materiais reativos orgânicos}

Para verificar se os quatro compostos orgânicos eram adequados na retenção dos metais potencialmente tóxicos, principalmente devido às suas propriedades geológicas e geotécnicas, foram realizados distintos ensaios de caracterização com todos os compostos: indiano, alambrado, estático e total. Também foram realizadas caracterizações geológicas e geotécnicas com a turfa in natura, sem ativação.

Alguns métodos empregados na caracterização são usados para solos (não tendo uma metodologia para materiais orgânicos). Desta forma, em alguns ensaios foram utilizados mais de um método para confirmação dos resultados e garantia da viabilidade de aplicação também para materiais reativos orgânicos.

O Quadro 10 sintetiza os ensaios realizados visando à caracterização geológica e geotécnica dos materiais e os ensaios de adsorção, bem como suas respectivas metodologias. 
Quadro 10 - Síntese dos parâmetros estudados e suas respectivas metodologias

\begin{tabular}{|c|c|c|c|c|c|c|c|}
\hline \multirow{2}{*}{ Ensaio } & \multirow{2}{*}{ Parâmetro } & \multirow{2}{*}{ Método } & \multicolumn{5}{|c|}{ Materiais ensaiados } \\
\hline & & & $\mathrm{T}$ & $\mathrm{Ct}$ & $\mathrm{Ci}$ & $\mathrm{Ce}$ & $\mathrm{Ca}$ \\
\hline \multirow{22}{*}{ 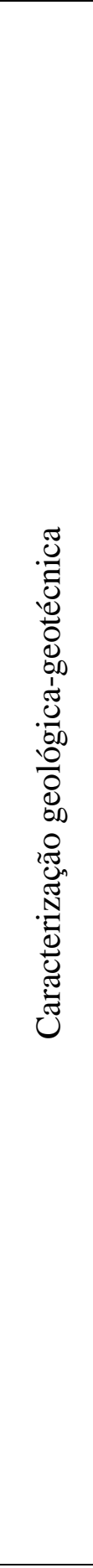 } & $\begin{array}{l}\text { Análise granulométrica } \\
\text { conjunta }\end{array}$ & Vaz et al. (1997) & $\checkmark$ & & & & \\
\hline & $\begin{array}{l}\text { Análise granulométrica } \\
\text { peneiramento }\end{array}$ & Nogueira (1995) & & $\checkmark$ & $\checkmark$ & $\checkmark$ & $\checkmark$ \\
\hline & $\begin{array}{l}\text { Massa específica dos } \\
\text { sólidos }\end{array}$ & ABNT NBR 6508 - 84 & $\checkmark$ & $\checkmark$ & $\checkmark$ & $\checkmark$ & $\checkmark$ \\
\hline & Densidade & MAPA (2007) & $\checkmark$ & $\checkmark$ & $\checkmark$ & $\checkmark$ & $\checkmark$ \\
\hline & Teor de umidade & $\begin{array}{l}\text { ABNT NBR 6457; ASTM D2974; Franchi, } \\
\text { Sígolo e De Lima (2003); Kiehl (1985) }\end{array}$ & $\checkmark$ & $\checkmark$ & $\checkmark$ & $\checkmark$ & $\checkmark$ \\
\hline & CRA & MAPA $(2007)$ & $\checkmark$ & $\checkmark$ & $\checkmark$ & $\checkmark$ & $\checkmark$ \\
\hline & $\begin{array}{l}\text { Parâmetros físico-químicos } \\
\quad(\mathrm{pH}, \Delta \mathrm{pH}, \text { Eh e CE) }\end{array}$ & Embrapa (2011) & $\checkmark$ & $\checkmark$ & $\checkmark$ & $\checkmark$ & $\checkmark$ \\
\hline & PESN & Titulação potenciométrica & $\checkmark$ & & & & \\
\hline & $\begin{array}{l}\text { Composição elementar } \\
\text { (CHN) }\end{array}$ & CHNS/O da PerkinElmer & $\checkmark$ & $\checkmark$ & $\checkmark$ & $\checkmark$ & $\checkmark$ \\
\hline & Potássio total & MAPA (2013) & $\checkmark$ & $\checkmark$ & $\checkmark$ & $\checkmark$ & $\checkmark$ \\
\hline & Fósforo total & MAPA (2013) & $\checkmark$ & $\checkmark$ & $\checkmark$ & $\checkmark$ & $\checkmark$ \\
\hline & Cálcio e magnésio totais & MAPA (2013) & $\checkmark$ & $\checkmark$ & $\checkmark$ & $\checkmark$ & $\checkmark$ \\
\hline & Enxofre total & MAPA (2013) & $\checkmark$ & $\checkmark$ & $\checkmark$ & $\checkmark$ & $\checkmark$ \\
\hline & Carbono orgânico & MAPA (2013) & $\checkmark$ & $\checkmark$ & $\checkmark$ & $\checkmark$ & $\checkmark$ \\
\hline & Matéria orgânica & Kiehl (1985); Lamim et al. (2001) & $\checkmark$ & $\checkmark$ & $\checkmark$ & $\checkmark$ & $\checkmark$ \\
\hline & Teor de cinzas & ASTM D2974 - 14; Kiehl (1985) & $\checkmark$ & $\checkmark$ & $\checkmark$ & $\checkmark$ & $\checkmark$ \\
\hline & AA & $\begin{array}{l}\text { Espectrofotômetro de Absorção Atômica de } \\
\text { Sequência Rápida Varian modelo 240FS }\end{array}$ & $\checkmark$ & $\checkmark$ & $\checkmark$ & $\checkmark$ & $\checkmark$ \\
\hline & CTC e SE & Pejon (1992); MAPA (2013) & $\checkmark$ & $\checkmark$ & $\checkmark$ & $\checkmark$ & $\checkmark$ \\
\hline & DRX & $\begin{array}{l}\text { Guimarães (2007); Difratômetro com } \\
\text { unidade de raios-X da marca Ultima IV e } \\
\text { modelo Rigaku Ultima IV }\end{array}$ & $\checkmark$ & $\checkmark$ & $\checkmark$ & $\checkmark$ & $\checkmark$ \\
\hline & FRX & $\begin{array}{c}\text { Guimarães (2007); Espectrômetro de } \\
\text { Fluorescência de Raios-X modelo Axios } \\
\text { Advantage da Panalytical }\end{array}$ & $\checkmark$ & $\checkmark$ & $\checkmark$ & $\checkmark$ & $\checkmark$ \\
\hline & MEV/EDS & $\begin{array}{c}\text { Raimondi (2014); Microscópio Eletrônico } \\
\text { ZEISS LEO } 440\end{array}$ & $\checkmark$ & $\checkmark$ & $\checkmark$ & $\checkmark$ & $\checkmark$ \\
\hline & ATD & $\begin{array}{l}\text { Petroni (1999); Sistema de Análise Térmica } \\
\text { - Modelo RB-3000-20 da BP Engenharia }\end{array}$ & & $\checkmark$ & $\checkmark$ & $\checkmark$ & $\checkmark$ \\
\hline \multirow{3}{*}{ 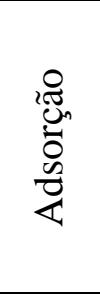 } & $\begin{array}{l}\text { Etapa preliminar - Melhor } \\
\text { razão }\end{array}$ & $\begin{array}{c}\text { Roy et al. (1992); } \\
\text { Zuquette, Silva Jr e Garcia (2008) }\end{array}$ & $\checkmark$ & & & & \\
\hline & $\begin{array}{l}\text { Etapa preliminar - Melhor } \\
\text { composto }\end{array}$ & $\begin{array}{c}\text { Roy et al. (1992); } \\
\text { Zuquette, Silva Jr e Garcia (2008) }\end{array}$ & & $\checkmark$ & $\checkmark$ & $\checkmark$ & $\checkmark$ \\
\hline & $\begin{array}{l}\text { Ensaio de equilíbrio em } \\
\text { lote }\end{array}$ & $\begin{array}{l}\text { Roy et al. (1992); } \\
\text { Zuquette, Silva Jr e Garcia (2008) }\end{array}$ & $\checkmark$ & & $\checkmark$ & & \\
\hline
\end{tabular}

T: Turfa; Ct: composto total; Ci: composto indiano; Ce: composto estático; Ca: composto alambrado Fonte: A autora. 


\section{A) Análise granulométrica - Analisador granulométrico automático}

O ensaio granulométrico, para a turfa, foi realizado empregando o analisador granulométrico automático, desenvolvido pela EMBRAPA Instrumentação - São Carlos. Este equipamento baseia-se no princípio da atenuação de um feixe de raios gama que incide em um recipiente de acrílico contendo a amostra dispersa e em processo de sedimentação.

Segundo EMBRAPA (2011), para solos ricos em matéria orgânica (contendo um teor orgânico acima de 5\%), esse tipo de determinação granulométrica deve ser realizado apenas com a parte mineral da amostra. Para tanto, é necessário incinerar a amostra em mufla antes de utilizá-la no ensaio. Assim, como a turfa apresenta elevado teor orgânico, a amostra já seca em estufa $\left(50^{\circ} \mathrm{C}\right.$ por 48 horas), foi levada para mufla, onde permaneceu a $450^{\circ} \mathrm{C}$ por 24 horas. Esta separação da parte mineral da turfa ocorreu no Laboratório de Geotecnia Ambiental do Departamento de Geotecnia da Escola de Engenharia de São Carlos (EESC) - Universidade de São Paulo (USP).

Para efeito comparativo, optou-se por realizar esse ensaio granulométrico com a amostra total (sem a retirada da matéria orgânica) e somente com a parte mineral (com a retirada da matéria orgânica por combustão). Para cada caso o ensaio foi desenvolvido com defloculante e sem defloculante (apenas com água destilada). Esse experimento foi executado em triplicata para cada um dos tipos mencionados anteriormente. Os defloculantes utilizados foram hidróxido de sódio $(\mathrm{NaOH})$ e hexametafosfato de sódio $\left(\mathrm{NaPO}_{3}\right)_{6}$. Desta forma, no caso das amostras com defloculantes, foram usadas três amostras com $\mathrm{NaOH}$ e três, com $\left(\mathrm{NaPO}_{3}\right)_{6}$. Estas análises experimentais foram realizadas em conformidade com os procedimentos descritos em Vaz et al. (1997).

Como etapa inicial, foi realizada a medida do coeficiente de atenuação em massa, que se refere a um parâmetro de entrada do analisador granulométrico que é intrínseco para cada tipo de material. Para isso, as cubetas de acrílico foram preenchidas (Figura 40), uma com a amostra total de turfa (sem a retirada de matéria orgânica) e outra contendo apenas sua parcela mineral (com a retirada de matéria orgânica). A massa de cada cubeta foi aferiada, já que este é um dos dados de entrada para a atenuação e, posteriormente, foram realizadas leituras das cubetas pelo equipamento. 
Figura 40 - Cubetas para medida do coeficiente de atenuação em massa - Ensaio granulométrico

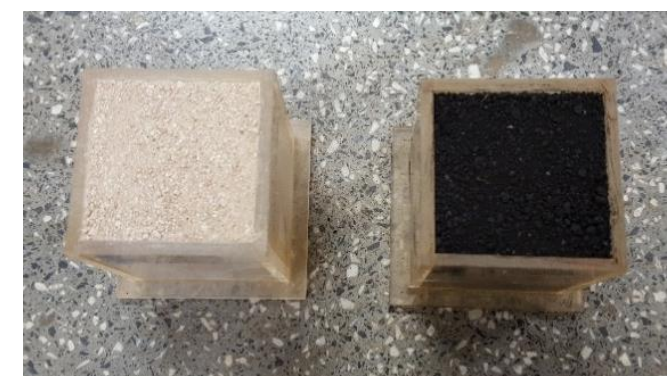

Fonte: A autora.

Sucessivamente, a preparação das amostras foi iniciada para a análise granulométrica propriamente dita. Nessa etapa, como optou-se por realizar o ensaio em várias modalidades, foi trabalhado com amostras totais de turfa (sem a retirada de matéria orgânica) e amostras da parte mineral da turfa (com a retirada de matéria orgânica). Para cada uma delas, foi separada uma massa de $40 \mathrm{~g}$ de material seco, com o auxílio de uma balança. Atentou-se para que cada exemplar contivesse uma massa não inferior a $40 \mathrm{~g}$ ou superior a 40,05 g do respectivo material.

Para cada amostra trabalhada com defloculante, foi adicionado $10 \mathrm{~mL}$ de solução de hidróxido de sódio, preparada seguindo a proporção de $1 \mathrm{~N}$, ou hexametafosfato de sódio, a uma concentração de 45,7 $\mathrm{g} \mathrm{L}^{-1}$, conforme o caso, e água destilada. Já para as amostras nas quais foi efetuada a análise sem defloculante foi acrescentada apenas água destilada (Figura 41). Em seguida, promoveu-se uma mistura inicial com o auxílio de uma espátula.

Figura 41 - Da esquerda para à direita: amostras da porção mineral com $\mathrm{NaOH}$ e água, amostras da turfa total com $\mathrm{NaOH}$ e água e amostras da turfa total apenas com água destilada

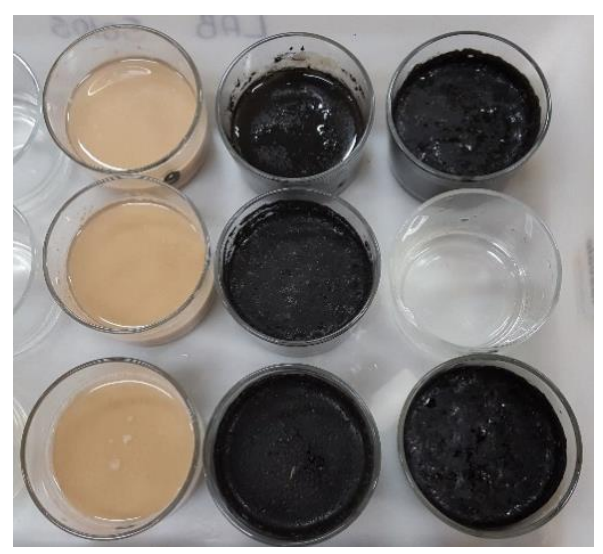

Fonte: A autora.

Cada uma das amostras foi transferida para uma garrafa do Agitador tipo Wagner (Figura 42), acrescentando-se água destilada até completa transferência, visando evitar a perda 
de material. A solução foi agitada por 16 horas ininterruptas, com velocidade de aproximadamente $60 \mathrm{rpm}$, a fim de dispersar as partículas.

Figura 42 - Agitação do conjunto de amostras no agitador tipo Wagner.

A) Porção mineral; B) Amostras totais de turfa
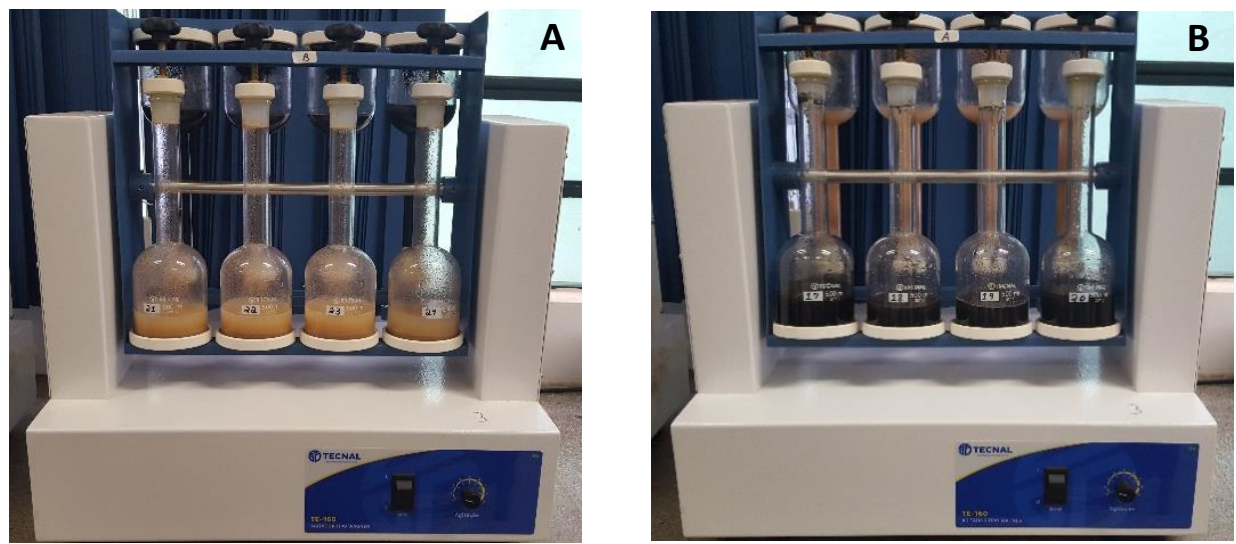

Fonte: A autora.

Cada uma das soluções foi transferida para uma cubeta retangular de acrílico e o volume foi completado com água destilada, até se atingir a altura recomendada (Figura 43).

Figura 43 - Cubetas já preparadas para serem encaminhadas para análise. Da esquerda para à direita: amostras da porção mineral com $\mathrm{NaOH}$ e água, amostras da turfa total com $\mathrm{NaOH}$ e água e amostras da turfa total apenas com água destilada

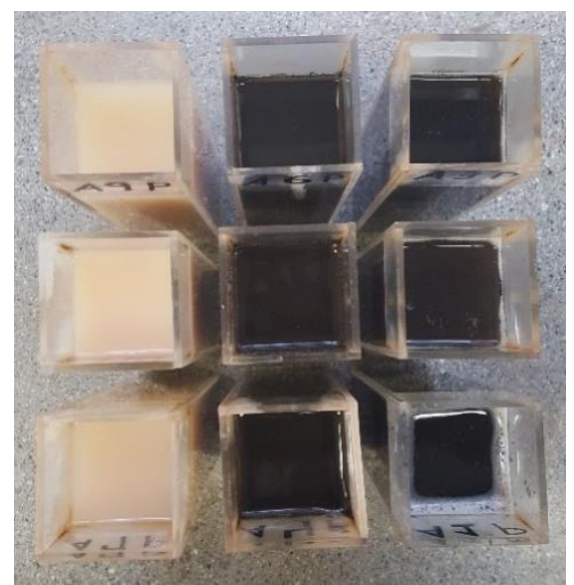

Fonte: A autora.

Após os procedimentos descritos, as medidas foram efetuadas no analisador granulométrico (Figura 44). Para cada amostra o equipamento realiza leituras em triplicata, levando cerca de 23 minutos para completar cada leitura. 
Figura 44 - Analisador granulométrico da EMBRAPA. Atentar para a presença, na parte superior do equipamento, de um agitador, pois cada leitura se inicia após agitação, e de um termômetro, já que a viscosidade da água é dependente da temperatura e é um dos parâmetros usados no cálculo

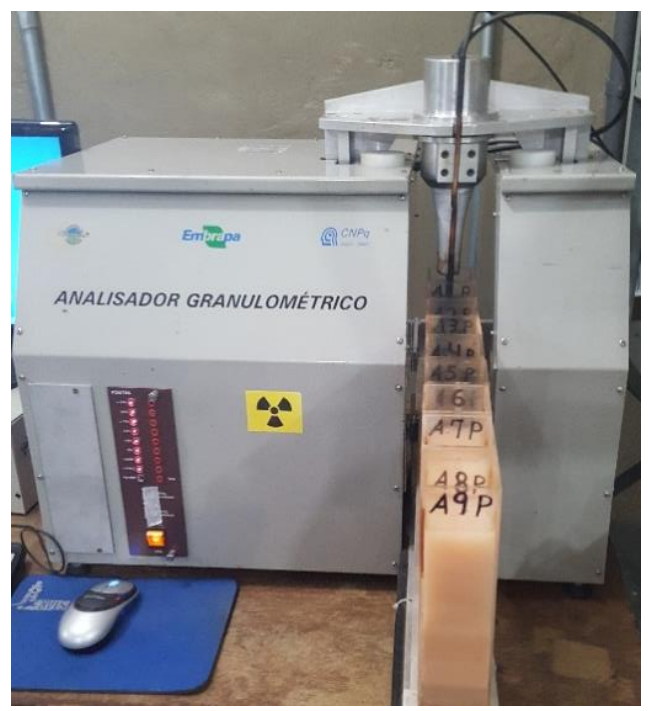

Fonte: A autora.

A Figura 45 exibe as cubetas após a leitura no analisador. Atentar para o fato de já ter decorrido o período de sedimentação. As amostras contendo o defloculante ainda exibem uma porção das partículas dispersas. $\mathrm{Na}$ amostra do meio, referente à porção mineral com $\left(\mathrm{NaPO}_{3}\right)_{6}$, é possível distinguir nitidamente as partículas sedimentadas, no fundo do recipiente, e as partículas dispersas na porção líquida.

Figura 45 - Cubetas após sedimentação. Da esquerda para à direita: amostra da porção mineral apenas com água, amostra da porção mineral com hexametafosfato de sódio e água e amostra da turfa total com hexametafosfato de sódio e água

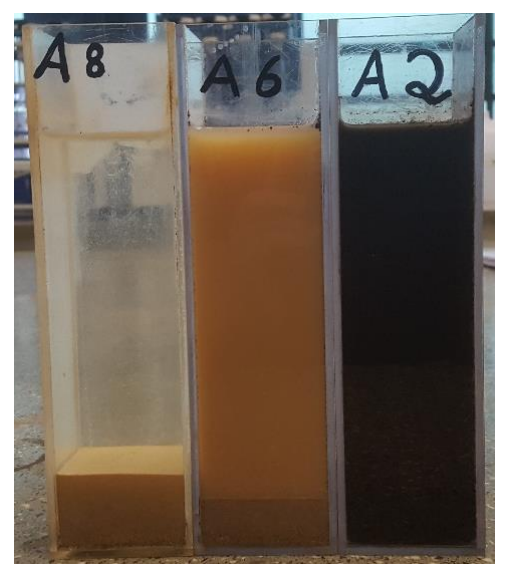

Fonte: A autora.

Devido ao fato das partículas maiores, principalmente aquelas contidas no intervalo de tamanho da fração areia, apresentarem uma maior velocidade de sedimentação, o analisador granulométrico consegue capturar apenas alguns pontos, implicando em uma curva 
granulométrica com poucos dados na sua região superior. Dessa forma, com o intuito de minimizar este fato, após as leituras realizadas pelo analisador granulométrico, cada amostra deve passar pela etapa chamada fração. Para isso, ocorreu um peneiramento em água (Figura 46), através de um conjunto de peneiras com aberturas decrescentes, respectivamente, de 1,00 $\mathrm{mm} ; 0,50 \mathrm{~mm} ; 0,25 \mathrm{~mm} ; 0,10 \mathrm{~mm}$ e $0,05 \mathrm{~mm}$.

Figura 46 - Peneiramento em água corrente e transferência da amostra para o recipiente de evaporação

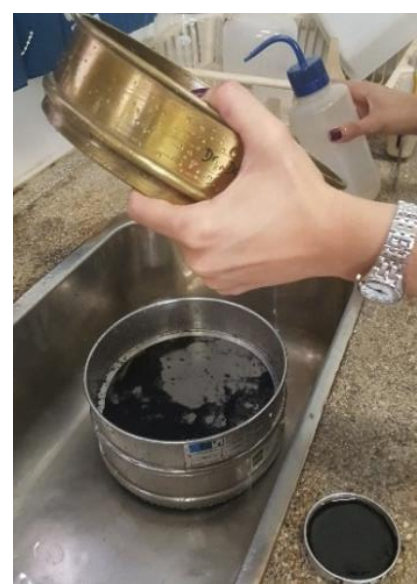

Fonte: A autora.

$\mathrm{Na}$ sequência, as porções de partículas retidas em cada uma das peneiras (Figura 47) foram secas em estufa por um intervalo de 24 horas e suas massas foram determinadas em balança convencional.

Figura 47 - Partículas retidas em cada peneira. Em A e B, amostra de turfa total, respectivamente, antes e após secagem. Em C e D, porção mineral da turfa, respectivamente, antes e após secagem

A

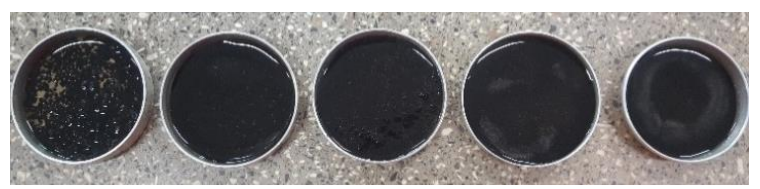

B

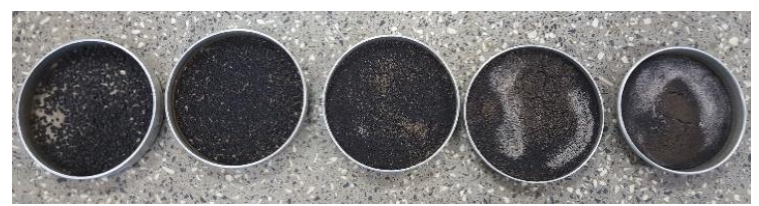

C

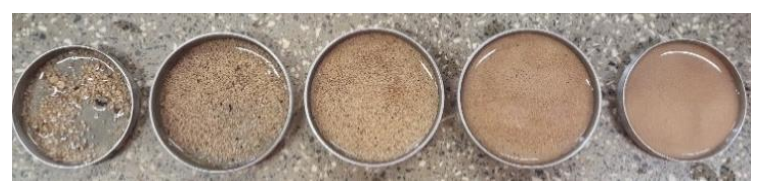

D

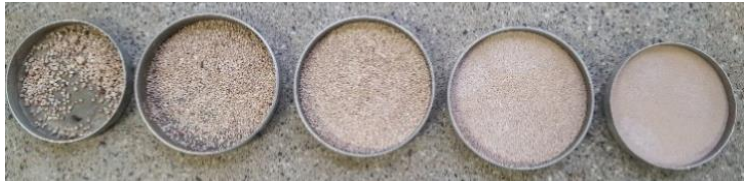

Fonte: A autora. 
A partir destes dados foi possível efetuar o cálculo da fração relacionada a cada intervalo de diâmetro das partículas, através da Equação 14, resultando em novos pontos que relacionam o diâmetro das partículas com suas respectivas porcentagens de ocorrência, que foram também lançados na curva granulométrica.

$$
\text { Fração }=\frac{M_{r e c+m s}-M_{r e c}}{40}
$$

Onde:

$M_{\text {rec }+m s}:$ massa do recipiente e material seco $(\mathrm{g})$;

$M_{\text {rec }}$ : massa do recipiente $(\mathrm{g})$.

Construíram-se gráficos mostrando as curvas granulométricas de cada amostra, compilando os dados resultantes do analisador granulométrico e da etapa de fração, relacionando a porcentagem acumulada em função do diâmetro das partículas. A partir das curvas acumuladas foi possível determinar as porcentagens de cada fração contidas na amostra de turfa.

Esse ensaio foi executado nos Laboratórios de Solos e de Técnicas Nucleares localizados nas dependências da EMBRAPA Instrumentação - São Carlos. Devido à característica distinta do composto, não foi possível realizar este tipo de ensaio com esse material.

\section{B) Análise granulométrica - Peneiramento}

Como as amostras dos compostos eram formadas majoritariamente por partículas mais grossas, a análise granulométrica deste material consistiu apenas no seu peneiramento, realizado segundo Nogueira (1995). Para isso, foram separaradas alíquotas de aproximadamente $100 \mathrm{~g}$ de cada material seco ao ar para seu posterior peneiramento. Foram escolhidas 14 peneiras com aberturas de $4,75 \mathrm{~mm} ; 4,00 \mathrm{~mm} ; 3,36 \mathrm{~mm} ; 2,83 \mathrm{~mm} ; 2,00 \mathrm{~mm}$; $1,41 \mathrm{~mm} ; 1,00 \mathrm{~mm} ; 0,84 \mathrm{~mm} ; 0,59 \mathrm{~mm} ; 0,42 \mathrm{~mm} ; 0,297 \mathrm{~mm} ; 0,149 \mathrm{~mm} ; 0,105 \mathrm{~mm}$ e 0,075 mm, que foram divididas em dois conjuntos devido à capacidade do agitador mecânico (Figura 48) e montadas com as aberturas decrescentes no sentido do topo para a base. Em cada conjunto, sobre a primeira peneira foi colocada uma tampa, a fim de se evitar a perda de material, e 
embaixo da última peneira foi colocado um prato, com o intuito de coletar a amostra passante na última peneira.

Figura 48 - Agitador mecânico com conjunto de peneiras - Ensaio granulométrico com o composto

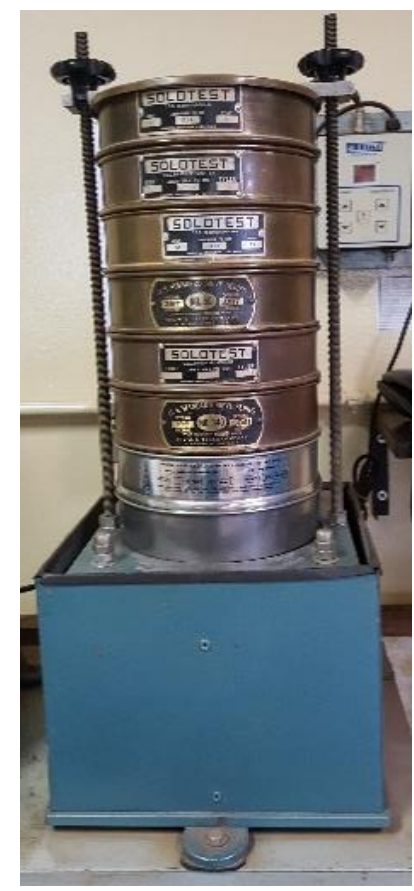

Fonte: A autora.

Inicialmente, a massa de sólidos de cada composto foi determinada em uma balança com resolução de $0,01 \mathrm{~g}$ e transferida para o conjunto contendo as peneiras (conjunto contendo as peneiras com malha de maior abertura). $\mathrm{O}$ conjunto foi transferido para um agitador mecânico e deixado em movimento por um período de 15 minutos. Na sequência, o montante de partículas retido no prato foi transferido para a peneira superior do outro conjunto (com peneiras de menor abertura da malha) que permaneceu também em movimento no agitador por mais 15 minutos. Findada a separação das partículas, os grãos retidos em cada peneira foram recolhidos e foram determinadas suas respectivas massas na mesma balança utilizada no início do ensaio. 
Figura 49 - Compostos fracionados após o peneiramento. A) Composto indiano; B) Composto total; C) Composto alambrado; D) Composto estático
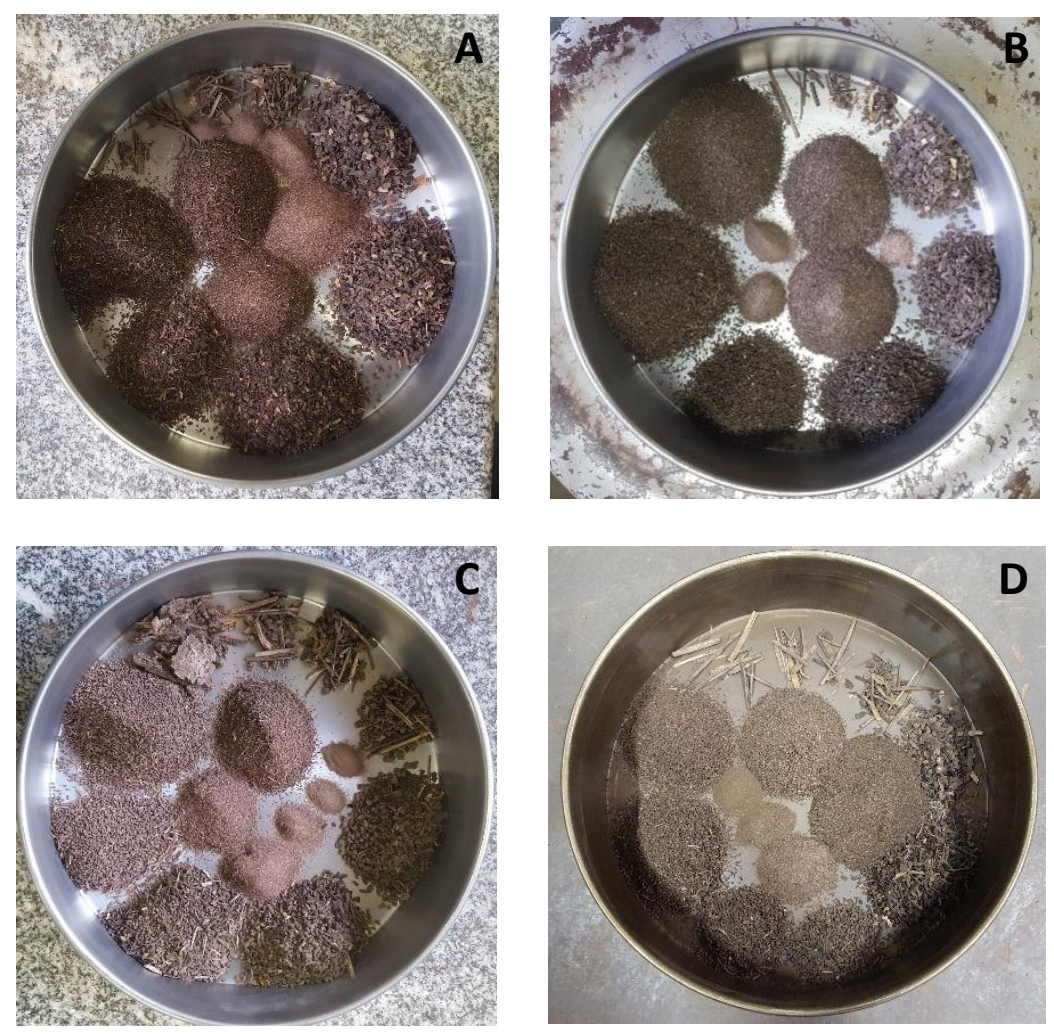

Fonte: A autora.

Com as curvas granulométricas traçadas foi possível determinar os níveis de uniformidade. Essa característica pode ser estudada através dos coeficientes de uniformidade $\left(\mathrm{C}_{\mathrm{U}}\right)$ e de curvatura $\left(\mathrm{C}_{\mathrm{C}}\right)$. Segundo Pinto (2002), o coeficiente de uniformidade está intimamente relacionado à amplitude dos diâmetros dos grãos, enquanto o coeficiente de curvatura é menos utilizado e se associa ao formato da curva de distribuição granulométrica, possibilitando a identificação de possíveis descontinuidades ou concentração excessiva de grãos mais grossos.

Esses coeficientes podem ser calculados através das Equações 15 e 16 (PINTO, 2002).

$$
\begin{array}{cc}
C_{U}=\frac{D_{60}}{D_{10}} & \text { (Equação 15) } \\
C_{C}=\frac{\left(D_{30}\right)^{2}}{D_{10} \cdot D_{60}} & \text { (Equação } 16)
\end{array}
$$

Onde:

$\mathrm{D}_{10}$ : diâmetro do grão da amostra que apresenta $10 \%$ de grãos com diâmetros menores que ele;

$\mathrm{D}_{30}$ : diâmetro do grão da amostra que apresenta $30 \%$ de grãos com diâmetros menores que ele; 
$\mathrm{D}_{60}$ : diâmetro do grão da amostra que apresenta $60 \%$ de grãos com diâmetros menores que ele.

Em termos práticos estes diâmetros correspondem à porcentagem passante (eixo das abcissas da curva de distribuição granulométrica) que é igual a 10, 30 e 60\%, respectivamente.

Este procedimento foi executado, em triplicata, com os compostos orgânicos no Laboratório de Mecânica dos Solos do Departamento de Geotecnia da EESC - USP.

\section{C) Massa específica dos sólidos}

Esse ensaio foi realizado em triplicata segundo a norma brasileira ABNT NBR 6508 84. Para tanto, como a análise tátil visual da turfa e dos compostos orgânicos revelaram que todas as amostras apresentavam considerável presença de partículas com tamanho pertencente ao intervalo areia, foram separaradas três alíquotas de cada um dos materiais contendo cerca de $60 \mathrm{~g}$, uma para cada triplicata. As amostras foram cobertas com água destilada até completa imersão, depois foram agitadas com haste de vidro e as suspensões foram deixadas em repouso por 12 horas (Figura 50).

Figura 50 - Amostras com água destilada, em repouso (ensaio de massa específica dos sólidos). A) Triplicata de turfa; B) Amostra do composto total, indiano, estático e alambrado, respectivamente
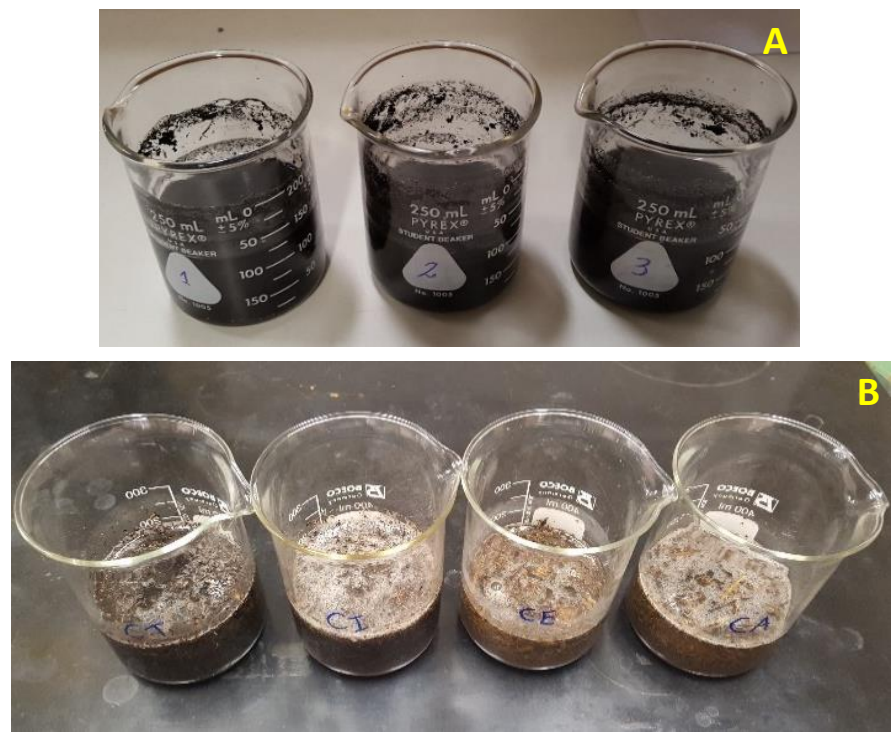

Fonte: A autora.

Após o repouso, cada amostra foi agitada por 15 minutos no dispersor de partículas. A seguir, as amostras foram transferidas para balões volumétricos minimizando a perda de material. Aplicou-se vácuo visando a deaeração das suspensões por cerca de 40 minutos, até 
que cessasse o aparecimento de bolhas de ar (Figura 51). Para cada amostra, foi determinada a massa do conjunto (frasco, água e sólidos) para cinco diferentes temperaturas contidas no intervalo entre 15 a $25^{\circ} \mathrm{C}$, atentando-se para o ajuste do menisco, com água deaerada, sempre que necessário.

Figura 51 - Ensaio de massa específica dos sólidos. A) Deaeração da amostra de turfa; B) Balões volumétricos contendo as amostras de compostos para posterior determinação da temperatura e massa
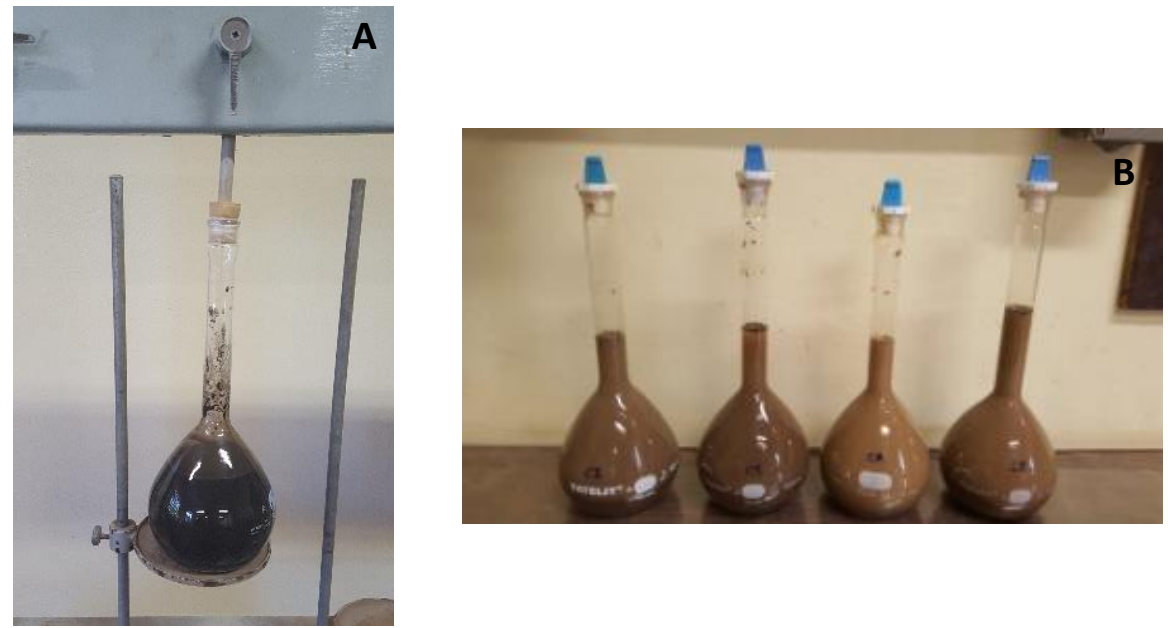

Fonte: A autora.

Findado o ensaio, cada suspensão foi transferida para um recipiente de evaporação que foi levado para estufa a fim de se determinar a massa de sólidos (Figuras 52 e 53).

Figura 52 - Etapa final do ensaio de massa específica. A) Transferência da amostra de turfa após ensaio para um recipiente de evaporação; B) Recipiente de evaporação com amostra de turfa após secagem final
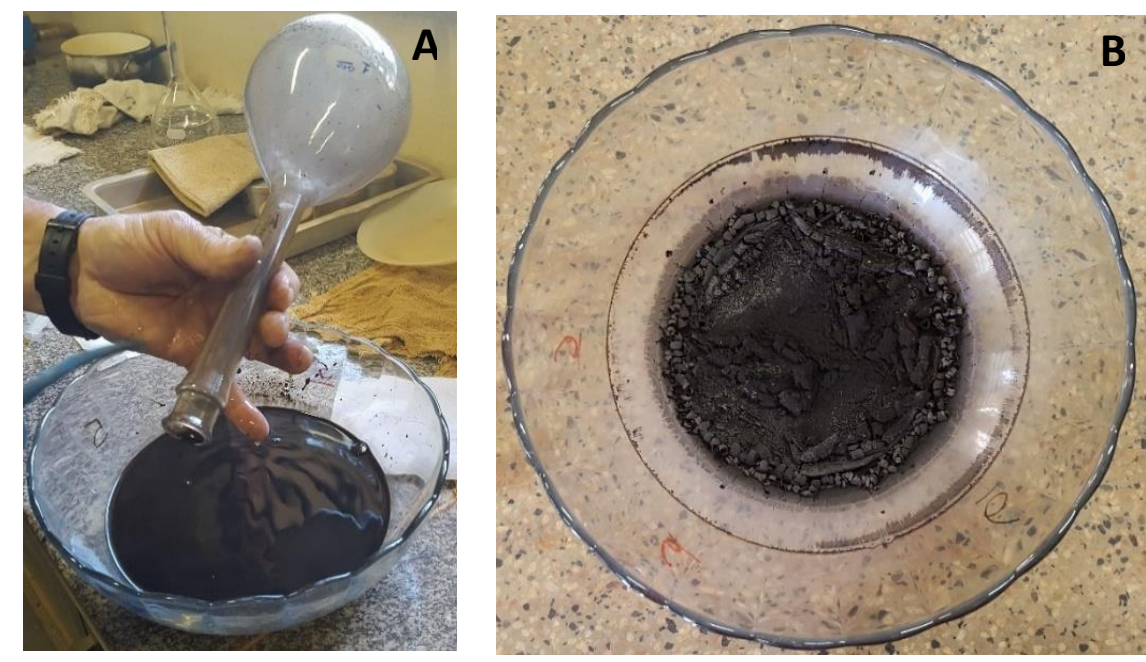

Fonte: A autora. 
Figura 53 - Recipientes de evaporação com compostos após secagem final. A) Composto indiano; B) Composto total; C) Composto alambrado; D) Composto estático
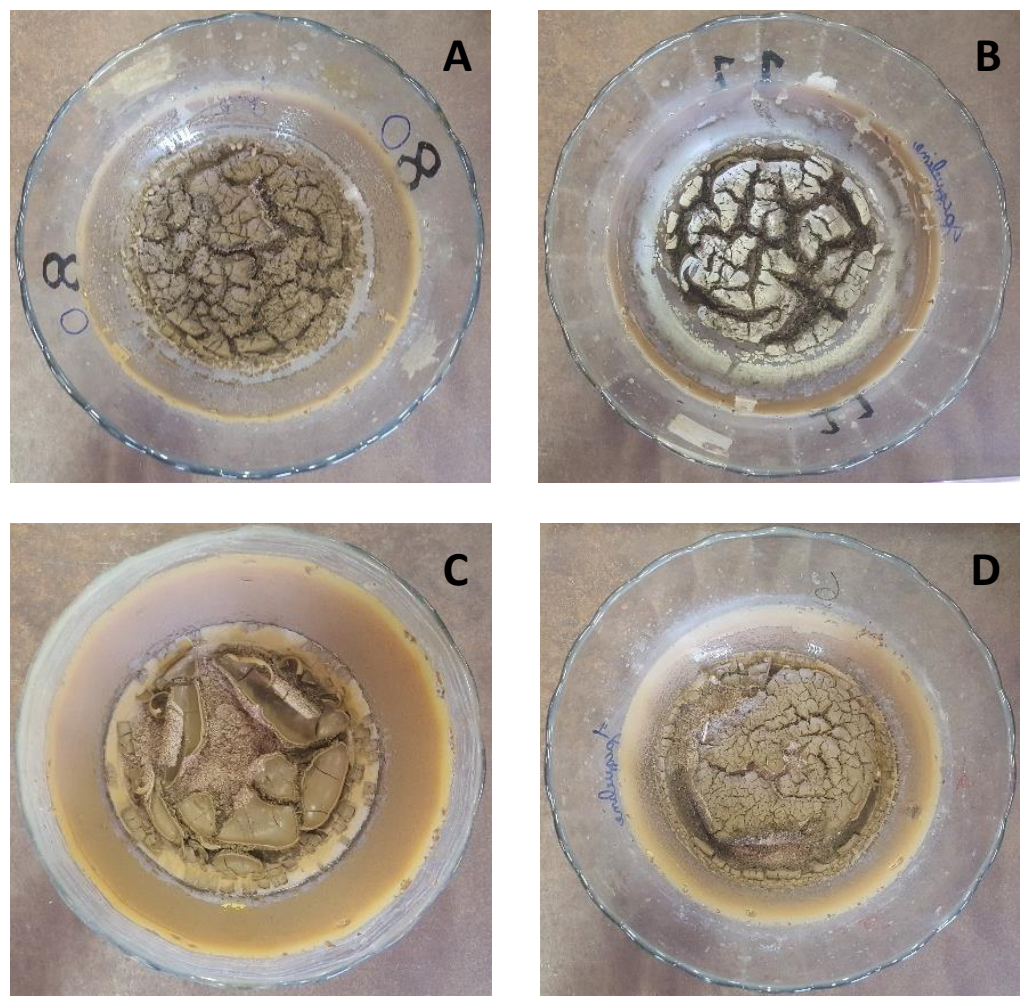

Fonte: A autora.

Com os dados obtidos foi calculada a massa específica dos sólidos de cada amostra através do emprego da Equação 17, apresentada em Nogueira (1995).

$$
\rho_{s}=\frac{M_{s}}{M_{I I}+M_{s}-M_{I}} \rho_{w}
$$

Onde:

$\rho_{s}:$ massa específica dos sólidos $\left(\mathrm{g} \mathrm{cm}^{-3}\right)$;

$M_{s}$ : massa de sólidos que ocupa o volume $\mathrm{V}_{\mathrm{s}}(\mathrm{g})$;

$M_{I I}$ : massa do balão volumétrico e água $(\mathrm{g})$;

$M_{I}$ : massa do balão volumétrico, água e sólidos (g);

$\rho_{w}$ : massa específica da água $\left(\mathrm{g} \mathrm{cm}^{-3}\right)$.

Nota-se que os valores de $\mathrm{M}_{\mathrm{I}}, \mathrm{M}_{\mathrm{II}}$ e $\rho_{\mathrm{w}}$ devem estar relacionados a uma mesma temperatura, sendo que $M_{I}$ é obtida pelo ensaio, $M_{I I}$, através da curva de calibração, e $\rho_{\mathrm{w}}$, de dados da literatura. Cada balão volumétrico foi previamente calibrado. 
Esse ensaio foi realizado com a turfa e os compostos orgânicos, em triplicata, no Laboratório de Mecânica dos Solos do Departamento de Geotecnia da EESC-USP.

\section{D) Teor de umidade}

A umidade da turfa e dos compostos orgânicos foi determinada através de diferentes métodos. Para a turfa, a amostra já havia sido parcialmente seca ao ar. Então, o primeiro método empregado foi baseado na secagem da amostra em estufa com temperatura entre 105 e $110^{\circ} \mathrm{C}$, até obtenção de massa constante, que comumente é encontrada após 16 a 24 horas, conforme recomendação da ABNT NBR 6457 - 86 para solos, e da ASTM D2974 - 14 para turfas. Outro método adotado para a turfa consistiu em uma adaptação da norma brasileira em questão para turfas e da metodologia descrita em Franchi, Sígolo e De Lima (2003). Segundo a ABNT NBR 6457 - 86, o teor de umidade para solos orgânicos ou turfosos deve ser resultado de secagem em estufa à temperatura de 60 a $65^{\circ} \mathrm{C}$, até a obtenção de massa constante. De forma similar, Franchi, Sígolo e De Lima (2003) utilizaram uma temperatura de $70^{\circ} \mathrm{C}$. Nesta pesquisa, no entanto, visando avaliar comparativamente o impacto da temperatura na determinação da umidade, optou-se por empregar uma temperatura ainda inferior, variando de 40 a $50^{\circ} \mathrm{C}$. Para os compostos orgânicos, devido ao fato de não terem sido secos ao ar, primeiramente, tais amostras foram secas ao ar (temperatura ambiente, próxima a $25^{\circ} \mathrm{C}$ ). Na sequência, de forma similar ao que foi realizado com a turfa, os compostos foram colocados em estufa, com temperatura de 105 a $110^{\circ} \mathrm{C}$ ou de 40 a $50^{\circ} \mathrm{C}$.

Outro procedimento adotado para determinação da umidade dos compostos orgânicos e da turfa seguiu metodologia com temperaturas combinadas, conforme descrito por Kiehl (1985) para fertilizantes orgânicos. Assim, amostras de turfa e compostos orgânicos foram submetidas a uma temperatura inicial de 60 a $65^{\circ} \mathrm{C}$ e, em seguida, estes mesmos materiais foram expostos a uma temperatura de 105 a $110^{\circ} \mathrm{C}$. Neste caso, diz-se que a umidade total, é igual à soma entre as duas umidades obtidas.

Para a turfa, o teor de umidade foi determinado conforme a norma ABNT NBR 6457 86 (Equação 18). Já para os compostos foi utilizada a formulação apresentada em MAPA (2013) para fertilizantes orgânicos (Equação 19). Os resultados foram expressos em termos percentuais.

$$
h=\frac{M_{1}-M_{2}}{M_{2}-M_{3}} \times 100=\frac{M_{w}}{M_{s}} \times 100
$$




$$
h=\frac{M_{1}-M_{2}}{M_{1}-M_{3}} \times 100=\frac{M_{w}}{M_{a}} \times 100
$$

Onde:

$h$ : teor de umidade $(\%)$;

$M_{1}$ : massa da amostra úmida mais a massa do recipiente $(\mathrm{g})$;

$M_{2}$ : massa da amostra seca mais a massa do recipiente $(\mathrm{g})$;

$M_{3}$ : massa do recipiente $(\mathrm{g})$;

$M_{w}$ : massa de água na amostra $(\mathrm{g})$;

$M_{S}:$ massa de sólidos na amostra $(\mathrm{g})$;

$M_{a}$ : massa total da amostra (sólidos e água) $(\mathrm{g})$.

Esse ensaio foi realizado em triplicata, para a turfa e os compostos orgânicos, no Laboratório de Geotecnia Ambiental do Departamento de Geotecnia da EESC - USP.

\section{E) Parâmetros físico-químicos (pH, $\Delta \mathrm{pH}$, Eh e CE)}

A primeira etapa da obtenção dos parâmetros físico-químicos é a minuciosa calibração dos equipamentos de medição com as soluções tampão específicas para esta finalidade.

A determinação do potencial hidrogeniônico $(\mathrm{pH})$ ocorreu em água e em cloreto de potássio $(\mathrm{KCl})$, para manter a força iônica do meio. As determinações de $\mathrm{pH}$ em água e em cloreto de potássio foram realizadas em triplicata conforme metodologia apresentada em EMBRAPA (2011). Neste caso, esse ensaio envolveu uma suspensão contendo turfa ou compostos orgânicos e líquido (água ou $\mathrm{KCl}$ ) na proporção de $1 / 2,5$, ou seja, contendo $10 \mathrm{~g}$ de material reativo (turfa ou compostos) e $25 \mathrm{~mL}$ de água destilada ou $25 \mathrm{~mL}$ de $\mathrm{KCl}(1 \mathrm{M})$. Cada uma das amostras foi agitada com bastão de vidro e deixada em repouso por 1 hora. Em seguida, elas foram filtradas em papel filtro e as leituras de $\mathrm{pH}$ foram realizadas a partir do uso de um eletrodo de vidro. Neste ensaio foi utilizado pHmetro Digimed DM 21 (Figura 54). A medida do $\mathrm{pH}$ em água e do $\mathrm{pH}$ em $\mathrm{KCl}$ permitiu o cálculo do $\Delta \mathrm{pH}$ (Equação 20):

$$
\Delta p H=p H_{K C l}-p H_{H_{2} O}
$$


Figura 54 - PHmetro Digimed DM 21

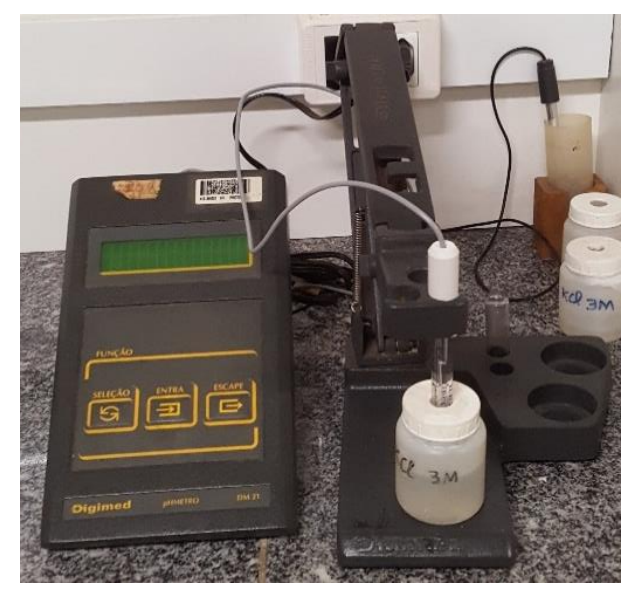

Fonte: A autora.

Foram obtidos ainda, também em triplicata, o potencial de oxi-redução (Eh) e a condutividade elétrica (CE), empregando as mesmas soluções contendo água usadas na determinação do $\mathrm{pH}$. O Eh foi determinado com um eletrodo de anel de platina conectado a um pHmetro Micronal B374 (Figura 55), sendo o eletrodo de referência combinado Ag/ClAg.

Figura 55 - PHmetro Micronal B374. Leitura do Eh

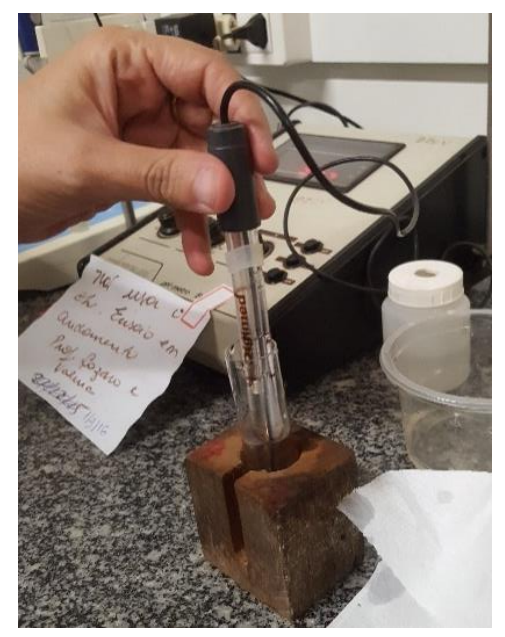

Fonte: A autora.

A CE foi obtida com condutivímetro Analyser 650 e célula condutimétrica Analyser 7A04 (Figura 56). 
Figura 56 - Leitura da CE em condutivímetro Analyser 650

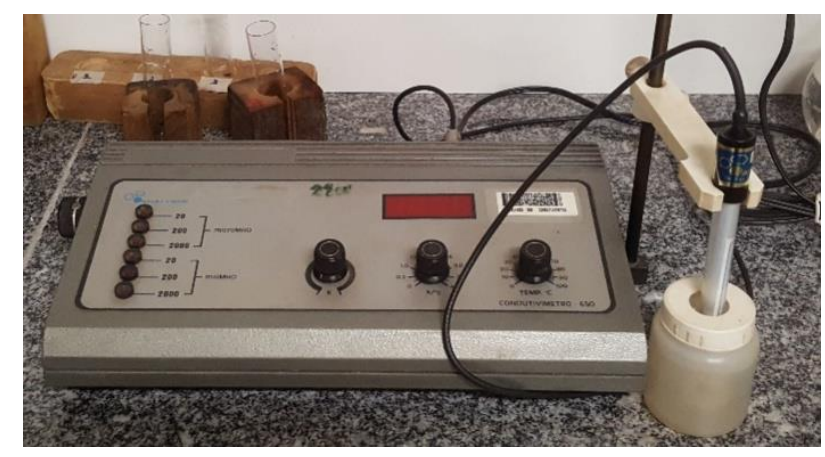

Fonte: A autora.

Os parâmetros físico-químicos foram determinados para a turfa e para os compostos orgânicos, em triplicata, no Laboratório de Geotecnia Ambiental do Departamento de Geotecnia da EESC - USP.

\section{F) Ponto de carga zero (PCZ) e ponto de efeito salino nulo (PESN)}

O ponto de carga zero (PCZ) foi estimado a partir da Equação 21 proposta por Keng e Uehara (1973):

$$
P C Z=2 p H_{K C l}-p H_{H_{2} O} \quad \text { (Equação 21) }
$$

Já o ponto de efeito salino nulo (PESN) foi determinado experimentalmente. No entanto, não existe um ensaio padronizado e normatizado visando a avaliação do comportamento das cargas superficiais das partículas do solo e de materiais reativos. Contudo, um método bem difundido na determinação do ponto de efeito salino nulo é a titulação potenciométrica. Segundo Keng e Uehara (1973) pode ser empregado um eletrólito indiferente, como $\mathrm{KCl}$ ou $\mathrm{NaCl}$, visando o objetivo da determinação que é o cruzamento das curvas em um único ponto.

Assim, nesta pesquisa, o PESN foi determinado a partir do cruzamento das curvas resultantes da titulação potenciométrica ácido-base realizada com várias forças iônicas. Esta metodologia envolveu um amplo conjunto de soluções usando o $\mathrm{KCl}$ como eletrólito. Para simplificação, inicialmente foram preparadas três soluções estoque: $\mathrm{KCl}(1 \mathrm{M}), \mathrm{HCl}(0,1 \mathrm{M})$ e $\mathrm{NaOH}(0,1 \mathrm{M})$, e a partir destas soluções, as demais foram sendo preparadas.

Através da diluição da solução de $\mathrm{KCl}(1 \mathrm{M})$ foram obtidas três soluções eletrolíticas de $\mathrm{KCl}$ nas concentrações de $0,1 \mathrm{M}, 0,01 \mathrm{M}$ e 0,001 M. Utilizando cada uma delas como solvente foi criada uma sequência de novas soluções com concentrações crescentes de ácido $(\mathrm{HCl})$ ou 
base $(\mathrm{NaOH})$, ambos nas molaridades de 0,002 M; 0,004 M; 0,008 M; 0,016 M; 0,032 M e 0,064 M, totalizando um conjunto de 18 soluções ácidas e 18 soluções básicas.

Utilizando a Equação 22 foram determinados os volumes requeridos para o preparo da solução de $\mathrm{HCl}(0,002 \mathrm{M})$ empregando como solvente $\mathrm{KCl}(0,1 \mathrm{M})$. Nesse caso, os dados de

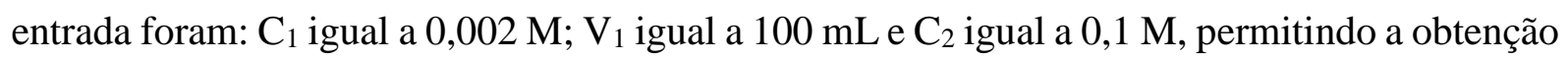
de $\mathrm{V}_{2}$ igual a $2 \mathrm{~mL}$.

$$
C_{1} x V_{1}=C_{2} x V_{2} \quad \text { (Equação 22) }
$$

Onde:

$\mathrm{C}_{1}$ : concentração desejada $(\mathrm{M})$;

$\mathrm{V}_{1}$ : volume desejado $(\mathrm{mL})$;

$\mathrm{C}_{2}$ : concentração da solução estoque $(\mathrm{M})$;

$\mathrm{V}_{2}$ : volume da solução estoque $(\mathrm{mL})$.

Assim, para se preparar 100 mL da solução ácida com concentração de $\mathrm{HCl}$ de 0,002 M e utilizando $\mathrm{KCl}(0,1 \mathrm{M})$ como solvente, adicionaram-se $2 \mathrm{~mL}$ de $\mathrm{HCl}(0,1 \mathrm{M})$ em um balão volumétrico de $100 \mathrm{~mL}$ e completou-se o volume do balão com $\mathrm{KCl}(0,1 \mathrm{M})$ até se atingir o menisco. De maneira análoga foram calculados os volumes requeridos na preparação das demais soluções.

A seguir, foi adicionado um volume de $20 \mathrm{~mL}$ de cada solução em uma massa de turfa de 4,00 g, mantendo, portanto, constante a razão material reativo/solução (1/5) ao longo de todo o ensaio (Figura 57).

Figura 57 - Soluções eletrolíticas e material reativo durante o ensaio de ponto de efeito salino nulo

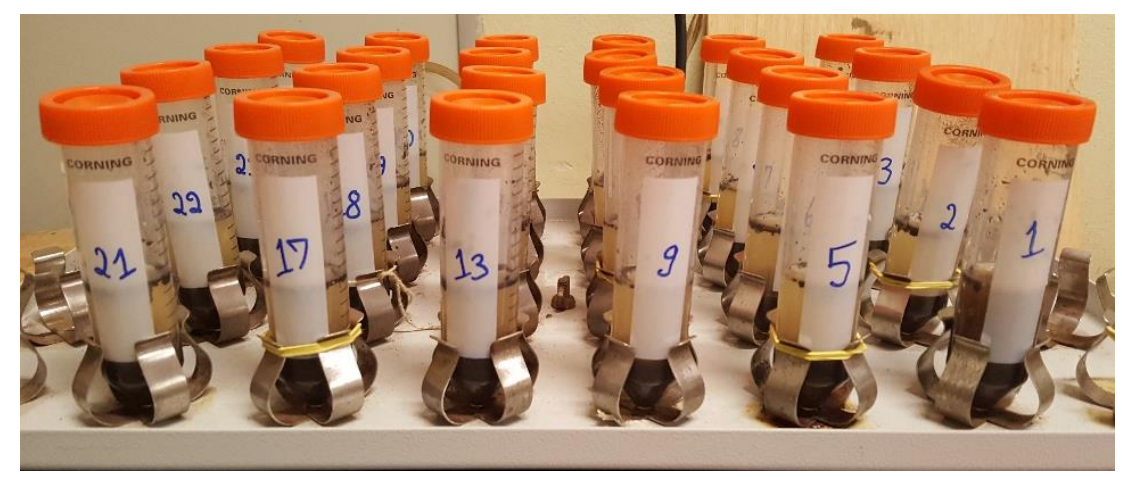

Fonte: A autora. 
Estas soluções foram mantidas em temperatura e pressão constante até que atingissem o estado de equilíbrio, alcançado após 24 horas. Durante este período de tempo, as amostras foram agitadas de modo manual. Na sequência, mediu-se o $\mathrm{pH}$ das soluções, utilizando o pHmetro Digimed DM 21. A Figura 58 exibe algumas soluções imediatamente antes da leitura de seus respectivos pHs de equilíbrio. Observa-se uma sedimentação mais intensa na solução ácida em comparação com a solução básica.

Figura 58 - Soluções de turfa preparadas em $\mathrm{KCl}(0,001 \mathrm{M})$. À esquerda, contendo $\mathrm{HCl}(0,064 \mathrm{M})$ e à direita, $\mathrm{NaOH}(0,064 \mathrm{M})$

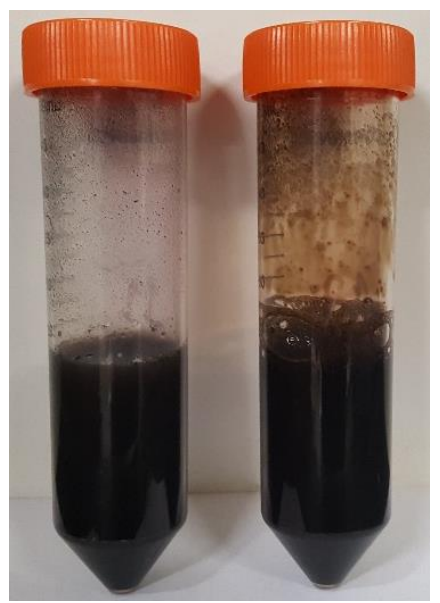

Fonte: A autora.

Este procedimento foi efetuado com a amostra de turfa no Laboratório de Geotecnia Ambiental do Departamento de Geotecnia da EESC - USP.

\section{G) Matéria orgânica (MO)}

O teor de matéria orgânica (MO) presente na turfa e nos compostos orgânicos foi determinado através da combustão da amostra, em mufla, a $550^{\circ} \mathrm{C}$, de acordo com metodologia apresentada em Kiehl (1985) e adotada por Lamim et al. (2001), durante 24 horas (Figuras 59 e 60). A amostra de turfa ensaiada foi anteriormente seca em estufa entre 40 e $50^{\circ} \mathrm{C}$ e as amostras de compostos orgânicos foram secas a temperatura ambiente (próxima a $25^{\circ} \mathrm{C}$ ). 
Figura 59 - Ensaio para determinação do teor de matéria orgânica da turfa.

A) amostra antes da mufla; B) Amostra após a mufla
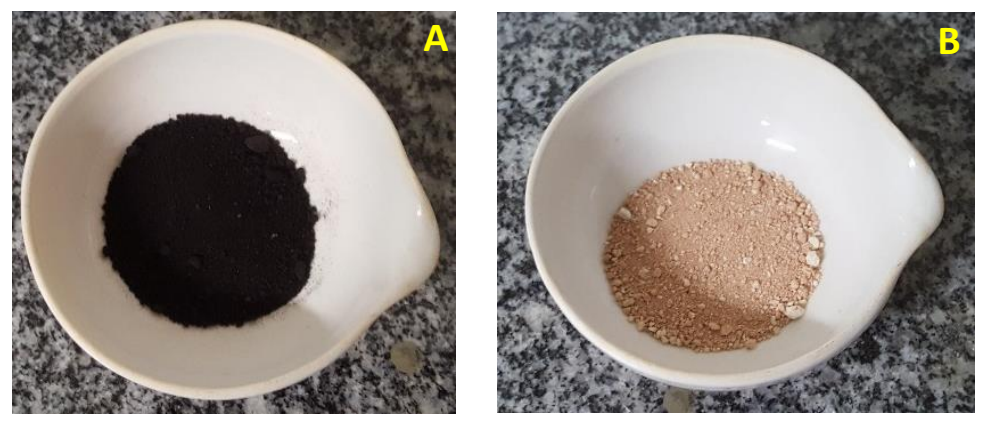

Fonte: A autora.

Figura 60 - Ensaio para determinação do teor de matéria orgânica dos compostos.

A) Amostras de compostos antes da mufla, na sequência, compostos total, indiano, estático e alambrado; B) Amostras de compostos após a mufla, dispostos em similar sequência

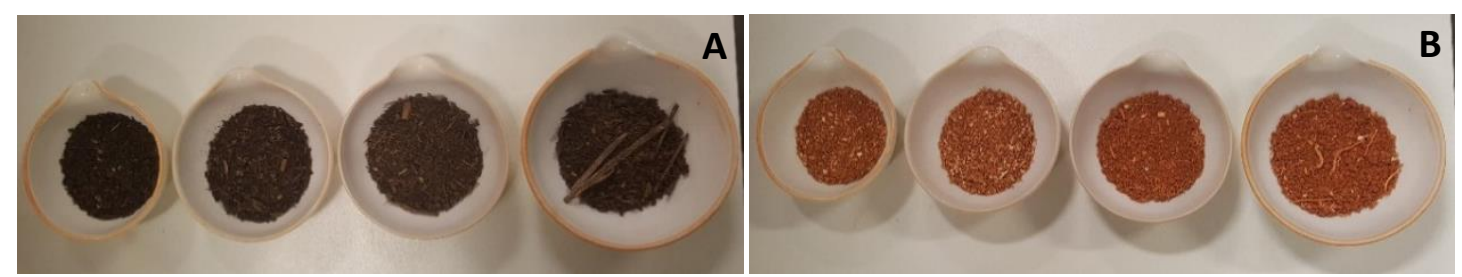

Fonte: A autora.

O teor de matéria orgânica foi determinado através da Equação 23.

$$
M O=\frac{M_{i}-M_{f}}{M_{i}} \times 1000
$$

Onde:

$M O$ : teor de matéria orgânica $\left(\mathrm{g} \mathrm{kg}^{-1}\right)$;

$M_{i}$ : massa da amostra antes da mufla $(\mathrm{g})$;

$M_{f}$ : massa da amostra após a mufla $(\mathrm{g})$.

A determinação do teor de matéria orgânica foi realizada com a turfa e os compostos organicos, em triplicata, no Laboratório de Geotecnia Ambiental da EESC - USP.

\section{H) Teor de cinzas $(\mathrm{Cz})$}

O teor de cinzas $(\mathrm{Cz})$ seguiu os pressupostos apresentados na norma ASTM D2974 - 14 (Método C). Conforme a referida norma, própria para turfas e outros solos orgânicos, as 
amostras são compostas por matéria orgânica e cinzas. Sendo assim, após a incineração da matéria orgânica, o material resultante corresponde justamente à fração inorgânica ou teor de cinzas. Segundo essa norma, as amostras devem ser calcinadas a uma temperatura de $440 \pm$ $40^{\circ} \mathrm{C}$. No entanto, esta temperatura foi elevada para $550^{\circ} \mathrm{C}$, segundo metodologia adotada para determinação dos teores de matéria orgânica (KIEHL, 1985). Desse modo, o teor de cinza pode ser calculado pela Equação 24:

$$
C_{z}=1000-M O \quad \text { (Equação 24) }
$$

Onde:

$\mathrm{C}_{\mathrm{z}}$ : teor de cinza $\left(\mathrm{g} \mathrm{kg}^{-1}\right)$;

MO: teor de matéria orgânica $\left(\mathrm{g} \mathrm{kg}^{-1}\right)$.

No entanto, é importante ressaltar que não existe um consenso entre os autores sobre essa determinação. Crescêncio Junior (2008) e Petroni, Pires e Munita (2000), por exemplo, encontraram o teor de cinza de suas amostras de turfa mediante análise gravimétrica, com a queima do material a $1100^{\circ} \mathrm{C}$ por 2 horas. Já Franchi (2004) determinou o teor de cinza da turfa a partir de um aquecimento progressivo, com patamares sucessivos de $50^{\circ} \mathrm{C}$ até se atingir $550^{\circ} \mathrm{C}$, com tempo de residência de 30 minutos por patamar e de 4 horas na temperatura final.

Este parâmetro foi resultante de um cálculo complementar do ensaio de matéria orgânica desenvolvido, para a turfa e os compostos orgânicos, no Laboratório de Geotecnia Ambiental do Departamento de Geotecnia da EESC - USP.

\section{I) Capacidade de troca catiônica (CTC) e superfície específica (SE)}

A capacidade de troca catiônica (CTC) e a superfície específica (SE) da turfa e dos compostos orgânicos foram determinadas através do método de adsorção de azul de metileno descrito em Pejon (1992). O azul de metileno é um corante orgânico que apresenta o nome químico de cloridrato de metilamina e a formulação molecular $\mathrm{C}_{16} \mathrm{H}_{18} \mathrm{~N}_{3} \mathrm{SCl} \cdot 3 \mathrm{H}_{2} \mathrm{O}$. Esse método se baseia no princípio de que a CTC e a SE de solos podem ser determinadas a partir da quantidade de azul de metileno necessária para ocupar todos os sítios de adsorção presentes no material de interesse, uma vez conhecida as dimensões da molécula de azul de metileno e considerando que a camada do corante adsorvida sobre as partículas é monomolecular.

De acordo com o referido procedimento, este ensaio deve envolver uma massa de 2 a 4 g do material úmido. Entretanto, como esperava-se obter um valor consideravelmente elevado 
de CTC, optou-se por utilizar uma massa inferior a $2 \mathrm{~g}$ dos materiais reativos orgânicos. Para cada umas das análises, primeiramente foi adicionada uma quantidade de turfa ou composto, dentro do intervalo especificado, em um béquer, sendo determinada sua massa em balança convencional com precisão de 4 casas decimais. Preparou-se uma suspensão do material com água destilada. A referida metodologia recomendava o uso de $10 \mathrm{~mL}$ de água destilada. Contudo, devido as características peculiares da turfa e dos compostos, empregou-se um volume de 20 a $30 \mathrm{~mL}$.

Em seguida, procedeu-se a execução do ensaio propriamente dito, através da titulação individual de cada uma das suspensões contendo turfa ou composto e água destilada com a solução de azul de metileno, preparada segundo uma concentração de $1,5 \mathrm{~g} \mathrm{~L}^{-1}$, sob agitação constante, possibilitada pelo emprego de um agitador magnético. No início, foi adicionado um volume de $5 \mathrm{~mL}$ da solução de azul de metileno e transcorrido um minuto, foi colocada uma gota da suspensão de turfa ou composto, com o auxílio da haste de vidro, sobre o papel de filtro Whatman $n^{\circ} 42$. Ao verificar-se a formação de apenas uma mancha escura, esta etapa do teste é considerada inacabada. Entretanto, ao constatar-se a presença de uma auréola azul mais claro em torno da mancha escura, esta etapa é dita acabada. No primeiro caso, é adicionada mais uma quantidade de azul de metileno, espera-se novamente mais 1 minuto, é retirada novamente a gota e repete-se este procedimento até o aparecimento da auréola. No segundo caso, espera-se mais 2 minutos e é retirada outra gota. Caso a auréola não mais apareça, é adicionado novamente mais azul de metileno. Já no caso dela aparecer novamente o teste pode ser considerado acabado, uma vez que atingiu o chamado ponto de saturação. A auréola evidencia que existe azul de metileno em excesso na suspensão, podendo-se assumir que todos os sítios com potencial de adsorverem azul de metileno se encontram cobertos por moléculas dessa solução. Assim, o volume de azul de metileno gasto deve ser conferido na bureta e anotado. 
Figura 61 - Ensaio de adsorção com azul de metileno

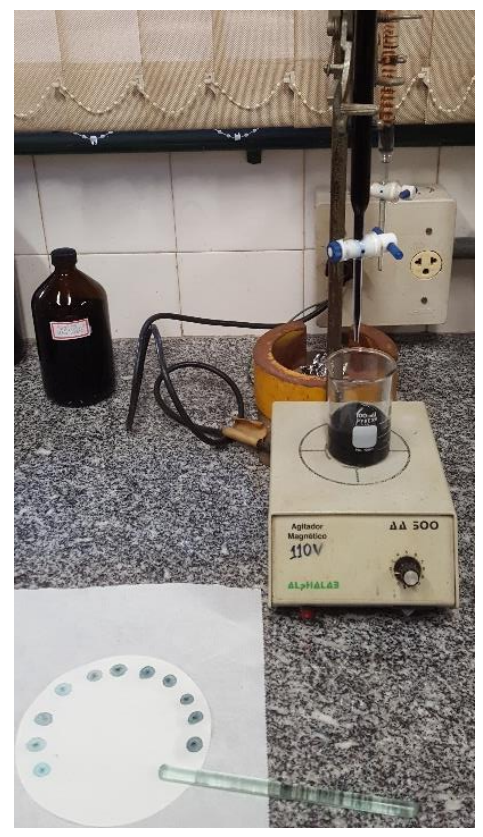

Fonte: A autora.

Nota-se que é de indubitável importância que o volume de azul de metileno a ser adicionado vá sendo reduzido, a fim de refinar o resultado. No final, deve-se utilizar um volume de $0,5 \mathrm{~mL}$ ou, no máximo, $1,0 \mathrm{~mL}$.

Findada a parte experimental, deve-se proceder aos cálculos. De acordo com Chen et al. (1974) ${ }^{10}$ apud Pejon (1992), a capacidade de troca catiônica pode ser obtida por intermédio da Equação 25:

$$
C T C=\frac{V \times C \times 100}{M}
$$

Onde:

CTC: Capacidade de troca catiônica $\left(\mathrm{cmol}_{\mathrm{c}} \mathrm{kg}^{-1}\right)$;

V: Volume da solução de azul de metileno gasto $(\mathrm{mL})$;

C: Concentração da solução de azul de metileno (normalidade);

M: Massa de solo seco (g).

${ }^{10}$ CHEN, T. J.; SANTOS, P. S.; FERREIRA, H. C.; CALIL, S. F.; ZANDONADI, A. R.; CAMPOS, L. V. Determinação da capacidade de troca de cátions e da área específica de algumas argilas e caulins cerâmicos brasileiros pelo azul de metileno e sua correlação com algumas propriedades tecnológicas. 1974. 
Quanto à superfície específica, apresentada em termos da área por unidade de massa do material, ela pode ser calculada conforme Beaulieu (1979) ${ }^{11}$ apud Pejon (1992) pela Equação 26:

$$
S E=\frac{3,67 \times V}{M}
$$

Onde:

SE: Superfície específica $\left(\mathrm{m}^{2} \mathrm{~g}^{-1}\right)$;

V: Volume da solução de azul de metileno gasto $(\mathrm{mL})$;

M: Massa de solo seco (g).

Esse ensaio foi realizado com a turfa e com os compostos orgânicos, em triplicata, no Laboratório de Geotecnia Ambiental do Departamento de Geotecnia da EESC - USP.

\section{J) Composição elementar (C, H, N)}

A determinação da composição elementar de carbono $(\mathrm{C})$, hidrogênio $(\mathrm{H})$ e nitrogênio (N) presentes na turfa e nos compostos foi realizada através da técnica instrumental da análise elementar (CHN). Em termos operacionais, este método envolve a oxidação da amostra contida em uma cápsula de estanho, liberando uma mistura de gases, contendo $\mathrm{CO}_{2}, \mathrm{H}_{2} \mathrm{O}$ e $\mathrm{N}_{2}$, os quais são separados através de uma coluna cromatográfica e quantificados através do emprego de um detector de termocondutividade, produzindo um sinal elétrico que é convertido para teores percentuais de, respectivamente, C, H e N (SANTOS, 2014). Para essa determinação foi utilizado um equipamento CHNS/O da PerkinElmer. Devido ao S não ser um elemento de rotina nas análises realizadas por esse equipamento, o mesmo não foi detectado nas amostras de turfa e de composto. Esse ensaio foi realizado, em triplicata, no Laboratório de Caracterização FísicoQuímica da EMBRAPA Instrumentação - São Carlos.

\section{K) Difratometria de Raios-X (DRX)}

A preparação das lâminas foi realizada conforme Guimarães (2007). Assim, inicialmente foi preparada uma suspensão contendo cerca de 0,8 a 1,5 g do material peneirado (turfa e compostos), $500 \mathrm{~mL}$ de água destilada e $100 \mathrm{~mL}$ de hexametafosfato de sódio (45,7 g

\footnotetext{
${ }^{11}$ BEAULIEU, J.. Identification géotechnique des matériaux argileux naturels par la mesure de leur surface au moyen du bleu de méthylène. Thèse de doctorat de $3^{\circ}$ cycle, Univ. de Paris-Sud, Orsay. 1979.
} 
$\mathrm{L}^{-1}$ ), empregado como defloculante. Após agitação, com o auxílio de um bastão de vidro, esta suspensão foi dividida entre três recipientes contendo em cada um deles uma lâmina de vidro apoiada sobre um suporte cilíndrico. Os conjuntos permaneceram em repouso a fim de garantir a sedimentação das partículas sólidas sobre as lâminas. Cessada essa deposição, foi retirado o excedente de suspensão existente em cada conjunto e as lâminas foram secas em temperatura ambiente. As Figuras 62 e 63 exibem momentos da preparação das lâminas.

Figura 62 - Preparação das lâminas com a amostra de turfa - ensaio de DRX. A) Dispersão da suspensão; B) Lâminas após secagem
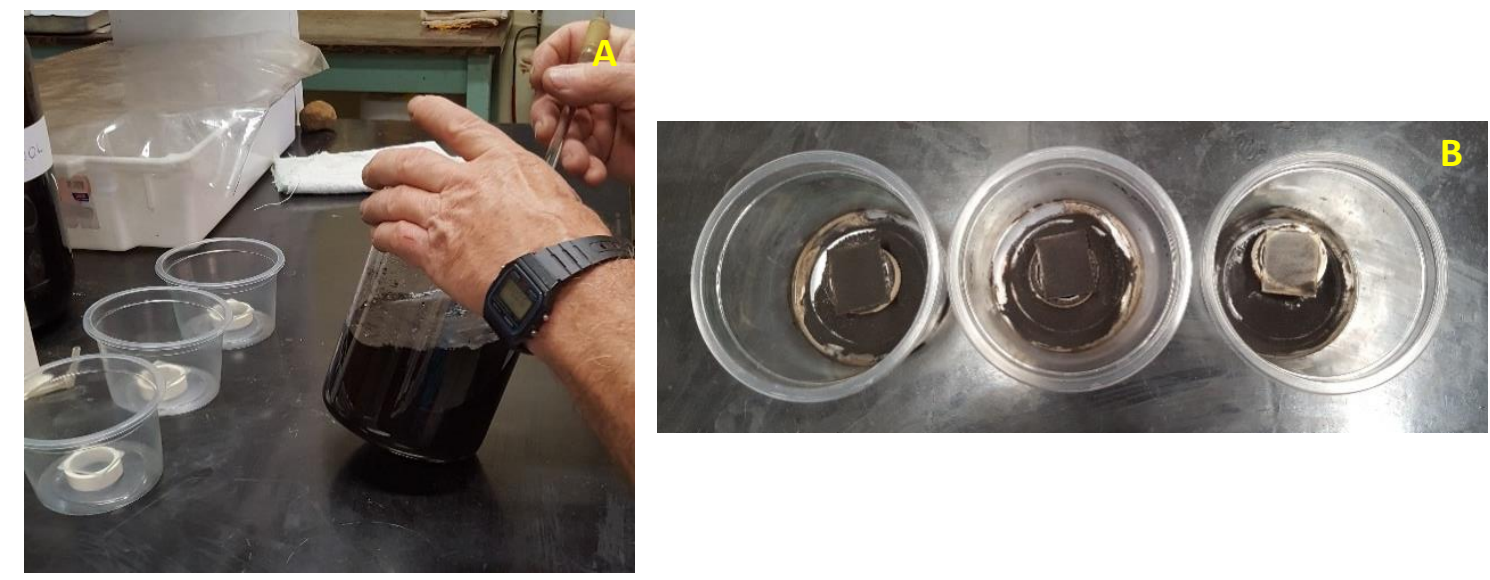

Fonte: A autora.

Figura 63 - Preparação das lâminas com a parte mineral dos compostos para execução do DRX. A) Recipientes contendo a suspensão durante sua deposição sobre as lâminas; B) Lâminas após secagem; C) Lâminas secas e prontas para serem enviadas para a análise em DRX
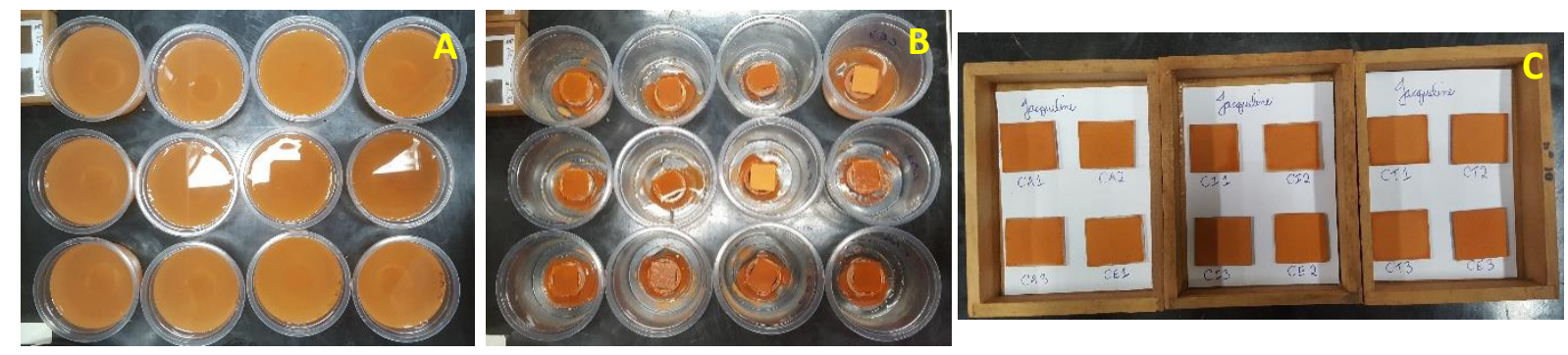

Fonte: A autora.

Em seguida, estas lâminas foram analisadas em difratômetro com unidade de raios-X da marca Ultima IV e modelo Rigaku Ultima IV, analisadas sob as condições de 2 theta/theta de $5^{\circ}$ a $100^{\circ}$, passo $0,0200 /$ segundo, velocidade de $1,000 /$ minuto, com um total de 95 minutos para cada amostra, tensão de $40 \mathrm{kV}$ e $30 \mathrm{~mA}$ e tubo de $\mathrm{Cu}$. Esta análise forneceu dados para a construção de gráficos relacionando a "intensidade" versus "2-theta". Com os dados de "2theta" referentes aos picos de "intensidade", calcularam-se as respectivas distâncias basais e, a 
partir de dados tabelados apresentados por Brindley e Brown (1980), foi possível identificar o mineral mais provável.

Este ensaio foi realizado, em triplicata, para a turfa (amostra total e porção mineral) e para a parte mineral dos compostos orgânicos (resultante da queima da matéria orgânica). A etapa envolvendo a preparação das lâminas ocorreu no Laboratório de Geotecnia Ambiental do Departamento de Geotecnia da EESC - USP e a execução da análise em DRX foi realizada no Laboratório de Cristalografia do Instituto de Física de São Carlos (IFSC) da USP.

\section{L) Fluorescência de Raios-X (FRX)}

Esta análise foi realizada em amostras prensadas e os teores foram encontrados seguindo a calibração STD-1 (Standardless), que se relaciona a análise sem a utilização de padrões dos elementos químicos compreendidos entre o flúor e o urânio, mesma metodologia adotada por Guimarães (2007). Além dos resultados semiquantitativos, como rotina complementar o laboratório responsável analisou ainda a Perda ao Fogo pela técnica de Gravimetria. As pastilhas foram analisadas em Espectrômetro de Fluorescência de Raios-X modelo Axios Advantage da Panalytical. Este ensaio foi realizado no Laboratório de Caracterização Tecnológica (LCT) da Escola Politécnica da (POLI) da USP, com as amostras de turfa e de compostos, em triplicata.

\section{M) Microscopia Eletrônica de Varredura/ Espectroscopia de Energia Dispersiva por Raios-X (MEV/EDS)}

Este ensaio foi executado para a turfa e para os compostos conforme a metodologia adotada por Raimondi (2014). No entanto, foram ensaiadas amostras com e sem matéria orgânica e na forma de pastilhas (Figura 64) e de stubs (Figura 65). As pastilhas continham cerca de $10 \mathrm{mg}$ de material prensado. 
Figura 64 - Pastilhador e esquema simplificado de operação da obtenção das pastilhas

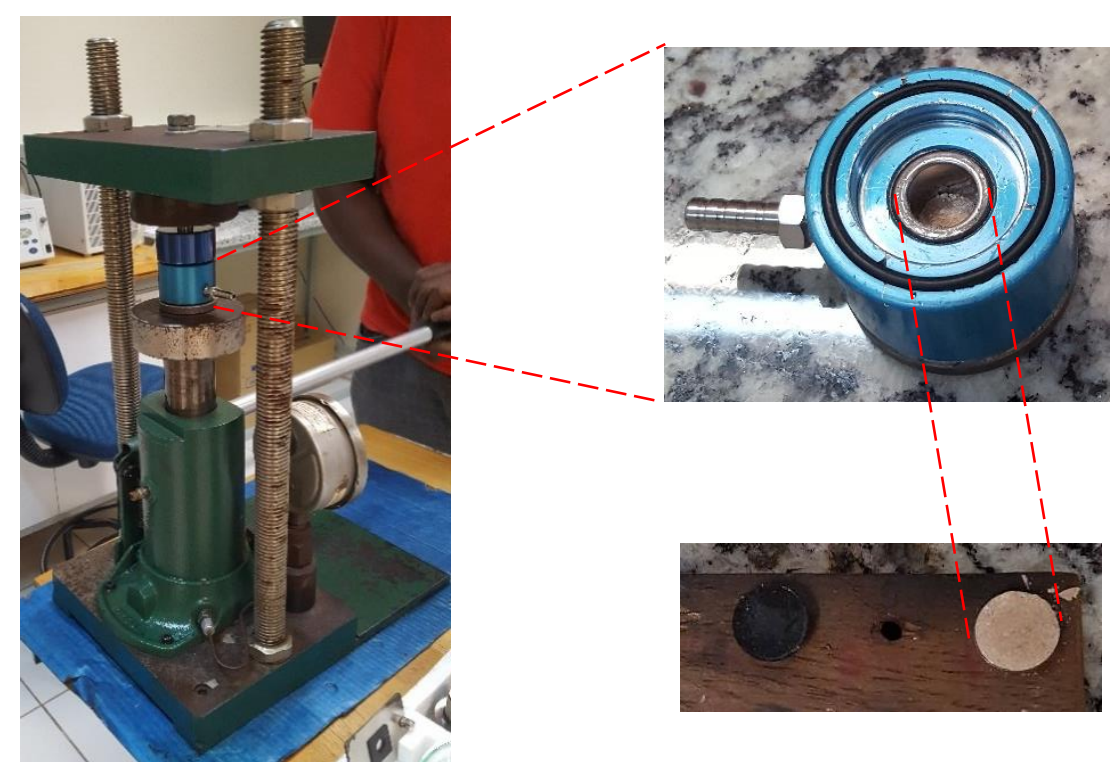

Fonte: A autora.

Figura 65 - Stubs (suportes) usados em MEV.

A) Compostos totais; B) Apenas parte mineral dos compostos

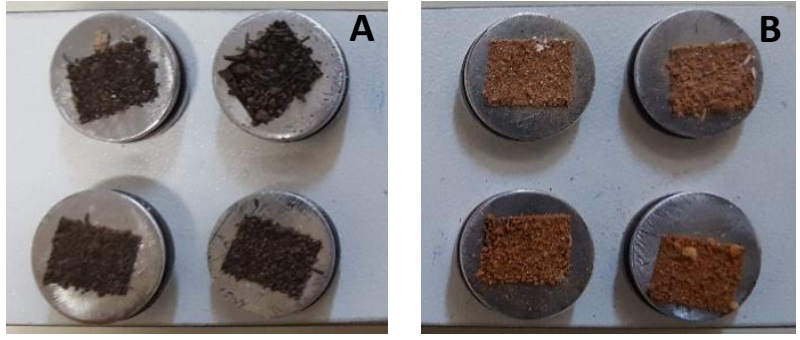

Fonte: A autora.

As amostras preparadas em pastilhas e em stubs foram recobertas com $6 \mathrm{~nm}$ de carbono em um metalizador Coating System BAL-TEC MED 020 (BAL-TEC Liechtenstein), sendo posteriormente analisadas em Microscópio Eletrônico de Varredura acoplado com Espectrômetro de Dispersão de Energia de Raios-X. As imagens foram obtidas em equipamento ZEISS LEO 440 (Cambridge, England) com detector OXFORD (model 7060), operando com feixes de elétrons de $20 \mathrm{kV}$, corrente de 2,82 A e I probe de $200 \mathrm{pA}$.

O dispositivo empregado para a análise em EDS foi o EDX Link Analytical (Isis System Series 300), com detector de SiLi Pentafet, janela ultrafina ATW II (Atmosphere Thin Window), com resolução de $133 \mathrm{eV}$ à $5,9 \mathrm{keV}$ e área de $10 \mathrm{~mm}^{2}$, acoplado a um Microscópio Eletrônico ZEISS LEO 440. Empregou-se padrão de Co para calibração, feixe de elétrons de $20 \mathrm{kV}$, distância focal de $25 \mathrm{~mm}$, dead time de $30 \%$, corrente de 2,82 A e I probe de 2,5 nA. 
Ademais, cada ponto de análise cobriu uma área de 320 x $320 \mu \mathrm{m}$. Estes equipamentos são mostrados na Figura 66.

Figura 66 - Visão geral do MEV/EDS

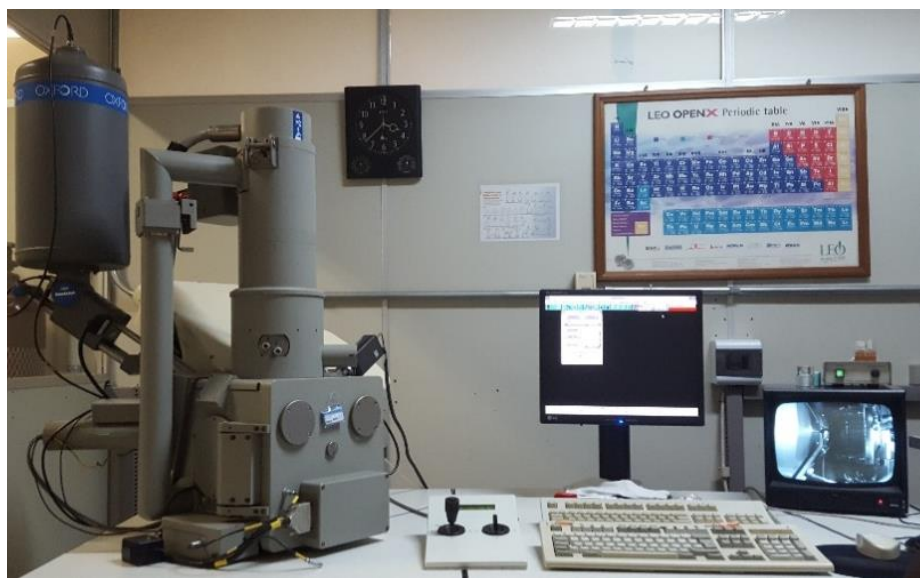

Fonte: A autora.

Este procedimento foi realizado, com a turfa e os compostos, na Central de Análises Químicas Instrumentais (CAQI) no Instituto de Química de São Carlos (IQSC) da USP.

\section{N) Absorção Atômica (AA)}

Os materiais reativos orgânicos sólidos foram analisados em Espectrofotômetro de Absorção Atômica de Sequência Rápida Varian modelo 240FS, conforme método 3111B do Standard Methods for the Examination of Water and Wastewater (APHA, 2012). As amostras sólidas foram digeridas segundo método 3030F do Standard Methods for the Examination of Water and Wastewater (APHA, 2012), sendo que tal digestão foi realizada com $\mathrm{HNO}_{3}$ e $\mathrm{HCl}$ 50\% (relação 3:1). Esses procedimentos foram realizados no Laboratório de Saneamento do Departamento de Hidráulica e Saneamento da EESC - USP (São Carlos).

\section{O) Análise Térmica Diferencial (ATD)}

A Análise Térmica Diferencial (ATD) foi realizada utilizando o Sistema de Análise Térmica - Modelo RB-3000-20 da BP Engenharia (Figura 67), seguindo metodologia adotada por Petroni (1999). Como material inerte de referência empregou-se alumina calcinada. Foi utilizado um aquecimento até $1000^{\circ} \mathrm{C}$, com velocidade de $12,8^{\circ} \mathrm{C}$ por minuto. 
Figura 67 - Ensaio de ATD. A) Visão geral do equipamento de ATD; B) Dois porta amostras preenchidos por alumina calcinada (branca) e um terceiro repleto de amostra

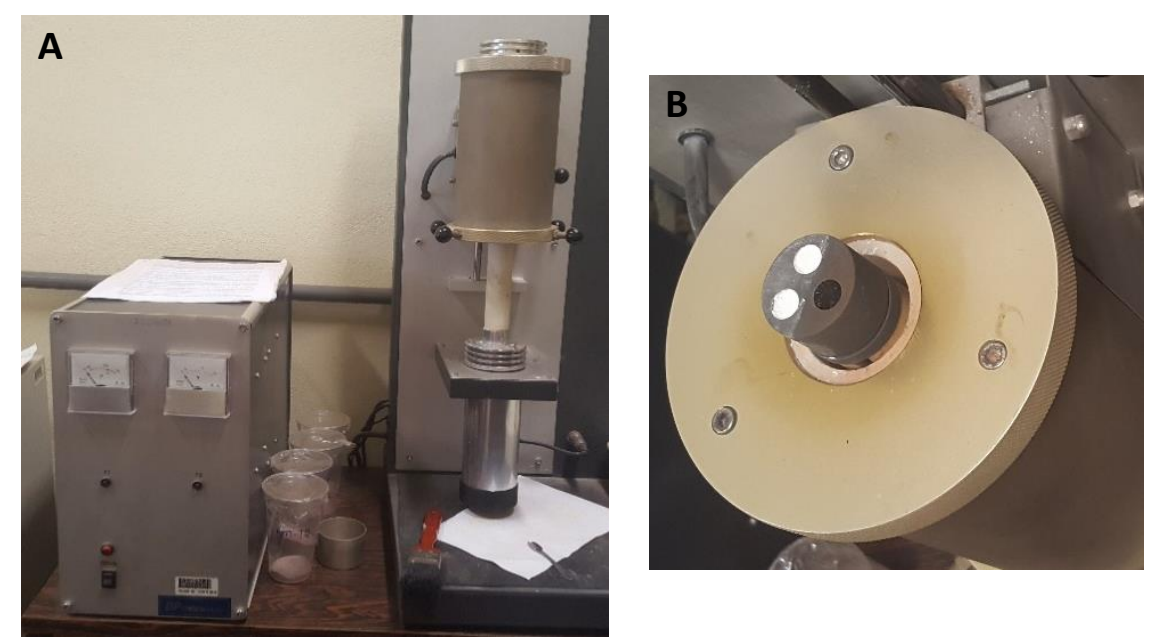

Fonte: A autora.

Esta análise foi realizada para os compostos (amostra total e apenas parte mineral) no Laboratório de Geotecnia Ambiental do Departamento de Geotecnia da EESC - USP.

\section{P) Caracterizações realizadas na ESALQ}

Como complemento da caracterização geológica-geotécnica dos materiais reativos estudados, outras análises foram também executadas no Laboratório de Corretivos, Fertilizantes e Resíduos Orgânicos do Departamento de Ciência do Solo da Escola Superior de Agricultura Luiz de Queiroz (ESALQ) de Piracicaba - USP. As metodologias empregadas estão sintetizadas no Quadro 11. O preparo das amostras para as análises químicas ocorreu conforme descrito em MAPA (2013) no Capítulo III - Análise dos fertilizantes orgânicos e organominerais destinados à aplicação via solo, tópico específico para fertilizantes sólidos. Desse modo, os materiais reativos foram secos em estufa com temperatura de $65 \pm 5^{\circ} \mathrm{C}$, até obtenção de massa constante; homogeneizados; moídos e passados em peneira com abertura de malha de $500 \mu \mathrm{m}$. 
Quadro 11 - Metodologias empregadas pela ESALQ na caracterização dos materiais reativos orgânicos

\begin{tabular}{|c|c|}
\hline Parâmetros & Metodologia \\
\hline Densidade & Método da autocompactação (MAPA, 2007) \\
\hline $\begin{array}{l}\text { Capacidade de retenção de } \\
\text { água (CRA 10) }\end{array}$ & $\begin{array}{c}\text { Método da mesa de tensão ajustada para } 10 \mathrm{~cm} \text { de coluna de } \\
\text { água - } 1 \mathrm{kPa} \text { ou } 10 \mathrm{hPa} \text { (MAPA, 2007) } \\
\end{array}$ \\
\hline Carbono orgânico & $\begin{array}{l}\text { Método volumétrico com a oxidação do carbono orgânico com } \\
\text { dicromato de potássio e ácido sulfúrico concentrado, seguida } \\
\text { da determinação do dicromato remanescente por titulação com } \\
\text { solução de sulfato ferroso amoniacal padronizada (MAPA, } \\
\text { 2013) }\end{array}$ \\
\hline Fósforo total & $\begin{array}{c}\text { Extração utilizando ácido clorídrico e determinação pelo } \\
\text { método espectrofotométrico do ácido } \\
\text { molibdovanadofosfórico (MAPA, 2013) }\end{array}$ \\
\hline Potássio total & $\begin{array}{l}\text { Extração utilizando ácido clorídrico e quantificação pelo } \\
\text { método por fotometria de chama (MAPA, 2013) }\end{array}$ \\
\hline $\begin{array}{l}\text { Cálcio total e magnésio } \\
\text { total }\end{array}$ & $\begin{array}{l}\text { Extração do Ca e do Mg com ácido clorídrico e determinação } \\
\text { pelo método da espectrometria de absorção atômica } \\
\text { (MAPA, 2013) }\end{array}$ \\
\hline Enxofre total & Método gravimétrico do sulfato de bário (MAPA, 2013) \\
\hline $\begin{array}{l}\text { Capacidade de troca } \\
\text { catiônica }\end{array}$ & $\begin{array}{l}\text { Método da titulometria baseado na ocupação dos sítios de } \\
\text { troca do material orgânico com íons hidrogênio, advindos de } \\
\text { uma solução de ácido clorídrico; eliminação do excesso de } \\
\text { ácido; deslocamento dos íons hidrogênio adsorvidos com } \\
\text { solução de acetato de cálcio e titulação do ácido acético } \\
\text { formado com solução padronizada de NaOH, utilizando a } \\
\text { fenolftaleína como indicador (MAPA, 2013) }\end{array}$ \\
\hline
\end{tabular}

Fonte: A autora.

\subsection{Ensaio de adsorção dos materiais reativos orgânicos - Equilíbrio em lote}

O ensaio de equilíbrio em lote foi baseado na promoção do contato da turfa e do composto com soluções eletrolíticas monoelementares, por um tempo de contato predeterminado, a fim de se estudar a capacidade intrínseca e individual de cada um dos materiais reativos orgânicos por cada metal, sem que houvesse uma competição direta pelos sítios de adsorção. Foram escolhidos os cátions metálicos $\mathrm{Pb}^{2+}, \mathrm{Zn}^{2+}$ e $\mathrm{Cd}^{2+}$, já que eles são contaminantes importantes e frequentes nos resíduos de mineração de minérios metálicos.

De modo geral, este ensaio foi baseado nos seguintes procedimentos:

a) definição do tempo de contato;

b) preparação dos materiais reativos orgânicos; 
c) preparação das soluções contaminantes e análise de seus parâmetros físico-químicos ( $\mathrm{pH}$, Eh e CE) e de suas concentrações iniciais;

d) pesagem dos materiais reativos orgânicos e adição das soluções contaminantes com imediata determinação dos respectivos parâmetros físico-químicos ( $\mathrm{pH}$, Eh e CE);

e) agitação horizontal das amostras em mesa agitadora (marca Novatecnica e velocidade entre 10 e $20 \%$ ) com controle de temperatura;

f) centrifugação e filtração;

g) medição dos parâmetros físico-químicos $(\mathrm{pH}$, Eh e $\mathrm{CE}$ ) finais e das concentrações de equilíbrio.

A seguir, são descritos mais minuciosamente alguns destes procedimentos.

\section{A) Definição do tempo de contato}

Um fator importante em ensaios de adsorção é o tempo de contato. Segundo Roy et al. (1992) a adsorção pode ser considerada como uma reação rápida, sendo que uma posterior remoção de solutos pode estar associada a outros processos. Assim, é recomendado que o tempo de equilíbrio seja o mínimo necessário para que a variação na concentração do soluto seja igual ou inferior a 5\% para um período de 24 horas, podendo ser testado para cada sistema solutoadsorvente. Contudo, o tempo de equilíbrio típico é de 24 horas. A ASTM D4646 - 03 complementa que se presume que após 24 horas de contato ocorre o equilíbrio entre as fases sólida e líquida, sendo que para tempos mais longos a degradação microbiana pode vir a ser um problema. McKay e Porter (1997), Qin et al. (2006) e Koivula et al. (2009) utilizaram 24 horas de contato em seus ensaios turfa/solução metálica.

Diversos autores consideram inclusive que a adsorção de metais por materiais reativos orgânicos atinge o equilíbrio em tempos menores, sendo que Franchi (2004) adota um tempo de contato de 8 horas em seus ensaios para construção das isotermas de adsorção em turfa, Petroni (1999; 2004) utiliza 3 horas também para turfa e Paradelo e Barral (2012) assume 16 horas em experimentos com compostos de resíduos orgânicos municipais. Nesta pesquisa foi empregado, em todos os ensaios, um tempo de contato de 24 horas, garantindo um razoável excesso, e seguindo o que tipicamente é utilizado para ensaios com solos, conforme experiências anteriores. 


\section{B) Preparação dos materiais reativos orgânicos}

A turfa foi seca em estufa a uma temperatura de cerca de $50^{\circ} \mathrm{C}$ por 48 horas. Os compostos foram secos ao ar, em temperatura ambiente (próxima a $25^{\circ} \mathrm{C}$ ), por 5 dias e, em seguida, foram passados em peneira com abertura da malha de 2,00 $\mathrm{mm}$, por conterem partículas grosseiras, principalmente resquícios de plantas.

\section{C) Preparação das soluções}

Para preparo das soluções contaminantes monoelementares foram dissolvidos em água deionizada os correspondentes sais de Pb (cloreto de chumbo da marca VETEC com 99\% de pureza), Zn (cloreto de zinco da marca Panreac com 97\% de pureza) e Cd (cloreto de cádmio hidratado da marca VETEC com $99 \%$ de pureza).

Inicialmente, foram determinadas as porcentagens em massa de cada elemento de interesse em relação a massa molar de seu respectivo sal e os resultados obtidos estão apresentados nos Quadros 12, 13 e 14.

Quadro 12 - Massa molar referente ao cloreto de chumbo $\left(\mathrm{PbCl}_{2}\right)$

\begin{tabular}{|c|c|c|c|c|}
\hline \hline Elemento & $\begin{array}{c}\text { Número de } \\
\text { íons }\end{array}$ & $\begin{array}{c}\text { Massa atômica } \\
(\mathbf{u})\end{array}$ & $\begin{array}{c}\text { Massa molar } \\
\left(\mathbf{g ~ m o l}^{-1} \mathbf{)}\right.\end{array}$ & Porcentagem \\
\hline $\mathrm{Pb}$ & 1 & 207,20 & 207,20 & $74,50 \%$ \\
\hline $\mathrm{Cl}$ & 2 & 35,45 & 70,90 & $25,50 \%$ \\
\hline \hline & Total & 278,10 & $100 \%$ \\
\cline { 2 - 5 }
\end{tabular}

Fonte: A autora.

Quadro 13 - Massa molar referente ao cloreto de zinco $\left(\mathrm{ZnCl}_{2}\right)$

\begin{tabular}{|c|c|c|c|c|}
\hline \hline Elemento & $\begin{array}{c}\text { Número de } \\
\text { íons }\end{array}$ & $\begin{array}{c}\text { Massa atômica } \\
(\mathbf{u})\end{array}$ & $\begin{array}{c}\text { Massa molar } \\
\left(\mathbf{g ~ m o l}^{-1}\right)\end{array}$ & Porcentagem \\
\hline \hline $\mathrm{Zn}$ & 1 & 65,38 & 65,38 & $47,97 \%$ \\
\hline $\mathrm{Cl}$ & 2 & 35,45 & 70,90 & $52,03 \%$ \\
\hline \hline & \multicolumn{2}{|r}{ Total } & 136,28 & $100 \%$ \\
\cline { 2 - 5 }
\end{tabular}

Fonte: A autora. 
Quadro 14 - Massa molar referente ao cloreto de cádmio hidratado $\left(\mathrm{CdCl}_{2} \cdot \mathrm{H}_{2} \mathrm{O}\right)$

\begin{tabular}{|c|c|c|c|c|}
\hline Elemento & $\begin{array}{c}\text { Número de } \\
\text { íons }\end{array}$ & $\begin{array}{c}\text { Massa atômica } \\
(\mathbf{u})\end{array}$ & $\begin{array}{c}\text { Massa molar } \\
\left(\mathbf{g ~ m o l}^{-1}\right)\end{array}$ & Porcentagem \\
\hline \hline $\mathrm{Cd}$ & 1 & 112,41 & 112,41 & $55,83 \%$ \\
\hline $\mathrm{Cl}$ & 2 & 35,45 & 70,90 & $35,22 \%$ \\
\hline $\mathrm{H}$ & 2 & 1,01 & 2,02 & $1,00 \%$ \\
\hline $\mathrm{O}$ & 1 & 16,00 & 16,00 & $7,95 \%$ \\
\hline \hline
\end{tabular}

Fonte: A autora.

Foi utilizada a Equação 27 (VEGA, 2016) para o cálculo da massa de sal necessária para cada litro de água em cada caso:

$$
\text { Massa de sal necessária }(m g)=\frac{\text { Concentração desejada }\left(m g L^{-1}\right)}{\% \text { em massa do cátion presente no sal }} \quad \text { (Equação 27) }
$$

Foram preparadas como solução mãe para cada elemento a maior concentração desejada e, posteriormente, as demais soluções foram sendo obtidas por diluição em água deionizada.

Figura 68 - Solução mãe com concentração de $240 \mathrm{mg} \mathrm{L}^{-1}$ de cádmio (à esquerda) e solução diluída com concentração de $30 \mathrm{mg} \mathrm{L}^{-1}$ de cádmio (à direita)

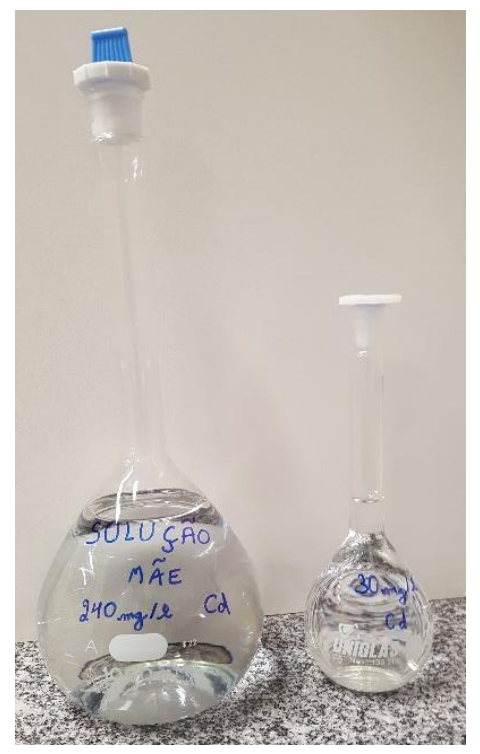

Fonte: A autora. 
Foram feitas soluções separadas para cada teste (melhor razão e melhor composto) e para cada conjunto de amostras (turfa e $\mathrm{Pb}$, turfa e $\mathrm{Zn}$, turfa e $\mathrm{Cd}$, composto e $\mathrm{Pb}$, composto e $\mathrm{Zn}$, composto e $\mathrm{Cd}$ ). As soluções foram preparadas e já foram utilizadas na sequência.

No teste para determinação da melhor razão turfa/solução foi empregada uma concentração de $\mathrm{Pb}$ de aproximadamente $100 \mathrm{mg} \mathrm{L}^{-1}$, no teste para definição do composto com maior capacidade adsortiva foram utilizadas concentração de $\mathrm{Pb}, \mathrm{Zn}$ e Cd de cerca de $150 \mathrm{mg}$ $\mathrm{L}^{-1}$ e nos ensaios de equilíbrio em lote propriamente ditos foram empregadas concentrações teóricas de 30, 60, 90, 120, 150, 180, 210 e $240 \mathrm{mg} \mathrm{L}^{-1}$ para cada metal, tanto para a turfa, como para o composto.

\section{D) Controle da temperatura}

Esta metodologia foi realizada com controle de temperatura, conforme descrito em Zuquette, Silva Jr e Garcia (2008), afinal, segundo Roy et al. (1992), a temperatura deve ser constante e medida, pois ela é útil na interpretação dos resultados.

\section{E) Centrifugação e filtração}

Decorrido o tempo de contato preestabelecido, todas as amostras foram centrifugadas em centrifuga para tubos da marca Quimis por um tempo entre 2 e 3 minutos, conforme mostrado na Figura 69.

Figura 69 - Centrifugação de amostras de turfa em solução contendo Cd

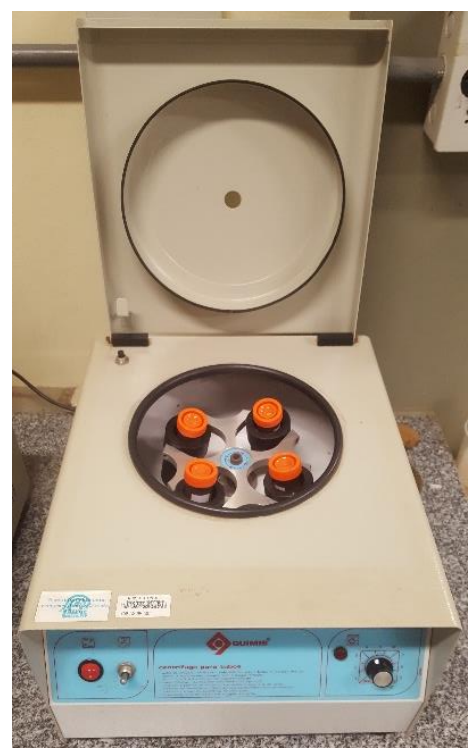

Fonte: A autora. 
Em seguida, as amostras foram filtradas em papel filtro qualitativo (marca Unifil com gramatura de $80 \mathrm{~g} \mathrm{~m}^{-2}$ ) e colocados em funil de vidro alocado em suporte metálico, exibido na Figura 70.

Figura 70 - Filtração de amostras de composto indiano após contato com solução contendo $\mathrm{Pb}$

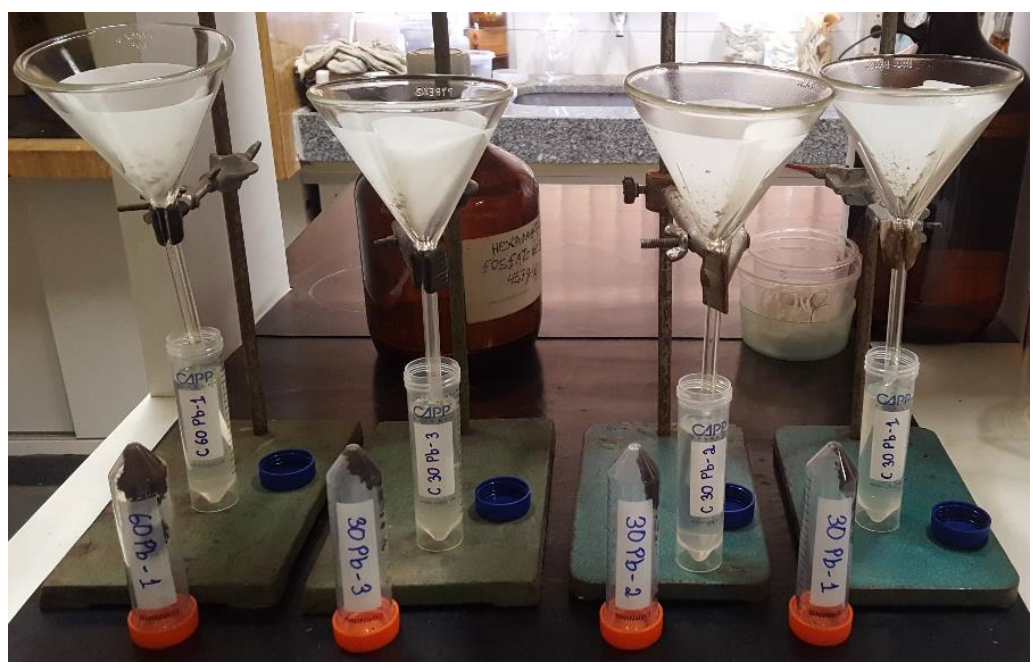

Fonte: A autora.

\section{F) Acompanhamento dos parâmetros físico-químicos}

A sorção é fortemente influenciada, se não controlada, pelas condições de pH e Eh (ASTM D4319 - 01). Assim, estes parâmetros foram acompanhados, bem como a condutividade elétrica, sendo medidos seus valores no início e no final do ensaio. Os equipamentos utilizados foram os mesmos já descritos na caracterização das amostras.

\section{G) Determinação das concentrações}

Este ensaio foi baseado no acompanhamento da variação na concentração dos metais, advinda da adsorção. Portanto, nas soluções provenientes do ensaio de equilíbrio em lote (extratos) foram obtidas, antes e após a adsorção, as concentrações inicial e de equilíbrio, respectivamente.

Findado o ensaio de equilíbrio em lote todas as amostras foram armazenadas em refrigerador até a posterior leitura de suas concentrações. Para análise dos extratos foi utilizada como instrumentação analítica a absorção atômica (Espectrofotômetro de Absorção Atômica modelo PinAAcle 900F do fabricante PerkinElmer) (Figura 71), conforme metodologia da APHA (2012). 
Figura 71 - Espectrofotômetro de Absorção Atômica da PerkinElmer

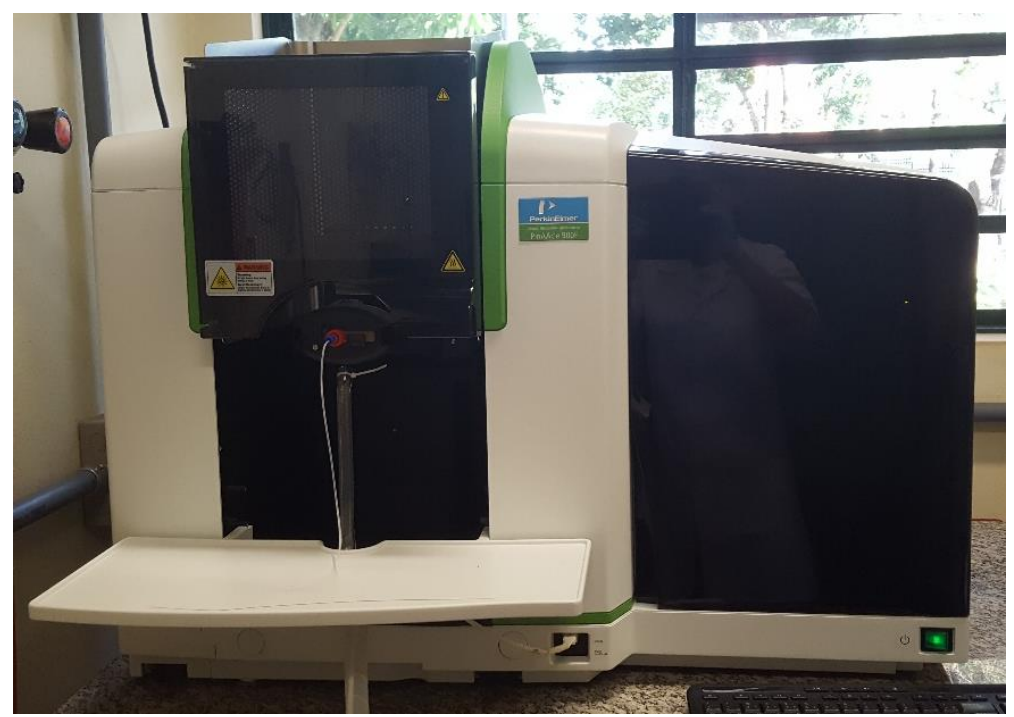

Fonte: A autora.

Ademais, para as curvas de calibração foram utilizados 3 pontos, com diferentes concentrações, obtidas a partir da diluição dos respectivos padrões PerkinElmer em água deionizada. Esses padrões apresentam certificação de pureza (ISO 9001) datada de novembro e dezembro de 2016 e com validade até maio e junho de 2018. O valor certificado do padrão de $\mathrm{Pb}$ é de $1000 \pm 5 \mu \mathrm{g} \mathrm{mL}^{-1}$ e dos padrões de $\mathrm{Zn}$ e de $\mathrm{Cd}$ é de $1001 \pm 5 \mu \mathrm{g} \mathrm{mL} \mathrm{mL}^{-1}$. Atentou-se para que todas as curvas de calibração apresentassem coeficiente de correlação superior a 0,995. A Figura 72 mostra os padrões para os elementos estudados.

Figura 72 - Padrões de calibração PerkinElmer Pure com certificação de análise
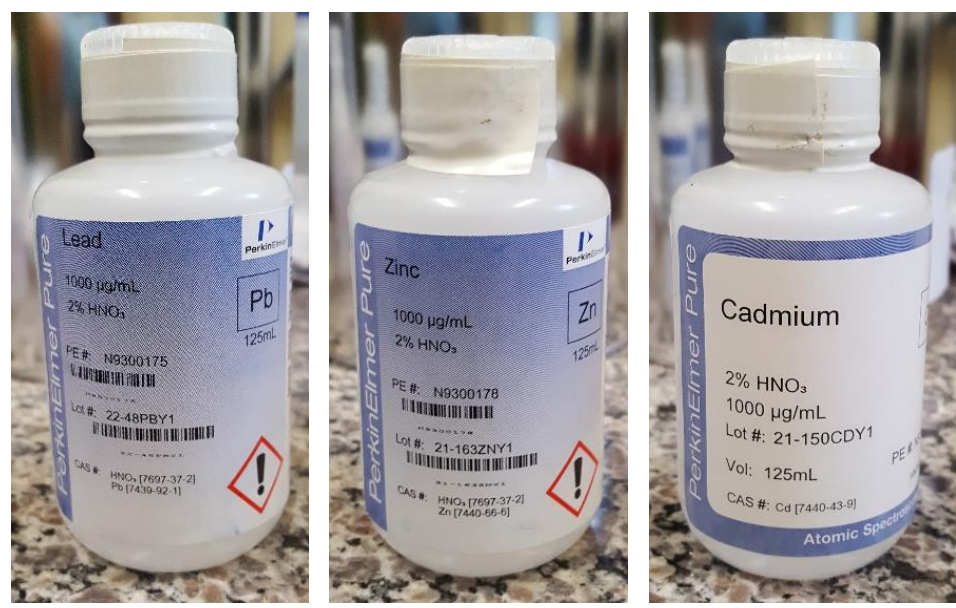

Fonte: A autora.

Em alguns casos, foi necessária a promoção da diluição das amostras (em água deionizada) para que se adequassem ao intervalo de medição. 
Antes da realização do ensaio propriamente dito foram executadas duas etapas preliminares, a primeira delas com a turfa, a fim de se determinar a melhor razão material reativo/solução, e uma segunda, visando avaliar comparativamente a capacidade adsortiva dos quatro compostos caracterizados.

\subsubsection{Etapa preliminar - Teste da melhor razão turfa/solução}

A etapa preliminar foi realizada de acordo com os métodos empregados por Roy et al. (1992) com o intuito de se obter a massa e a razão material reativo/solução mais favoráveis para a realização do ensaio de equilíbrio em lote com os materiais reativos. Assim, optou-se por trabalhar com a amostra de turfa e uma concentração de $\mathrm{Pb}$ de aproximadamente $100 \mathrm{mg} \mathrm{L}^{-1}$ (valor adotado superior à maior concentração do metal no lixiviado do resíduo de mineração proveniente de Adrianópolis - Vale do Ribeira - PR, obtido por Raimondi, 2014), variando a massa de turfa e, por conseguinte, a razão turfa/solução. Dados bibliográficos revelaram uma ampla variação entre as razões utilizadas por diversos autores. De modo geral, quando o solo é utilizado como adsorvente são empregadas razões solo/solução mais elevadas, enquanto materiais reativos orgânicos, como turfas e compostos, frequentemente estão associados a razões mais reduzidas, conforme pode ser constatado no Quadro 15.

Quadro 15 - Análise comparativa de razões adsorvente/solução empregadas por diversos autores

\begin{tabular}{|c|c|c|c|}
\hline \hline $\begin{array}{c}\text { Elementos } \\
\text { estudados }\end{array}$ & Adsorvente & $\begin{array}{c}\text { Razão } \\
\text { adsorvente/solução }\end{array}$ & Autor \\
\hline \hline $\mathrm{Cd} \mathrm{e} \mathrm{Pb}$ & Latossolo roxo & $1 / 4$ & Vega (2016) \\
\hline $\mathrm{K}, \mathrm{Zn} \mathrm{e} \mathrm{Cu}$ & $\begin{array}{c}\text { Materiais } \\
\text { inconsolidados }\end{array}$ & $1 / 5$ & $\begin{array}{c}\text { Zuquette, Silva Jr } \\
\text { e Garcia (2008) }\end{array}$ \\
\hline $\mathrm{Cu}, \mathrm{Zn}, \mathrm{Ni}$ e Cr & $\begin{array}{c}\text { Composto de resíduos } \\
\text { orgânicos municipais }\end{array}$ & $1 / 25$ & $\begin{array}{c}\text { Kocasoy e } \\
\text { Güvener (2009) }\end{array}$ \\
\hline $\mathrm{Cd} \mathrm{e} \mathrm{Zn}$ & Turfa & $1 / 50$ & Petroni (1999) \\
\hline $\mathrm{Cu}, \mathrm{Pb}$ e $\mathrm{Zn}$ & $\begin{array}{c}\text { Composto de resíduos } \\
\text { orgânicos municipais }\end{array}$ & $1 / 50$ & $\begin{array}{c}\text { Paradelo e Barral } \\
(2012)\end{array}$ \\
\hline $\mathrm{Pb}, \mathrm{Cr}, \mathrm{Cu}$ e As & Turfa & $1 / 60$ & $\begin{array}{c}\text { Koivula et al. } \\
\text { (2009) }\end{array}$ \\
\hline $\mathrm{Pb}, \mathrm{Cu}$ e Cd & Turfa & $1 / 200$ & Qin et al. (2006) \\
\hline $\mathrm{Cd}, \mathrm{Cu}$ e Ni & Turfa & $1 / 250$ & Petroni (2004) \\
\hline $\mathrm{Pb}, \mathrm{Cu}, \mathrm{Zn}, \mathrm{Cd}$ & Turfa & $1 / 250$ & Franchi (2004) \\
\hline $\mathrm{Cu}$ e Cd & Turfa & $1 / 600(\mathrm{Cu})$ e & $\begin{array}{c}\text { Crescêncio Júnior } \\
\text { (2008) }\end{array}$ \\
\hline \hline
\end{tabular}

Fonte: A autora. 
Desse modo, para efeito comparativo, optou-se por analisar, nesta etapa prévia, cinco diferentes razões, variando de 1/5 a 1/100, elencadas com base na literatura e atentando-se para que elas fossem grandes o suficiente para serem representativas e, ao mesmo tempo, reduzidas de modo a se adequarem às condições laboratoriais e às necessidades de análise. Ademais, para cada razão foram empregadas duas massas de turfa diferenciadas, a fim de se verificar também a possibilidade da existência de uma influência considerável advinda da variação da massa de adsorvente empregada e, consequentemente, do volume da solução contendo o contaminante. A Tabela 1 esquematiza a constituição destas amostras empregadas no ensaio prévio de equilíbrio em lote.

Tabela 1 - Constituição das amostras empregadas na etapa prévia do ensaio de equilíbrio em lote

\begin{tabular}{ccc}
\hline $\begin{array}{c}\text { Razão } \\
\text { turfa/solução }\end{array}$ & $\begin{array}{c}\text { Massa de turfa } \\
(\mathbf{g})\end{array}$ & $\begin{array}{c}\text { Volume de } \\
\text { solução }(\mathbf{m L})\end{array}$ \\
\hline \hline \multirow{2}{*}{$1 / 5$} & 10 & 50 \\
\cline { 2 - 3 } & 20 & 100 \\
\cline { 2 - 3 } $1 / 10$ & 5 & 50 \\
\cline { 2 - 3 } & 10 & 100 \\
\cline { 2 - 3 } $1 / 50$ & 1 & 50 \\
\hline \multirow{2}{*}{$1 / 80$} & 2 & 100 \\
\hline \multirow{2}{*}{$1 / 100$} & 0,625 & 50 \\
\cline { 2 - 3 } & 1,25 & 100 \\
\hline
\end{tabular}

Fonte: A autora.

Complementando este experimento foram ensaiadas ainda duas amostras da solução mãe de $\mathrm{Pb}$ (retiradas logo após a preparação da solução e que não participaram diretamente do ensaio), duas amostras do branco da solução, contendo apenas a solução de $\mathrm{Pb}$ em volumes de 50 e $100 \mathrm{~mL}$ (que permaneceram em agitação, foram centrifugadas e filtradas juntamente com as demais amostras) e duas amostras contendo apenas turfa e água deionizada (seguindo a maior razão (1/5) e as respectivas massas utilizadas anteriormente). Essa razão foi a escolhida pois o objetivo dessa análise é justamente avaliar uma possível liberação de elementos da turfa. A Figura 73 ilustra a presença de turfa nas amostras que compuseram este teste. 
Figura 73 - Presença de turfa nas amostras do ensaio prévio de equilíbrio em lote

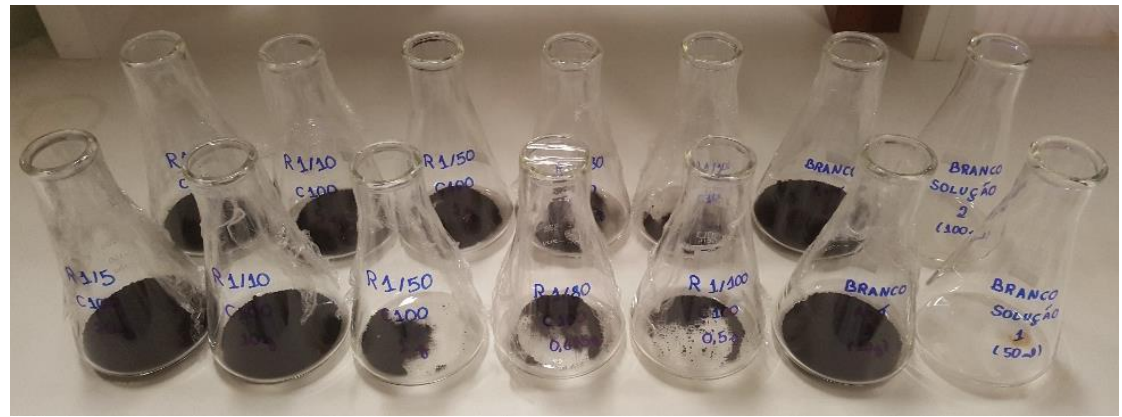

Fonte: A autora.

Conforme apresentado posteriormente, no item "Resultados e Discussão", a melhor razão turfa/solução foi 1/50, com a utilização de $1 \mathrm{~g}$ de turfa e $50 \mathrm{~mL}$ de solução. Sendo assim, a fim de promover uma análise comparativa final, esta passou a ser a razão utilizada no teste com os compostos e nos ensaios propriamente ditos com $\mathrm{Pb}, \mathrm{Zn}$ e $\mathrm{Cd}$, tanto para a turfa como para o composto.

\subsubsection{Etapa preliminar - Teste do composto com maior capacidade adsortiva}

A fim de se avaliar comparativamente a capacidade adsortiva dos quatro compostos caracterizados foi realizada uma etapa preliminar contendo cada um desses materiais para cada metal estudado $(\mathrm{Pb}, \mathrm{Zn}$ e $\mathrm{Cd})$ em uma solução com uma concentração intermediária de aproximadamente $150 \mathrm{mg} \mathrm{L}^{-1}$, seguindo uma razão composto/solução de 1/50 (melhor razão do teste turfa, conforme descrito no item "Resultados e Discussão"). A Figura 74 exibe cada composto, em contato com a solução contaminante de $\mathrm{Cd}$, logo após agitação, podendo-se observar a variação na presença de finos entre estes materiais.

Figura 74 - Teste melhor composto em relação à adsorção de Cd.

A) Composto total; B) Composto indiano; C) Composto alambrado; D) Composto estático

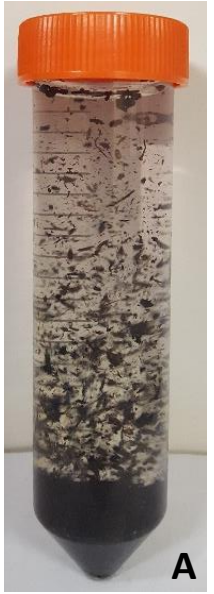

A
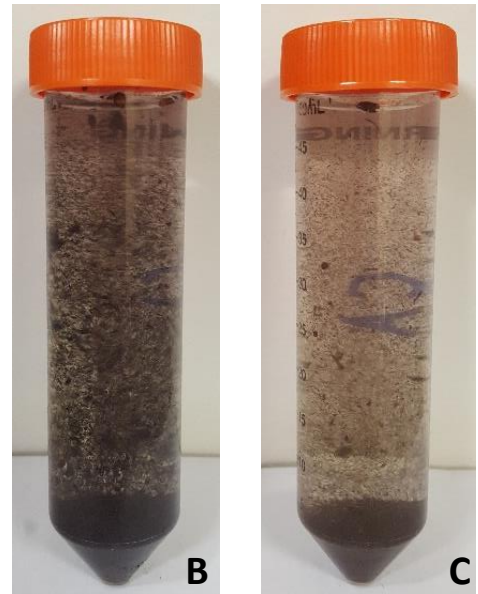

Fonte: A autora.

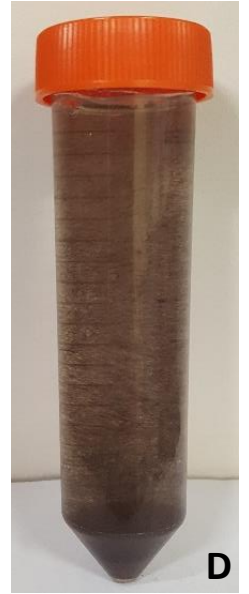

D 
Complementarmente, foi retirada uma solução branco de cada metal e foi ensaiada uma amostra de cada composto contendo apenas água deionizada, a fim de se avaliar uma possível liberação de elementos.

Conforme apresentado no item "Resultados e Discussão", optou-se por avaliar mais detalhadamente o composto indiano.

\subsubsection{Ensaio de equilíbrio em lote para turfa e composto indiano}

O ensaio de equilíbrio em lote propriamente dito foi realizado, em triplicata, com a turfa e com o composto indiano em contato com concentrações monoelementares de $\mathrm{Pb}, \mathrm{Zn}$ e $\mathrm{Cd}$ de aproximadamente 30, 60, 90, 120, 150, 180, 210 e $240 \mathrm{mg} \mathrm{L}^{-1}$ (concentrações teóricas).

Para cada conjunto de amostras (turfa e $\mathrm{Pb}$, turfa e $\mathrm{Zn}$, turfa e $\mathrm{Cd}$, composto e $\mathrm{Pb}$, composto e Zn, composto e Cd) foi preparado um litro de solução mãe (concentração de 240 $\mathrm{mg} \mathrm{L}^{-1}$ ) que foi sendo diluída para a preparação de $200 \mathrm{~mL}$ de cada solução com menor concentração. Desse volume de $200 \mathrm{~mL}$ foram separados três volumes de $50 \mathrm{~mL}$, um para cada amostra da triplicata contendo $1 \mathrm{~g}$ do material reativo orgânico (Figura 75 A) e os $50 \mathrm{~mL}$ restantes foram denominados de branco da respectiva solução. As amostras permaneceram em agitação em mesa agitadora (Figura 75 B) e foram ocasionalmente agitadas manualmente, de modo mais intenso.

Figura 75 - Ensaio de equilíbrio em lote. A) Determinação da massa de turfa; B) Agitação do conjunto de amostras da turfa em contato com soluções contendo $\mathrm{Pb}$
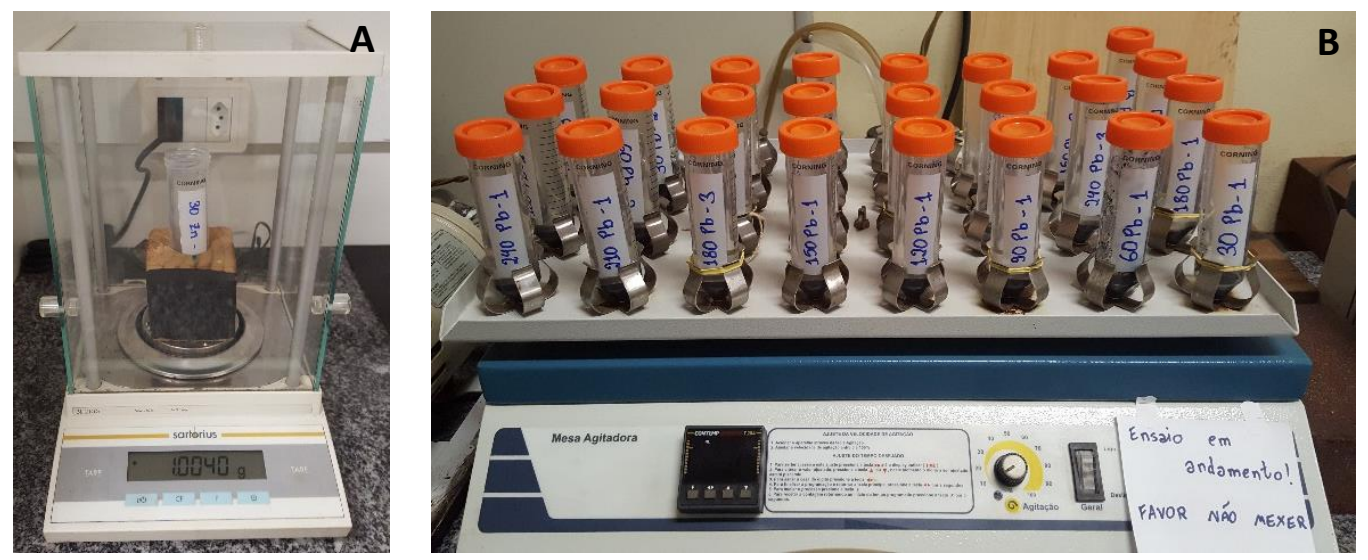

Fonte: A autora.

Nas amostras contendo material reativo e solução, seus parâmetros físico-químicos foram determinados antes e após o tempo de contato, já nos brancos das soluções, estes parâmetros foram medidos apenas inicialmente e estas amostras já foram armazenadas em 
geladeira, visto que na etapa preliminar do teste da melhor razão turfa/solução não foi observada uma variação significativa entre os dados referentes às amostras de solução mãe (retiradas logo após sua preparação) e às amostras de branco da solução (que acompanharam as demais amostras).

Figura 76 - Amostras do ensaios de equilíbrio em lote. À esquerda, parte líquida e soluções branco e à direita, parte sólida. A) Amostras de turfa e $\mathrm{Pb}$; B) Conjunto de amostras de composto indiano e $\mathrm{Pb}$
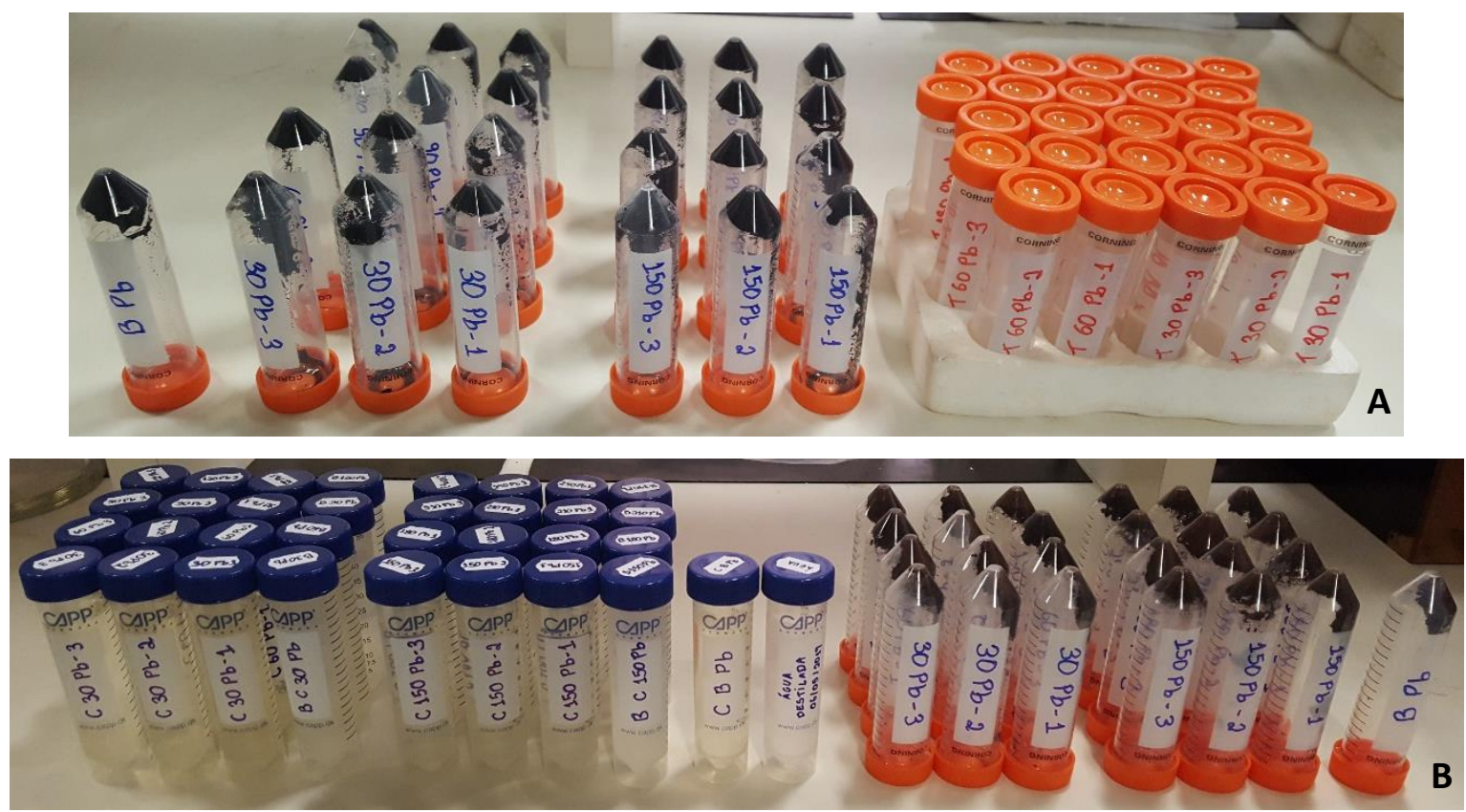

Fonte: A autora.

Ademais, cada conjunto de amostras foi acompanhado de um exemplar contendo apenas o material reativo orgânico em análise e água deionizada e um exemplar contendo apenas água deionizada (equipamento marca Permution).

A preparação das soluções e dos materiais reativos orgânicos, o ensaio de equilíbrio em lote, a leitura dos parâmetros físico-químicos, as análises das concentrações metálicas presentes nos extratos, bem como as diluições das amostras, quando necessário, foram executados no Laboratório de Geotecnia Ambiental do Departamento de Geotecnia da EESC - USP. 


\section{RESULTADOS E DISCUSSÃO}

\subsection{Caracterização geológica e geotécnica dos materiais reativos orgânicos}

\subsubsection{Turfa}

\subsubsection{Análise granulométrica}

Conforme apresentado anteriormente, a análise granulométrica da turfa foi realizada para a amostra total e apenas para a porção mineral. Desta maneira, para facilitar a compreensão optou-se por apresentar estes resultados separadamente, na forma de subtópicos.

\section{A) Amostras de turfa total: com defloculante ( $\mathrm{NaOH}$ e hexametafosfato) e sem defloculante}

Para efeito comparativo, as Tabelas 2 e 3 exibem as porcentagens médias obtidas da triplicata, seguidas dos respectivos desvios padrão, referentes à ocorrência de cada fração granulométrica nas amostras de turfa total, utilizando, respectivamente, os limites estabelecidos por EMBRAPA (2011) e pela ABNT NBR 6502 - 95. Comparando estes valores, observa-se que a presença de argila é análoga, uma vez que ambas as classificações adotam a mesma faixa de diâmetro para esta fração (inferior a $0,002 \mathrm{~mm}$ ). Contudo, o intervalo correspondente à fração silte segundo a NBR 6502 varia de 0,002 a 0,06 mm, enquanto de acordo com EMBRAPA (2011), ele é mais restrito e seu limite superior é 0,05 mm. Assim, comparando ambas as classificações, segundo a NBR 6502 as amostras apresentaram uma presença superior de silte. Consequentemente, como o limiar superior para a classe areia fina é o mesmo em ambas as classificações $(0,2 \mathrm{~mm})$, conforme a NBR 6502 as amostras apresentaram um menor teor de fração areia fina. Contudo, levando em consideração o desvio padrão, as classes silte e areia fina se tornam similares em ambas as classificações. Por fim, a NBR 6502 divide o intervalo de classificação que segundo EMBRAPA (2011) corresponde a areia grossa (0,2 a 2,0 mm) em duas classes: areia média $(0,2$ a $0,6 \mathrm{~mm})$ e areia grossa $(0,6$ a 2,0 $\mathrm{mm})$. 
Tabela 2 - Distribuição granulométrica das amostras de turfa total, segundo limites de frações estabelecidos por EMBRAPA (2011)

\begin{tabular}{|c|c|c|c|c|}
\hline \multirow{2}{*}{ Amostra } & \multirow{2}{*}{$\begin{array}{c}\text { Argila } \\
\left(\mathrm{g} \mathrm{kg}^{-1}\right)\end{array}$} & \multirow{2}{*}{$\begin{array}{c}\text { Silte } \\
\left(\mathrm{g} \mathrm{kg}^{-1}\right)\end{array}$} & \multicolumn{2}{|c|}{ Areia $\left(\mathrm{g} \mathrm{kg}^{-1}\right)$} \\
\hline & & & fina & grossa \\
\hline $\begin{array}{l}\text { Total com } \\
\mathrm{NaOH}\end{array}$ & $78,1 \pm 34,7$ & $193,7 \pm 65,5$ & $252,0 \pm 24,6$ & $476,2 \pm 27,9$ \\
\hline $\begin{array}{c}\text { Total com } \\
\text { hexametafosfato }\end{array}$ & $90,4 \pm 29,7$ & $151,0 \pm 15,4$ & $217,0 \pm 5,0$ & $541,6 \pm 21,0$ \\
\hline $\begin{array}{c}\text { Total sem } \\
\text { defloculante }\end{array}$ & $42,3 \pm 11,2$ & $160,9 \pm 28,8$ & $246,8 \pm 34,7$ & $550,0 \pm 15,5$ \\
\hline
\end{tabular}

Fonte: A autora.

Tabela 3 - Distribuição granulométrica das amostras de turfa total, segundo limites de frações estabelecidos por ABNT NBR 6502 - 95

\begin{tabular}{|c|c|c|c|c|c|}
\hline \multirow{2}{*}{ Amostra } & \multirow{2}{*}{$\begin{array}{l}\text { Argila } \\
\left(\mathrm{g} \mathrm{kg}^{-1}\right)\end{array}$} & \multirow{2}{*}{$\begin{array}{c}\text { Silte } \\
\left(\mathrm{g} \mathrm{kg}^{-1}\right)\end{array}$} & \multicolumn{3}{|c|}{ Areia $\left(\mathrm{g} \mathrm{kg}^{-1}\right)$} \\
\hline & & & fina & média & grossa \\
\hline $\begin{array}{l}\text { Total com } \\
\mathrm{NaOH}\end{array}$ & $78,1 \pm 34,7$ & $215,8 \pm 70,3$ & $229,9 \pm 20,3$ & $243,2 \pm 7,9$ & $233,0 \pm 20,5$ \\
\hline $\begin{array}{c}\text { Total com } \\
\text { hexametafosfato }\end{array}$ & $90,4 \pm 29,7$ & $173,7 \pm 17,2$ & $194,2 \pm 3,5$ & $246,2 \pm 10,7$ & $295,5 \pm 14,0$ \\
\hline $\begin{array}{c}\text { Total sem } \\
\text { defloculante }\end{array}$ & $42,3 \pm 11,2$ & $180,3 \pm 32,8$ & $227,4 \pm 38,7$ & $262,9 \pm 8,8$ & $287,1 \pm 23,8$ \\
\hline
\end{tabular}

Fonte: A autora.

Levando em consideração os limites de diâmetros impostos pelo boletim publicado por EMBRAPA (2011) a ocorrência de finos (argila + silte) foi de 271,8 $\mathrm{g} \mathrm{kg}^{-1}(\mathrm{NaOH}) ; 241,4 \mathrm{~g}$ $\mathrm{kg}^{-1}$ (hexametafosfato) e 203,2 $\mathrm{g} \mathrm{kg}^{-1}$ (sem defloculante). Por conseguinte, o teor de areia foi de 728,2 $\mathrm{g} \mathrm{kg}^{-1}(\mathrm{NaOH}) ; 758,6 \mathrm{~g} \mathrm{~kg}^{-1}$ (hexametafosfato) e 796,8 $\mathrm{g} \mathrm{kg}^{-1}$ (sem defloculante). Já considerando a ABNT NBR 6502 - 95, as porcentagens de ocorrência de finos foram de 293,9 $\mathrm{g} \mathrm{kg}^{-1}(\mathrm{NaOH}) ; 264,1 \mathrm{~g} \mathrm{~kg}^{-1}$ (hexametafosfato) e 222,6 $\mathrm{g} \mathrm{kg}^{-1}$ (sem defloculante). Como consequência, a presença de areia foi de 706,1 $\mathrm{g} \mathrm{kg}^{-1}(\mathrm{NaOH}) ; 735,9 \mathrm{~g} \mathrm{~kg}^{-1}$ (hexametafosfato) e 777,4 $\mathrm{g} \mathrm{kg}^{-1}$ (sem defloculante). Assim, a amostra de turfa total é majoritariamente constituída por grãos com intervalo de diâmetro compreendido na fração areia.

A granulometria de um material está diretamente associada às suas propriedades de superfície (incluindo propriedades de sorvente), sendo que aumentando proporcionalmente sua área superficial, ocorre uma elevação do número de locais carregados por unidade de área ou massa, já que as habilidades de sorção de minerais são proporcionais às suas áreas superficiais (LANGMUIR, 1997). Dessa forma, mesmo com grande presença de grãos com diâmetro de 
areia, a considerável presença de partículas finas na turfa é essencial, já que elas são dotadas justamente de uma maior área superficial, desempenhando uma função substancial no mecanismo de adsorção.

De modo geral, ambas as classificações revelaram variações sucintas e se adequaram bem a esta análise. Todavia, é válido ressaltar que os limites estabelecidos pela ABNT NBR 6502 - 95 apresentam a vantagem de promover uma divisão mais pormenorizada do intervalo areia, por exibir uma classe a mais, o que, neste caso, se mostrou de grande valia, já que se trata de um material turfoso com partículas majoritariamente enquadradas no intervalo de diâmetro areia. Assim, segundo esta classificação as amostras de turfa total apresentaram teores semelhantes para as três subdivisões dentro da classe areia, sendo um indicativo de que há uma certa uniformidade na distribuição de partículas nesta categoria.

Analisando comparativamente os dados apresentados nas Tabelas 2 e 3 e a Figura 77, em relação às amostras de turfa total, em termos do uso de defloculante, é possível perceber que para as partículas com diâmetro de até cerca de $20 \mu \mathrm{m}$, as porcentagens médias de ocorrência para ambos os defloculante $(\mathrm{NaOH}$ e hexametafosfato de sódio) foram bem similares. Já para partículas com diâmetros superiores, as amostras com $\mathrm{NaOH}$ resultaram em uma presença sucintamente maior de partículas com diâmetros inferiores em relação às amostras com hexametafosfato de sódio, o que fica evidenciado pelo ligeiro deslocamento à esquerda entre as curvas granulométricas nesta porção. Já as porcentagens médias das amostras sem defloculante, de modo geral, resultaram em uma menor presença de partículas contidas nos intervalos das chamadas frações finas (argila e silte). Em detrimento, a fração areia é maior, conforme mostrado pelo deslocamento à direita entre a curva granulométrica destas amostras com as curvas das análises com defloculante. Em condições naturais (sem defloculante) esse valor superior de areia provavelmente é devido ao elevado teor de matéria orgânica que atua como agente aglutinador de partículas, conforme verificado em análise macroscópica. 
Figura 77 - Distribuição granulométrica da turfa total (com NaOH, com hexametafosfato e sem defloculante)

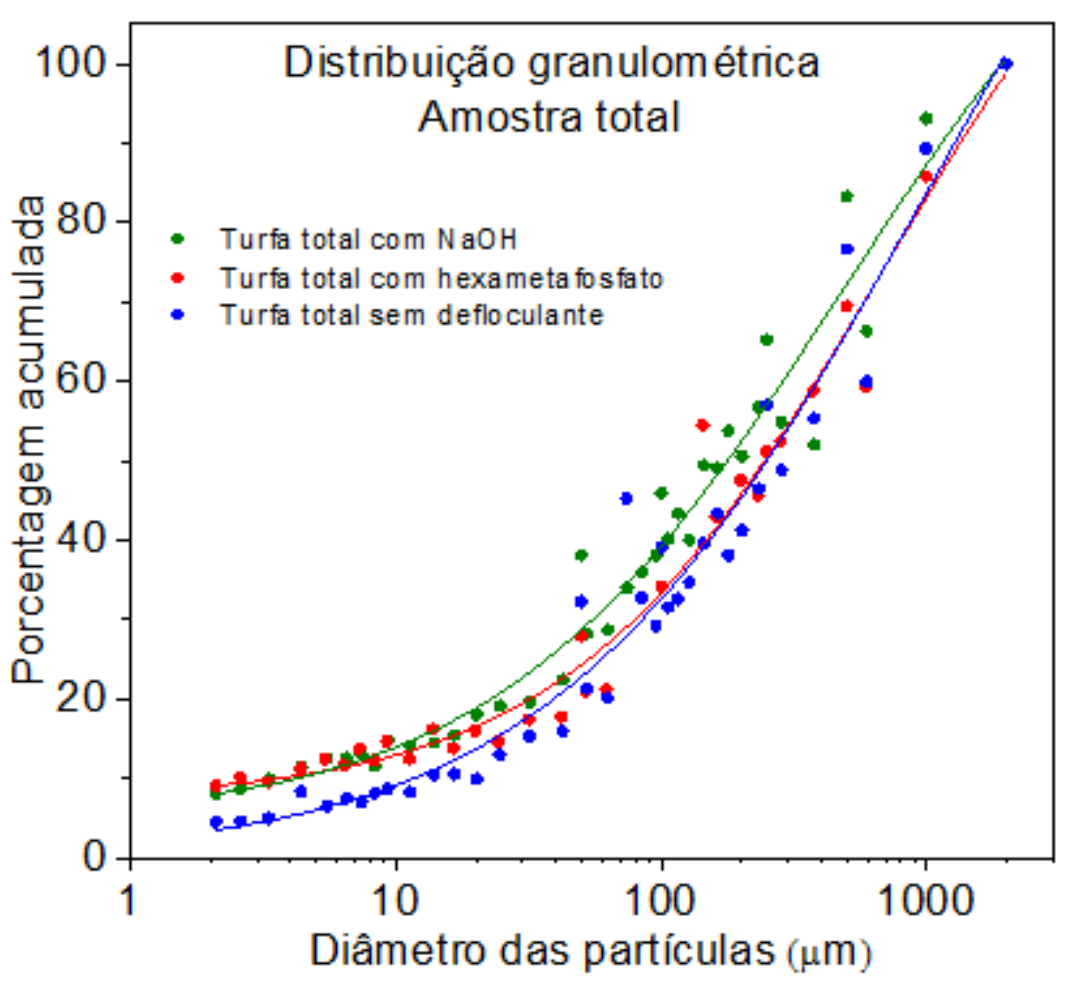

Fonte: A autora.

Contudo, estas constatações em relação às consequências intrínsecas ao uso de defloculante são válidas em se tratando dos valores médios obtidos. Ademais, a análise da Figura 77 deixa clara a turbulência típica da sedimentação das partículas maiores, constatada através da desordem que culminou na formação de uma nuvem contendo os pontos resultantes nessa faixa. Diferentemente, os dados referentes às partículas menores apresentam uma disposição consideravelmente uniforme e ordenada.

\section{B) Amostras apenas da porção mineral da turfa: com defloculante (NaOH e hexametafosfato) e sem defloculante}

Similar análise foi realizada apenas para a porção mineral da turfa (sem matéria orgânica) e os resultados de distribuição granulométrica se encontram nas Tabelas 4 e 5 considerando, respectivamente, os limites de frações estabelecidos por EMBRAPA (2011) e pela ABNT NBR 6502 - 95. Comparando os dados associados a ambas classificações é possível estabelecer conclusões similares àquelas levantadas para os resultados referentes à amostra total de turfa, como a presença análoga de argila em ambas as categorizações, uma maior porcentagem de silte e uma consequente menor ocorrência de areia fina, em se tratando do uso 
da NBR 6502. Ademais, similar à amostra total, considerando os desvios padrão em relação às frações silte e areia fina, estas faixas de porcentagem revelam um valor semelhante para as duas classificações, com a maior variação de valores no tocante a amostra sem defloculante.

Tabela 4 - Distribuição granulométrica das amostras da porção mineral da turfa, segundo limites de frações estabelecidos por EMBRAPA (2011)

\begin{tabular}{ccccc}
\hline \hline \multirow{2}{*}{ Amostra } & \multirow{2}{*}{$\begin{array}{c}\text { Argila } \\
\left(\mathbf{g ~ k g}^{-1}\right)\end{array}$} & $\begin{array}{c}\text { Silte } \\
\left(\mathbf{g ~ k g}^{-1}\right)\end{array}$ & fina & grossa \\
\hline \hline $\begin{array}{c}\text { Porção mineral com } \\
\mathrm{NaOH}\end{array}$ & $123,4 \pm 13,8$ & $337,7 \pm 15,9$ & $278,4 \pm 21,4$ & $260,5 \pm 5,4$ \\
\hline $\begin{array}{c}\text { Porção mineral com } \\
\text { hexametafosfato }\end{array}$ & $97,1 \pm 3,7$ & $312,8 \pm 24,0$ & $272,9 \pm 19,9$ & $317,2 \pm 2,4$ \\
\hline $\begin{array}{c}\text { Porção mineral sem } \\
\text { defloculante }\end{array}$ & $0,0 \pm 0,0$ & $400,7 \pm 5,2$ & $279,9 \pm 14,0$ & $319,4 \pm 10,4$ \\
\hline \hline
\end{tabular}

Fonte: A autora.

Tabela 5 - Distribuição granulométrica das amostras da porção mineral da turfa, segundo limites de frações estabelecidos por ABNT NBR 6502

\begin{tabular}{|c|c|c|c|c|c|}
\hline \multirow{2}{*}{ Amostra } & \multirow{2}{*}{$\begin{array}{c}\text { Argila } \\
\left(\mathrm{g} \mathrm{kg}^{-1}\right)\end{array}$} & \multirow{2}{*}{$\begin{array}{c}\text { Silte } \\
\left(\mathrm{g} \mathrm{kg}^{-1}\right)\end{array}$} & \multicolumn{3}{|c|}{ Areia $\left(\mathrm{g} \mathrm{kg}^{-1}\right)$} \\
\hline & & & fina & média & grossa \\
\hline $\begin{array}{l}\text { Porção mineral com } \\
\qquad \mathrm{NaOH}\end{array}$ & $123,4 \pm 13,8$ & $374,8 \pm 16,8$ & $241,3 \pm 23,6$ & $170,3 \pm 15,4$ & $90,2 \pm 20,7$ \\
\hline $\begin{array}{l}\text { Porção mineral com } \\
\text { hexametafosfato }\end{array}$ & $97,1 \pm 3,7$ & $344,7 \pm 25,5$ & $241,0 \pm 21,0$ & $185,4 \pm 10,5$ & $131,8 \pm 8,4$ \\
\hline $\begin{array}{l}\text { Porção mineral sem } \\
\text { defloculante }\end{array}$ & $0,0 \pm 0,0$ & $439,2 \pm 4,9$ & $241,4 \pm 5,5$ & $181,4 \pm 13,0$ & $138,0 \pm 6,5$ \\
\hline
\end{tabular}

Fonte: A autora.

Considerando os limites estabelecidos pelo manual publicado pela EMBRAPA (2011) a presença de finos (argila + silte) foi de 461,1 $\mathrm{g} \mathrm{kg}^{-1}(\mathrm{NaOH}) ; 409,9 \mathrm{~g} \mathrm{~kg}^{-1}$ (hexametafosfato) e 400,7 $\mathrm{g} \mathrm{kg}^{-1}$ (sem defloculante). Por conseguinte, o teor de areia foi de 538,9 $\mathrm{g} \mathrm{kg}^{-1}(\mathrm{NaOH})$; $590,1 \mathrm{~g} \mathrm{~kg}^{-1}$ (hexametafosfato) e 599,3 $\mathrm{g} \mathrm{kg}^{-1}$ (sem defloculante). Já considerando a ABNT NBR 6502 - 95, as porcentagens de ocorrência de finos foram de 498,2 $\mathrm{g} \mathrm{kg}^{-1}(\mathrm{NaOH}) ; 441,8 \mathrm{~g}$ $\mathrm{kg}^{-1}$ (hexametafosfato) e 439,2 $\mathrm{g} \mathrm{kg}^{-1}$ (sem defloculante). Como consequência, a presença de areia foi de 501,8 $\mathrm{g} \mathrm{kg}^{-1}(\mathrm{NaOH}) ; 558,2 \mathrm{~g} \mathrm{~kg}^{-1}$ (hexametafosfato) e 560,8 $\mathrm{g} \mathrm{kg}^{-1}$ (sem defloculante). Dessa forma, a amostra da parte mineral também é predominantemente constituída por grãos com intervalo de diâmetro compreendido no intervalo de areia. Contudo, a parcela de finos também é bem elevada, correspondendo a quase metade da amostra. 
Comparando os resultados exibidos nas Tabelas 4 e 5 e na Figura 78, referentes às três modalidades do ensaio granulométrico realizados para a amostra da porção mineral da turfa, é válido destacar que as distribuições granulométricas referentes ao emprego dos dois defloculantes foram bem similares, com um suave deslocamento à esquerda da curva referente às amostras com $\mathrm{NaOH}$, indicando, neste caso, uma maior presença de partículas com diâmetros inferiores. Já quanto à distribuição granulométrica referente às análises realizadas sem defloculante, a porção da curva referente às partículas maiores que cerca de $10 \mu \mathrm{m}$ também foi bem similar às curvas das amostras com defloculante. Porém, a curva granulométrica teve início justamente nas proximidades de partículas com tamanho próximo a $10 \mu \mathrm{m}$, evidenciando uma ausência de uma parcela mais fina do material.

Figura 78 - Distribuição granulométrica da porção mineral da turfa (com $\mathrm{NaOH}$, com hexametafosfato e sem defloculante)

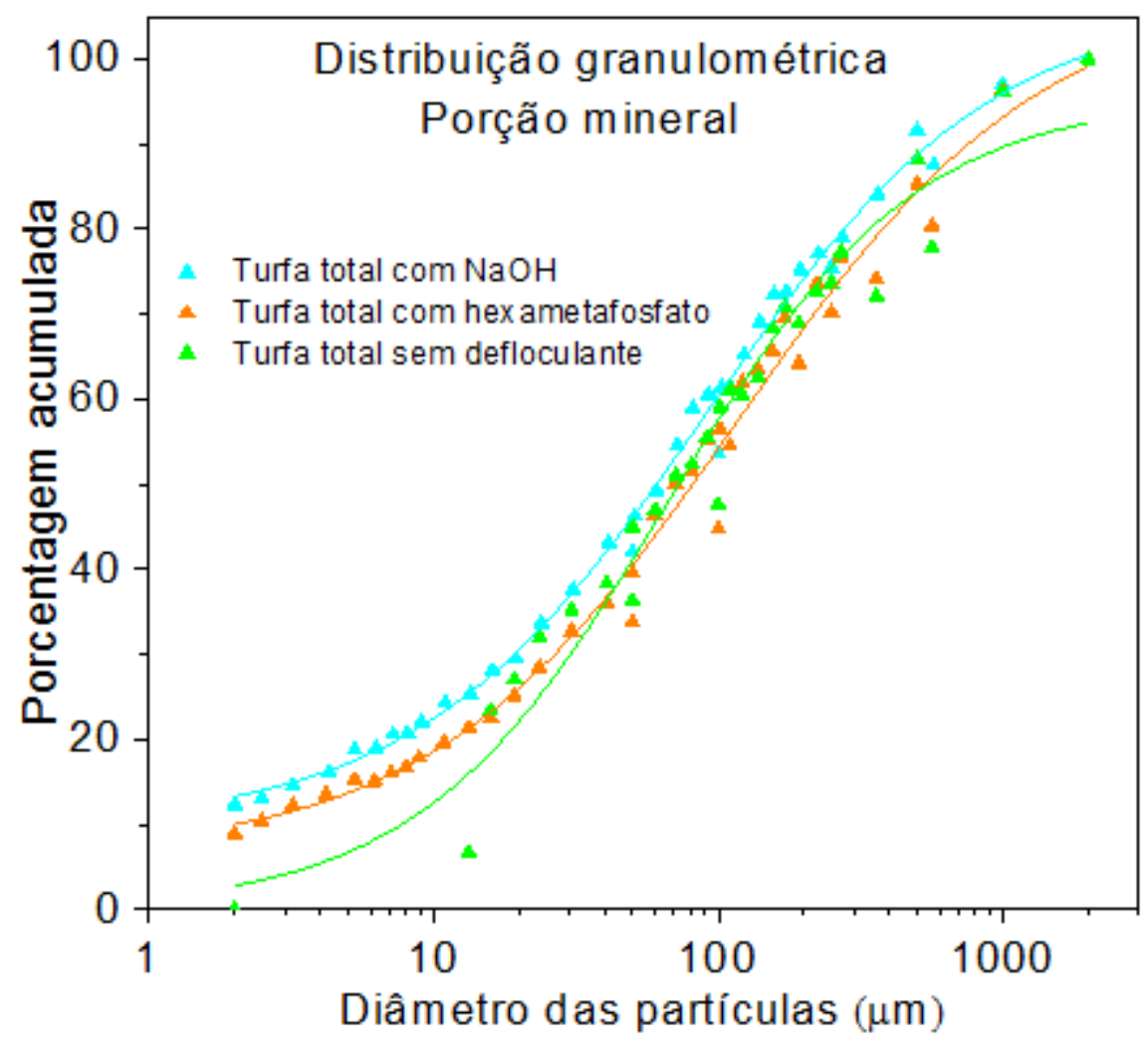

Fonte: A autora.

Todavia, estas deduções em se tratando do emprego de defloculante são válidas, novamente, em relação aos valores médios obtidos. Além disso, diferentemente da Figura 77 referente a turfa total, a análise da Figura 78 revela curvas granulométricas obtidas a partir da distribuição de pontos alinhados. 


\section{C) Diagnóstico comparativo entre os resultados obtidos para as análises com a turfa total e apenas com a porção mineral da turfa}

Conforme apresentado nas Tabelas 2, 3, 4 e 5 e sintetizado na Figura 79 é possível constatar que, de modo geral, a porção mineral apresentou uma granulometria mais fina do que a amostra total de turfa. Nesse sentido, se destaca primordialmente a elevação na porcentagem de partículas contidas no intervalo da fração silte. Essa constatação sugere que a matéria orgânica, que essencialmente apresenta tamanho coloidal, consequentemente sendo contabilizada pelas frações finas, sobretudo argila, formou agregados tão intimamente ligados que nem o defloculante foi capaz de separá-los.

Ademais, ao que tudo indica, o emprego do defloculante $\mathrm{NaOH}$ promoveu uma maior desagregação das partículas, já que tanto para a amostra total, como para a porção mineral, a presença de finos (argila + silte) foi superior com a utilização do $\mathrm{NaOH}$ em relação ao uso do hexametafosfato de sódio. Especificamente, separando as frações silte e argila, apenas o conteúdo de partículas compreendidas no intervalo de diâmetro de argila para a amostra total foi superior utilizando-se o hexametafosfato de sódio em relação ao $\mathrm{NaOH}$.

Figura 79 - Distribuição granulométrica comparativa da turfa total e da porção mineral (com NaOH, com hexametafosfato e sem defloculante)

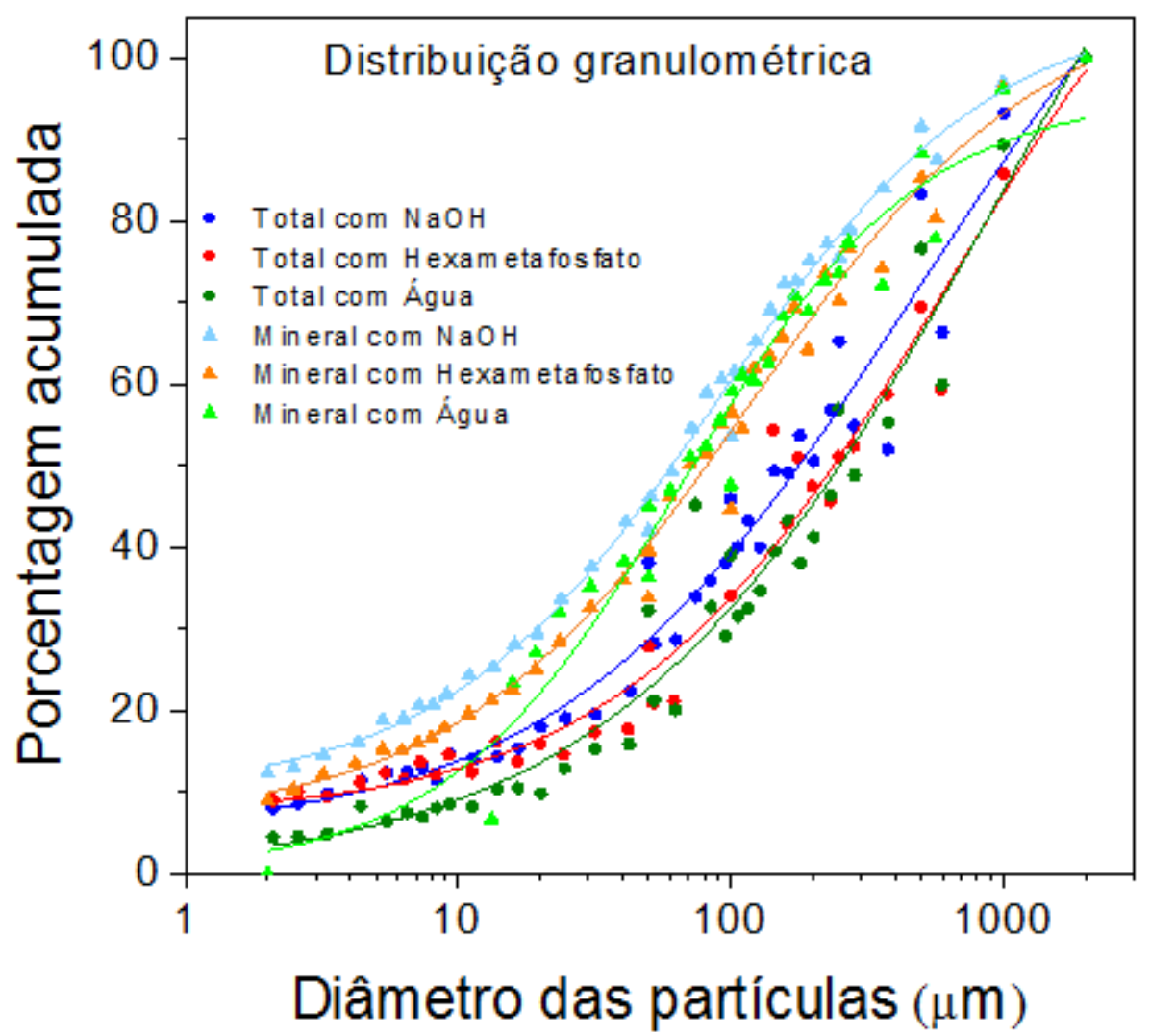

Fonte: A autora. 
A distribuição do tamanho das partículas que compõem a turfa é diferente dos solos inorgânicos e, mais especificamente, até mesmo de turfas originadas de outras regiões. Isso ocorre em virtude dos materiais de origem (sobretudo orgânicos) e das condições a que foram submetidos ao longo de sua formação, que conferem à substância final características únicas.

De modo geral, para se estabelecer uma visão holística de distribuições granulométricas típicas de turfas advindas de diversas localidades brasileiras serão apresentados os dados de algumas pesquisas.

Petroni (2004) ao trabalhar com uma turfa fibrosa extra comercialmente disponível proveniente de uma turfeira localizada em Balneário Arroio do Silva (Santa Catarina) obteve, através do peneiramento da turfa, uma presença de partículas contidas no intervalo de areia média e grossa (superiores a $0,2 \mathrm{~mm}$ ) de $850 \mathrm{~g} \mathrm{~kg}^{-1}$.

Franchi (2004) estudou a turfa de Eugênio de Melo, localizada no Vale do Rio Paraíba do Sul (estado de São Paulo). Os valores granulométricos encontrados pelo autor para o peneiramento a seco após a moagem das amostras foi de $323,8 \mathrm{~g} \mathrm{~kg}^{-1}$ das partículas com diâmetro inferior a $0,063 \mathrm{~mm}$ (silte e argila) e $363,3 \mathrm{~g} \mathrm{~kg}^{-1}$ com tamanho igual ou superior a $0,25 \mathrm{~mm}$ (areia média e grossa).

Crescêncio Júnior (2008) caracterizou dois tipos de turfa. A primeira vendida comercialmente e explorada de uma turfeira também localizada em Mogi Guaçu (estado de São Paulo), de natureza fibrosa, e outra advinda de Resende (estado do Rio de Janeiro), com caráter argiloso. Para a primeira turfa, o referido autor obteve um teor de partículas com diâmetro de areia (superior a $0,06 \mathrm{~mm}$ ) de, aproximadamente, $750 \mathrm{~g} \mathrm{~kg}^{-1}$. Já em se tratando da segunda turfa mencionada, este valor foi drasticamente reduzido para a ordem de apenas $60 \mathrm{~g} \mathrm{~kg}^{-1}$.

Por fim, Messias (2004) avaliou a turfa coletada também em Mogi Guaçu, às margens do rio homônimo, no município de Luis Antônio (estado de São Paulo). Em termos granulométricos, seguindo a norma do Departamento Nacional de Estradas e Rodagem (DNERME 051/94), com etapas de sedimentação (método de densímetro) e peneiramento e uso de hexametafosfato de sódio como defloculante, o autor encontrou uma porcentagem de areia (partículas superiores a $0,06 \mathrm{~mm}$ ) de $670 \mathrm{~g} \mathrm{~kg}^{-1}$, valor próximo ao encontrado nesta pesquisa $\left(735,9 \mathrm{~g} \mathrm{~kg}^{-1}\right)$.

Estes relatos evidenciam a amplitude de variação granulométrica entre diferentes tipos de turfa que devem ser atenciosamente analisados em virtude de sua consequente influência nos usos pretendidos para esse material. 


\subsubsection{Massa específica dos sólidos e densidade aparente}

A massa específica média encontrada para a turfa foi de $1,811 \pm 0,020 \mathrm{~g} \mathrm{~cm}^{-3}$, conforme exibido na Tabela 6. Esse resultado é inferior ao valor típico referente a solos minerais $(2,600$ a 2,700 $\mathrm{g} \mathrm{cm}^{-3}$, segundo Don Scott, 2000). Tal fato se justifica, principalmente, devido ao alto teor de matéria orgânica presente na turfa, que confere maior leveza a esse material.

Tabela 6 - Massa específica dos sólidos para a turfa

\begin{tabular}{cc}
\hline \hline $\begin{array}{c}\text { Amostra } \\
\text { (Triplicata) }\end{array}$ & $\begin{array}{c}\text { Massa específica } \\
\left(\mathbf{g ~ c m}^{-3}\right)\end{array}$ \\
\hline \hline $\mathrm{T} 1$ & 1,813 \\
\hline $\mathrm{T} 2$ & 1,830 \\
\hline $\mathrm{T} 3$ & 1,790 \\
\hline \hline Valor médio & $\mathbf{1 , 8 1 1}$ \\
\hline Desvio padrão & $\mathbf{0 , 0 2 0}$ \\
\hline
\end{tabular}

Fonte: A autora.

Esse valor médio de massa específica é condizente com os dados da literatura. Petroni (2004) determinou a massa específica de uma turfa fibrosa extra (coletada em Santa Catarina), sendo que esse valor foi de $1,410 \pm 0,005 \mathrm{~g} \mathrm{~cm}^{-3}$ (método do picnômetro a gás hélio). Messias (2004) obteve uma massa específica para a turfa coletada na bacia do rio Mogi Guaçu de 1,658 $\pm 0,019 \mathrm{~g} \mathrm{~cm}^{-3}$, valor próximo ao encontrado na amostra analisada no presente estudo, que também foi coletada na bacia do rio Mogi Guaçu.

Ademais, foi determinada ainda a densidade aparente para a amostra de turfa, obtendose um valor de $0,71 \mathrm{~g} \mathrm{~cm}^{-3}$. Este resultado se enquadra ao apresentado por Kiehl (1985), de acordo com o qual turfas secas em estufa revelam uma densidade aparente entre 0,08 e 0,90 g $\mathrm{cm}^{-3}$, sendo que são esperados valores mais altos quanto maior for a quantidade de material inorgânico presente na amostra de turfa.

\subsubsection{Teor de umidade e capacidade de retenção de água (CRA)}

Como existem vários métodos empregados na determinação do teor de umidade de turfas, nesta pesquisa, optou-se por usar três métodos distintos, visando à comparação entre eles.

O teor de umidade da turfa, apresentado na Tabela 7, resultou em um valor superior para as amostras secas em estufa entre 105 e $110^{\circ} \mathrm{C}(26,97 \pm 0,10 \%)$ se comparado às amostras secas 
a uma temperatura de 40 a $50^{\circ} \mathrm{C}(18,23 \pm 0,19 \%)$. Esta variação no teor de umidade pode ser justificada, pelo fato de que a faixa de temperatura de 40 a $50^{\circ} \mathrm{C}$ não seja suficiente para retirar a água que se encontra mais intimamente ligada às partículas sólidas da amostra. Ou ainda, a temperatura de secagem de $110^{\circ} \mathrm{C}$ pode já incinerar alguma porção de matéria orgânica, mesmo que pequena, conferindo uma maior diferença de massa antes e após secagem (sendo assim, o valor determinado não seria só do teor de umidade). Ademais, estes dois fatores podem também estar atuando conjuntamente.

Tabela 7 - Teor de umidade obtido para a turfa, resultante de secagem entre 40 e $50^{\circ} \mathrm{C}$ e 105 e $110^{\circ} \mathrm{C}$

\begin{tabular}{ccc}
\hline $\begin{array}{c}\text { Amostra } \\
(\text { Triplicata) }\end{array}$ & $\begin{array}{c}\text { Teor de Umidade } \\
(\mathbf{\%}) \\
\mathbf{4 0}-\mathbf{5 0}{ }^{\circ} \mathbf{C}\end{array}$ & $\begin{array}{c}\text { Teor de Umidade } \\
(\mathbf{\%})\end{array}$ \\
\hline \hline $\mathrm{T} 1$ & 18,14 & 27,08 \\
\hline $\mathrm{T} 2$ & 18,45 & 26,90 \\
\hline $\mathrm{T} 3$ & 18,10 & 26,93 \\
\hline \hline Valor médio & $\mathbf{1 8 , 2 3}$ & $\mathbf{2 6 , 9 7}$ \\
\hline Desvio padrão & $\mathbf{0 , 1 9}$ & $\mathbf{0 , 1 0}$ \\
\hline \hline
\end{tabular}

Fonte: A autora.

A Tabela 8 apresenta os resultados de umidade para a turfa seguindo uma outra metodologia. Nesse caso, a amostra inicial foi seca em estufa entre 60 e $65^{\circ} \mathrm{C}$, resultando em uma perda de umidade de $26,22 \%$ e, na sequência, esta mesma amostra foi conduzida para uma estufa com temperatura entre 105 e $110^{\circ} \mathrm{C}$, promovendo uma nova perda de $2,29 \%$. Assim, a soma entre estes teores de umidade culminou em uma umidade total de $28,51 \%$.

Tabela 8 - Teor de umidade obtido para a turfa resultante do ensaio com temperaturas combinadas $\left(60-65^{\circ} \mathrm{C}\right.$ e $\left.105-110^{\circ} \mathrm{C}\right)$

\begin{tabular}{cc}
\hline $\begin{array}{c}\text { Teor de Umidade } \\
(\boldsymbol{\%})\end{array}$ & Turfa \\
\hline \hline $60-65^{\circ} \mathrm{C}$ & 26,22 \\
\hline $105-110^{\circ} \mathrm{C}$ & 2,29 \\
\hline \hline Total & $\mathbf{2 8 , 5 1}$ \\
\hline
\end{tabular}

Fonte: A autora. 
Portanto, comparando-se a umidade resultante de uma combinação de secagem em temperaturas fracionadas $\left(60-65^{\circ} \mathrm{C}\right.$ e $\left.105-110^{\circ} \mathrm{C}\right)$ e a umidade decorrente da secagem apenas à temperatura de 105 a $110^{\circ} \mathrm{C}$, é possível observar que o valor para o primeiro caso é ligeiramente superior $(1,54 \%)$.

A umidade da turfa é de complexa comparação, pois diversos autores recomendam o emprego de diferentes temperaturas e composições variadas de turfa interferem diretamente em uma diversificada capacidade de retenção de água. Contudo, é importante que alguns dados gerais sejam apresentados. Petroni (2004) avaliou em termos de umidade a $100 \pm 5^{\circ} \mathrm{C}$, separadamente, as três tipologias de turfa in natura coletadas em Santa Catarina, sendo elas: decomposta, fibrosa e fibrosa extra. Os resultados referentes ao teor de umidade foram de, respectivamente, $7,1 \pm 0,1 \%, 6,4 \pm 0,1 \%$ e $8,4 \pm 0,2 \%$. Todos esses valores são bem inferiores se comparados aos encontrados nessa pesquisa. Por outro lado, Messias (2004) determinou a umidade para a turfa coletada na bacia do rio Mogi Guaçu através da metodologia de temperaturas combinadas, mas este teor foi calculado em relação à massa inicial da amostra. Segundo este método, a turfa permaneceu em estufa por 12 horas a uma temperatura de $65^{\circ} \mathrm{C}$ e depois, mais 12 horas a $105-110^{\circ} \mathrm{C}$. A umidade parcial encontrada foi de, respectivamente, $24,15 \%$ e $3,41 \%$, resultando em uma umidade total de $27,56 \%$, valor próximo ao obtido nessa pesquisa. Como comentado anteriormente, a turfa empregada na presente pesquisa também foi coletada na bacia do rio Mogi Guaçu.

Além do teor de umidade, também foi determinada a capacidade de retenção de água (CRA) da turfa submetida a uma tensão de $10 \mathrm{hPa}$. As turfas apresentam uma considerável capacidade de retenção de água que é diretamente dependente do grau de decomposição e dos materiais de origem, sendo que a tensão analisada nesta metodologia permite determinar a umidade próxima a capacidade de campo, representando, de forma geral, a água facilmente assimilável pelas plantas. Segundo Boelter (1968), o avanço da decomposição propicia a redução do tamanho das partículas orgânicas. Assim, com a decomposição, o conteúdo de fibras é reduzido, acarretando no aumento da densidade e em uma maior presença proporcional de poros pequenos, favorecendo lentas taxas de movimentação de água.

Nessa perspectiva, a turfa em questão apresentou uma reduzida CRA, da ordem de 36,28\% (massa/massa), não favorecendo o crescimento das plantas, neste parâmetro físico. Este valor foi inferior aos resultados obtidos, para este mesmo parâmetro e pela mesma metodologia, com relação aos compostos total, indiano e estático, conforme será apresentado posteriormente. 


\subsubsection{Parâmetros físico-químicos (pH, $\Delta \mathrm{pH}$, Eh e CE)}

$\mathrm{O}$ pH das turfas, comumente, varia de 3 a 6, sendo que quanto menor for o grau de decomposição, maior será o nível de acidez (IPT, 1979). Valentin (1986) ${ }^{12}$ citado por Coiullard (1994) complementa que a turfa normalmente apresenta um $\mathrm{pH}$ em torno de 4,0, justamente devido à presença de ácidos húmicos. Esse caráter ácido típico de substâncias húmicas é comumente relacionado à ionização dos grupamentos polares $\mathrm{COOH}$ e $\mathrm{OH}$ presentes predominantemente em sua estrutura (DOS SANTOS; MENEZES; LEAL FILHO, 2001).

$\mathrm{O}$ pH interfere diretamente na estrutura e nas propriedades características da turfa, por isso sua determinação é de extrema importância. Os valores de $\mathrm{pH}$ determinados em água, para a turfa estudada estão listados na Tabela 9, sendo que o valor médio do pH para a turfa foi de $5,1 \pm 0,1$.

Tabela 9 - Valores de $\mathrm{pH}$ em $\mathrm{H}_{2} \mathrm{O}$ para a turfa

\begin{tabular}{cc}
\hline $\begin{array}{c}\text { Amostra } \\
\text { (Triplicata) }\end{array}$ & pH em $\mathbf{H}_{2} \mathbf{O}$ \\
\hline $\mathrm{T} 1$ & 5,0 \\
\hline $\mathrm{T} 2$ & 5,0 \\
\hline $\mathrm{T} 3$ & 5,1 \\
\hline Valor médio & $\mathbf{5 , 1}$ \\
\hline Desvio padrão & $\mathbf{0 , 1}$ \\
\hline \hline
\end{tabular}

Fonte: A autora.

O Quadro 16 traz a classificação da turfa segundo o pH apresentada por Lucas, Riecke e Farnham (sem data) ${ }^{13}$ citado por Kiehl, (1985) e o Quadro 17 contém uma classificação similar elaborada pela ASTM (ASTM D4427 - 13).

\footnotetext{
${ }^{12}$ VALENTIN, F. H. H.; Peat beds for odour control: recent developments and practical details. Filtn Sepn 23, p. 224-226, 1986.

${ }^{13}$ LUCAS, R. E.; P. R. RIECKE; FARHAM, R. S.; Peats for soil improvement and soil mixes. Cooperative Extension Service. Michigan State University. Sem data.
} 
Quadro 16 - Classificação da turfa segundo o pH, apresentada por Lucas, Riecke e Farnham

\begin{tabular}{|c|c|}
\hline Classificação da Turfa & Intervalos de pH \\
\hline \hline Muito ácida & 3,6 a 4,2 \\
\hline Ácida & 4,2 a 5,0 \\
\hline Com baixa acidez & 5,0 a 7,0 \\
\hline Alcalina & Acima de 7,0 \\
\hline \hline
\end{tabular}

Fonte: Lucas, Riecke e Farnham (sem data) citados por Kiehl (1985).

Quadro 17 - Classificação da turfa segundo o pH, apresentada pela ASTM

\begin{tabular}{|c|c|}
\hline \hline Classificação da Turfa & Intervalo de $\mathbf{p H}$ \\
\hline \hline Altamente ácida & Inferior a 4,5 \\
\hline Moderadamente ácida & 4,5 a 5,5 \\
\hline Ligeiramente ácida & 5,5 a 7,0 \\
\hline Básica & Acima de 7,0 \\
\hline \hline
\end{tabular}

Fonte: ASTM D4427 - 13

Segundo a classificação de Lucas, Riecke e Farnham, a turfa empregada nesta pesquisa pode ser enquadrada como de baixa acidez ( $\mathrm{pH}$ no intervalo de 5,0 a 7,0), mas no limite desta classe com a ácida (pH no intervalo de 4,2 a 5,0). Já de acordo com a classificação da ASTM, esse material enquadra-se na classe moderadamente ácida ( $\mathrm{pH}$ no intervalo de 4,5 a 5,5).

Para efeito comparativo, a Tabela 10 apresenta valores de $\mathrm{pH}$ para turfas de variadas origens, tanto nacionais como internacionais. De modo geral, todos esses resultados são para metodologias que utilizam água, favorecendo essa comparação, mesmo que cada uma delas apresente suas peculiaridades, sobretudo em termos de massa de turfa envolvida e período para leitura. Nota-se que os valores de $\mathrm{pH}$ realmente oscilam nas proximidades de 4,0, conforme relatado anteriormente, salvo um valor bem discrepante de turfa turca com $\mathrm{pH}$ 7,61. 
Tabela 10 - Valores de $\mathrm{pH}$ em $\mathrm{H}_{2} \mathrm{O}$ para turfas de diversas localidades nacionais e internacionais

\begin{tabular}{cccc}
\hline \hline Origem & Tipologia & pH em H2O & Autor \\
\hline $\begin{array}{c}\text { Bairro Monte Belo } \\
\text { (Mogi das Cruzes - SP) }\end{array}$ & - & $3,2-3,9$ & Kiehl (1985) \\
\hline Saquarema (RJ) & $\begin{array}{c}\text { Avançada } \\
\text { humificação }\end{array}$ & $2,8-3,5$ & $\begin{array}{c}\text { Dos Santos, Menezes e } \\
\text { Leal Filho (2001) }\end{array}$ \\
\hline Resende (RJ) & Argilosa & 4,36 & $\begin{array}{c}\text { Crescêncio Júnior } \\
\text { (2004) }\end{array}$ \\
\hline Mogi Guaçu (SP) & Fibrosa & 4,35 & Gündoğan, Acemioğlu, \\
e Alma (2004)
\end{tabular}

Fonte: A autora.

O pH apresenta uma influência crucial na adsorção de íons metálicos pela turfa, na medida em que afeta os grupos funcionais presentes na superfície do adsorvente, bem como a forma química dos íons metálicos. Segundo Coupal e Lalancette (1976), em condições de pH acima de 8,5 a turfa não é estável, enquanto que em um pH inferior a 3,0, a maioria dos metais serão lixiviados. Assim, entre estes valores (condição observada neste estudo), sabe-se que a turfa apresenta o potencial de adsorver grande parte dos metais de forma mais eficiente. Couillard (1994) complementa que em situações caracterizadas por baixos valores de $\mathrm{pH}$, as reações de troca iônica envolvendo metais estão em competição com as altas concentrações de $\mathrm{H}^{+}$presentes em solução. Em contrapartida, em valores de $\mathrm{pH}$ elevados, a remoção de metais é aumentada em decorrência da formação de precipitados de óxidos metálicos.

Assim, a capacidade de retenção apresentada por solos em geral e por materiais reativos para a maioria dos elementos é consideravelmente elevada em função do aumento de $\mathrm{pH}$, atingindo uma adsorção máxima em condições de $\mathrm{pH}$ neutro ou ligeiramente alcalino (ADRIANO, 1986). Brown, Gill e Allen (2000) acrescentam que o pH ótimo de adsorção é diferente para cada metal. Contudo, de forma generalizada, o pH ótimo de adsorção para a maioria dos íons metálicos bivalentes pode ser considerado como estando entre o intervalo de 
3,5 a 6,5. Portanto, o valor de $\mathrm{pH}$ de $5,1 \pm 0,1$ da turfa estudada nesta pesquisa é um fator positivo na potencialização deste material reativo na adsorção de metais potencialmente tóxicos.

Posteriormente, determinou-se também o pH da turfa em cloreto de potássio $(\mathrm{KCl})$. A Tabela 11 exibe os valores encontrados para o pH, em água e em $\mathrm{KCl}$, assim como os resultados do posterior cálculo do $\Delta \mathrm{pH}$. Pode-se observar que o valor médio de $\mathrm{pH}$ em $\mathrm{KCl}(4,1 \pm 0,0)$ foi inferior ao valor médio de $\mathrm{pH}$ em $\mathrm{H}_{2} \mathrm{O}(5,1 \pm 0,1)$.

Tabela 11 - Parâmetros físico-químicos (pH em KCl, $\mathrm{pH}$ em $\mathrm{H}_{2} \mathrm{O}$ e $\left.\Delta \mathrm{pH}\right)$ da turfa

\begin{tabular}{|c|c|c|c|}
\hline $\begin{array}{c}\text { Amostra } \\
\text { (Triplicata) }\end{array}$ & pH em KCl & pH em $\mathrm{H}_{2} \mathrm{O}$ & $\begin{array}{c}\Delta \mathrm{pH} \\
\left(\mathrm{pH} \mathrm{KCl}-\mathrm{pH} \mathrm{H_{2 } O}\right)\end{array}$ \\
\hline $\mathrm{T} 1$ & 4,1 & 5,1 & $-1,0$ \\
\hline $\mathrm{T} 2$ & 4,1 & 5,0 & $-0,9$ \\
\hline $\mathrm{T} 3$ & 4,1 & 5,1 & $-1,0$ \\
\hline Valor médio & 4,1 & 5,1 & $-1,0$ \\
\hline Desvio padrão & $\mathbf{0 , 0}$ & $\mathbf{0 , 1}$ & $\mathbf{0 , 1}$ \\
\hline
\end{tabular}

Fonte: A autora.

Para justificar essa diminuição de $\mathrm{pH}\left(\mathrm{pH}\right.$ em $\mathrm{KCl}$ inferior ao $\mathrm{pH}$ em $\mathrm{H}_{2} \mathrm{O}$ ) pode-se fazer uma analogia a constatação de Petroni (2004) ao empregar $\mathrm{CaCl}_{2}$ na determinação do $\mathrm{pH}$ e observar também uma redução dos valores de $\mathrm{pH}$. Segundo o referido autor, isso se deve ao chamado "efeito de sais" que faz com que o pH diminua em função da elevação da concentração salina. Isso ocorre pois são predominantes as reações de troca iônica, implicando em um aumento de $\mathrm{H}^{+}$em solução e, por conseguinte, em um decréscimo do $\mathrm{pH}$. Essa relação pode ser representada simplificadamente através de uma adaptação da fórmula de Puri e Asghar (1938) ${ }^{14}$ citada por Petroni (2004):

$$
\text { TURFA }-\mathrm{H}+\mathrm{KCl} \rightleftharpoons \mathrm{H}^{+}+\mathrm{Cl}^{-}+\text {TURFA-K }
$$

A Tabela 12 exibe os valores de $\mathrm{pH}$ também calculados em $\mathrm{KCl}$, mas determinados por outros autores. Esses valores de $\mathrm{pH}$ em $\mathrm{KCl}$ foram mais baixos do que o determinado nesta pesquisa.

\footnotetext{
${ }^{14}$ PURI, A. N.; ASGHAR, A. G.; Influence of salts and soil-water ratio on $\mathrm{pH}$ value of soils. Soil Science, v.46, p.249-257, 1938.
} 
Tabela 12 - Valores de $\mathrm{pH}$ em $\mathrm{KCl}$ para uma turfa nacional e outra internacional

\begin{tabular}{cccc}
\hline \hline Origem & Tipologia & pH em KCl & Autor \\
\hline \hline Mogi Guaçu (SP) & - & $3,52 \pm 0,02$ & Messias (2004) \\
\hline Sul da Polônia & $\begin{array}{c}\text { Fibrosa a } \\
\text { altamente } \\
\text { humificada }\end{array}$ & $3,16-3,56$ & $\begin{array}{c}\text { Smieja-Król et al. } \\
(2010)\end{array}$ \\
\hline \hline
\end{tabular}

Fonte: A autora.

O $\Delta \mathrm{pH}$ por sua vez está intimamente associado ao balanço de cargas do material, possibilitando estimar o predomínio de cargas positivas ou negativas. Como para as amostras de turfa analisadas esse parâmetro resultou em um valor negativo $(-1,0 \pm 0,1)$, isso significa que a presença de cargas negativas na superfície das partículas de turfa é superior à de cargas positivas. Como consequência, a capacidade de troca catiônica é favorecida, possibilitando uma maior retenção de cátions do que de ânions. Este pode ser considerado outro fator positivo do emprego desta tipologia de turfa na adsorção dos íons metálicos estudados nesta pesquisa: $\mathrm{Zn}^{2+}$, $\mathrm{Pb}^{2+} \mathrm{e} \mathrm{Cd}^{2+}$.

Smieja-Król et al. (2010) não calcularam o valor do $\Delta \mathrm{pH}$. Contudo, a partir dos resultados apresentados no tocante ao $\mathrm{pH}$ em $\mathrm{H}_{2} \mathrm{O}$ e em $\mathrm{KCl}$ nas Tabelas 10 e 12, esse parâmetro pôde ser calculado, resultando também em um valor negativo dado pelo intervalo de $-0,80 \mathrm{a}$ 0,74 ao longo dos $40 \mathrm{~cm}$ do perfil de turfa amostrado no sul da Polônia.

Outra propriedade físico-química estudada foi o potencial de oxi-redução (Eh). Este parâmetro pode ser considerado como de indubitável importância biogeoquímica, na medida em que diversos metais potencialmente tóxicos se tornam solúveis em condições de redução. Segundo Kabata-Pendias e Pendias (1984) alterações no Eh de solos e materiais reativos podem afetar o estado de oxidação de vários elementos, tais como As, Se e Cr, o que, por conseguinte, implica em modificações referentes à especiação, mobilidade, solubilidade e toxicidade. Todavia, outros metais, como o $\mathrm{Pb}, \mathrm{Cu}, \mathrm{Zn}$ e Ni mesmo não mudando seus estados de oxidação podem ser indiretamente influenciados, já que, geralmente, eles estão fortemente ligados a óxidos de Fe e Mn, elementos estes suscetíveis de transformações quanto a seus potenciais de oxi-redução. Dessa forma, esses óxidos, quando em condições redutoras, se tornam mais solúveis, disponibilizando os metais que se encontravam, até então, adsorvidos a eles.

$\mathrm{Na}$ Tabela 13 são listados os resultados de Eh obtidos para as amostras de turfa. O valor médio de Eh obtido para a turfa analisada nesta pesquisa foi de $+432 \pm 46 \mathrm{mV}$. Assim, notou- 
se que esse material se encontra em condições oxidantes, contribuindo positivamente na retenção dos metais.

Tabela 13 - Valores de potencial de oxi-redução (Eh) para a turfa

\begin{tabular}{cc}
\hline $\begin{array}{c}\text { Amostra } \\
\text { (Triplicata) }\end{array}$ & $\begin{array}{c}\text { Eh } \\
(\mathbf{m V})\end{array}$ \\
\hline $\mathrm{T} 1$ & +413 \\
\hline $\mathrm{T} 2$ & +485 \\
\hline $\mathrm{T} 3$ & +399 \\
\hline \hline Valor médio & $\mathbf{+ 4 3 2}$ \\
\hline Desvio padrão & $\mathbf{4 6}$ \\
\hline
\end{tabular}

Fonte: A autora.

O terceiro e último parâmetro físico-químico determinado foi a condutividade elétrica (CE). A Tabela 14 exibe os valores de condutividade elétrica para a turfa. O valor médio de CE obtido foi de $448 \pm 4 \mu \mathrm{S} \mathrm{cm}^{-1}$, indicando a presença de sais dissolvidos.

Tabela 14 - Valores de condutividade elétrica (CE) para a turfa

\begin{tabular}{cc}
\hline $\begin{array}{c}\text { Amostra } \\
\text { (Triplicata) }\end{array}$ & $\begin{array}{c}\mathbf{C E} \\
\left(\boldsymbol{\mu S} \mathbf{~ c m}^{-\mathbf{1}}\right)\end{array}$ \\
\hline $\mathrm{T} 1$ & 446 \\
\hline $\mathrm{T} 2$ & 453 \\
\hline $\mathrm{T} 3$ & 446 \\
\hline Valor médio & $\mathbf{4 4 8}$ \\
\hline Desvio padrão & $\mathbf{4}$ \\
\hline \hline
\end{tabular}

Fonte: A autora.

\subsubsection{Ponto de carga zero (PCZ) e ponto de efeito salino nulo (PESN)}

$\mathrm{O}$ ponto de carga zero $(\mathrm{PCZ})$ de um solo está diretamente relacionado à presença de coloides, principalmente a matéria orgânica e a fração mineralógica. Assim, é possível estimar o PCZ de um solo com base em sua composição da fase sólida. De modo geral, valores mais elevados estão relacionados à presença marcante de hematita, goethita e gibbsita. Enquanto isso, valores mais reduzidos se relacionam a maiores teores de caulinita e matéria orgânica. A fração húmica, por exemplo exibe um baixo valor de PCZ, comumente inferior a 3,0 
(ALLEONI; MELLO; ROCHA, 2016). Assim, o PCZ de um solo normalmente diminui com o aumento do conteúdo orgânico. Portanto, é comum que o PCZ aumente com o aumento da profundidade do solo, já que geralmente camadas superficiais apresentam maiores teores orgânicos (KENG, UEHARA, 1973).

O PCZ estimado para a turfa, a partir dos valores de $\mathrm{pH}$ em água e em $\mathrm{KCl}$, pela equação proposta por Keng e Uehara (1973), foi de 3,1, valor este provavelmente associado a forte presença húmica.

De modo análogo, estas mesmas constatações teóricas podem ser comprovadas para o ponto de efeito salino nulo (PESN). Nessa perspectiva, Silva et al. (1996) sugerem que a tipologia e o grau de decomposição da matéria orgânica apresentam mais efeito sobre o PESN que seu próprio teor. No caso da turfa, devido ao seu considerável caráter orgânico, provavelmente o valor do PESN é fortemente influenciado por esse elevado teor de matéria orgânica.

Assim, para a turfa analisada, foi obtido valor de PESN da ordem de 3,6 (Figura 80). Segundo Sparks (1995), o baixo valor de PESN indica que o material apresenta carga negativa sobre uma ampla faixa de $\mathrm{pH}$.

Figura 80 - Ponto de efeito salino nulo (PESN) da turfa

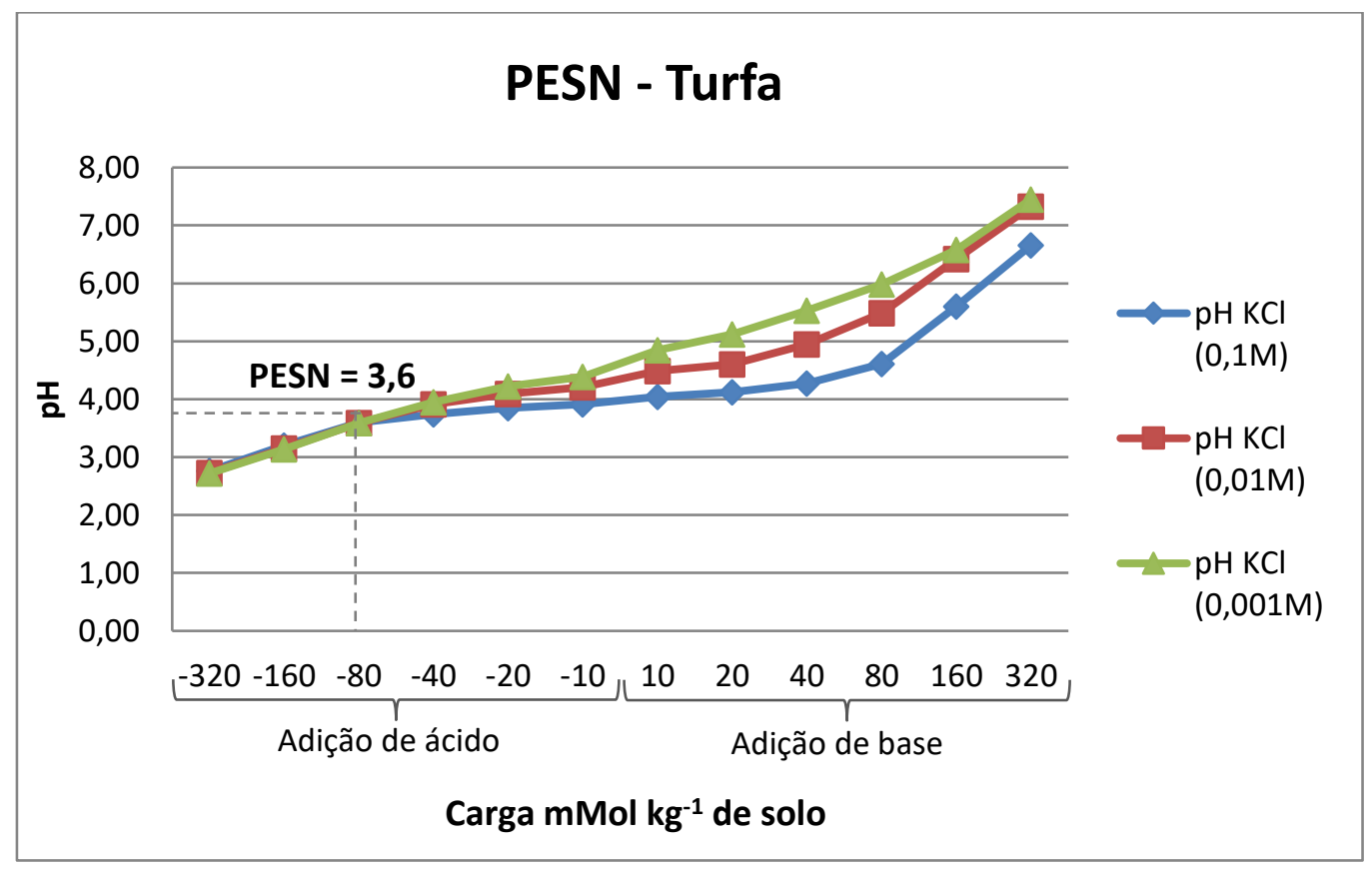

Fonte: A autora.

Para efeito comparativo, Silva e colaboradores (1996), ao estudarem 19 latossolos brasileiros, encontraram valores de PESN na faixa de 3,4 a 4,4 e mesmo estas medidas não 
apresentando correlação significativa com os teores de matéria orgânica, os referidos autores atribuíram estes valores reduzidos justamente ao fator orgânico.

Como o $\mathrm{pH}$ em $\mathrm{H}_{2} \mathrm{O}$ encontrado para a turfa estudada foi de 5,1 , medida esta maior que o valor do PCZ estimado de 3,1 e do PESN experimental de 3,6, pode-se concluir que nas superfícies das partículas da turfa há um predomínio de cargas negativas, contribuindo favoravelmente para a adsorção dos cátions metálicos de interesse nesta pesquisa $\left(\mathrm{Pb}^{2+}, \mathrm{Zn}^{2+} \mathrm{e}\right.$ $\left.\mathrm{Cd}^{2+}\right)$. Esta constatação corrobora com a obtenção do $\Delta \mathrm{pH}$ negativo $(-1,0 \pm 0,1)$.

\subsubsection{Composição elementar $(C, H, N)$}

Na Tabela 15 são listados os resultados de carbono $(\mathrm{C})$, hidrogênio $(\mathrm{H})$ e nitrogênio $(\mathrm{N})$ obtidos para a turfa. De modo geral, pode-se verificar presença dominante de C $(21,13 \pm$ $0,94 \%)$, seguida por $\mathrm{H}(2,42 \pm 0,12 \%)$ e $\mathrm{N}(0,67 \pm 0,06 \%)$. Esses três elementos juntos perfazem cerca de $24,22 \%$ da amostra total de turfa.

De acordo com Food and Agriculture Organization of the United Nations - FAO (2016) o intervalo esperado para o $\mathrm{C}$ vai de 12,0 a $60,0 \%$, o do $\mathrm{H}$ vai de 2,0 a $6,0 \%$ e o do $\mathrm{N}$ vai de 0,3 a $4,0 \%$. Todos os resultados desta pesquisa se enquadram nessas faixas de valores.

Tabela 15 - Composição elementar das amostras de turfa, relacionando a presença de C, H e N

\begin{tabular}{cccl}
\hline $\begin{array}{c}\text { Amostra } \\
\text { (Triplicata) }\end{array}$ & $\begin{array}{c}\mathbf{C} \\
(\boldsymbol{\%})\end{array}$ & $\begin{array}{c}\mathbf{H} \\
(\boldsymbol{\%})\end{array}$ & $\begin{array}{c}\mathbf{N} \\
(\mathbf{\%})\end{array}$ \\
\hline $\mathrm{T} 1$ & 20,19 & 2,53 & 0,61 \\
\hline $\mathrm{T} 2$ & 22,06 & 2,30 & 0,68 \\
\hline $\mathrm{T} 3$ & 21,15 & 2,44 & 0,72 \\
\hline Valor médio & $\mathbf{2 1 , 1 3}$ & $\mathbf{2 , 4 2}$ & $\mathbf{0 , 6 7}$ \\
\hline Desvio padrão & $\mathbf{0 , 9 4}$ & $\mathbf{0 , 1 2}$ & $\mathbf{0 , 0 6}$ \\
\hline \hline
\end{tabular}

Fonte: A autora.

A partir dos resultados da composição elementar (Tabela 15), foi possível calcular as relações $\mathrm{C} / \mathrm{N}$ e H/C (Tabela 16), como sendo o simples quociente da divisão das porcentagens em massa dos elementos, e as razões atômicas C/N e H/C (Tabela 16), procedendo previamente à divisão das porcentagens dos elementos pelas suas respectivas massas atômicas.

Os parâmetros $\mathrm{C} / \mathrm{N}$ e $\mathrm{H} / \mathrm{C}$ são considerados como um indicativo do grau de decomposição em que se encontra a matéria orgânica. De modo geral, as condições que favorecem a decomposição contribuem para o estreitamento da relação $\mathrm{C} / \mathrm{N}$. Dessa forma, a 
relação $\mathrm{C} / \mathrm{N}$ de um solo bem decomposto é menor do que esta mesma relação para uma turfa fibrosa. Além disso, esta razão quase sempre diminui acentuadamente em função do aumento da profundidade de um perfil; sendo que para certos solos subsuperficiais esta taxa pode ser, até mesmo, inferior a 5 (STEVENSON, 1982). Ainda segundo este autor, altos valores de razões atômicas $\mathrm{C} / \mathrm{N}$ indicam maior grau de humificação, em razão da diminuição da acidez, dos teores de carboidratos e dos aminoácidos/proteínas. Desta forma, a turfa analisada nesta pesquisa apresentou relação de $\mathrm{C} / \mathrm{N}$ de $31,70 \%$ e razão atômica $\mathrm{C} / \mathrm{N}$ de $36,98 \%$ (Tabela 16).

$\mathrm{O}$ parâmetro H/C está diretamente associado ao grau de aromaticidade, onde um alto valor de $\mathrm{H} / \mathrm{C}$ indica maior quantidade de grupamentos alifáticos, enquanto que valores menores estão associados a grupamentos aromáticos (CANELLAS et al., 2005; DICK et al., 2016). Dick et al. (2016) complementam que empregando o benzeno como referência, que apresenta uma razão $\mathrm{H} / \mathrm{C}$ igual a 1 , o aparecimento de estruturas aromáticas condensadas comumente deve vir associado à baixos valores $\mathrm{H} / \mathrm{C}$, enquanto espera-se que uma maior alifaticidade implique em valores da razão $\mathrm{H} / \mathrm{C}$ superiores a 1 . Nessa perspectiva, a turfa estudada apresentou uma razão atômica H/C igual a 1,37, uma evidência da ocorrência de grupos alifáticos na amostra, possivelmente associados a estruturas não tão bem decompostas (Tabela 16).

Tabela 16 - Relações e razões atômicas C/N e H/C para a turfa

\begin{tabular}{ccc}
\hline \hline & Relação & Razão atômica \\
\hline \hline $\mathbf{C} / \mathbf{N}$ & 31,70 & 36,98 \\
\hline $\mathbf{H} / \mathbf{C}$ & 0,11 & 1,37 \\
\hline \hline
\end{tabular}

Fonte: A autora.

Kiehl (1985) apresentou resultados referentes à composição de turfas da região de Mogi das Cruzes (Bairro Monte Belo), encontrando valores de $\mathrm{C}$ variando de 23,1\% a 38,7\%, de $\mathrm{N}$ entre $0,7 \%$ e $1,7 \%$ e, consequentemente relações $\mathrm{C} / \mathrm{N}$ de 21 a 33. Em termos comparativos, a turfa objeto de estudo apresentou uma concentração de C inferior que a obtida por Kiehl (1985) em turfas coletadas em Mogi das Cruzes, mas uma relação $\mathrm{C} / \mathrm{N}$ dentro da faixa de variação obtida por este autor.

Sanches, Campos e Vieira (2007) ao estudarem a fração com tamanho molecular inferior à 30KDa que faz parte das substâncias húmicas advindas da turfa coletada às margens do rio Mogi Guaçu (mesma bacia hidrográfica onde foi coletada a turfa empregada nesta pesquisa), 
encontraram valores similares, da ordem de $23,39 \%$ para o C, 3,87\% para o $\mathrm{He} 0,94 \%$ para o $\mathrm{N}$, que resultaram em uma razão atômica $\mathrm{C} / \mathrm{N}$ de 28,91 e H/C de 1,99.

\subsubsection{Composição elementar complementar (P, K, Ca, Mg e S)}

Como complemento para os dados elementares anteriores, foram determinadas também as concentrações totais de fósforo $(\mathrm{P})$, potássio $(\mathrm{K})$, cálcio $(\mathrm{Ca})$, magnésio $(\mathrm{Mg})$ e enxofre $(\mathrm{S})$.

De forma geral, foram constatadas reduzidas concentrações para todos estes elementos na turfa analisada (Tabela 17).

Tabela 17 - Composição elementar adicional das amostras de turfa estudadas, secas a $65^{\circ} \mathrm{C}$, e valores esperados para turfas (FAO, 2016), relacionando a presença de P, K, Ca, Mg e S

\begin{tabular}{ccc}
\hline \hline $\begin{array}{c}\text { Elementos } \\
\left(\mathbf{g ~ k g}^{-1}\right)\end{array}$ & $\begin{array}{c}\text { Concentração na } \\
\text { turfa estudada }\end{array}$ & $\begin{array}{c}\text { Valores esperados para } \\
\text { turfas - FAO (2016) }\end{array}$ \\
\hline \hline $\mathrm{P}$ & 0,66 & 0,1 a 5,0 \\
\hline $\mathrm{K}$ & 0,66 & 0,01 a 8,0 \\
$\mathrm{Ca}$ & 1,80 & 0,1 a 60 \\
\hline $\mathrm{Mg}$ & 1,10 & 0,1 a 15 \\
\hline $\mathrm{S}$ & 0,80 & 0,04 a 40 \\
\hline
\end{tabular}

Fonte: A autora.

As turfas, segundo FAO (2016), possuem valores esperados de P, K, Ca, Mg e S. Esses valores, também em termos de base seca a $65^{\circ} \mathrm{C}$, estão listados na Tabela 17 . Pode-se perceber que todas as medidas encontradas para a turfa estudada estão enquadradas na faixa típica de concentrações, sendo que estes valores permitem considerar o material trabalhado como dotado de reduzida presença de $\mathrm{P}, \mathrm{K}, \mathrm{Ca}, \mathrm{Mg}$ e $\mathrm{S}$.

\subsubsection{Carbono orgânico}

A turfa estudada, seca a $65^{\circ} \mathrm{C}$, exibiu um montante de carbono orgânico de $21,49 \%$. Assim, de modo geral, observa-se uma considerável proporção de carbono orgânico (superior a 20\%), como era esperado, devido ao caráter orgânico do material.

Comparando este teor de carbono orgânico com os dados encontrados pela análise elementar e exibidos na Tabela $15(\mathrm{C}=21,13 \pm 0,94 \%)$, nota-se que os valores são bem similares. Por conseguinte, a presença de carbono inorgânico na turfa estudada é mínima. 
Messias (2004) também encontrou uma situação similar. Ele utilizou o aparelho TOCV CPH Shimadzu que permite a detecção do carbono total e do carbono inorgânico na análise de uma turfa. Desse modo, por diferença, é possível o cálculo do carbono na forma orgânica. Este autor encontrou para a turfa um teor de carbono total de 34,9\% e um teor de carbono inorgânico não quantificado, permitindo o cálculo de um carbono na forma orgânica também de $34,9 \%$.

A Tabela 18 contém valores para carbono orgânico de turfas nacionais. A análise destes dados permite observar que a turfa estudada apresenta um teor de carbono orgânico intermediário, quando comparado com os dados da literatura (Tabela 18). Contudo, é válido ressaltar que neste estudo a amostra ensaiada havia sido seca em estufa e no caso de Petroni (1999), por exemplo, as amostras haviam sido secas apenas ao ar. Assim, a presença de água pode interferir de alguma forma no resultado final. Os demais autores da tabela não deixaram claro como se deu o preparo de suas amostras para este ensaio.

Tabela 18 - Valores de carbono orgânico para turfas nacionais

\begin{tabular}{cccc}
\hline \hline Origem & Tipologia & $\begin{array}{c}\text { Carbono } \\
\text { orgânico (\%) }\end{array}$ & Autor \\
\hline $\begin{array}{c}\text { Balneário Arroio do } \\
\text { Silva (SC) }\end{array}$ & $\begin{array}{c}\text { Fibrosa e } \\
\text { moderadamente } \\
\text { decomposta }\end{array}$ & $39 \pm 2 *$ & $\begin{array}{c}\text { Petroni } \\
(1999)\end{array}$ \\
\hline Resende (RJ) & Argilosa & 18,9 & $\begin{array}{c}\text { Crescêncio } \\
\text { Júnior } \\
(2004)\end{array}$ \\
\hline Mogi Guaçu (SP) & Fibrosa & 43,7 & $\begin{array}{c}\text { Messias } \\
(2004)\end{array}$ \\
\hline Mogi Guaçu (SP) & - & $39,4 \pm 0,1$ & \\
\hline Relativo a massa de turfa seca ao ar. & & & \\
\hline
\end{tabular}

Fonte: A autora.

\subsubsection{Matéria orgânica (MO)}

A Tabela 19 apresenta os valores de matéria orgânica (MO) encontrados para três réplicas da turfa estudada, lembrando que este material havia sido seco em estufa no intervalo de temperatura entre 40 a $50^{\circ} \mathrm{C}$, antes desta determinação. É possível constatar que, em média, o teor de matéria orgânica correspondeu a $520,43 \pm 2,08 \mathrm{~g} \mathrm{~kg}^{-1}$, ou seja, mais da metade da amostra total é constituída por materiais orgânicos. 
Tabela 19 - Teor de matéria orgânica (MO) obtido na amostra de turfa

\begin{tabular}{cc}
\hline \hline $\begin{array}{c}\text { Amostra } \\
\text { (Triplicata) }\end{array}$ & $\begin{array}{c}\text { MO } \\
\left(\mathbf{g ~ k g}^{-1}\right)\end{array}$ \\
\hline \hline $\mathrm{T} 1$ & 520,10 \\
\hline $\mathrm{T} 2$ & 522,66 \\
\hline $\mathrm{T} 3$ & 518,54 \\
\hline \hline Valor médio & $\mathbf{5 2 0 , 4 3}$ \\
\hline Desvio padrão & $\mathbf{2 , 0 8}$ \\
\hline
\end{tabular}

Fonte: A autora.

A matéria orgânica apresenta um elevado potencial de imobilizar metais potencialmente tóxicos, sobretudo por conter uma elevada presença de grupos carboxílicos e fenólicos. Assim, é favorecida a formação de complexos ligando as partículas de matéria orgânica com íons metálicos, similares aos microagregados formados com argilas (STEVENSON, 1982).

A determinação da matéria orgânica na turfa pode seguir diversas metodologias, diretas e indiretas. A Tabela 20 exibe valores de MO para turfas de diferentes localidades. A análise dos dados apresentados permite uma confirmação do elevado teor de matéria orgânica típico deste material. Além disso, é possível constatar que a turfa estudada nesta pesquisa apresentou uma MO que pode ser enquadrada como intermediária dentre os dados listados na Tabela 20, sendo, portanto, mais um fator positivo que potencializa a adsorção de metais tóxicos.

Tabela 20 - Valores de matéria orgânica (MO) para turfas de localidades nacionais e internacionais

\begin{tabular}{|c|c|c|c|c|}
\hline Origem & Tipologia & $\begin{array}{c}\text { MO } \\
\left(\mathrm{g} \mathrm{kg}^{-1}\right)\end{array}$ & Metodologia & Autor \\
\hline $\begin{array}{l}\text { Saquarema } \\
\text { (RJ) }\end{array}$ & $\begin{array}{c}\text { Avançada } \\
\text { humificação }\end{array}$ & 653 & Não especificado & $\begin{array}{c}\text { Dos Santos, } \\
\text { Menezes e Leal } \\
\text { Filho (2001) } \\
\end{array}$ \\
\hline $\begin{array}{c}\text { Resende } \\
(\mathrm{RJ})\end{array}$ & Argilosa & 325 & \multirow{2}{*}{$\begin{array}{l}\text { Multiplicando } \\
\text { carbono orgânico } \\
\text { por } 1,725\end{array}$} & \multirow{2}{*}{$\begin{array}{l}\text { Crescêncio Júnior } \\
\text { (2004) }\end{array}$} \\
\hline $\begin{array}{l}\text { Mogi Guaçu } \\
\text { (SP) }\end{array}$ & Fibrosa & 682 & & \\
\hline $\begin{array}{l}\text { Gavurgolu } \\
\text { (Turquia) }\end{array}$ & Herbácea & 496,4 & Não especificado & $\begin{array}{l}\text { Gündoğan, } \\
\text { Acemioğlu, e } \\
\text { Alma (2004) }\end{array}$ \\
\hline $\begin{array}{l}\text { Mogi Guaçu } \\
\text { (SP) }\end{array}$ & - & 520,8 & $\begin{array}{l}\text { A partir das curvas } \\
\text { termogravimétricas }\end{array}$ & Messias (2004) \\
\hline $\begin{array}{l}\text { Balneário } \\
\text { Arroio do } \\
\text { Silva (SC) }\end{array}$ & $\begin{array}{l}\text { Decomposta (D), } \\
\text { Fibrosa }(\mathrm{F}), \\
\text { Fibrosa extra }(\mathrm{FE})\end{array}$ & $\begin{array}{l}734 \pm 0(\mathrm{D}) \\
752 \pm 1(\mathrm{~F}) \\
971 \pm 1(\mathrm{FE})\end{array}$ & $\begin{array}{c}\mathrm{Chama} / 30 \text { min e } \\
\text { mufla a } 550 \pm \\
25^{\circ} \mathrm{C} / 2 \mathrm{~h}\end{array}$ & Petroni (2004) \\
\hline
\end{tabular}

Fonte: A autora. 


\subsubsection{Teor de cinzas $(\mathrm{Cz})$}

A Tabela 21 exibe os teores de cinza $(\mathrm{Cz})$ encontrados para a turfa, com base nos teores médios de matéria orgânica apresentados na Tabela 19. A observação dos resultados permite concluir que, complementarmente ao relatado anteriormente na análise dos valores de matéria orgânica, a turfa apresenta um considerável teor de cinza $\left(479,57 \pm 2,08 \mathrm{~g} \mathrm{~kg}^{-1}\right)$.

Tabela 21 - Teor de cinzas $(\mathrm{Cz})$ obtido para a turfa

\begin{tabular}{cc}
\hline $\begin{array}{c}\text { Amostra } \\
\text { (Triplicata) }\end{array}$ & $\begin{array}{c}\mathbf{C z} \\
\left(\mathbf{g ~ k g}^{-1}\right)\end{array}$ \\
\hline \hline $\mathrm{T} 2$ & 479,90 \\
\hline $\mathrm{T} 2$ & 477,34 \\
\hline $\mathrm{T} 3$ & 481,46 \\
\hline \hline Valor médio & $\mathbf{4 7 9 , 5 7}$ \\
\hline Desvio padrão & $\mathbf{2 , 0 8}$ \\
\hline
\end{tabular}

Fonte: A autora.

A ASTM propõe uma classificação para as turfas em função de seu conteúdo de cinza (Quadro 18), determinado de acordo com outra norma do órgão (ASTM D2974). Contudo, como ela difere apenas quanto à temperatura de calcinação (segundo a referida norma deve-se utilizar uma temperatura de $440 \pm 40^{\circ} \mathrm{C}$ e nesta pesquisa adotou-se uma temperatura de $550^{\circ} \mathrm{C}$ ), para efeito comparativo, esta classificação será empregada, destacando que ela foi elaborada com base em turfas de clima temperado. Desse modo, a turfa em questão pode ser categorizada como de alto teor de cinza (Tabela 21 e Quadro 18).

Quadro 18 - Classificação da turfa segundo o teor de cinzas

\begin{tabular}{|c|c|}
\hline \hline Classificação da Turfa & Teor de cinza \\
\hline Baixo teor de cinza & Inferior a $50 \mathrm{~g} \mathrm{~kg}^{-1}$ \\
\hline Médio teor de cinza & Entre 50 a $150 \mathrm{~g} \mathrm{~kg}^{-1}$ \\
\hline Alto teor de cinza & Superior a $150 \mathrm{~g} \mathrm{~kg}^{-1}$ \\
\hline
\end{tabular}

Fonte: Adaptado de ASTM D4427 - 13.

A Tabela 22 expõe os teores de cinza para algumas turfas nacionais. É possível constatar que como este parâmetro é uma análise diretamente associada ao teor de matéria orgânica, a 
conclusão é complementar. Assim, com base nesses valores, a turfa estudada contém presença de cinzas em uma proporção intermediária a elevada (aqui cabe lembrar das diferenças metodológicas empregadas em cada uma das determinações).

Tabela 22 - Valores de teor de cinzas $(\mathrm{Cz})$ para turfas nacionais

\begin{tabular}{|c|c|c|c|c|}
\hline Origem & Tipologia & $\begin{array}{c}\mathrm{Cz} \\
\left(\mathrm{g} \mathrm{kg}^{-1}\right)\end{array}$ & Metodologia & Autor \\
\hline $\begin{array}{l}\text { Resende } \\
\quad(\mathrm{RJ})\end{array}$ & Argilosa & 425 & \multirow{2}{*}{$\begin{array}{l}\text { Análise gravimétrica } \\
\qquad\left(1100^{\circ} \mathrm{C} / 2 \mathrm{~h}\right)\end{array}$} & \multirow{2}{*}{$\begin{array}{l}\text { Crescêncio } \\
\text { Júnior (2004) }\end{array}$} \\
\hline $\begin{array}{l}\text { Mogi Guaçu } \\
\text { (SP) }\end{array}$ & Fibrosa & 254 & & \\
\hline $\begin{array}{l}\text { São José dos } \\
\text { Campos - Vale } \\
\text { do Paraíba } \\
\text { (SP) }\end{array}$ & Hêmica & $183,1 \pm 1,3$ & $\begin{array}{c}\text { Aquecimento } \\
\text { progressivo por } \\
\text { patamares de } 50^{\circ} \mathrm{C} / 30 \\
\text { min até } 550^{\circ} \mathrm{C} / 4 \mathrm{~h}\end{array}$ & $\begin{array}{l}\text { Franchi } \\
(2004)\end{array}$ \\
\hline $\begin{array}{l}\text { Balneário } \\
\text { Arroio do } \\
\text { Silva (SC) }\end{array}$ & $\begin{array}{l}\text { Decomposta }(\mathrm{D}), \\
\text { Fibrosa }(\mathrm{F}), \\
\text { Fibrosa extra }(\mathrm{FE})\end{array}$ & $\begin{array}{c}270 \pm 8(\mathrm{D}) \\
248 \pm 1(\mathrm{~F}) \\
28 \pm 0,0(\mathrm{FE})\end{array}$ & $\begin{array}{l}\text { Chama oxidante/30 } \\
\text { min e mufla a } 800 \pm \\
25^{\circ} \mathrm{C} / 2 \mathrm{~h}(\mathrm{NBR} 8289)\end{array}$ & $\begin{array}{l}\text { Petroni } \\
\text { (2004) }\end{array}$ \\
\hline
\end{tabular}

\subsubsection{Absorção Atômica (AA)}

A Tabela 23 apresenta as concentrações naturais de $\mathrm{Pb}$ e $\mathrm{Zn}$ na turfa, resultantes do ensaio de absorção atômica e o Quadro 19 exibe os valores médios das concentrações destes mesmos metais em diferentes tipos de solos ao redor do mundo. Analisando comparativamente estes dados, é possível constatar que os teores de $\mathrm{Pb}$ e $\mathrm{Zn}$ se encontraram dentro do esperado.

Tabela 23 - Concentrações naturais de $\mathrm{Pb}$ e $\mathrm{Zn}$ obtidas na turfa empregada na presente pesquisa

\begin{tabular}{cc}
\hline $\begin{array}{c}\mathbf{P b} \\
\left(\mathbf{m g ~ k g}^{-\mathbf{1}}\right)\end{array}$ & $\begin{array}{c}\mathbf{Z n} \\
\left(\mathbf{m g ~ k g}^{-1}\right)\end{array}$ \\
\hline \hline 39,0 & 13,29 \\
\hline \multicolumn{2}{c}{ Fonte: A autora. }
\end{tabular}

Quadro 19 - Intervalo de variação média para concentrações de Pb e Zn em diferentes solos

\begin{tabular}{|c|c|}
\hline Metais & $\begin{array}{c}\text { Concentração } \\
\left(\mathbf{m g ~ k g}^{-1}\right)\end{array}$ \\
\hline \hline $\mathrm{Pb}$ & 3 a 90 \\
\hline $\mathrm{Zn}$ & 60 a 89 \\
\hline \hline
\end{tabular}

Fonte: Kabata-Pendias (2011). 
Shotyk (1996) também estudou a composição de turfas, porém extraídas de turfeiras suíças (clima temperado) e encontrou valores de $\mathrm{Pb}$ variando nas proximidades de 5 até $85 \mathrm{mg}$ $\mathrm{kg}^{-1}$ e de $\mathrm{Zn}$, na faixa de 5 a $80 \mathrm{mg} \mathrm{kg}^{-1}$. Silva et al. (2009) avaliaram a composição de turfeiras localizadas na Serra do Espinhaço Meridional - MG (turfas de clima tropical), encontrando concentrações de $\mathrm{Pb}$ de 2 a $60 \mathrm{mg} \mathrm{kg}{ }^{-1}$ e de $\mathrm{Zn}$ de 4 a $53 \mathrm{mg} \mathrm{kg}^{-1}$. Todos estes valores se enquadram no intervalo típico para solos em geral (Quadro 19) e permitem classificar a turfa estudada como dotada de concentrações medianas a baixas de $\mathrm{Pb}$ e $\mathrm{Zn}$.

\subsubsection{Capacidade de troca catiônica (CTC) e superfície específica (SE)}

A Tabela 24 apresenta os valores obtidos através do ensaio de adsorção de azul de metileno para a capacidade de troca catiônica (CTC) e a superfície específica (SE) das amostras de turfa. Os resultados encontrados foram de 10,72 $\pm 0,74 \mathrm{cmol}_{\mathrm{c}} \mathrm{kg}^{-1}$ para a CTC e 83,91 $\pm 5,80$ $\mathrm{m}^{2} \mathrm{~g}^{-1}$ para a SE. Segundo Sparks (1995a), a matéria orgânica do solo revela uma CTC da ordem de 150 a $300 \mathrm{cmol}_{\mathrm{c}} \mathrm{kg}^{-1}$ e uma elevada superfície específica, comumente compreendida no intervalo de 800 a $900 \mathrm{~m}^{2} \mathrm{~g}^{-1}$.

Tabela 24 - Capacidade de troca catiônica e superfície específica para as amostras de turfa (Ensaio do azul de metileno)

\begin{tabular}{|c|c|c|}
\hline $\begin{array}{c}\text { Amostra } \\
\text { (Triplicata) }\end{array}$ & $\begin{array}{c}\text { CTC } \\
\left(\mathrm{cmol}_{\mathrm{c}} \mathrm{kg}^{-1}\right)\end{array}$ & $\begin{array}{c}\mathrm{SE} \\
\left(\mathrm{m}^{2} \mathrm{~g}^{-1}\right)\end{array}$ \\
\hline $\mathrm{T} 1$ & 11,54 & 90,32 \\
\hline $\mathrm{T} 2$ & 10,10 & 79,03 \\
\hline $\mathrm{T} 3$ & 10,52 & 82,38 \\
\hline Valor médio & 10,72 & 83,91 \\
\hline Desvio padrão & 0,74 & 5,80 \\
\hline
\end{tabular}

Fonte: A autora.

Sendo assim, como a turfa em questão exibiu um considerável teor de matéria orgânica, esperava-se, como consequência, valores superiores de CTC e SE. Desta maneira, foi realizada a CTC segundo outra metodologia: a titulometria. Nesse caso, a CTC obtida foi de 91,00 $\mathrm{cmol}_{\mathrm{c}}$ $\mathrm{kg}^{-1}$, valor este mais condizente com o esperado.

A CTC de materiais sorventes, como a turfa, refletem contribuições variáveis da matéria orgânica (LANGMUIR, 1997) que, por sua vez, revela uma carga líquida negativa, culminando em uma CTC bem superior a CTA (ALLEONI; MELLO; ROCHA, 2016). Portanto, esta é uma 
característica de extrema importância na retenção de metais (LANGMUIR, 1997). Assim, a CTC encontrada para a turfa possivelmente se deve, em grande parte, a forte presença húmica e indica uso favorável para adsorção.

A Tabela 25 expõe valores de CTC respectivos a turfas originadas de localidades nacionais e internacionais. Promovendo uma análise comparativa, é possível notar que a CTC encontrada para a turfa pesquisada é consideravelmente elevada em comparação aos dados literários apresentados.

Tabela 25 - Valores de CTC para turfas de diversas localidades nacionais e internacionais

\begin{tabular}{|c|c|c|c|c|}
\hline Origem & Tipologia & $\begin{array}{c}\text { CTC } \\
\left(\mathrm{cmol}_{\mathrm{c} \mathrm{kg}}{ }^{-1}\right)\end{array}$ & Metodologia & Autor \\
\hline $\begin{array}{l}\text { Saquarema } \\
\text { (RJ) }\end{array}$ & $\begin{array}{c}\text { Avançada } \\
\text { humificação }\end{array}$ & 53,7 & $\begin{array}{c}\text { Soma das bases e } \\
\text { ácidos trocáveis } \\
\text { (EMBRAPA, 1979) }\end{array}$ & $\begin{array}{c}\text { Dos Santos, } \\
\text { Menezes e Leal } \\
\text { Filho (2001) } \\
\end{array}$ \\
\hline $\begin{array}{l}\text { Resende } \\
\text { (RJ) }\end{array}$ & Argilosa & 67 & \multirow{2}{*}{$\begin{array}{l}\text { Método adaptado pelo } \\
\text { IPEN de Gillman } \\
\text { (1979) que utiliza } \\
\mathrm{BaCl}_{2}\end{array}$} & \multirow{2}{*}{$\begin{array}{l}\text { Crescêncio } \\
\text { Júnior (2004) }\end{array}$} \\
\hline $\begin{array}{l}\text { Mogi Guaçu } \\
\text { (SP) }\end{array}$ & Fibrosa & 71 & & \\
\hline $\begin{array}{l}\text { São José dos } \\
\text { Campos - Vale } \\
\text { do Paraíba } \\
\text { (SP) }\end{array}$ & Hêmica & 34,89 & $\begin{array}{l}\text { Metodologia da } \\
\text { ESALQ - USP }\end{array}$ & Franchi (2004) \\
\hline $\begin{array}{l}\text { Gavurgolu } \\
\text { (Turquia) }\end{array}$ & Herbácea & 97,10 & $\begin{array}{l}\text { Não especificado, mas } \\
\text { aparentemente soma } \\
\text { de bases e ácidos } \\
\text { trocáveis }\end{array}$ & $\begin{array}{l}\text { Gündoğan, } \\
\text { Acemioğlu e } \\
\text { Alma (2004) }\end{array}$ \\
\hline $\begin{array}{l}\text { Mogi Guaçu } \\
\text { (SP) }\end{array}$ & - & $4,47 \pm 0,13$ & $\begin{array}{l}\text { Soma das bases } \\
\text { trocáveis }\left(\mathrm{Na}^{+}, \mathrm{K}^{+},\right. \\
\left.\mathrm{Ca}^{2+} \text { e } \mathrm{Mg}^{2+}\right) \text { mais } \\
\text { acidez trocável }\end{array}$ & Messias (2004) \\
\hline $\begin{array}{c}\text { Balneário } \\
\text { Arroio do Silva } \\
\text { (SC) } \\
\end{array}$ & $\begin{array}{c}\text { Decomposta } \\
\text { a fibrosa } \\
\text { extra } \\
\end{array}$ & $135-181,9$ & $\begin{array}{l}\text { Saturação com } \mathrm{Ba}^{2+}, \\
\text { troca com } \mathrm{Mg}^{2+}, \\
\text { titulação com EDTA }\end{array}$ & Petroni (2004) \\
\hline Sul da Suécia & $\begin{array}{l}\text { Fracamente } \\
\text { decomposta }\end{array}$ & 30,9 & Não especificado & $\begin{array}{c}\text { Kalmykova, } \\
\text { Strömvall e } \\
\text { Steenari (2008) }\end{array}$ \\
\hline Malásia & - & $45-50$ & $\begin{array}{l}\text { Método do acetato de } \\
\text { amônio em pH 7,0 } \\
\text { (Thomas, 1982) }\end{array}$ & $\begin{array}{l}\text { Abat et al. } \\
\text { (2012) }\end{array}$ \\
\hline
\end{tabular}

Fonte: A autora. 


\subsubsection{Difratometria de Raios-X (DRX)}

Os resultados obtidos na Difração de Raios-X revelam a presença marcante de quartzo na amostra total e na porção mineral da turfa (Figura 81).

Figura 81 - DRX da turfa. A) Amostra total; B) Porção mineral
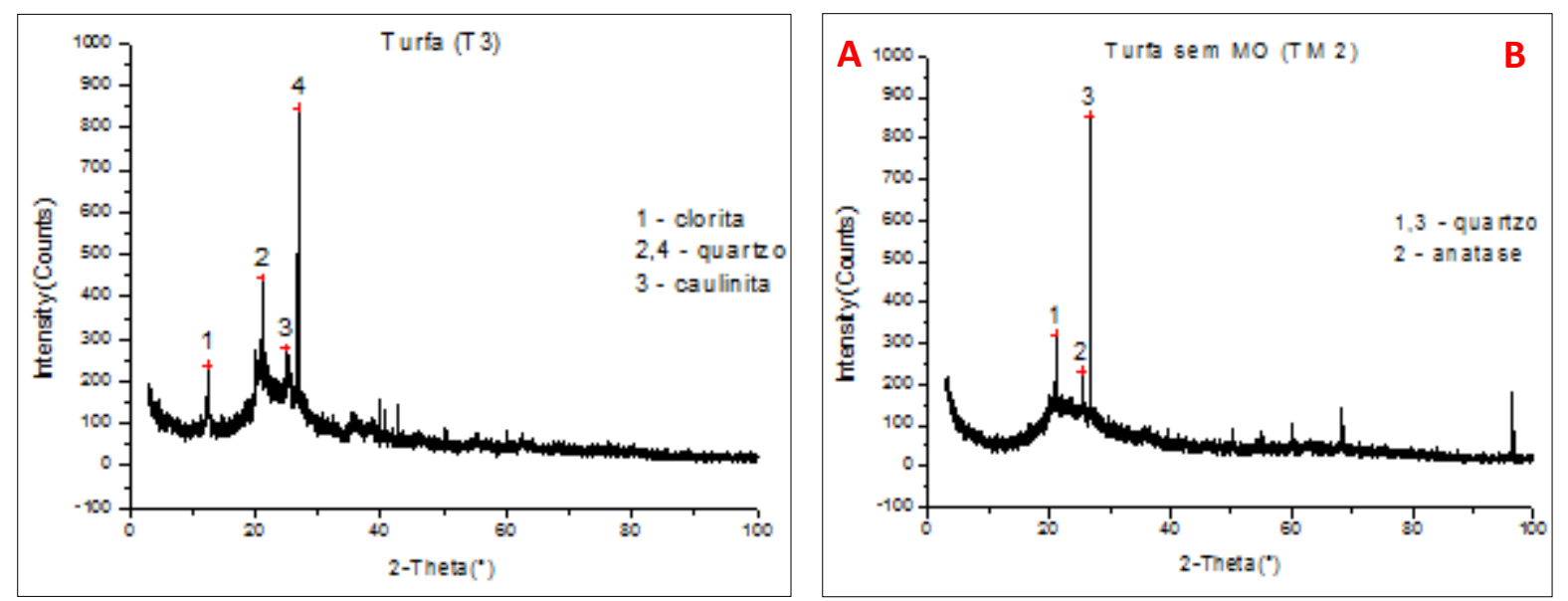

Fonte: A autora.

\subsubsection{Fluorescência de Raios-X (FRX)}

A Tabela 26 contém os resultados do ensaio de Fluorescência de Raios-X para as amostras de turfa total, sendo que os valores apresentados foram normalizados a $100 \%$. É possível constatar que sobressaíram as concentrações dos óxidos $\mathrm{SiO}_{2}, \mathrm{Al}_{2} \mathrm{O}_{3}, \mathrm{Fe}_{2} \mathrm{O}_{3}$ e $\mathrm{TiO}_{2}$, que juntos perfizeram 50,44\%. Nesta análise, alguns elementos não foram detectados, não necessariamente por não existirem nas amostras, mas por não estarem em rotina no equipamento usado $(\mathrm{Cd}, \mathrm{Pb}, \mathrm{C}$, entre outros). 
Tabela 26 - Análise química da turfa por Fluorescência de Raios-X

\begin{tabular}{|c|c|c|c|c|c|}
\hline $\begin{array}{c}\text { Óxidos } \\
(\%)\end{array}$ & $\mathbf{T 1}$ & $\mathbf{T} 2$ & T3 & Média & $\begin{array}{l}\text { Desvio } \\
\text { Padrão }\end{array}$ \\
\hline $\mathrm{SiO}_{2}$ & 31,7 & 34,2 & 35,8 & 33,900 & 2,066 \\
\hline $\mathrm{Al}_{2} \mathrm{O}_{3}$ & 12,3 & 12,6 & 12 & 12,300 & 0,300 \\
\hline $\mathrm{Fe}_{2} \mathrm{O}_{3}$ & 2,73 & 2,07 & 1,79 & 2,197 & 0,483 \\
\hline $\mathrm{TiO}_{2}$ & 2,44 & 2,02 & 1,67 & 2,043 & 0,386 \\
\hline $\mathrm{P}_{2} \mathrm{O}_{5}$ & 0,291 & 0,289 & 0,27 & 0,283 & 0,012 \\
\hline $\mathrm{CaO}$ & 0,32 & 0,27 & 0,235 & 0,276 & 0,045 \\
\hline $\mathrm{SO}_{3}$ & 0,264 & 0,238 & 0,216 & 0,239 & 0,024 \\
\hline $\mathrm{MgO}$ & 0,222 & 0,243 & 0,246 & 0,237 & 0,013 \\
\hline $\mathrm{K}_{2} \mathrm{O}$ & 0,212 & 0,196 & 0,132 & 0,180 & 0,042 \\
\hline $\mathrm{V}_{2} \mathrm{O}_{5}$ & $<0,001^{*}$ & 0,069 & 0,056 & 0,042 & 0,036 \\
\hline $\mathrm{Cr}_{2} \mathrm{O}_{3}$ & 0,068 & 0,051 & 0,051 & 0,057 & 0,010 \\
\hline $\mathrm{Cl}$ & 0,06 & 0,04 & 0,04 & 0,047 & 0,012 \\
\hline $\mathrm{MnO}$ & 0,034 & 0,03 & 0,022 & 0,029 & 0,006 \\
\hline $\mathrm{CuO}$ & 0,038 & 0,027 & 0,022 & 0,029 & 0,008 \\
\hline $\mathrm{CeO}_{2}$ & 0,029 & $<0,001 *$ & $<0,001 *$ & 0,010 & 0,016 \\
\hline $\mathrm{ZrO}_{2}$ & 0,02 & 0,025 & 0,02 & 0,022 & 0,003 \\
\hline $\mathrm{NiO}$ & 0,01 & 0,006 & 0,005 & 0,007 & 0,003 \\
\hline $\mathrm{ZnO}$ & 0,009 & 0,007 & 0,006 & 0,007 & 0,002 \\
\hline $\mathrm{Y}_{2} \mathrm{O}_{3}$ & $<0,001^{*}$ & 0,008 & 0,006 & 0,005 & 0,004 \\
\hline $\mathrm{SrO}$ & $<0,001^{*}$ & 0,003 & 0,002 & 0,002 & 0,001 \\
\hline $\mathrm{Ga}_{2} \mathrm{O}_{3}$ & $<0,001^{*}$ & 0,002 & $<0,001 *$ & 0,001 & 0,001 \\
\hline $\mathrm{Br}$ & $<0,001^{*}$ & 0,002 & 0,001 & 0,001 & 0,001 \\
\hline $\mathrm{Nb}_{2} \mathrm{O}_{5}$ & $<0,001^{*}$ & $<0,001^{*}$ & 0,00 & 0,001 & 0,001 \\
\hline $\mathrm{PF}^{* * *}$ & 49,3 & 47,6 & 47,4 & 48,1 & 1,0 \\
\hline echamento & 100,058 & 99,998 & 99,994 & 100,017 & 0,036 \\
\hline
\end{tabular}

* Nos cálculos de média, desvio padrão e fechamento foi considerado igual a 0,001;

** PF: Perda ao fogo a $1020^{\circ} \mathrm{C}$ por 2 horas.

Fonte: A autora.

Além disso, na fluorescência foram detectadas pequenas concentrações de óxidos associados aos minerais carbonatados, como a presença de apenas 0,276 $\pm 0,045 \%$ de $\mathrm{CaO}$. Conforme relatado anteriormente, a turfa apresentou um teor mínimo, se não desprezível, de 
carbono inorgânico que está justamente comumente relacionado a minerais carbonatados. Assim, se os teores de minerais carbonatados são mínimos, é plausível que a presença de carbono inorgânico também seja.

\subsubsection{Microscopia Eletrônica de Varredura/Espectroscopia de Energia Dispersiva por}

\section{Raios-X (MEV/EDS)}

Inicialmente, foram analisadas as amostras na forma de pastilha através da Espectrometria de Dispersão de Energia de Raios-X aplicada a áreas, visando-se ter uma ideia generalizada da composição elementar total presente, tanto na amostra total (matéria orgânica e porção mineral) como só na porção mineral (resultante do processo de combustão da matéria orgânica).

A Tabela 27 apresenta os dados para as três áreas observadas na pastilha sem matéria orgânica e na pastilha da amostra com matéria orgânica. Pode-se observar que em ambos os casos, há predominância dos elementos carbono e oxigênio, que perfazem juntos, em média, $91,40 \%$ da amostra total e $64,03 \%$ da porção mineral da turfa. Essa redução se deve principalmente à diminuição no teor de $\mathrm{C}$, como era esperado, já que a matéria orgânica é uma reserva de carbono que, nesse caso, encontra-se ausente. Já o oxigênio manteve-se praticamente constante, com uma ligeira redução. Ademais, como compensação à drástica redução de $\mathrm{C}$ na amostra sem matéria orgânica, outros elementos ganharam destaque, sobretudo Si (18,02 \pm $1,40 \%), \mathrm{Al}(12,72 \pm 1,09 \%)$ e Fe $(2,84 \pm 0,64 \%)$. Esses elementos podem ser considerados como indicativos da presença de quartzo e de argilominerais, detectados também através da Difratometria de Raios-X e da Fluorescência de Raios-X. 
Tabela 27 - Composição elementar da porção mineral e da amostra total da turfa estudada

\begin{tabular}{|c|c|c|c|c|c|c|}
\hline$\%$ & $\begin{array}{l}\text { Amostra } \\
\text { ensaiada }\end{array}$ & Área 1 & Área 2 & Área 3 & Média & Desvio Padrão \\
\hline \multirow{2}{*}{$\mathbf{C}$} & Sem MO & 16,92 & 16,24 & 16,96 & 16,71 & 0,40 \\
\hline & Com MO & 41,97 & 43,51 & 43,10 & 42,86 & 0,80 \\
\hline \multirow{2}{*}{$\mathbf{O}$} & Sem MO & 50,36 & 44,34 & 47,27 & 47,32 & 3,01 \\
\hline & Com MO & 48,47 & 45,86 & 51,28 & 48,54 & 2,71 \\
\hline \multirow{2}{*}{ Mg } & Sem MO & 0,27 & 0,15 & 0,22 & 0,21 & 0,06 \\
\hline & Com MO & 0,02 & 0,05 & 0,03 & 0,03 & 0,02 \\
\hline \multirow{2}{*}{ Al } & Sem MO & 12,07 & 13,98 & 12,12 & 12,72 & 1,09 \\
\hline & Com MO & 3,52 & 3,93 & 2,49 & 3,31 & 0,74 \\
\hline \multirow{2}{*}{$\mathbf{S i}$} & Sem MO & 16,53 & 19,31 & 18,23 & 18,02 & 1,40 \\
\hline & Com MO & 5,22 & 5,76 & 2,90 & 4,63 & 1,52 \\
\hline \multirow{2}{*}{$\mathbf{K}$} & Sem MO & 0,20 & 0,28 & 0,25 & 0,24 & 0,04 \\
\hline & Com MO & 0,00 & 0,06 & 0,00 & 0,02 & 0,03 \\
\hline \multirow{2}{*}{$\mathbf{C a}$} & Sem MO & 0,26 & 0,45 & 0,37 & 0,36 & 0,10 \\
\hline & Com MO & 0,08 & 0,09 & 0,02 & 0,06 & 0,04 \\
\hline \multirow{2}{*}{$\mathbf{T i}$} & Sem MO & 1,25 & 1,91 & 1,52 & 1,56 & 0,33 \\
\hline & Com MO & 0,28 & 0,26 & 0,06 & 0,20 & 0,12 \\
\hline \multirow{2}{*}{$\mathbf{F e}$} & Sem MO & 2,13 & 3,36 & 3,04 & 2,84 & 0,64 \\
\hline & Com MO & 0,41 & 0,50 & 0,12 & 0,34 & 0,20 \\
\hline
\end{tabular}

Fonte: A autora.

Os teores de $\mathrm{Al}, \mathrm{Mg}, \mathrm{Ca}$ e $\mathrm{K}$ determinados por EDS na porção mineral (Tabela 27) são similares aos que foram determinados pelo método de FRX na amostra total (Tabela 26), indicando que esses elementos estão diretamente ligados com a porção mineral da turfa. Contudo, o teor de Si detectado na amostra total por FRX (Tabela 26) foi maior que o determinado por EDS na porção mineral (Tabela 27).

Em seguida, procedeu-se a análise das partículas da turfa (grãos soltos nos stubs) sem e com matéria orgânica no MEV/EDS e determinou-se a composição elementar pontual, também por espectrometria, apenas de pontos com potencial de apresentarem características de interesse. 
A Figura 82 exibe uma imagem compartilhada (com detector retro espalhado e com detector secundário) da amostra sem matéria orgânica. Observa-se que, no primeiro caso, há uma maior facilidade na visualização e detecção de minerais, enquanto, no segundo, é favorecido o estudo morfológico. Sendo assim, optou-se pela continuação da análise com o detector retro espalhado.

Figura 82 - Fotomicrografia em Microscopia Eletrônica de Varredura da porção mineral da turfa. À esquerda, detector retro espalhado e à direita detector secundário

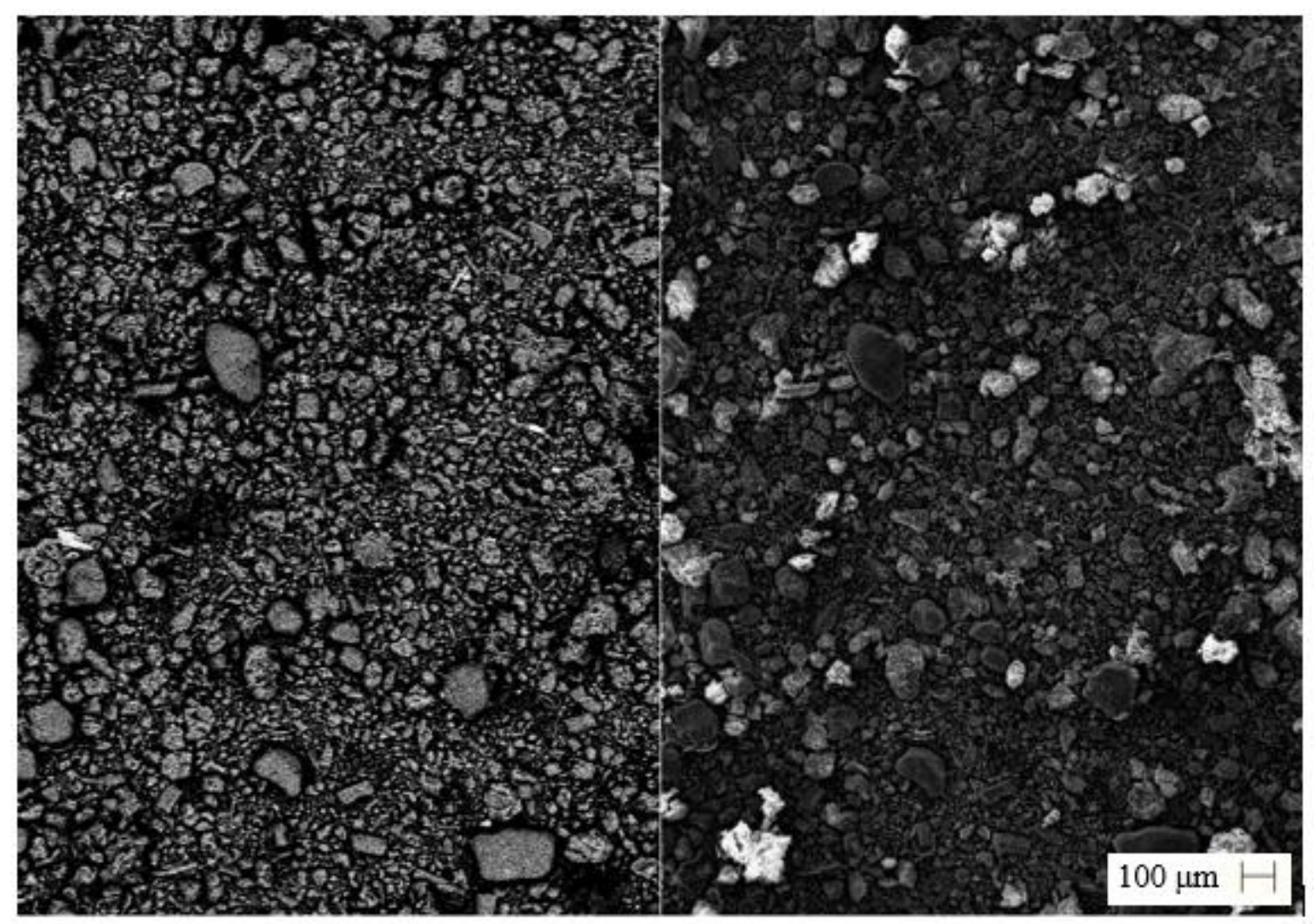

Fonte: A autora. 
A Figura 83 exibe uma fotomicrografia da porção mineral da turfa. No ponto 1 destacouse a presença de oxigênio $(33,92 \%)$ e silício $(66,08 \%)$, possivelmente tratando-se de um grão de quartzo. No ponto 2 , além de oxigênio (50,84\%), estavam presentes silício $(38,78 \%)$ e alumínio $(4,82 \%)$, a princípio indicando tratar-se de um argilomineral, com cobre $(2,75 \%)$ associado. No ponto 3, se destacou a presença de titânio $(18,47 \%)$, alumínio $(30,20)$, oxigênio $(25,43 \%)$ e silício $(15,88 \%)$. No ponto 4 , similarmente, apareceram silício $(28,60 \%)$, alumínio $(24,92 \%)$, ferro $(7,58 \%)$ e cobre $(7,03 \%)$.

Figura 83 - Fotomicrografia em MEV da porção mineral da turfa com os respectivos espectros EDS

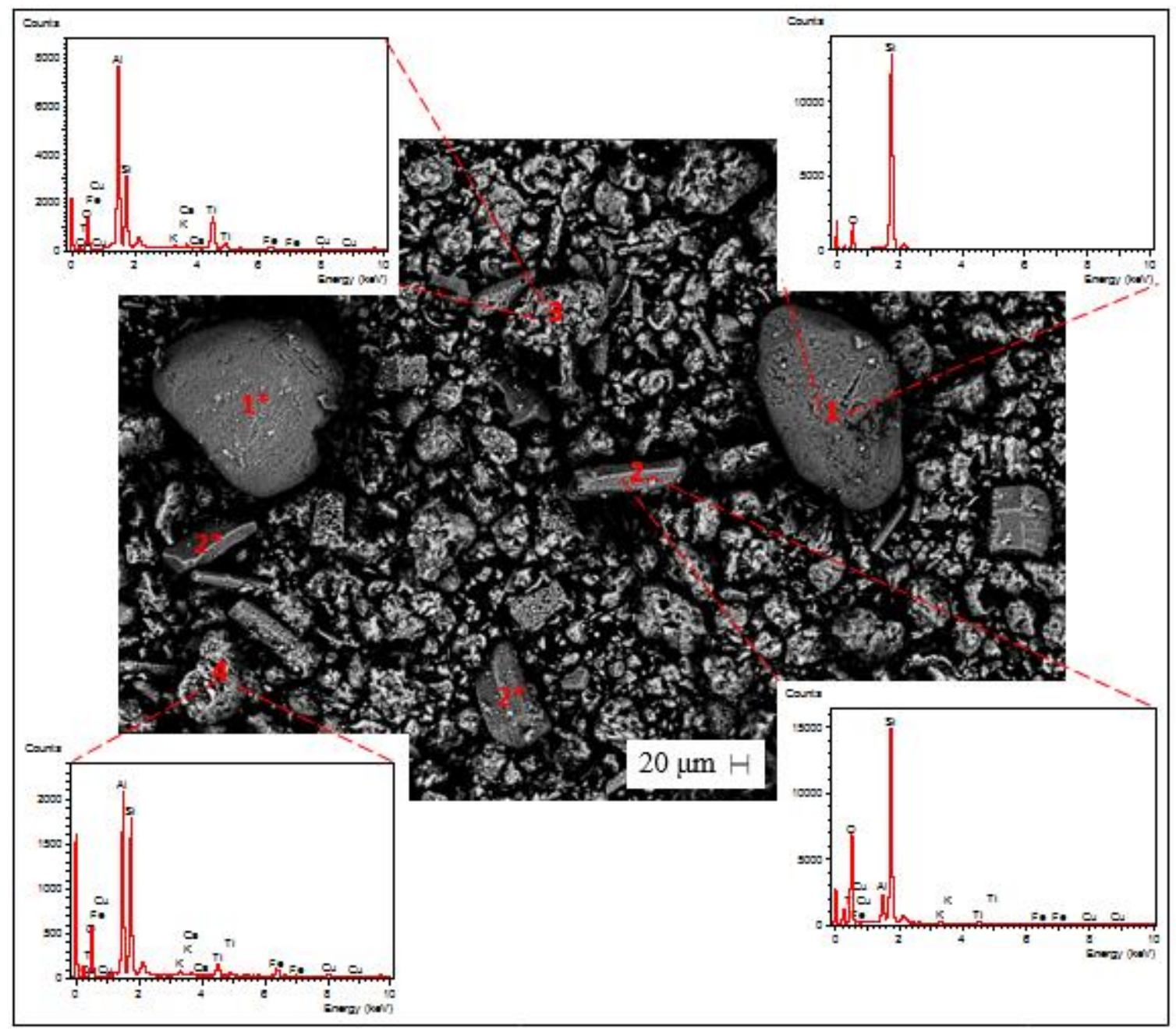

Na figura: Os pontos marcados com um número seguido de um asterisco, apresentam considerável similaridade com os pontos marcados unicamente pelo mesmo número.

Fonte: A autora. 
A Figura 84 traz outra fotomicrografia da parcela mineral da turfa. Nos pontos 1 e 2 se destacou a presença de ferro e titânio, que apareceram em proporções inversas. Em 1, a composição elementar do ferro foi de $57,51 \%$, enquanto a do titânio foi de 22,96\%. Já em 2, a presença de ferro caiu para 18,09\% e o teor de titânio se elevou para 45,07\%. O aparecimento do ponto 3 contendo 2,48\% de chumbo, 1,42\% de estanho e 63,13\% de cobre, pode indicar, a contaminação do stub usado, sendo que nesse stub foi colocado (anteriormente) rejeitos de mineração contendo os elementos acima mencionados. No ponto 4, por sua vez, apareceram, novamente oxigênio (35,92\%), silício $(23,98 \%)$ e alumínio $(21,48 \%)$, seguidos da presença, decrescente de ferro $(6,61 \%)$, titânio $(5,12 \%)$ e cobre $(4,99 \%)$.

Figura 84 - Fotomicrografia em MEV da porção mineral da turfa com os respectivos espectros EDS

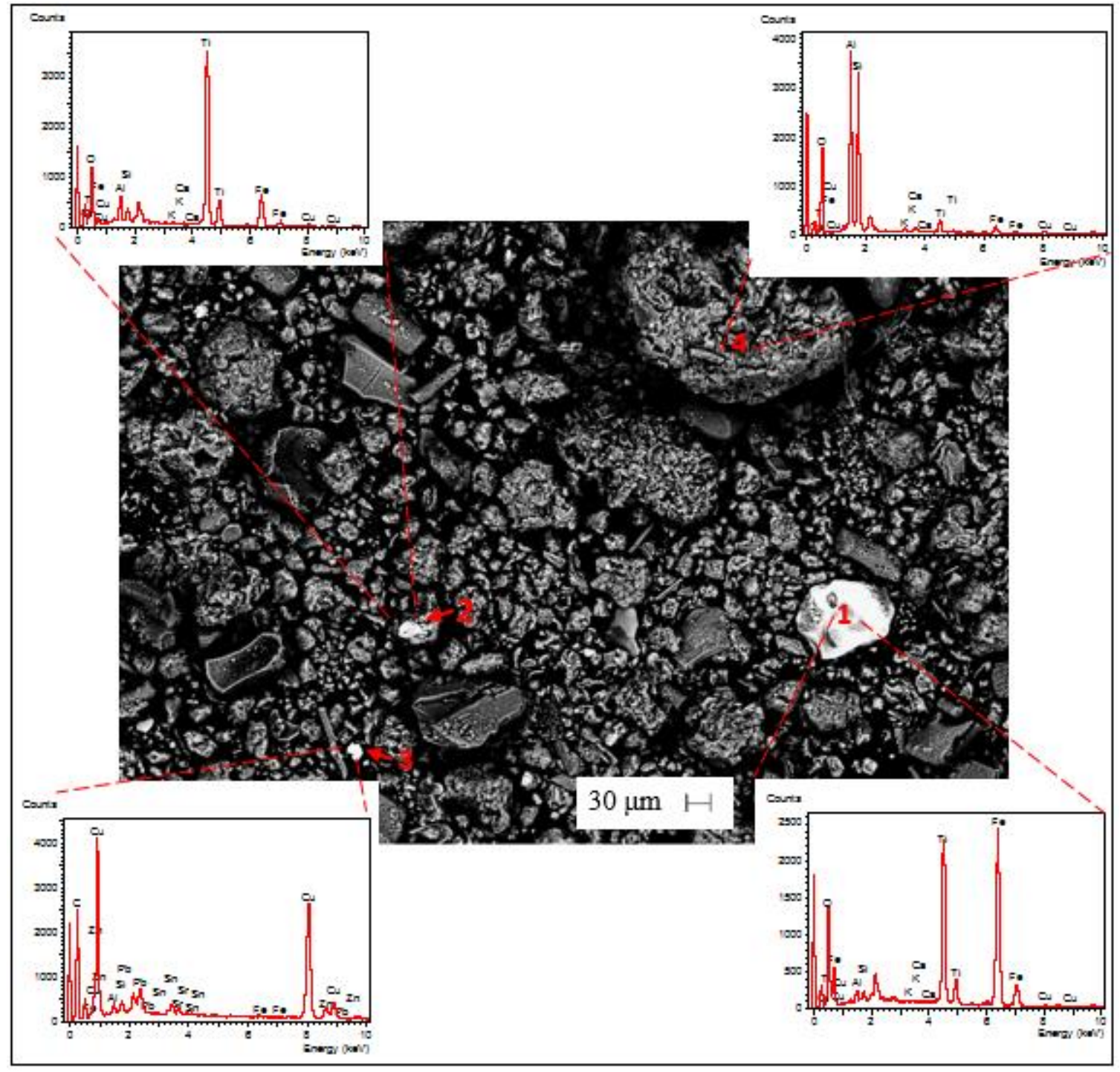

Fonte: A autora. 
A Figura 85 exibe uma imagem compartilhada (com detector retro espalhado e com detector secundário) da amostra de turfa contendo matéria orgânica. Novamente, optou-se pela continuação da análise com o detector retro espalhado.

Figura 85 - Fotomicrografia em Microscopia Eletrônica de Varredura da amostra total da turfa. À esquerda, detector retro espalhado e à direita detector secundário

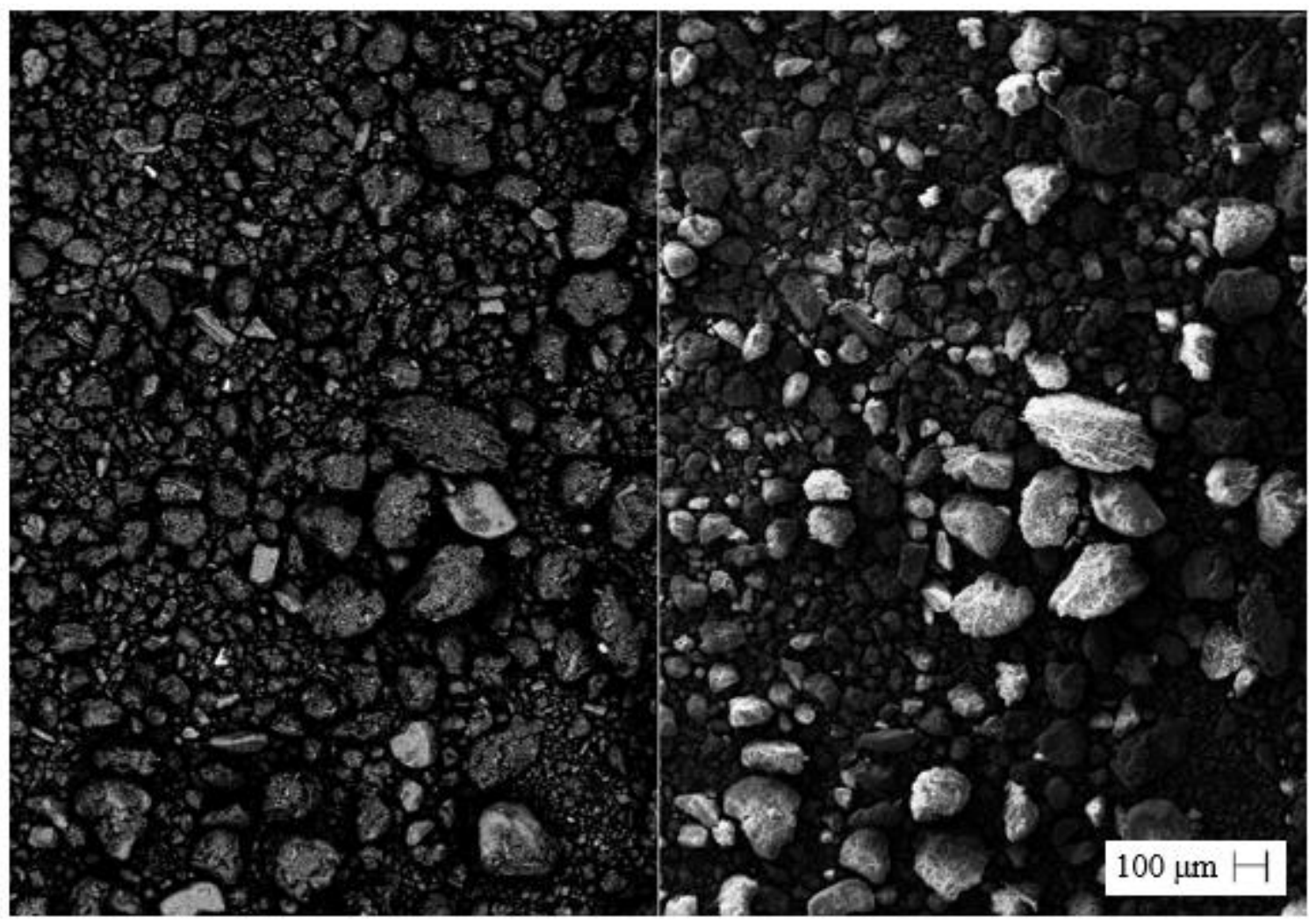

Fonte: A autora. 
A Figura 86 exibe, com maior detalhe, uma partícula da amostra total da turfa. Pode-se observar que, provavelmente trata-se de um grão mineral recoberto por matéria orgânica. Justamente essa cobertura é responsável por fazer com que essa partícula apresente certa esfericidade e arredondamento.

Figura 86 - Fotomicrografia em MEV, destacando um grão da turfa

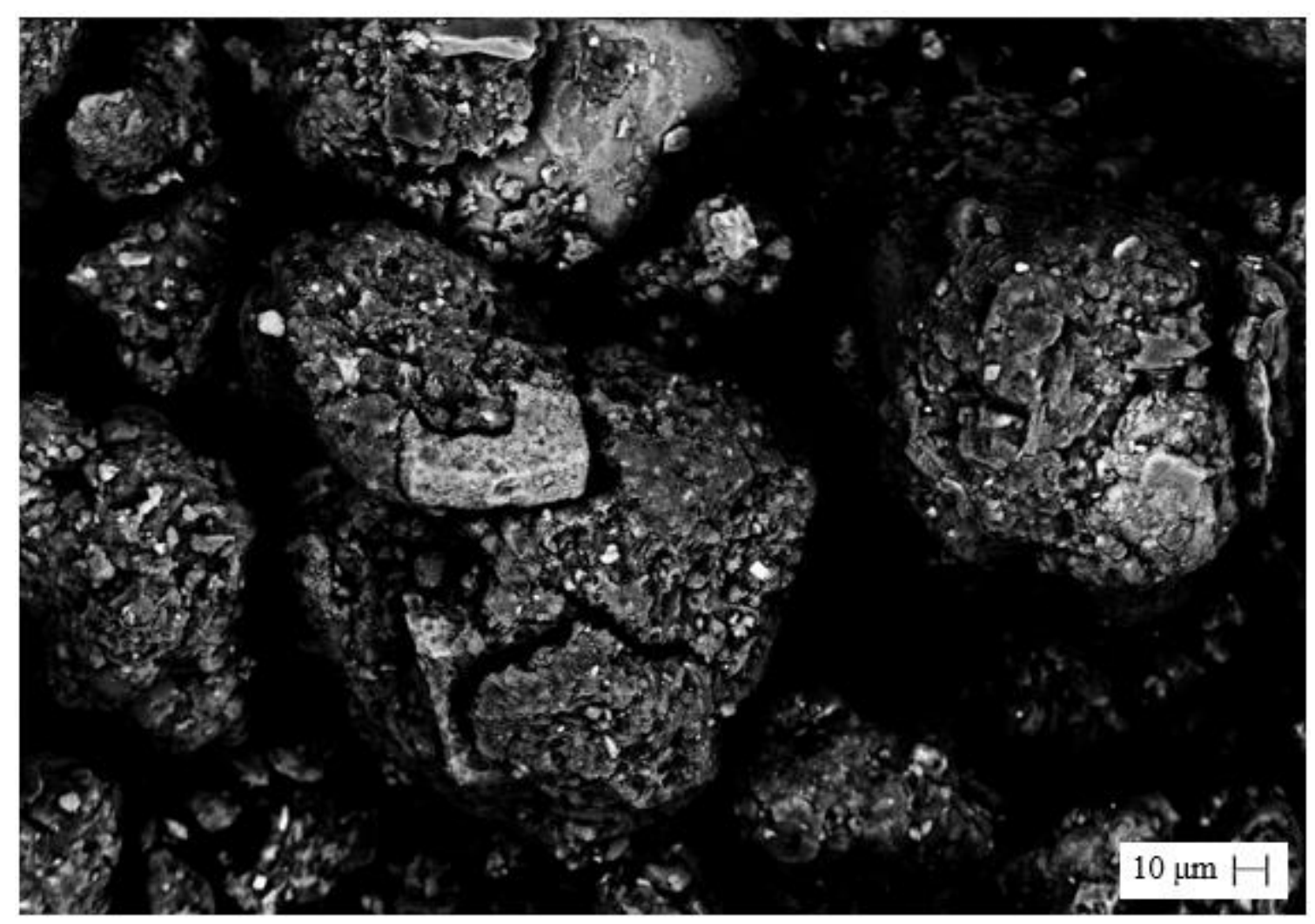

Fonte: A autora. 
A Figura 87 exibe uma fotomicrografia da amostra total da turfa. No ponto 1 estavam presentes os elementos ferro $(66,52 \%)$ e oxigênio $(19,43)$, seguidos de silício $(6,62 \%)$ e alumínio (6,18), evidenciando uma partícula mineral da turfa (possivelmente um aluminossilicato). Já na porção escura desse mesmo grão, ponto 2, se destacaram o carbono $(48,35 \%)$ e o oxigênio $(28,51 \%)$, atestando para o caráter orgânico do fragmento. Portanto, trata-se de um grão onde matéria orgânica e fração mineral se encontram agregados. A análise visual permite que se confirme esta constatação. No ponto 3, novamente apareceram carbono $(44,38 \%)$ e oxigênio $(33,18 \%)$, em maior concentração, e silício $(10,44 \%)$ e alumínio $(7,65 \%)$, em menor. Assim, trata-se de outro grão combinado.

Figura 87 - Fotomicrografia em MEV da turfa (total) com os respectivos espectros EDS

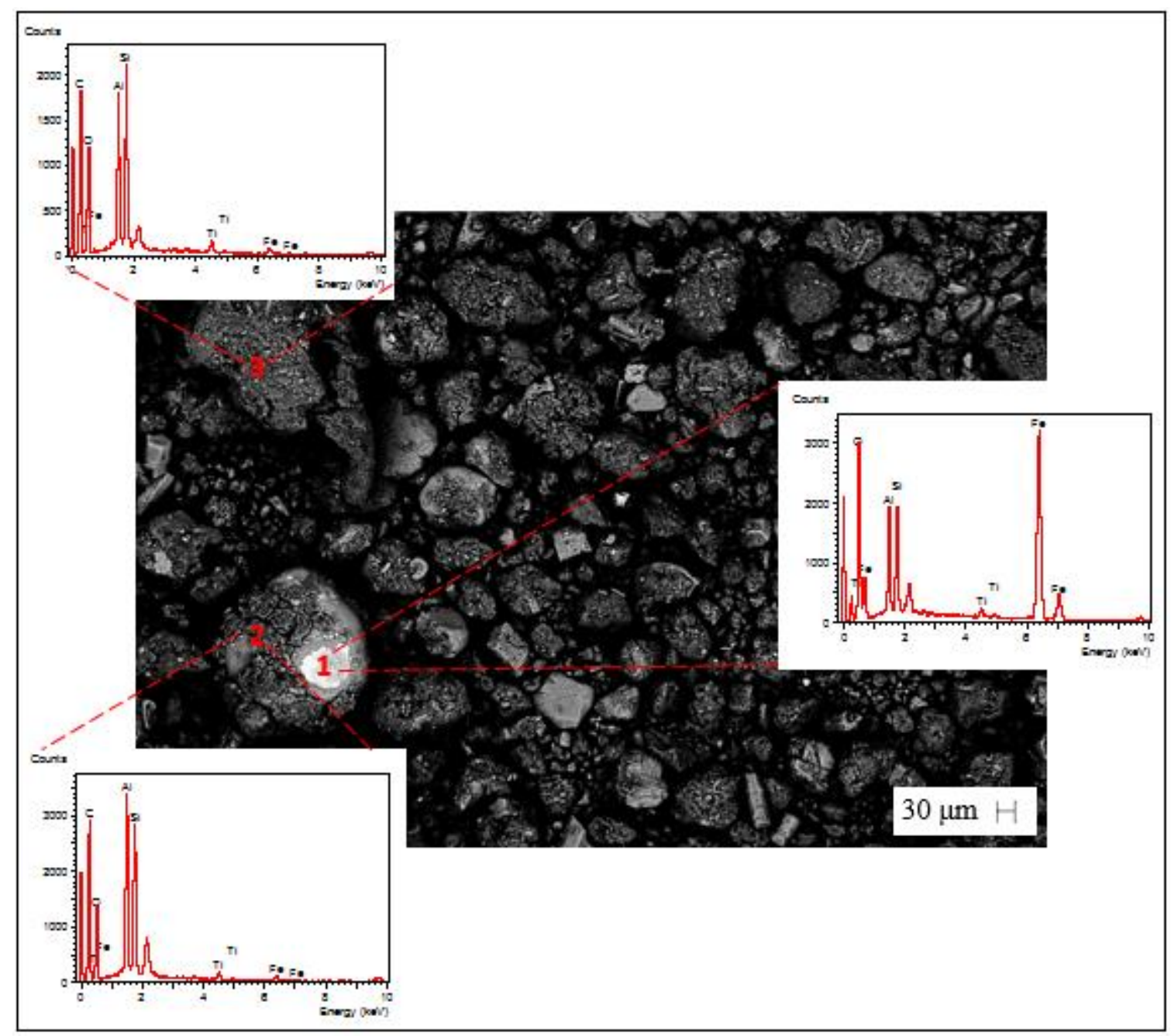

Fonte: A autora. 
Por fim, a Figura 88 revela uma segunda fotomicrografia da amostra total da turfa. No ponto 1 , houve destaque de titânio $(42,52 \%)$ e ferro $(29,85 \%)$ e em 2 , carbono $(53,84 \%)$, oxigênio $(29,57)$, silício $(7,40 \%)$ e alumínio $(6,00 \%)$. Assim, é evidenciado novamente um agregado de porções minerais e orgânicas.

Figura 88 - Fotomicrografia em MEV da turfa (total) com os respectivos espectros EDS

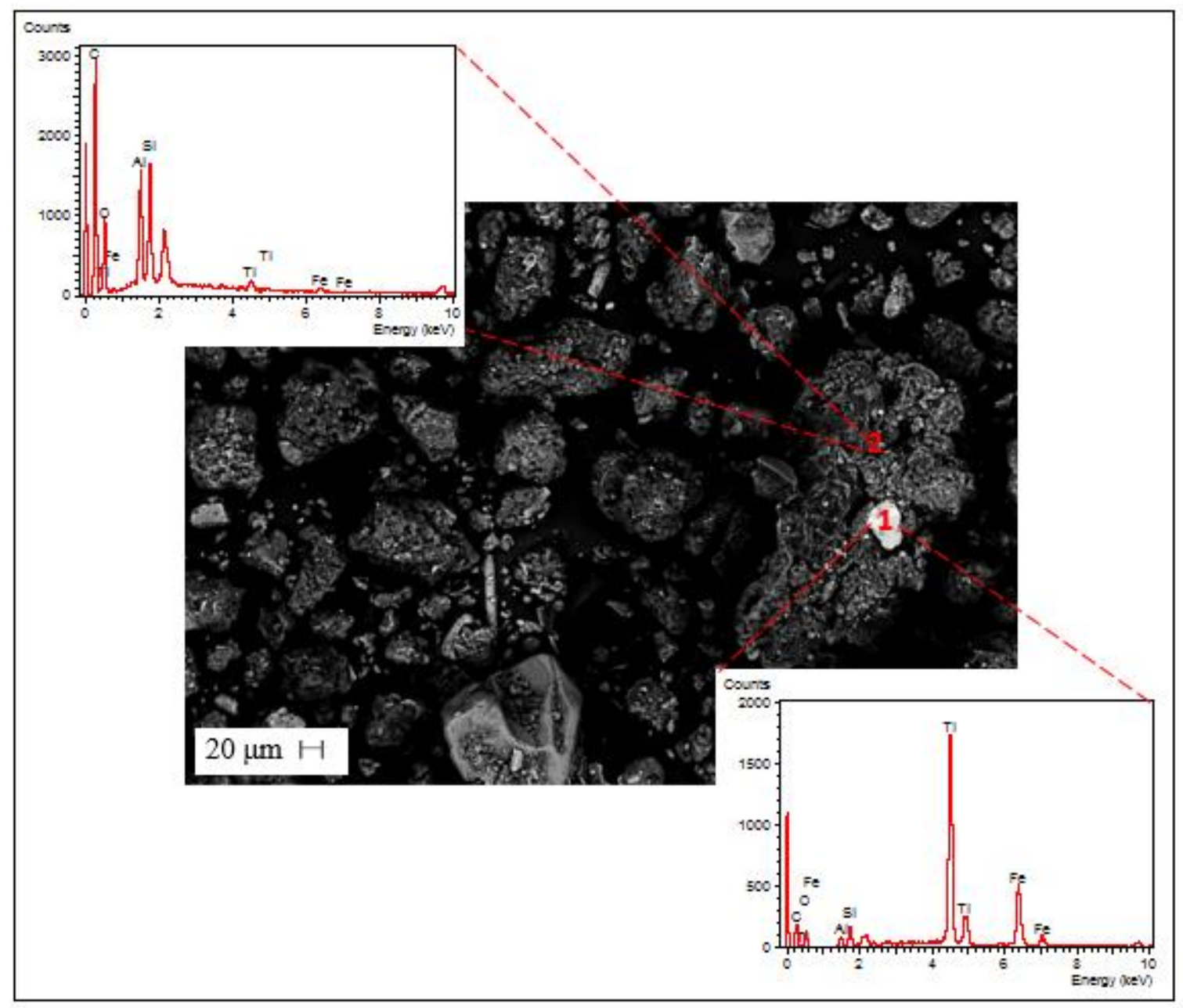

Fonte: A autora.

Comparando as fotomicrografias obtidas nesta pesquisa com Franchi (2004), pode-se perceber que a turfa estudada pelo referido autor apresentava uma maior heterogeneidade. 


\subsubsection{Compostos orgânicos}

\subsubsection{Análise granulométrica - Peneiramento}

Para os compostos orgânicos foi realizado apenas o peneiramento a seco das amostras secas em estufa, em virtude da reduzida presença de partículas contidas no intervalo de diâmetro das frações finas, identificadas através de análise tátil visual.

De acordo com a ABNT NBR 6502 - 95, de modo geral, a fração de finos inclui as partículas de solo passantes na peneira ${ }^{\circ} 200$, ou seja, aquelas com dimensões inferiores a 0,075 $\mathrm{mm}$. Na prática, por esta ser uma peneira frequentemente utilizada nos laboratórios, ela é comumente empregada como limite de separação entre silte e areia. Sendo assim, este foi o critério adotado para se determinar a fração de finos (argila + silte) apresentada na Tabela 28. As demais frações seguiram os intervalos determinados na norma em questão.

Para os compostos, optou-se por utilizar apenas a classificação de acordo com a ABNT NBR 6502 - 95, já que comparando os limites estabelecidos nesta norma com aqueles apresentados em EMBRAPA (2011) as variações se encontram na classe silte, que neste caso foi determinada em conjunto com a argila, como sendo aproximadamente o material passante na peneira de $\mathrm{n}^{\circ} 200$, e as subdivisões da categoria areia que são justamente mais detalhadas na classificação adotada.

A Tabela 28 apresenta as porcentagens médias de ocorrência de cada fração granulométrica e seus respectivos desvios padrão associados aos diferentes compostos e a Figura 89 exibe as respectivas curvas granulométricas. A análise destes dados permitiu concluir que os quatro compostos estudados apresentaram uma pequena porcentagem de finos (inferior a 1,5\%) e, por conseguinte, uma elevada concentração de partículas com dimensão de areia, principalmente nas modalidades média e grossa, que perfazem, em conjunto, mais de $80 \%$ em todos os casos. 
Tabela 28 - Distribuição granulométrica das amostras de compostos: total, indiano, alambrado e estático

\begin{tabular}{cccccc}
\hline \hline \multirow{2}{*}{ Amostras } & \multirow{2}{*}{$\begin{array}{c}\text { Argila }+ \text { Silte } \\
\left(\mathbf{g ~ k g} \mathbf{~ k g}^{-1}\right)\end{array}$} & fina & média & grossa & Pedregulho fino \\
\cline { 3 - 5 } & $\mathbf{g ~ \text { kg} ^ { - 1 } )}$ \\
\hline $\begin{array}{c}\text { Composto } \\
\text { total }\end{array}$ & $7,0 \pm 0,6$ & $75,1 \pm 27,8$ & $452,1 \pm 23,5$ & $426,1 \pm 16,0$ & $39,7 \pm 5,7$ \\
\hline $\begin{array}{c}\text { Composto } \\
\text { indiano }\end{array}$ & $4,2 \pm 0,7$ & $52,2 \pm 7,1$ & $364,7 \pm 40,5$ & $508,8 \pm 30,2$ & $70,1 \pm 7,8$ \\
\hline $\begin{array}{c}\text { Composto } \\
\text { alambrado }\end{array}$ & $4,8 \pm 1,1$ & $55,9 \pm 32,7$ & $407,1 \pm 142,2$ & $449,6 \pm 98,8$ & $82,6 \pm 75,7$ \\
\hline $\begin{array}{c}\text { Composto } \\
\text { estático }\end{array}$ & $11,2 \pm 1,7$ & $122,0 \pm 30,3$ & $455,4 \pm 33,0$ & $359,1 \pm 56,2$ & $52,3 \pm 9,6$ \\
\hline \hline
\end{tabular}

Fonte: A autora.

Figura 89 - Distribuição granulométrica dos compostos: total, indiano, alambrado e estático

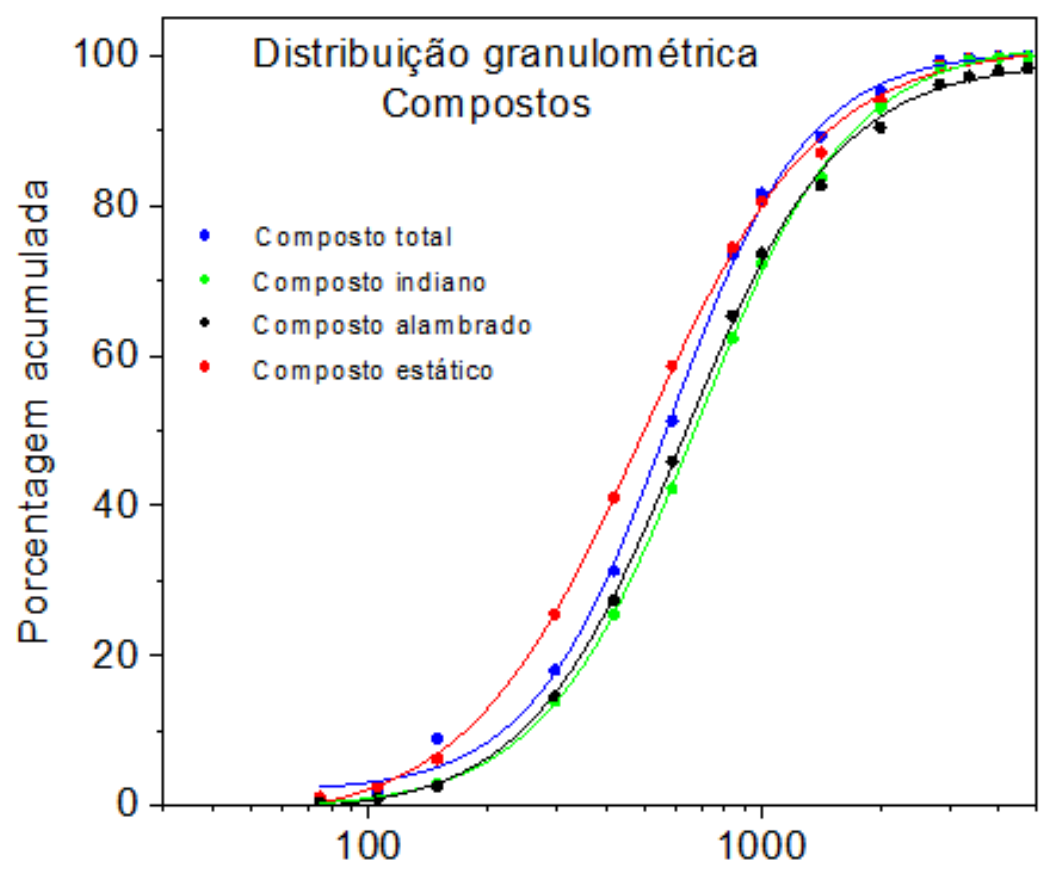

Diâmetro das partículas $(\mu \mathrm{m})$

Fonte: A autora.

Como os compostos apresentaram menos de $5 \%$ de sólidos passantes na peneira $\mathrm{n}^{\circ} 200$, eles correspondem, em termos granulométricos, a materiais granulares. Sendo assim, é importante verificar seus níveis de graduação. De acordo com Pinto (2002), dizer que um material é "bem graduado" significa que ele é constituído de grãos com variados tamanhos o que, por conseguinte, confere ao material, em geral, um melhor comportamento no campo da engenharia. Isso se dá devido ao fato de existirem partículas menores que ocupam os vazios 
formados entre as maiores, proporcionando um maior entrosamento, o que produz uma menor compressibilidade e uma maior resistência.

Essa característica foi estudada através dos coeficientes de uniformidade $\left(\mathrm{C}_{U}\right)$ e de curvatura $\left(C_{C}\right)$, que relacionam os diâmetros $D_{10}, D_{30}$ e $D_{60}$, característicos desses materiais. Esses valores no tocante aos compostos se encontram na Tabela 29, assim como os resultados para os cálculos dos coeficientes em questão. Como pode-se observar, os coeficientes obtidos foram iguais para os quatro compostos, como era de se esperar, já que as curvas granulométricas apresentaram forma similar, com um pequeno deslocamento vertical entre elas, tendendo a um paralelismo.

Tabela 29 - Diâmetros característicos $\left(D_{10}, D_{30}\right.$ e $\left.D_{60}\right)$ e coeficientes de uniformidade $\left(C_{U}\right)$ e curvatura $\left(\mathrm{C}_{\mathrm{C}}\right)$ para os compostos: total, indiano, alambrado e estático

\begin{tabular}{cccccc}
\hline Amostras & $\begin{array}{c}\mathbf{D}_{\mathbf{1 0}} \\
(\boldsymbol{\mu \mathbf { m }})\end{array}$ & $\begin{array}{c}\mathbf{D}_{\mathbf{3 0}} \\
(\boldsymbol{\mu m})\end{array}$ & $\begin{array}{c}\mathbf{D}_{\mathbf{6 0}} \\
(\boldsymbol{\mu m})\end{array}$ & $\mathbf{C}_{\mathbf{U}}$ & $\mathbf{C}_{\mathbf{C}}$ \\
\hline $\begin{array}{c}\text { Composto } \\
\text { total }\end{array}$ & 221,57 & 400,29 & 681,62 & 3 & 1 \\
\hline $\begin{array}{c}\text { Composto } \\
\text { indiano }\end{array}$ & 260,41 & 459,87 & 808,42 & 3 & 1 \\
\hline $\begin{array}{c}\text { Composto } \\
\text { alambrado }\end{array}$ & 247,69 & 443,43 & 779,53 & 3 & 1 \\
\hline $\begin{array}{c}\text { Composto } \\
\text { estático }\end{array}$ & 176,09 & 335,97 & 620,93 & 3 & 1 \\
\hline \hline
\end{tabular}

Fonte: A autora.

No tocante ao coeficiente de uniformidade, valores próximos a 1, referem-se a materiais com uma curva de distribuição granulométrica próxima da vertical, apresentando, portanto, uma reduzida variação nos diâmetros dos grãos. Já valores maiores que 1, se relacionam ao abatimento da curva granulométrica, ampliando o intervalo de variação nos tamanhos dos grãos. Todos os compostos revelaram um coeficiente de uniformidade igual a 3. Segundo a norma ABNT NBR 6502 - 95 este valor permite classificá-los como medianamente uniformes.

De acordo com Pinto (2002) um material é considerado como bem graduado quando apresenta um coeficiente de curvatura entre 1 e 3 . Valores inferiores a 1 indicam uma curva granulométrica descontínua, devido à falta de grãos com um certo tamanho. Já um coeficiente superior a 3 se refere a uma curva granulométrica de uma amostra muito uniforme na porção central. Contudo, medidas entre 1 e 3 se associam a curvas granulométricas suaves. Para areias, esse coeficiente é muitas vezes ignorado já que a maioria delas apresenta $C_{C}$ entre 1 e 3 . Assim, 
seu uso poderá, justamente, destacar comportamentos anômalos. Todos os compostos exibiram um coeficiente de curvatura igual a 1, podendo, assim, ser classificados como bem graduados.

\subsubsection{Massa específica dos sólidos e densidade aparente}

Os compostos apresentaram valores de massa específica dos sólidos maiores que a turfa, conforme exibido na Tabela 30. A massa específica referente aos compostos total $(2,163 \pm$ $\left.0,014 \mathrm{~g} \mathrm{~cm}^{-3}\right)$ e indiano $\left(2,195 \pm 0,018 \mathrm{~g} \mathrm{~cm}^{-3}\right)$ foram similares e inferiores aos respectivos valores para os compostos alambrado $\left(2,490 \pm 0,007 \mathrm{~g} \mathrm{~cm}^{-3}\right)$ e estático $\left(2,421 \pm 0,011 \mathrm{~g} \mathrm{~cm}^{-3}\right)$, também semelhantes. De fato, durante a realização deste ensaio, já havia sido observada a maior leveza dos compostos total e indiano.

Tabela 30 - Massa específica dos sólidos $\left(\mathrm{g} \mathrm{cm}^{-3}\right)$ para os compostos: total, indiano, alambrado e estático

\begin{tabular}{ccccc}
\hline $\begin{array}{c}\text { Amostra } \\
\text { (Triplicata) }\end{array}$ & $\begin{array}{c}\text { Composto } \\
\text { total }\end{array}$ & $\begin{array}{c}\text { Composto } \\
\text { indiano }\end{array}$ & $\begin{array}{c}\text { Composto } \\
\text { alambrado }\end{array}$ & $\begin{array}{c}\text { Composto } \\
\text { estático }\end{array}$ \\
\hline \hline $\mathrm{C} 1$ & 2,156 & 2,179 & 2,482 & 2,414 \\
\hline $\mathrm{C} 2$ & 2,154 & 2,192 & 2,494 & 2,434 \\
\hline $\mathrm{C} 3$ & 2,180 & 2,215 & 2,493 & 2,415 \\
\hline \hline Valor médio & $\mathbf{2 , 1 6 3}$ & $\mathbf{2 , 1 9 5}$ & $\mathbf{2 , 4 9 0}$ & $\mathbf{2 , 4 2 1}$ \\
\hline Desvio padrão & $\mathbf{0 , 0 1 4}$ & $\mathbf{0 , 0 1 8}$ & $\mathbf{0 , 0 0 7}$ & $\mathbf{0 , 0 1 1}$ \\
\hline \hline
\end{tabular}

Fonte: A autora.

No tocante aos compostos orgânicos, Messias (2004) analisou uma amostra de vermicomposto, que revelou uma massa específica de $2,168 \pm 0,012 \mathrm{~g} \mathrm{~cm}^{-3}$, valor similar aos obtidos neste estudo para os compostos total e indiano.

A Tabela 31 exibe as densidades respectivas de cada composto. Similar à massa específica dos sólidos, os compostos total $\left(0,61 \mathrm{~g} \mathrm{~cm}^{-3}\right)$ e indiano $\left(0,52 \mathrm{~g} \mathrm{~cm}^{-3}\right)$ exibiram densidades similares, assim como os compostos estático $\left(0,79 \mathrm{~g} \mathrm{~cm}^{-3}\right)$ e alambrado $\left(0,87 \mathrm{~g} \mathrm{~cm}^{-}\right.$ 3 ). 
Tabela 31 - Densidade $\left(\mathrm{g} \mathrm{cm}^{-3}\right)$ dos compostos: total, indiano, alambrado e estático

\begin{tabular}{cc}
\hline Amostras & $\begin{array}{c}\text { Densidade } \\
\left(\mathrm{g} \mathrm{cm}^{-3}\right)\end{array}$ \\
\hline Composto total & 0,61 \\
\hline Composto indiano & 0,52 \\
\hline Composto alambrado & 0,87 \\
\hline Composto estático & 0,79 \\
\hline \hline
\end{tabular}

Fonte: A autora.

Em relação à turfa, sua densidade foi de $0,71 \mathrm{~g} \mathrm{~cm}^{-3}$, valor intermediário em relação aos compostos estudados, sendo inferior aos compostos alambrado e estático e superior aos compostos total e indiano.

\subsubsection{Teor de umidade e capacidade de retenção de água (CRA)}

O teor de umidade dos compostos com secagem ao ar e posterior secagem em estufa com temperatura entre 40 e $50^{\circ} \mathrm{C}$ é apresentado na Tabela 32 e o teor de umidade com secagem ao ar e sucessiva secagem em estufa com temperatura de 105 a $110^{\circ} \mathrm{C}$ é apresentado na Tabela 33. De modo geral, as umidades totais resultantes para os compostos total e indiano foram semelhantes e superiores aos respectivos valores encontrados para os compostos alambrado e estático, também semelhantes.

Tabela 32 - Teor de umidade dos compostos: total, indiano, alambrado e estático, resultante de secagem em estufa entre 40 e $50^{\circ} \mathrm{C}$

\begin{tabular}{ccccc}
\hline \hline $\begin{array}{c}\text { Teor de } \\
\text { Umidade } \\
(\boldsymbol{\%})\end{array}$ & $\begin{array}{c}\text { Composto } \\
\text { total }\end{array}$ & $\begin{array}{c}\text { Composto } \\
\text { indiano }\end{array}$ & $\begin{array}{c}\text { Composto } \\
\text { alambrado }\end{array}$ & $\begin{array}{c}\text { Composto } \\
\text { estático }\end{array}$ \\
\hline $\mathrm{Ar}$ & $43,90 \pm 0,43$ & $42,77 \pm 0,30$ & $24,43 \pm 0,30$ & $24,17 \pm 0,67$ \\
\hline $40-50^{\circ} \mathrm{C}$ & $2,53 \pm 0,02$ & $2,18 \pm 0,02$ & $1,33 \pm 0,02$ & $1,85 \pm 0,03$ \\
\hline \hline Total & $\mathbf{4 6 , 4 3 \pm \mathbf { 0 , 4 5 }}$ & $\mathbf{4 4 , 9 5} \pm \mathbf{0 , 3 2}$ & $\mathbf{2 5 , 7 6} \pm \mathbf{0 , 3 2}$ & $\mathbf{2 6 , 0 2} \pm \mathbf{0 , 7 0}$ \\
\hline & \multicolumn{5}{c}{ Fonte: A autora. }
\end{tabular}


Tabela 33 - Teor de umidade dos compostos: total, indiano, alambrado e estático, resultante de secagem em estufa entre 105 e $110^{\circ} \mathrm{C}$

\begin{tabular}{ccccc}
\hline \hline $\begin{array}{c}\text { Teor de } \\
\text { Umidade } \\
(\%)\end{array}$ & $\begin{array}{c}\text { Composto } \\
\text { total }\end{array}$ & $\begin{array}{c}\text { Composto } \\
\text { indiano }\end{array}$ & $\begin{array}{c}\text { Composto } \\
\text { alambrado }\end{array}$ & $\begin{array}{c}\text { Composto } \\
\text { estático }\end{array}$ \\
\hline $\mathrm{Ar}$ & $43,91 \pm 0,06$ & $43,11 \pm 0,59$ & $24,99 \pm 0,73$ & $23,80 \pm 0,41$ \\
\hline $105-110^{\circ} \mathrm{C}$ & $3,92 \pm 0,02$ & $3,32 \pm 0,04$ & $1,97 \pm 0,02$ & $2,75 \pm 0,03$ \\
\hline \hline Total & $\mathbf{4 7 , 8 3 \pm \mathbf { 0 , 0 8 }}$ & $\mathbf{4 6 , 4 3} \pm \mathbf{0 , 6 3}$ & $\mathbf{2 6 , 9 6 \pm \mathbf { 0 , 7 5 }}$ & $\mathbf{2 6 , 5 5 \pm \mathbf { 0 , 4 4 }}$ \\
\hline \hline
\end{tabular}

Fonte: A autora.

Conforme exibido nas tabelas anteriores e visualizado na Figura 90 é possível perceber nitidamente que nos compostos a água se encontra majoritariamente ligada de modo simples às partículas sólidas. Afinal, mais de $90 \%$ da fração líquida presente em cada composto foi perdida naturalmente apenas pela secagem em temperatura ambiente (próxima a $25^{\circ} \mathrm{C}$ ). Ademais, em termos comparativos, como esperado, a temperatura de 105 a $110^{\circ} \mathrm{C}$ propiciou uma perda de água superior à temperatura inferior $\left(40\right.$ a $\left.50^{\circ} \mathrm{C}\right)$. Contudo, esta variação foi reduzida.

Figura 90 - Água perdida acumulada para os compostos: total, indiano, alambrado e estático
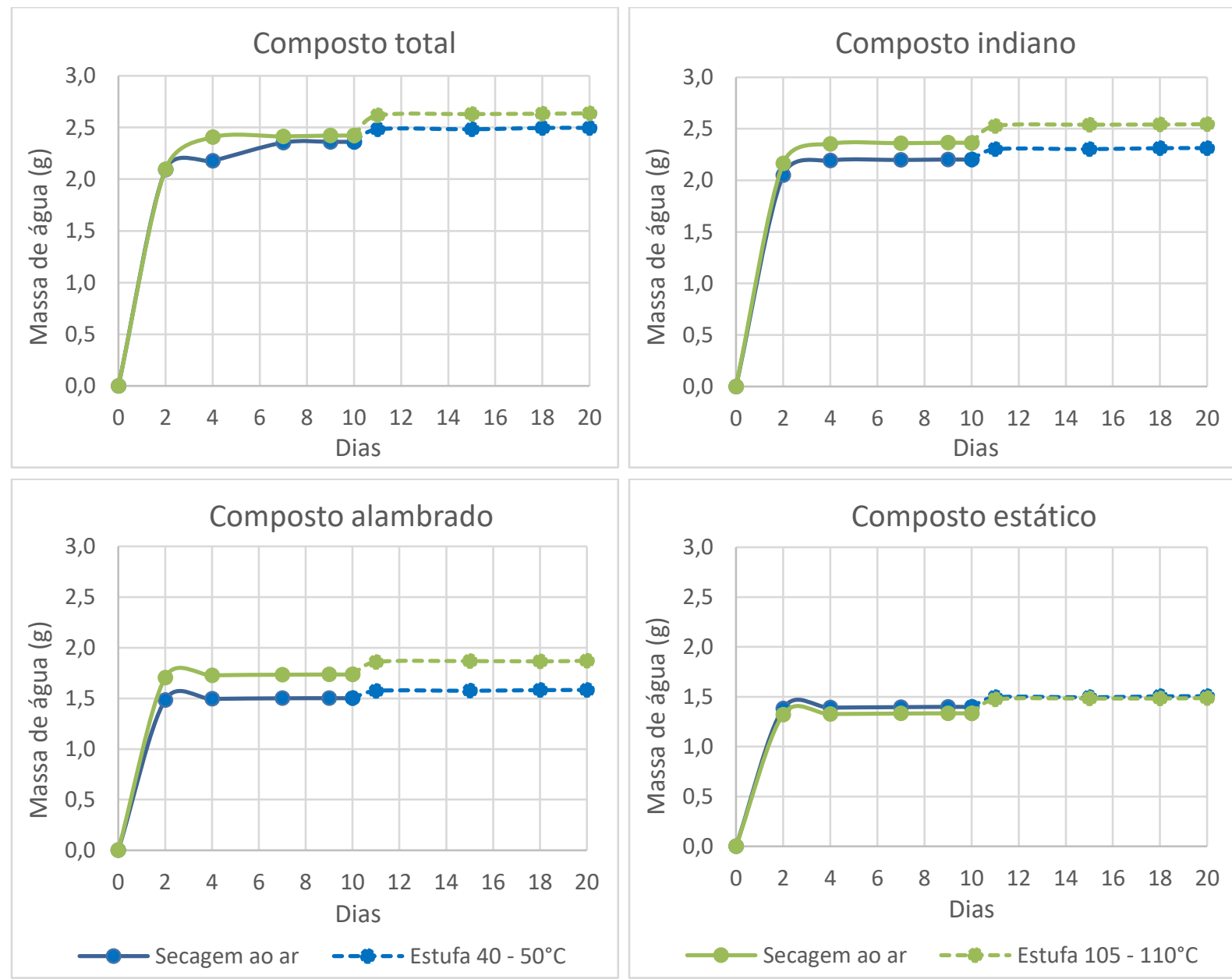

Fonte: A autora. 
É válido ressaltar que, de modo geral, a secagem ao ar atingiu uma constância de massa após cerca de 4 dias, indicando que cessou a perda de água após este período. Já para a secagem em estufa, independentemente da temperatura, as massas dos compostos se tornaram constantes após 1 dia. Todavia, visando garantir esta observação, foi adotado que cada período de secagem durasse 10 dias.

A Tabela 34 apresenta os resultados de umidade para os compostos seguindo uma outra metodologia. Nesse caso, amostras iniciais in natura foram secas em estufa entre 60 e $65^{\circ} \mathrm{C}$ e, na sequência, estas mesmas amostras foram conduzidas para uma temperatura superior, entre 105 e $110^{\circ} \mathrm{C}$, promovendo uma nova perda de umidade. A análise dos resultados permite observar que quase a totalidade da água é perdida até a temperatura de 60 a $65^{\circ} \mathrm{C}$.

Tabela 34 - Teor de umidade dos compostos: total, indiano, alambrado e estático, resultante do ensaio com temperaturas combinadas $\left(60-65^{\circ} \mathrm{C}\right.$ e $\left.105-110^{\circ} \mathrm{C}\right)$

\begin{tabular}{ccccc}
\hline $\begin{array}{c}\text { Teor de } \\
\text { Umidade } \\
(\boldsymbol{\%})\end{array}$ & $\begin{array}{c}\text { Composto } \\
\text { total }\end{array}$ & $\begin{array}{c}\text { Composto } \\
\text { indiano }\end{array}$ & $\begin{array}{c}\text { Composto } \\
\text { alambrado }\end{array}$ & $\begin{array}{c}\text { Composto } \\
\text { estático }\end{array}$ \\
\hline $60-65^{\circ} \mathrm{C}$ & 47,17 & 44,66 & 23,24 & 22,27 \\
\hline $105-110^{\circ} \mathrm{C}$ & 1,17 & 0,87 & 0,33 & 0,50 \\
\hline \hline Total & $\mathbf{4 8 , 3 3}$ & $\mathbf{4 5 , 5 3}$ & $\mathbf{2 3 , 5 7}$ & $\mathbf{2 2 , 7 8}$ \\
\hline \hline
\end{tabular}

Fonte: A autora.

Em termos gerais, comparando o teor de umidade obtido conforme o primeiro procedimento (secagem ao ar associada a posterior secagem em temperatura entre 40 a $50^{\circ} \mathrm{C}$ ), o segundo ensaio (secagem ao ar associada a posterior secagem em temperatura entre 105 a $110^{\circ} \mathrm{C}$ ) e o terceiro método (secagem em temperatura entre 60 a $65^{\circ} \mathrm{C}$ com sucessiva secagem de 105 a $110^{\circ} \mathrm{C}$ ), os resultados gerados foram similares, com variação percentual, para mais ou para menos, inferior a $15 \%$.

Além do teor de umidade, foram obtidos para os compostos os resultados da capacidade de retenção de água (CRA) (Tabela 35), para as amostras submetidas a uma tensão de $10 \mathrm{hPa}$. Este resultado é interessante, na medida em que o uso desta tensão simula encontrar uma umidade próxima a capacidade de campo e, portanto, a água facilmente disponível para as plantas, sendo interessante principalmente em se tratando do emprego destes compostos em barreiras reativas vegetadas, por exemplo. Observa-se uma considerável variação de valores, sendo que, de modo geral, o composto indiano revelou a maior capacidade de retenção de água 
$(65,26 \%)$. O composto alambrado apresentou a menor capacidade de retenção de água $(22,75 \%)$.

Tabela 35 - Capacidade de retenção de água para os compostos: total, indiano, alambrado e estático, em \% (massa/massa)

\begin{tabular}{cc}
\hline Amostra & $\begin{array}{c}\text { CRA } \\
(\boldsymbol{\%})\end{array}$ \\
\hline \hline Composto total & 54,93 \\
\hline Composto indiano & 65,26 \\
\hline Composto alambrado & 22,75 \\
\hline Composto estático & 43,43 \\
\hline \hline
\end{tabular}

Para efeito comparativo são apresentados os resultados de alguns autores que utilizaram um sistema mais simples, composto por um papel filtro acondicionado sobre um funil colocado sobre um erlenmeyer. Melo, Silva e Dias (2008) estudando diversas matrizes orgânicas, obtiveram uma CRA de $81,0 \pm 1,8 \%$ para um composto comercial e de $63,0 \pm 5,1 \%$ para um material húmico comercial com predominância de ácido húmico. Massukado (2008) avaliou dois compostos resultantes da compostagem de resíduos orgânicos municipais ocorrida em um pátio de compostagem e na horta municipal, ambos em São Carlos, e encontrou valores de CRA de, respectivamente $83,83 \%$ e $102,85 \%$. Já Guermandi (2015), ao trabalhar com compostos obtidos a partir da compostagem de resíduos orgânicos municipais com diversos tratamentos de leiras, encontrou valores de CRA bem superiores, variando entre 352,1 a 534,3\%.

Já empregando a mesa de tensão a $10 \mathrm{hPa}$, Zorzeto et al. (2014) obtiveram valores de CRA de 13 a 67\% para substratos de fibra de coco, casca de pinus, casca de arroz e combinações entre eles, valores próximos aos obtidos para os compostos nesta pesquisa.

Em relação à turfa, sua CRA foi de $36,28 \%$, valor intermediário em relação aos compostos, sendo superior ao composto alambrado e inferior aos compostos total, indiano e estático, sendo que ela foi determinada pelo mesmo método utilizado para os compostos orgânicos.

\subsubsection{Parâmetros físico-químicos (pH, $\Delta \mathrm{pH}$, Eh e CE)}

Os compostos diferentemente das turfas, apresentam $\mathrm{pH}$ na faixa de valores neutros a básicos. Valente et al. (2009) afirmam que ao longo do processo da compostagem haverão 
inúmeras reações químicas, regulando a condição ácida, acarretando na geração de um produto final com $\mathrm{pH}$ na faixa de 7,0 a 8,5.

Os valores encontrados para o $\mathrm{pH}$, em água, para as diferentes modalidades de compostos estudados se encontram na Tabela 36. A análise dos resultados permitiu observar que os compostos total e estático apresentaram valores similares de $\mathrm{pH}$, respectivamente, 6,5 \pm 0,0 e 6,4 \pm 0,1. Estas medidas permitem classificá-los como ligeiramente ácidos, por apresentarem uma reduzida acidez. Já os compostos indiano e alambrado apresentaram maiores valores de $\mathrm{pH}$, respectivamente, 7,4 $\pm 0,0$ e 7,7 $\pm 0,1$, sendo, portanto, classificados como ligeiramente básicos. De modo geral, os quatro compostos oscilaram próximos da neutralidade. Este fato pode ser considerado como um indicativo da maturidade dos compostos estudados.

Tabela 36 - Valores de $\mathrm{pH}$ em $\mathrm{H}_{2} \mathrm{O}$ para os compostos: total, indiano, alambrado e estático

\begin{tabular}{ccccc}
\hline \hline $\begin{array}{c}\text { Amostra } \\
\text { Triplicata) }\end{array}$ & $\begin{array}{c}\text { Composto } \\
\text { total }\end{array}$ & $\begin{array}{c}\text { Composto } \\
\text { indiano }\end{array}$ & $\begin{array}{c}\text { Composto } \\
\text { alambrado }\end{array}$ & $\begin{array}{c}\text { Composto } \\
\text { estático }\end{array}$ \\
\hline \hline $\mathrm{C} 1$ & 6,5 & 7,4 & 7,7 & 6,3 \\
\hline $\mathrm{C} 2$ & 6,5 & 7,4 & 7,6 & 6,4 \\
\hline $\mathrm{C} 3$ & 6,5 & 7,4 & 7,7 & 6,5 \\
\hline \hline Valor médio & $\mathbf{6 , 5}$ & $\mathbf{7 , 4}$ & $\mathbf{7 , 7}$ & $\mathbf{6 , 4}$ \\
\hline Desvio padrão & $\mathbf{0 , 0}$ & $\mathbf{0 , 0}$ & $\mathbf{0 , 1}$ & $\mathbf{0 , 1}$ \\
\hline \hline
\end{tabular}

Fonte: A autora.

Para efeito comparativo, diferentes autores apresentam valores de $\mathrm{pH}$ para compostos nacionais e internacionais originados do emprego de variadas metodologias de compostagem, porém, que apresentaram sempre como origem a fração orgânica dos resíduos sólidos urbanos (Tabela 37). Mesmo que ajam peculiaridades entre os métodos adotados na determinação do $\mathrm{pH}$, de modo geral, todos eles utilizaram água. Nota-se que todos os valores oscilam nas proximidades da neutralidade. 
Tabela 37 - Valores de $\mathrm{pH}$ em $\mathrm{H}_{2} \mathrm{O}$ para compostos nacionais e internacionais

\begin{tabular}{|c|c|c|c|}
\hline Origem & Material compostado & pH em $\mathrm{H}_{2} \mathrm{O}$ & Autor \\
\hline $\begin{array}{c}\text { Usinas de } \\
\text { compostagem do } \\
\text { estado de São Paulo }\end{array}$ & Resíduo sólido urbano & $5,05-8,17$ & Barreira (2005) \\
\hline Europa & Resíduo sólido municipal & $7,28 \pm 0,03$ & $\begin{array}{l}\text { Farrell e Jones } \\
(2010 b)^{*}\end{array}$ \\
\hline \multirow{2}{*}{ Grécia } & $\begin{array}{c}\text { Resíduo orgânico } \\
\text { municipal (1 semana de } \\
\text { maturação) }\end{array}$ & $5,4-6,7$ & \multirow{2}{*}{$\begin{array}{l}\text { Simantiraki et } \\
\text { al. (2013) }\end{array}$} \\
\hline & $\begin{array}{c}\text { Resíduo orgânico } \\
\text { municipal ( } 8 \text { meses de } \\
\text { maturação) }\end{array}$ & $8,2-8,7$ & \\
\hline São Carlos (SP) & $\begin{array}{c}\text { Resíduo orgânico } \\
\text { municipal, grama e } \\
\text { serragem }\end{array}$ & $7,93-8,36$ & $\begin{array}{l}\text { Guermandi } \\
(2015)^{* *}\end{array}$ \\
\hline \multirow{2}{*}{ Espanha } & $\begin{array}{l}\text { Resíduo orgânico } \\
\text { municipal }\end{array}$ & 8,3 & \multirow{2}{*}{$\begin{array}{l}\text { Venegas, Rigol } \\
\text { e Vidal (2015) }\end{array}$} \\
\hline & Resíduo sólido municipal & 8,1 & \\
\hline
\end{tabular}

* Apenas a fração de finos dos resíduos sólidos urbanos $(<5 \mathrm{~cm})$ foi utilizada e ela continha $64 \pm 3 \%$ de matéria orgânica;

** Foram empregados variados tratamentos em cada leira: trituração e revolvimento, não trituração e revolvimento, não trituração e não-revolvimento e não trituração e não revolvimento com tubos de PVC.

Fonte: A autora.

Conforme relatado anteriormente, mesmo o pH ótimo de adsorção sendo diferente para cada metal, a adsorção é favorecida em condições de pH neutro ou ligeiramente alcalino. Portanto, o pH encontrado para os compostos pode ser considerado como um fator positivo na potencialização destes materiais reativos na adsorção de metais.

Posteriormente, foi determinado o $\mathrm{pH}$ em $\mathrm{KCl}$, resultando em valores de 5,5 a 6,8, todos eles inferiores aos respectivos resultados de $\mathrm{pH}$ em água, possibilitando o cálculo do $\Delta \mathrm{pH}$ que, por conseguinte, culminou em valores negativos para todos os compostos (Tabela 38). Messias (2004) analisou o pH em KCl para um vermicomposto, advindo da compostagem de esterco bovino sob a atuação de minhocas da espécie Eisenia foetida por um período de 4 meses, obtendo um resultado de 4,96 0,02 (pH em KCl), valor inferior ao encontrado nesta pesquisa.

Os valores de $\Delta \mathrm{pH}$ obtidos para os compostos indiano, alambrado e estático foram em torno de - 0,9; já para o composto total este valor foi de - 0,4 (Tabela 38). Esse valores negativos para todos os compostos permitem estimar que há um predomínio de cargas negativas na superfície das partículas, favorecendo a retenção de cátions. Esta característica pode ser 
enquadrada como mais um fator positivo da utilização destes compostos na adsorção dos íons metálicos estudados nesta pesquisa $\left(\mathrm{Zn}^{2+}, \mathrm{Pb}^{2+} \mathrm{e} \mathrm{Cd}^{2+}\right)$.

Tabela 38 - Valores de $\Delta \mathrm{pH}$ para os compostos: total, indiano, alambrado e estático

\begin{tabular}{ccccc}
\hline $\begin{array}{c}\text { Amostra } \\
\text { (Triplicata) }\end{array}$ & $\begin{array}{c}\text { Composto } \\
\text { total }\end{array}$ & $\begin{array}{c}\text { Composto } \\
\text { indiano }\end{array}$ & $\begin{array}{c}\text { Composto } \\
\text { alambrado }\end{array}$ & $\begin{array}{c}\text { Composto } \\
\text { estático }\end{array}$ \\
\hline \hline $\mathrm{C} 1$ & $-0,4$ & $-1,1$ & $-1,0$ & $-0,8$ \\
\hline $\mathrm{C} 2$ & $-0,4$ & $-1,0$ & $-0,8$ & $-0,9$ \\
\hline $\mathrm{C} 3$ & $-0,3$ & $-0,9$ & $-1,0$ & $-0,9$ \\
\hline \hline Valor médio & $\mathbf{- 0 , 4}$ & $\mathbf{- 1 , 0}$ & $\mathbf{- 0 , 9}$ & $\mathbf{- 0 , 9}$ \\
\hline Desvio padrão & $\mathbf{0 , 1}$ & $\mathbf{0 , 1}$ & $\mathbf{0 , 1}$ & $\mathbf{0 , 1}$ \\
\hline \hline
\end{tabular}

Fonte: A autora.

Foi estudada ainda outra propriedade físico-química: o potencial de oxi-redução (Eh). A Tabela 39 apresenta os resultados encontrados para os quatro compostos avaliados. Notouse que todos eles se encontram em condições oxidantes, contribuindo favoravelmente para a imobilização dos metais. De modo geral, o Eh dos compostos indiano (+ $268 \pm 9 \mathrm{mV})$ e alambrado (+284 $\pm 4 \mathrm{mV})$ foram semelhantes, assim como dos compostos total $(+347 \pm 5 \mathrm{mV})$ e estático $(+330 \pm 10 \mathrm{mV})$.

Tabela 39 - Valores de potencial de oxi-redução - Eh (mV) para os compostos: total, indiano, alambrado e estático

\begin{tabular}{ccccc}
\hline $\begin{array}{c}\text { Amostra } \\
\text { (Triplicata) }\end{array}$ & $\begin{array}{c}\text { Composto } \\
\text { total }\end{array}$ & $\begin{array}{c}\text { Composto } \\
\text { indiano }\end{array}$ & $\begin{array}{c}\text { Composto } \\
\text { alambrado }\end{array}$ & $\begin{array}{c}\text { Composto } \\
\text { estático }\end{array}$ \\
\hline \hline $\mathrm{C} 1$ & +343 & +265 & +288 & +324 \\
\hline $\mathrm{C} 2$ & +346 & +260 & +280 & +341 \\
$\mathrm{C} 3$ & +352 & +278 & +285 & +325 \\
\hline \hline Valor médio & $+\mathbf{3 4 7}$ & $+\mathbf{2 6 8}$ & $+\mathbf{2 8 4}$ & $+\mathbf{3 3 0}$ \\
\hline Desvio padrão & $\mathbf{5}$ & $\mathbf{9}$ & $\mathbf{4}$ & $\mathbf{1 0}$ \\
\hline \hline
\end{tabular}

Fonte: A autora.

O último parâmetro físico-químico analisado foi a condutividade elétrica (CE). A Tabela 40 contém os valores referentes as quatro modalidades de compostos. Observou-se que o composto total apresentou uma CE consideravelmente superior aos demais compostos (2200 $\left.\pm 0 \mu \mathrm{S} \mathrm{cm}^{-1}\right)$. Provavelmente isso se deve a matéria-prima compostada, constituída tanto por 
resíduos de frutas e verduras cruas como por sobras de alimentos já processados e cozidos que continham, provavelmente, temperos, elevando a salinidade do material final. Por outro lado, o composto estático revelou a menor condutividade elétrica $\left(157 \pm 2 \mu \mathrm{S} \mathrm{cm}^{-1}\right)$. Nesse caso, isto possivelmente está relacionado a considerável presença de solo no material final.

Tabela 40 - Valores de condutividade elétrica - $\mathrm{CE}\left(\mu \mathrm{S} \mathrm{cm}^{-1}\right)$ para os compostos: total, indiano, alambrado e estático

\begin{tabular}{ccccc}
\hline $\begin{array}{c}\text { Amostra } \\
\text { (Triplicata) }\end{array}$ & $\begin{array}{c}\text { Composto } \\
\text { total }\end{array}$ & $\begin{array}{c}\text { Composto } \\
\text { indiano }\end{array}$ & $\begin{array}{c}\text { Composto } \\
\text { alambrado }\end{array}$ & $\begin{array}{c}\text { Composto } \\
\text { estático }\end{array}$ \\
\hline \hline $\mathrm{C} 1$ & 2210 & 612 & 705 & 160 \\
\hline $\mathrm{C} 2$ & 2170 & 681 & 703 & 156 \\
\hline $\mathrm{C} 3$ & 2220 & 701 & 718 & 156 \\
\hline \hline Valor médio & $\mathbf{2 2 0 0}$ & $\mathbf{6 6 5}$ & $\mathbf{7 0 9}$ & $\mathbf{1 5 7}$ \\
\hline Desvio padrão & $\mathbf{0}$ & $\mathbf{4 7}$ & $\mathbf{8}$ & $\mathbf{2}$ \\
\hline \hline
\end{tabular}

Fonte: A autora.

\subsubsection{Composição elementar $(C, H, N)$}

As Tabelas 41 e 42 exibem os resultados obtidos no tocante à composição elementar (carbono, hidrogênio e oxigênio) dos quatro compostos estudados. De modo geral, verificou-se a presença majoritária de $\mathrm{C}$, seguida por $\mathrm{H}$ e $\mathrm{N}$. Ademais, é importante salientar uma considerável variação nas concentrações resultantes para diferentes amostras relativas a um mesmo composto (triplicatas). Provavelmente isso se deve ao fato dos compostos apresentarem uma ampla variação granulométrica, contendo, inclusive, partículas grosseiras (estes materiais são heterogêneos, como observado em análise tátil visual). Assim, como as pastilhas utilizadas neste ensaio continham massas reduzidas de material, elas não eram homogêneas, por conterem diferentes granulometrias e em diferentes proporções.

Tabela 41 - Composição elementar dos compostos total e indiano relacionando a presença de C, H e N

\begin{tabular}{c|ccc|ccc}
\hline \hline \multirow{2}{*}{$\begin{array}{c}\text { Amostra } \\
\text { (Triplicata) }\end{array}$} & \multicolumn{3}{|c|}{ Composto total } & \multicolumn{3}{c}{ Composto indiano } \\
\cline { 2 - 7 } & $\mathbf{C ~ ( \% )}$ & $\mathbf{H}(\boldsymbol{\%})$ & $\mathbf{N}(\boldsymbol{\%})$ & $\mathbf{C}(\boldsymbol{\%})$ & $\mathbf{H}(\boldsymbol{\%})$ & $\mathbf{N}(\boldsymbol{\%})$ \\
\hline \hline $\mathrm{C} 1$ & 11,64 & 2,06 & 1,22 & 6,86 & 1,10 & 0,56 \\
\hline $\mathrm{C} 2$ & 9,79 & 1,63 & 1,04 & 10,60 & 1,43 & 0,76 \\
\hline $\mathrm{C} 3$ & 9,01 & 1,48 & 0,92 & 7,41 & 1,40 & 0,57 \\
\hline \hline Valor médio & 10,15 & 1,72 & 1,06 & 8,29 & 1,31 & 0,63 \\
\hline Desvio padrão & 1,35 & 0,30 & 0,15 & 2,02 & 0,18 & 0,11 \\
\hline \hline
\end{tabular}

Fonte: A autora. 
Tabela 42 - Composição elementar dos compostos alambrado e estático relacionando a presença de C, $\mathrm{He} \mathrm{N}$

\begin{tabular}{c|ccc|ccc}
\hline \hline \multirow{2}{*}{$\begin{array}{c}\text { Amostra } \\
\text { (Triplicata) }\end{array}$} & \multicolumn{3}{|c|}{ Composto alambrado } & \multicolumn{3}{c}{ Composto estático } \\
\cline { 2 - 8 } & $\mathbf{C ~ ( \% )}$ & $\mathbf{H}(\boldsymbol{\%})$ & $\mathbf{N}(\boldsymbol{\%})$ & $\mathbf{C ~ ( \% )}$ & $\mathbf{H}(\boldsymbol{\%})$ & $\mathbf{N}(\boldsymbol{\%})$ \\
\hline \hline $\mathrm{C} 1$ & 3,44 & 0,74 & 0,36 & 3,69 & 0,74 & 0,35 \\
\hline $\mathrm{C} 2$ & 3,66 & 0,80 & 0,37 & 5,76 & 1,33 & 0,48 \\
\hline $\mathrm{C} 3$ & 3,78 & 0,82 & 0,35 & 11,55 & 1,77 & 0,98 \\
\hline \hline Valor médio & 3,63 & 0,79 & 0,36 & 7,00 & 1,28 & 0,60 \\
\hline Desvio padrão & 0,17 & 0,04 & 0,01 & 4,07 & 0,52 & 0,33 \\
\hline \hline
\end{tabular}

Fonte: A autora.

A partir dos dados expostos nas Tabelas 41 e 42, notou-se que os valores médios mais baixos para o $\mathrm{C}, \mathrm{H}$ e $\mathrm{N}$ foram obtidos para o composto alambrado $(\mathrm{C}=3,63 \pm 0,17 \%, \mathrm{H}=0,79$ $\pm 0,04 \%$ e $\mathrm{N}=0,36 \pm 0,01 \%)$ e que os valores mais elevados foram determinados para o composto total $(\mathrm{C}=10,15 \pm 1,35 \%, \mathrm{H}=1,72 \pm 0,30 \%$ e $\mathrm{N}=1,06 \pm 0,15 \%)$.

A partir dos valores médios encontrados para a composição elementar dos compostos, foi possível calcular suas respectivas relações e razões C/N e H/C (Tabelas 43 e 44). Desta maneira, observou-se que o menor valor referente à relação $\mathrm{C} / \mathrm{N}$ foi obtido para o composto total $(9,57)$ e que o maior valor foi determinado para o composto indiano $(13,16)$. Já quanto à relação $\mathrm{H} / \mathrm{C}$, o menor valor foi observado para o composto indiano $(0,16)$ e o maior valor foi apresentado pelo composto alambrado $(0,22)$.

De modo análogo, quanto às razões atômicas, notou-se que o composto total apresentou a menor razão $\mathrm{C} / \mathrm{N}(11,43)$ e o composto indiano a maior $(15,17)$ (Tabela 44). O composto estático exibiu a menor razão atômica H/C $(1,84)$ e, por outro lado o composto alambrado apresentou a maior $(2,60)$.

Tabela 43 - Relações C/N e H/C para os compostos: total, indiano, alambrado e estático

\begin{tabular}{ccccc}
\hline \hline Relações & $\begin{array}{c}\text { Composto } \\
\text { total }\end{array}$ & $\begin{array}{c}\text { Composto } \\
\text { indiano }\end{array}$ & $\begin{array}{c}\text { Composto } \\
\text { alambrado }\end{array}$ & $\begin{array}{c}\text { Composto } \\
\text { estático }\end{array}$ \\
\hline $\mathbf{C} / \mathbf{N}$ & 9,57 & 13,16 & 10,07 & 11,60 \\
\hline $\mathbf{H} / \mathbf{C}$ & 0,17 & 0,16 & 0,22 & 0,18 \\
\hline
\end{tabular}

Fonte: A autora. 
Tabela 44 - Razões atômicas C/N e H/C para os compostos: total, indiano, alambrado e estático

\begin{tabular}{ccccc}
\hline $\begin{array}{c}\text { Razões } \\
\text { atômicas }\end{array}$ & $\begin{array}{c}\text { Composto } \\
\text { total }\end{array}$ & $\begin{array}{c}\text { Composto } \\
\text { indiano }\end{array}$ & $\begin{array}{c}\text { Composto } \\
\text { alambrado }\end{array}$ & $\begin{array}{c}\text { Composto } \\
\text { estático }\end{array}$ \\
\hline $\mathbf{C} / \mathbf{N}$ & 11,43 & 15,17 & 12,60 & 13,75 \\
\hline $\mathbf{H} / \mathbf{C}$ & 1,97 & 2,27 & 2,60 & 1,84 \\
\hline \hline
\end{tabular}

Fonte: A autora.

De maneira geral, a decomposição favorece a diminuição da relação $\mathrm{C} / \mathrm{N}$ e menores relações $\mathrm{H} / \mathrm{C}$ indicam um grau mais elevado de aromaticidade, também característico de estruturas mais decompostas. Assim, como o composto total apresentou a menor relação $\mathrm{C} / \mathrm{N} \mathrm{e}$ uma das menores relações H/C (Tabela 43), esse pode ser considerado como um indicativo de seu maior grau de decomposição.

Kiehl (1985) afirma que a relação $\mathrm{C} / \mathrm{N}$ apresenta a finalidade de indicar o grau de decomposição dos compostos quando se parte da matéria orgânica crua, sendo que valores próximos a 18 indicam que o material se encontra em um estado semicurado, já resultados abaixo desse valor até 10 apontam para um material curado. Nessa perspectiva, os compostos estudados podem ser enquadrados como curados. Ademais, ainda segundo o mesmo autor, no fertilizante curado, uma relação $\mathrm{C} / \mathrm{N}$ entre 8 e 12 pode ser considerada como ótima em se tratando de fertilizantes orgânicos. Uma análise dos compostos permitiu enquadrá-los justamente nesta categoria, com exceção do composto indiano, mas sua relação $\mathrm{C} / \mathrm{N}$ se encontra próxima do limite superior desta classe. Essa é uma informação interessante, sobretudo em se tratando de um possível uso destes compostos em sistemas de cobertura de resíduos, que comumente são vegetados. Assim, os próprios compostos poderiam funcionar também como um substrato favorável para o crescimento e desenvolvimento das plantas.

Guermandi (2015) caracterizou, em condições iniciais, o substrato bruto de suas composteiras (grama, resíduos orgânicos e serragem) também pela análise elementar e obteve 38,54\% de C, 1,03\% de $\mathrm{N}$ e, por conseguinte, uma relação C/N de 37,34. Já seus compostos finais, apresentaram C, variando de 38,02 a 40,40\%; N, oscilando de 1,92 a 2,48\% e, consequentemente, uma relação $\mathrm{C} / \mathrm{N}$ de 15,38 a 20,12. Assim, os resultados desta autora foram superiores aos determinados nesta pesquisa em termos de $\mathrm{C}, \mathrm{N}$ e $\mathrm{C} / \mathrm{N}$. Como não se tem os valores destes parâmetros para o substrato inicial dos compostos aqui investigados, uma hipótese é que, neste caso, os valores iniciais de $\mathrm{C}$ e $\mathrm{N}$ eram inferiores aos respectivos valores iniciais encontrados pela autora. 
A Tabela 45 lista outros dados comparativos dos teores de carbono e nitrogênio e suas consequentes relações $\mathrm{C} / \mathrm{N}$ para compostos nacionais e internacionais. De modo geral, pode-se observar que os compostos estudados nesta pesquisa exibiram reduzidos teores de carbono e nitrogênio, culminando em menores relações $\mathrm{C} / \mathrm{N}$ que se aproximam das encontradas por Massukado (2008) e Simantiraki et al. (2013), para compostos maturados. Contudo, observando a ampla faixa de variação da relação $\mathrm{C} / \mathrm{N}$ para usinas paulistas de compostagem (BARREIRA, 2005), os dados obtidos podem ser enquadrados como dentro do esperado.

Tabela 45 - Valores de carbono, nitrogênio e relação C/N para compostos nacionais e internacionais

\begin{tabular}{|c|c|c|c|c|c|}
\hline Origem & $\begin{array}{c}\text { Material } \\
\text { compostado }\end{array}$ & $\mathrm{C}(\%)$ & $\mathbf{N}(\%)$ & $\mathbf{C} / \mathbf{N}$ & Autor \\
\hline $\begin{array}{c}\text { Usinas de } \\
\text { compostagem } \\
\text { do estado de } \\
\text { São Paulo }\end{array}$ & $\begin{array}{l}\text { Resíduo sólido } \\
\text { urbano }\end{array}$ & n.a & n.a. & $\begin{array}{c}14,15- \\
40,72\end{array}$ & $\begin{array}{l}\text { Barreira } \\
(2005)\end{array}$ \\
\hline São Carlos & $\begin{array}{l}\text { Resíduo orgânico } \\
\text { municipal }\end{array}$ & $\begin{array}{l}12,11- \\
23,47 * *\end{array}$ & $0,95-2,38$ & $8,3-12,75$ & $\begin{array}{l}\text { Massukado } \\
(2008) * * *\end{array}$ \\
\hline Europa & $\begin{array}{l}\text { Resíduo sólido } \\
\text { municipal }\end{array}$ & $24,6 \pm 4,3$ & $0,97 \pm 0,17$ & $25^{*}$ & $\begin{array}{c}\text { Farrell e } \\
\text { Jones } \\
(2010 \mathrm{~b})^{* * * *} \\
\end{array}$ \\
\hline \multirow{2}{*}{ Grécia } & $\begin{array}{l}\text { Resíduo orgânico } \\
\text { municipal (1 semana } \\
\text { de maturação) }\end{array}$ & $26-29,2$ & $1,1-1,3$ & $22-24 *$ & \multirow{2}{*}{$\begin{array}{l}\text { Simantiraki } \\
\text { et al. (2013) }\end{array}$} \\
\hline & $\begin{array}{l}\text { Resíduo orgânico } \\
\text { municipal ( } 8 \text { meses } \\
\text { de maturação) }\end{array}$ & $15,3-21$ & $1,5-1,6$ & $10-13 *$ & \\
\hline \multirow{2}{*}{ Espanha } & $\begin{array}{l}\text { Resíduo orgânico } \\
\text { municipal }\end{array}$ & 27 & 1,8 & 15 & \multirow{2}{*}{$\begin{array}{c}\text { Venegas, } \\
\text { Rigol e } \\
\text { Vidal (2015) }\end{array}$} \\
\hline & $\begin{array}{l}\text { Resíduo sólido } \\
\text { municipal }\end{array}$ & 31 & 1,7 & 18 & \\
\hline
\end{tabular}

* Valores calculados com os dados de $\mathrm{C}$ e $\mathrm{N}$ apresentados pelos respectivos autores;

** Referente ao conteúdo de carbono orgânico;

*** Considerando os dados referentes às compostagens do pátio e da horta de São Carlos;

**** Apenas a fração de finos dos resíduos sólidos urbanos $(<5 \mathrm{~cm})$ foi utilizada e ela continha $64 \pm 3 \%$ de matéria orgânica;

n.a. = não apresentado.

Fonte: A autora.

\subsubsection{Composição elementar complementar (P, K, Ca, Mg e S)}

Com o intuito de complementar as informações referentes à composição elementar dos compostos, apresentadas anteriormente, foram determinadas também as concentrações totais 
de fósforo, potássio, cálcio, magnésio e enxofre (Tabela 46). Essa determinação foi realizada para a base seca em estufa a $65^{\circ} \mathrm{C}$, justamente visando uma menor interferência da umidade nos valores finais.

Tabela 46 - Composição elementar adicional das amostras dos compostos: total, indiano, alambrado e estático, secos a $65^{\circ} \mathrm{C}$, relacionando a presença de $\mathrm{P}, \mathrm{K}, \mathrm{Ca}, \mathrm{Mg}$ e S $\left(\mathrm{g} \mathrm{kg}^{-1}\right)$

\begin{tabular}{ccccc}
\hline \hline $\begin{array}{c}\text { Elementos } \\
\left(\mathbf{g ~ k g}^{-1}\right)\end{array}$ & $\begin{array}{c}\text { Composto } \\
\text { total }\end{array}$ & $\begin{array}{c}\text { Composto } \\
\text { indiano }\end{array}$ & $\begin{array}{c}\text { Composto } \\
\text { alambrado }\end{array}$ & $\begin{array}{c}\text { Composto } \\
\text { estático }\end{array}$ \\
\hline \hline $\mathrm{P}$ & 2,31 & 2,01 & 2,01 & 1,35 \\
\hline $\mathrm{K}$ & 1,33 & 1,58 & 1,99 & 0,66 \\
\hline $\mathrm{Ca}$ & 16,4 & 28,6 & 6,4 & 11,2 \\
\hline $\mathrm{Mg}$ & 0,2 & 1,3 & 1,3 & 0,9 \\
\hline $\mathrm{S}$ & 1,3 & 0,3 & 0,5 & 0,4 \\
\hline \hline
\end{tabular}

Fonte: A autora.

$\mathrm{Na}$ Tabela 46, notou-se que o composto total apresentou os maiores teores de P e S; o composto alambrado exibiu a maior presença de $\mathrm{K}$; o composto indiano mostrou o maior acúmulo de $\mathrm{Ca}$; o composto indiano e o composto alambrado reveralaram as maiores concentrações de $\mathrm{Mg}$.

A Tabela 47 exibe as concentrações destes mesmos elementos (P, K, Ca, Mg e S) para compostos nacionais e internacionais a partir da compostagem de resíduos sólidos municipais ou resíduos orgânicos. Observa-se que, de modo geral, os compostos analisados nesta pesquisa apresentaram concentrações inferiores destes elementos quando comparados com dados da literatura. Destaque deve ser dado ao P, K e Ca. O Ca, por exemplo, resultou em concentrações elevadas para os compostos de comparação (todos superiores a $20 \mathrm{~g} \mathrm{~kg}^{-1}$ ). Similar, o K revelou concentrações de até $32,2 \mathrm{~g} \mathrm{~kg}^{-1}$ nos compostos de comparação e nos compostos estudados sua concentração não excedeu $2 \mathrm{~g} \mathrm{~kg}^{-1}$. 
Tabela 47 - Concentrações de alguns elementos $\left(\mathrm{g} \mathrm{kg}^{-1}\right)$ para compostos nacionais e internacionais

\begin{tabular}{ccccc}
\hline $\begin{array}{c}\text { Elementos } \\
\left(\mathbf{g ~ k g}^{-1}\right)\end{array}$ & $\begin{array}{c}\text { Massukado } \\
(\mathbf{2 0 0 8}) *\end{array}$ & $\begin{array}{c}\text { Farrell e Jones } \\
(\mathbf{2 0 1 0 b}) * *\end{array}$ & $\begin{array}{c}\text { Guermandi } \\
(\mathbf{2 0 1 5}) * * *\end{array}$ & $\begin{array}{c}\text { Venegas, Rigol e } \\
\text { Vidal } \\
(\mathbf{2 0 1 5}) * * * *\end{array}$ \\
\hline \hline $\mathrm{P}$ & $2,72-5,85$ & $0,9 \pm 0,2$ & $17,05-20,22$ & 9,43 \\
\hline $\mathrm{K}$ & $6,31-12,88$ & $10,10 \pm 0,6$ & $26,4-32,2$ & 10,53 \\
\hline $\mathrm{Ca}$ & $22,57-32,88$ & $51,80 \pm 5,3$ & $34,48-180,00$ & 99,27 \\
\hline $\mathrm{Mg}$ & $1,99-3,91$ & n.a. & $3,04-5,41$ & 9,11 \\
\hline $\mathrm{S}$ & $2,14-3,15$ & n.a. & n.a. & 6,17 \\
\hline \hline
\end{tabular}

* Considerando os dados referentes às compostagens do pátio e da horta de São Carlos;

** Apenas a fração de finos dos resíduos sólidos municipais $(<5 \mathrm{~cm})$ foi utilizada e ela continha $64 \pm 3 \%$ de matéria orgânica;

*** Foram empregados variados tratamentos em cada leira: trituração e revolvimento, não trituração e revolvimento, não trituração e não-revolvimento e não trituração e não revolvimento com tubos de PVC;

**** Compostos a partir de resíduos orgânicos municipais; n.a. = não apresentado.

Fonte: A autora.

O Quadro 20 exibe intervalos de valores de $\mathrm{P}, \mathrm{K}, \mathrm{Ca}, \mathrm{Mg}$ e $\mathrm{S}$, para fertilizantes orgânicos, que permitem classificar os compostos em geral com baixa, média ou alta concentração destes respectivos elementos. Analisando os compostos estudados, com exceção da ocorrência do P para o composto total e do Ca para os compostos total e indiano que podem ser enquadradas como médias concentrações, os teores de todos os outros elementos para todos os compostos podem ser categorizados como baixos para uma possível aplicação agrícola. Esse é um fator que não favorece o crescimento vegetal, por exemplo, em uma utilização destes compostos como um sistema de cobertura vegetada em área de disposição de resíduo de mineração.

Quadro 20 - Escala de valores $\left(\mathrm{g} \mathrm{kg}^{-1}\right.$ ) para fertilizantes orgânicos com umidade natural

\begin{tabular}{|c|c|c|c|}
\hline \hline $\begin{array}{c}\text { Elementos } \\
\left(\mathbf{g ~ k g}^{-1}\right)\end{array}$ & Baixo & Médio & Alto \\
\hline \hline $\mathrm{P}$ & Abaixo de 2,18 & Entre 2,18 e 6,55 & Acima de 6,55 \\
\hline $\mathrm{K}$ & Abaixo de 4,15 & Entre 4,15 e 12,45 & Acima de 12,45 \\
\hline $\mathrm{Ca}$ & Abaixo de 15 & Entre 15 e 30 & Acima de 30 \\
\hline $\mathrm{Mg}$ & Abaixo de 6 & Entre 6 e 12 & Acima de 12 \\
\hline $\mathrm{S}$ & Abaixo de 2 & Entre 2 e 5 & Acima de 5 \\
\hline \hline
\end{tabular}

Fonte: Kiehl (1985). 


\subsubsection{Carbono orgânico}

A Tabela 48 exibe os resultados referentes aos teores de carbono orgânico para os quatro compostos analisados, considerando os materiais secos em estufa a $65^{\circ} \mathrm{C}$. De modo geral, é possível constatar baixos teores de carbono orgânico nas amostras, variando de 8,08\% para o composto estático até $10,69 \%$ para o composto total.

Tabela 48 - Teor de carbono orgânico obtido nos compostos: total, indiano, alambrado e estático, secos a $65^{\circ} \mathrm{C}$

\begin{tabular}{cc}
\hline \hline Amostras & $\begin{array}{c}\text { Carbono orgânico } \\
(\boldsymbol{\%})\end{array}$ \\
\hline Composto total & 10,69 \\
\hline Composto indiano & 8,32 \\
\hline Composto alambrado & 10,16 \\
\hline Composto estático & 8,08 \\
\hline \hline
\end{tabular}

Fonte: A autora.

Comparando os teores de carbono orgânico (Tabela 48) com os valores de carbono total obtidos pela análise elementar (Tabelas 41 e 42) é possível perceber que os valores são bem similares, principalmente para os compostos total e indiano. A única exceção mais marcante é o composto alambrado. Contudo, novamente como estes materiais apresentam certa heterogeneidade (principalmente quanto ao tamanho), essa pode ser uma hipótese para essa divergência de valores, já que se espera que os compostos apresentem valores bem reduzidos de carbono inorgânico.

\subsubsection{Matéria orgânica (MO)}

A Tabela 49 apresenta os teores de matéria orgânica (MO) dos compostos, lembrando que estes materiais haviam sido secos ao ar. É possível observar que os maiores valores são similares e referentes aos compostos total $\left(376,17 \pm 51,00 \mathrm{~g} \mathrm{~kg}^{-1}\right)$ e indiano $(418,70 \pm 24,21 \mathrm{~g}$ $\mathrm{kg}^{-1}$ ), que apresentam justamente uma coloração mais escura, característica da matéria orgânica em avançado grau de decomposição. O composto alambrado exibiu o menor valor $(193,92 \pm$ $\left.21,70 \mathrm{~g} \mathrm{~kg}^{-1}\right)$. 
Tabela 49 - Teor de matéria orgânica - MO $\left(\mathrm{g} \mathrm{kg}^{-1}\right)$ para os compostos: total, indiano, alambrado e estático

\begin{tabular}{ccccc}
\hline \hline $\begin{array}{c}\text { Amostra } \\
\text { (Triplicata) }\end{array}$ & $\begin{array}{c}\text { Composto } \\
\text { total }\end{array}$ & $\begin{array}{c}\text { Composto } \\
\text { indiano }\end{array}$ & $\begin{array}{c}\text { Composto } \\
\text { alambrado }\end{array}$ & $\begin{array}{c}\text { Composto } \\
\text { estático }\end{array}$ \\
\hline \hline $\mathrm{C} 1$ & 431,28 & 416,98 & 218,98 & 220,57 \\
\hline $\mathrm{C} 2$ & 330,63 & 443,73 & 181,13 & 213,50 \\
\hline $\mathrm{C} 3$ & 366,60 & 395,40 & 181,66 & 220,51 \\
\hline \hline Valor médio & $\mathbf{3 7 6 , 1 7}$ & $\mathbf{4 1 8 , 7 0}$ & $\mathbf{1 9 3 , 9 2}$ & $\mathbf{2 1 8 , 1 9}$ \\
\hline Desvio padrão & $\mathbf{5 1 , 0 0}$ & $\mathbf{2 4 , 2 1}$ & $\mathbf{2 1 , 7 0}$ & $\mathbf{4 , 0 6}$ \\
\hline \hline
\end{tabular}

Fonte: A autora.

Para efeito de comparação, a Tabela 50 exibe valores de matéria orgânica para compostos de variadas localidades. A análise destes dados permite perceber que os compostos total e indiano, estudados nesta pesquisa, revelaram teores de matéria orgânica medianos a baixos, em relação aos compostos de comparação. Já os compostos alambrado e estático exibiram valores bem reduzidos de matéria orgânica. Por conseguinte, como as moléculas de matéria orgânica favorecem a adsorção de íons metálicos, neste quesito, os compostos indiano e total podem ser categorizados como mais favoráveis para a adsorção em relação aos compostos alambrado e estático.

Em relação à turfa, seu teor de matéria orgânica foi de $520,43 \pm 2,08 \mathrm{~g} \mathrm{~kg}^{-1}$, valor superior a todos os compostos orgânicos estudados. Como a matéria orgânica apresenta uma função tão crucial na adsorção, seria interessante não apenas a comparação de turfa e compostos orgânicos em termos totais, mas também em relação a humificação, através, por exemplo, da presença de ácidos húmicos e fúlvicos. 
Tabela 50 - Teores de matéria orgânica (MO) para compostos de localidades nacionais e internacionais

\begin{tabular}{|c|c|c|c|c|}
\hline $\begin{array}{l}\text { Origem do } \\
\text { composto }\end{array}$ & $\begin{array}{c}\text { Material } \\
\text { compostado }\end{array}$ & $\begin{array}{c}\text { MO } \\
\left(\mathrm{g} \mathrm{kg}^{-1}\right)\end{array}$ & Metodologia & Autor \\
\hline São Carlos & $\begin{array}{l}\text { Resíduo orgânico } \\
\text { municipal }\end{array}$ & $218-422,4$ & $\begin{array}{c}\text { Perda por ignição } \\
\text { a } 550^{\circ} \mathrm{C}(\text { KIEHL, } \\
1985)\end{array}$ & $\begin{array}{l}\text { Massukado } \\
(2008)^{*}\end{array}$ \\
\hline Europa & $\begin{array}{l}\text { Resíduo sólido } \\
\text { municipal }\end{array}$ & $422 \pm 37$ & $\begin{array}{l}450^{\circ} \mathrm{C} \text { por uma } \\
\text { noite }\end{array}$ & $\begin{array}{l}\text { Farrell e Jones } \\
(2010 \mathrm{~b})^{* *}\end{array}$ \\
\hline São Carlos & $\begin{array}{l}\text { Resíduo orgânico } \\
\text { municipal, grama } \\
\text { e serragem }\end{array}$ & $811,3-861,8$ & $550^{\circ} \mathrm{C}$ por 4 horas & $\begin{array}{l}\text { Guermandi } \\
(2015)^{* * *}\end{array}$ \\
\hline \multirow{2}{*}{ Espanha } & $\begin{array}{l}\text { Resíduo orgânico } \\
\text { municipal }\end{array}$ & 560 & \multirow{2}{*}{ Perda por ignição } & \multirow{2}{*}{$\begin{array}{l}\text { Venegas, Rigol } \\
\text { e Vidal (2015) }\end{array}$} \\
\hline & $\begin{array}{l}\text { Resíduo sólido } \\
\text { municipal }\end{array}$ & 770 & & \\
\hline
\end{tabular}

Fonte: A autora.

\subsubsection{Teor de cinzas $(\mathrm{Cz})$}

A Tabela 51 apresenta os teores de cinza $(\mathrm{Cz})$ encontrados para os compostos orgânicos. Como este parâmetro é inversamente dependente da presença orgânica, estes resultados possibilitam concluir que como os compostos ensaiados revelaram medianos a baixos teores de matéria orgânica, por conseguinte, seus teores de cinza foram medianos a elevados.

Tabela 51 - Teor de cinzas - $\mathrm{Cz}\left(\mathrm{g} \mathrm{kg}^{-1}\right)$ para os compostos: total, indiano, alambrado e estático

\begin{tabular}{ccccc}
\hline $\begin{array}{c}\text { Amostra } \\
\text { (Triplicata) }\end{array}$ & $\begin{array}{c}\text { Composto } \\
\text { total }\end{array}$ & $\begin{array}{c}\text { Composto } \\
\text { indiano }\end{array}$ & $\begin{array}{c}\text { Composto } \\
\text { alambrado }\end{array}$ & $\begin{array}{c}\text { Composto } \\
\text { estático }\end{array}$ \\
\hline $\mathrm{C} 1$ & 568,72 & 583,02 & 781,02 & 779,43 \\
\hline $\mathrm{C} 2$ & 669,37 & 556,27 & 818,87 & 786,50 \\
\hline $\mathrm{C} 3$ & 633,40 & 604,60 & 818,34 & 779,49 \\
\hline \hline Valor médio & $\mathbf{6 2 3 , 8 3}$ & $\mathbf{5 1 8 , 3 0}$ & $\mathbf{8 0 6 , 0 8}$ & $\mathbf{7 8 1 , 8 1}$ \\
\hline Desvio padrão & $\mathbf{5 1 , 0 0}$ & $\mathbf{2 4 , 2 1}$ & $\mathbf{2 1 , 7 0}$ & $\mathbf{4 , 0 6}$ \\
\hline \hline
\end{tabular}

Fonte: A autora. 
O maior teor de cinzas foi obtido para o composto alambrado $(806,08 \pm 21,70 \%)$ e o menor para o composto indiano $(518,30 \pm 24,21 \%)$ (Tabela 51). Todos os compostos exibiram valores de teor de cinzas superiores a $50 \%$.

Em caso de utilização agrícola, é vantajoso que o fertilizante orgânico apresente elevada porcentagem de resíduo mineral solúvel. Inclusive, durante o processo de compostagem, ocorre uma transformação da matéria orgânica em sais solúveis, elevando o teor de resíduo mineral solúvel. Uma vez que as plantas assimilam somente sais minerais solúveis e sabendo que os nutrientes presentes na matéria orgânica precisam passar para a forma mineral para se tornarem passíveis de assimilação, altos teores de resíduos minerais solúveis presentes em um composto podem indicar uma adiantada fase de mineralização da matéria orgânica (KIEHL, 1985). Desse modo, como as concentrações de $\mathrm{P}, \mathrm{K}, \mathrm{Ca}, \mathrm{Mg}$ e S foram reduzidas, provavelmente a fração de resíduo mineral solúvel presentes nos compostos também é reduzida.

Em relação à turfa estudada, como seu teor de matéria orgânica foi superior aos compostos, seu teor de cinzas foi de 479,57 $\pm 2,08 \mathrm{~g} \mathrm{~kg}^{-1}$, valor inferior a todos os compostos orgânicos.

\subsubsection{Absorção Atômica (AA)}

A Tabela 52 mostra as concentrações de uma série de metais (chumbo, zinco, cádmio, cobre, cromo, níquel, ferro e alumínio) para cada um dos compostos estudados. Em relação aos metais de interesse nessa pesquisa ( $\mathrm{Pb}, \mathrm{Zn}$ e $\mathrm{Cd}$ ), conforme dados da Tabela 52, os valores de $\mathrm{Pb}$ variaram de 3,0 a 21,0 $\mathrm{mg} \mathrm{kg}^{-1}$, sendo que o composto estático exibiu a maior concentração de $\mathrm{Pb}$ e o composto indiano a menor. Para o $\mathrm{Zn}$, observou-se que a concentração deste metal nos quatro compostos variou de 50,60 a 132,80 mg kg-1. A maior concentração de $\mathrm{Zn}$ foi obtida no composto total e a menor no composto alambrado. Nos compostos indiano e alambrado o Cd apresentou valores abaixo do limite de quantificação do aparelho usado nesta determinação $\left(<0,06 \mathrm{mg} \mathrm{kg}^{-1}\right)$. A maior concentração de Cd foi obtida para o composto total $\left(1,3 \mathrm{mg} \mathrm{kg}^{-1}\right)$.

Notou-se ainda, concentrações elevadas de Fe nos quatro compostos, sendo que esses valores variaram de 14.660 a $27.190 \mathrm{mg} \mathrm{kg}^{-1}$. A maior concentração de Fe foi obtida no composto estático e a menor no composto indiano. O Al também foi outro elemento que apresentou elevada concentração, sendo que essa variou de 22.170 a $37.520 \mathrm{mg} \mathrm{kg}^{-1}$. A maior concentração de Al foi obtida na amostra de composto estático e a menor no composto indiano, similar ao que ocorreu com o Fe (Tabela 52). A maior concentração de $\mathrm{Cr}$ foi determinada no composto alambrado $\left(6,1 \mathrm{mg} \mathrm{kg}^{-1}\right)$ e a menor no composto total $\left(1,8 \mathrm{mg} \mathrm{kg}^{-1}\right)$ (Tabela 52). Já a 
menor presença de $\mathrm{Cu}$ foi referente ao composto alambrado (abaixo do limite de quantificação $\left.<0,3 \mathrm{mg} \mathrm{kg}^{-1}\right)$ e a maior concentração foi obtida para o composto total $\left(12,8 \mathrm{mg} \mathrm{kg}^{-1}\right)$.

Tabela 52 - Concentrações de metais $\left(\mathrm{mg} \mathrm{kg}^{-1}\right)$ para os compostos: total, indiano, alambrado e estático

\begin{tabular}{ccccc}
\hline $\begin{array}{c}\text { Elementos } \\
\left(\mathbf{m g ~ k g}^{-1}\right)\end{array}$ & $\begin{array}{c}\text { Composto } \\
\text { total }\end{array}$ & $\begin{array}{c}\text { Composto } \\
\text { indiano }\end{array}$ & $\begin{array}{c}\text { Composto } \\
\text { alambrado }\end{array}$ & $\begin{array}{c}\text { Composto } \\
\text { estático }\end{array}$ \\
\hline \hline $\mathrm{Pb}$ & 11,0 & 3,0 & 6,0 & 21,0 \\
\hline $\mathrm{Zn}$ & 132,80 & 54,01 & 50,60 & 55,80 \\
\hline $\mathrm{Cd}$ & 1,3 & $<0,06$ & $<0,06$ & 0,5 \\
\hline $\mathrm{Cu}$ & 12,8 & 3,8 & $<0,3$ & 1,9 \\
\hline $\mathrm{Cr}$ & 1,8 & 5,9 & 6,1 & 4,5 \\
\hline $\mathrm{Ni}$ & 1,6 & $<0,8$ & $<0,8$ & 1,7 \\
\hline $\mathrm{Fe}$ & 16.390 & 14.660 & 23.430 & 27.190 \\
\hline $\mathrm{Al}$ & 25.260 & 22.170 & 31.780 & 37.520 \\
\hline \hline
\end{tabular}

Fonte: A autora.

A título de comparação, o Quadro 21 contém os limites máximos admitidos para alguns destes metais em fertilizantes orgânicos, segundo o Anexo V da Instrução Normativa n²7/2006 (MAPA, 2006). Analisando os dados pode-se observar que para os metais apresentados na Instrução Normativa e nos resultados da absorção atômica, os valores encontrados para todos os compostos estudados são, de modo geral, inferiores aos presentes na norma. Por conseguinte, esta constatação favorece a utilização destes compostos como materiais reativos em barreiras, afinal, mesmo sendo outra finalidade daquela apresentada na norma, trata-se também de uma aplicação no ambiente, com um posterior contato direto com o solo e o ecossistema do entorno.

Quadro 21 - Limites máximos de alguns metais admitidos em fertilizantes orgânicos

\begin{tabular}{|c|c|}
\hline \hline Metais & $\begin{array}{c}\text { Concentração } \\
\left(\mathbf{m g ~ k g}^{-1}\right)\end{array}$ \\
\hline \hline $\mathrm{Pb}$ & 150,00 \\
\hline $\mathrm{Cd}$ & 3,00 \\
\hline $\mathrm{Cr}$ & 200,00 \\
\hline $\mathrm{Ni}$ & 70,00 \\
\hline \hline
\end{tabular}

Fonte: Instrução Normativa n²27/2006 (MAPA, 2006). 
Estudos de diferentes autores também apresentam concentrações de metais para compostos de diferentes origens, nacionais e internacionais a partir da compostagem de resíduos sólidos municipais ou resíduos orgânicos (Tabela 53). A análise destes dados permite observar uma grande amplitude de variação entre as concentrações metálicas, sendo que, os compostos trabalhados nesta pesquisa, apresentaram reduzidas concentrações, mas que podem ser enquadradas como típicas desse tipo de compostos. De modo geral, chama a atenção as elevadas concentrações de $\mathrm{Pb}$ referentes aos compostos internacionais exibidos nos trabalhos de Farrell e Jones (2010b) e Simantiraki et al. (2013) e a grande variação de concentrações de $\mathrm{Pb}$ encontrada por Guermandi (2015) variando a tipologia de leira. Estas constatações sugerem a necessidade de um acompanhamento e de uma análise mais pormenorizada a fim de se descobrir como esse $\mathrm{Pb}$ foi assimilado ao composto, seja através do substrato inicial, seja ao longo do processo de compostagem. Farrell e Jones (2010a), avaliaram alguns parâmetros referentes a resíduos verdes e resíduos alimentares utilizados como matéria prima para a compostagem e encontraram, respectivamente, concentrações de $\mathrm{Pb}$ de $51,9 \pm 6,9 \mathrm{mg} \mathrm{kg}^{-1} \mathrm{e}$ 4,3 $\pm 1,9 \mathrm{mg} \mathrm{kg}^{-1}$, em termos de matéria seca. Além disso, estudos mostram conteúdos de nutrientes maiores e de metais potencialmente tóxicos significativamente menores na matriz compostável originada da segregação na fonte em relação a fração orgânica advinda da posterior segregação, a qual pode potencializar a migração de metais presentes nos materiais não compostáveis (SAHA; PANWAR; SINGH, 2010; HUERTA-PUJOL et al., 2011).

Tabela 53 - Concentrações de metais $\left(\mathrm{mg} \mathrm{kg}^{-1}\right)$ para compostos nacionais e internacionais

\begin{tabular}{cccccc}
\hline $\begin{array}{c}\text { Metais } \\
\left(\mathbf{m g ~ k g}^{-1}\right)\end{array}$ & $\begin{array}{c}\text { Massukado } \\
\mathbf{( 2 0 0 8 ) *}\end{array}$ & $\begin{array}{c}\text { Farrell e } \\
\text { Jones } \\
(\mathbf{2 0 1 0 b}) * *\end{array}$ & $\begin{array}{c}\text { Simantiraki et } \\
\text { al. }(\mathbf{2 0 1 3}) * * *\end{array}$ & $\begin{array}{c}\text { Guermandi } \\
(\mathbf{2 0 1 5}) * * * *\end{array}$ & $\begin{array}{c}\text { Venegas, } \\
\text { Rigol e Vidal } \\
(\mathbf{2 0 1 5}) * * * * *\end{array}$ \\
\hline \hline $\mathrm{Pb}$ & $<1,0-23,0$ & $906 \pm 324$ & $77,52-774,53$ & $12-131,6$ & 89 \\
\hline $\mathrm{Zn}$ & $49,5-147,18$ & $505 \pm 216$ & $218,81-1.697,00$ & $119,6-155,6$ & 523 \\
\hline $\mathrm{Cd}$ & $<0,5-<1,0$ & n.a. & $<1 . q$. & $<0,04$ & 2,9 \\
\hline $\mathrm{Cu}$ & $16,2-57,76$ & $329 \pm 83$ & $126,15-1.269,14$ & $12,4-29,2$ & 168 \\
\hline $\mathrm{Cr}$ & $<0,5-31,1$ & $48,1 \pm 13,3$ & $38,45-258,72$ & $2,0-23,2$ & n.a. \\
\hline $\mathrm{Ni}$ & $<0,5-2,1$ & $87,2 \pm 19,2$ & $19,49-203,15$ & $26,0-48,0$ & 40 \\
\hline $\mathrm{Fe}$ & $25.240-33.270$ & n.a. & n.a & $2.072,0-3.344,0$ & 9.660 \\
\hline $\mathrm{Al}$ & n.a. & n.a. & n.a. & n.a. & 18.240 \\
\hline \hline
\end{tabular}


Continuação da Tabela 53.

* Considerando os dados referentes às compostagens do pátio e da horta de São Carlos;

** Apenas a fração de finos dos resíduos sólidos municipais $(<5 \mathrm{~cm})$ foi utilizada e ela continha $64 \pm 3 \%$ de matéria orgânica;

*** As concentrações metálicas apresentaram uma grande variação em função da sazonalidade e entre os compostos fresco e maturado. Os dados tabelados apresentam, de modo geral, os valores menor e maior;

**** Foram empregados variados tratamentos em cada leira: trituração e revolvimento, não trituração e revolvimento, não trituração e não-revolvimento e não trituração e não revolvimento com tubos de PVC;

***** Compostos a partir de resíduos orgânicos municipais;

< 1.q. = inferior ao limite de quantificação;

n.a. = não apresentado.

Fonte: A autora.

\subsubsection{Capacidade de troca catiônica (CTC) e superfície específica (SE)}

A Tabela 54 apresenta os valores de capacidade de troca catiônica (CTC) e a Tabela 55 lista os dados de superfície específica (SE), ambos os parâmetros determinados pelo método de azul de metileno.

Tabela 54 - Capacidade de troca catiônica $\left(\mathrm{cmol}_{\mathrm{c}} \mathrm{kg}^{-1}\right)$ para os compostos: total, indiano, alambrado e estático (Ensaio do azul de metileno)

\begin{tabular}{ccccc}
\hline \hline $\begin{array}{c}\text { Amostra } \\
\text { (Triplicata) }\end{array}$ & $\begin{array}{c}\text { Composto } \\
\text { total }\end{array}$ & $\begin{array}{c}\text { Composto } \\
\text { indiano }\end{array}$ & $\begin{array}{c}\text { Composto } \\
\text { alambrado }\end{array}$ & $\begin{array}{c}\text { Composto } \\
\text { estático }\end{array}$ \\
\hline \hline $\mathrm{C} 1$ & 15,84 & 14,48 & 9,60 & 10,96 \\
\hline $\mathrm{C} 2$ & 14,37 & 15,81 & 7,83 & 10,20 \\
\hline $\mathrm{C} 3$ & 17,73 & 12,42 & 7,66 & 9,33 \\
\hline \hline Valor médio & $\mathbf{1 5 , 9 8}$ & $\mathbf{1 4 , 2 4}$ & $\mathbf{8 , 3 6}$ & $\mathbf{1 0 , 1 6}$ \\
\hline Desvio padrão & $\mathbf{1 , 6 9}$ & $\mathbf{1 , 7 1}$ & $\mathbf{1 , 0 7}$ & $\mathbf{0 , 8 1}$ \\
\hline \hline
\end{tabular}

Fonte: A autora.

Tabela 55 - Superfície específica $\left(\mathrm{m}^{2} \mathrm{~g}^{-1}\right)$ para os compostos: total, indiano, alambrado e estático (Ensaio do azul de metileno)

\begin{tabular}{ccccc}
\hline $\begin{array}{c}\text { Amostra } \\
\text { (Triplicata) }\end{array}$ & $\begin{array}{c}\text { Composto } \\
\text { total }\end{array}$ & $\begin{array}{c}\text { Composto } \\
\text { indiano }\end{array}$ & $\begin{array}{c}\text { Composto } \\
\text { alambrado }\end{array}$ & $\begin{array}{c}\text { Composto } \\
\text { estático }\end{array}$ \\
\hline $\mathrm{C} 1$ & 123,95 & 113,32 & 75,13 & 85,75 \\
\hline $\mathrm{C} 2$ & 112,47 & 123,78 & 61,26 & 79,83 \\
\hline $\mathrm{C} 3$ & 138,79 & 97,18 & 59,97 & 73,01 \\
\hline \hline Valor médio & $\mathbf{1 2 5 , 0 7}$ & $\mathbf{1 1 1 , 4 2}$ & $\mathbf{6 5 , 4 5}$ & $\mathbf{7 9 , 5 3}$ \\
\hline Desvio padrão & $\mathbf{1 3 , 2 0}$ & $\mathbf{1 3 , 4 0}$ & $\mathbf{8 , 4 1}$ & $\mathbf{6 , 3 7}$ \\
\hline \hline
\end{tabular}

Fonte: A autora. 
A partir da determinação da CTC pelo método de azul de metileno, notou-se que o composto total exibiu o maior valor médio para este parâmetro $\left(15,98 \pm 1,69 \mathrm{cmol}_{\mathrm{c}} \mathrm{kg}^{-1}\right)$ e o composto alambrado apresentou o menor valor médio $\left(8,36 \pm 1,07 \mathrm{cmol}_{\mathrm{c}} \mathrm{kg}^{-1}\right)$ (Tabela 54). Quanto a SE, verificou-se como esperado, novamente que o composto total apresentou maior valor médio $\left(125,07 \pm 13,20 \mathrm{~m}^{2} \mathrm{~g}^{-1}\right)$ e o composto alambrado o menor valor médio $(65,45 \pm$ $\left.8,41 \mathrm{~m}^{2} \mathrm{~g}^{-1}\right)$ (Tabela 55).

A CTC também foi determinada segundo o método de titulometria (Tabela 56). Comparando-se os resultados listados nas Tabelas 54 e 56 (CTC pelo método de azul de metileno e CTC pelo método de titulometria, respectivamente), foi possível constatar que foram obtidos resultados superiores no método de titulometria, que variaram de 29,00 a 75,00 $\mathrm{cmol}_{\mathrm{c}}$ $\mathrm{kg}^{-1}$.

Tabela 56 - Capacidade de troca catiônica $\left(\mathrm{cmol}_{\mathrm{c}} \mathrm{kg}^{-1}\right)$ para os compostos: total, indiano, alambrado e estático (Titulometria)

\begin{tabular}{cc}
\hline \hline Amostras & $\begin{array}{c}\text { CTC } \\
\left(\mathbf{c m o l}_{\mathbf{~ k g}} \mathbf{~ k}^{-1}\right)\end{array}$ \\
\hline \hline Composto total & 75,00 \\
\hline Composto indiano & 34,00 \\
\hline Composto alambrado & 32,00 \\
\hline Composto estático & 29,00 \\
\hline \hline
\end{tabular}

Fonte: A autora.

A Tabela 57 exibe valores de CTC para compostos de diferentes localidades, tanto nacionais como internacionais. Realizando uma comparação com esta pesquisa, pode-se notar que a CTC dos compostos estudados é mediana a elevada em relação aos dados da literatura apresentados. 
Tabela 57 - Valores de CTC para compostos de diversas localidades nacionais e internacionais

\begin{tabular}{ccccc}
\hline Origem & $\begin{array}{c}\text { Material } \\
\text { compostado }\end{array}$ & $\begin{array}{c}\text { CTC } \\
\left(\mathbf{c m o l} \mathbf{~ k g}^{-1}\right)\end{array}$ & Metodologia & Autor \\
\hline \hline $\begin{array}{c}\text { Usinas de } \\
\text { compostagem } \\
\text { do estado de } \\
\text { São Paulo }\end{array}$ & $\begin{array}{c}\text { Resíduo sólido } \\
\text { urbano }\end{array}$ & $23,87-32,67$ & Não especificado & Barreira (2005) \\
\hline São Carlos & $\begin{array}{c}\text { Resíduo orgânico } \\
\text { municipal }\end{array}$ & $19,4-38,7$ & $\begin{array}{c}\text { Titulometria (extração } \\
\text { com HCl, adição de } \\
\text { acetato de cálcio e } \\
\text { titulação com NaOH) }\end{array}$ & $\begin{array}{c}\text { Massukado } \\
(2008)^{*}\end{array}$ \\
\hline São Carlos & $\begin{array}{c}\text { Resíduo orgânico } \\
\text { municipal, grama } \\
\text { e serragem }\end{array}$ & $76,2-90,8$ & $\begin{array}{c}\text { Titulometria (extração } \\
\text { com HCl, adição de } \\
\text { acetato de cálcio e } \\
\text { titulação com NaOH) }\end{array}$ & $\begin{array}{c}\text { Guermandi } \\
\text { (2015)** }\end{array}$ \\
\hline Espanha & $\begin{array}{c}\text { Resíduo orgânico } \\
\text { municipal }\end{array}$ & 105 & Não especificado & $\begin{array}{c}\text { Venegas, Rigol } \\
\text { e Vidal (2015) }\end{array}$ \\
\cline { 2 - 4 } & $\begin{array}{c}\text { Resíduo sólido } \\
\text { municipal }\end{array}$ & 102 & & \\
\hline
\end{tabular}

* Considerando os dados referentes às compostagens do pátio e da horta de São Carlos;

** Foram empregados variados tratamentos em cada leira: trituração e revolvimento, não trituração e revolvimento, não trituração e não-revolvimento e não trituração e não revolvimento com tubos de PVC.

Fonte: A autora.

\subsubsection{Difratometria de Raios-X (DRX)}

A análise das informações resultantes da Difratometria de Raios-X para a porção mineral dos compostos revela, assim como para a turfa, uma presença marcante de quartzo e alumina, conforme pode ser visualizado pelos gráficos apresentados na Figura 91. 
Figura 91 - DRX da porção mineral dos compostos.

A) Composto total; B) Composto indiano; C) Composto alambrado D) Composto estático
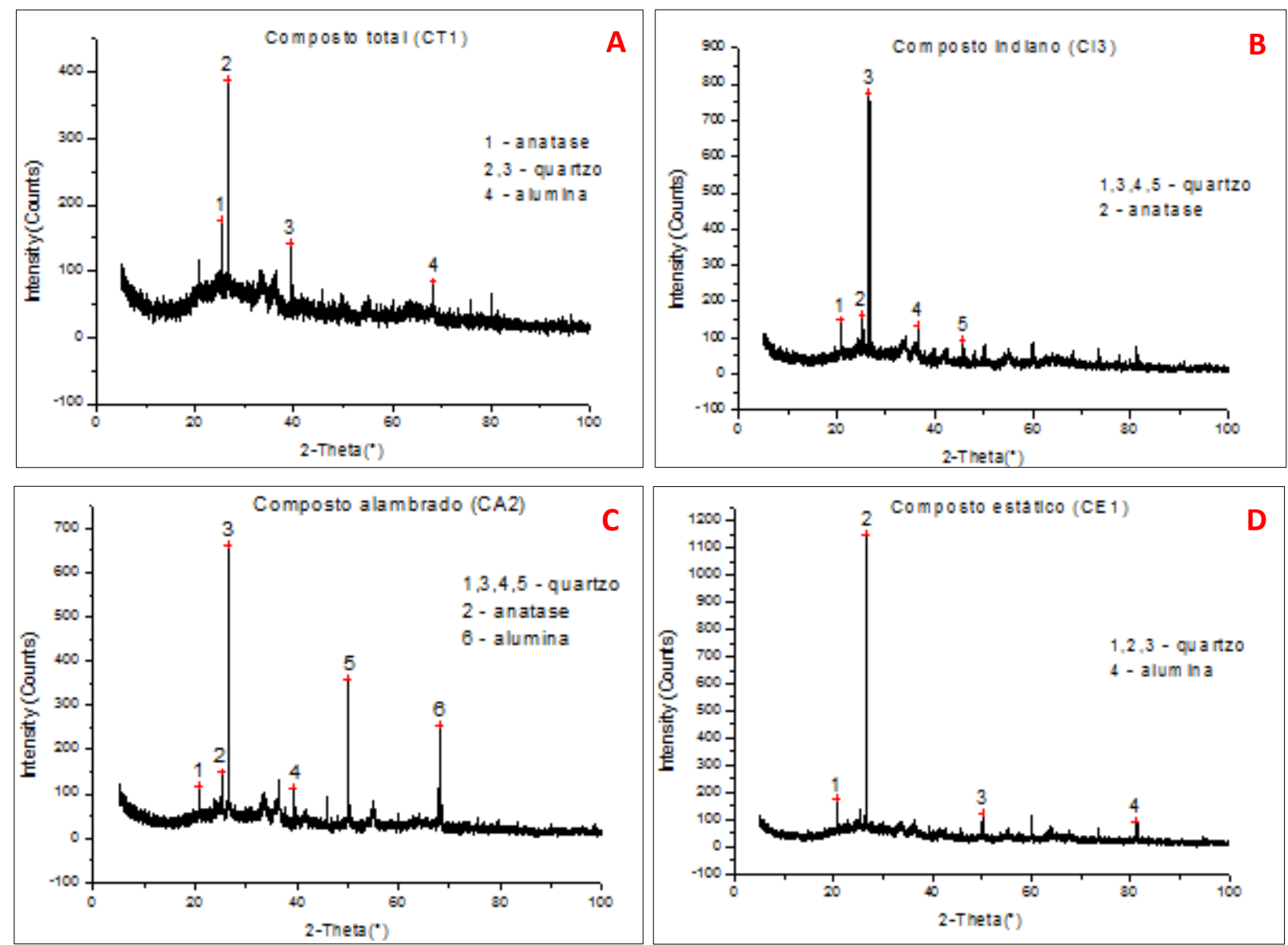

Fonte: A autora.

\subsubsection{Fluorescência de Raios-X (FRX)}

A Tabela 58 revela as médias seguidas dos respectivos desvios padrões obtidos para as análises em triplicata de cada composto. Esses dados permitem constatar que sobressaíram as concentrações dos óxidos $\mathrm{SiO}_{2}, \mathrm{Al}_{2} \mathrm{O}_{3}$ e $\mathrm{Fe}_{2} \mathrm{O}_{3}$, que juntos perfazem mais de $50 \%$ da composição de todos os compostos. Corroborando com estes resultados, na absorção atômica foi encontrada uma grande quantidade dos elementos Fe e Al e no DRX foi detectada a presença de quartzo e alumina. De modo geral, posteriormente, se destaca a presença de $\mathrm{CaO}, \mathrm{P}_{2} \mathrm{O}_{5} \mathrm{e}$ $\mathrm{SO}_{3}$, sendo que as concentrações destes óxidos são consideravelmente superiores no composto total. Novamente, é quase certo que isso se deve as matérias-primas compostadas, que diferentemente dos demais compostos apresentam, neste caso, condimentos. 
Tabela 58 - Valores médios para a análise química dos compostos por Fluorescência de Raios-X

\begin{tabular}{|c|c|c|c|c|}
\hline $\begin{array}{c}\text { Óxidos } \\
(\%)\end{array}$ & $\begin{array}{c}\text { Composto } \\
\text { total }\end{array}$ & $\begin{array}{l}\text { Composto } \\
\text { indiano* }\end{array}$ & $\begin{array}{l}\text { Composto } \\
\text { alambrado* }\end{array}$ & $\begin{array}{l}\text { Composto } \\
\text { estático* }\end{array}$ \\
\hline $\mathrm{SiO}_{2}$ & $38,367 \pm 2,312$ & $44,467 \pm 1,002$ & $57,867 \pm 2,802$ & $55,200 \pm 1,908$ \\
\hline $\mathrm{Al}_{2} \mathrm{O}_{3}$ & $10,630 \pm 0,807$ & $11,000 \pm 0,300$ & $14,667 \pm 1,069$ & $14,800 \pm 0,346$ \\
\hline $\mathrm{Fe}_{2} \mathrm{O}_{3}$ & $5,567 \pm 0,549$ & $5,807 \pm 0,087$ & $6,813 \pm 0,287$ & $6,657 \pm 0,318$ \\
\hline $\mathrm{CaO}$ & $3,837 \pm 0,581$ & $1,640 \pm 0,125$ & $0,876 \pm 0,121$ & $0,762 \pm 0,029$ \\
\hline $\mathrm{P}_{2} \mathrm{O}_{5}$ & $1,147 \pm 0,099$ & $0,591 \pm 0,053$ & $0,635 \pm 0,051$ & $0,619 \pm 0,013$ \\
\hline $\mathrm{SO}_{3}$ & $1,140 \pm 0,075$ & $0,563 \pm 0,033$ & $0,349 \pm 0,043$ & $0,398 \pm 0,020$ \\
\hline $\mathrm{TiO}_{2}$ & $1,103 \pm 0,093$ & $1,110 \pm 0,036$ & $1,430 \pm 0,104$ & $1,430 \pm 0,070$ \\
\hline $\mathrm{K}_{2} \mathrm{O}$ & $0,423 \pm 0,043$ & $0,761 \pm 0,068$ & $0,443 \pm 0,069$ & $0,205 \pm 0,003$ \\
\hline $\mathrm{MgO}$ & $0,333 \pm 0,024$ & $0,379 \pm 0,015$ & $0,246 \pm 0,031$ & $0,194 \pm 0,031$ \\
\hline $\mathrm{Cr}_{2} \mathrm{O}_{3}$ & $0,127 \pm 0,021$ & $0,145 \pm 0,012$ & $0,104 \pm 0,014$ & $0,093 \pm 0,016$ \\
\hline $\mathrm{Na}_{2} \mathrm{O}$ & $0,108 \pm 0,013$ & $0,001 \pm 0,000$ & $0,001 \pm 0,000$ & $0,021 \pm 0,034$ \\
\hline $\mathrm{Cl}$ & $0,090 \pm 0,010$ & $0,050 \pm 0,000$ & $0,033 \pm 0,006$ & $0,017 \pm 0,015$ \\
\hline $\mathrm{WO}_{3}$ & $0,039 \pm 0,065$ & $0,023 \pm 0,022$ & $0,001 \pm 0,000$ & $0,001 \pm 0,000$ \\
\hline $\mathrm{MnO}$ & $0,033 \pm 0,006$ & $0,043 \pm 0,003$ & $0,031 \pm 0,004$ & $0,029 \pm 0,002$ \\
\hline $\mathrm{ZrO}_{2}$ & $0,032 \pm 0,001$ & $0,035 \pm 0,002$ & $0,046 \pm 0,002$ & $0,047 \pm 0,003$ \\
\hline $\mathrm{ZnO}$ & $0,025 \pm 0,004$ & $0,013 \pm 0,001$ & $0,013 \pm 0,002$ & $0,011 \pm 0,001$ \\
\hline $\mathrm{SrO}$ & $0,014 \pm 0,003$ & $0,008 \pm 0,001$ & $0,005 \pm 0,001$ & $0,004 \pm 0,000$ \\
\hline $\mathrm{NiO}$ & $0,010 \pm 0,008$ & $0,009 \pm 0,002$ & $0,006 \pm 0,001$ & $0,006 \pm 0,000$ \\
\hline $\mathrm{CuO}$ & $0,010 \pm 0,003$ & $0,007 \pm 0,001$ & $0,006 \pm 0,001$ & $0,006 \pm 0,001$ \\
\hline $\mathrm{MoO}_{3}$ & $0,008 \pm 0,012$ & $0,004 \pm 0,006$ & $0,001 \pm 0,000$ & $0,001 \pm 0,000$ \\
\hline $\mathrm{CeO}_{2}$ & $0,008 \pm 0,016$ & $0,007 \pm 0,010$ & $0,010 \pm 0,016$ & $0,007 \pm 0,010$ \\
\hline $\mathrm{Nb}_{2} \mathrm{O}_{5}$ & $0,005 \pm 0,001$ & $0,003 \pm 0,002$ & $0,006 \pm 0,001$ & $0,006 \pm 0,001$ \\
\hline $\mathrm{SeO}_{2}$ & $0,002 \pm 0,002$ & $0,001 \pm 0,000$ & $0,001 \pm 0,000$ & $0,001 \pm 0,000$ \\
\hline $\mathrm{V}_{2} \mathrm{O}_{5}$ & $0,001 \pm 0,000$ & $0,001 \pm 0,000$ & $0,011 \pm 0,017$ & $0,012 \pm 0,020$ \\
\hline $\mathrm{Ga}_{2} \mathrm{O}_{3}$ & $0,001 \pm 0,000$ & $0,001 \pm 0,000$ & $0,002 \pm 0,001$ & $0,001 \pm 0,000$ \\
\hline $\mathrm{PF}^{* *}$ & $37,0 \pm 0,4$ & $33,3 \pm 0,8$ & $16,4 \pm 1,3$ & $19,5 \pm 1,5$ \\
\hline Fechamento & $100,064 \pm 0,016$ & $100,002 \pm 0,038$ & $99,969 \pm 0,049$ & $100,003 \pm 0,044$ \\
\hline
\end{tabular}


Especificamente para cada composto, se destaca a presença de $\mathrm{Si}, \mathrm{Al}$ e Fe nos compostos estático e alambrado. Como estes elementos são típicos de solos, isso possivelmente se deve a interferência com participação direta do solo nestes produtos finais da compostagem.

\subsubsection{Microscopia Eletrônica de Varredura/Espectroscopia de Energia Dispersiva por Raios-X (MEV/EDS)}

De modo análogo a metodologia empregada para a turfa, inicialmente, foram analisadas as amostras na forma de pastilha através da Espectrometria de Dispersão de Energia de Raios$\mathrm{X}$ (EDS) aplicada a áreas, visando-se ter uma ideia generalizada da composição elementar total dos compostos, tanto na amostra total (matéria orgânica e porção mineral) como só na porção mineral (resultante do processo de calcinação da matéria orgânica).

A Tabela 59 apresenta os dados médios para as três áreas observadas das pastilhas de amostras de compostos sem matéria orgânica e com matéria orgânica. Similar ao verificado para a turfa, pode-se comprovar que para todos os compostos e em ambos os casos, há predominância dos elementos carbono e oxigênio, que perfazem juntos, mais de $90 \%$ da amostra total dos compostos total, indiano e estático, mais de $80 \%$ da amostra total do composto alambrado e mais de $60 \%$ da porção mineral de todos os compostos. Essa distinção do composto alambrado se deve ao fato de sua amostra total ter apresentado a menor presença de carbono $(27,42 \%)$, provavelmente como consequência de sua também menor presença de matéria orgânica em comparação aos demais compostos estudados. Conforme relatado anteriormente a redução no teor de $\mathrm{C}$ da porção mineral em relação à amostra total se deve, justamente a ausência de matéria orgânica. Ademais, como compensação desta drástica redução de $\mathrm{C}$ nas amostras sem matéria orgânica, outros elementos ganharam destaque, sobretudo Al, $\mathrm{Si}, \mathrm{Ca}$ e Fe. Esses elementos podem ser considerados como indicativos da presença de quartzo e de argilominerais. A presença de $\mathrm{Si}$ foi superior nos compostos alambrado e estático, provavelmente devido a presença de solo nestes compostos, confirmando os dados apresentados no FRX. 
Tabela 59 - Composição elementar das porções minerais e amostras totais dos compostos

\begin{tabular}{|c|c|c|c|c|c|}
\hline$\%$ & $\begin{array}{l}\text { Material } \\
\text { ensaiado }\end{array}$ & $\begin{array}{c}\text { Composto } \\
\text { total }\end{array}$ & $\begin{array}{c}\text { Composto } \\
\text { indiano }\end{array}$ & $\begin{array}{c}\text { Composto } \\
\text { alambrado }\end{array}$ & $\begin{array}{c}\text { Composto } \\
\text { estático }\end{array}$ \\
\hline \multirow{2}{*}{ C } & Sem MO & 15,90 & 14,53 & 15,43 & 15,75 \\
\hline & Com MO & 37,40 & 40,51 & 27,42 & 35,27 \\
\hline \multirow{2}{*}{$\mathbf{O}$} & Sem MO & 52,17 & 48,16 & 49,54 & 49,73 \\
\hline & Com MO & 54,23 & 52,36 & 57,20 & 55,21 \\
\hline \multirow{2}{*}{ Mg } & Sem MO & 0,63 & 1,14 & 0,25 & 0,12 \\
\hline & Com MO & 0,09 & 0,10 & 0,07 & 0,03 \\
\hline \multirow{2}{*}{ Al } & Sem MO & 10,08 & 11,38 & 9,93 & 8,91 \\
\hline & Com MO & 4,05 & 2,32 & 4,91 & 4,08 \\
\hline \multirow{2}{*}{$\mathbf{S i}$} & Sem MO & 8,75 & 11,98 & 17,82 & 19,17 \\
\hline & Com MO & 2,92 & 3,92 & 9,19 & 4,38 \\
\hline \multirow{2}{*}{$\mathbf{P}$} & Sem MO & 0,85 & 0,66 & 0,41 & 0,32 \\
\hline & Com MO & 0,18 & 0,08 & 0,11 & 0,11 \\
\hline \multirow{2}{*}{$\mathbf{S}$} & Sem MO & 0,86 & 0,58 & 0,24 & 0,22 \\
\hline & Com MO & 0,12 & 0,05 & 0,04 & 0,06 \\
\hline \multirow{2}{*}{$\mathbf{K}$} & Sem MO & 0,49 & 1,62 & 0,48 & 0,19 \\
\hline & Com MO & 0,10 & 0,11 & 0,07 & 0,04 \\
\hline \multirow{2}{*}{$\mathbf{C a}$} & Sem MO & 6,53 & 4,53 & 1,02 & 0,82 \\
\hline & Com MO & 0,35 & 0,24 & 0,12 & 0,14 \\
\hline \multirow{2}{*}{$\mathbf{T i}$} & Sem MO & 0,66 & 0,86 & 0,74 & 0,68 \\
\hline & Com MO & 0,12 & 0,07 & 0,17 & 0,13 \\
\hline \multirow{2}{*}{$\mathbf{F e}$} & Sem MO & 3,08 & 4,56 & 4,14 & 4,08 \\
\hline & Com MO & 0,48 & 0,23 & 0,70 & 0,56 \\
\hline
\end{tabular}

Fonte: A autora.

Em seguida, procedeu-se a varredura das amostras não pastilhadas (em stubs), sem e com MO, para os compostos organicos, determinando a composição elementar pontual, também por espectrometria, apenas de pontos com potencial de apresentarem características de interesse. De maneira análoga às análises para a turfa, procedeu-se inicialmente o estudo dos compostos sem matéria orgânica, gerando fotomicrografias com o detector retro espalhado. 
A Figura 92 revela uma fotomicrografia da parcela mineral do composto total. O ponto 1 exibiu concentrações de $48,15 \%$ de oxigênio, $22,53 \%$ de carbono, $12,41 \%$ de silício, $10,76 \%$ de alumínio e $3,71 \%$ de ferro. O ponto 2 expressou caráter mineral, contendo $17,87 \%$ de alumínio, $10,47 \%$ de silício, $8,55 \%$ de ferro e $8,01 \%$ de cálcio.

Figura 92 - Fotomicrografia em MEV da porção mineral do composto total com os respectivos espectros EDS

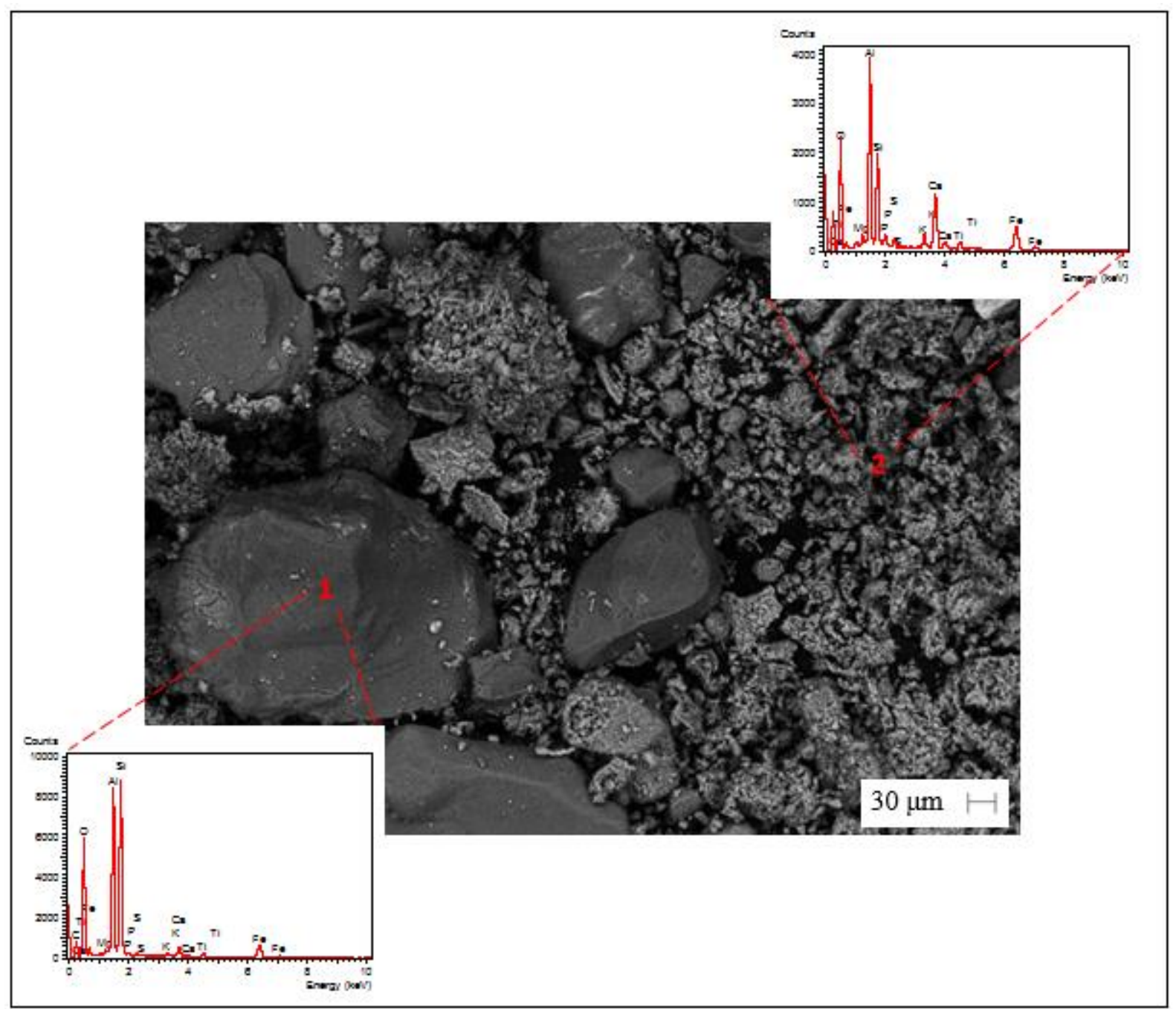

Fonte: A autora. 
A Figura 93 exibe uma outra fotomicrografia da parcela mineral do composto total. $\mathrm{O}$ ponto 1 , de coloração clara, apresentou, majoritariamente, $48,63 \%$ de ferro, seguido de $31,47 \%$ de oxigênio, $13,33 \%$ de carbono e 5,54\% de titânio.

Figura 93 - Fotomicrografia em MEV da porção mineral do composto total com os respectivos espectros EDS

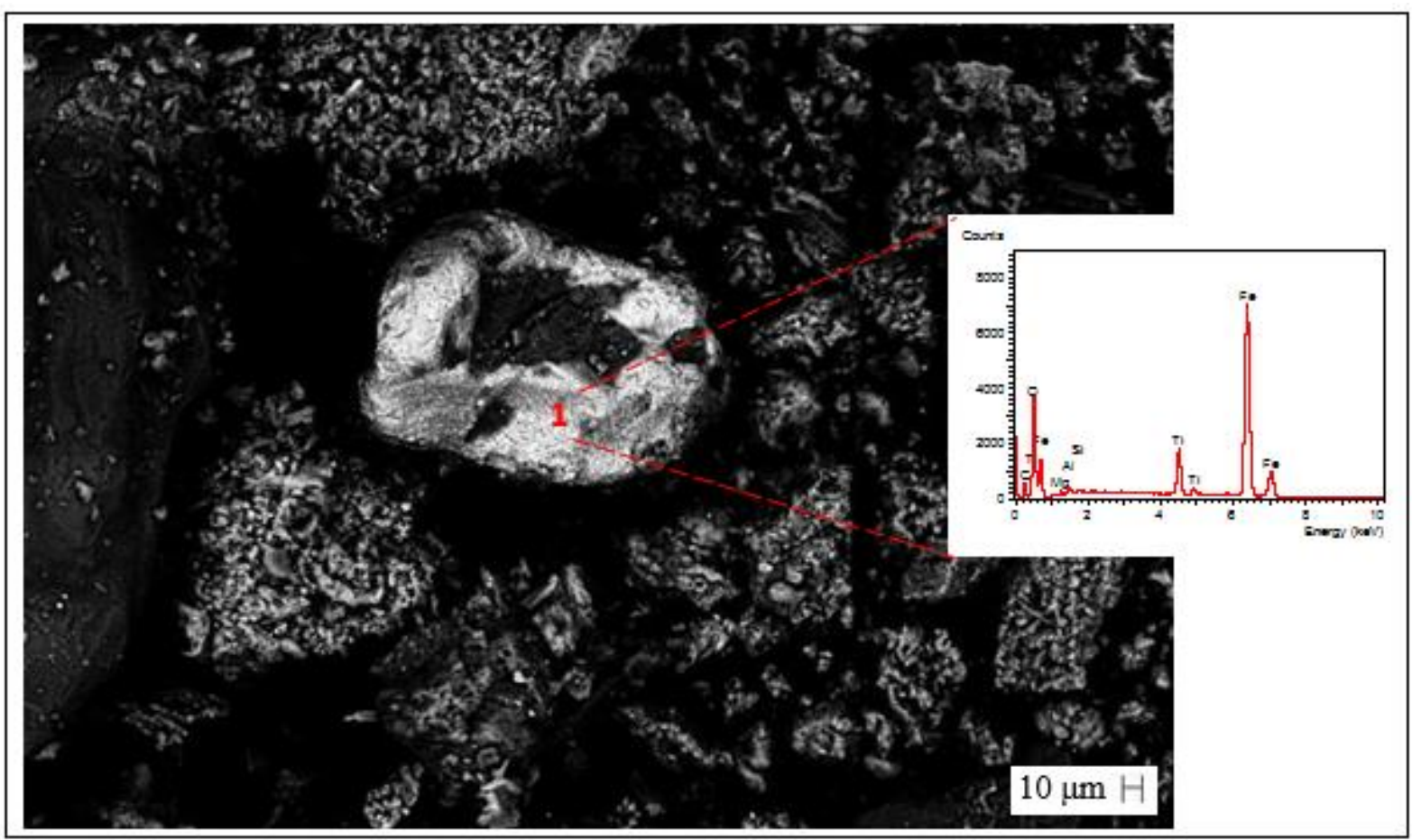

Fonte: A autora. 
A Figura 94 apresenta uma fotomicrografia da parcela mineral do composto indiano. O ponto 1 , de coloração clara, exibiu $37,64 \%$ de oxigênio, 31,29\% de zircônio, $17,86 \%$ de carbono, $10,88 \%$ de silício e $1,73 \%$ de cálcio, evidenciando o caráter predominantemente mineral do grão. O ponto 2 revelou 45,83\% de oxigênio, 32,14\% de silício e 19,01\% de carbono.

Figura 94 - Fotomicrografia em MEV da porção mineral do composto indiano com os respectivos espectros EDS

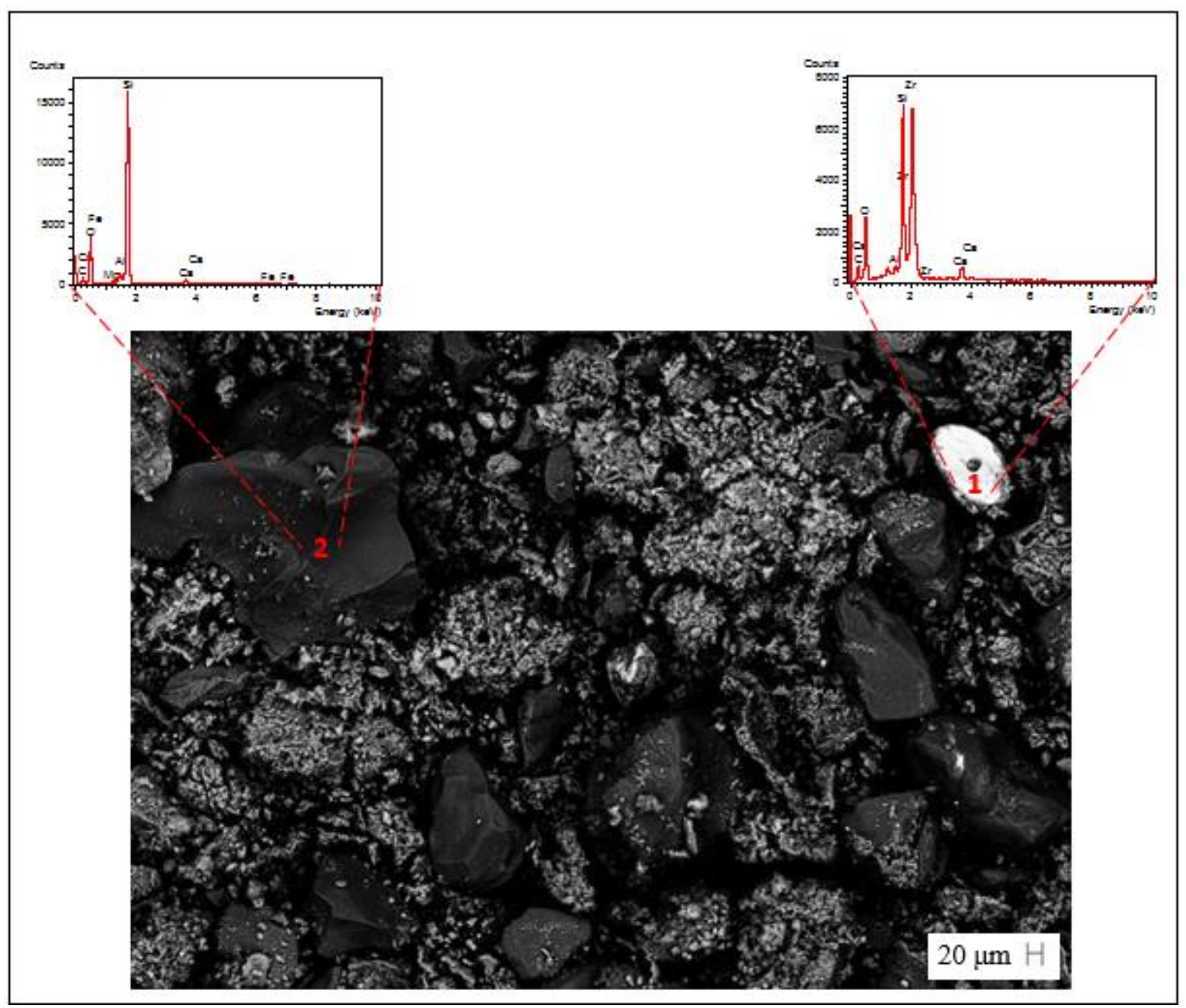

Fonte: A autora. 
A Figura 95 mostra uma fotomicrografia da parcela mineral do composto alambrado. $\mathrm{O}$ ponto 1 exibiu 50,12\% de oxigênio e 49,52\% de silício, evidenciando, possivelmente um grão de sílica (dióxido de silício). O ponto 2, por sua vez, refletiu uma elevada concentração de oxigênio (50,62\%), seguida de alumínio $(17,51 \%)$, cálcio $(8,04 \%)$, silício $(7,99 \%)$, ferro $(6,96 \%)$ e fósforo $(4,01 \%)$.

Figura 95 - Fotomicrografia em MEV da porção mineral do composto alambrado com os respectivos espectros EDS

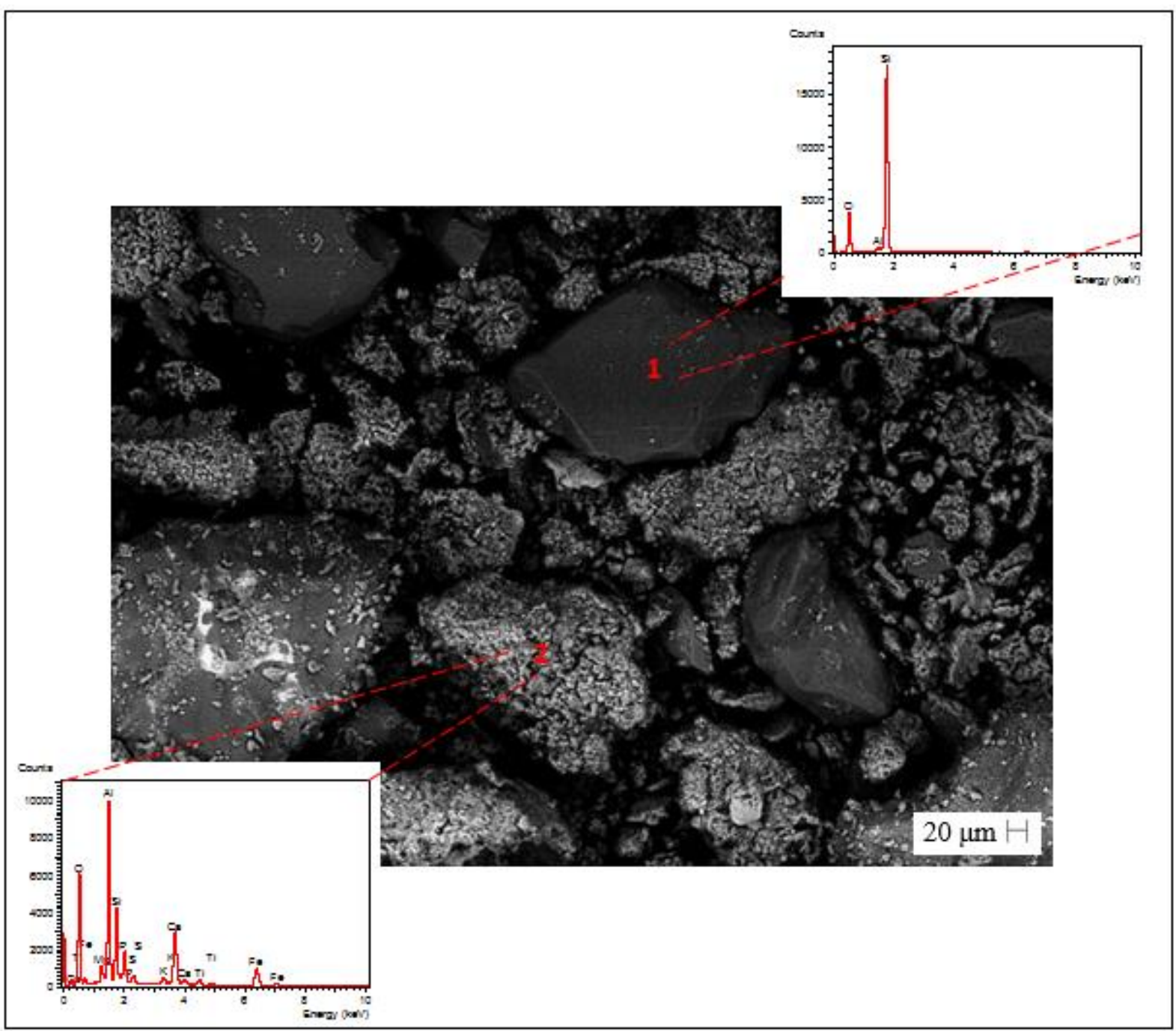

Fonte: A autora. 
A Figura 96 traz uma fotomicrografia da parcela mineral do composto estático. O ponto 1 se associa as partículas pequenas que aparecem em grande quantidade na imagem, formando a matriz de base. Ele exibiu concentrações de 38,76\% de oxigênio, 19,79\% de ferro, 19,60\% de alumínio, 3,58\% de cálcio e 3,25\% de titânio. O ponto 2 também apresentou caráter mineral, se destacando a presença de silício (50,52\%), oxigênio (45,30\%), ferro (2,53\%) e alumínio $(1,64 \%)$.

Figura 96 - Fotomicrografia em MEV da porção mineral do composto estático com os respectivos espectros EDS

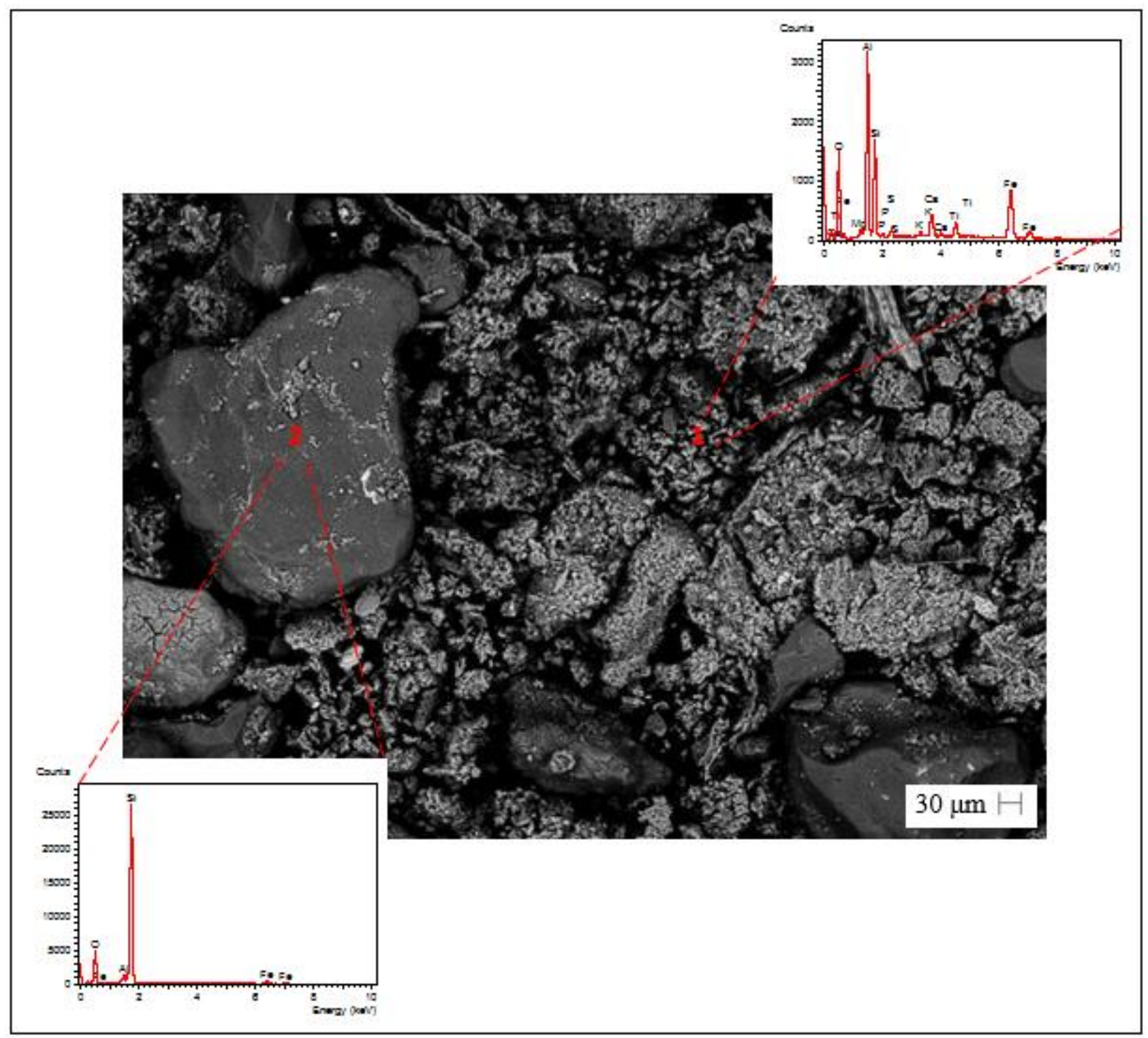

Fonte: A autora.

Findada a análise da porção mineral, procedeu-se o estudo dos compostos com matéria orgânica, gerando fotomicrografias também com o detector retro espalhado. 
A Figura 97 exibe uma fotomicrografia da amostra com matéria orgânica do composto total. Nos pontos 1 e 3 se destacou a presença de carbono, com concentrações de, respectivamente, $36,69 \%$ e $44,69 \%$, e oxigênio, respectivamente, $37,82 \%$ e 40,57\%, evidenciando o caráter orgânico destes fragmentos. Já em 2, foi revelado o aparecimento de oxigênio $(53,67 \%)$ e de silício $(37,72 \%)$, provavelmente indicando tratar-se de um grão de quartzo.

Figura 97 - Fotomicrografia em MEV do composto total com os respectivos espectros EDS

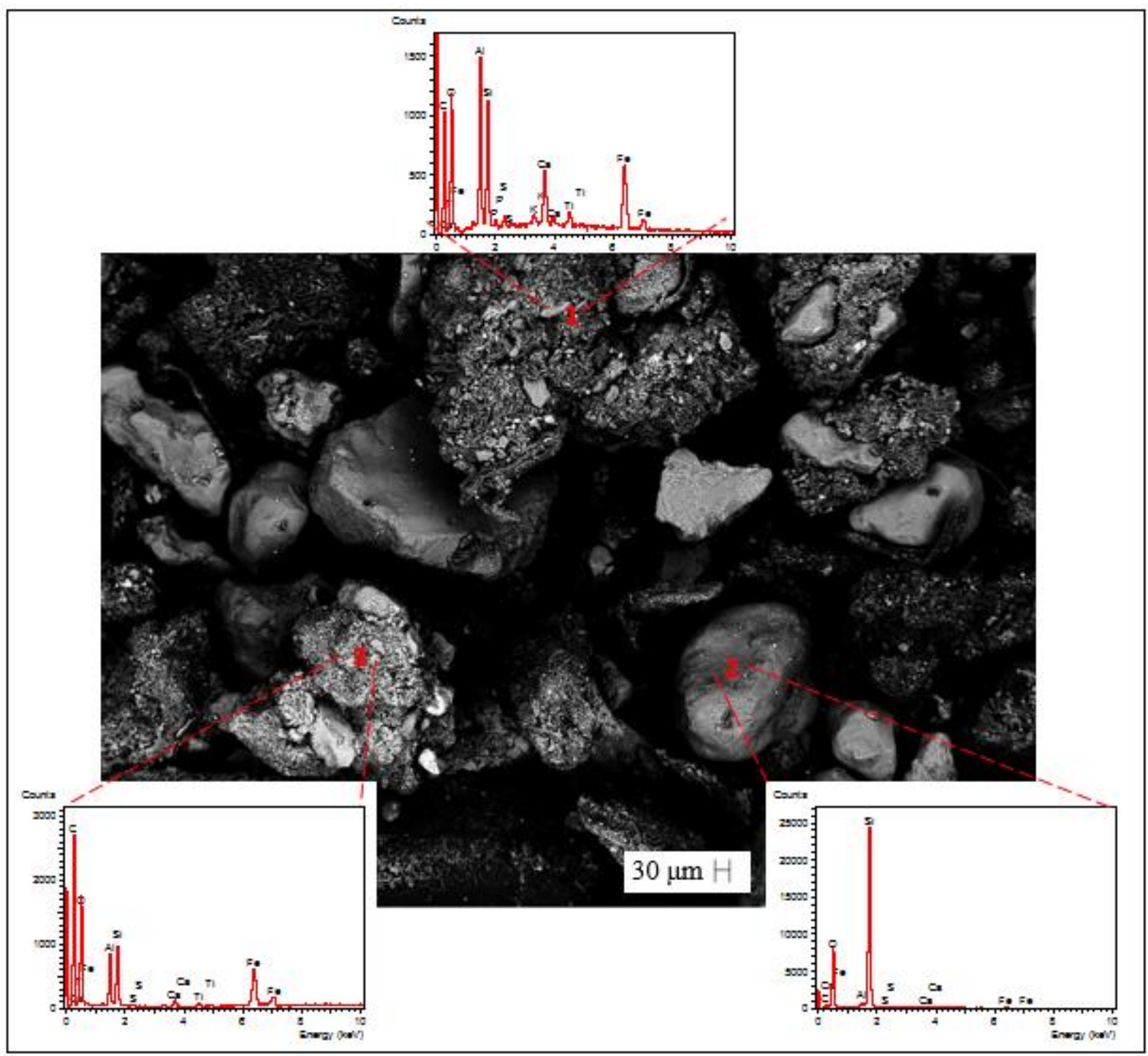

Fonte: A autora. 
A Figura 98 apresenta uma fotomicrografia da amostra com matéria orgânica do composto indiano. No ponto 1 estão presentes concentrações dos elementos oxigênio $(50,38 \%)$ e silício $(38,91 \%)$, atestando o caráter mineral desta partícula. Em contrapartida, em 2 e 3, se destacou a presença massiva de carbono, que aparece em teores de 55,51\% e 44,29\%, respectivamente, e secundariamente de oxigênio, presente nas concentrações de $38,77 \%$ e 43,30\%, respectivamente. Assim, tratam-se de partículas com caráter orgânico e, provavelmente, estes elementos se remetem a existência de celulose. $\mathrm{O}$ componente associado ao ponto 3 apresentou forma e textura similares a um tronco vegetal.

Figura 98 - Fotomicrografia em MEV do composto indiano com os respectivos espectros EDS

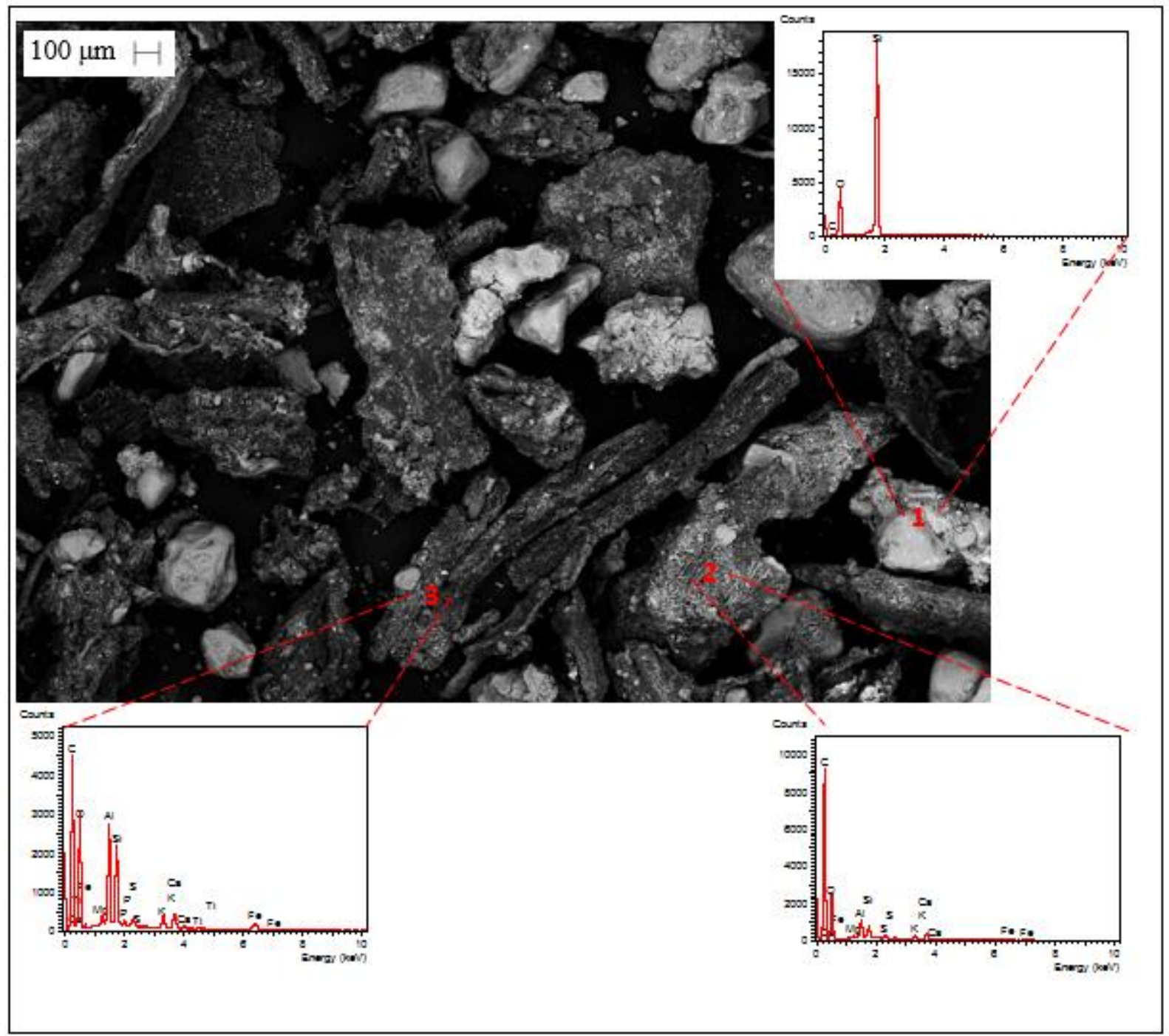

Fonte: A autora. 
A Figura 99 exibe uma fotomicrografia da amostra com matéria orgânica do composto alambrado. O ponto 1 apresenta aspecto visual de uma partícula mineral e nele se destacaram as concentrações de oxigênio (35,62\%), carbono (33,00\%), silício $(26,38 \%)$, alumínio $(2,94 \%)$ e ferro $(1,47 \%)$. No ponto 2 , devido a sua coloração, fica evidente seu caráter orgânico, com a presença de $41,09 \%$ de oxigênio, 28,22\% de carbono, 15,19\% de ferro, 8,02\% de alumínio, $3,45 \%$ de silício, $1,83 \%$ de titânio e $1,20 \%$ de cálcio. No ponto 3 , de coloração mais clara, apareceram $45,26 \%$ de oxigênio, $29,79 \%$ de ferro, $16,16 \%$ de carbono, 5,38\% de alumínio e $2,36 \%$ de silício. Por fim, no ponto 4, estão presentes $44,79 \%$ de oxigênio, $20,86 \%$ de carbono, 17,08\% de alumínio, 7,81\% de ferro, 6,44\% de silício e 1,49\% de titânio. Dessa forma, estes pontos refletem grãos onde a matéria orgânica se encontra agregada à porção mineral.

Figura 99 - Fotomicrografia em MEV do composto alambrado com os respectivos espectros EDS

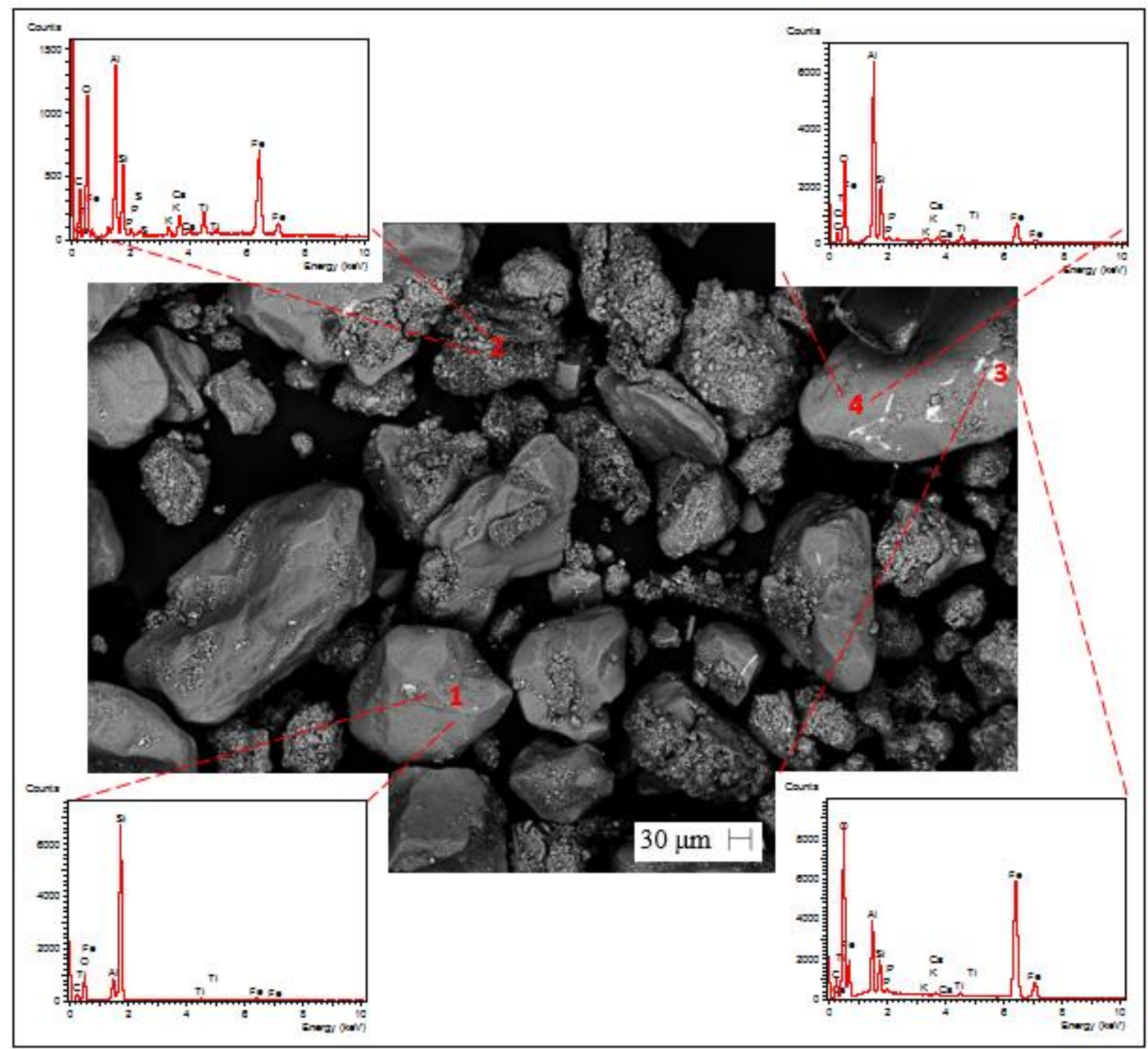

Fonte: A autora. 
A Figura 100 traz uma fotomicrografia da amostra com matéria orgânica do composto estático. O ponto 1 revelou 46,60\% de oxigênio, 30,29\% de carbono, 10,43\% de alumínio, $6,48 \%$ de silício e $3,52 \%$ de ferro, atestando ser um grão mineral, visualmente, envolto por uma camada orgânica. Os pontos 2 e 4 apresentaram características similares, com uma elevada presença de silício $(41,30 \%$ e 41,67\%, respectivamente), oxigênio $(33,66 \%$ e 45,64\%, respectivamente) e carbono (23,85\% e $12,54 \%$, respectivamente). De fato, o ponto 2 que exibe um aspecto visual de partícula mineral recoberta por uma camada não uniforme de matéria orgânica apresentou uma maior presença de carbono em comparação ao ponto 4. No ponto 3, de coloração mais clara, é válido ressaltar sua tipologia férrica, contendo 32,53\% de ferro.

Figura 100 - Fotomicrografia em MEV do composto estático com os respectivos espectros EDS

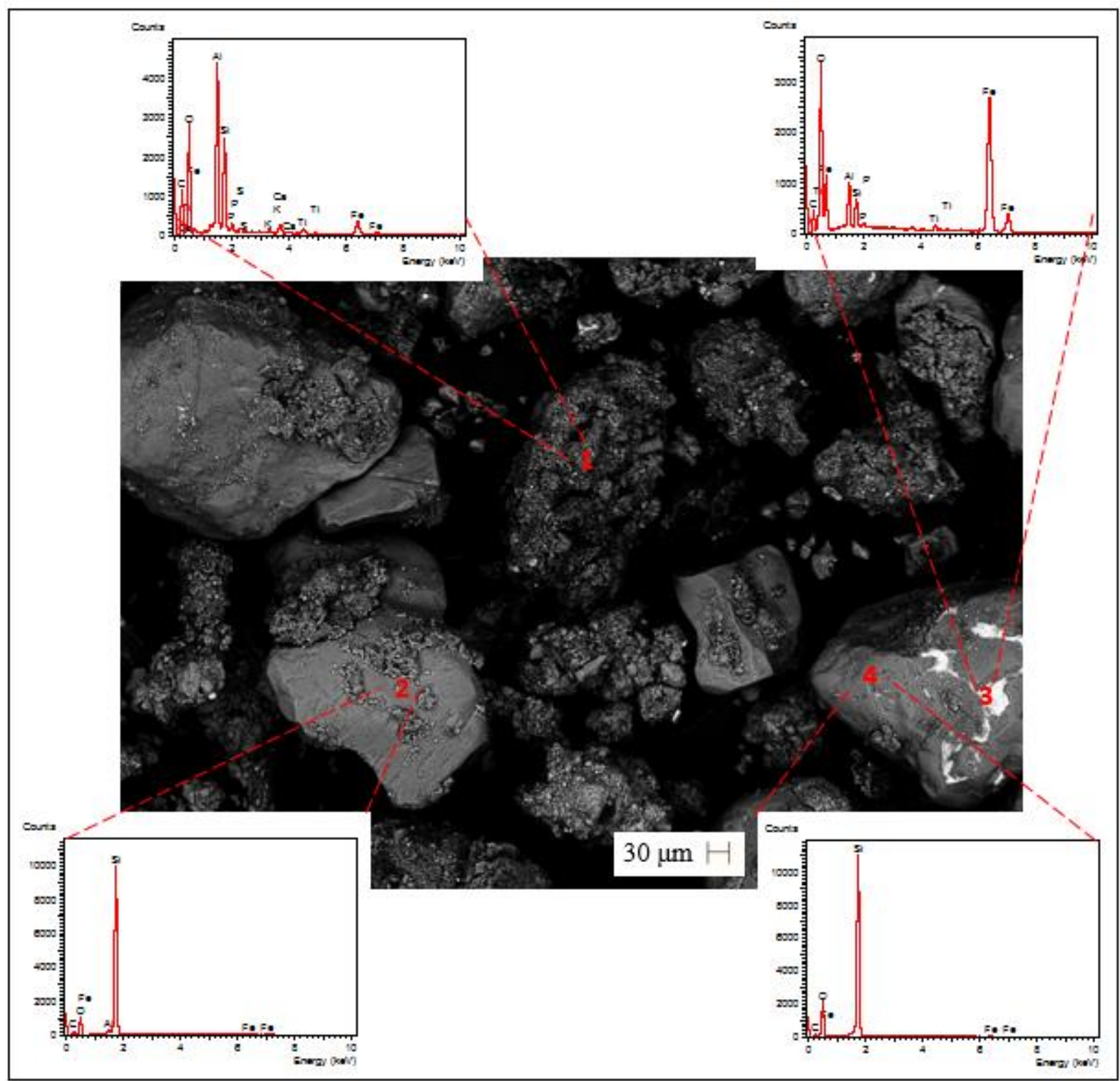

Fonte: A autora. 
A Figura 101 mostra uma segunda fotomicrografia da amostra com matéria orgânica do composto estático. Nela se destaca a presença de alguns microrganismos. O ponto 1, com detecção de $68,38 \%$ de carbono e $29,17 \%$ de oxigênio, é justamente um microrganismo.

Figura 101 - Fotomicrografia em MEV do composto estático com os respectivos espectros EDS. Destaque para os microrganismos

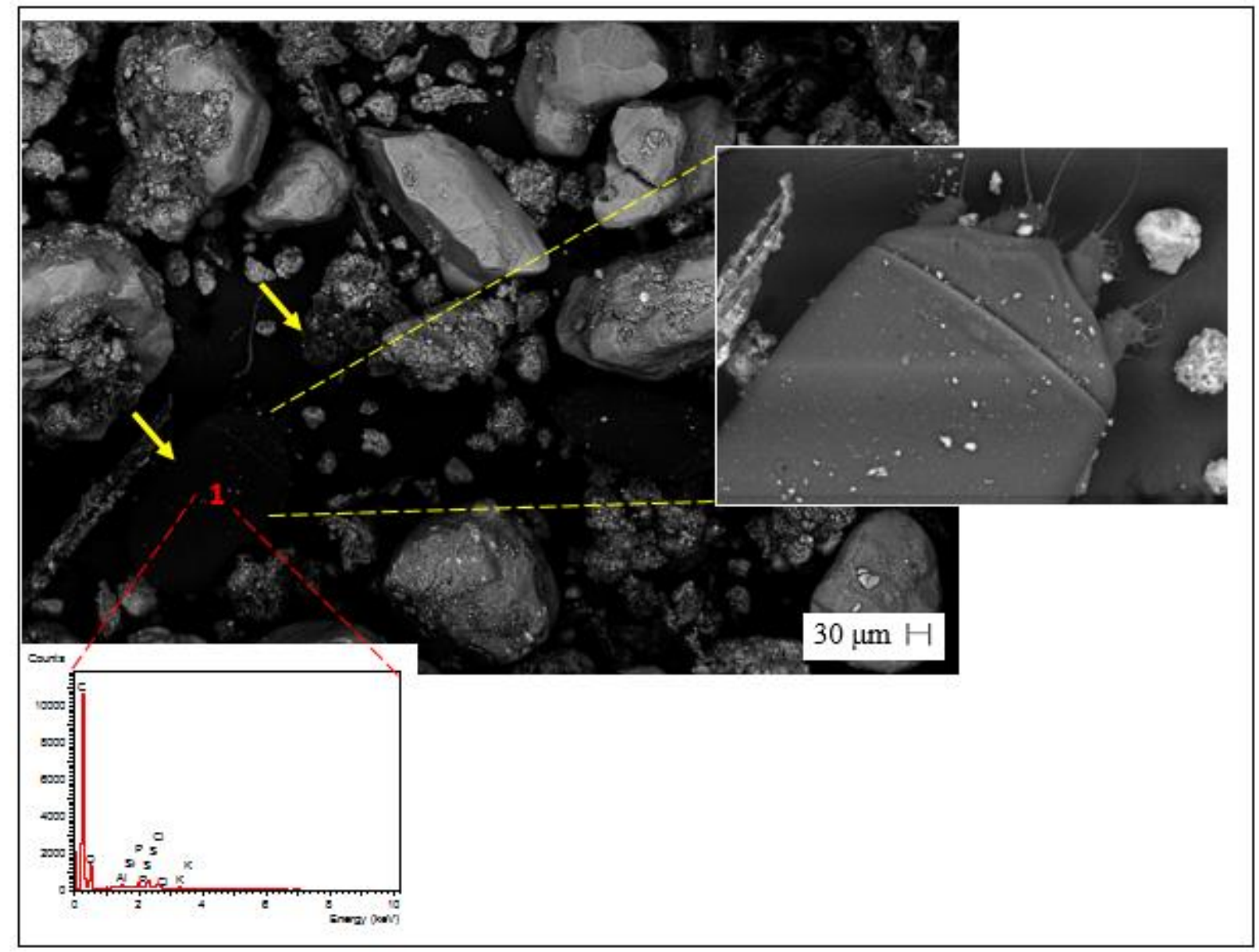

Fonte: A autora.

\subsubsection{Análise Térmica Diferencial (ATD)}

As curvas térmicas diferenciais para as amostras totais dos compostos, apresentadas na Figura 102, revelam picos possivelmente associados à oxidação da matéria orgânica. Assim, pode-se observar que, de modo geral, a matéria orgânica é oxidada no intervalo compreendido entre as temperaturas de 150 a $570^{\circ} \mathrm{C}$. O pico inicial para os compostos total e indiano foi superior ao pico inicial referente aos compostos estático e alambrado, possivelmente devido aos maiores teores de matéria orgânica observados nos dois primeiros compostos. Para os compostos total e indiano os picos iniciais apresentam forma e magnitude similares, sendo um 
indicativo que a matéria orgânica destes compostos também é parecida, sobretudo em termos de humificação. Conclusão análoga pode ser feita para os compostos estático e alambrado. Ademais, todos os compostos exibem picos iniciais da oxidação mais intensos que o pico final, sendo um indicativo que estão presentes em menor concentração estruturas alifáticas, evidenciando um menor grau de humificação.

Figura 102 - Curva da análise térmica diferencial para os compostos com matéria orgânica (MO)

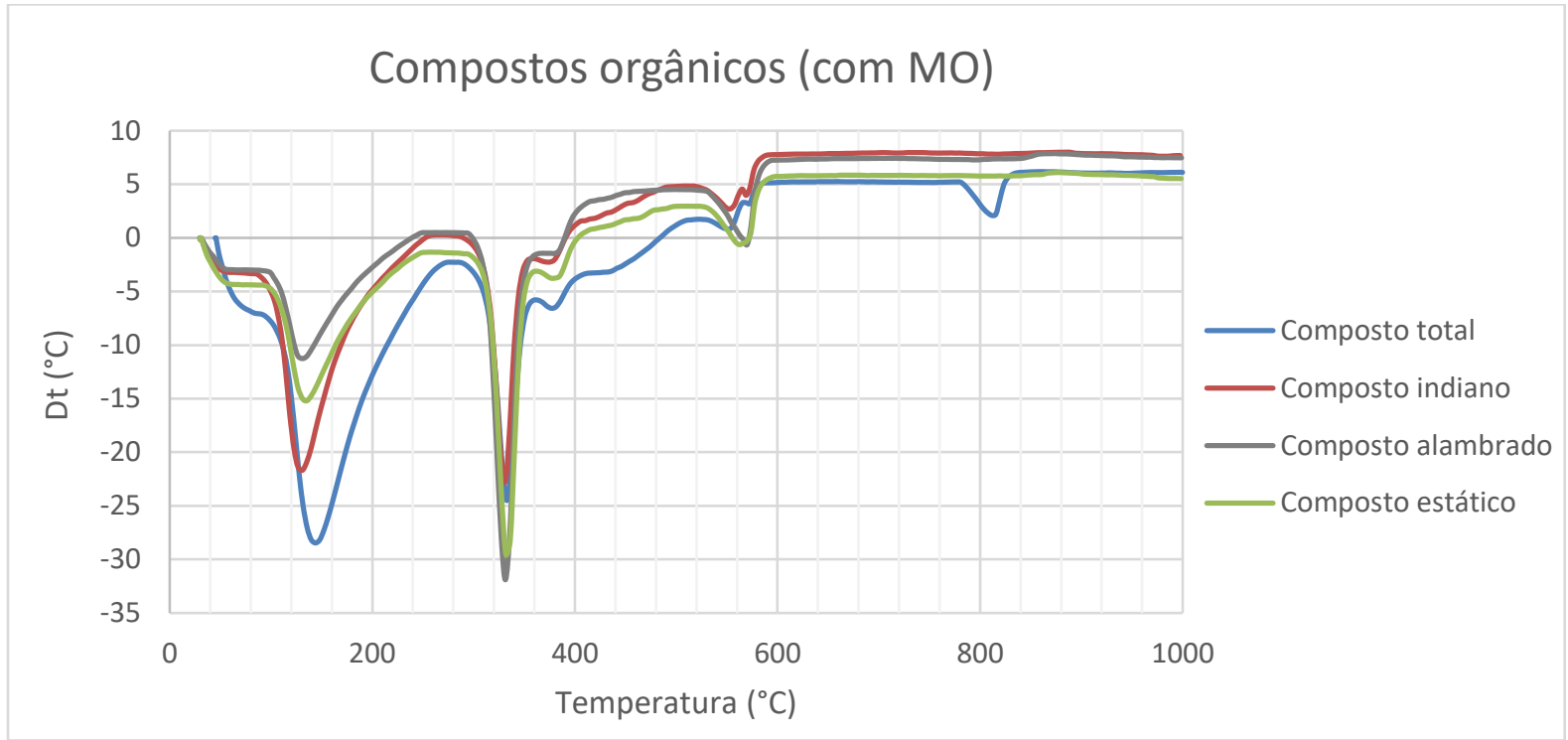

Fonte: A autora.

A Figura 103 exibe as curvas térmicas diferenciais apenas para as porções minerais dos compostos. Nota-se a existência de picos endotérmicos, de localização análoga às amostras totais de compostos, mas o primeiro pico apresenta intensidade inferior, o segundo pico não aparece e o terceiro pico revela uma intensidade similar. Possivelmente eles se associam a oxidação de vestígios da matéria orgânica, sendo os primeiros picos menores por se tratarem da MO menos humificada e mais facilmente calcinada e o último pico similar por se referir justamente a MO mais humificada e menos facilmente calcinada. Uma vez que na análise das amostras totais foi observado que a matéria orgânica foi perdida até cerca de $570^{\circ} \mathrm{C}$, é plausível supor que a amostra analisada em questão, supostamente da porção mineral da turfa, por ter sido incinerada na mufla à $550^{\circ} \mathrm{C}$ pode apresentar ainda resquícios orgânicos. 
Figura 103 - Curva da análise térmica diferencial para a porção mineral dos compostos (sem MO)

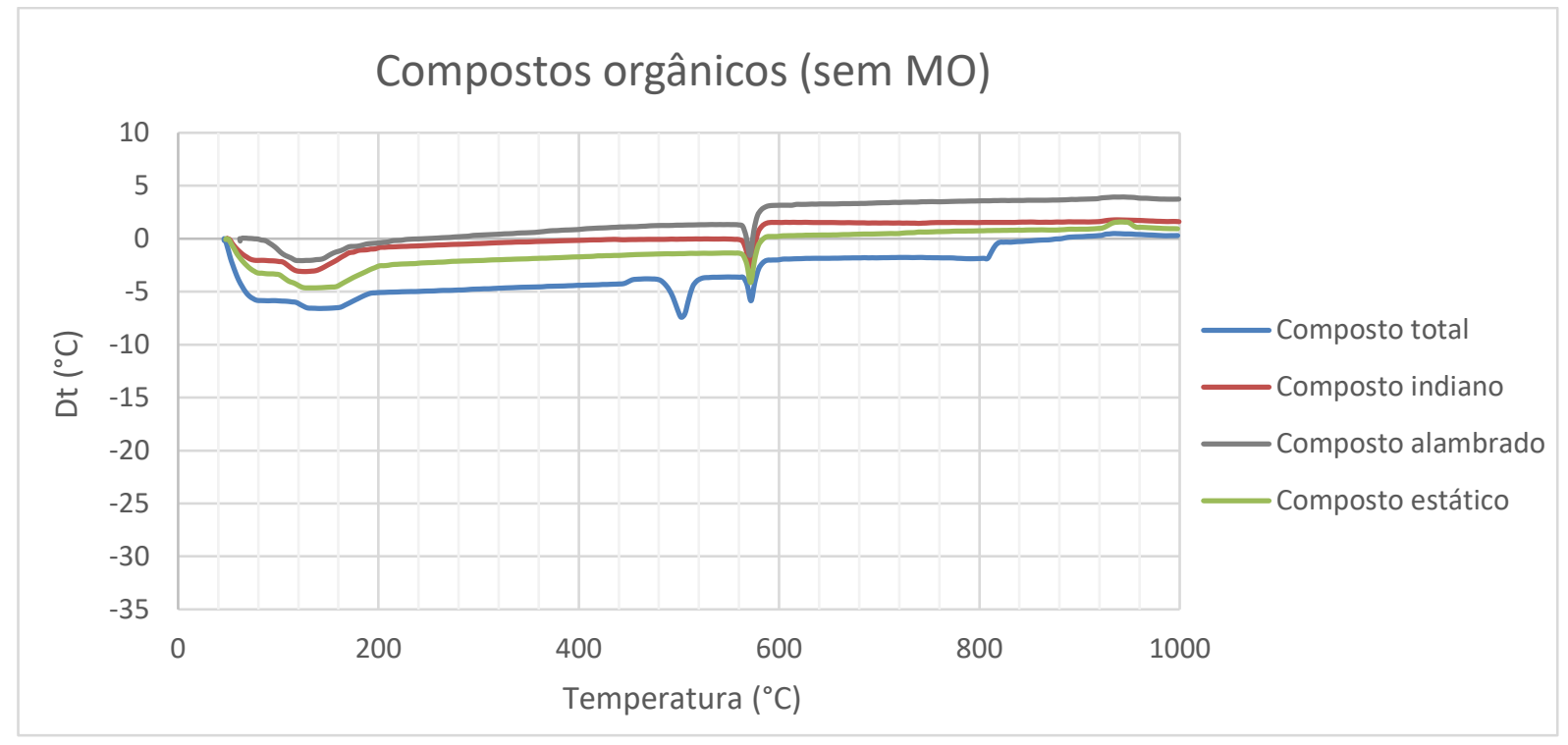

Fonte: A autora.

\subsubsection{Considerações referentes à caracterização geológica-geotécnica de turfa e compostos orgânicos}

A turfa apresentou características granulométricas majoritariamente enquadradas no intervalo de diâmetro de areia (superior a 50\% da amostra total mesmo com variações quanto ao uso de defloculante). Contudo, como a granulometria da porção mineral se mostrou mais fina em relação a amostra total, esta constatação confirma o agregamento dos grãos de matéria orgânica que pode ser visto em análise tátil visual. Esta característica diminui a área superficial disponível para a adsorção, mas, ao mesmo tempo, pode elevar a estabilidade do material em um possível uso em barreira. Os compostos, por sua vez, revelaram teores ainda superiores de partículas com diâmetro de areia (superior a $80 \%$ em todos os casos).

Quanto ao pH, a turfa exibiu um valor de 5,1 e os compostos valores na faixa de 6,4 a 7,7 , sendo que os compostos se sobressaem por apresentarem valores de $\mathrm{pH}$ mais próximos da neutralidade, condição que favorece a adsorção. O $\Delta \mathrm{pH}$ para todos os materiais foi negativo, indicando o predomínio de cargas negativas em superfície, sendo de -1,0 para a turfa e de -0,4 a $-1,0$ para os compostos, com valor de $-1,0$ para o composto indiano. Confirmando a presença de cargas negativas na turfa, seu PESN $(3,6)$ foi inferior ao seu respectivo $\mathrm{pH}(5,1)$.

Dentre todos os materiais, a turfa exibiu a maior CTC $\left(91,00 \mathrm{cmol}_{\mathrm{c}} \mathrm{kg}^{-1}\right)$ possivelmente como resultado do maior teor de matéria orgânica $\left(520,43 \mathrm{~g} \mathrm{~kg}^{-1}\right)$ e da maior porcentagem de carbono orgânico $(21,49 \%)$. Essa grande presença orgânica provavelmente se associa ainda a maior CRA (36,28\%). Em se tratando dos compostos, sua CTC variou de 29,00 a 75,00 $\mathrm{cmol}_{\mathrm{c}}$ 
$\mathrm{kg}^{-1}$, com um dos maiores valores para o composto indiano $\left(34,00 \mathrm{cmol}_{\mathrm{c}} \mathrm{kg}^{-1}\right)$; a matéria orgânica oscilou de 193,92 a 418,70 $\mathrm{g} \mathrm{kg}^{-1}$, com maior valor para o composto indiano, e o carbono orgânico foi de 8,08 a 10,69\%. A CRA variou de 22,75 a 65,26\%, com maior valor para o composto indiano, sendo um indicativo de que este parâmetro apesar de estar diretamente ligado a MO, não apresenta uma relação direta com a MO, já que a CRA do composto indiano, por exemplo, foi superior que a CRA da turfa, mas a MO do composto indiano foi inferior a MO da turfa.

Em relação à composição elementar, a presença de $\mathrm{C}, \mathrm{H}$ e $\mathrm{N}$ foi superior para a turfa em comparação com os compostos orgânicos culminando em relações C/N de 31,70 e H/C de 0,11. Já para os compostos as relações C/N variaram de 9,57 a 13,16 e as relações H/C oscilaram de 0,16 a 0,22 , com a maior $\mathrm{C} / \mathrm{N}$ e a menor $\mathrm{H} / \mathrm{C}$ justamente associadas ao composto indiano. Esta constatação indica um maior grau de humificação para a turfa, conforme esperado, e dentre os compostos o do tipo indiano revela ser aquele dotado de maior grau de decomposição.

Os resultados da FRX e do EDS trazem valores semi-quantitativos que indicam a presença majoritária de $\mathrm{Si}, \mathrm{Al}$ e Fe para a turfa e de $\mathrm{Si}, \mathrm{Al}, \mathrm{Fe}$ e Ca para os compostos. Já o DRX revela a presença de quartzo para a turfa e de quartzo e alumina para os compostos. De modo geral, esta composição mineral é típica de materiais naturais, como o solo, e não inviabiliza o uso da turfa ou dos compostos como adsorventes.

Por fim, os teores de $\mathrm{Pb}$ e $\mathrm{Zn}$ para a turfa foram reduzidos, respectivamente, 39,0 e 13,29 mg kg-1 e para os compostos, respectivamente, 3,0 a 21,0 $\mathrm{g} \mathrm{kg}^{-1}$ e 50,60 a 132,80 $\mathrm{g} \mathrm{kg}^{-1}$. Para os compostos foi analisado ainda a concentração de Cd que não excedeu $1,3 \mathrm{~g} \mathrm{~kg}^{-1}$. Dentre os compostos, o indiano apresentou a menor presença de $\mathrm{Pb}$ e $\mathrm{Cd}$ e uma das menores concentrações de Zn. Como estes três metais potencialmente tóxicos são os elementos adsorvíveis desta pesquisa, estas reduzidas concentrações nos materiais reativos orgânicos é outra caraterística positiva.

De modo geral, turfa e compostos apresentam características favoráveis que podem ser consideradas como potencializadoras de sua capacidade de adsorção de cátions metálicos e, consequentemente, um possível uso na construção de barreiras reativas e selantes. Dentre os compostos se destaca o indiano por apresentar características mais promissoras para a adsorção, como maior $\Delta \mathrm{pH}, \mathrm{MO}, \mathrm{CRA}$ e relação $\mathrm{C} / \mathrm{N}$ e menor relação $\mathrm{H} / \mathrm{C}$. 


\subsection{Ensaio de adsorção de equilíbrio em lote com materiais reativos orgânicos (turfa e compostos)}

\subsubsection{Etapa preliminar - Determinação da melhor razão turfa/solução}

A Figura 104 exibe os valores de $\mathrm{pH}$ (iniciais e finais) obtidos no ensaio de equilíbrio em lote empregado para a determinação da melhor razão turfa/solução. Em todos os casos foi mantida a mesma solução de $\mathrm{Pb}$ com igual concentração e volume da fase líquida de 50 ou 100 $\mathrm{mL}$, com a variação da massa de turfa para alcance da razão desejada. Assim notou-se que, com exceção das amostras de razão 1/5 com massa de $20 \mathrm{~g}$, razão 1/10 com massa de $10 \mathrm{~g}$ e razão 1/50 com massa de $2 \mathrm{~g}$, as quais exibiram uma considerável elevação de $\mathrm{pH}$ ao longo do ensaio, em todas as demais amostras não houveram mudanças bruscas de $\mathrm{pH}$ (comparando o início e o fim do ensaio), sendo que 0s valores permaneceram aproximadamente constantes (Figura 104).

Figura 104 - Valores de pH iniciais e finais para as diversas razões turfa/solução empregadas no ensaio de equilíbrio em lote preliminar

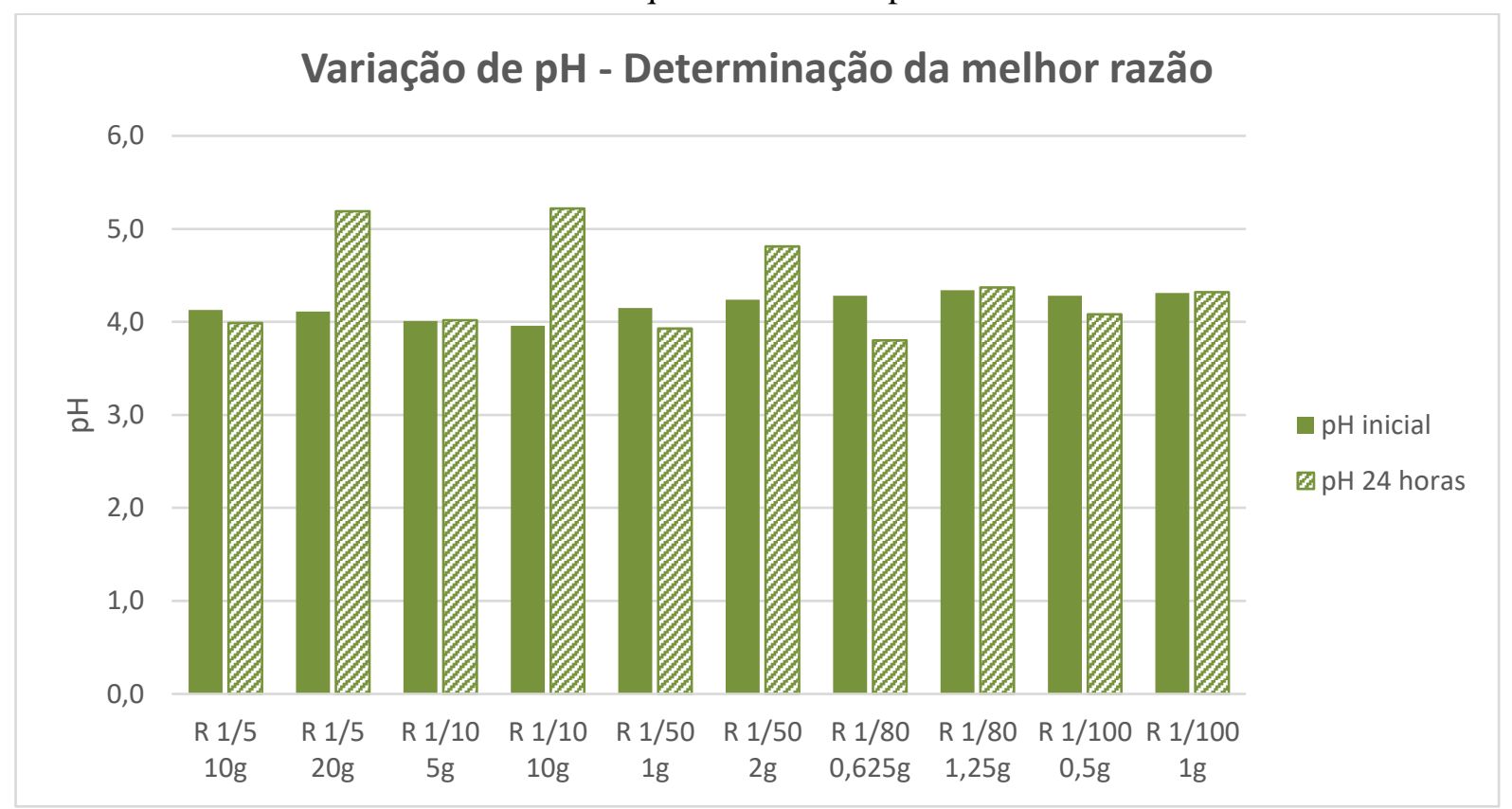

Fonte: A autora.

De modo geral, os valores iniciais de $\mathrm{pH}$ para os brancos do material sólido, contendo apenas turfa e água deionizada (Branco $\mathrm{A}+\mathrm{T}$ ) são ligeiramente inferiores aos brancos da solução contendo $\mathrm{Pb}$ (Figura 105). Quanto aos valores de $\mathrm{pH}$ iniciais e finais, notou-se variação para as amostras de branco contendo turfa e água deionizada (Branco A + T). Para as amostras de branco da solução, os valores de $\mathrm{pH}$ praticamente não variaram durante o ensaio de equilíbrio em lote realizado no tempo de 24 horas. 
Figura 105 - Valores de pH iniciais e finais para os brancos da solução e para os brancos da turfa empregados no ensaio de equilíbrio em lote preliminar

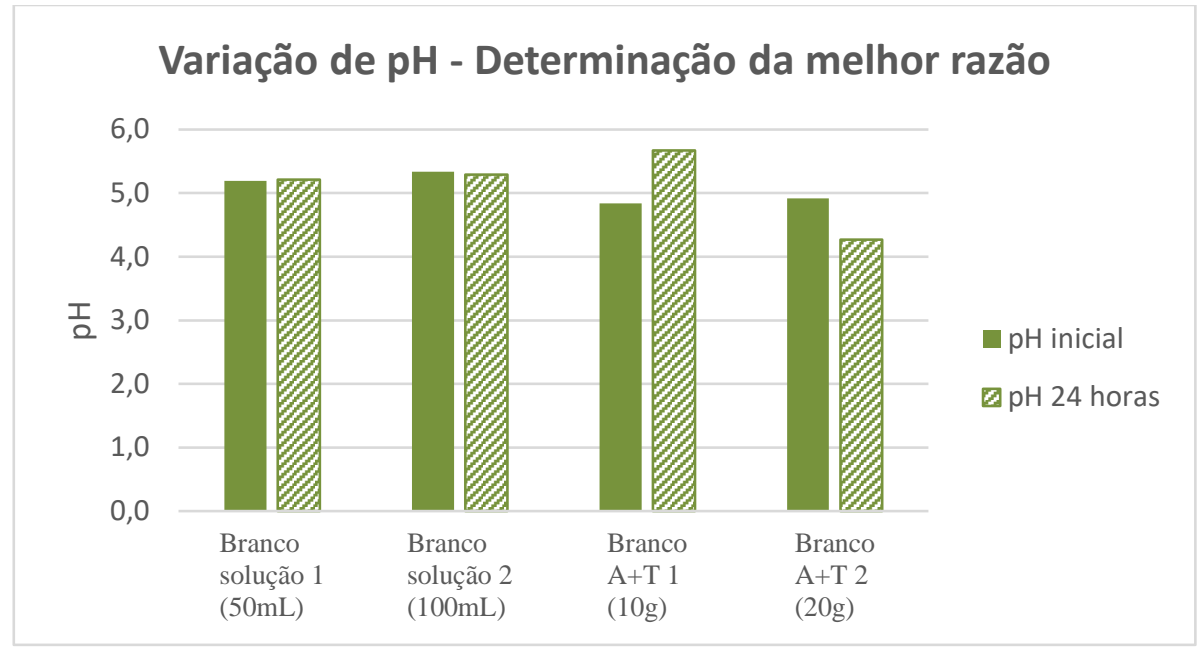

Fonte: A autora.

Os resultados de Eh (iniciais e finais) obtidos nos ensaios de equilíbrio em lote para todas as razões turfa/solução são apresentados na Figura 106. Em todas as amostras é possível observar uma diminuição do Eh decorrido o tempo de contato do ensaio. Em algumas amostras esta redução foi mínima, como na razão $1 / 5$ com massa de turfa de $10 \mathrm{~g}$, já em outras, este decaimento foi mais pronunciado, como na razão 1/5 com massa de turfa de $20 \mathrm{~g}$.

Figura 106 - Valores de Eh iniciais e finais para as diversas razões turfa/solução empregadas no ensaio de equilíbrio em lote preliminar

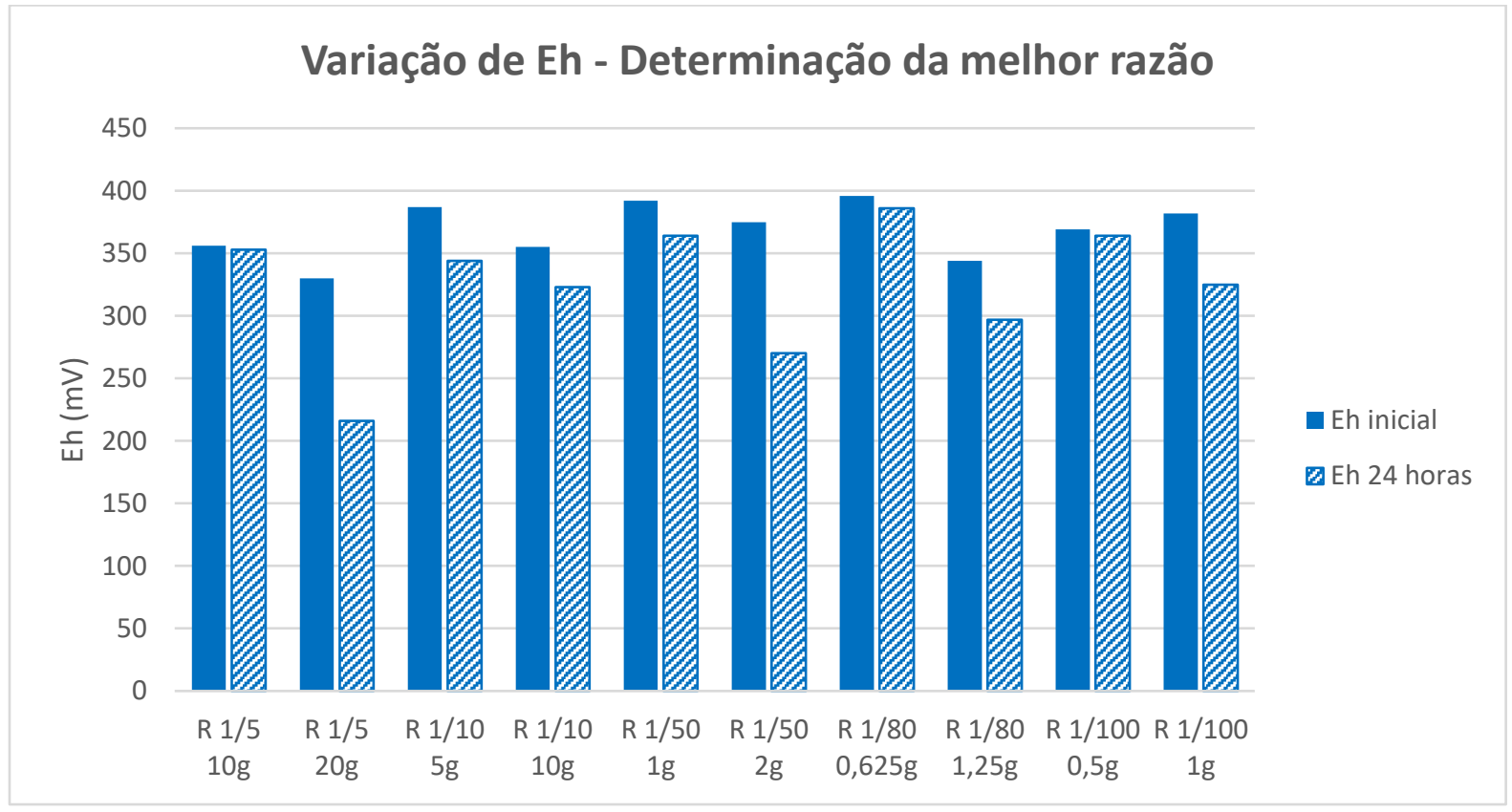

Fonte: A autora. 
Na Figura 107, por sua vez, foi possível verificar que os valores de Eh para os brancos da turfa (Branco $\mathrm{A}+\mathrm{T}$ ) são menores que os valores para os brancos da solução contendo $\mathrm{Pb}$. Os valores de Eh no início do ensaio foram maiores que no final para a amostras de branco da solução contendo $\mathrm{Pb}$ (nos dois volumes analisados) e para o branco da turfa com massa de 10 g.

Figura 107 - Valores de Eh iniciais e finais para os brancos da solução e para os brancos da turfa empregados no ensaio de equilíbrio em lote preliminar

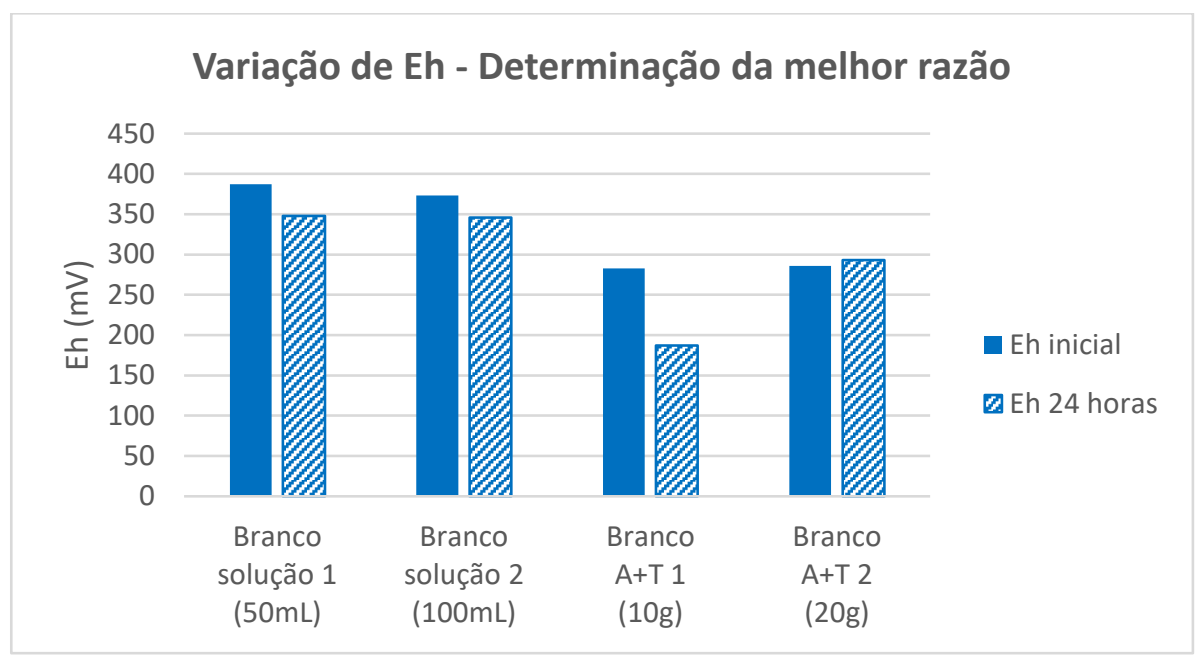

Fonte: A autora.

A Figura 108 mostra os valores de condutividade elétrica. De modo geral, com exceção das amostras de razão 1/50 e massa de turfa de 2 g, razão 1/80 e massa de 1,25 g e razão 1/100 e massa de $1 \mathrm{~g}$, as quais apresentaram uma constância de condutividade, todas as demais amostras revelaram um aumento de valores após 24 horas. Ademais, a redução da massa de turfa, associada à diminuição da razão turfa/solução, propiciaram nitidamente uma diminuição dos valores de condutividade elétrica até a razão 1/50 com massa de $2 \mathrm{~g}$. A partir de então, os valores de CE se tornaram aproximadamente constantes, possivelmente devido à adoção de massas bem reduzidas de turfa. Exceção foi notada para a amostra com razão 1/100 e massa de $1 \mathrm{~g}$ que apresentou um dos maiores valores de condutividade elétrica. 
Figura 108 - Valores de condutividade elétrica (CE) iniciais e finais para as diversas razões turfa/solução empregadas no ensaio de equilíbrio em lote preliminar

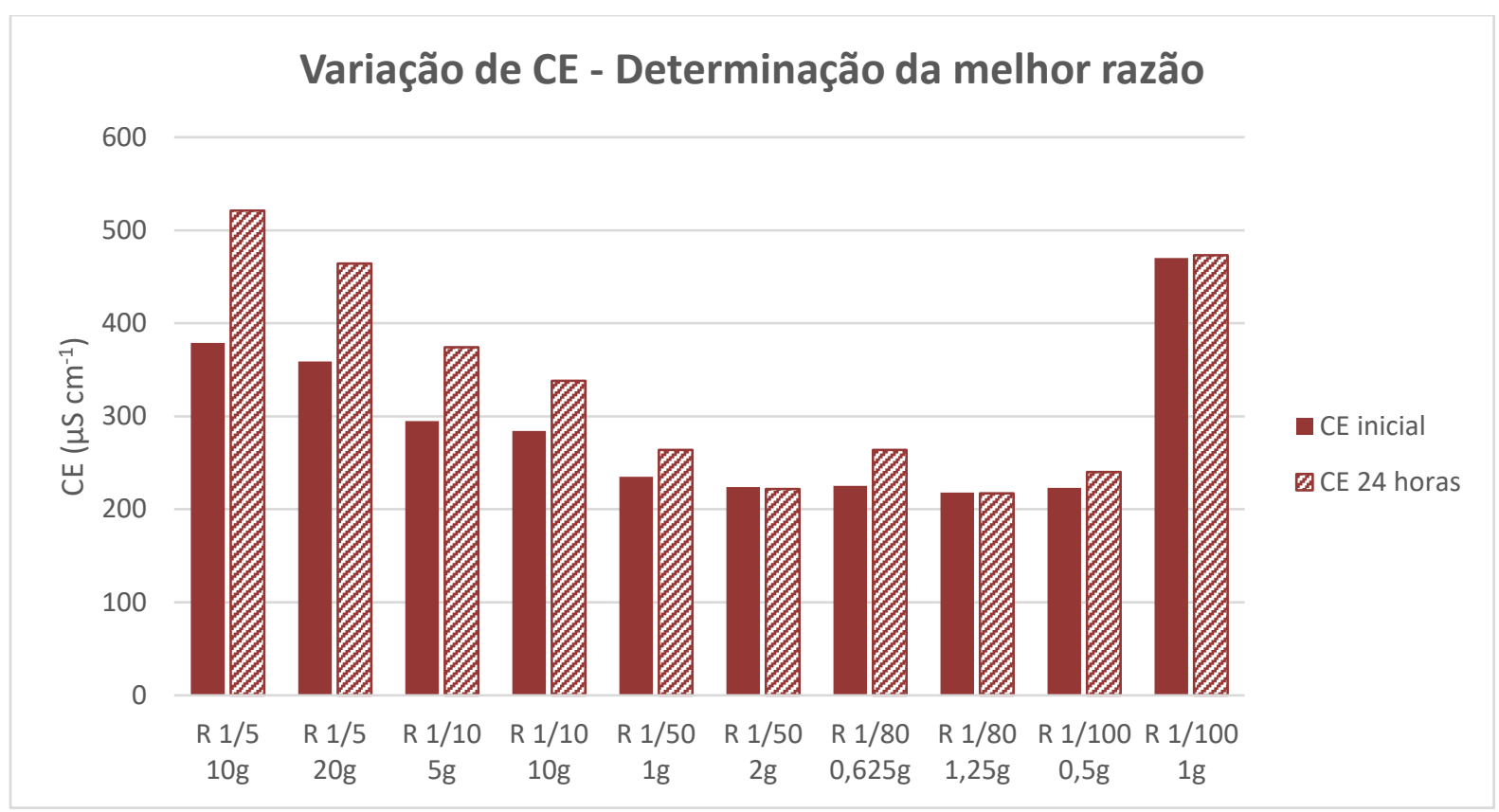

Fonte: A autora.

A Figura 109 exibe que os brancos da solução de $\mathrm{Pb}$ apresentaram valores inicias de $\mathrm{CE}$ ligeiramente maiores que as respectivas medidas em relação aos brancos contendo turfa e água deionizada. Notou-se, entretanto, que as amostras de branco contendo turfa e água deionizada apresentaram maiores valores de CE no final do ensaio que as amostras de branco da solução de $\mathrm{Pb}$.

Figura 109 - Valores de condutividade elétrica (CE) iniciais e finais para os brancos da solução e para os brancos da turfa empregados no ensaio de equilíbrio em lote preliminar

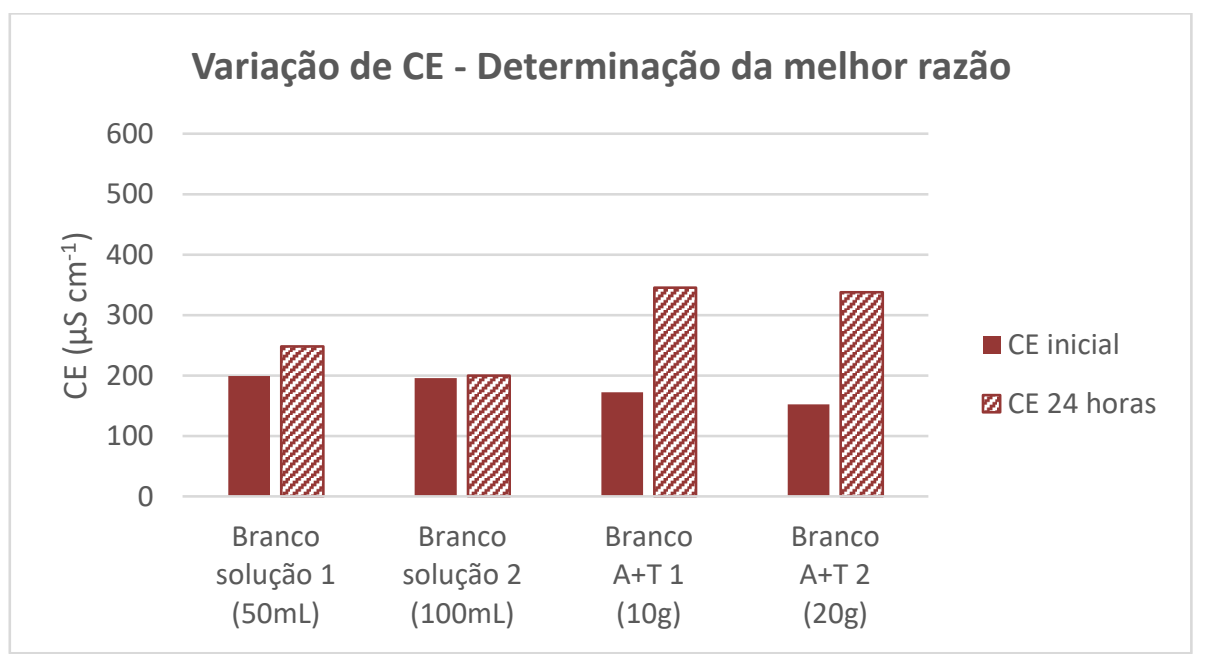

Fonte: A autora. 
Com o intuito de melhor visualizar a variação da sorção de $\mathrm{Pb}$ pela turfa frente às diferentes razões turfa/solução foram construídas, a partir dos dados obtidos, as respectivas isotermas, segundo os modelos Linear, Freundlich, Langmuir I e Langmuir II. Como parâmetros de entrada foram empregados: massa de turfa (g), volume de solução (L), concentração inicial de $\mathrm{Pb}\left(\mathrm{mg} \mathrm{L}^{-1}\right)$ e concentração de $\mathrm{Pb}$ no equilíbrio $\left(\mathrm{mg} \mathrm{L}^{-1}\right)$.

A partir das formulações obtidas e dos cálculos realizados, principalmente com base nos respectivos coeficientes angular e linear, conforme exibido no tópico "3.5.2.1 Equilíbrio de adsorção - Isotermas" da Revisão Bibliográfica, foi possível estimar os parâmetros de adsorção. A Tabela 60 apresenta os parâmetros derivados das equações associadas às isotermas linear e de Freundlich. Já a Tabela 61, de modo similar, exibe os parâmetros advindos das isotermas de Langmuir (I e II). Com base na análise dos coeficientes de determinação $\left(\mathrm{R}^{2}\right)^{15}$ é possível observar a seguinte ordem decrescente de modelos quanto ao melhor ajuste dos dados experimentais: Langmuir I > Langmuir II > Freundlich > Linear (sem passar pela origem). Já a isoterma Linear passando pela origem pode ser desconsiderada por apresentar uma correlação desprezível com os dados experimentais.

Tabela 60 - Parâmetros de adsorção estimados a partir das isotermas Linear e de Freundlich

\begin{tabular}{|c|c|c|c|c|}
\hline \multicolumn{2}{|c|}{ Linear* } & \multicolumn{3}{|c|}{ Freundlich } \\
\hline$K_{d}\left(L g^{-1}\right)$ & $\mathbf{R}^{2}$ & $K_{\mathbf{f}}\left(\mathbf{L} \mathbf{g}^{-1}\right)$ & $\mathbf{n}$ & $\mathbf{R}^{2}$ \\
\hline 0,313 & 0,822 & 6,422 & 0,216 & 0,945 \\
\hline \multicolumn{2}{|c|}{$q_{e}=0,313 \mathrm{C}_{\mathrm{e}}+6,844$} & \multicolumn{3}{|c|}{$\log q_{e}=0,216 \log C_{e}+0,808$} \\
\hline
\end{tabular}

* Isoterma linear sem passar pela origem.

Fonte: A autora.

Tabela 61 - Parâmetros de adsorção estimados a partir das isotermas de Langmuir (I e II)

\begin{tabular}{ccc|ccc}
\hline \hline \multicolumn{2}{c|}{ Langmuir $\mathbf{I}$} & \multicolumn{3}{c}{ Langmuir II } \\
\hline $\mathbf{q m}\left(\mathbf{m g ~ g}^{-\mathbf{1}}\right)$ & $\mathbf{K}_{\mathbf{L}}\left(\mathbf{L ~} \mathbf{~ m g}^{-\mathbf{1}}\right)$ & $\mathbf{R}^{\mathbf{2}}$ & $\mathbf{q m}\left(\mathbf{m g ~ g}^{\mathbf{- 1}}\right)$ & $\mathbf{K}_{\mathbf{L}}\left(\mathbf{L} \mathbf{~ m g}^{-\mathbf{1}}\right)$ & $\mathbf{R}^{\mathbf{2}}$ \\
\hline \hline 12,195 & 0,848 & 0,992 & 11,751 & 1,074 & 0,963 \\
\hline \hline \multicolumn{2}{c|}{$\frac{\mathrm{C}_{\mathrm{e}}}{\mathrm{q}_{\mathrm{e}}}=0,082 \mathrm{C}_{\mathrm{e}}+0,097$} & & \multicolumn{3}{c}{$\frac{1}{\mathrm{q}_{\mathrm{e}}}=0,079 \frac{1}{\mathrm{C}_{\mathrm{e}}}+0,085$} \\
\hline \hline
\end{tabular}

Fonte: A autora.

${ }^{15} \mathrm{O}$ coeficiente de determinação $\left(\mathrm{R}^{2}\right)$ mede o ajuste da linha de tendência com os valores observados. Ele varia de 0 a 1, sendo que quanto mais próximo de 1 for seu valor, melhor é este ajuste. 
A Figura 110 exibe a comparação entre os dados obtidos experimentalmente e as isotermas trabalhadas.

Figura 110 - Comparação entre os dados obtidos experimentalmente e as isotermas trabalhadas

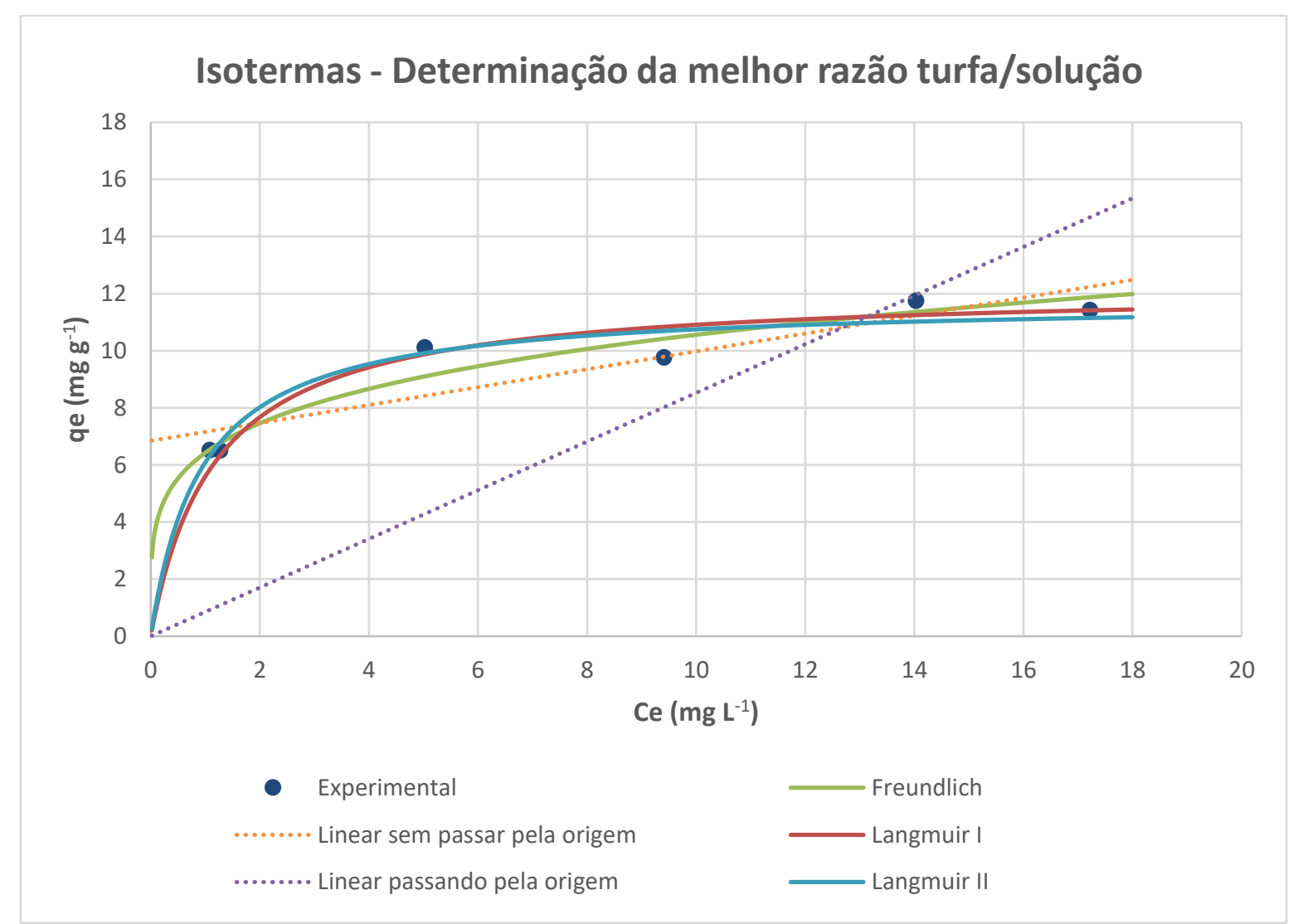

Fonte: A autora.

Com as bases experimentais foi possível calcular a porcentagem de remoção de $\mathrm{Pb}(\mathrm{A} \%)$ e a concentração de soluto adsorvida pelo adsorvente $\left(\mathrm{q}_{\mathrm{e}}\right)$, associada a capacidade de remoção de $\mathrm{Pb}$ pela turfa. Esses dados estão apresentados na Figura 111, em função da razão turfa/solução de interesse e, mais especificamente, do volume empregado (50 ou $100 \mathrm{~mL}$ ). 
Figura 111 - Análise comparativa da porcentagem de remoção de $\mathrm{Pb}(\mathrm{A} \%)$ e da capacidade de remoção de $\mathrm{Pb}$ pela turfa $\left(\mathrm{q}_{\mathrm{e}}\right)$ em função da razão turfa/solução

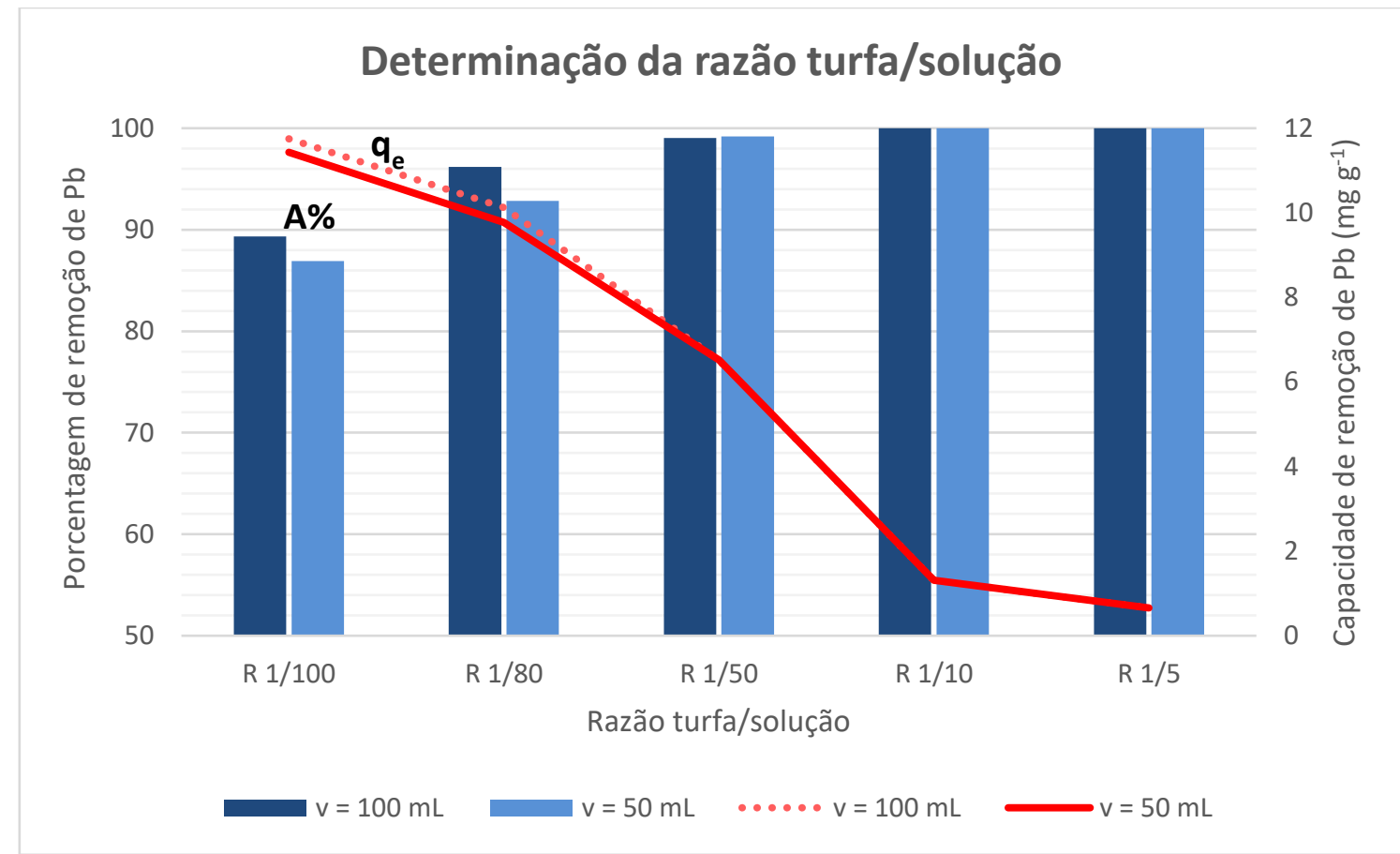

Fonte: A autora.

Em termos gerais, em se tratando do A\% (ilustrado pelas barras do gráfico), observa-se que para as menores razões (1/100 e 1/80) seu valor para o volume de $100 \mathrm{~mL}$ (consequentemente, com a maior massa de turfa para manter a razão) foi ligeiramente superior em comparação ao volume de $50 \mathrm{~mL}$ (consequentemente, com a menor massa de turfa para manter a razão). Por conseguinte, nesses casos, mesmo mantida a razão turfa/solução, uma maior massa de turfa propiciou uma porcentagem de remoção de $\mathrm{Pb}$ ligeiramente maior. Já para as maiores razões (1/50, 1/10 e 1/5), que utilizaram massas maiores de turfa, ambos os volumes resultaram em valores de A\% aproximadamente iguais, mostrando, nessas situações, sua menor dependência com a massa de turfa. É válido atentar que a razão 1/50 atingiu um valor de A\% em torno de $99 \%$ e as razões de 1/10 e 1/5 culminaram em A\% máximo (100\%), significando uma total remoção de $\mathrm{Pb}$ da fase líquida.

Em se tratando da capacidade de remoção de $\mathrm{Pb}$ pela turfa (ilustrada pelas linhas do gráfico), como esta variável está diretamente ligada a porcentagem de remoção, é possível estabelecer uma constatação similar em relação ao emprego dos volumes de 50 e $100 \mathrm{~mL}$, sendo que seus valores para as razões 1/100 e 1/80 são próximas, enquanto para as demais razões são coincidentes (atentar para a sobreposição das linhas contínua e tracejada no gráfico). Ademais, 
com o aumento da razão até 1/10 o qe sofre uma queda brusca de valores e, na sequência, atinge um patamar quase constante, associado ao A\% máximo característico destas amostras.

A Figura 111 permitiu ainda a escolha da razão mais viável de utilização para as posteriores análise: 1/50, com $1 \mathrm{~g}$ de turfa e $50 \mathrm{~mL}$ de solução. Nos ensaios de equilíbrio em lote com a turfa e o composto foram utilizadas concentrações de $\mathrm{Pb}$ inferiores e superiores. Portanto, a razão de 1/50 mesmo atingindo no ensaio teste um A\% próximo de 100\%, garantiu uma variação de valores, para mais e para menos, nos ensaios finais. Por outro lado, em relação à capacidade de remoção, a razão de 1/50 apresentou um valor intermediário, mas ainda favorável à adsorção. Por fim, dentro da razão de 1/50 optou-se por adotar $1 \mathrm{~g}$ de turfa e $50 \mathrm{~mL}$ de solução e não 2 g de turfa e 100 mL de solução, pois para ambos os casos os valores de A\% e $\mathrm{q}_{\mathrm{e}}$ foram praticamente iguais e, assim, a utilização de $1 \mathrm{~g}$ de turfa alia, simultaneamente, uma porcentagem considerável de remoção com um menor consumo de turfa. Além disso, o volume de $50 \mathrm{~mL}$ de solução propicia o emprego de tubos menores de polipropileno, garantindo uma melhor funcionalidade laboratorial. Ao mesmo tempo, essa relação e, por conseguinte, a massa e o volume adotados, são considerados representativos em se tratando da amostra total de adsorvente e de solução.

Como término desta análise foram determinadas as concentrações de $\mathrm{Pb}$ nos brancos do adsorvente (turfa e água deionizada), obtendo em ambas amostras (Branco A+T1 e Branco $\mathrm{A}+\mathrm{T} 2$ ) concentrações inferiores ao limite de quantificação do equipamento. Esta informação indica uma baixa solubilidade em água da reduzida concentração de $\mathrm{Pb}$ detectada na caracterização química da turfa, favorecendo o uso deste material em condições naturais e garantindo que as concentrações encontradas nas amostras constituídas por turfa e solução contaminante são, de fato, advindas das respectivas soluções sintéticas.

\subsubsection{Etapa preliminar - Teste do composto com maior capacidade adsortiva}

A Figura 112 mostra os valores de $\mathrm{pH}$ (iniciais e finais) para o teste do composto com maior capacidade adsortiva, para os três metais estudados isoladamente: $\mathrm{Pb}, \mathrm{Zn}$ e $\mathrm{Cd}$, e para os brancos (composto e água deionizada), em relação aos quatro compostos: total, indiano,

alambrado e estático. É válido ressaltar que para cada metal, todos os compostos foram submetidos a mesma concentração da solução contaminante. A análise dos gráficos revelou que para os quatro compostos em presença de $\mathrm{Pb}, \mathrm{Cd}$ e água houve um aumento do $\mathrm{pH}$ decorridas as 24 horas de contato, enquanto para o $\mathrm{Zn}$ houve um decréscimo dos valores de pH. Em relação aos brancos das soluções contaminantes foram observados valores crescentes de $\mathrm{pH}$ no sentido 
de $\mathrm{Cd}, \mathrm{Pb}$ e $\mathrm{Zn}$. Quanto aos brancos dos compostos (composto e água deionizada) seus valores de $\mathrm{pH}$ foram próximos ao $\mathrm{pH}$ da água deionizada.

Figura 112 - Valores de pH iniciais e finais para os quatro compostos:total, indiano, alambrado e estático, com $\mathrm{Pb}, \mathrm{Zn}, \mathrm{Cd}$ e água deionizada

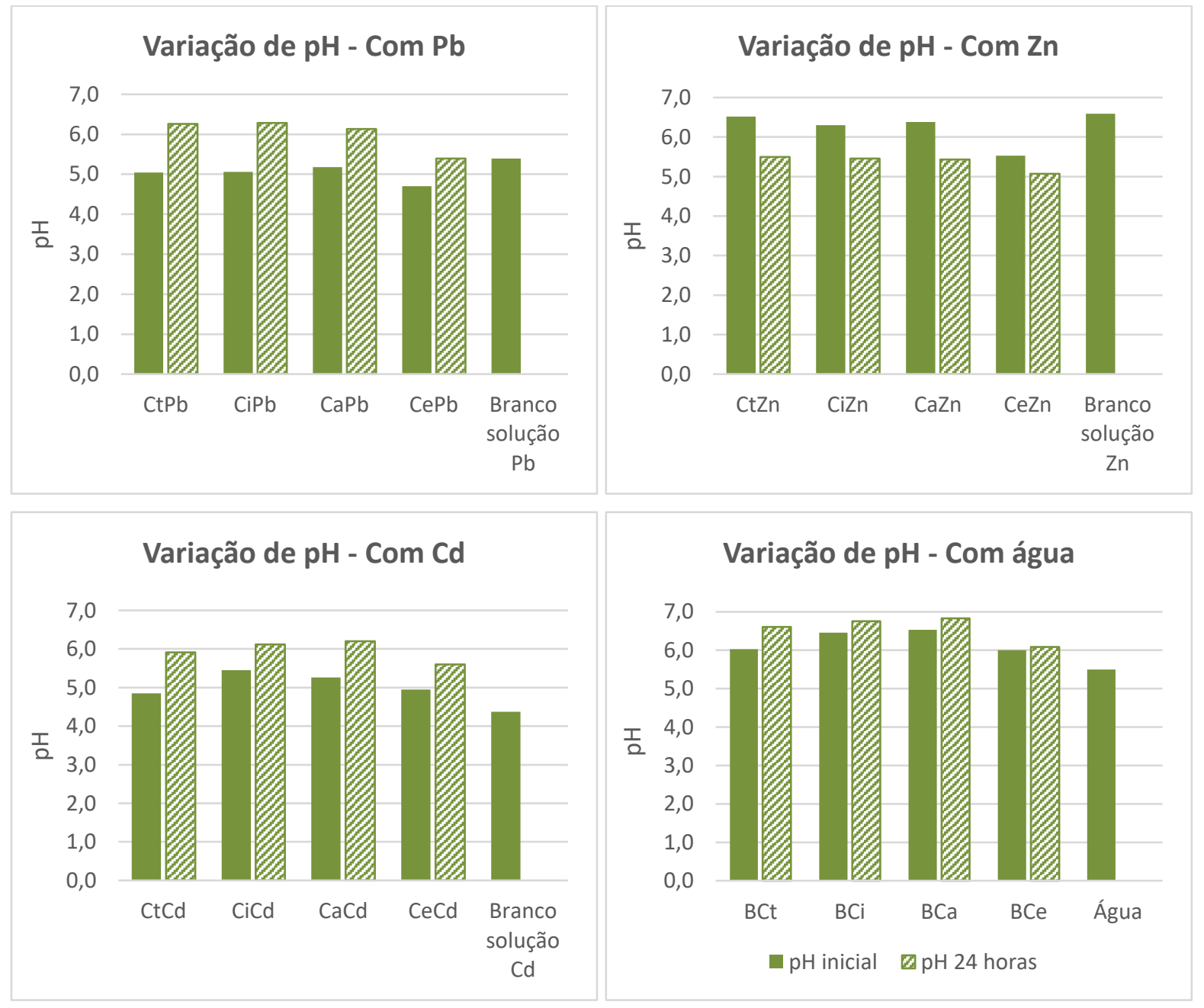

Na figura: $\mathrm{Ct}=$ composto total, $\mathrm{Ci}=$ composto indiano, $\mathrm{Ca}=$ composto alambrado, $\mathrm{Ce}=$ composto estático e $\mathrm{B}=$ branco do composto (composto + água deionizada).

Fonte: A autora.

A Figura 113 apresenta os valores de Eh (iniciais e finais) para o teste do composto envolvendo os quatro materiais: composto total, indiano, alambrado e estático, em relação aos três metais estudados: $\mathrm{Pb}, \mathrm{Zn}$ e $\mathrm{Cd}$, e aos brancos (composto e água deionizada). Em todos os casos, os valores de Eh inicias foram superiores aos valores de Eh após decorridas as 24 horas de contato, sendo que as menores variações foram constatadas para os brancos dos compostos (composto e água deionizada). Em relação aos brancos das soluções contaminantes, os gráficos deixam evidente sua indubitável influência nos valores das amostras contendo compostos e 
soluções, já que nos três primeiros gráficos os valores de Eh dos compostos acrescidos de solução contaminante exibiram valores de Eh iniciais semelhantes aos valores de Eh referentes aos respectivos brancos da solução. Quanto aos brancos dos compostos seus valores de Eh foram próximos, mas ligeiramente inferiores ao Eh da água deionizada.

Figura 113 - Valores de Eh iniciais e finais para os quatro compostos:total, indiano, alambrado e estático, com $\mathrm{Pb}, \mathrm{Zn}, \mathrm{Cd}$ e água deionizada

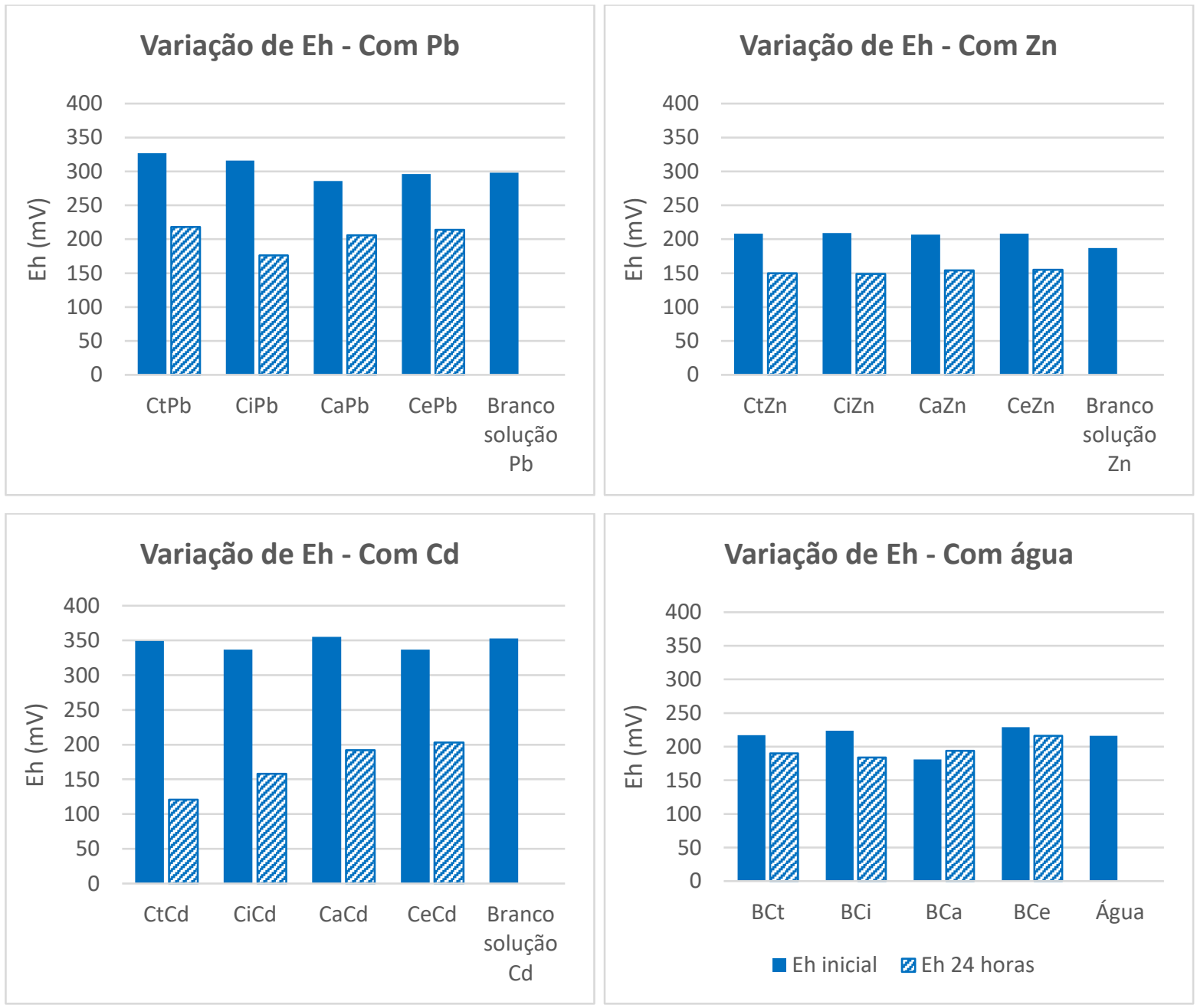

Na figura: $\mathrm{Ct}=$ composto total, $\mathrm{Ci}=$ composto indiano, $\mathrm{Ca}=$ composto alambrado, $\mathrm{Ce}=$ composto estático e $\mathrm{B}=$ branco do composto (composto + água deionizada).

Fonte: A autora.

A Figura 114, por sua vez, exibe a variação de CE (valores iniciais e finais) para o teste dos compostos total, indiano, alambrado e estático, submetidos a uma solução monoelementar (contendo $\mathrm{Pb}, \mathrm{Zn}$ ou $\mathrm{Cd}$ ) ou apenas água deionizada. Todas as amostras apresentaram valores crescentes de CE após decorrido o tempo de contato, sendo a maior variação observada para o composto total, em todos os casos. No tocante aos brancos das soluções contaminantes é notória 
sua influência direta na CE das amostras contendo os compostos e as soluções contaminantes, já que o branco da solução de Zn exibiu a maior CE (em relação aos demais brancos) e as amostras contendo compostos e esta solução também revelaram as maiores condutividades elétricas (em relação às amostras constituídas por compostos e os demais brancos). Constatações similares podem ser formuladas em se tratando do $\mathrm{Pb}$, do $\mathrm{Cd}$ e, até mesmo, da água deionizada, sendo que as menores condutividades elétricas estão associadas aos brancos do composto (composto e água deionizada), o que é plausível já que a condutividade da água foi de $5 \mu \mathrm{S} \mathrm{cm}^{-1}$ (como esperado).

Figura 114 - Valores de condutividade elétrica (CE) iniciais e finais para os quatro compostos:total, indiano, alambrado e estático, com $\mathrm{Pb}, \mathrm{Zn}, \mathrm{Cd}$ e água deionizada
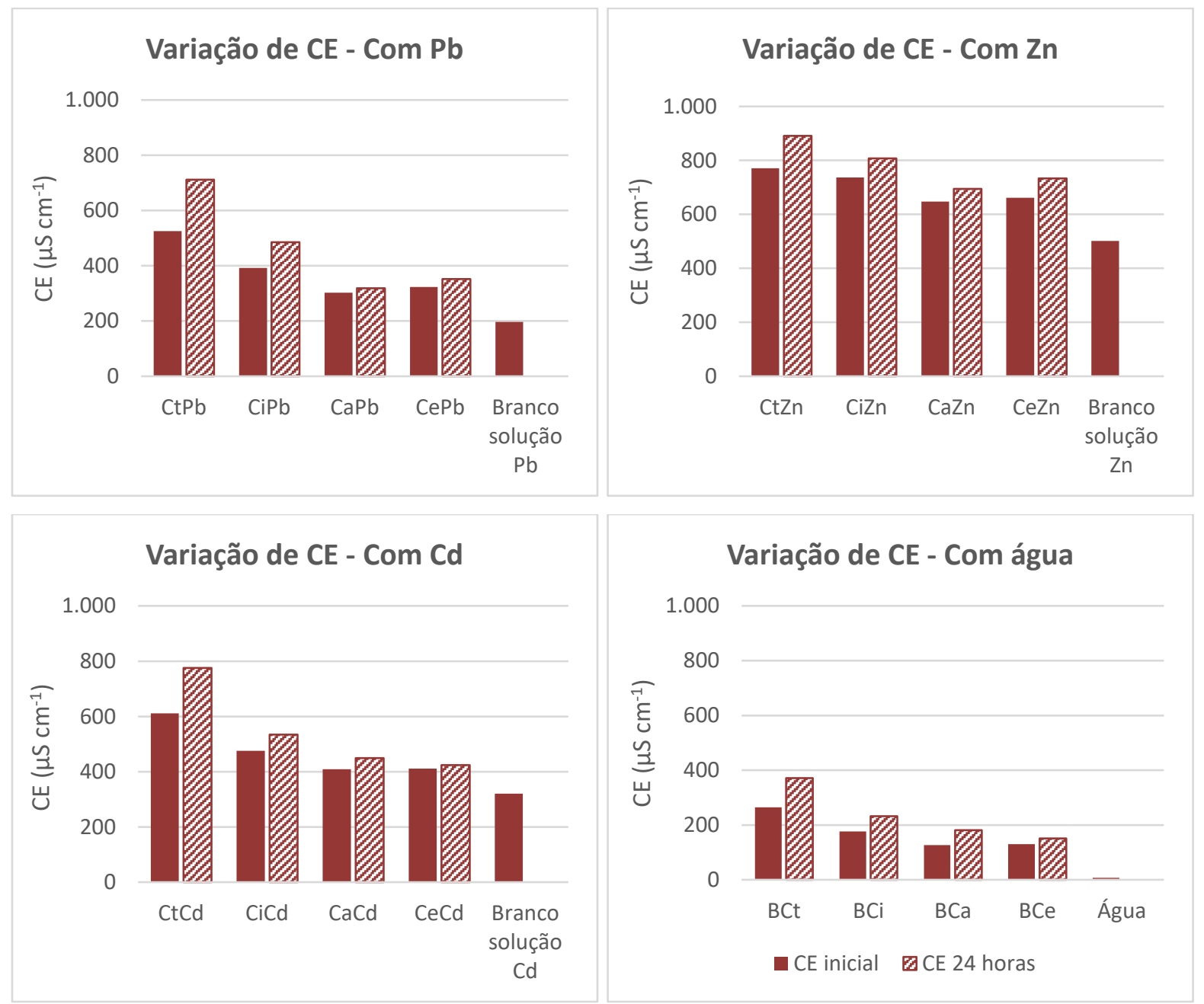

Na figura: $\mathrm{Ct}=$ composto total, $\mathrm{Ci}=$ composto indiano, $\mathrm{Ca}=$ composto alambrado, $\mathrm{Ce}=$ composto estático e $\mathrm{B}=$ branco do composto (composto + água deionizada).

Fonte: A autora. 
A fim de avaliar, de fato, o composto dotado da maior capacidade adsortiva para os metais de interesse, foram utilizados os dados de concentração inicial e de concentração em equilíbrio, sendo calculados os valores referentes à porcentagem de remoção $(\mathrm{A} \%)$ e a capacidade de remoção $\left(\mathrm{q}_{\mathrm{e}}\right)$ de cada metal e para cada composto. Estas informações se encontram apresentadas nas Figuras 115 e 116, respectivamente. Estes gráficos mostram que, de maneira geral, todos os compostos estudados apresentaram a seguinte tendência de remoção metálica: $\mathrm{Pb}>\mathrm{Cd}>\mathrm{Zn}$. Nota-se ainda que os compostos total e indiano se comportaram de maneira similar e é nítida a unanimidade da maior capacidade de remoção de $\mathrm{Pb}$ pelos quatro compostos, exibindo valores de porcentagem de remoção superiores a 94\%.

Figura 115 - Análise comparativa da porcentagem de remoção de $\mathrm{Pb}, \mathrm{Zn}$ e $\mathrm{Cd}$ (A\%) para os compostos estudados (total, indiano, alambrado e estático)

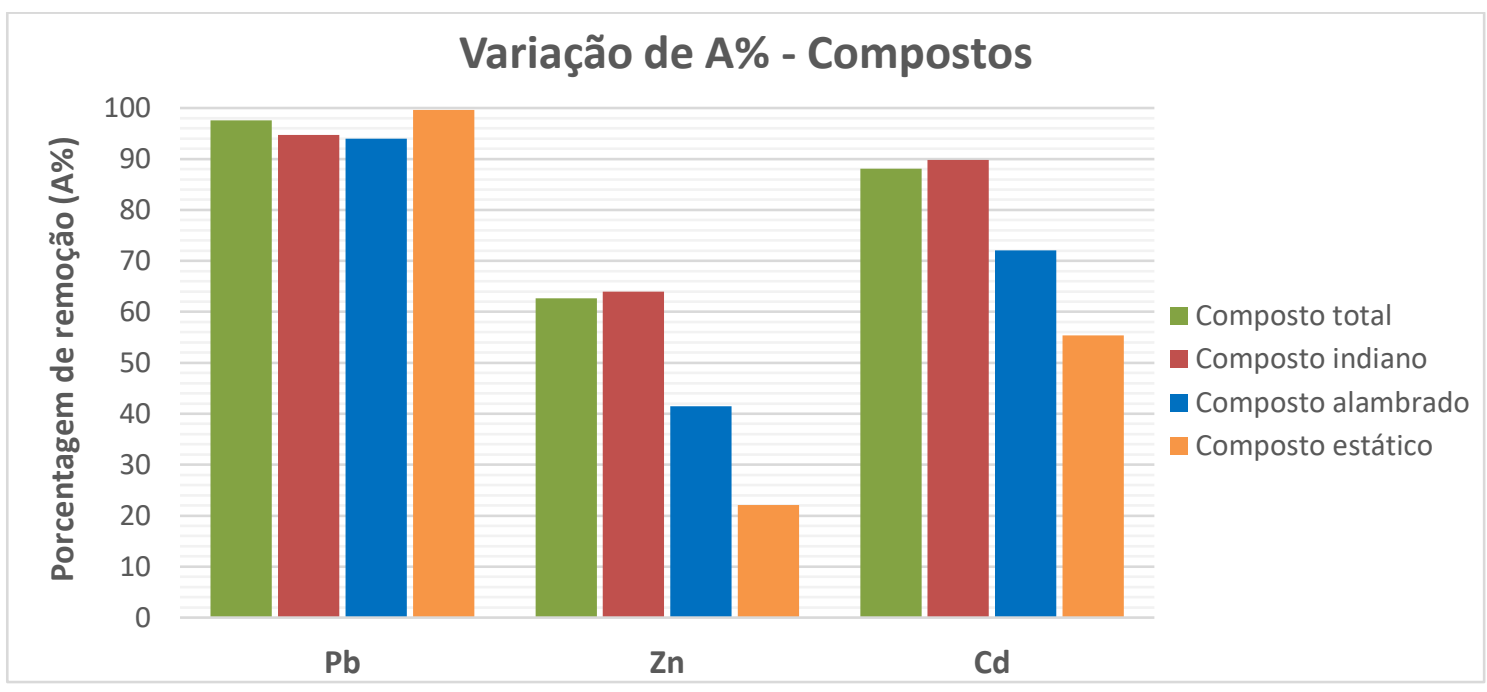

Fonte: A autora.

Figura 116 - Análise comparativa da capacidade de remoção de $\mathrm{Pb}, \mathrm{Zn}$ e $\mathrm{Cd}\left(\mathrm{q}_{\mathrm{e}}\right)$ pelos compostos estudados (total, indiano, alambrado e estático)

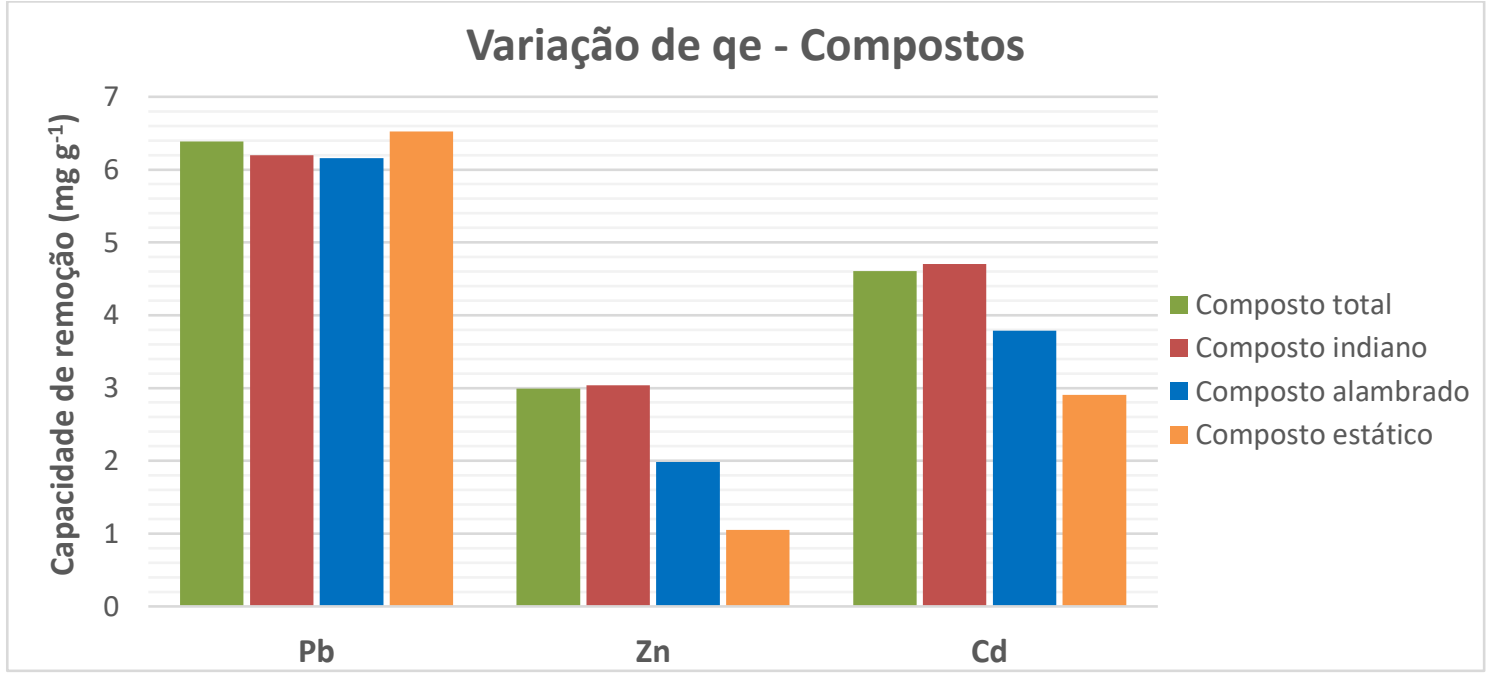

Fonte: A autora. 
Todavia, o objetivo desta análise era justamente destacar o composto dotado da maior capacidade adsortiva para que ele fosse o escolhido para as análises de equilíbrio em lote finais, visando a comparação dos resultados com a turfa. Nessa perspectiva, nota-se que os compostos se comportaram de maneira variada frente ao metal de interesse, sendo que para o $\mathrm{Pb}, \mathrm{o}$ composto com maior capacidade de remoção foi o estático e para o $\mathrm{Zn}$ e o $\mathrm{Cd}$, o indiano. Contudo, a remoção de $\mathrm{Pb}$ para todos os compostos foi bem próxima e as maiores variações se deram justamente em relação ao $\mathrm{Zn}$ e ao $\mathrm{Cd}$. Sendo assim, o composto escolhido para as posteriores análises foi o indiano. Ademais, é válido observar que os compostos total e indiano resultaram em dados bem próximos, mas, mesmo assim, o composto indiano revelou valores ligeiramente superiores. Quanto às características geológicas e geotécnicas, ambos os compostos (total e indiano) se destacaram em relação aos outros compostos orgânicos (alambrado e estático) e apresentaram valores, de modo geral, próximos, com destaque ora para um, ora para outro material. Por exemplo, o composto indiano revelou o maior teor de matéria orgânica (520,43 $\left.\mathrm{g} \mathrm{kg}^{-1}\right)$, enquanto o composto total exibiu a maior CTC $\left(75,00 \mathrm{cmol}_{\mathrm{c}} \mathrm{kg}^{-1}\right)$. Além disso, a utilização do composto indiano foi preferida já que o processo de compostagem indiana foi mais controlado em comparação à compostagem total, tanto em termos de material de entrada, como em termos de acompanhamento ao longo do desenvolvimento do método.

Como fechamento desta análise, a Tabela 62 contém as concentrações de $\mathrm{Pb}, \mathrm{Zn}$ e Cd presentes nos brancos dos compostos (composto e água deionizada). Conforme apresentado na caracterização química destes materiais orgânicos, em todos os compostos estão presentes estes metais, mesmo que em baixas concentrações. Além disso, pode-se constatar que a capacidade de solubilização em água de $\mathrm{Pb}, \mathrm{Zn}$ e Cd pelos compostos estudados é bem reduzida, haja vista as concentrações mínimas observadas nos brancos. Esta informação é útil no sentido de garantir que a presença intrínseca de $\mathrm{Pb}, \mathrm{Zn}$ e Cd não interfira nas concentrações das amostras contendo os compostos acrescidos das soluções contaminantes. Assim, pode-se considerar que os metais presentes nestas amostras são majoritariamente advindos das soluções sintéticas.

Tabela 62 - Concentração de $\mathrm{Pb}, \mathrm{Zn}$ e Cd nos brancos dos compostos (composto + água deionizada)

\begin{tabular}{|c|c|c|c|c|}
\hline $\begin{array}{c}\text { Metais } \\
\left(\mathrm{mg} \mathrm{L}^{-1}\right) \\
\end{array}$ & $\begin{array}{c}\text { Composto } \\
\text { total }\end{array}$ & $\begin{array}{c}\text { Composto } \\
\text { indiano } \\
\end{array}$ & $\begin{array}{c}\text { Composto } \\
\text { alambrado }\end{array}$ & $\begin{array}{c}\text { Composto } \\
\text { estático } \\
\end{array}$ \\
\hline $\mathrm{Pb}$ & $<$ l.q. & $<1 . q$. & $<$ l.q. & $<$ l.q. \\
\hline $\mathrm{Zn}$ & 0,017 & 0,056 & 0,027 & 0,047 \\
\hline $\mathrm{Cd}$ & 0,003 & 0,003 & 0,001 & 0,001 \\
\hline
\end{tabular}

< 1.q. = inferior ao limite de quantificação do equipamento.

Fonte: A autora. 


\subsubsection{Ensaio de equilíbrio em lote para turfa e composto indiano}

O ensaio de equilíbrio em lote propriamente dito, conforme relatado anteriormente, foi realizado para a turfa e para o composto indiano, sendo todas as amostras na razão adsorvente/solução de 1/50, contendo $1 \mathrm{~g}$ de material orgânico e $50 \mathrm{~mL}$ de solução contaminante. Cada material reativo foi colocado em contato por 24 horas com soluções monoelementares de $\mathrm{Pb}, \mathrm{Zn}$ e $\mathrm{Cd}$ em oito concentrações diferentes e inferiores a $220 \mathrm{mg} \mathrm{L}^{-1}$. Para todos os metais, as soluções preparadas apresentaram concentrações médias inferiores aos valores teóricos estimados. Contudo, não houve subestimação ou superestimação dos parâmetros resultantes, já que nos cálculos foram empregadas as concentrações reais das soluções (brancos).

Os resultados destes ensaios estão apresentados para cada metal. Estão sendo mostrados os parâmetros físico-químicos ( $\mathrm{pH}$, Eh e $\mathrm{CE}$ ) antes e após o contato dos materiais reativos orgânicos com as soluções metálicas, análises comparativas relacionando as concentrações adsorvidas e em equilíbrio e as isotermas de sorção.

A fim de melhor avaliar a variação da sorção de $\mathrm{Pb}, \mathrm{Zn}$ e Cd pela turfa e pelo composto indiano, considerando as diferentes concentrações da solução contaminante, foram construídas, a partir dos resultados obtidos, as respectivas isotermas, segundo os modelos Linear, Freundlich e Langmuir, similar ao apresentado para o teste da melhor razão turfa/solução. Como parâmetros de entrada foram empregados: massa de adsorvente - turfa ou composto indiano (g), volume de solução (L), concentração inicial de $\mathrm{Pb}, \mathrm{Zn}$ ou $\mathrm{Cd}\left(\mathrm{mg} \mathrm{L}^{-1}\right)$ e concentração de $\mathrm{Pb}, \mathrm{Zn}$ ou Cd no equilíbrio $\left(\mathrm{mg} \mathrm{L}^{-1}\right)$. Em relação a isoterma Linear foi seguida a formulação literária mais usual, exibida em diversos trabalhos, como Sparks (1995a), Stumm e Morgan (1996), Don Scott (2000) e Soares e Casagrande (2000), de acordo com a qual a reta deve passar obrigatoriamente pela origem, o que propicia na formulação a não existência de um termo independente, e a título comparativo, foi construída a forma proposta por Young (2001), segundo a qual a reta não apresenta obrigatoriedade de passar pela origem proporcionando, dessa forma, o aparecimento de um termo independente na fórmula. Quanto às demais isotermas foram empregadas suas formas linearizadas (Freundlich, Langmuir I e Langmuir II) com o intuito de se estimar os respectivos parâmetros de adsorção.

\subsubsection{Chumbo}

A Figura 117 ilustra a variação de $\mathrm{pH}$ para as soluções contendo turfa e composto indiano em contato com $\mathrm{Pb}$. Em termos gerais, em ambos os casos houve uma leve tendência de diminuição dos valores de $\mathrm{pH}$ das amostras contendo material adsorvente e solução 
contaminante (inicial e final), em função do aumento da concentração de $\mathrm{Pb}$. Mais especificamente, para uma mesma amostra se manifestou um aumento de $\mathrm{pH}$ decorridas as 24 horas de contato, sendo esta elevação menos pronunciada para as maiores concentrações. Para as amostras contendo turfa, o $\mathrm{pH}$ dos brancos das soluções oscilou em torno de 5,0, e a partir da concentração de $81 \mathrm{mg} \mathrm{L}^{-1}$, este valor foi superior ao $\mathrm{pH}$ inicial e final. Diferentemente, para os compostos, mesmo o $\mathrm{pH}$ dos brancos também oscilando nas proximidades de 5,0, o próprio material orgânico propiciou condições de $\mathrm{pH}$ mais elevado, sendo que o $\mathrm{pH}$ final foi superior ao $\mathrm{pH}$ inicial e ao próprio $\mathrm{pH}$ das soluções em todas as concentrações de $\mathrm{Pb}$.

Figura 117 - Variação de $\mathrm{pH}$ ao longo do ensaio de equilíbrio em lote com $\mathrm{Pb}$ para a turfa e para o composto indiano
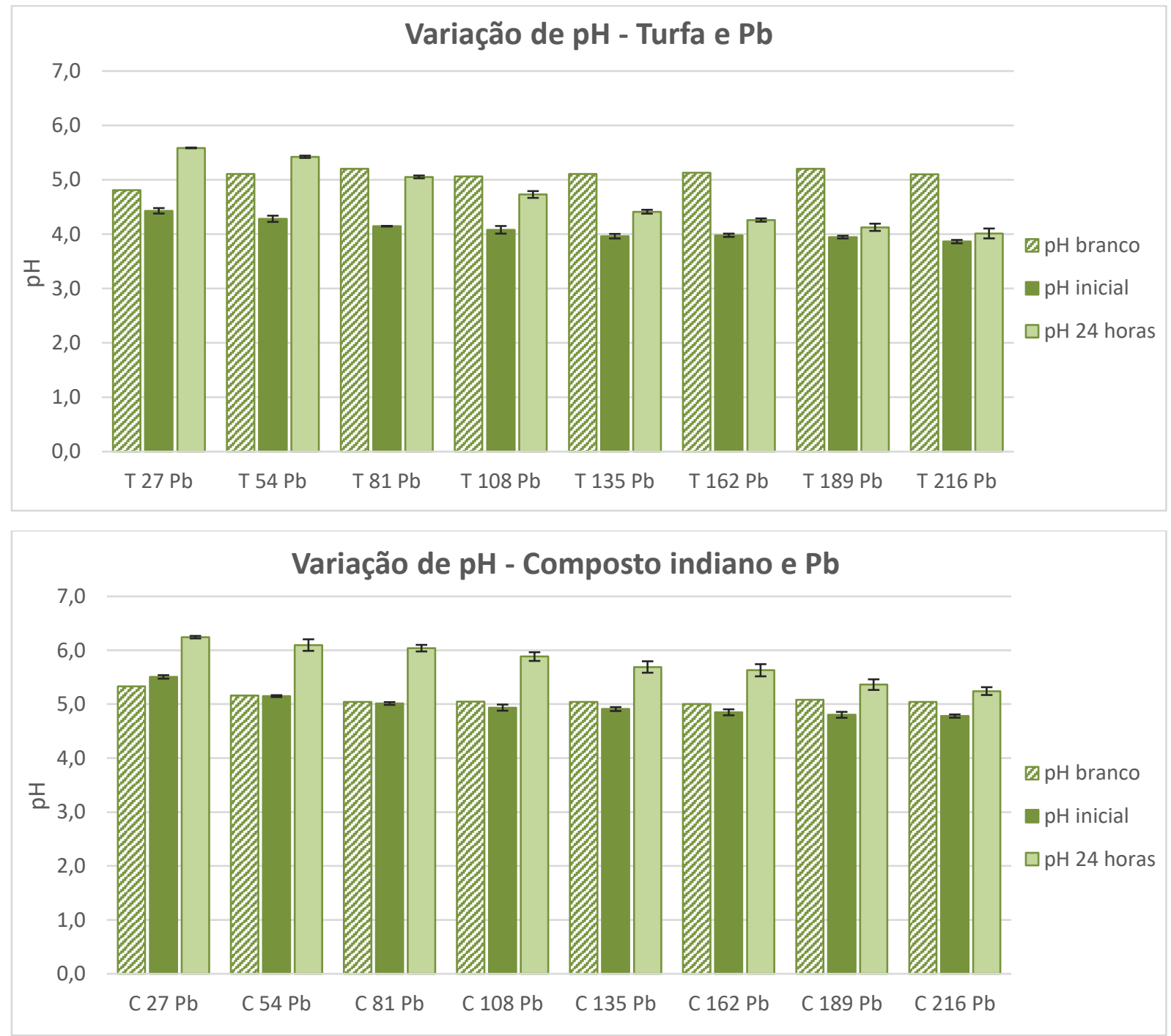

pH branco: $\mathrm{pH}$ das soluções branco (contendo $\mathrm{Pb}$ );

pH inicial: pH das amostras iniciais (imediatamente após mistura do material orgânico com a solução); pH 24 horas: $\mathrm{pH}$ das amostras finais (decorrido 24 horas de contato, imediatamente após a filtração);

No eixo das abscissas: T: turfa; $\mathrm{C}$ : composto indiano; e o número se refere a concentração de $\mathrm{Pb}$ na solução inicialmente adicionada (branco da solução).

Fonte: A autora. 
Para a comparação com os dados deste estudo, Silva (2013) avaliou a adsorção de $\mathrm{Pb}$ por três diferentes materiais inconsolidados transportados e um material inconsolidado residual, todos eles originados de Eldorado Paulista (SP) na razão solo/solução de 1/5 (20 g de solo e $100 \mathrm{~mL}$ de solução). A autora trabalhou com concentrações variando nas proximidades de $23 \mathrm{a}$ $131 \mathrm{mg} \mathrm{L}^{-1}$ (concentrações menores que as avaliadas neste estudo), e obteve valores de $\mathrm{pH}$ finais das soluções filtradas levemente superiores aos valores de $\mathrm{pH}$ iniciais (o que se encontra em conformidade com os resultados obtidos e apresentados na Figura 117), em praticamente todos os casos, salvo algumas exceções para as maiores concentrações, principalmente para o material residual. Ainda segundo a autora, seus valores de $\mathrm{pH}$ dos brancos da solução de $\mathrm{Pb}$ foram superiores aos valores de $\mathrm{pH}$ das soluções finais após filtração, semelhante ao ocorrido para a turfa (a partir da concentração de $81 \mathrm{mg} \mathrm{L}^{-1}$ ) e diferentemente do que pode ser observado para as duas menores concentrações de turfa e para todas as concentrações dos compostos, mostrando que a turfa se aproxima mais do comportamento esperado de solos que o composto.

Similarmente, Marques (2014) e Araújo (2015) também estudaram materiais inconsolidados transportados de Eldorado Paulista (SP) na razão solo/solução de 1/5. Marques (2014) trabalhou com concentrações variando em torno de 20 a $100 \mathrm{mg} \mathrm{L}^{-1}$ e obteve valores de $\mathrm{pH}$ finais levemente superiores aos valores de $\mathrm{pH}$ iniciais e valores de $\mathrm{pH}$ dos brancos superiores aos valores de $\mathrm{pH}$ finais para todas as concentrações de $\mathrm{Pb}$. Os resultados de Araújo (2015) também revelaram valores de $\mathrm{pH}$ finais superiores aos iniciais para as concentrações utilizadas (50 a $250 \mathrm{mg} \mathrm{L}^{-1}$ ), e $\mathrm{pH}$ dos brancos superiores aos valores de $\mathrm{pH}$ finais apenas para concentrações maiores que $150 \mathrm{mg} \mathrm{L}^{-1}$.

Estes exemplos confirmam que o comportamento da turfa em comparação com o composto, em se tratando da variação de $\mathrm{pH}$, é mais próximo do comportamento típico de solos e mostram a influência do $\mathrm{pH}$ do adsorvente no $\mathrm{pH}$ das amostras contendo o material reativo e a solução contaminante. De fato, provavelmente devido ao menor $\mathrm{pH}$ dos materiais inconsolidados em relação aos materiais orgânicos, a faixa de variação deste parâmetro no caso dos referidos autores foi inferior, em torno de 3,5 a 5,5.

A Figura 118 mostra a variação de Eh para as soluções contendo turfa e composto indiano em contato com $\mathrm{Pb}$. De modo geral, para ambos os materiais adsorventes o Eh das amostras após decorrido o tempo de contato de 24 horas foi inferior ao Eh dos brancos e das amostras iniciais. Ademais, o Eh das amostras finais apresentou uma tendência não uniforme, mas crescente com o aumento das concentrações, de modo mais acentuado para a turfa. A análise comparativa permite ainda observar que os valores de Eh foram maiores para a turfa (+224 a +383 mV) em relação ao composto (+170 a +270 mV). Para o composto, os valores de 
Eh do branco e da solução inicial foram parecidos, principalmente para as concentrações $27 \mathrm{mg}$ $\mathrm{L}^{-1}, 54 \mathrm{mg} \mathrm{L}^{-1}, 81 \mathrm{mg} \mathrm{L}^{-1}, 189 \mathrm{mg} \mathrm{L}^{-1}$ e $216 \mathrm{mg} \mathrm{L}^{-1}$. É válido ressaltar que salvo variações de valor todos os resultados de Eh foram positivos, categorizando o meio como oxidante.

Figura 118 - Variação de Eh ao longo do ensaio de equilíbrio em lote com Pb para a turfa e para o composto indiano
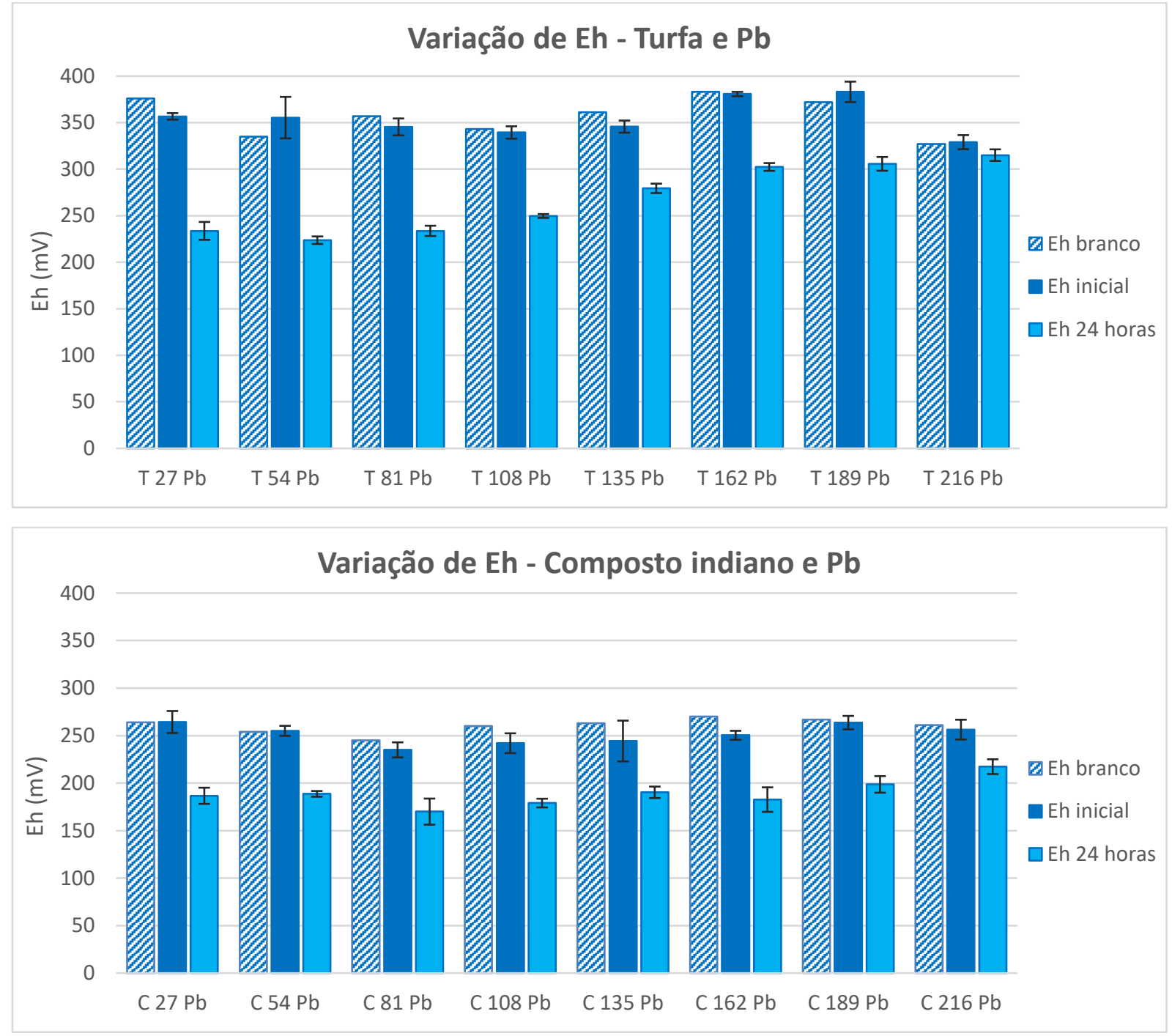

Eh branco: Eh das soluções branco (contendo $\mathrm{Pb}$ );

Eh inicial: Eh das amostras iniciais (imediatamente após mistura do material orgânico com a solução); Eh 24 horas: Eh das amostras finais (decorrido 24 horas de contato, imediatamente após a filtração);

No eixo das abscissas: T: turfa; $\mathrm{C}$ : composto indiano; e o número se refere a concentração de $\mathrm{Pb}$ na solução inicialmente adicionada (branco da solução).

Fonte: A autora.

Os resultados de Silva (2013) corroboram com os dados desta pesquisa, já que a autora obteve valores de Eh para suas amostras finais filtradas superiores aos respectivos valores de Eh do início do ensaio. Em contrapartida, Marques (2014) não verificou esta constatação para todas as suas amostras. 
A Figura 119 exibe a variação de condutividade elétrica para as soluções contendo turfa e composto indiano em contato com $\mathrm{Pb}$. Especificamente para a turfa, foram obtidos valores de CE bem similares, antes e após o tempo de contato. Para o composto, a CE medida após as 24 horas foi superior às medidas iniciais. Em relação aos brancos das soluções contaminantes, a $\mathrm{CE}$ medida, para as mesmas concentrações de $\mathrm{Pb}$, para o ensaio com a turfa e com o composto, foram bem próximas e apresentaram valores crescentes com a concentração, como era esperado. Assim, as amostras contendo material reativo e estas soluções também revelaram valores de CE crescentes com a concentração, sendo estes valores superiores para o composto, provavelmente em função da condutividade intrínseca do composto ser maior em comparação com a turfa.

Figura 119 - Variação de condutividade elétrica (CE) ao longo do ensaio de equilíbrio em lote com $\mathrm{Pb}$ para a turfa e para o composto indiano
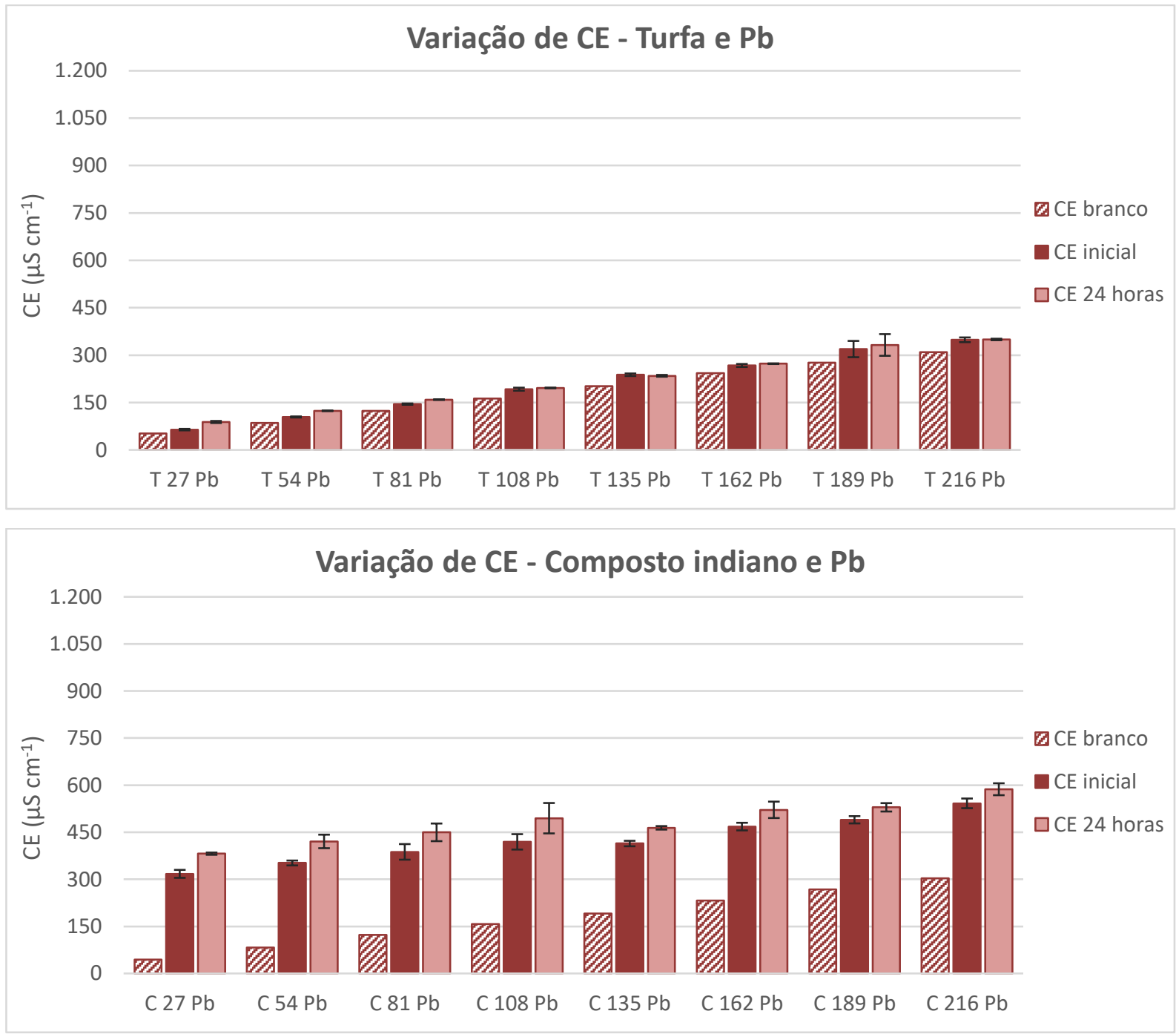

CE branco: $\mathrm{CE}$ das soluções branco (contendo $\mathrm{Pb}$ );

CE inicial: CE das amostras iniciais (imediatamente após mistura do material orgânico com a solução);

CE 24 horas: CE das amostras finais (decorrido 24 horas de contato, imediatamente após a filtração);

No eixo das abscissas: $\mathrm{T}$ : turfa; $\mathrm{C}$ : composto indiano; e o número se refere a concentração de $\mathrm{Pb}$ na solução inicialmente adicionada (branco da solução).

Fonte: A autora. 
Silva (2013) e Araújo (2015) também exibiram dados de condutividade elétrica que se elevaram com o aumento da concentração de Pb. No entanto, segundo Silva (2013) não foram todas as amostras com material inconsolidado que apresentaram padrão de crescimento em relação à CE ao longo do ensaio. Já os dados de Araújo (2015) revelaram valores de CE finais inferiores aos respectivos valores iniciais para concentrações de $\mathrm{Pb}$ maiores que $100 \mathrm{mg} \mathrm{L}^{-1}$.

A partir dos resultados experimentais foi possível relacionar as concentrações adsorvida e em equilíbrio (não adsorvida) conforme a Figura 120. Assim, pode-se observar que tanto a turfa como o composto se mostraram altamente eficientes em se tratando da retenção de $\mathrm{Pb}$. Ademais, em ambos os casos houve uma tendência crescente de aumento da concentração de $\mathrm{Pb}$ adsorvida pelo material reativo em função da elevação da concentração inicial de $\mathrm{Pb}$ em solução. Contudo, o composto se mostrou mais eficiente, principalmente para as concentrações mais elevadas, revelando um menor potencial de saturação dos seus sítios de adsorção.

Figura 120 - Análise comparativa das concentrações adsorvida e em equilíbrio ao longo do ensaio de equilíbrio em lote com $\mathrm{Pb}$ para a turfa e para o composto indiano

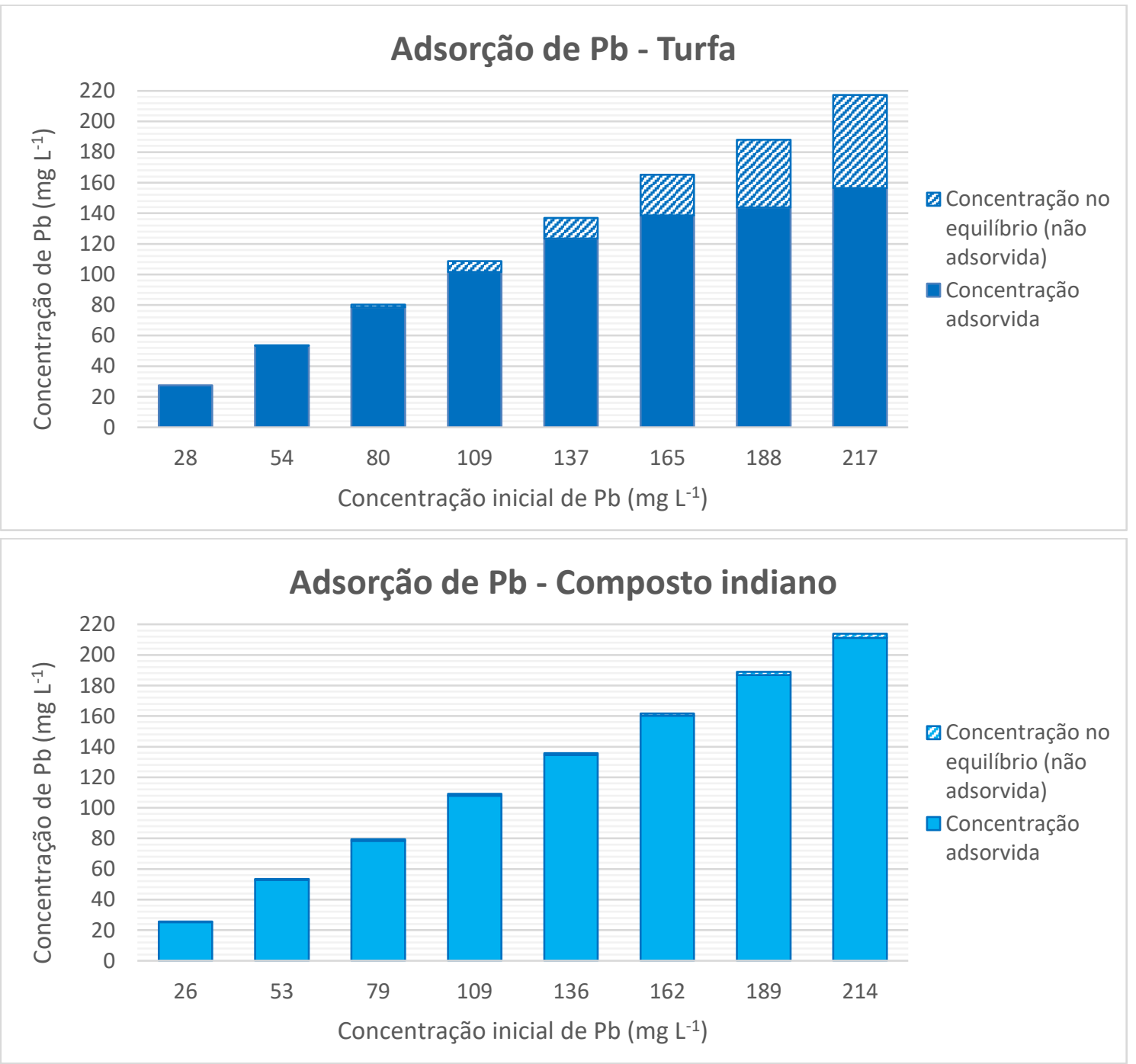

Fonte: A autora. 
Com o intuito de refinar a análise adsortiva foram construídas as isotermas de adsorção na forma linearizada e, a partir delas, foram estimados os respectivos parâmetros de adsorção. Estas informações se encontram nas Tabelas 63 e 64, onde estão destacados o maior coeficiente de determinação para cada material reativo orgânico, associado ao modelo que melhor se ajustou aos dados laboratoriais. Os dados referentes a isoterma Linear passando pela origem para a turfa foram desconsiderados por apresentarem uam correlação desprezível com os dados laboratoriais.

Tabela 63 - Parâmetros de adsorção para o Pb estimados a partir das isotermas Linear e de Freundlich

\begin{tabular}{|c|c|c|c|c|c|c|c|}
\hline \multirow{2}{*}{ Material } & \multicolumn{2}{|c|}{ Linear* } & \multicolumn{2}{|c|}{ Linear** } & \multicolumn{3}{|c|}{ Freundlich } \\
\hline & $\mathbf{K}_{\mathbf{d}}\left(\mathbf{L} \mathbf{g}^{-1}\right)$ & $\mathbf{R}^{2}$ & $K_{d}\left(L g^{-1}\right)$ & $\mathbf{R}^{2}$ & $\mathbf{R}^{2}$ & $\mathbf{n}$ & $\mathbf{R}^{2}$ \\
\hline \multirow{2}{*}{ Turfa } & 0,071 & 0,768 & -- & -- & 3,748 & 0,175 & 0,989 \\
\hline & \multicolumn{2}{|c|}{$q_{e}=0,071 \mathrm{C}_{\mathrm{e}}+4,096$} & \multicolumn{2}{|c|}{--} & \multicolumn{3}{|c|}{$\log q_{e}=0,175 \log C_{e}+0,574$} \\
\hline \multirow{2}{*}{ Composto } & 3,942 & 0,898 & 4,399 & 0,882 & 4,520 & 1,020 & 0,952 \\
\hline & \multicolumn{2}{|c|}{$q_{e}=3,942 \mathrm{C}_{\mathrm{e}}+0,788$} & \multicolumn{2}{|c|}{$q_{e}=4,399 \mathrm{C}_{\mathrm{e}}$} & \multicolumn{3}{|c|}{$\log q_{e}=1,020 \log C_{e}+0,655$} \\
\hline
\end{tabular}

* Isoterma Linear sem passar pela origem;

** Isoterma Linear passando pela origem.

Fonte: A autora.

Tabela 64 - Parâmetros de adsorção para o Pb estimados a partir das isotermas de Langmuir (I e II)

\begin{tabular}{|c|c|c|c|c|c|c|}
\hline \multirow{2}{*}{ Material } & \multicolumn{3}{|c|}{ Langmuir I } & \multicolumn{3}{|c|}{ Langmuir II } \\
\hline & $\mathrm{qm}_{\mathrm{m}}\left(\mathrm{mg} \mathrm{g}^{-1}\right)$ & $K_{L}\left(L \mathrm{mg}^{-1}\right)$ & $\mathbf{R}^{2}$ & $q_{m}\left(m g g^{-1}\right)$ & $\mathrm{K}_{\mathrm{L}}\left(\mathrm{L} \mathrm{mg}^{-1}\right)$ & $\mathbf{R}^{2}$ \\
\hline \multirow[b]{2}{*}{ Turfa } & 7,843 & 0,387 & 0,995 & 5,970 & 6,893 & 0,804 \\
\hline & \multicolumn{3}{|c|}{$\frac{\mathrm{C}_{\mathrm{e}}}{\mathrm{q}_{\mathrm{e}}}=0,127 \mathrm{C}_{\mathrm{e}}+0,330$} & \multicolumn{3}{|c|}{$\frac{1}{\mathrm{q}_{\mathrm{e}}}=0,024 \frac{1}{\mathrm{C}_{\mathrm{e}}}+0,167$} \\
\hline \multirow[b]{2}{*}{ Composto } & 185,185 & 0,025 & 0,015 & 40,984 & 0,098 & 0,986 \\
\hline & \multicolumn{3}{|c|}{$\frac{\mathrm{C}_{\mathrm{e}}}{\mathrm{q}_{\mathrm{e}}}=0,005 \mathrm{C}_{\mathrm{e}}+0,216$} & \multicolumn{3}{|c|}{$\frac{1}{\mathrm{q}_{\mathrm{e}}}=0,250 \frac{1}{\mathrm{C}_{\mathrm{e}}}-0,024$} \\
\hline
\end{tabular}

Fonte: A autora.

Com base nos coeficientes de determinação $\left(\mathrm{R}^{2}\right)$ foi possível observar a seguinte ordem decrescente de modelos quanto ao melhor ajuste dos dados experimentais:

Turfa: Langmuir I > Freundlich > Langmuir II > Linear

Composto: Langmuir II > Freundlich > Linear* $>$ Linear** > Langmuir I 
De acordo com Zuquette, Silva Jr e Garcia (2008) o valor de $n$ igual a 0,175 obtido pela isoterma de Freundlich para a turfa permite classificar esta sorção como desfavorável $(n<1)$ e o valor de $n$ igual a 1,020 para o composto indiano categoriza esta sorção como linear $(n=1)$.

Substituindo os parâmetros de adsorção encontrados em suas respectivas formas gerais de isotermas e, a partir destas formulações, escolhendo-se valores arbitrários de $\mathrm{C}_{\mathrm{e}}$ (dentro da amplitude em que se encontram os dados experimentais) foi possível calcular os valores correspondentes de $\mathrm{q}_{\mathrm{e}}$. Essas correlações foram graficadas para os modelos que apresentaram $\mathrm{R}^{2}$ igual ou superior a 0,8 na sua forma linearizada (valor associado a um ajuste considerado satisfatório para este estudo). Os resultados estão apresentados na Figura 121. Conforme concluído anteriormente, a partir dos coeficientes de determinação, estes gráficos evidenciam que as isotermas de Langmuir I e Freundlich se ajustaram melhor para a adsorção de Pb pela turfa e a isoterma de Langmuir II se ajustou melhor aos dados experimentais referentes à adsorção de $\mathrm{Pb}$ pelo composto indiano.

Figura 121 - Comparação entre os dados obtidos experimentalmente e as isotermas que apresentaram $\mathrm{R}^{2} \geq 0,8$ na forma linearizada em relação à adsorção de $\mathrm{Pb}$

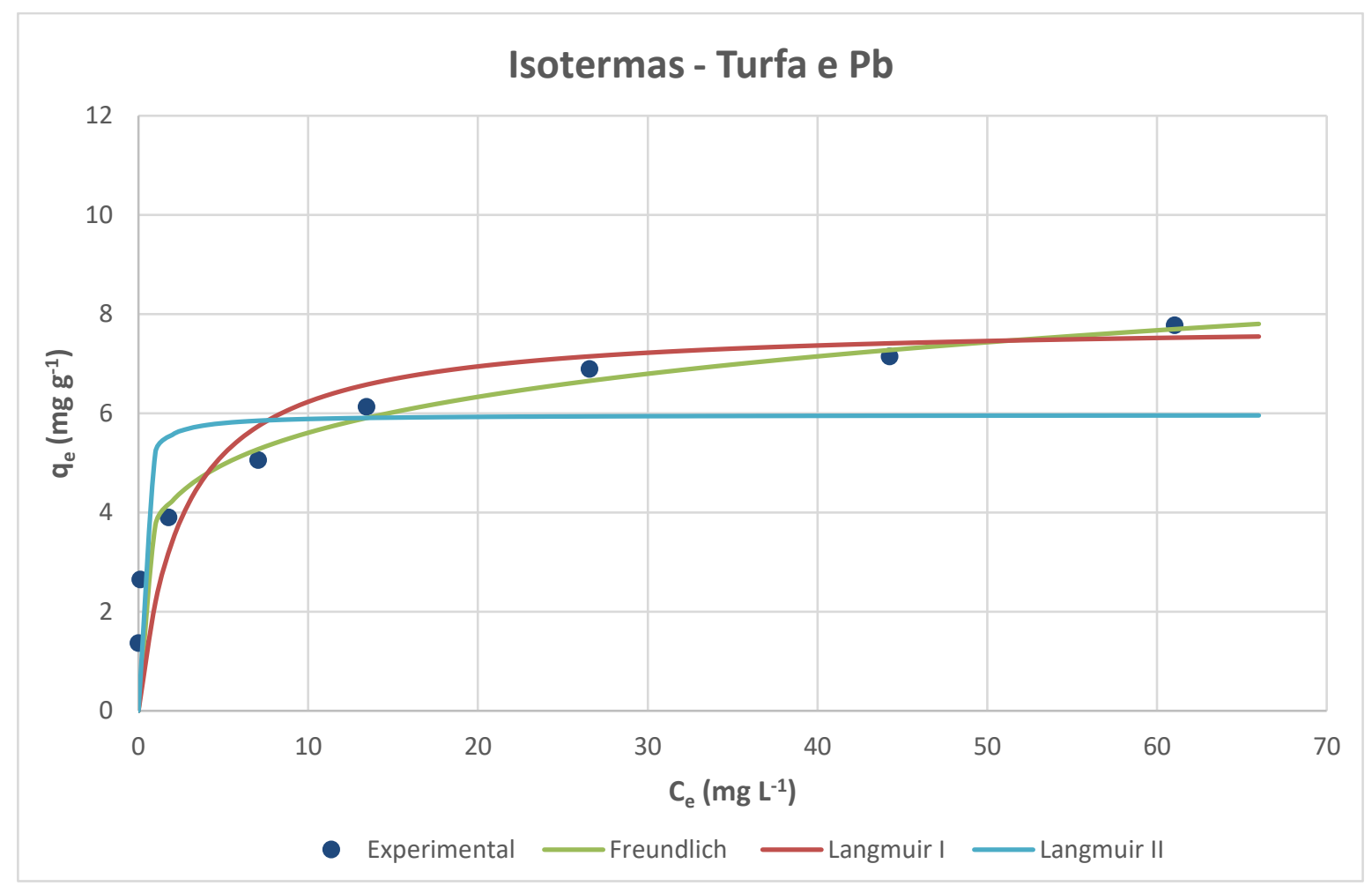




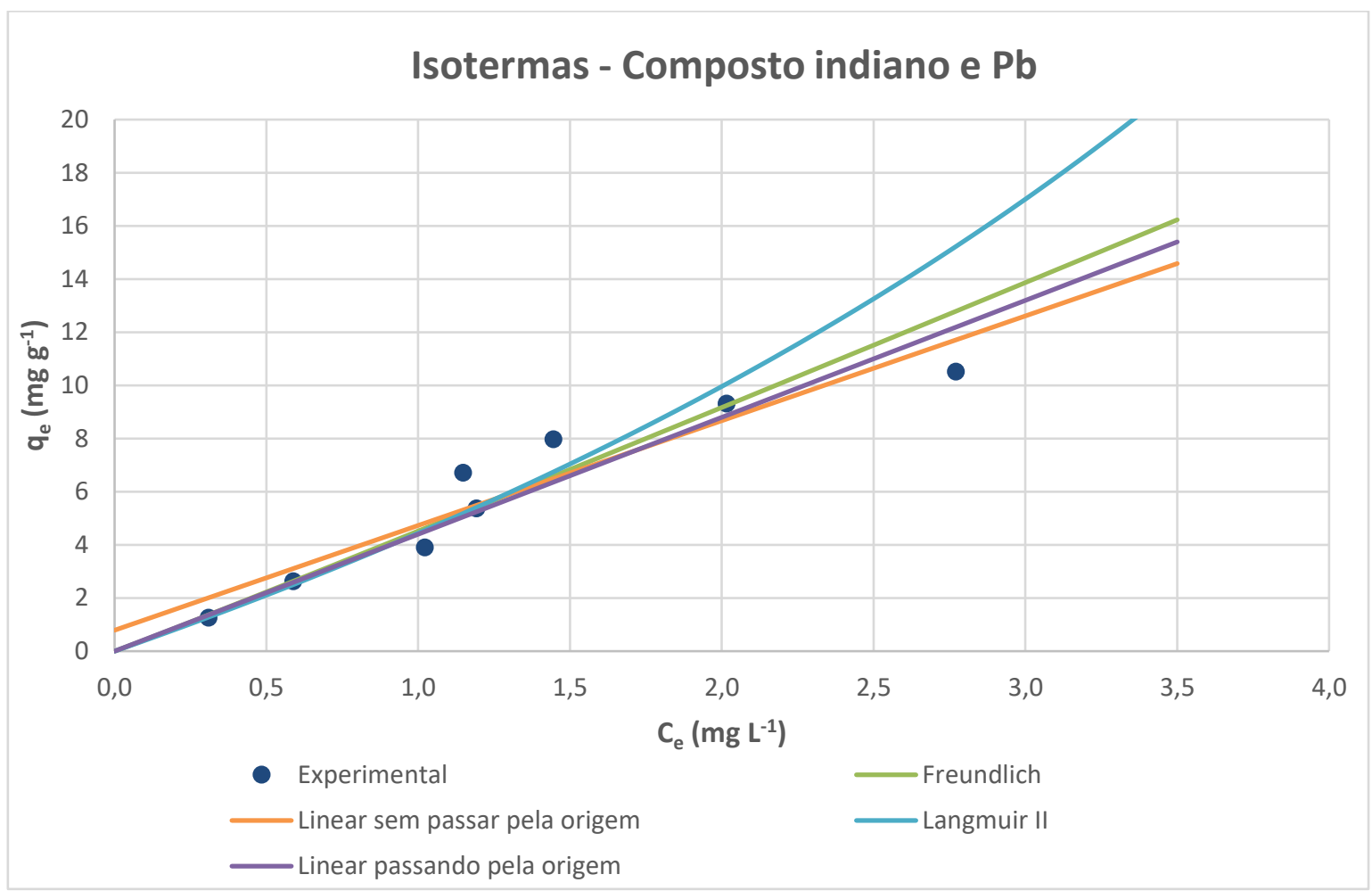

Fonte: A autora.

Conforme indicado anteriormente pela própria variação de concentração e confirmado pelo formato das isotermas, em termos comportamentais, a adsorção de $\mathrm{Pb}$ pela turfa e pelo composto indiano apresenta substanciais diferenças.

No caso da turfa, os dados de adsorção foram satisfatoriamente descritos por uma isoterma "tipo L" e, mais especificamente, segundo Giles, Smith e Huitson (1974) a isoterma em questão pode ser enquadrada no subgrupo 2, devido à formação de um platô. Este modelo é comumente encontrado na predição da adsorção de metais potencialmente tóxicos pelo solo. Ainda de acordo com Giles, Smith e Huitson (1974) a inclinação de uma isoterma, em qualquer ponto, é um indicativo da facilidade com que as moléculas do soluto podem encontrar sítios de adsorção vazios. $\mathrm{Na}$ isoterma "tipo L", esta inclinação cai constantemente em função do aumento da concentração, já que progressivamente os sítios vazios vão sendo mais difíceis de serem encontrados, até que se atinge a saturação, quando a inclinação se torna nula por não mais existirem sítios vazios. Sposito (1989) complementa que o adsorvato apresenta uma alta afinidade pela superfície do adsorvente, em pequenas concentrações. Todavia, com o aumento da concentração, ocorre a elevação da cobertura da superfície e a afinidade anteriormente apresentada diminui.

Em termos numéricos, observou-se ainda para o ensaio com a turfa que até a concentração da solução de $\mathrm{Pb}$ de $137 \mathrm{mg} \mathrm{L}^{-1}$ (associada a uma concentração de equilíbrio em 
torno de $13 \mathrm{mg} \mathrm{L}^{-1}$, justamente onde tende a se iniciar o platô de constância da isoterma) a quantidade do metal adsorvida (aqui no valor porcentual de 90\%) apresentou uma tendência uniforme de crescimento. Contudo, a partir desta concentração, as quantidades adsorvidas se tornaram consideravelmente cada vez menores, e na maior concentração de $\mathrm{Pb}\left(217 \mathrm{mg} \mathrm{L}^{-1}\right)$ a porcentagem de $\mathrm{Pb}$ adsorvida já foi de $72 \%$.

Já para o composto indiano os resultados de adsorção foram satisfatoriamente descritos por uma isoterma com formato intermediário entre "tipo $\mathrm{S}$ e C", apresentando uma tendência sigmoidal inicial a linear e, mais especificamente, segundo Giles, Smith e Huitson (1974) a isoterma em questão pode ser enquadrada no subgrupo 1, representando um sistema no qual a monocamada de adsorvente não foi completada. Ainda de acordo com Giles, Smith e Huitson (1974) em isotermas "tipo S" a inclinação da curva aumenta inicialmente com a concentração, haja vista que são mantidos sítios vazios mesmo com a elevação da quantidade de moléculas de soluto. Contudo, assim como as isotermas "tipo L", eventualmente, se atinge a saturação. Quanto às isotermas "tipo C", a quantidade de sítios de adsorção permanece constante ao longo de toda a gama de concentrações do soluto, revelando uma afinidade constante do adsorvente pelo soluto, até que se atinge a saturação.

Em termos numéricos, verificou-se ainda para o ensaio com o composto indiano que em nenhum momento ocorreu a total adsorção dos íons de $\mathrm{Pb}$, nem mesmo para a menor concentração (26 mg L $\mathrm{m}^{-1}$ ), diferentemente para a turfa que adsorveu $100 \%$ dos íons contaminantes quando presentes na menor das concentrações estudadas. Todavia, enquanto no ensaio com a turfa as concentrações de equilíbrio se tornaram cada vez maiores com o aumento das concentrações de $\mathrm{Pb}$, no caso do composto, mesmo em contato com concentrações dotadas de mais íons, a concentração de equilíbrio aumentou, mas de forma tão diminuta, que ela se manteve praticamente constante (haja vista a variação de escala no eixo das abscissas para ambas as isotermas). Assim, ao longo de toda a variação de concentração de $\mathrm{Pb}$ no ensaio com o composto indiano, a porcentagem de $\mathrm{Pb}$ adsorvida foi sempre superior a $98 \%$.

\subsubsection{Zinco}

A Figura 122 apresenta a variação de $\mathrm{pH}$ para as soluções contendo turfa e composto indiano em contato com $\mathrm{Zn}$. Em ambos os casos as amostras constituídas pelos materiais reativos e a solução contaminante apresentaram valores de $\mathrm{pH}$, iniciais e finais, inferiores aos respectivos brancos. Para o composto esta variação foi menor, possivelmente devido ao fato do composto indiano revelar um pH natural superior em relação ao mesmo parâmetro medido para a turfa. Em se tratando da turfa, até a concentração de $\mathrm{Zn}$ aproximada de $90 \mathrm{mg} \mathrm{L}^{-1}$, decorrido 
o tempo de contato do ensaio, houve uma elevação do valor do $\mathrm{pH}$, em relação ao $\mathrm{pH}$ inicial, e, partir da concentração de $108 \mathrm{mg} \mathrm{L}^{-1}$, é observado um comportamento contrário, haja vista a diminuição dos valores de pH. Já para o composto, esta inversão comportamental é observada anteriormente, apenas as amostras associadas à concentração de $18 \mathrm{mg} \mathrm{L}^{-1}$ passam pelo aumento de $\mathrm{pH}$ (muito próximo do valor inicial), uma vez que a partir da concentração de $36 \mathrm{mg} \mathrm{L}^{-1}$ já se verifica a diminuição, cada vez mais pronunciada, dos valores de $\mathrm{pH}$. Estes comportamentos são um pouco diferenciados do que foi observado em relação ao ensaio com $\mathrm{Pb}$.

Figura 122 - Variação de pH ao longo do ensaio de equilíbrio em lote com $\mathrm{Zn}$ para a turfa e para o composto indiano
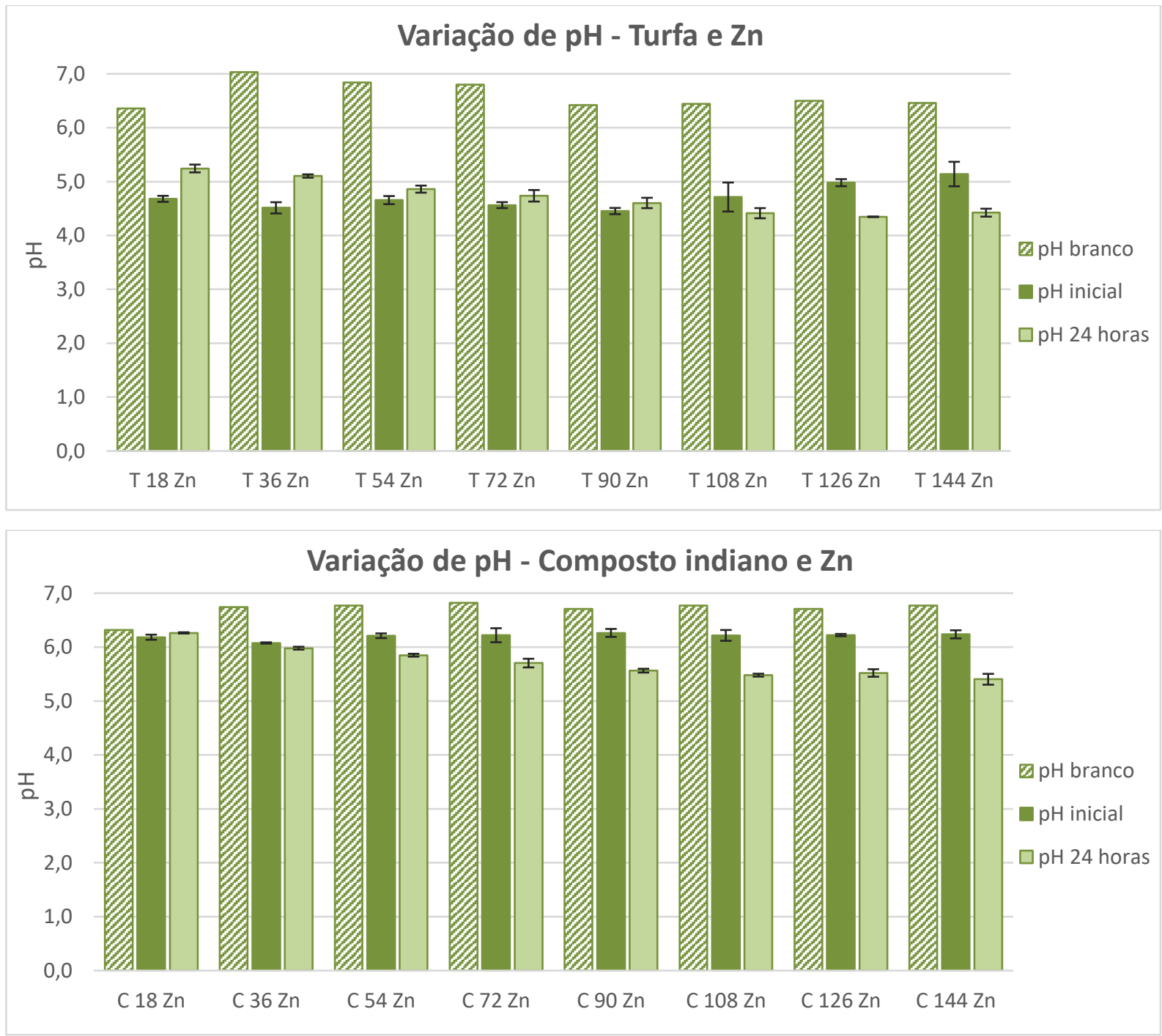

pH branco: $\mathrm{pH}$ das soluções branco (contendo $\mathrm{Zn}$ );

pH inicial: pH das amostras iniciais (imediatamente após mistura do material orgânico com a solução);

pH 24 horas: pH das amostras finais (decorrido 24 horas de contato, imediatamente após a filtração);

No eixo das abscissas: T: turfa; C: composto indiano; e o número se refere a concentração de Zn na solução inicialmente adicionada (branco da solução).

Fonte: A autora. 
Araújo (2015) também observou condições de pH crescentes, comparando os valores iniciais e decorrido o tempo de contato do ensaio de equilíbrio em lote, para concentrações de $\mathrm{Zn}$ variando de 50 a $250 \mathrm{mg} \mathrm{L}^{-1}$ em contato com um material inconsolidado transportado. Esta constatação é similar ao observado para as amostras de turfa submetidas às concentrações de $\mathrm{Zn}$ de até $90 \mathrm{mg} \mathrm{L}^{-1}$. Assim, em relação à variação de $\mathrm{pH}$ no ensaio com $\mathrm{Zn}$, novamente a turfa se aproxima mais do comportamento esperado para solos, análogo ao que foi verificado para o $\mathrm{Pb}$.

A Figura 123 revela a variação de Eh para as soluções contendo turfa e composto indiano em contato com Zn. Promovendo uma análise comparativa pode-se visualizar que, de forma geral, tanto para o ensaio com a turfa como para o ensaio com o composto, as amostras contendo material adsorvente e a solução contaminante revelaram potenciais de oxi-redução, após o tempo de contato, inferiores aos respectivos valores iniciais e, até mesmo, em relação aos brancos das soluções, exceto para as concentrações de $126 \mathrm{mg} \mathrm{L}^{-1}$ e $144 \mathrm{mg} \mathrm{L}^{-1}$ em contato com a turfa, onde os valores de Eh se mantém praticamente constantes. Ademais, as medidas de Eh foram maiores para a turfa $(+237 \mathrm{a}+338 \mathrm{mV})$ em comparação ao composto indiano (+134 $\mathrm{a}+236 \mathrm{mV}$ ). No entanto, como todos os valores de Eh resultantes foram positivos, é possível classificar o meio como oxidante. Estas conclusões são similares ao apresentado em relação ao $\mathrm{Pb}$, bem como os próprios valores obtidos.

Figura 123 - Variação de Eh ao longo do ensaio de equilíbrio em lote com Zn para a turfa e para o composto indiano

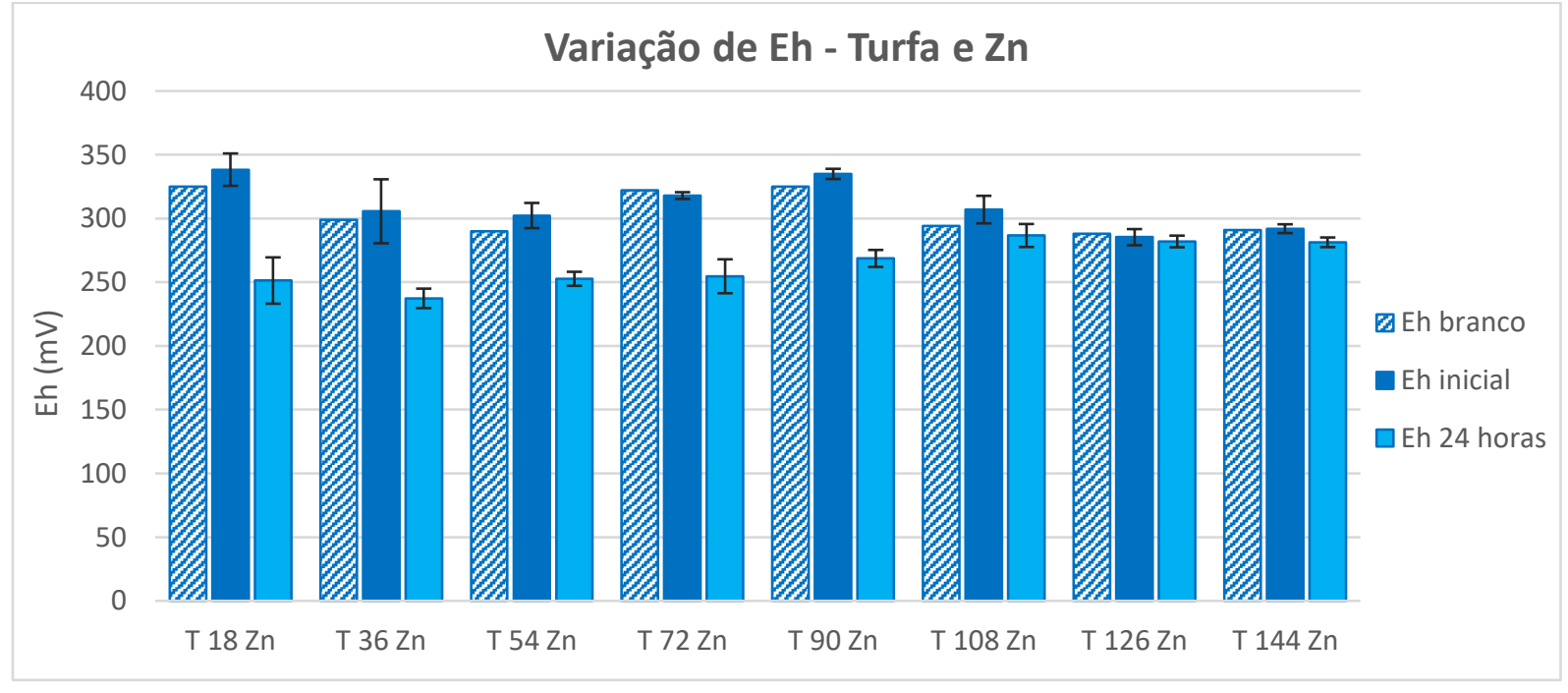




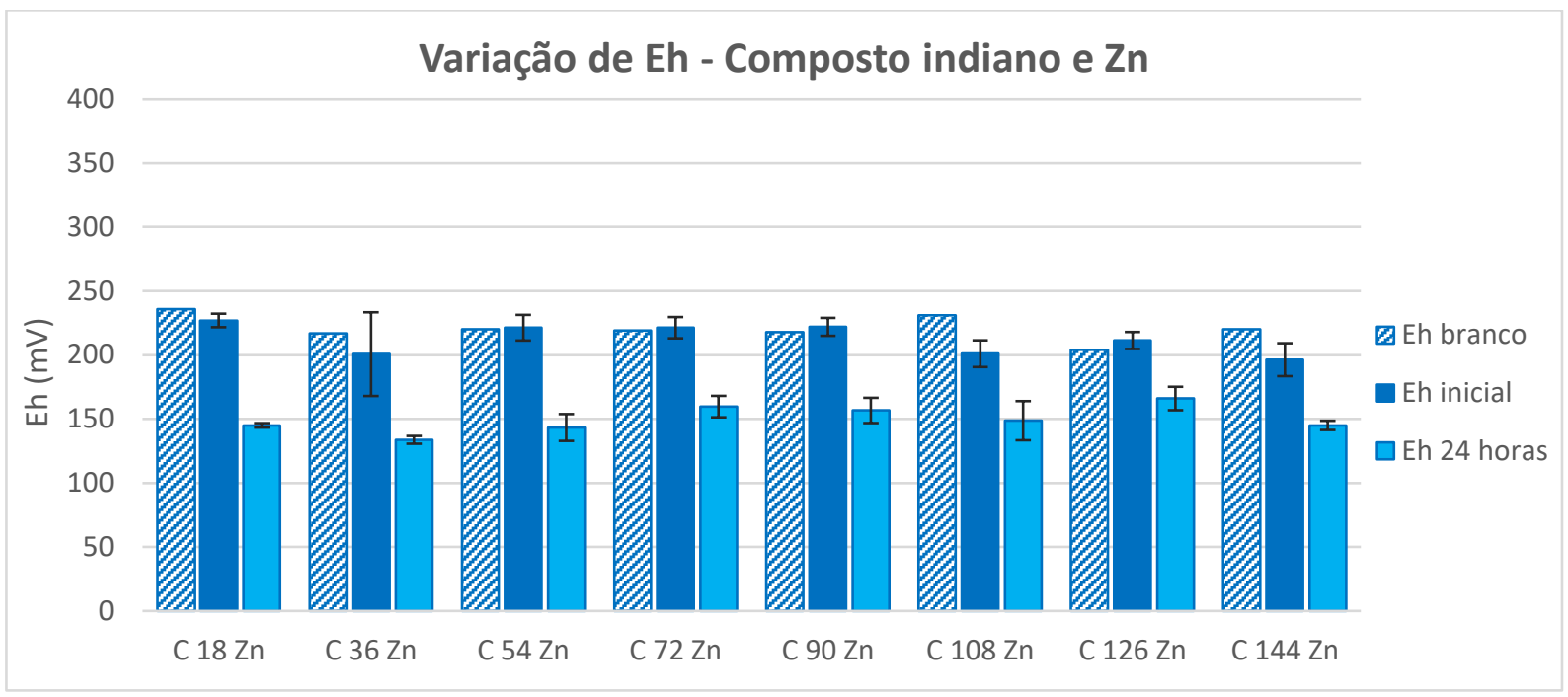

Eh branco: Eh das soluções branco (contendo $\mathrm{Zn}$ );

Eh inicial: Eh das amostras iniciais (imediatamente após mistura do material orgânico com a solução);

Eh 24 horas: Eh das amostras finais (decorrido 24 horas de contato, imediatamente após a filtração);

No eixo das abscissas: T: turfa; C: composto indiano; e o número se refere a concentração de Zn na solução inicialmente adicionada (branco da solução).

Fonte: A autora.

A Figura 124 expõe a variação de CE para as soluções contendo turfa e composto indiano em contato com Zn. Para a turfa, os dados de condutividade elétrica resultantes, antes e após o tempo de contato, foram de bem próximos a levemente superiores, enquanto para o composto indiano as medidas de $\mathrm{CE}$ finais foram mais pronunciadamente superiores às respectivas medidas iniciais. Em se tratando dos brancos das soluções contaminantes, as condutividades para as mesmas concentrações de $\mathrm{Zn}$, para a turfa e para o composto indiano, foram bem similares e apresentaram valores crescentes com o aumento da concentração, como era esperado. Consequentemente, as amostras contendo material reativo e estas soluções também exibiram medidas de condutividade elétrica crescentes com a concentração, sendo estes valores maiores para o composto indiano, possivelmente devido a maior CE intrínseca do composto em comparação com a turfa. Estas constatações em termos comportamentais são similares ao exposto em relação ao $\mathrm{Pb}$, salvo exceção que no caso do $\mathrm{Zn}$ os valores de condutividade foram superiores. 
Figura 124 - Variação de condutividade elétrica (CE) ao longo do ensaio de equilíbrio em lote com $\mathrm{Zn}$ para a turfa e para o composto indiano
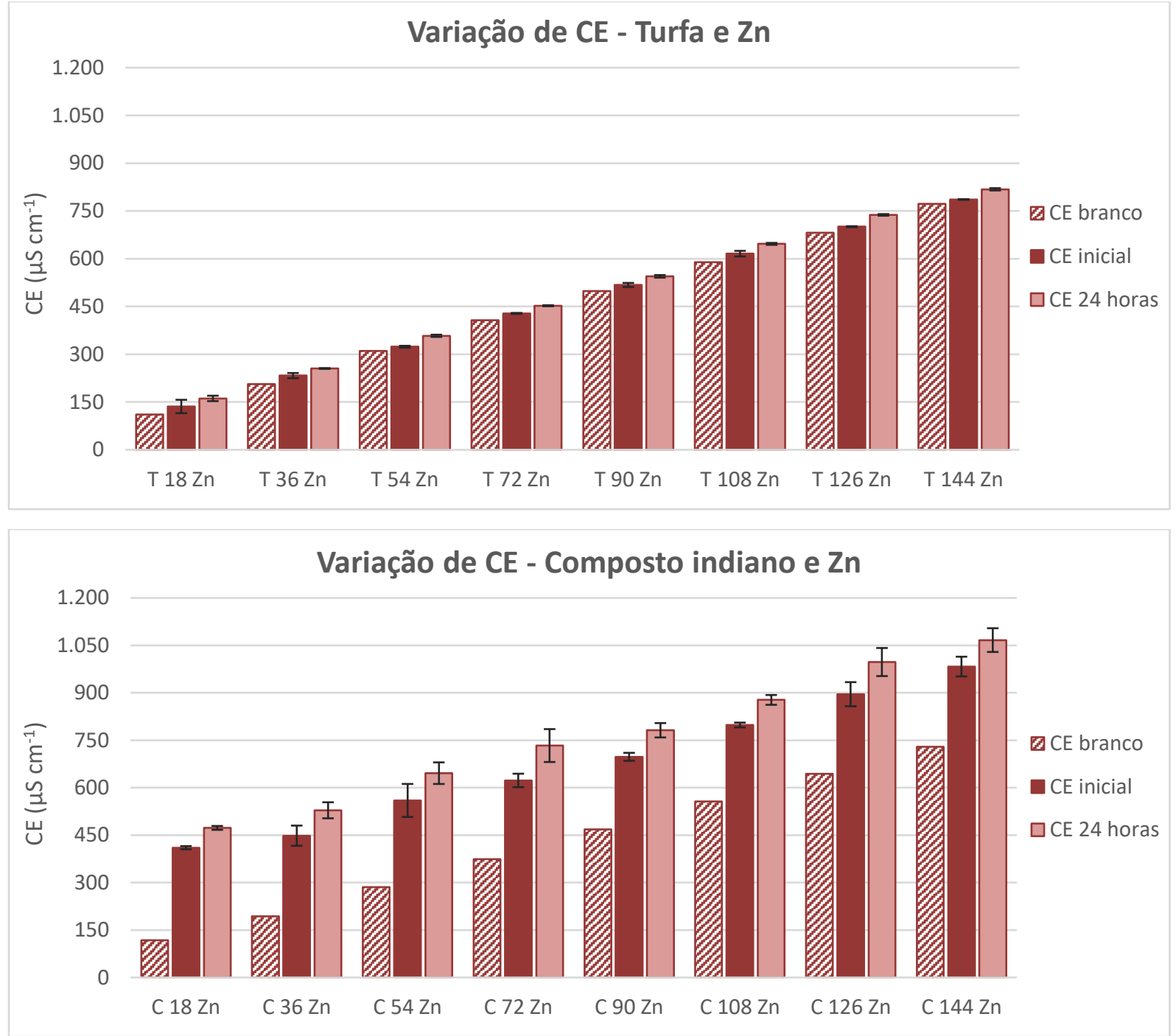

CE branco: $\mathrm{CE}$ das soluções branco (contendo $\mathrm{Zn}$ );

CE inicial: CE das amostras iniciais (imediatamente após mistura do material orgânico com a solução); CE 24 horas: CE das amostras finais (decorrido 24 horas de contato, imediatamente após a filtração);

No eixo das abscissas: T: turfa; C: composto indiano; e o número se refere a concentração de Zn na solução inicialmente adicionada (branco da solução).

Fonte: A autora.

Araújo (2015) apresentou dados que revelaram condições de CE decrescentes ao longo do ensaio de equilíbrio em lote para amostras contendo material inconsolidado e soluções de Zn. Contudo, de modo geral, estas condutividades elétricas foram próximas aos respectivos valores em relação aos brancos, se aproximando do ensaio com turfa apresentado nesta pesquisa.

Com os resultados experimentais em relação às concentrações adsorvida e em equilíbrio (não adsorvida) foi possível construir os gráficos comparativos mostrados na Figura 125. Os 
dados relativos à adsorção de Zn pela turfa mostraram já a partir da segunda menor concentração da solução branco $\left(35 \mathrm{mg} \mathrm{L}^{-1}\right)$ uma certa invariabilidade do valor referente à concentração adsorvida, indicando possivelmente a saturação do meio adsorvente. Contudo, na concentração da solução $128 \mathrm{mg} \mathrm{L}^{-1}$, ocorreu um novo incremento do valor adsorvido, que se manteve outra vez praticamente uniforme na concentração de $143 \mathrm{mg} \mathrm{L}^{-1}$. Assim, não ocorreu um aumento linear da concentração adsorvida, mas sim, uma constância de valores seguida de um salto positivo. Por conseguinte, seria como se nas maiores concentrações fossem atingidos sítios, até então não passíveis de adsorção, talvez por estarem ocupados por outros elementos. Fundamentando esta hipótese justamente a partir da concentração da solução branco de $108 \mathrm{mg}$ $\mathrm{L}^{-1}$, os valores de $\mathrm{pH}$ que vinham aumentando após decorrido o tempo de contato, passaram a sofrer uma redução. Isso pode ser inclusive um indicativo da ocorrência de outros mecanismos de adsorção.

Já para o ensaio de equilíbrio em lote com o composto indiano em contato com a solução monoelementar contendo Zn é possível observar uma maior eficiência na remoção metálica, haja vista as concentrações de $\mathrm{Zn}$ adsorvidas que, inclusive apresentaram uma tendência crescente de aumento em função da elevação da concentração inicial de $\mathrm{Zn}$ em solução. Analogamente, neste caso o pH sofreu uma diminuição ao longo do ensaio já a partir da concentração do branco de $37 \mathrm{mg} \mathrm{L}^{-1}$.

Figura 125 - Análise comparativa das concentrações adsorvida e em equilíbrio ao longo do ensaio de equilíbrio em lote com Zn para a turfa e para o composto indiano

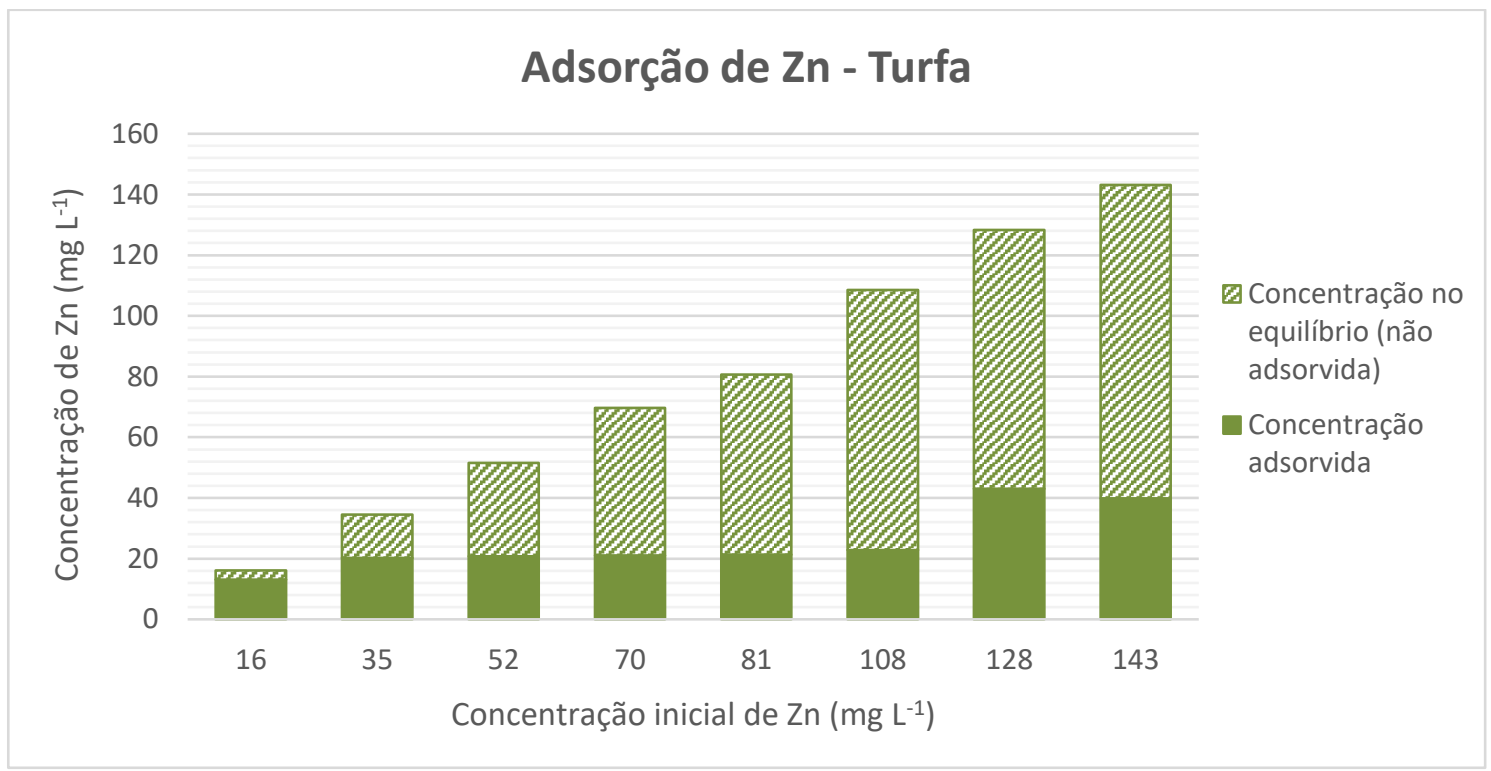




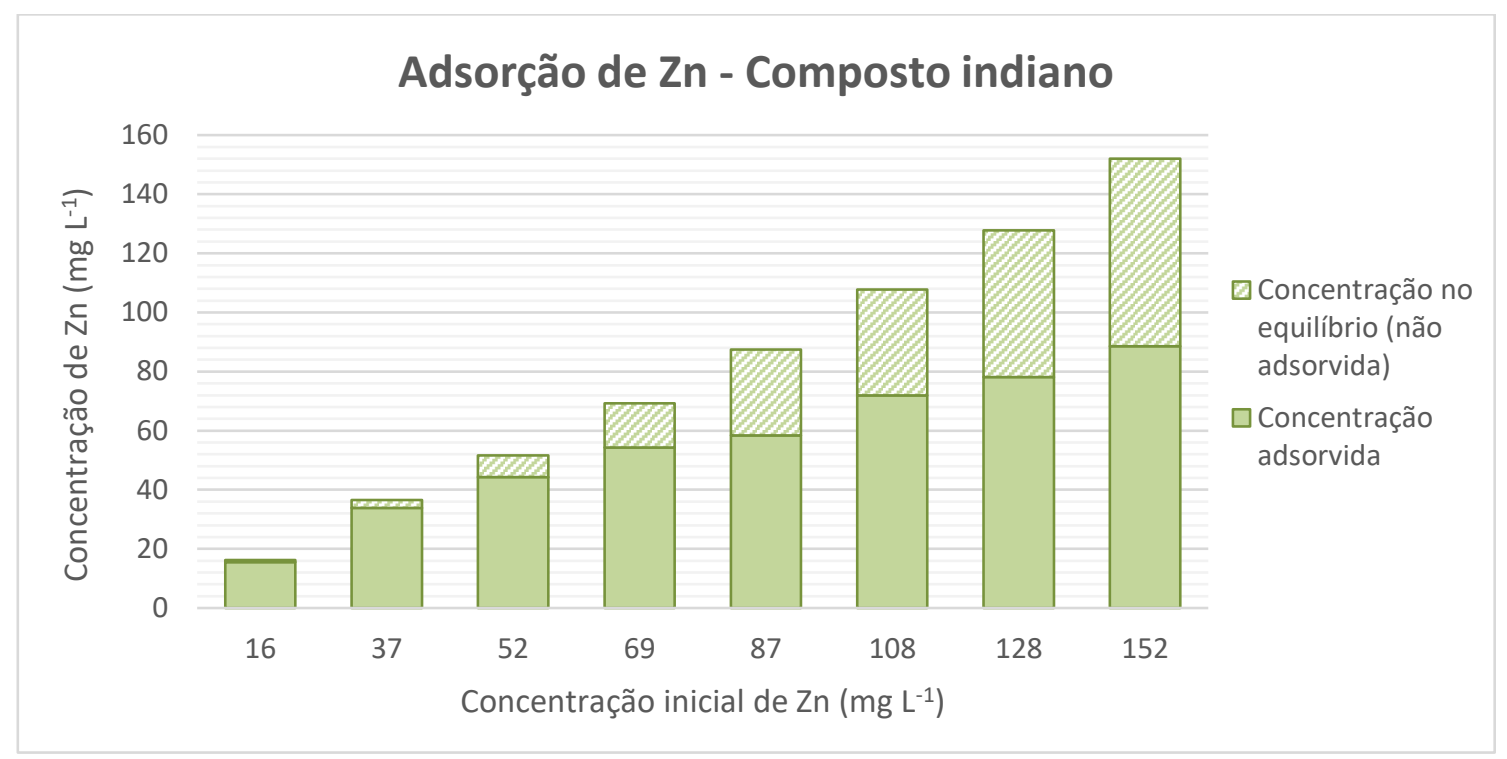

Fonte: A autora.

Com os dados experimentais foram construídas as isotermas de adsorção utilizando suas formas linearizadas e, a partir delas, estimaram-se os respectivos parâmetros de adsorção. Estes dados são mostrados nas Tabelas 65 e 66, nos quais estão destacados o maior coeficiente de determinação para cada material reativo orgânico, associado, consequentemente, ao modelo que revelou o melhor ajuste aos dados laboratoriais. A isoterma Linear passando pela origem não foi apresentada, pois para ambos materiais sua respectiva correleção com os dados experimentais foi desprezível.

Tabela 65 - Parâmetros de adsorção para o Zn estimados a partir das isotermas Linear e de Freundlich

\begin{tabular}{|c|c|c|c|c|c|}
\hline \multirow{2}{*}{ Material } & \multicolumn{2}{|c|}{ Linear* } & \multicolumn{3}{|c|}{ Freundlich } \\
\hline & $K_{d}\left(L^{-1}\right)$ & $\mathbf{R}^{2}$ & $K_{f}\left(L^{-1}\right)$ & $\mathbf{n}$ & $\mathbf{R}^{2}$ \\
\hline \multirow{2}{*}{ Turfa } & 0,011 & 0,648 & 0,466 & 0,257 & 0,638 \\
\hline & \multicolumn{2}{|c|}{$q_{e}=0,011 \mathrm{C}_{\mathrm{e}}+0,638$} & \multicolumn{3}{|c|}{$\log q_{e}=0,257 \log C_{e}-0,331$} \\
\hline \multirow{2}{*}{ Composto } & 0,049 & 0,895 & 1,015 & 0,351 & 0,965 \\
\hline & \multicolumn{2}{|c|}{$q_{e}=0,049 \mathrm{C}_{\mathrm{e}}+1,516$} & \multicolumn{3}{|c|}{$\log q_{e}=0,351 \log \mathrm{C}_{\mathrm{e}}+0,006$} \\
\hline
\end{tabular}

* Isoterma linear sem passar pela origem.

Fonte: A autora. 
Tabela 66 - Parâmetros de adsorção para o Zn estimados a partir das isotermas de Langmuir (I e II)

\begin{tabular}{|c|c|c|c|c|c|c|}
\hline \multirow{2}{*}{ Material } & \multicolumn{3}{|c|}{ Langmuir I } & \multicolumn{3}{|c|}{ Langmuir II } \\
\hline & $q_{m}\left(m g^{-1}\right)$ & $K_{L}\left(L\right.$ mg $\left.^{-1}\right)$ & $\mathbf{R}^{2}$ & $\mathrm{qm}_{\mathrm{m}}\left(\mathrm{mg} \mathrm{g}^{-1}\right)$ & $K_{L}\left(L \mathrm{mg}^{-1}\right)$ & $\mathbf{R}^{2}$ \\
\hline \multirow[b]{2}{*}{ Turfa } & 1,901 & 0,046 & 0,684 & 1,329 & 0,310 & 0,670 \\
\hline & \multicolumn{3}{|c|}{$\frac{\mathrm{C}_{\mathrm{e}}}{\mathrm{q}_{\mathrm{e}}}=0,526 \mathrm{C}_{\mathrm{e}}+11,532$} & \multicolumn{3}{|c|}{$\frac{1}{\mathrm{q}_{\mathrm{e}}}=2,424 \frac{1}{\mathrm{C}_{\mathrm{e}}}+0,752$} \\
\hline \multirow[b]{2}{*}{ Composto } & 4,541 & 0,129 & 0,962 & 3,487 & 0,394 & 0,982 \\
\hline & \multicolumn{3}{|c|}{$\frac{\mathrm{C}_{\mathrm{e}}}{\mathrm{q}_{\mathrm{e}}}=0,220 \mathrm{C}_{\mathrm{e}}+1,704$} & \multicolumn{3}{|c|}{$\frac{1}{q_{e}}=0,727 \frac{1}{C_{e}}+0,287$} \\
\hline
\end{tabular}

Fonte: A autora.

A partir dos coeficientes de determinação $\left(R^{2}\right)$ foram verificados melhores ajustes das isotermas aos dados experimentais referentes à adsorção de Zn pelo composto indiano (maior $\mathrm{R}^{2}=0,982$ ) em comparação à turfa (maior $\mathrm{R}^{2}=0,684$ ). Além disso, foi possível elencar a seguinte ordem decrescente de modelos quanto ao melhor ajuste dos dados experimentais:

Turfa: Langmuir I > Langmuir II > Linear $>$ Freundlich

Composto: Langmuir II > Freundlich > Langmuir I > Linear

Similar ao constatado para a adsorção de $\mathrm{Pb}$, novamente a isoterma de Langmuir I esteve associada ao melhor ajuste para a turfa e a isoterma de Langmuir II, para o composto indiano.

Segundo Zuquette, Silva Jr e Garcia (2008) os valores de n igual a 0,257 (turfa) e 0,351 (composto indiano) obtidos pelas respectivas isotermas de Freundlich permitem categorizar estas sorções como desfavoráveis $(\mathrm{n}<1)$.

As correlações observadas a partir da substituição dos parâmetros de adsorção nas formas gerais das isotermas foram graficadas para os modelos que apresentaram $\mathrm{R}^{2}$ igual ou superior a 0,6 na sua forma linearizada (valor associado a um ajuste considerado satisfatório para este estudo). Os resultados estão mostrados na Figura 126. Confirmando as conclusões anteriores, baseadas nos coeficientes de determinação, estes gráficos evidenciam que a isoterma de Langmuir I se ajustou melhor para a adsorção de Zn pela turfa e a isoterma de Langmuir II se ajustou melhor aos dados experimentais referentes à adsorção de $\mathrm{Zn}$ pelo composto indiano. 
Figura 126 - Comparação entre os dados obtidos experimentalmente e as isotermas que apresentaram $\mathrm{R}^{2} \geq 0,6$ na forma linearizada em relação à adsorção de $\mathrm{Zn}$
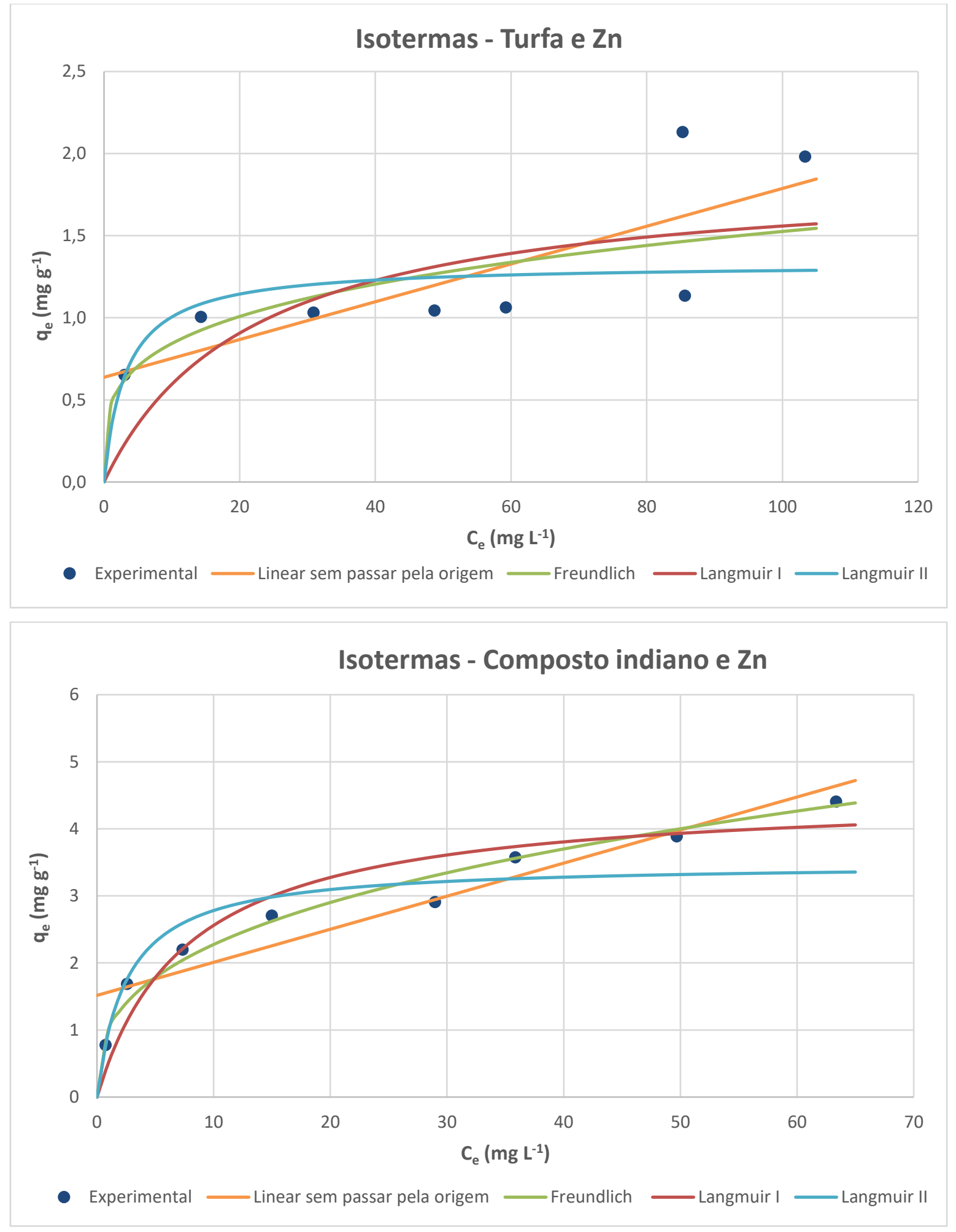

Fonte: A autora.

Os dados experimentais da adsorção de $\mathrm{Zn}$ pela turfa revelaram uma menor afinidade deste material orgânico pelo metal de interesse em relação ao composto indiano, conforme 
mostrado pelo próprio gráfico "Isotermas - Turfa e Zn" que exibiu maiores valores das concentrações de Zn em equilíbrio (eixo das abscissas) e, consequentemente, menores valores das concentrações de $\mathrm{Zn}$ adsorvidas pela turfa (eixo das ordenadas), em comparação com o gráfico "Isotermas - Composto indiano e Zn". Além disso, os resultados quanto à turfa, não se ajustaram tão minuciosamente bem a nenhuma das formulações de isotermas trabalhadas. Mesmo assim, de modo geral, pode-se dizer que dentro das possibilidades de cada caso, tanto a adsorção de Zn pela turfa como pelo composto indiano foram satisfatoriamente descritos por isotermas "tipo L" e, mais especificamente, segundo Giles, Smith e Huitson (1974) as isotermas em questão podem ser classificadas no subgrupo 2, haja vista a formação de um platô.

A análise dos gráficos referentes à turfa permitiu confirmar o que já foi observado anteriormente. Na concentração da solução de $\mathrm{Pb}$ de $35 \mathrm{mg} \mathrm{L}^{-1}$ (associada a uma concentração de equilíbrio em torno de $14 \mathrm{mg} \mathrm{L}^{-1}$ ) se iniciou a tendência clara de formação de um platô, advindo da saturação dos sítios de adsorção. Ao longo dessa quase constância de valores de qe associada a uma elevação de concentração de Zn nas soluções branco, por conseguinte ocorreu o decréscimo da porcentagem de $\mathrm{Zn}$ adsorvida de 59 a $21 \%$. Contudo, nas duas maiores concentrações se manifestou um novo salto na quantidade de $\mathrm{Zn}$ adsorvida por massa de turfa no equilíbrio e a quantidade de $\mathrm{Zn}$ adsorvida voltou a subir, atingindo $33 \%$.

Já para o composto indiano, em termos numéricos, observou-se uma tendência não tão nítida nas maiores concentrações de formação de um platô, haja vista que os valores da quantidade de $\mathrm{Zn}$ adsorvida por massa de composto no equilíbrio passou a variar cada vez menos, porém sem atingir uma quase constância de medidas, conforme verificado para a turfa. Nas quatro menores concentrações, associadas a maior inclinação da isoterma, a porcentagem de $\mathrm{Zn}$ adsorvida decresce de 96 a 78\%, enquanto nas quatro maiores concentrações, justamente associadas a menor inclinação, por consequência essa variação de porcentagem adsorvida diminuiu, indo de 67 a $58 \%$.

\subsubsection{Cádmio}

A Figura 127 aponta a variação de $\mathrm{pH}$ para as soluções contendo turfa e composto indiano em contato com Cd. Para ambos os ensaios, se observou uma tendência de diminuição dos valores de $\mathrm{pH}$ das amostras em função do aumento da concentração, sendo este comportamento bem uniforme para o composto indiano. Mais especificamente, houve ainda um aumento de $\mathrm{pH}$ considerável decorrido o tempo de contato, para todos os casos. Estes comportamentos são similares ao que foi verificado no ensaio com $\mathrm{Pb}$. 
Para as amostras contendo turfa e $\mathrm{Cd}$, os valores de $\mathrm{pH}$ findado o ensaio foram superiores aos respectivos valores de $\mathrm{pH}$ dos brancos das soluções. Já para o composto e $\mathrm{Cd}$, os valores de $\mathrm{pH}$ das amostras contendo o material reativo foram superiores aos valores de $\mathrm{pH}$ dos brancos, tanto no início como no término do contato, sugerindo que o próprio material orgânico propiciou condições de pH mais elevadas.

Figura 127 - Variação de pH ao longo do ensaio de equilíbrio em lote com Cd para a turfa e para o composto indiano
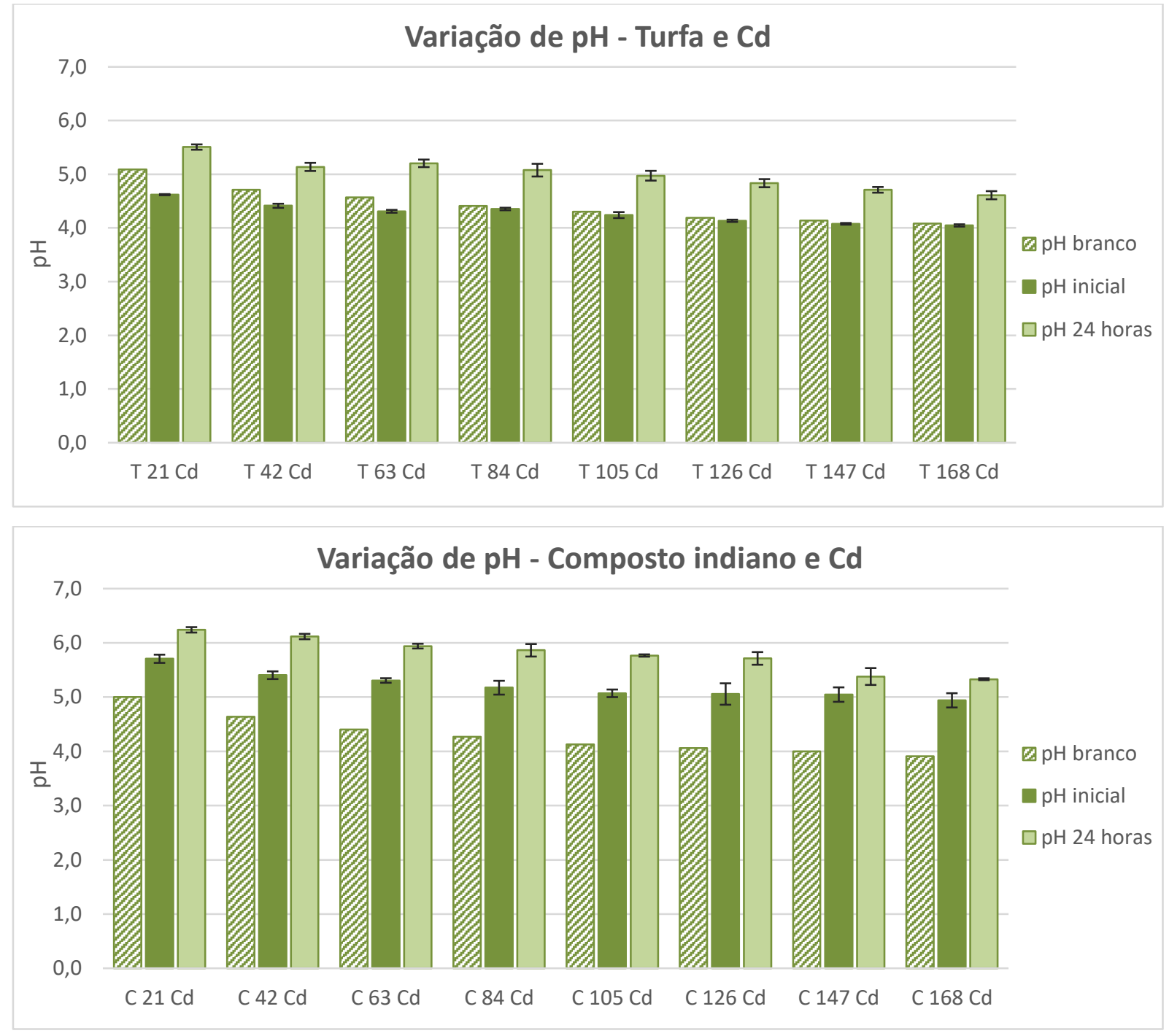

pH branco: $\mathrm{pH}$ das soluções branco (contendo $\mathrm{Cd}$ );

pH inicial: pH das amostras iniciais (imediatamente após mistura do material orgânico com a solução);

pH 24 horas: pH das amostras finais (decorrido 24 horas de contato, imediatamente após a filtração);

No eixo das abscissas: T: turfa; C: composto indiano; e o número se refere a concentração de $\mathrm{Cd}$ na solução inicialmente adicionada (branco da solução).

Fonte: A autora. 
Araújo (2015) também verificou condições de pH crescentes ao longo do ensaio de equilíbrio em lote para concentrações de Cd variando de 50 a $250 \mathrm{mg} \mathrm{L}^{-1}$ em contato com um material inconsolidado transportado. Contudo, estas variações foram bem pequenas. Diferentemente desta pesquisa, o referido autor obteve valores de $\mathrm{pH}$ superiores para os brancos de suas soluções em relação às amostras contendo o solo. Esta constatação confirma a forte interferência do pH intrínseco dos materiais reativos orgânicos nos ensaios de adsorção, comumente superior à valores de $\mathrm{pH}$ típicos de solos.

A Figura 128 expressa a variação de Eh para as soluções contendo turfa e composto indiano em contato com $\mathrm{Cd}$. De forma geral, as amostras contendo turfa e composto apresentaram valores de Eh após as 24 horas de contato inferiores aos respectivos valores iniciais e, até mesmo, em relação aos brancos das soluções. Especificamente para o composto indiano os valores de Eh finais apresentaram uma leve tendência de crescimento, em função do aumento da concentração de $\mathrm{Cd}$. Além disso, os valores de Eh foram maiores para a turfa (+201 a $+367 \mathrm{mV})$ em relação ao composto indiano (+226 a +300 mV). Todavia, como todos os valores de Eh foram positivos, é possível identificar o meio como oxidante. Estas conclusões são similares ao observado em relação ao $\mathrm{Pb}$ e ao $\mathrm{Zn}$.

Figura 128 - Variação de Eh ao longo do ensaio de equilíbrio em lote com Cd para a turfa e para o composto indiano

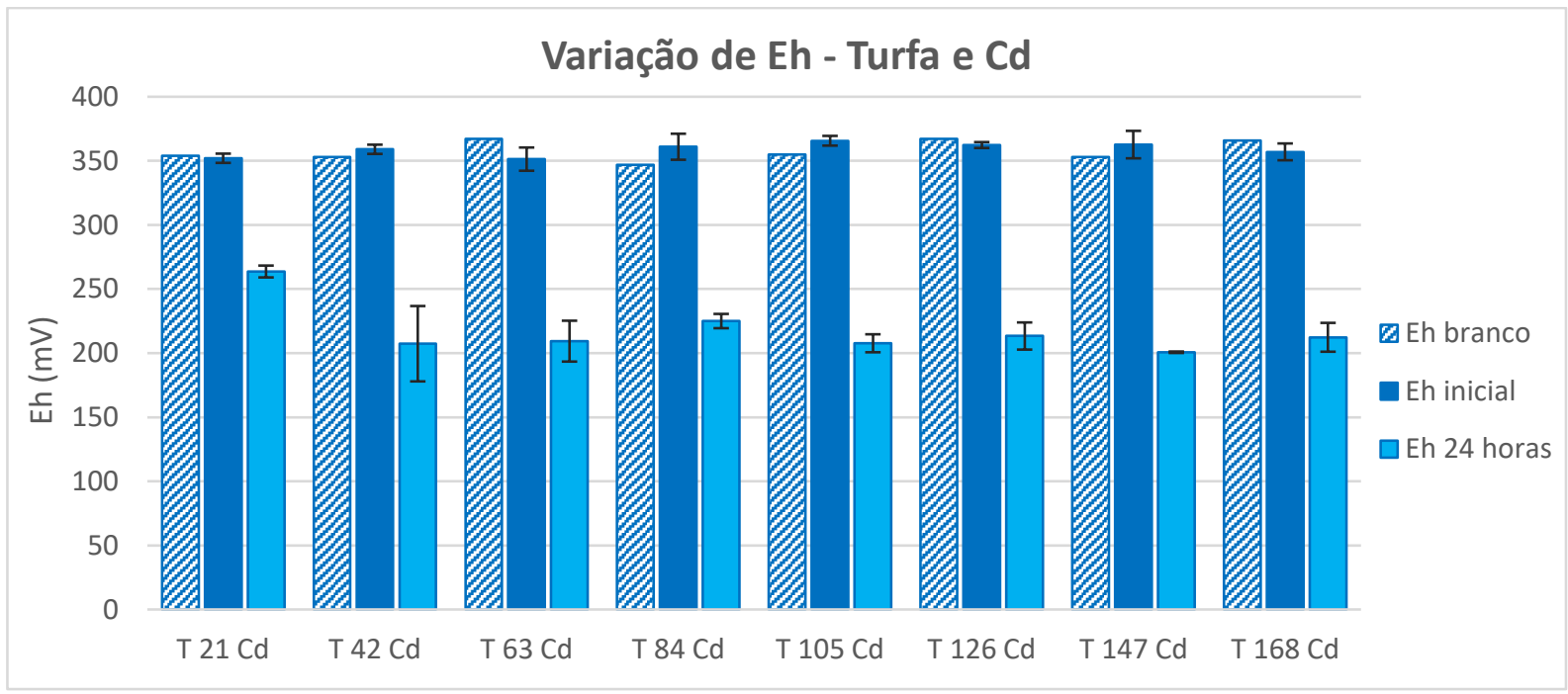




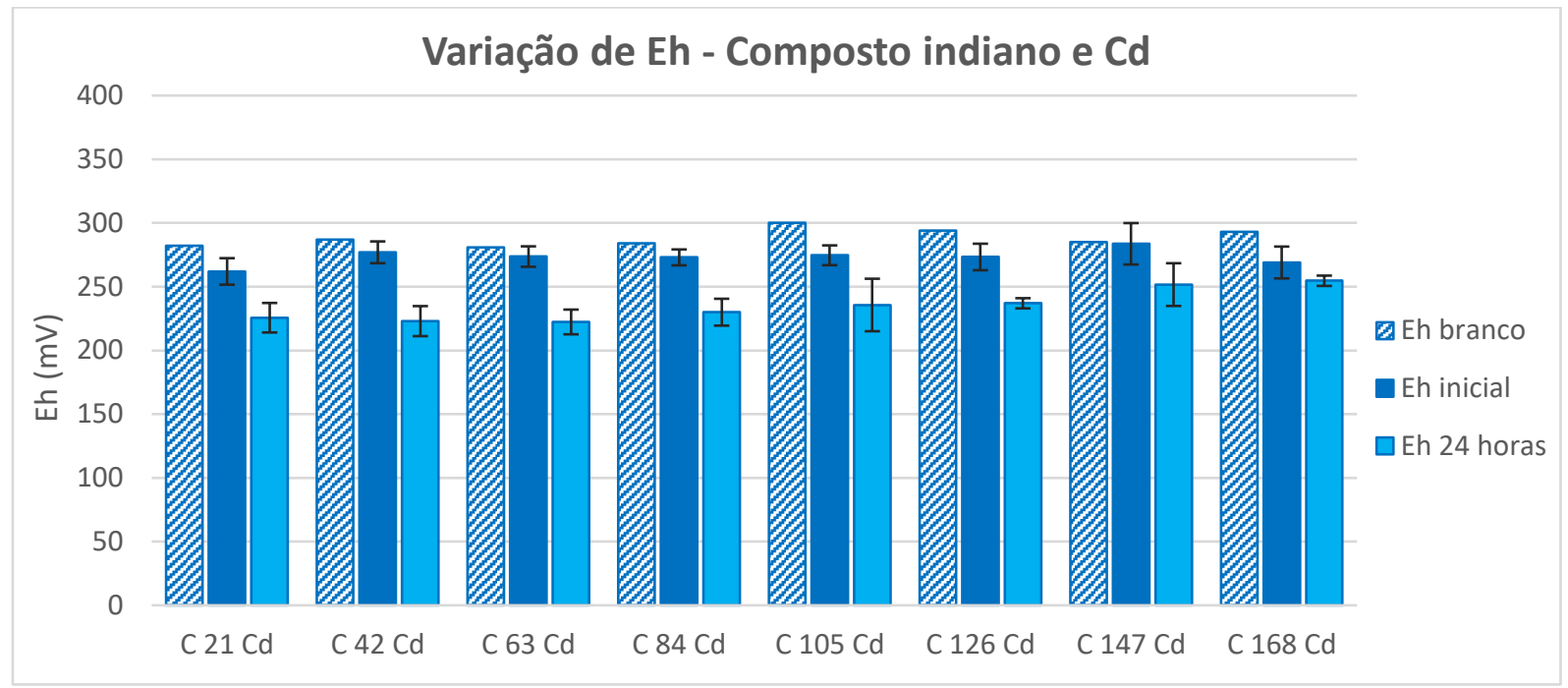

Eh branco: Eh das soluções branco (contendo Cd);

Eh inicial: Eh das amostras iniciais (imediatamente após mistura do material orgânico com a solução);

Eh 24 horas: Eh das amostras finais (decorrido 24 horas de contato, imediatamente após a filtração);

No eixo das abscissas: T: turfa; C: composto indiano; e o número se refere a concentração de Cd na solução inicialmente adicionada (branco da solução).

Fonte: A autora.

Diferentemente, Araújo (2015) encontrou potenciais de oxi-redução superiores para os brancos. Contudo, similar a este estudo, decorrido o contato houve uma redução no Eh para as amostras contendo o material inconsolidado em contato com a solução de Cd. Além disso, a variação dos valores de Eh, considerando os brancos da solução e as respectivas amostras iniciais e finais, foi bem inferior em termos quantitativos, em comparação aos resultados desta pesquisa.

A Figura 129 retrata a variação de CE para as soluções contendo turfa e composto indiano em contato com $\mathrm{Cd}$. Em relação ao ensaio envolvendo a turfa, as condutividades elétricas medidas, antes e após as 24 horas de contato, apresentaram valores bem próximos a levemente superiores. Já para o composto indiano os dados finais de CE foram mais pronunciadamente superiores às respectivas medidas iniciais. Analisando comparativamente os brancos das soluções contaminantes, suas condutividades elétricas para as mesmas concentrações de $\mathrm{Cd}$ (turfa e composto indiano) foram bem próximas e exibiram valores crescentes com a elevação da concentração, conforme esperado. Assim, as amostras constituídas por material reativo e estas soluções também apresentaram condutividades elétricas crescentes com o aumento da concentração, sendo estes resultados maiores para o composto indiano, supostamente devido a maior condutividade elétrica natural do composto em comparação com a turfa. Estas constatações comportamentais são similares ao que foi 
abordado em relação ao $\mathrm{Pb}$ e ao $\mathrm{Zn}$, salvo exceção que no caso do $\mathrm{Cd}$ os valores de $\mathrm{CE}$ foram intermediários.

Figura 129 - Variação de condutividade elétrica (CE) ao longo do ensaio de equilíbrio em lote com $\mathrm{Cd}$ para a turfa e para o composto indiano
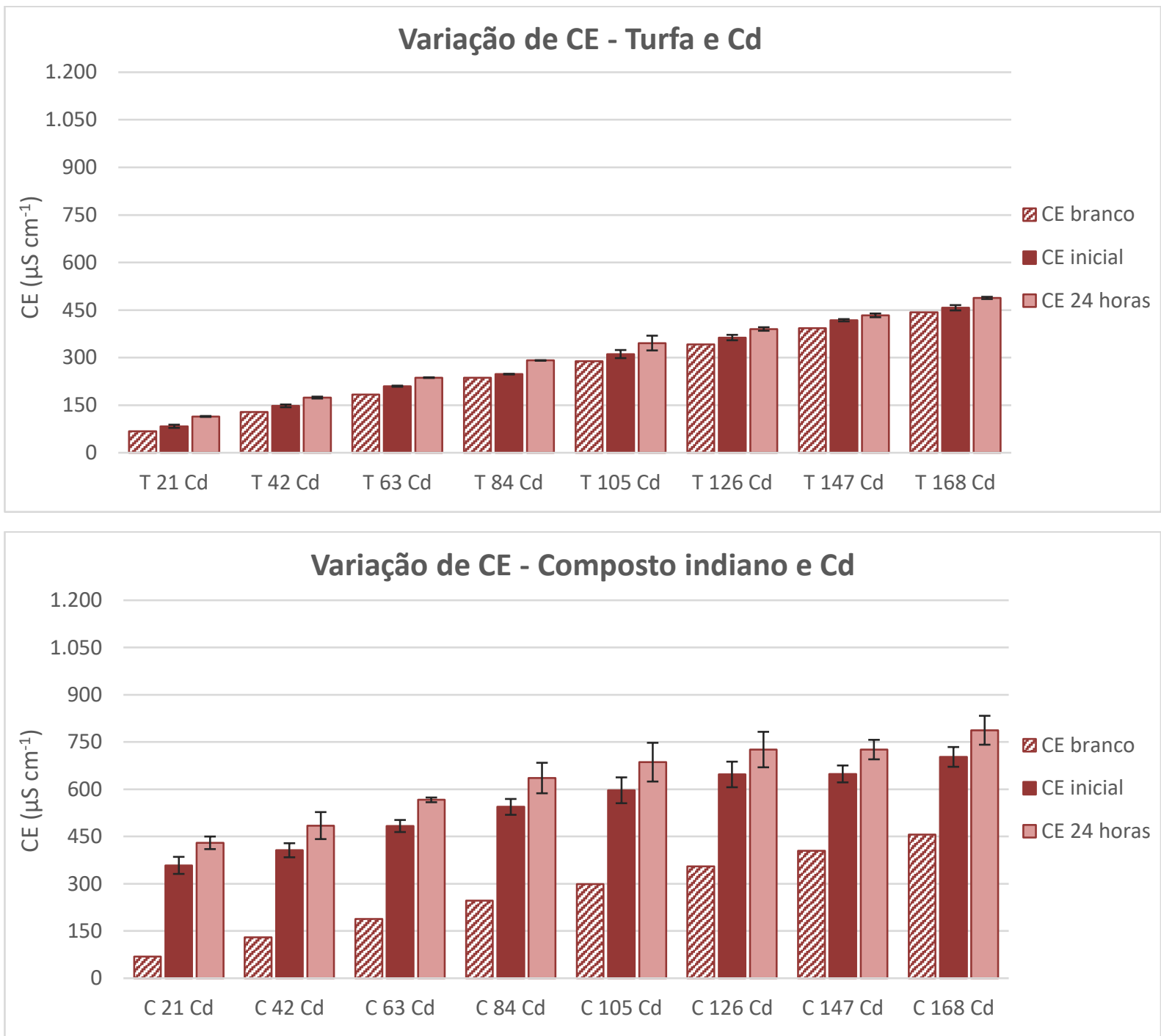

CE branco: $\mathrm{CE}$ das soluções branco (contendo $\mathrm{Cd}$ );

CE inicial: CE das amostras iniciais (imediatamente após mistura do material orgânico com a solução); CE 24 horas: CE das amostras finais (decorrido 24 horas de contato, imediatamente após a filtração);

No eixo das abscissas: T: turfa; $\mathrm{C}$ : composto indiano; e o número se refere a concentração de $\mathrm{Cd}$ na solução inicialmente adicionada (branco da solução).

Fonte: A autora.

Araújo (2015) também obteve condutividades elétricas finais para as amostras contendo material inconsolidado e soluções de Cd superiores aos respectivos valores iniciais e, até mesmo, aos brancos das soluções. Todavia, de modo geral, a variação deste parâmetro ao longo 
de todo o ensaio de equilíbrio em lote foi bem pequena, se aproximando mais do ensaio com turfa apresentado nesta pesquisa.

Os gráficos comparativos exibidos na Figura 130, retratam as concentrações adsorvida e em equilíbrio (não adsorvida). Os resultados no tocante à adsorção de Cd pela turfa revelaram que a partir da terceira menor concentração da solução branco $\left(58 \mathrm{mg} \mathrm{L}^{-1}\right)$ se inicia uma menor variação do valor referente à concentração adsorvida, indicando possivelmente a proximidade da saturação do meio adsorvente. Todavia, na maior concentração da solução de Cd (163 mg $\mathrm{L}^{-1}$ ), se manifesta um novo incremento do valor adsorvido, de forma mais substancial. Assim, não ocorre um aumento linear da concentração adsorvida, mas sim, dois saltos mais acentuados, um inicial e outro final, e, entre eles, se manifesta uma quase constância de valores.

Já em relação ao ensaio de equilíbrio em lote utilizando como adsorvente o composto indiano e como adsorvato o Cd é possível constatar uma maior afinidade de adsorção, manifestada através de uma maior eficiência na imobilização iônica. Esta constatação é embasada pelas maiores respectivas concentrações de $\mathrm{Cd}$ adsorvidas, as quais inclusive exibiram uma tendência crescente de aumento em decorrência da elevação da concentração inicial de Cd em solução.

Figura 130 - Análise comparativa das concentrações adsorvida e em equilíbrio ao longo do ensaio de equilíbrio em lote com Cd para a turfa e para o composto indiano

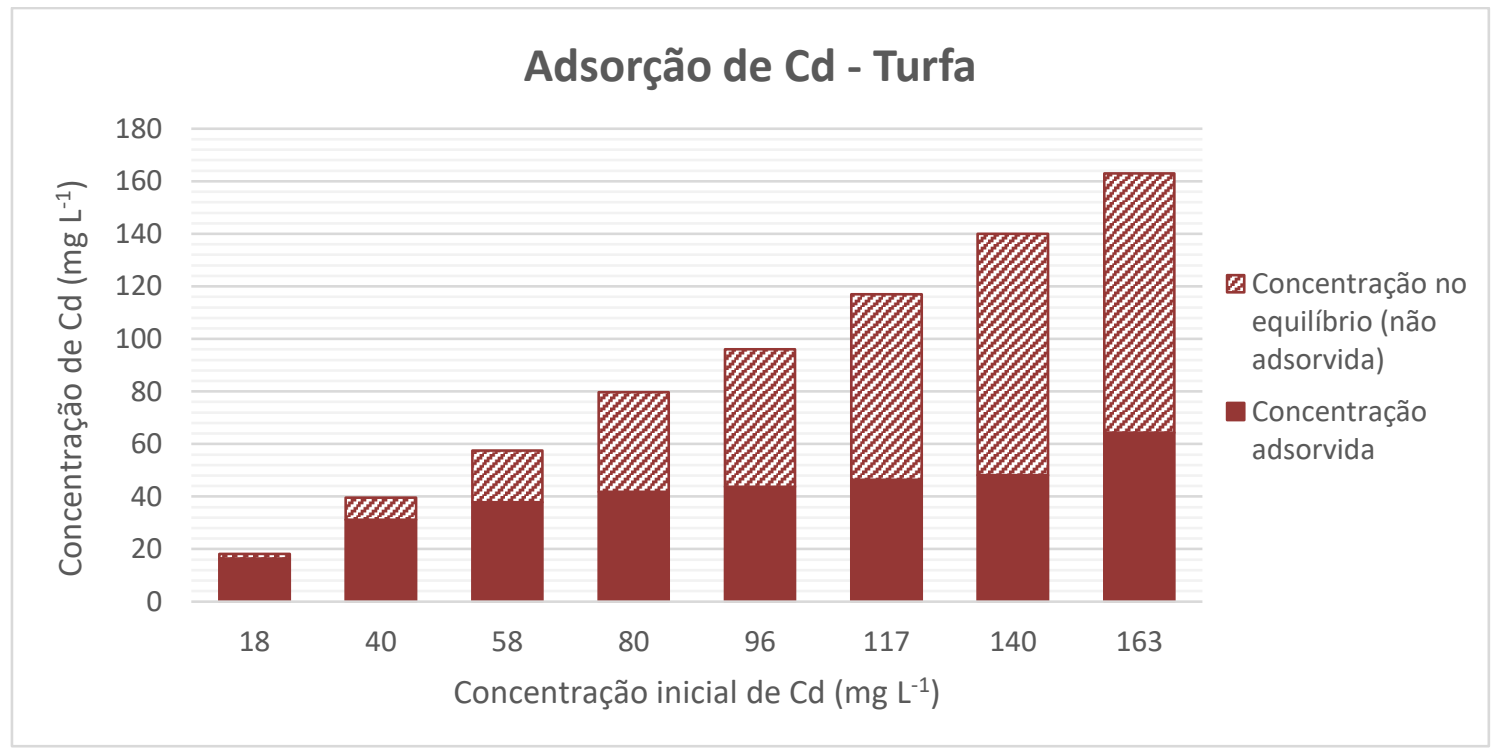




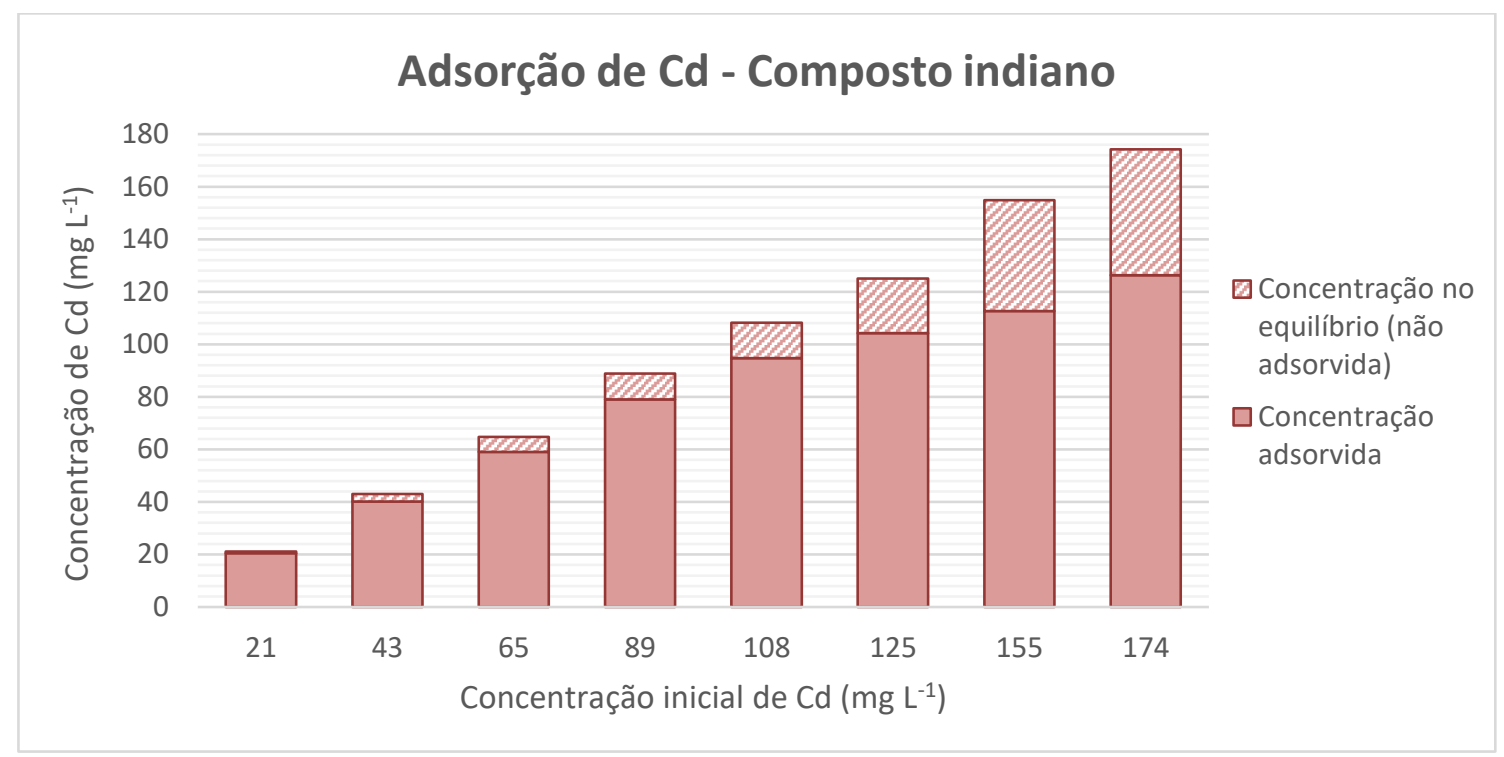

Fonte: A autora.

Com base nas informações experimentais foram construídas as formas linearizadas das isotermas de adsorção e, a partir delas, estimaram-se os respectivos parâmetros de adsorção. Estes resultados estão contidos nas Tabelas 67 e 68, com destaque para o maior coeficiente de determinação para cada material reativo orgânico. A isoterma Linear passando pela origem foi desconsiderada, já que para ambos materiais reativos sua respectiva correleção com os dados experimentais foi desprezível.

Tabela 67 - Parâmetros de adsorção para o Cd estimados a partir das isotermas Linear e de Freundlich

\begin{tabular}{|c|c|c|c|c|c|}
\hline \multirow{2}{*}{ Material } & \multicolumn{2}{|c|}{ Linear* } & \multicolumn{3}{|c|}{ Freundlich } \\
\hline & $K_{d}\left(L_{g^{-1}}\right)$ & $\mathbf{R}^{2}$ & $K_{f}\left(L^{-1}\right)$ & $\mathbf{n}$ & $\mathbf{R}^{2}$ \\
\hline \multirow{2}{*}{ Turfa } & 0,017 & 0,812 & 0,766 & 0,278 & 0,939 \\
\hline & \multicolumn{2}{|c|}{$q_{e}=0,017 \mathrm{C}_{\mathrm{e}}+1,253$} & \multicolumn{3}{|c|}{$\log q_{e}=0,278 \log C_{e}-0,116$} \\
\hline \multirow{2}{*}{ Composto } & 0,090 & 0,767 & 1,315 & 0,430 & 0,965 \\
\hline & \multicolumn{2}{|c|}{$q_{e}=0,090 \mathrm{C}_{\mathrm{e}}+2,351$} & \multicolumn{3}{|c|}{$\log q_{e}=0,430 \log C_{e}+0,119$} \\
\hline
\end{tabular}

* Isoterma linear sem passar pela origem.

Fonte: A autora. 
Tabela 68 - Parâmetros de adsorção para o Cd estimados a partir das isotermas de Langmuir (I e II)

\begin{tabular}{|c|c|c|c|c|c|c|}
\hline \multirow{2}{*}{ Material } & \multicolumn{3}{|c|}{ Langmuir I } & \multicolumn{3}{|c|}{ Langmuir II } \\
\hline & $q_{m}\left(m g^{-1}\right)$ & $K_{L}\left(L m^{-1}\right)$ & $\mathbf{R}^{2}$ & $q_{m}\left(m g ~ g^{-1}\right)$ & $K_{L}\left(L \mathrm{mg}^{-1}\right)$ & $\mathbf{R}^{2}$ \\
\hline \multirow[b]{2}{*}{ Turfa } & 2,916 & 0,094 & 0,937 & 2,393 & 0,307 & 0,961 \\
\hline & \multicolumn{3}{|c|}{$\frac{\mathrm{C}_{\mathrm{e}}}{\mathrm{q}_{\mathrm{e}}}=0,343 \mathrm{C}_{\mathrm{e}}+3,660$} & \multicolumn{3}{|c|}{$\frac{1}{\mathrm{q}_{\mathrm{e}}}=1,359 \frac{1}{\mathrm{C}_{\mathrm{e}}}+0,418$} \\
\hline \multirow[b]{2}{*}{ Composto } & 5,646 & 0,279 & 0,990 & 5,189 & 0,333 & 0,966 \\
\hline & \multicolumn{3}{|c|}{$\frac{\mathrm{C}_{\mathrm{e}}}{\mathrm{q}_{\mathrm{e}}}=0,178 \mathrm{C}_{\mathrm{e}}+0,636$} & \multicolumn{3}{|c|}{$\frac{1}{q_{e}}=0,579 \frac{1}{C_{e}}+0,193$} \\
\hline
\end{tabular}

Fonte: A autora.

Baseado nos coeficientes de determinação $\left(\mathrm{R}^{2}\right)$ foi plausível elencar a seguinte ordem decrescente de modelos quanto ao melhor ajuste dos resultados experimentais para o $\mathrm{Cd}$ :

Turfa: Langmuir II > Langmuir I > Freundlich $>$ Linear

Composto: Langmuir I > Langmuir II > Freundlich > Linear

Para o melhor ajuste em relação ao $\mathrm{Cd}$ foi observada uma situação contrária comparativamente as isotermas construídas para o $\mathrm{Pb}$ e para o $\mathrm{Zn}$, sendo que para o $\mathrm{Cd}$ a isoterma de Langmuir II está associada ao melhor ajuste para a turfa e a isoterma de Langmuir I, para o composto indiano. De modo geral, é valido ressaltar os bons ajustes, superiores a 0,9, obtidos para as isotermas de Freundlich, Langmuir I e II, tanto para a turfa como para o composto.

Além disso, conforme Zuquette, Silva Jr e Garcia (2008), os valores de n encontrados nesta pesquisa, sendo iguais a 0,278 (turfa) e 0,430 (composto indiano), resultantes das respectivas isotermas de Freundlich, possibilitam categorizar estas sorções como desfavoráveis $(\mathrm{n}<1)$.

Com a substituição dos parâmetros de adsorção nas formas gerais das isotermas foi possível graficar as respectivas correlações. Optou-se por apresentar na Figura 131 as isotermas referentes aos modelos que apresentaram $R^{2}$ igual ou superior a 0,9 na sua forma linearizada (valor associado a um ajuste considerado satisfatório para este estudo). Comprovando as constatações anteriores, baseadas nos coeficientes de determinação, estas curvas evidenciam que a isoterma de Langmuir II se ajustou melhor para a adsorção de Cd pela turfa e a isoterma de Langmuir I refletiu melhor os valores experimentais referentes à adsorção de Cd pelo composto indiano. 
Figura 131 - Comparação entre os dados obtidos experimentalmente e as isotermas que apresentaram $\mathrm{R}^{2} \geq 0,9$ na forma linearizada em relação à adsorção de $\mathrm{Cd}$
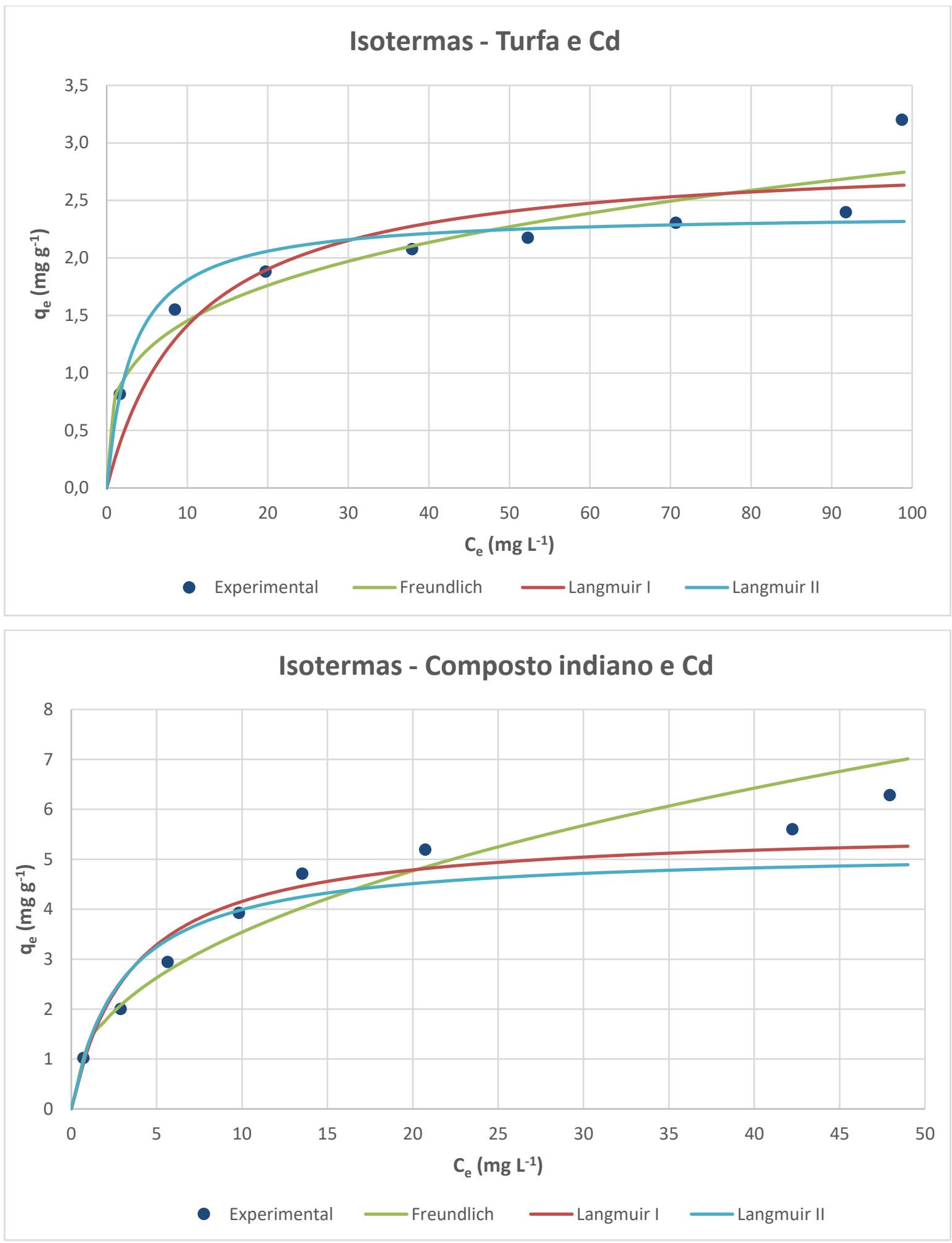

Fonte: A autora.

Na Figura 131, os maiores valores das concentrações de Cd no equilíbrio (eixo das abscissas) e, por conseguinte, os menores valores das concentrações adsorvidas (eixo das 
ordenadas), referentes à turfa em relação ao composto indiano, confirmam que a turfa revelou uma menor afinidade pelo $\mathrm{Cd}$. De modo geral, pode-se verificar que dentro das especificidades de cada caso, tanto a adsorção de Cd pela turfa como pelo composto indiano foram satisfatoriamente descritas por isotermas "tipo L" e, mais especificamente, segundo Giles, Smith e Huitson (1974) essas isotermas podem ser enquadradas no subgrupo 2, devido à formação de um platô para as maiores concentrações.

Em se tratando da turfa foi possível confirmar constatações já observadas anteriormente. $\mathrm{Na}$ concentração da solução de $\mathrm{Pb}$ de $58 \mathrm{mg} \mathrm{L}^{-1}$ (associada a uma concentração de equilíbrio em torno de $20 \mathrm{mg} \mathrm{L}^{-1}$ ) tem início a formação de um platô, resultante da proximidade da saturação dos sítios de adsorção do meio reativo. Esse trecho, a partir desta concentração, é marcado por uma menor inclinação da isoterma e, por conseguinte, a uma quase constância de valores de $\mathrm{q}_{\mathrm{e}}$. Mesmo assim, o aumento de concentração de Cd nas soluções branco, acarretou no decréscimo da porcentagem de Cd adsorvida de $66 \%\left(58 \mathrm{mg} \mathrm{L}^{-1}\right)$ a $34 \%\left(140 \mathrm{mg} \mathrm{L}^{-1}\right)$. No entanto, na maior concentração $\left(163 \mathrm{mg} \mathrm{L}^{-1}\right)$ ocorreu um novo ganho de adsorção fazendo com que a quantidade de $\mathrm{Zn}$ adsorvida voltasse a subir para $39 \%$.

Em relação ao composto indiano o comportamento da isoterma revelou uma tendência de constância nas maiores concentrações. Porém, essa formação de um platô não é tão nítida, uma vez que os valores da quantidade de Cd adsorvida por massa de composto no equilíbrio passou a variar cada vez menos, mas sem atingir uma quase constância de medidas, de acordo com o que foi verificado para a turfa. Nas cinco menores concentrações, associadas a maior inclinação da isoterma, se manifestando de forma bem uniforme, a porcentagem de $\mathrm{Cd}$ adsorvida decresceu proporcionalmente de $97 \%$ a $87 \%$, enquanto nas três maiores concentrações, associadas a menor inclinação, essa variação de porcentagem adsorvida justamente diminuiu, começando em torno de $83 \%$, caindo para $73 \%$ e, na última concentração, apresentando uma quase constância no patamar de $72 \%$.

Como controle da confiabilidade dos resultados obtidos por esses ensaios de equilíbrio em lote todos os brancos dos adsorventes, constituídos apenas por turfa ou composto indiano e água deionizada, exibiram concentrações médias de $\mathrm{Pb}, \mathrm{Zn}$ e $\mathrm{Cd}$ abaixo do limite de quantificação do equipamento, garantindo que as concentrações destes metais detectadas nas amostras eram, de fato, advindas das soluções sintéticas. Ademais, nas soluções-mãe de cada metal foram medidas as concentrações dos outros dois metais de interesse, que sempre resultaram em dados abaixo do limite de quantificação do equipamento, confirmando o caráter monoelementar das soluções trabalhadas. Foram também acompanhados os parâmetros físico- 
químicos e as concentrações dos metais de interesse intrínsecos da água deionizada empregada no preparo das soluções contaminantes e nas amostras branco da turfa e dos compostos. Foram encontrados valores habituais quanto ao $\mathrm{pH}(5,5 \pm 0,4)$, Eh $(+216 \pm 20 \mathrm{mV})$ e $\mathrm{CE}(7 \pm 4 \mu \mathrm{S}$ $\mathrm{cm}^{-1}$ ) e concentrações de $\mathrm{Pb}, \mathrm{Zn}$ e $\mathrm{Cd}$ abaixo do limite de quantificação do equipamento, garantindo a qualidade da água.

\subsubsection{Considerações referentes aos resultados de adsorção}

\subsubsection{1 pH}

$\mathrm{O}$ pH revela indubitável influência nos mecanismos de adsorção, afetando as cargas superficiais dos adsorventes e a ionização e especiação das espécies iônicas presentes em solução. Contudo, este comportamento é fortemente dependente da tipologia do adsorvente e do contaminante alvo. Por conseguinte, diversos autores já avaliaram a influência da variação de $\mathrm{pH}$ na capacidade de adsorção de seus adsorventes, a fim de descobrir o $\mathrm{pH}$ ótimo de adsorção, como sendo o valor que maximiza a retenção dos contaminantes.

A Tabela 69 apresenta os valores de $\mathrm{pH}$ iniciais e no equilíbrio para este estudo enquanto a Tabela 70 contém os valores de pH ótimos de adsorção encontrados por ensaios específicos para turfa e composto, sendo válido destacar que foram apresentadas apenas as informações referentes aos metais de interesse, não significando que estes trabalhos não estudaram também outros metais. No caso desta pesquisa, não constituiu como um de seus objetivos a avaliação da influência direta da variação do pH e, por conseguinte, os valores iniciais deste parâmetro não foram alterados. Contudo, esta opção se justifica pelos próprios dados da literatura, já que os valores de $\mathrm{pH}$ trabalhados para a turfa e para o composto encontraram-se margeando a faixa de valores de $\mathrm{pH}$ ótimos para estes meios reativos. Assim, apenas com um ligeiro aumento seria possível atingir estes valores ideais. Dessa forma, a escolha por trabalhar com os valores de $\mathrm{pH}$ naturais da turfa e do composto e, ao mesmo tempo, próximos das condições ideais pode ser considerada como uma vantagem destes meios reativos. 
Tabela 69 - Valores de pH inicial (imediatamente após o contato material reativo e solução contendo o contaminante) e no equilíbrio para $\mathrm{Pb}, \mathrm{Zn}$ e $\mathrm{Cd}$

\begin{tabular}{cccc}
\hline \hline Metal adsorvido & Adsorvente & pH inicial & pH no equilíbrio \\
\hline $\mathrm{Pb}^{2+}$ & Turfa & $3,9-4,4$ & $4,0-5,6$ \\
\hline $\mathrm{Zn}^{2+}$ & Turfa & $4,5-5,1$ & $4,3-5,2$ \\
\hline $\mathrm{Cd}^{2+}$ & Turfa & $4,0-4,6$ & $4,6-5,5$ \\
\hline $\mathrm{Pb}^{2+}$ & Composto & $4,8-5,5$ & $5,2-6,2$ \\
\hline $\mathrm{Zn}^{2+}$ & Composto & $6,1-6,3$ & $5,4-6,3$ \\
\hline $\mathrm{Cd}^{2+}$ & Composto & $4,9-5,7$ & $5,3-6,2$ \\
\hline \hline
\end{tabular}

Fonte: A autora.

Tabela 70 - Valores de $\mathrm{pH}$ ótimo para turfas temperadas e tropicais

\begin{tabular}{cccc}
\hline Metal adsorvido & Adsorvente & pH ótimo & Autor \\
\hline \hline $\mathrm{Zn}^{2+}$ & Turfa tropical & 4,5 & Petroni (1999) \\
\hline $\mathrm{Pb}^{2+}, \mathrm{Cd}^{2+} \mathrm{e} \mathrm{Zn} \mathrm{Zn}^{2+}$ & Turfa tropical & 6,5 & Franchi (2004) \\
\hline $\mathrm{Pb}^{2+}, \mathrm{Cd}^{2+}$ & Turfa temperada & 6,0 & Qin et al. (2006) \\
\hline $\mathrm{Pb}^{2+}$ & Turfa temperada & $5,0-7,0$ & $\begin{array}{c}\text { Bartczak et al. } \\
\text { (2015) }\end{array}$ \\
\hline $\mathrm{Cd}^{2+} \mathrm{e} \mathrm{Zn}^{2+}$ & Composto orgânico & $6,0-8,0$ & $\begin{array}{c}\text { Simantiraki, } \mathrm{e} \\
\text { Gidarakos (2015) }\end{array}$ \\
\hline \hline
\end{tabular}

Fonte: A autora.

Para o composto não foram encontrados muitos dados de ensaios específicos de variação de $\mathrm{pH}$, talvez porque este material reativo já apresente um $\mathrm{pH}$ natural elevado, favorecendo a adsorção iônica. De modo geral, Paradelo e Barral (2012) estudaram a adsorção de $\mathrm{Pb}^{2+}$ e $\mathrm{Zn}^{2+}$ por dois compostos orgânicos originados a partir de resíduos sólidos municipais com pH inicial de 8,2 e 9,2 em contato com concentrações metálicas de 1 a $1000 \mathrm{mg} \mathrm{L}^{-1}$. Os autores não realizaram testes para ajuste do $\mathrm{pH}$. Contudo, os valores de $\mathrm{pH}$ de equilíbrio variaram de 5,0 a 7,5, de modo geral com valores decrescentes com o aumento da concentração. Nesta pesquisa o pH intrínseco do composto foi inferior, mas os valores de $\mathrm{pH}$ no equilíbrio situaram-se na faixa de 5,2 a 6,2, lembrando que foram adotadas concentrações metálicas inferiores aos referidos autores.

Mesmo não sendo um objetivo específico deste estudo o aprofundamento nos mecanismos de adsorção atuantes, algumas constatações gerais podem ser formuladas nesse 
sentido. Para os três metais estudados nesta pesquisa ( $\mathrm{Pb}, \mathrm{Zn}$ e $\mathrm{Cd}), \mathrm{o} \mathrm{pH}$ das amostras iniciais (imediatamente após o contato adsorvente e solução) variou de 3,9 a 5,1, para a turfa, e de 4,8 a 6,3, para o composto. Segundo Dick et al. (2016), entre valores de pH 4 a 5 ocorre a dissociação do H da maioria (90 a 99\%) dos grupos COOH. Assim, as condições de pH desta pesquisa favoreceram a troca catiônica.

No tocante a ambos materiais reativos orgânicos, as amostras contendo $\mathrm{Pb}$ e $\mathrm{Cd}$, que justamente revelaram as maiores adsorções, apresentaram uma elevação de pH após o tempo de contato. Enquanto a adsorção de Zn majoritariamente se associou à diminuição dos valores de pH. Essa variação pode estar justamente associada aos mecanismos de adsorção atuantes.

Sharma e Forster (1993) encontraram um aumento de pH similar a esse estudo, associando que à medida que mais íons vão sendo adsorvidos, mais íons hidroxila $\left(\mathrm{OH}^{-}\right)$vão sendo liberados pela turfa. Franchi (2004) complementa que outra possibilidade para esta elevação do pH é que a turfa pode ocasionalmente, ao mesmo tempo em que retira íons metálicos da solução, remover íons hidrogênio.

Bartczak et al. (2015) confirmaram o mecanismo de troca iônica a partir da comparação do pH da solução antes e após a adsorção. Os valores de pH diminuíram e os autores associaram este processo à desprotonação dos grupos funcionais da turfa, liberando mais íons $\mathrm{H}^{+}$para a solução e, consequentemente, deixando um maior número de sítios livres para a adsorção de mais íons metálicos. Este mecanismo é consistente com a troca iônica, já que quanto mais íons metálicos foram adsorvidos, mais íons hidrogênio foram liberados e, por conseguinte, o pH se tornou menor. Estas conclusões se relacionam à adsorção de $\mathrm{Pb}$ e Ni pela turfa a um $\mathrm{pH}$ inicial de 5,0. A adsorção é altamente sensível a pequenas variações. No caso desta pesquisa, por exemplo, este mecanismo pode ser majoritariamente atuante na adsorção de Zn pela turfa (a maiores concentrações, com pH inicial variando de 4,7 a 5,1) e pelo composto (com pH inicial na faixa de 6,1 a 6,3), sendo válido ressaltar que neste estudo não houve ajuste inicial de $\mathrm{pH}$.

Ademais, pode estar atuando ainda na adsorção de $\mathrm{Pb}, \mathrm{Zn}$ e Cd tanto pela turfa, como pelo composto, o mecanismo de atração eletrostática das cargas negativas presentes na superfície dos adsorventes pelos íons metálicos positivos $\left(\mathrm{Pb}^{2+}, \mathrm{Zn}^{2+} \mathrm{e} \mathrm{Cd}^{2+}\right)$, haja vista os valores de $\Delta \mathrm{pH}$ negativo e $\mathrm{PESN}<\mathrm{pH}$, no caso da turfa. Ou ainda a adsorção física relacionada aos microporos, cuja presença foi indicada pelo MEV.

\subsubsection{Condutividade elétrica}

Para os três metais estudados $(\mathrm{Pb}, \mathrm{Zn}$ e $\mathrm{Cd})$, de modo geral, as amostras contendo os materiais reativos orgânicos e as soluções contaminantes apresentaram maiores valores de CE 
em comparação com as soluções branco. Este aumento pode ser devido a um mecanismo inerente da adsorção que é a troca catiônica, inclusive abordado anteriormente, com a liberação de cátions diversos anteriormente adsorvidos e a posterior ligação dos cátions metálicos presentes na solução sintética. Por conseguinte, esse aumento de cátions em solução pode ter vindo a elevar os valores de CE.

\subsubsection{Isotermas de sorção}

Vários pesquisadores utilizaram isotermas para examinar os variados fatores que interferem na sorção de íons metálicos, através de uma medida da posição de equilíbrio no processo de adsorção. A própria forma de uma isoterma pode ser considerada na previsão de um sistema de sorção, o qual pode ser "favorável" ou "desfavorável". As duas isotermas mais populares são a de Langmuir e de Freundlich (BROWN; GILL; ALLEN, 2000). Inclusive estes dois modelos são os mais abordados na literatura no tocante à adsorção de metais potencialmente tóxicos pelo solo (ZUQUETTE; SILVA JR; GARCIA, 2008; SILVA, 2013; MARQUES, 2014; ARAÚJO, 2015) e por materiais reativos orgânicos, como turfas e compostos orgânicos (MCKAY; PORTER, 1997; PETRONI, 2004; QIN et al., 2006; CRESCÊNCIO JÚNIOR, 2008; KOIVULA et al., 2009; PARADELO e BARRAL, 2012; BARTCZAK et al., 2015).

Nessa perspectiva, os parâmetros de adsorção obtidos através do emprego destes modelos para a turfa estão apresentados na Tabela 71 juntamente com outros valores similares da literatura. Em relação aos dados de Freundlich, segundo Sposito (1989) o valor de n está ligado aos sítios energéticos do adsorvente. Para os três metais observados, segundo todos os estudos apresentados na Tabela 71, o valor de $\mathrm{n}$ foi sempre inferior a 0,5 o que permite classificar estas sorções como desfavoráveis (ZUQUETTE; SILVA JR; GARCIA, 2008). Além disso, para o $\mathrm{Pb}$, o valor de $\mathrm{K}_{\mathrm{f}}$ obtido nesta pesquisa pode ser enquadrado como mediano, enquanto para o $\mathrm{Cd}$, ele pode ser tido como reduzido. Já em se tratando do modelo de Langmuir, o $K_{L}$ desta pesquisa foi mediano e refletiu a existência de diferentes energias de ligação para cada metal, com valores maiores para o $\mathrm{Pb}$, e o $\mathrm{q}_{\mathrm{m}}$ foi baixo comparado com outros autores, mas exibiu uma boa capacidade de adsorção. Observa-se ainda que foram apresentados os resultados de duas turfas tratadas quimicamente com HCl (FRANCHI, 2004; PETRONI, 2004), potencializando suas respectivas capacidades absortivas. É válido destacar que Franchi (2004) comparou a adsorção da turfa in natura e ativada e obteve uma considerável elevação de retenção, principalmente para $\mathrm{Zn}$ e $\mathrm{Cd}$. 
Tabela 71 - Dados comparativos quanto aos parâmetros de adsorção de $\mathrm{Pb}, \mathrm{Zn}$ e Cd pela turfa

\begin{tabular}{|c|c|c|c|c|c|c|c|c|c|c|}
\hline \multirow[b]{2}{*}{ Metal } & \multirow[b]{2}{*}{ Origem } & \multicolumn{3}{|c|}{ Parâmetros de Freundlich } & \multicolumn{3}{|c|}{ Parâmetros de Langmuir } & \multirow[b]{2}{*}{ Observações } & \multirow[b]{2}{*}{$\mathbf{R}^{2 *}$} & \multirow[b]{2}{*}{ Autor } \\
\hline & & $\begin{array}{c}\mathbf{K}_{\mathbf{f}} \\
\left(\mathbf{L g}^{-1}\right)\end{array}$ & $\mathbf{n}$ & $\mathbf{R}^{2}$ & $\begin{array}{c}\mathrm{K}_{\mathrm{L}} \\
\left(\mathrm{L} \mathrm{mg}^{-1}\right)\end{array}$ & $\begin{array}{c}\text { qm } \\
\left(\mathbf{m g ~ g ^ { - 1 }}\right)\end{array}$ & $\mathbf{R}^{2}$ & & & \\
\hline \multirow{8}{*}{$\mathbf{P b}$} & Vale do Rio & - & - & - & 1,239 & 31,153 & 0,991 & In natura & $\mathrm{L}$ & \multirow{4}{*}{ Qin et al. (2006)** } \\
\hline & $(\mathrm{SP})$ & - & - & - & 0,150 & 32,258 & 0,988 & Tratada com $\mathrm{HCl}$ & $\mathrm{L}$ & \\
\hline & China & 1,834 & 0,222 & 0,847 & 0,131 & 88,682 & 0,991 & \multirow{2}{*}{$\begin{array}{c}\text { Passadas na peneira } \\
\text { de } 100 \#\end{array}$} & $\mathrm{~L}>\mathrm{F}$ & \\
\hline & Dinamarca & 2,794 & 0,253 & 0,955 & 0,156 & 118,726 & 0,946 & & $\mathrm{~F} \cong \mathrm{L}$ & \\
\hline & Finlândia & 0,349 & 0,235 & 0,979 & - & - & - & H7 (Escala de Von Post) & $\mathrm{F}>\mathrm{L}$ & Koivula et al. (2009) \\
\hline & Irlanda & 8,57 & 0,448 & 0,973 & 0,415 & 29,5 & 0,996 & Sphagnum moss & $\mathrm{F}-\mathrm{L} * * * *$ & Нo (2006) \\
\hline & Polônia & - & - & - & 0,449 & 82,31 & 0,992 & - & $\mathrm{L}>\mathrm{F}$ & Bartczak et al. (2015) \\
\hline & Cravinhos (SP) & 3,748 & 0,175 & 0,989 & 0,387 & 7,843 & 0,995 & In natura & $\mathrm{L} \cong \mathrm{F}$ & Esta pesquisa $* * *$ \\
\hline \multirow{4}{*}{$\mathbf{Z n}$} & - & - & - & - & 0,068 & 11,703 & 0,999 & 355 a $500 \mu \mathrm{m}$ & $\mathrm{L} \cong \mathrm{F}$ & $\begin{array}{c}\text { McKay e Porter } \\
(1997)^{* *}\end{array}$ \\
\hline & Vale do Rio & - & - & - & 0,037 & 6,720 & 0,954 & In natura & $\mathrm{L}$ & \multirow{2}{*}{ Franchi (2004) } \\
\hline & $(\mathrm{SP})$ & - & - & - & 0,011 & 16,155 & 0,917 & Tratada com $\mathrm{HCl}$ & $\mathrm{L}$ & \\
\hline & Cravinhos (SP) & 0,466 & 0,257 & 0,638 & 0,046 & 1,901 & 0,684 & In natura & $\mathrm{L} \cong \mathrm{F}$ & Esta pesquisa $* * *$ \\
\hline \multirow{7}{*}{ Cd } & - & - & - & - & 0,052 & 21,133 & 0,999 & 355 a $500 \mu \mathrm{m}$ & $\mathrm{L} \cong \mathrm{F}$ & $\begin{array}{c}\text { McKay e Porter } \\
(1997)^{* *}\end{array}$ \\
\hline & Vale do Rio & - & - & - & 0,098 & 6,676 & 0,994 & In natura & $\mathrm{L}$ & \multirow{2}{*}{ Franchi (2004) } \\
\hline & $(\mathrm{SP})$ & - & - & - & 0,019 & 16,835 & 0,944 & Tratada com $\mathrm{HCl}$ & $\mathrm{L}$ & \\
\hline & $\begin{array}{c}\text { Balneário Arroio } \\
\text { do Silva (SC) }\end{array}$ & - & - & - & 0,149 & 14,47 & 0,995 & Tratada com $\mathrm{HCl}$ & $\mathrm{L} \cong \mathrm{F}$ & Petroni (2004) \\
\hline & China & 1,832 & 0,317 & 0,982 & 0,037 & 32,037 & 0,960 & \multirow{2}{*}{$\begin{array}{c}\text { Passadas na peneira } \\
\text { de } 100 \#\end{array}$} & $\mathrm{~F} \cong \mathrm{L}$ & \multirow{2}{*}{ Qin et al. (2006)** } \\
\hline & Dinamarca & 2,695 & 0,379 & 0,990 & 0,027 & 50,247 & 0,964 & & $\mathrm{~F} \cong \mathrm{L}$ & \\
\hline & Cravinhos (SP) & 0,766 & 0,278 & 0,939 & 0,307 & 2,393 & 0,961 & In natura & $\mathrm{L} \cong \mathrm{F}$ & Esta pesquisa $* * *$ \\
\hline
\end{tabular}


Continuação da Tabela 71 .

* Melhor ajuste (maior $\mathrm{R}^{2}$ ): L - Langmuir e F - Freundlich;

** As unidades dos parâmetros foram convertidas para facilitar a comparação com os demais dados tabelados;

*** Parâmetros de Langmuir referentes ao tipo de linearização com melhor ajuste (maior $\mathrm{R}^{2}$ );

**** São trabalhadas quatro linearizações de Langmuir. Aqui foram apresentados os resultados com maior $\mathrm{R}^{2}(\mathrm{~L}$

$>\mathrm{F})$, mas existem casos $(\mathrm{F}>\mathrm{L})$.

Fonte: A autora.

A Tabela 72 contém as principais informações no tocante às respectivas condições dos ensaios de adsorção dos trabalhos abordados na tabela anterior.

Tabela 72 - Condições dos ensaios de adsorção com turfa

\begin{tabular}{cc}
\hline \hline Autor & Condições do ensaio \\
\hline \hline Bartczak et al. (2015) & $\mathrm{C}: 15-100 \mathrm{mg} \mathrm{L}^{-1} ; \mathrm{pH}: 5,0 ; \mathrm{T}: 25^{\circ} \mathrm{C}$ \\
\hline Franchi (2004) & R: $1 / 250, \mathrm{C}: 10-250 \mathrm{mg} \mathrm{L}^{-1}, \mathrm{pH}: 6,5 ; \mathrm{t}: 8$ horas; \\
T: $22-27^{\circ} \mathrm{C} ; \mathrm{S}$
\end{tabular}

R: razão turfa/solução; C: intervalo de concentração; t: tempo de contato; T: temperatura; S/M: S-solução monoelementar, do inglês "single solute" e M-solução multielementar.

Fonte: A autora.

A Tabela 73 contém dados similares, mas em relação a compostos orgânicos. Considerando os dados de Freundlich, o maior valor de $\mathrm{n}$ foi referente à adsorção de $\mathrm{Pb}$ desta pesquisa. Contudo, os valores de $\mathrm{K}_{\mathrm{f}}$ para o composto indiano foram inferiores aos valores tabelados para os três metais de estudo ( $\mathrm{Pb}, \mathrm{Zn}$ e $\mathrm{Cd}$ ). Comparando os dados de Langmuir, os valores de $\mathrm{K}_{\mathrm{L}}$ desta pesquisa foram superiores aos outros estudos para os três metais e, especificamente, para o $\mathrm{Zn}$ foi encontrado um $\mathrm{q}_{\mathrm{m}}$ mediano em relação aos outros trabalhos e para o $\mathrm{Cd}$, seu $\mathrm{q}_{\mathrm{m}}$ foi superior ao outro estudo de comparação. 
Tabela 73 - Dados comparativos quanto aos parâmetros de adsorção de $\mathrm{Pb}, \mathrm{Zn}$ e Cd pelo composto

\begin{tabular}{|c|c|c|c|c|c|c|c|c|c|c|}
\hline \multirow[b]{2}{*}{ Metal } & \multirow[b]{2}{*}{ Origem } & \multicolumn{3}{|c|}{ Parâmetros de Freundlich } & \multicolumn{3}{|c|}{ Parâmetros de Langmuir } & \multirow{2}{*}{$\begin{array}{c}\text { Material } \\
\text { compostado }\end{array}$} & \multirow[b]{2}{*}{$\mathbf{R}^{2 *}$} & \multirow[b]{2}{*}{ Autor } \\
\hline & & $\begin{array}{c}\mathbf{K}_{\mathbf{f}} \\
\left(\mathbf{L g}^{-1}\right)\end{array}$ & $\mathbf{n}$ & $\mathbf{R}^{2}$ & $\begin{array}{c}\mathbf{K}_{\mathbf{L}} \\
\left(\mathbf{L} \mathbf{~ m g}^{-1}\right) \\
\end{array}$ & $\begin{array}{c}\mathbf{q} \mathbf{m} \\
\left(\mathbf{m g ~ g ^ { - 1 }}\right)\end{array}$ & $\mathbf{R}^{2}$ & & & \\
\hline \multirow{3}{*}{$\mathbf{P b}$} & $\begin{array}{l}\text { Catalunha } \\
\text { (Espanha) }\end{array}$ & 15,5 & 0,36 & 0,953 & 0,021 & 196 & 0,975 & $\begin{array}{c}\text { Fração orgânica de resíduos } \\
\text { sólidos + resíduos verdes }\end{array}$ & $\mathrm{L} \cong \mathrm{F}$ & \multirow{2}{*}{ Paradelo e Barral (2012) } \\
\hline & $\begin{array}{c}\text { Galiza } \\
\text { (Espanha) }\end{array}$ & 10,3 & 0,45 & 0,962 & 0,008 & 188 & 0,967 & $\begin{array}{c}\text { Fração orgânica de } \\
\text { resíduos sólidos }\end{array}$ & $\mathrm{L} \cong \mathrm{F}$ & \\
\hline & $\begin{array}{l}\text { São Carlos } \\
\text { (SP) }\end{array}$ & 4,520 & 1,020 & 0,952 & 0,098 & 40,984 & 0,986 & $\begin{array}{c}\text { Fração orgânica restaurante } \\
\text { + resíduos verdes }\end{array}$ & $\mathrm{L} \cong \mathrm{F}$ & Esta pesquisa** \\
\hline \multirow{4}{*}{$\mathbf{Z n}$} & $\begin{array}{l}\text { Catalunha } \\
\text { (Espanha) }\end{array}$ & 2,9 & 0,32 & 0,968 & 0,030 & 24 & 0,967 & $\begin{array}{l}\text { Fração orgânica de resíduos } \\
\text { sólidos + resíduos verdes }\end{array}$ & $\mathrm{F} \cong \mathrm{L}$ & \multirow{2}{*}{ Paradelo e Barral (2012) } \\
\hline & $\begin{array}{c}\text { Galiza } \\
\text { (Espanha) }\end{array}$ & 3,1 & 0,27 & 0,948 & 0,043 & 20 & 0,985 & $\begin{array}{c}\text { Fração orgânica de } \\
\text { resíduos sólidos }\end{array}$ & $\mathrm{L} \cong \mathrm{F}$ & \\
\hline & $\begin{array}{l}\text { Creta } \\
\text { (Grécia) }\end{array}$ & - & - & - & 0,023 & 1,11 & 0,929 & $\begin{array}{c}\text { Fração orgânica de } \\
\text { resíduos sólidos municipais }\end{array}$ & $\mathrm{F} \cong \mathrm{L}$ & $\begin{array}{c}\text { Simantiraki e Gidarakos } \\
(2015)\end{array}$ \\
\hline & $\begin{array}{l}\text { São Carlos } \\
\text { (SP) }\end{array}$ & 1,015 & 0,351 & 0,965 & 0,394 & 3,487 & 0,982 & $\begin{array}{l}\text { Fração orgânica restaurante } \\
\text { + resíduos verdes }\end{array}$ & $\mathrm{L} \cong \mathrm{F}$ & Esta pesquisa** \\
\hline \multirow{2}{*}{ Cd } & $\begin{array}{c}\text { Creta } \\
\text { (Grécia) } \\
\end{array}$ & - & - & - & 0,015 & 2,96 & 0,913 & $\begin{array}{l}\text { Fração orgânica de } \\
\text { resíduos sólidos municipais }\end{array}$ & $\mathrm{F} \cong \mathrm{L}$ & $\begin{array}{c}\text { Simantiraki e Gidarakos } \\
(2015)\end{array}$ \\
\hline & $\begin{array}{l}\text { São Carlos } \\
\text { (SP) }\end{array}$ & 1,315 & 0,430 & 0,965 & 0,279 & 5,646 & 0,990 & $\begin{array}{l}\text { Fração orgânica restaurante } \\
+ \text { resíduos verdes }\end{array}$ & $\mathrm{L} \cong \mathrm{F}$ & Esta pesquisa** \\
\hline
\end{tabular}

* Melhor ajuste (maior $\mathrm{R}^{2}$ ): L - Langmuir e F - Freundlich;

** Parâmetros de Langmuir referentes ao tipo de linearização com melhor ajuste (maior $\mathrm{R}^{2}$ ).

Fonte: A autora. 
A Tabela 74 exibe as principais condições dos ensaios de adsorção dos trabalhos abordados na tabela anterior.

Tabela 74 - Condições dos ensaios de adsorção com composto orgânico

\begin{tabular}{cc}
\hline Autor & Condições do ensaio \\
\hline \hline Paradelo e Barral (2012) & R: $1 / 50 ;$ C: $1-2000 \mathrm{mg} \mathrm{L}^{-1} ; \mathrm{t}: 16$ horas; $\mathrm{pH}$ : natural; \\
T: $20^{\circ} \mathrm{C} ; \mathrm{S}$ \\
\hline $\begin{array}{c}\text { Simantiraki e Gidarakos } \\
(2015)\end{array}$ & R: $1 / 40 ; \mathrm{t}: 48$ horas; $\mathrm{T}: 20^{\circ} \mathrm{C} ;$ \\
\hline \hline
\end{tabular}

R: razão turfa/solução; C: intervalo de concentração; t: tempo de contato; T: temperatura; S/M: S-solução monoelementar, do inglês "single solute" e M-solução multielementar.

Fonte: A autora.

Conforme ressaltado nas Tabelas 71 a 74, estudos de adsorção comumente são realizados com diferentes adsorventes e em diferentes condições (pH, temperatura, concentração e razão solo/solução) dificultando comparações diretas. Por conseguinte, a análise das tabelas anteriores não visa concluir quais são os melhores ou piores adsorventes, mas permite observar que os parâmetros de adsorção encontrados nesta pesquisa, de modo geral, estão satisfatoriamente enquadrados na faixa de valores usuais.

As Tabelas 71 e 73 contém ainda informações referentes ao modelo que mais se adequou aos dados experimentais com base no ajuste pelo coeficiente de determinação, levando em conta apenas Freundlich e Langmuir. Um modelo foi considerado com melhor ajuste quando seu $\mathrm{R}^{2}$ foi maior ou igual a 0,05 que o $\mathrm{R}^{2}$ referente ao outro modelo ou quando não foram apresentados ambos coeficientes e a informação de melhor ajuste foi trazida pelo autor. De modo geral, ambas formulações apresentaram bons resultados, inclusive com diversos trabalhos nos quais seus respectivos $\mathrm{R}^{2}$ foram similares, como nesta pesquisa. Todavia, é possível perceber que avaliando a adsorção de $\mathrm{Pb}, \mathrm{Zn}$ e Cd em turfa e composto orgânico, o modelo de Langmuir se sobressai, mesmo que discretamente.

\subsubsection{Porcentagens adsorvidas e capacidades de remoção de metais em função da afinidade metal - material reativo}

Diversos mecanismos atuam na adsorção de metais pela turfa, mas cada um deles não atraem os íons igualmente. Assim, um importante fator é a afinidade de cada metal pelo sorvente (BROWN; GILL; ALLEN, 2000). Como o modelo de Langmuir revelou o melhor ajuste aos dados experimentais é possível se ter uma ideia da afinidade de adsorção de cada 
material reativo orgânico e por cada metal através da comparação dos respectivos valores de capacidade de adsorção, relacionando a massa máxima de metal que pode ser adsorvida em função da massa do meio reativo $\left(\mathrm{q}_{\mathrm{m}}\right)$. Esta análise permite concluir que para ambos os materiais orgânicos a ordem de afinidade é: $\mathrm{Pb}>\mathrm{Cd}>\mathrm{Zn}$ (Tabelas 71 e 73).

No entanto, a fim de observar se esta ordem é mantida ao longo de todo o ensaio e para todas as concentrações estudadas, a Figura 132 contém comparações entre a turfa e o composto em termos da porcentagem de remoção de $\mathrm{Pb}, \mathrm{Zn}$ e $\mathrm{Cd}$ e da capacidade de remoção de cada metal por cada material reativo orgânico. É difícil promover uma comparação direta entre as afinidades verificadas, já que uma mínima alteração em um parâmetro interfere em todo o ensaio. Contudo, como a razão material reativo/solução, a temperatura, a agitação, a filtração e as demais condições do equilíbrio em lote foram aproximadamente iguais, dentro das condições de cada caso, é possível avaliar, a partir da Figura 132, que para o intervalo de concentrações inicias comum em cada ensaio, variando nas proximidades de 30 a $140 \mathrm{mg} \mathrm{L}^{-1}$ (período delimitado pelas linhas tracejadas nos gráficos) a afinidade dos metais varia na seguinte ordem decrescente: $\mathrm{Pb}>\mathrm{Cd}>\mathrm{Zn}$. Mais especificamente, levando em consideração cada adsorvente: $\mathrm{Pb}-$ Composto $>\mathrm{Pb}-$ Turfa $>\mathrm{Cd}-$ Composto $>\mathrm{Zn}-$ Composto $>\mathrm{Cd}-$ Turfa $>\mathrm{Zn}-$ Turfa.

Figura 132 - Análise comparativa da porcentagem de remoção $(\mathrm{A} \%)$ e da capacidade de remoção (qe) de cada metal $(\mathrm{Pb}, \mathrm{Zn}$ e $\mathrm{Cd})$ por cada material reativo (turfa e composto indiano)

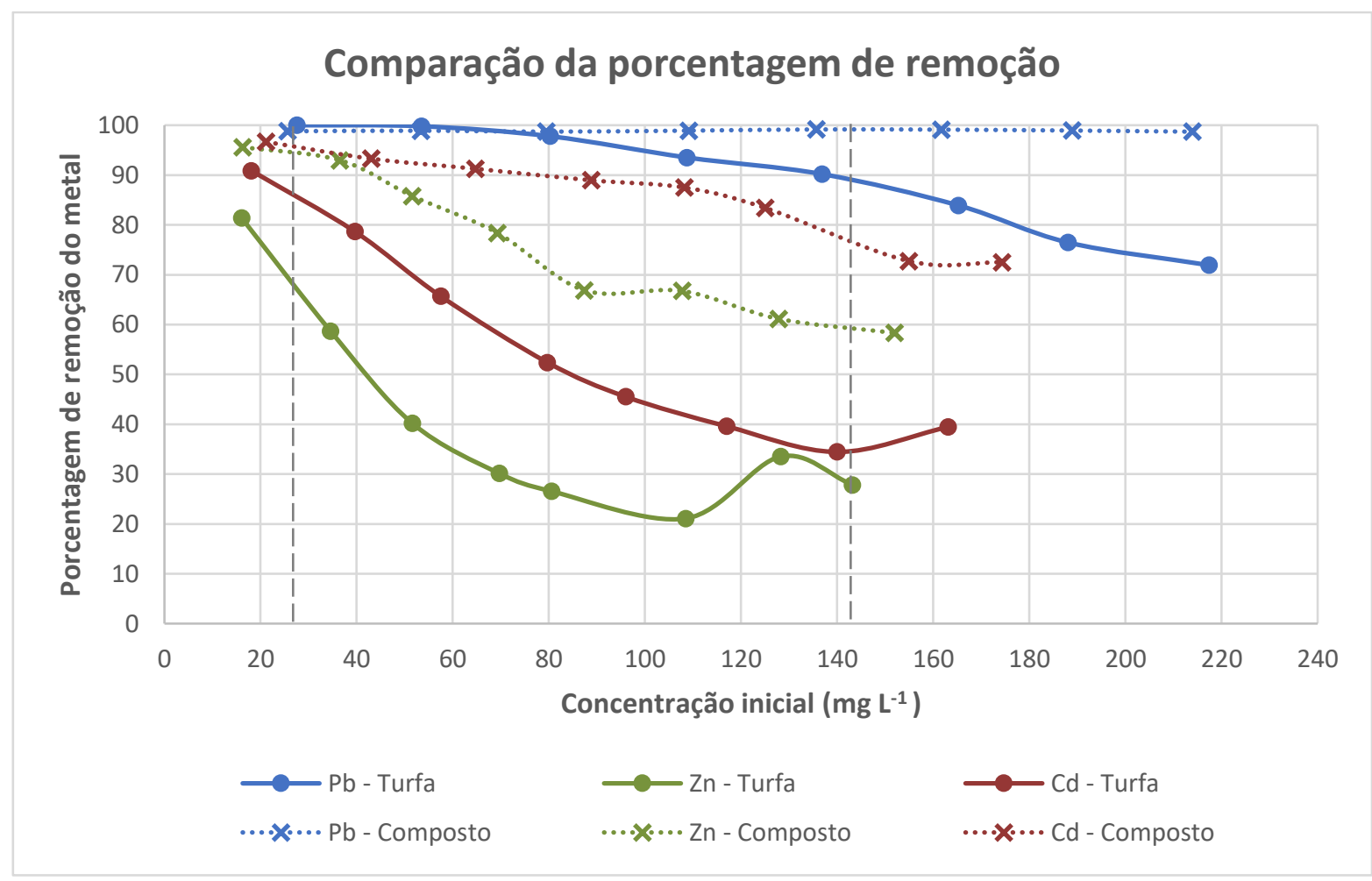




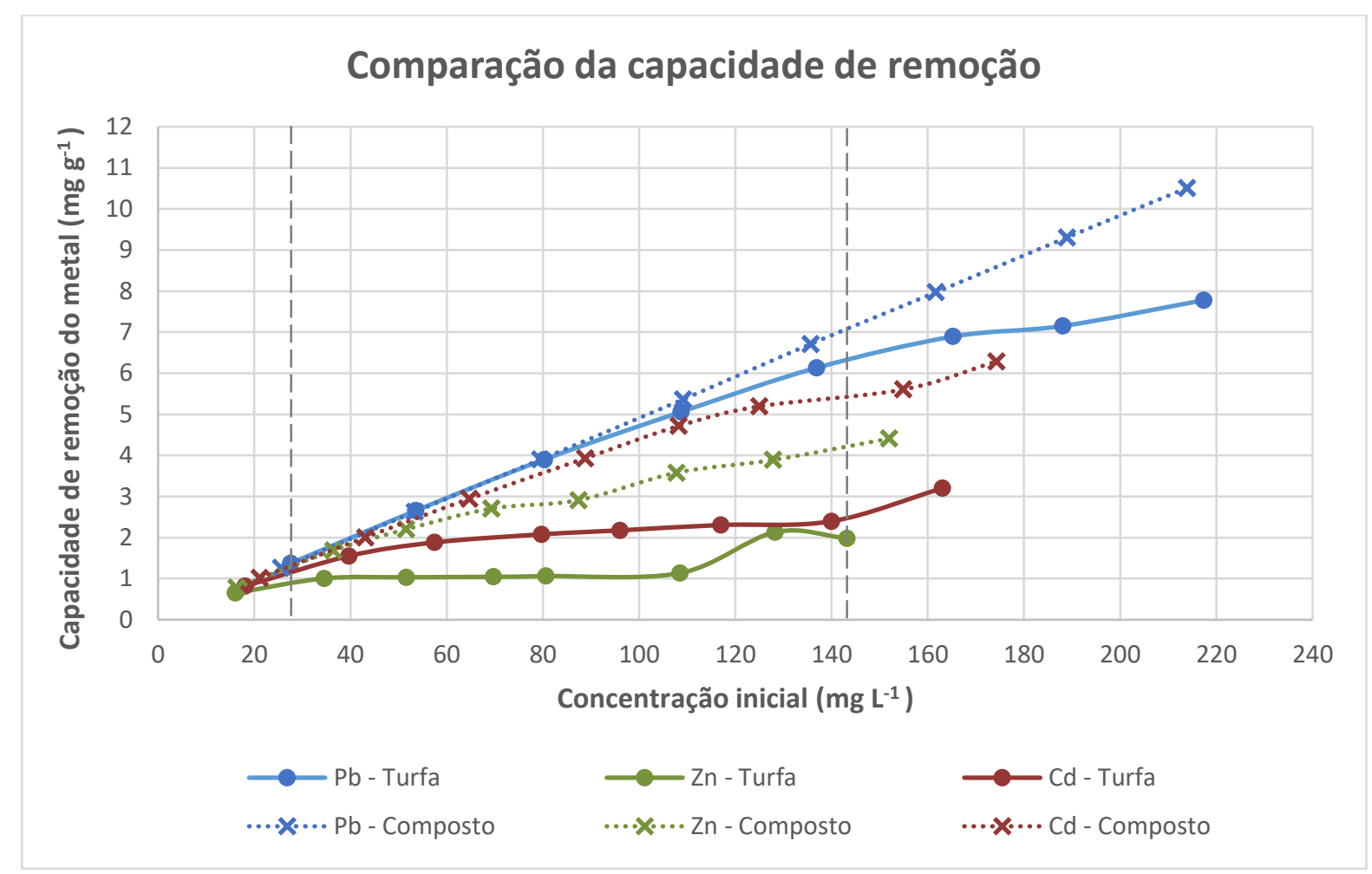

Fonte: A autora.

A Tabela 75 confirma que esta mesma ordem de afinidade já foi similarmente encontrada por outros autores que estudaram $\mathrm{Pb}, \mathrm{Zn}$ e $\mathrm{Cd}$ e, até mesmo, outros metais, mas todos em soluções monoelementares.

Tabela 75 - Ordem de afinidade de adsorção de $\mathrm{Pb}, \mathrm{Zn}$ e Cd por turfas e compostos orgânicos

\begin{tabular}{ccc}
\hline \hline Material reativo & $\begin{array}{c}\text { Ordem } \\
\text { de } \\
\text { afinidade }\end{array}$ & Autor \\
\hline \hline \multirow{2}{*}{ Turfa } & $\mathrm{Pb}>\mathrm{Cd}>\mathrm{Zn}$ & Esta pesquisa \\
\cline { 2 - 3 } & $\mathrm{Cd}>\mathrm{Zn}$ & Petroni (1999) \\
\cline { 2 - 3 } & $\mathrm{Pb}>>\mathrm{Cu}>\mathrm{Cd} \cong \mathrm{Zn} \cong \mathrm{Mn}$ & Franchi (2004) \\
\cline { 2 - 3 } & $\mathrm{Pb}>\mathrm{Cu}>\mathrm{Cd}$ & Qin et al. (2006) \\
\cline { 2 - 3 } Composto & $\mathrm{Pb}>\mathrm{Cu}>\mathrm{Ni}>\mathrm{Cd}>\mathrm{Zn}$ & $\begin{array}{c}\text { Kalmykova, Strömvall } \mathrm{C} \\
\text { Steenari (2008) }\end{array}$ \\
\cline { 2 - 3 } & $\mathrm{Pb}>\mathrm{Cu}>\mathrm{Zn}$ & Esta pesquisa \\
\cline { 2 - 3 } & $\mathrm{Cd}>\mathrm{Zn}$ & Paradelo e Barral (2012) \\
\hline
\end{tabular}

Fonte: A autora. 
A adsorção de cátions presentes em solução está diretamente relacionada a atração entre as cargas negativas de superfície e as cargas positivas dos íons metálicos (ONG; SWANSON, 1966). A Tabela 76 exibe algumas propriedades em relação aos íons divalentes $\mathrm{Pb}^{2+}, \mathrm{Zn}^{2+} \mathrm{e}$ $\mathrm{Cd}^{2+}$.

Tabela 76 - Propriedades em relação aos íons divalentes $\mathrm{Pb}^{2+}, \mathrm{Zn}^{2+}$ e $\mathrm{Cd}^{2+}$

\begin{tabular}{ccc}
\hline \hline Íon & $\begin{array}{r}\text { Raio iônico } \\
(\mathbf{A}) *\end{array}$ & $\begin{array}{c}\text { Eletronegatividade** } \\
\text { kcal/g átomo }\end{array}$ \\
\hline $\mathrm{Pb}^{2+}$ & 1,20 & 2,38 \\
\hline $\mathrm{Zn}^{2+}$ & 0,74 & 1,65 \\
\hline $\mathrm{Cd}^{2+}$ & 0,97 & 1,69 \\
\hline \hline
\end{tabular}

Fonte: * Ahrens (1952); ** Soares e Casagrande (2000).

Para justificar os resultados deste estudo, considerando dois metais em solução, em concentrações semelhantes e sem interferência de outros efeitos, a valência de cada íon será um fator determinante na adsorção, de forma que mesmo a energia cinética presente sendo a mesma para cada elemento, aquele dotado de maior valência será mais fortemente atraído para um sítio de adsorção de carga elétrica contrária (FRANCHI, 2004). Quando esta condição for igual, o íon com menor raio iônico terá preferência para a adsorção de uma maior quantidade de moléculas (PETRONI, 1999; FRANCHI, 2004).

Contudo, Ong e Swanson (1966) ao invés de tratarem do raio iônico, ampliam esta regra para que o potencial iônico possa ser usado para explicar estas forças de atração. O potencial iônico é o resultado da relação existente entre a carga e o raio iônico. Assim, o potencial iônico aumenta, em função da elevação da carga e/ou da diminuição do raio iônico e, por conseguinte, a atração aumenta proporcionalmente. Em soluções contendo muitos metais aqueles dotados de maior potencial iônico serão adsorvidos primeiro e se sítios de adsorção não forem ocupados, os íons com menor potencial iônico serão adsorvidos na sequência.

Como os três íons estudados apresentam a mesma carga (íons divalentes), o raio iônico será o fator determinante do potencial iônico. Assim, quanto menor o raio iônico, maior o potencial iônico e segundo Ong e Swanson (1966), maior a adsorção. Contudo, a análise das tabelas anteriores permite observar que os dados desta pesquisa não estão em conformidade com esta constatação, similar ao verificado por Petroni (1999) e Franchi (2004).

McKay e Porter (1997), por sua vez, associam a afinidade de adsorção à eletronegatividade, sendo que eles concluíram a partir de seus estudos de adsorção de $\mathrm{Cu}, \mathrm{Cd}$ e 
Zn, que quanto mais eletronegativos forem os íons metálicos, mais eles serão atraídos para a superfície do adsorvente.

A análise da Tabela 76 permite concluir que a ordem de eletronegatividade de $\mathrm{Pb}, \mathrm{Zn}$ e $\mathrm{Cd}$ e de afinidade destes metais pelos adsorventes trabalhados nesta pesquisa (turfa e composto) foram as mesmas, confirmando os pressupostos apresentados em McKay e Porter (1997) e que já haviam sido averiguados por Petroni (1999) e Franchi (2004).

Pardo (2000) ao estudar a adsorção de metais em solos, também observou uma maior afinidade de $\mathrm{Pb}$ para as superfícies adsorventes sugerindo que este metal forma complexos mais fortes do que $\mathrm{Cd}$ e $\mathrm{Zn}$ e que talvez os sítios de sorção do $\mathrm{Pb}$ sejam diferentes em relação aos outros dois metais, embora tal possibilidade não pode ser confirmada ou rejeitada com base apenas em dados de sorção.

Complementarmente, McBride (1994) afirma que as diferenças do comportamento adsortivo do $\mathrm{Pb}$ e do $\mathrm{Cd}$ podem ser parcialmente explicadas pelas configurações eletrônicas destes metais, sendo que o $\mathrm{Pb}$ apresenta elétrons desemparelhados, mais facilmente compartilhados, e espaços vazios em seu orbital, favorecendo a formação de complexos.

\subsubsection{Comparação da adsorção de $\mathrm{Pb}, \mathrm{Zn}$ e $\mathrm{Cd}$ em outros materiais reativos orgânicos de baixo custo}

O potencial de adsorção de metais vem sendo estudado por cada vez mais tipologias de materiais reativos orgânicos de baixo custo, ampliando a gama de possibilidades de utilizações.

Conforme relatado anteriormente, os estudos de adsorção geralmente são realizados em diversas condições dificultando comparações diretas. Inclusive, neste caso, são diferentes tipos de materiais, o que implica em variadas estruturas e grupos funcionais, por exemplo. No entanto, o objetivo desta análise é promover uma comparação geral entre os materiais estudados dentro do panorama envolvendo os mais diversos adsorventes de caráter orgânico e suas peculiaridades positivas e negativas.

A Tabela 77 contém dados relativos a capacidade de adsorção de $\mathrm{Pb}, \mathrm{Zn}$ e Cd por estes adsorventes. Estes valores são resultado de análise de informações experimentais a partir da utilização do modelo de Langmuir. Similar ao observado para a turfa e para o composto, o emprego dos modelos de Freundlich e Langmuir é bem usual, com um leve destaque de melhor ajuste proporcionado pela formulação de Langmuir. Considerando qualitativamente os dados apresentados é possível confirmar que a capacidade de retenção de metais pelas amostras estudadas nesta pesquisa, principalmente pelo composto orgânico, é comparável à de outros materiais, refletindo um uso potencial em comparação com outros adsorventes de baixo custo. 
Tabela 77 - Dados comparativos quanto aos parâmetros de adsorção de $\mathrm{Pb}, \mathrm{Zn}$ e Cd por materiais reativos orgânicos de baixo custo

\begin{tabular}{|c|c|c|c|c|c|c|c|c|c|c|}
\hline \multirow[b]{2}{*}{ Adsorvente } & \multirow{2}{*}{$\begin{array}{c}\text { Razão } \\
\text { adsorvente/ } \\
\text { solução }\end{array}$} & \multirow{2}{*}{$\begin{array}{c}\text { Variação } \\
\text { da concentração } \\
\left(\mathrm{mg} \mathrm{L}^{-1}\right)\end{array}$} & \multirow[b]{2}{*}{$\begin{array}{l}\text { Tempo de } \\
\text { contato (h) }\end{array}$} & \multirow[b]{2}{*}{ pH } & \multirow[b]{2}{*}{$\begin{array}{c}\text { Temperatura } \\
\left({ }^{\circ} \mathbf{C}\right)\end{array}$} & \multicolumn{3}{|c|}{$q_{m}\left(m_{g} g^{-1}\right)$} & \multirow[b]{2}{*}{$\mathbf{R}^{2 *}$} & \multirow[b]{2}{*}{ Autor } \\
\hline & & & & & & $\mathbf{P b}^{2+}$ & $\mathrm{Zn}^{2+}$ & $\mathrm{Cd}^{2+}$ & & \\
\hline $\begin{array}{l}\text { Casca de laranja } \\
\text { modificada } \\
\text { (copolimerização) }\end{array}$ & $1 / 500$ & $50-1200$ & 3 & - & - & 476,1 & - & 293,3 & $\mathrm{~L}>\mathrm{F}$ & $\begin{array}{l}\text { Feng et al. } \\
\quad(2011)\end{array}$ \\
\hline $\begin{array}{c}\text { Resíduos de casca } \\
\text { de manga }\end{array}$ & $1 / 400$ & $10-600(S)$ & 1 & 5,0 & $25 \pm 2$ & 96,32 & - & 67,08 & $\mathrm{~L}>\mathrm{F}$ & $\begin{array}{l}\text { Iqbal, Saeed e } \\
\text { Zafar (2009) }\end{array}$ \\
\hline Casca de café & - & $50-100(\mathrm{~S})$ & 72 & 4,0 & 25 & - & 5,565 & 6,854 & $\mathrm{~L}>\mathrm{F}$ & $\begin{array}{l}\text { Oliveira et al. } \\
(2008)\end{array}$ \\
\hline Resíduos de chá & - & $25-200(\mathrm{M})$ & 1,5 & $5,5 \pm 0,5$ & $22 \pm 2$ & 65 & - & - & $\mathrm{F}>\mathrm{L}$ & $\begin{array}{c}\text { Amarasinghe } \\
\text { Williams (2007) }\end{array}$ \\
\hline Serragem & $1 / 50$ & $5-200(S)$ & - & 5,1 & $\begin{array}{l}\text { Temperatura } \\
\text { ambiente }\end{array}$ & & 2,17 & 3,5 & $\mathrm{~L}>\mathrm{F}$ & $\begin{array}{c}\text { Božić et al. } \\
(2009)\end{array}$ \\
\hline Casca de arroz & - & $0,125-50(\mathrm{M})$ & - & - & 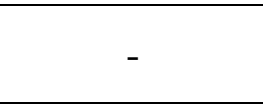 & - & 2,33 & - & $\mathrm{L}>\mathrm{F}$ & $\begin{array}{l}\text { Lattuada et al. } \\
\text { (2014) }\end{array}$ \\
\hline $\begin{array}{c}\text { Carvão ativado } \\
\text { derivado do } \\
\text { bagaço de cana } \\
\end{array}$ & - & $1-1000(\mathrm{~S})$ & 12 & 4,5 & 25 & - & 31,11 & 38,03 & $\mathrm{~F}>\mathrm{L}$ & $\begin{array}{l}\text { Mohan e Singh } \\
\quad(2002)\end{array}$ \\
\hline $\begin{array}{l}\text { Bucha (Luffa } \\
\text { cylindrica) }\end{array}$ & $1 / 500$ & $50-400$ & 5 & - & 25 & 75,853 & - & - & $\mathrm{L}>\mathrm{F}$ & $\begin{array}{c}\text { Adewuyi e Pereira } \\
\text { (2017) }\end{array}$ \\
\hline
\end{tabular}

* Melhor ajuste: L - Langmuir e F - Freundlich;

S/M: S-solução monoelementar, do inglês "single solute" e M-solução multielementar.

Fonte: A autora. 
A Tabela 78 inclui diversas ordens de afinidades de metais encontradas por alguns destes materiais diferentes dos empregados nesta pesquisa. Observa-se que majoritariamente é seguida a sequência $\mathrm{Pb}>\mathrm{Cd}>\mathrm{Zn}$, salvo uma troca de posição entre $\mathrm{Zn}$ e Cd (REDDAD et al., 2002).

Tabela 78 - Ordem de afinidade de adsorção de $\mathrm{Pb}, \mathrm{Zn}$ e Cd por materiais reativos orgânicos de baixo custo

\begin{tabular}{ccc}
\hline Material reativo & $\begin{array}{c}\text { Ordem } \\
\text { de } \\
\text { afinidade }\end{array}$ & Autor \\
\hline $\begin{array}{c}\text { Grânulos de celulose e } \\
\text { quitina }\end{array}$ & $\mathrm{Pb}>\mathrm{Cd}>\mathrm{Cu}$ & Zhou et al. (2004) \\
\hline $\begin{array}{c}\text { Casca de laranja } \\
\text { modificada } \\
\text { (copolimerização) }\end{array}$ & $\mathrm{Pb}>\mathrm{Cd}>\mathrm{Ni}$ & Feng et al. (2011) \\
\hline $\begin{array}{c}\text { Pó de tabaco } \\
\text { aarvão de cascas de } \\
\text { amendoim }\end{array}$ & $\mathrm{Pb}>\mathrm{Cu}>\mathrm{Cd}>\mathrm{Ni} \cong \mathrm{Zn}$ & Qi e Aldrich (2008) \\
\hline $\begin{array}{c}\text { Resíduos de casca de } \\
\text { manga }\end{array}$ & $\mathrm{Pb}>\mathrm{Cd}>\mathrm{Ni}>\mathrm{Zn}$ & Ricordel et al. (2001) \\
\hline $\begin{array}{c}\text { Casca de café } \\
\text { Biocarvão de bambu } \\
(\text { Phyllostachys pubescens })\end{array}$ & $\mathrm{Cu}>\mathrm{Cr}>\mathrm{Cd}>\mathrm{Zn}$ & Oliveira et al. (2008) \\
\hline $\begin{array}{c}\text { Polpa de beterraba } \\
\text { produzida pelas fábricas de } \\
\text { refinação de açúcar }\end{array}$ & $\mathrm{Pb}>\mathrm{Cu}>\mathrm{Zn}>\mathrm{Cd}>\mathrm{Ni}$ & Reddad et al. (2002) \\
\hline \hline
\end{tabular}

Fonte: A autora.

\subsubsection{Matriz de correlação de Pearson}

O coeficiente de correlação ou coeficiente de Pearson analisa a relação existente entre duas variáveis, expressando o seu grau de dependência linear. Seu valor pode variar entre os extremos de -1 a 1 , sendo que medidas positivas indicam que uma das variáveis aumenta com o aumento da outra, ou seja, elas são diretamente proporcionais, enquanto índices negativos representam que uma das variáveis diminuiu com o aumento da outra, ou seja, elas são inversamente proporcionais. Já quando o coeficiente for igual a zero, as varáveis não exibem dependência linear, podendo, entretanto, apresentar dependência não linear.

Estes coeficientes de correlação foram calculados relacionando diversos parâmetros, dois a dois, formando matrizes de correlação. Foram trabalhados com dados de caracterização geológica e geotécnica da turfa e dos compostos total, indiano, estático e alambrado (Tabela 
79), relação entre resultados físicos e químicos dos quatro compostos com medidas de adsorção, obtidas pelo teste do melhor composto (Tabela 80), porcentagens de metais ( $\mathrm{Pb}, \mathrm{Zn}$ e $\mathrm{Cd}$ ) adsorvidos para turfa e composto indiano, em função das concentrações dos brancos (Tabela 81) e capacidade de remoção, relacionando as quantidades de metais ( $\mathrm{Pb}, \mathrm{Zn}$ e $\mathrm{Cd}$ ) adsorvidos em relação à massa de material reativo (turfa e composto indiano), também em função das concentrações dos brancos (Tabela 82). Nas matrizes, foram consideradas como altas correlações positivas os valores superiores a 0,9000 (marcados em verde) e como altas correlações negativas os valores inferiores a -0,9000 (marcados em vermelho).

$\mathrm{Na}$ matriz de correlação dos parâmetros geológicos-geotécnicos da turfa e dos compostos (Tabela 79) verificou-se uma alta correlação entre as frações finas (argila e silte) com o carbono e o carbono orgânico. Isso sugere que a matéria orgânica, que também revelou uma considerável correlação com as frações finas, se encontra majoritariamente nesta faixa granulométrica. Corroborando com esta constatação, na fração areia, por sua vez, se observou o contrário, com baixas correlações com o C e o C orgânico. A massa específica dos sólidos revelou uma correlação negativa com a matéria orgânica, o que já era esperado, haja vista que as partículas orgânicas apresentam maior leveza em relação aos minerais. Por conseguinte, é usual que quanto maior for o teor orgânico do material reativo, menor seja sua massa específica, o que foi confirmado nesta pesquisa.

Na Tabela 80 que traz os dados de caracterização apenas referentes aos compostos, bem como valores de adsorção, verificaram-se algumas correlações diferentes em relação à tabela anterior, sendo um indicativo de que as tipologias diferentes de materiais estudados (turfa e compostos) apresentam parâmetros físicos e químicos com comportamentos variados. Assim, entre os compostos, a fração areia se associou positivamente com o carbono orgânico, provavelmente porque os compostos ainda apresentam resquícios vegetais, constituídos majoritariamente de carbono. Contudo, a fração areia e o carbono total, exibiu uma correlação positiva, mas em pequena magnitude, como possível consequência da ampla variação entre os teores C e C orgânico encontrados para o composto alambrado, devido a maior heterogeneidade do material. Esta observação reflete justamente a alta sensibilidade da análise através das matrizes de correlação. Além disso, apareceram correlações positivas entre o $\Delta \mathrm{pH}$ e a CTC, sendo que os resultados de $\Delta \mathrm{pH}$ foram todos negativos, indicando a presença principal de partículas com superfícies carregadas negativamente, o que favorece indubitavelmente a troca catiônica; entre a MO e a CRA, já que a matéria orgânica apresenta um conhecido potencial na retenção de água; e C, H e N se mostraram intimamente relacionados. Já em relação aos metais, verificou-se que a presença intrínseca de $\mathrm{Zn}$ e Cd se correlacionou positivamente com o $\Delta \mathrm{pH}$ e 
os parâmetros da adsorção de $\mathrm{Pb}$ se correlacionam negativamente com o $\mathrm{pH}$ e positivamente com as frações argila e silte, podendo ser indícios de que diferentes mecanismos de adsorção predominam na imobilização dos metais estudados, ou ainda, pode ser uma simples consequência do fato de que a adsorção do $\mathrm{Pb}$ pelo composto não atingiu a saturação com o intervalo de concentração estudado. Ademais, corroborando com uma possível similaridade entre os mecanismos que regem a retenção do $\mathrm{Zn}$ e do $\mathrm{Cd}$, todos os parâmetros de adsorção destes dois metais refletiram altas correlações positivas. Por fim, a capacidade de adsorção apresentou uma correlação positiva máxima $(1,0000)$ com a porcentagem de retenção, para todos os metais, conforme esperado.

Ao correlacionar as porcentagens adsorvidas da turfa e do composto indiano, para $\mathrm{Pb}$, $\mathrm{Zn}$ e Cd (Tabela 81), verificou-se que em termos do mesmo material reativo, tanto para a turfa como para o composto, houve apenas uma alta correlação positiva entre Zn e Cd. Já relacionando os dois materiais, o $\mathrm{A} \%$ do $\mathrm{Pb}$ pela turfa se correlacionou aos respectivos $\mathrm{A} \%$ do $\mathrm{Zn}$ e do Cd pelo composto indiano e o A\% do Cd pela turfa se correlacionou ao A\% do Zn pelo composto indiano.

Já ao correlacionar as capacidades de adsorção (Tabela 82), observou-se que em termos do mesmo material reativo, para a turfa, $\mathrm{o} \mathrm{q}_{\mathrm{e}}$ do $\mathrm{Pb}$ revelou uma alta correlação positiva com o $\mathrm{q}_{\mathrm{e}}$ do $\mathrm{Cd}$, as outras correlações foram positivas, mas em menor magnitude. Enquanto para o composto, os três metais exibiram altas correlações positivas. Considerando os dois materiais, todas as correlações foram positivas e superiores a 0,8 , sendo que os menores valores foram verificados em relação ao $\mathrm{Zn}$ da turfa.

Estas matrizes de correlação mostram que, de uma maneira geral, a adsorção de $\mathrm{Pb}, \mathrm{Zn}$ e Cd pela turfa e pelo composto apresenta uma tendência de correlação linear, a qual não pode ser confirmada apenas com os ensaios de sorção realizados. 
Tabela 79 - Matriz de correlação de Pearson relacionando a caracterização geológica e geológica da turfa e dos compostos

\begin{tabular}{|c|c|c|c|c|c|c|c|c|c|c|c|c|}
\hline & $\begin{array}{l}\text { Argila } \\
+ \text { Silte } \\
\end{array}$ & Areia & $\begin{array}{c}\text { Massa } \\
\text { específica }\end{array}$ & pH & $\Delta \mathbf{p H}$ & MO & CTC & CRA & $\mathbf{C}$ & $\mathbf{H}$ & $\mathbf{N}$ & C org \\
\hline Argila + Silte & 1 & & & & & & & & & & & \\
\hline Areia & $-0,9986$ & 1 & & & & & & & & & & \\
\hline Massa específica & $-0,8250$ & 0,8297 & 1 & & & & & & & & & \\
\hline pH & $-0,8442$ & 0,8279 & 0,7334 & 1 & & & & & & & & \\
\hline$\Delta \mathbf{p H}$ & $-0,3555$ & 0,3927 & 0,0421 & 0,0137 & 1 & & & & & & & \\
\hline MO & 0,7005 & $-0,7147$ & $-0,9694$ & $-0,6198$ & $-0,0684$ & 1 & & & & & & \\
\hline CTC & 0,7485 & $-0,7255$ & $-0,8362$ & $-0,7292$ & 0,3181 & 0,7004 & 1 & & & & & \\
\hline CRA & $-0,2840$ & 0,2619 & $-0,2115$ & 0,0624 & 0,2394 & 0,4227 & $-0,1311$ & 1 & & & & \\
\hline $\mathbf{C}$ & 0,9336 & $-0,9316$ & $-0,9432$ & $-0,9053$ & $-0,1318$ & 0,8664 & 0,8229 & 0,0374 & 1 & & & \\
\hline $\mathbf{H}$ & 0,8426 & $-0,8349$ & $-0,9269$ & $-0,9238$ & 0,0586 & 0,8615 & 0,8422 & 0,1614 & 0,9755 & 1 & & \\
\hline $\mathbf{N}$ & 0,0146 & 0,0066 & $-0,4351$ & $-0,3868$ & 0,7929 & 0,4666 & 0,5164 & 0,6061 & 0,3452 & 0,5355 & 1 & \\
\hline C org & 0,9769 & $-0,9691$ & $-0,8400$ & $-0,8061$ & $-0,2078$ & 0,6937 & 0,8532 & $-0,3384$ & 0,9154 & 0,8352 & 0,0844 & 1 \\
\hline
\end{tabular}

Fonte: A autora. 
Tabela 80 - Matriz de correlação de Pearson relacionando a caracterização geológica e geológica dos compostos e parâmetros do teste melhor composto

\begin{tabular}{|c|c|c|c|c|c|c|c|c|c|c|c|c|c|c|c|c|c|c|c|c|}
\hline & $\begin{array}{l}\text { Argila } \\
+ \text { Silte }\end{array}$ & Areia & pH & $\Delta \mathbf{p H}$ & MO & CTC & CRA & C & $\mathbf{H}$ & $\mathbf{N}$ & C org & $\mathbf{P b}$ & $\mathbf{Z n}$ & Cd & $\mathbf{q}_{\mathrm{e}}-\mathbf{P b}$ & $\mathbf{A} \%-\mathbf{P b}$ & $\mathbf{q}_{\mathrm{e}}-\mathbf{Z n}$ & $\mathbf{A} \%-\mathbf{Z n}$ & $q_{e}-C d$ & A\% - Cd \\
\hline $\begin{array}{l}\text { Argila } \\
+ \text { Silte }\end{array}$ & 1 & & & & & & & & & & & & & & & & & & & \\
\hline Areia & $-0,0213$ & 1 & & & & & & & & & & & & & & & & & & \\
\hline pH & $-0,7665$ & $-0,2145$ & 1 & & & & & & & & & & & & & & & & & \\
\hline$\Delta \mathbf{p H}$ & 0,0351 & 0,8311 & $-0,5508$ & 1 & & & & & & & & & & & & & & & & \\
\hline MO & $-0,5023$ & $-0,1913$ & $-0,0723$ & 0,2797 & 1 & & & & & & & & & & & & & & & \\
\hline CTC & $-0,2601$ & 0,8467 & $-0,2788$ & 0,9532 & 0,3590 & 1 & & & & & & & & & & & & & & \\
\hline CRA & $-0,1586$ & $-0,4020$ & $-0,3244$ & 0,1555 & 0,9185 & 0,1266 & 1 & & & & & & & & & & & & & \\
\hline $\mathbf{C}$ & 0,0378 & 0,0545 & $-0,6397$ & 0,5997 & 0,8087 & 0,5094 & 0,8698 & 1 & & & & & & & & & & & & \\
\hline $\mathbf{H}$ & 0,1547 & 0,1978 & $-0,7447$ & 0,7083 & 0,6949 & 0,5873 & 0,7647 & 0,9821 & 1 & & & & & & & & & & & \\
\hline $\mathbf{N}$ & 0,0546 & 0,4202 & $-0,6817$ & 0,8537 & 0,6485 & 0,7693 & 0,6354 & 0,9286 & 0,9688 & 1 & & & & & & & & & & \\
\hline C org & $-0,3905$ & 0,9285 & 0,0972 & 0,7425 & $-0,0044$ & 0,8677 & $-0,3269$ & 0,0188 & 0,1080 & 0,3509 & 1 & & & & & & & & & \\
\hline $\mathbf{P b}$ & 0,9906 & 0,0975 & $-0,8279$ & 0,1716 & $-0,4636$ & $-0,1252$ & $-0,1432$ & 0,1127 & 0,2437 & 0,1665 & $-0,2789$ & 1 & & & & & & & & \\
\hline $\mathbf{Z n}$ & $-0,0347$ & 0,7207 & $-0,5549$ & 0,9816 & 0,4545 & 0,9433 & 0,3373 & 0,7299 & 0,8097 & 0,9288 & 0,6644 & 0,0987 & 1 & & & & & & & \\
\hline Cd & 0,2842 & 0,6797 & $-0,7776$ & 0,9516 & 0,2819 & 0,8206 & 0,2799 & 0,7171 & 0,8299 & 0,9110 & 0,5088 & 0,4090 & 0,9483 & 1 & & & & & & \\
\hline $\mathbf{q}_{\mathrm{e}}-\mathbf{P b}$ & 0,9148 & 0,0891 & $-0,9594$ & 0,3379 & $-0,1545$ & 0,0377 & 0,1610 & 0,4286 & 0,5395 & 0,4478 & $-0,2640$ & 0,9459 & 0,3160 & 0,5950 & 1 & & & & & \\
\hline $\mathbf{A} \%-\mathbf{P b}$ & 0,9115 & 0,0866 & $-0,9613$ & 0,3402 & $-0,1452$ & 0,0403 & 0,1702 & 0,4368 & 0,5466 & 0,4542 & $-0,2653$ & 0,9429 & 0,3200 & 0,5979 & 1,0000 & 1 & & & & \\
\hline $\mathbf{q}_{\mathrm{e}}-\mathbf{Z n}$ & $-0,8151$ & 0,1192 & 0,2596 & 0,3719 & 0,8682 & 0,5680 & 0,6013 & 0,5438 & 0,4460 & 0,5146 & 0,4022 & $-0,7561$ & 0,4968 & 0,2202 & $-0,5129$ & $-0,5057$ & 1 & & & \\
\hline $\mathbf{A} \%-\mathbf{Z n}$ & $-0,8139$ & 0,1117 & 0,2585 & 0,3674 & 0,8717 & 0,5628 & 0,6069 & 0,5465 & 0,4477 & 0,5143 & 0,3948 & $-0,7555$ & 0,4935 & 0,2175 & $-0,5114$ & $-0,5041$ & 1,0000 & 1 & & \\
\hline$q_{e}-C d$ & $-0,8371$ & 0,1047 & 0,2978 & 0,3419 & 0,8570 & 0,5468 & 0,5838 & 0,5121 & 0,4105 & 0,4798 & 0,3975 & $-0,7817$ & 0,4659 & 0,1836 & $-0,5463$ & $-0,5392$ & 0,9992 & 0,9992 & 1 & \\
\hline A\% - Cd & $-0,8326$ & 0,1053 & 0,2902 & 0,3464 & 0,8603 & 0,5494 & 0,5888 & 0,5190 & 0,4179 & 0,4865 & 0,3963 & $-0,7767$ & 0,4710 & 0,1899 & $-0,5395$ & $-0,5323$ & 0,9995 & 0,9995 & 1,0000 & 1 \\
\hline
\end{tabular}


Tabela 81 - Matriz de correlação de Pearson relacionando as porcentagens de metais adsorvidos (A\%) para turfa e composto indiano, em função das concentrações dos brancos

\begin{tabular}{c|cccccc}
\hline & $\begin{array}{c}\text { Pb } \\
\text { Turfa }\end{array}$ & $\begin{array}{c}\text { Zn } \\
\text { Turfa }\end{array}$ & $\begin{array}{c}\text { Cd } \\
\text { Turfa }\end{array}$ & $\begin{array}{c}\text { Pb } \\
\text { Composto }\end{array}$ & $\begin{array}{c}\text { Zn } \\
\text { Composto }\end{array}$ & $\begin{array}{c}\text { Cd } \\
\text { Composto }\end{array}$ \\
\hline Pb - Turfa & 1 & & & & \\
Zn - Turfa & 0,6426 & 1 & & & & \\
Cd - Turfa & 0,8537 & 0,9232 & 1 & & & \\
Pb - Composto & $-0,0493$ & $-0,4128$ & $-0,3828$ & 1 & 1 & 1 \\
Zn - Composto & 0,9329 & 0,8312 & 0,9650 & $-0,3077$ & & \\
Cd - Composto & 0,9821 & 0,6453 & 0,8578 & $-0,0055$ & 0,9125 & \\
\hline
\end{tabular}


Tabela 82 - Matriz de correlação de Pearson relacionando as capacidades de remoção $\left(\mathrm{q}_{\mathrm{e}}\right)$ para turfa e composto indiano, em função das concentrações dos brancos

\begin{tabular}{c|cccccc}
\hline & $\begin{array}{c}\text { Pb } \\
\text { Turfa }\end{array}$ & $\begin{array}{c}\text { Zn } \\
\text { Turfa }\end{array}$ & $\begin{array}{c}\text { Cd } \\
\text { Turfa }\end{array}$ & $\begin{array}{c}\text { Pb } \\
\text { Composto }\end{array}$ & $\begin{array}{c}\text { Zn } \\
\text { Composto }\end{array}$ & $\begin{array}{c}\text { Cd } \\
\text { Composto }\end{array}$ \\
\hline Pb - Turfa & 1 & & & & \\
Zn - Turfa & 0,7777 & 1 & & & \\
Cd - Turfa & 0,9379 & 0,7969 & 1 & & \\
Pb - Composto & 0,9844 & 0,8576 & 0,9413 & 1 & 1 \\
Zn - Composto & 0,9861 & 0,8433 & 0,9656 & 0,9907 & 0,9903 & 1 \\
Cd - Composto & 0,9983 & 0,8011 & 0,9493 & 0,9907 & & \\
\hline
\end{tabular}




\section{CONCLUSÕES}

A partir dos resultados obtidos no tocante à caracterização geológica e geotécnica da turfa oriunda da bacia hidrográfica do rio Mogi Guaçu, no município de Cravinhos, foi possível constatar a presença de características promissoras para a adsorção de cátions metálicos, como um $\triangle \mathrm{pH}$ negativo $(-1,0)$, um $\operatorname{PESN}(3,6)$ inferior ao $\mathrm{pH}(5,1)$, um elevado teor de matéria orgânica $\left(520,43 \mathrm{~g} \mathrm{~kg}^{-1}\right)$ e uma considerável CTC $\left(91,00\right.$ cmol $\left._{\mathrm{c}} \mathrm{kg}^{-1}\right)$.

Já em relação aos compostos orgânicos estudados, que apresentaram diferenças básicas quanto ao método de compostagem, suas características geológicas e geotécnicas também foram favoráveis à retenção de metais, como $\Delta \mathrm{pH}$ negativo $(-0,4$ a -1,0), teores consideráveis e bem variáveis de matéria orgânica (193,92 a 418,70 $\mathrm{g} \mathrm{kg}^{-1}$ ) e CTC oscilando entre 29,00 a 75,00 $\mathrm{cmol}_{\mathrm{c}} \mathrm{kg}^{-1}$.

De modo geral, a análise da porção mineral dos materiais reativos orgânicos estudados não indicou a presença de nenhum elemento que inviabilizasse seu uso, refletindo inclusive uma presença majoritária de quartzo e minerais relacionados. Ademais, as concentrações dos metais potencialmente tóxicos de interesse $(\mathrm{Pb}, \mathrm{Zn}$ e $\mathrm{Cd})$ também se mostraram reduzidas, garantindo a possibilidade de seu uso como material adsorvente.

Em se tratando da adsorção, foram realizados ensaios de equilíbrio em lote a fim de avaliar a capacidade de adsorção dos materiais reativos estudados. Foi desenvolvida uma etapa preliminar para se determinar a melhor razão material reativo/solução, haja vista que este parâmetro varia consideravelmente em função das especificidades do material reativo e é de indubitável importância por interferir substancialmente na eficiência da adsorção. Optou-se por analisar a turfa e o $\mathrm{Pb}$, sendo definida experimentalmente como razão de trabalho a relação $1 / 50$, com $1 \mathrm{~g}$ de material reativo e $50 \mathrm{~mL}$ de solução contaminante. Esta razão foi escolhida por conciliar uma boa porcentagem de remoção de $\mathrm{Pb}^{2+}$ com uma capacidade de remoção de $\mathrm{Pb}^{2+}$ intermediária, garantindo a possibilidade de utilização de uma amplitude inferior e superior de concentrações. Definida as condições deste ensaio elas foram seguidas para as posteriores análises a fim de garantir a possibilidade de comparação.

$\mathrm{Na}$ sequência foi determinado o composto com maior capacidade de adsorção analisando os três metais de interesse $(\mathrm{Pb}, \mathrm{Zn}$ e $\mathrm{Cd}$ ) sendo encontradas porcentagens de adsorção de $\mathrm{Pb}$ de 94,02\% (composto alambrado) a 99,64\% (composto estático), de $\mathrm{Zn}$ de 22,13\% (composto estático) a 63,96\% (composto indiano) e de Cd de 55,35\% (composto estático) a 89,84\% (composto indiano). De forma geral, os compostos total e indiano revelaram a maior eficiência adsortiva, mas o composto indiano foi o escolhido por revelar uma ligeira 
maior capacidade de adsorção, bem como por apresentar um maior controle durante o processo de compostagem.

O ensaio de equilíbrio em lote final avaliou a adsorção de $\mathrm{Pb}, \mathrm{Zn}$ e $\mathrm{Cd}$ por turfa e composto indiano. Em relação à turfa como material adsorvente, o incremento de concentrações (considerando a primeira e a última concentração empregada no ensaio) propiciou que a porcentagem de adsorção de $\mathrm{Pb}$ caísse de 100 para 71,92\%, de Zn diminuísse de 81,41 para 27,84\% e de Cd reduzisse de 90,87 para 39,46\%. Já em se tratando do composto indiano, a porcentagem de adsorção de $\mathrm{Pb}$ se manteve nas proximidades entre 98 e 92\%, de $\mathrm{Zn}$ diminuiu de 95,60 para $58,32 \%$ e de Cd reduziu de 96,65 para $72,50 \%$. Ambos materiais se mostraram como bons adsorvedores e a ordem de afinidade para os dois, foi de $\mathrm{Pb}>\mathrm{Cd}>\mathrm{Zn}$.

Relacionando os resultados de adsorção com a caracterização geológica e geotécnica, pode-se concluir que o composto orgânico mesmo exibindo menores valores de matéria orgânica e de CTC em relação à turfa, parâmetros de inegável importância para a adsorção, indicou uma maior afinidade pelos metais estudados em comparação com a turfa. Assim, é interessante uma análise mais pormenorizada para se identificar a quais parâmetros se deve esta adsorção, quais mecanismos estão envolvidos e qual a estabilidade dessa imobilização.

Com os dados de adsorção foram construídas isotermas Linear, de Freundlich e de Langmuir, a partir das respectivas formas linearizadas, sendo que a saturação não foi obtida apenas na adsorção de $\mathrm{Pb}$ pelo composto orgânico. Para os três metais e para os dois materiais, a isoterma de Langmuir se mostrou mais adequada, devido aos maiores coeficientes de linearização obtidos $\left(\mathrm{R}^{2}\right)$. Contudo, na maioria dos casos a isoterma de Freundlich também revelou coeficientes com valor similar.

Diante disso, os materiais reativos orgânicos ensaiados se mostraram adequados para a adsorção, principalmente de $\mathrm{Pb}$ e $\mathrm{Cd}$, sendo potenciais adsorvedores para utilização em barreiras reativas e selantes, agregando baixo custo e considerável disponibilidade com a prevenção e remediação de áreas contaminadas. 


\section{RECOMENDAÇÕES}

Algumas sugestões de pesquisas futuras:

- Os materiais orgânicos são caracterizados por uma rica matriz, já que o material húmico funciona como um suporte que retém nutrientes e os libera paulatinamente, principalmente os compostos. Esta pesquisa revelou um incremento substancial dos valores de condutividade elétrica para as amostras do ensaio de equilíbrio em lote contendo o composto indiano e as soluções contaminantes. Nessa perspectiva, um assunto de estudos futuros pode ser a análise detalhada destes elementos solubilizados, seus possíveis impactos no meio ambiente e a possibilidade da promoção de um pré-tratamento (físico, químico e/ou biológico) para a liberação anterior destes componentes, o qual inclusive poderia potencializar as características adsortivas deste meio;

- Nesta pesquisa foram utilizadas as formas linearizadas das isotermas. Contudo, esta é uma forma simplificada de análise, na qual, por exemplo, em se tratando do modelo de Langmuir é plotado $\mathrm{C}_{\mathrm{e}} / \mathrm{q}_{\mathrm{e}}$ versus $\mathrm{C}_{\mathrm{e}}$. Assim, $\mathrm{C}_{\mathrm{e}}$ aparece nos dois eixos, diminuindo a variabilidade dos dados. Sugere-se, portanto, uma análise complementar utilizando-se também as equações dos modelos em suas formas não-lineares, possibilitando inclusive a comparação dos resultados;

- Como os metais potencialmente tóxicos apresentam massas molares diferentes sugerese que a comparação da capacidade de um mesmo material reativo orgânico em adsorver um metal seja feita convertendo os resultados referentes a adsorção máxima para mmol kg-1, haja vista que os sítios de adsorção são ocupados em relação molar e não em massa. Novamente é possível uma comparação dos resultados;

- Em condições ambientais comumente os lixiviados contaminantes são constituídos por diversos elementos. Nesta pesquisa foram trabalhadas apenas com soluções monoelementares, mas é também interessante o estudo de soluções multielementares, inclucive com combinações diferenciadas dos metais (por exemplo: $\mathrm{Pb}-\mathrm{Cd}, \mathrm{Pb}-\mathrm{Zn}, \mathrm{Cd}-\mathrm{Zn}, \mathrm{Pb}-\mathrm{Cd}-\mathrm{Zn}$ ), visando-se conhecer mais intimanete a competição pelos sítios de adsorção;

- Diversos mecanismos de adsorção podem estar atuando simultaneamente. Uma alternativa de estudo é a sua análise através de ensaios comparativos antes e após a adsorção. O FTIR (Fourier Transfom Infrared Spectroscopy) espectroscopia no infravermelho com transformada de Fourier, por exemplo, pode fazer inferências sofre a atuação dos grupos funcionais e uma possível troca iônica, conforme realizado por Bartczak et al. (2015). Já estudos relacionados a microporos, podem dar indicativos de adsorção física; 
- Como a utilização de materiais reativos orgânicos em barreiras propicia a introdução de novas substâncias em um ecossistema é interessante a realização de análises ecotoxicológicas e de ensaios de bioacessibilidade dos metais após a adsorção;

- Os adsorventes apresentam capacidades finitas de adsorção. Dessa forma, é importante que a vida útil da barreira seja determinada, bem como as condições do material reativo pósadsorção e sua destinação final. 


\section{REFERÊNCIAS}

ABAT, M.; MCLAUGHLIN, M. J.; JIRBY, J. K.; STACEY, S. P.; Adsorption and desorption of copper and zinc in tropical peat soils of Sarawak, Malaysia. Geoderma, v.175, p.5863, 2012.

ADEWUYI, A.; PEREIRA, F. V.; Underutilized Luffa cylindrica sponge: A local bio-adsorbent for the removal of $\mathrm{Pb}$ (II) pollutant from water system. Beni-Suef University Journal of Basic and Applied Sciences, p.118-126, 2017.

ADRIANO, D. C.; Trace elements in the terrestrial environments. New York: SpringerVerlang, 1986. 533p.

AGENCY FOR TOXIC SUBSTANCES AND DISEASES REGISTRY - ATSDR. Toxicological profile for cadmium. Atlanta, 487p., 2012. Disponível em: < http://www.atsdr.cdc.gov/toxprofiles/tp5.pdf>. Acesso em 21 de março de 2016.

AGENCY FOR TOXIC SUBSTANCES AND DISEASES REGISTRY - ATSDR. Toxicological profile for lead. Atlanta, 582p., 2007. Disponível em: < http://www.atsdr.cdc.gov/toxprofiles/tp13.pdf>. Acesso em 21 de março de 2016.

AGENCY FOR TOXIC SUBSTANCES AND DISEASES REGISTRY - ATSDR. Toxicological profile for zinc. Atlanta, 352p., 2005. Disponível em: < http://www.atsdr.cdc.gov/toxprofiles/tp60.pdf>. Acesso em 21 de março de 2016.

AGUIAR, M. R. M. P.; NOVAES, A. C.; GUARINO, A. W. S.; Remoção de metais pesados de efluentes industriais por aluminossilicatos. Química Nova, v.25, n.6/B, p.11451154, 2002.

AHARONI, C.; SPARKS, D. L.; Kinetics of Soil Chemical Reactions - A Theoretical Treatment. In: SPARKS, D. L.; SUAREZ, D. L.; Rates of Soil Chemical Processes, Soil Science Society of America, Madison, WI, p.1-18, 1991.

ALlEONI, L. R. F.; CAMARGO, O. A.; Ponto de efeito salino nulo: proposição de nomenclatura. Boletim Informativo da Sociedade Brasileira de Ciência do Solo, v.18, n.1, p.5-11, 1993.

ALLEONI, L. R. F.; MELLO, J. W. V.; ROCHA, W. S. D.; XII - Eletroquímica, adsorção e troca iônica no solo. In: MELO, V. F.; ALLEONI, L. R. F.; Química e mineralogia do solo: Parte II - Aplicações. Sociedade Brasileira de Ciência do Solo, Viçosa, Minas Gerais, $1^{\text {a }}$ ed., v.2, 2016.

AllowAY, B. J.; Cadmium; In: AllowAY, B. J.; Heavy Metals in Soils. 2nd edition. London: Blackie Academic and Professional, 1995a. 
ALLOWAY, B. J.; Soil processes and the behavior of metals; In: ALLOWAY, B. J.; Heavy Metals in Soils. 2nd edition. London: Blackie Academic and Professional, 1995b.

AMARASINGHE, B. M. W. P. K.; WILLIAMS, R. A.; Tea waste as a low cost adsorbent for the removal of $\mathrm{Cu}$ and $\mathrm{Pb}$ from wastewater. Chemical Engineering Journal, v.132, p.299-309, 2007.

AMERICAN PUBLIC HEALTH ASSOCIATION - APHA. Standard methods for the examination of water and wastewater (22th ed.).Washington, D. C: American Public Health Association. 2012.

AMERICAN SOCIETY FOR TESTING AND MATERIALS - ASTM. D2487: Standard Practice for Classification of Soils for Engineering Purposes (Unified Soil Classification System). 2006.

AMERICAN SOCIETY FOR TESTING AND MATERIALS - ASTM. D2974: Standard Test Methods for Moisture, Ash, and Organic Matter of Peat and Other Organic Soils. 2014.

AMERICAN SOCIETY FOR TESTING AND MATERIALS - ASTM. D2976: Standard Test Method for $\mathrm{pH}$ of Peat Materials. 2015.

AMERICAN SOCIETY FOR TESTING AND MATERIALS - ASTM. D2980: Standard Test Method for Volume Mass, Moisture-Holding Capacity, and Porocity of Saturated Peat Materials. 2010.

AMERICAN SOCIETY FOR TESTING AND MATERIALS - ASTM. D4319: Standard Test Method for Distribution Ratios by the Short-Term Batch Method. 2001.

AMERICAN SOCIETY FOR TESTING AND MATERIALS - ASTM. D4427: Standard Classification of Peat Samples by Laboratory Testing. 2013.

AMERICAN SOCIETY FOR TESTING AND MATERIALS - ASTM. D4646: Standard Test Method for 24-h Batch -Type Measurement of Contaminant Sorption by Soils and Sediments. 2003.

AMERICAN SOCIETY FOR TESTING AND MATERIALS - ASTM. D653: Standard Terminology Relating to Soil, Rock, and Contained Fluids. 2014.

ANDERSON, P. R.; CHRISTENSEN, T. H.; Distribution coefficients of Cd, Co, Ni, and Zn in soils. European Journal of Soil Science, v.39, n.1, p.15-22, 1988.

ANDRIESSE, J. P.; Nature and Management of Tropical Peat Soils. Soil Resources, Management and Conservation Service. FAO Land and Water Development Division. 1988.

ARAÚJO, H. A. S.; Estudo da adsorção de $\mathbf{P b}, \mathbf{Z n}$ e Cd por material inconsolidado transportado da região do Vale do Ribeira (SP). 81p. Monografia (Graduação em 
Engenharia Ambiental). Escola de Engenharia de São Carlos, Universidade de São Paulo, São Carlos, 2015.

ASSOCIAÇÃO BRASILEIRA DE NORMAS TÉCNICAS - ABNT. NBR 13600. Solo Determinação do teor de matéria orgânica por queima a $440^{\circ} \mathrm{C}$. Rio de Janeiro. 1996.

ASSOCIAÇÃO BRASILEIRA DE NORMAS TÉCNICAS - ABNT. NBR 6457. Amostras de solo - Preparação para ensaios de compactação e ensaios de caracterização. Rio de Janeiro. 1986.

ASSOCIAÇÃO BRASILEIRA DE NORMAS TÉCNICAS - ABNT. NBR 6502. Rochas e solos. Rio de Janeiro. 1995.

ASSOCIAÇÃO BRASILEIRA DE NORMAS TÉCNICAS - ABNT. NBR 6508. Determinação da massa específica. Rio de Janeiro. 1984.

BABEL, S.; KURNIAWAN, T. A. Low-cost adsorbents for heavy metals uptake from contaminated water: a review. Journal Hazardous Materials, v.97, p.219-243, 2003.

BAIRD, C.; Química Ambiental. Tradução Maria Angeles Lobo Recio; Luiz Carlos Marques Carrera. 2ed. Porto Alegre: Bookman, 2002, 622p.

BARBOSA, P. R. C.; BORBA, R. P.; SILVA, W. L.; COSCIONE, A. R.; CAMARGO, O.A. Uso do biocarvão de bagaço de cana na remoção de metais pesados de água sob diferentes condições de pH’s. Revista Águas Subterrâneas. São Paulo, Brasil. 2013.

BARREIRA, L. P.; Avaliação das usinas de compostagem do estado de São Paulo em função da qualidade dos compostos e processos de produção. Tese de Doutorado. Faculdade de Saúde Pública, Universidade de São Paulo. 2005.

BARROW, N. J.; Reactions with variable-charge soils. Martinus Nijhoff Publishers. 1987.

BARTCZAK, P.; NORMAN, M.; KLAPISZEWSKI, L.; KARWAŃSKA, N.; KAWALEC, M.; BACZYŃSKA, M.; WYSOKOWSKI, M.; ZDARTA, J.; CIESIELCZYK, F.; JESIONOWSKI, T.; Removal of nickel(II) and lead(II) ions from aqueous solution using peat as a low-cost adsorbent: A kinetic and equilibrium study. Arabian Journal of Chemistry, 2015.

BEESLEY, L.; INNEH, O. S.; NORTON, G. J.; MORENO-JIMENEZ, E.; PARDO, T. CLEMENTE, R.; DAWSON, J. J. C. Assessing the influence of compost and biochar amendments on the mobility and toxicity of metals and arsenic in a naturally contaminated mine soil. Environmental Pollution, v.186, p.195-202, 2014.

BENITES, V. M.; MADARI, B.; MACHADO, P. L. O. A.; Extração e Fracionamento Quantitativo de Substâncias Húmicas do Solo: um Procedimento Simplificado de Baixo Custo. Comunicado Técnico 16. 2003. Disponível em: < 
http://www.infoteca.cnptia.embrapa.br/bitstream/doc/337076/1/comtec162003extracao. pdf $>$. Acesso em 31 de julho de 2015.

BENITES, V. M.; MENDONÇA, E. S.; Propriedades eletroquímicas de um solo eletropositivo influenciadas pela adição de diferentes fontes de matéria orgânica. Revista Brasileira de Ciência do Solo, v.22, n.2, p.215-221, 1998.

BERTONI, J.; LOMBARDI NETO, F.; Conservação do Solo. Piracicaba: Livroceres. 1985. $368 \mathrm{p}$.

BLOWES, D. W.; PTACEK, C. J.; BENNER, S. G.; MCRAE, C. W. T.; BENNETT, T. A.; PULS, R. W.; Treatment of inorganic contaminants using permeable reactive barriers. Journal of Contaminant Hydrology, Elsevier, n.45, p.123-137. 2000.

BOELTER, D. H.; Important physical properties of materials. In: Proceedings Third International Peat Congress, Quebec, Canada, p.150-154, 1968.

BOELTER, D. H.; Physical properties of peats as related to degree of decomposition. Soil Science Society of America Journal, v.33, n.4, p.606-609, 1969.

BOSCOV, M. E. G.; Geotecnia Ambiental. Oficina de textos. São Paulo. 2008. 248p.

BOSSO, S. T.; ENZWEILER, J.; Evaluation of heavy metal removal from aqueous solution onto scolecite. Water Research, v.36, p.4795-4800, 2002.

BOURG, A. C. M.; Speciation of Heavy Metals in Soils and Groundwater and Implications for Their Natural and Provoked Mobility. In: SALOMONS, W.; FÖRSTNER, U.; MADER, P.; Heavy Metals: problems and solutions. Springer, Berlin. 1995. 412p.

BOŽIĆ, D.; STANKOVIĆ, V.; GORGIEVSKI, M.; BOGDANOVIĆ, G.; KOVAČEVIĆ, R.; Adsorption of heavy metal ions by sawdust of deciduous trees. Journal of Hazardous Materials, v.171, p.684-692. 2009.

BRANDYK, T; SZATYLOWICZ, J; OLESZCZUK, R; GNATOWSKI, T; Water-Related Physical Attributes of Organic Soils. In: PARENT, L. E.; ILNICKI, P.; Organic soils and peat materials for sustainable agriculture. CRC Press, 2003.

BRASIL, LEI FEDERAL $\mathbf{N}^{\circ}$ 12.305. 2010. Disponível em: < https://www.planalto.gov.br/ccivil_03/_ato2007-2010/2010/lei/112305.htm>. Acesso em 01 de setembro de 2015.

BRITO, J. C.; Processo de compostagem de resíduos urbanos em pequena escala e potencial de utilização do composto como substrato. Tese de Mestrado. Universidade Tiradentes, UNIT. Aracaju. 2008.

BRONSTEIN, K.; Permeable Reactive Barriers for Inorganic and Radionuclide Contamination. National Network of Environmental Management Studies Fellow. U.S. 
Environmental Protection Agency, Office of Solid Waste and Emergency Response, Office of Superfund Remediation and Technology Innovation, Washington, DC, 2005. Disponível em: <https://clu-in.org/download/studentpapers/bronsteinprbpaper.pdf>. Acesso em 23 de fevereiro de 2016.

BROWN, G.; BRINDLEY, G. W.; X-ray Diffraction Procedures for Clay Mineral Identification. In: BRINDLEY, G. W.; BROWN, G.; Crystal Structures of Clay Minerals and their X-ray Identification. Mineralogical Society, 1980.

BROWN; P. A.; GILL, S. A.; ALLEN, S. J.; Metal removal from wastewater using peat. Water Research, v.34, n.16, p.3907-3916, 2000.

CABRAL JUNIOR, M.; MOTTA, J. F. M.; MELlO, I. S. C.; TANNO, L. C.; SINTONI, A.; SALVADOR, E. D.; CHIEREGATTI, L. A.; Recursos minerais do fanerozoico do Estado de São Paulo. São Paulo, UNESP, Geociências, v.20, n.1, p.105-159, 2001.

CAMARGO, O. A.; ALLEONI, L. R. F.; Alguns Métodos e Terminologias em Eletroquímica de Solos. 2006.

Disponível

em: <http://www.infobibos.com/artigos/solos/eletroquimica/eletroquimica.htm>.

Acesso em 01 de fevereiro de 2017.

CANEllaS, L. P.; GURIDI, F.; VElloso, A. C. X.; SANTOS, G. A.; Isolamento, purificação e métodos químicos de análise de substâncias húmicas. In: CANELLAS, L. P.; SANTOS, G. A.; Humosfera: tratado preliminar sobre a química das substâncias húmicas. Campos dos Goyatacazes. 2005. 309p.

CANELlAS, L. P.; MENDONÇA, E. S.; DOBBSS, L. B.; BALDOTTO, M. A.; VELLOSO, A. C. X.; SANTOS, G. A.; AMARAL SOBRINHO, N. M. B.; Reações da Matéria Orgânica. In: SANTOS, G. A.; SILVA, L. S.; CANELLAS, L. P.; CAMARGO, F. A. O.; Fundamentos da Matéria Orgânica do Solo - Ecossistemas Tropicais e Subtropicais. Porto Alegre: Metrópole. 2ed. 2008. 654p.

CAREY, M. A.; FRETWELL, B. A.; MOSLEY, N. G.; SMITH, J. W. N.; Guidance on the use of permeable reactive barriers for remediating contaminated groundwater. National Groundwater \& Contaminated Land Centre. 2002.

CETESB - COMPANHIA DE TECNOLOGIA DE SANEAMENTO AMBIENTAL. Decisão de Diretoria $\mathbf{N}^{\mathbf{0}}$ 195-2005-E. São Paulo. 2005. 4p. Disponível em: $<\quad$ http://solo.cetesb.sp.gov.br/wpcontent/uploads/sites/34/2014/12/tabela_valores_2005.pdf >. Acesso em 04 de abril de 2016.

CETESB - COMPANHIA DE TECNOLOGIA DE SANEAMENTO AMBIENTAL. Diário Oficial Poder Executivo - Seção I. São Paulo, 2014. Disponível em: $<\quad$ http://solo.cetesb.sp.gov.br/wp-content/uploads/sites/34/2014/12/DD-045-2014P53.pdf > . Acesso em 04 de abril de 2016. 
CETESB - COMPANHIA DE TECNOLOGIA DE SANEAMENTO AMBIENTAL. Manual de gerenciamento de áreas contaminadas. São Paulo. CETESB - GTZ. 2ª ed., 2001a. $389 \mathrm{p}$.

CETESB - COMPANHIA DE TECNOLOGIA DE SANEAMENTO AMBIENTAL. Relatório de estabelecimento de valores orientadores para solos e águas subterrâneas no estado de São Paulo. São Paulo: CETESB, 2001b. 232p. Disponível em: < http://residuossolidos.cetesb.sp.gov.br/residuos-solidos/residuos-urbanossaudeconstrucao-civil/publicacoes-e-relatorios/> . Acesso em 27 de janeiro de 2017.

CHASIN, A. A. M.; CARDOSO, L. M. N.; Cádmio. In: AZEVEDO, F. A.; CHASIN, A. A. M.; Metais: Gerenciamento da Toxicidade. São Paulo: Editora Atheneu, 2003.

CHEN, X. H.; GOSSET, T.; THÉVENOT, D. R; Batch copper ion binding and exchange properties of peat. Water Research, v.24, n.12, p.1463-1471, 1990.

CHRISTENSEN, T. H.; COSSU, R.; STEGMANN, R.; Principles of Landfill Barrier Systems. In: CHRISTENSEN, T. H.; COSSU, R.; STEGMANN, R.; Landfilling of waste: barriers. 1994.

COCHRANE, E. L.; LU, S.; GIBB, S. W.; VILLAESCUSA, I.; A comparison of low-cost biosorbents and commercial sorbents for the removal of copper from aqueous media. Journal of Hazardous Materials, p.198-206, 2006.

COUILLARD, D.; The use of peat in wastewater treatment. Water Research, v.28, n.6, p.1261-1274, 1994.

COUPAL, B.; LALANCETTE, J. M.; The treatment of waste waters with peat moss. Water Research, v.10, p.1071-1076, 1976.

CRESCÊNCIO JÚNIOR, F.; Estudo de Turfas em Laboratório como Barreira Reativa na Remediação de Aquíferos. Tese de Doutorado. Universidade Federal do Rio de Janeiro, COPPE. Rio de Janeiro. 2008.

D’ÁVILA, J. S.; MATOS, C. M.; CAVALCANTI, M. R.; Heavy metals removal from wastewater by using activated peat. Water Science \& Technology, v.26, n.9-11, p.2309-2312, 1992.

DAL BOSCO, S. M.; JIMENEZ, R. S.; CARVALHO, W. A.; Aplicação da zeólita natural escolecita na remoção de metais pesados de efluentes industriais: competição entre os cátions e processo de dessorção. Eclética Química, v.29, n.1, p. 47-56, 2004.

DAVIES, B. E.; Lead; In: ALLOWAY, B. J.; Heavy Metals in Soils. 2nd edition. London: Blackie Academic and Professional, 1995.

DICK, D. P.; NOVOTNY, E. H.; DIECHOW, J.; BAYER, C.; XI - Química da matéria orgânica do solo. In: MELO, V. F.; ALLEONI, L. R. F.; Química e mineralogia do 
solo: Parte II - Aplicações. Sociedade Brasileira de Ciência do Solo, Viçosa, Minas Gerais, $1^{\text {a }}$ ed., v.2, 2016.

DOMINGO, J. L.; NADAL, M.; Domestic waste composting facilities: A review of human health risks. Environmental International, v.35, p.382-389. 2009.

DON SCOTT, H.; Soil Physics - Agricultural and Environmental Applications. 2000. 421p.

DOS SANTOS, M. D. C.; MENEZES, C. T. B; LEAL FILHO, L. S.; Uso de turfa na remoção de metais de um efluente ácido. VI SHMMT/XVIII ENTMME. Rio de Janeiro. 2001.

EMPRESA BRASILEIRA DE PESQUISA AGROPECUÁRIA - EMBRAPA. Manual de Métodos de Análise de Solo. Rio de Janeiro, RJ. $2^{a}$ edição revista. 2011. 230p.

ENVIRONMENTAL PROTECTION AGENCY - EPA. Permeable Reactive Barrier Technologies for Contaminant Remediation. Washington, 1998. 102p.

EPSTEIN, E. The science of composting. CRC Press LLC. 1997.

FAGERIA, N. K.; STONE, L. F.; Qualidade do Solo e Meio Ambiente. Santo Antônio de Goiás. $\quad$ Embrapa. 2006. Disponível em: < http://ainfo.cnptia.embrapa.br/digital/bitstream/CNPAF/25088/1/doc_197.pdf>. Acesso em 15 de maio de 2016.

FAGUNDES, J. R. T.; ZUQUETTE, L. V.; Capacidade de sorção de materiais inconsolidados residuais da Formação Botucatu, região de São Carlos (SP), Brasil. Revista Brasileira de Geociências, v.39, p.494-506, 2009.

FARRELL, M.; JONES, D. L.; Food waste composting: Its use as a peat replacement. Waste Management, v.30, n.8, p.1495-1501, 2010a.

FARRELL, M.; JONES, D. L.; Use of composts in the remediation of heavy metal contaminated soil. Journal of Hazardous Materials, v.175, n.1, p.575-582, $2010 \mathrm{~b}$.

FARRELL, M.; PERKINS, W. T.; HOBBS, P. J.; GRIFFITH, G. W.; JONES, D. L.; Migration of heavy metals in soil as influenced by compost amendments. Environmental Pollution, v.158, n.1, p55-64, 2010.

FENG, N.; GUO, X.; LIANG, S.; ZHU, Y.; LIU, J.; Biosorption of heavy metals from aqueous solutions by chemically modified orange peel. Journal of Hazardous Materials, v.185, p.49-54, 2011.

FERGUSSON, J. E.; The Heavy Elements: Chemistry, Environmental Impact and Health Effects. Pergamon Press, Oxford. 1990.

FERNANDES, F.; SILVA, S. M. C. P.; Manual prático para compostagem de biossólidos. Rio de Janeiro: PROSAB-FINEP, 1999. 
FEUSTEL, I. C.; BYERS, H. G.; The physical and chemical characteristics of certain American peat profiles. Technical Bulletin $\mathbf{n}^{\circ}$ 214. United States Department of Agriculture, Economic Research Service. 1930.

FONTES, M. P. F.; CAMARGO, O. A.; SPOSITO, G.; Eletroquímica das partículas coloidais e sua relação com a mineralogia de solos altamente intemperizados. Scientia Agricola, v.58, n.3, p.627-646, 2001.

FÖRSTner, U.; WITtMann, G. T. W.; Metal Pollution in the Aquatic Environment. Springer-Verlag, 1983.

FRANCHI, J. G.; A utilização de turfa como adsorvente de metais pesados: $O$ exemplo da contaminação da bacia do rio Ribeira de Iguape por chumbo e metais associados. Tese de Doutorado. Instituto de Geociências. São Paulo. Universidade de São Paulo (USP), 2004. 198p.

FRANCHI, J. G.; SÍGOLO, J. B.; DE LIMA, J. R. B. Turfa utilizada na recuperação ambiental de áreas mineradas: Metodologia para avaliação laboratorial. Revista Brasileira de Geociências, v.33, p.255-262, 2003.

FRANCIOSO, O.; CIAVATTA, C.; MONTECCHIO, D.; TUGNOLI, V.; SÁNCHEZCORTÉS, S.; GESSA, C.; Quantitative estimation of peat, brown coal and lignite humic acids using chemical parameters, 1H-NMR and DTA analyses. Bioresource Technology, p.189-195. 2003.

FREEZE, R. A.; CHERRY, J. A.; Groundwater. Prentice Hall. 1979. 604p.

FRÉSCA, F. R. C.; Estudo da geração de resíduos sólidos domiciliares no município de São Carlos, SP, a partir da caracterização física. Dissertação (Mestrado) - Escola de Engenharia de São Carlos Universidade de São Paulo, São Carlos, 2007.

FUCHSMAN, C. H.; Peat - Industrial Chemistry and Technology. Academic Press, New York. 1980. 279p.

GABAS, S. G.; Avaliação da adsorção de cádmio e chumbo em solo laterítico compactado por meio de extração sequencial. Tese de Doutorado. Departamento de Engenharia de Estruturas e Fundações. Escola Politécnica da Universidade de São Paulo (USP), 2005. 240p.

GARCIA-GOMEZ, A.; BERNAL, M. P.; ROIG, A.; Organic matter fractions involved in degradation and humification processes during composting. Compost Science \& Utilization, v.13, n.2, p.127-135. 2005.

GHORBEL-ABID, I.; TRABELSI-AYADI, M.; Competitive adsorption of heavy metals on local landfill clay. Arabian Journal of Chemistry, v.8, p.25-31, 2015. 
GILES, C. H.; SMITH, D.; HUITSON, A; A General Treatment and Classification of the Solute Adsorption Isotherm - I. Theoretical. Journal of Colloid and Interface Science, v.47, n.3, p.775-765, 1974.

GOBBO, L. A.; Aplicação da Difração de Raios-X e Método de Rietveld no Estudo de Cimento Portland. Dissertação (Doutorado) - Instituto de Geociências, Universidade de São Paulo. 2009.

GOSSET, T.; TRANCART, J. L.; THÉVENOT, D. R.; Batch metal removal by peat - kinetics and thermodynamics. Water Research, v.20, n.1, p.21-26, 1986.

GOYAL, S.; DHUL, S. K.; KAPOOR, K. K.; Chemical and biological changes during composting of different organic wastes and assessment of compost maturity. Bioresource Technology, Elsevier, v.96, n.14, p.1584-1591, 2005.

GUERMANDI, J. I.; Avaliação dos parâmetros físicos, químicos e microbiológicos dos fertilizantes orgânicos produzidos pelas técnicas de compostagem e vermicompostagem da fração orgânica dos resíduos sólidos urbanos coletada em estabelecimentos alimentícios de São Carlos/SP. 2015. 163f. Dissertação (Mestrado) Escola de Engenharia de São Carlos Universidade de São Paulo, São Carlos, 2015.

GUIMARÃES, V.; Resíduos de mineração e metalurgia: efeitos poluidores em sedimentos e em espécie biomonitora - Rio Ribeira de Iguape - SP. Tese de Doutorado USP. Instituto de Geociências. São Paulo. Universidade de São Paulo (USP), 2007. 160p.

GÜNDOĞAN, R.; ACEMIOĞLU, B.; ALMA, M. H.; Copper (II) adsorption from aqueous solution by herbaceous peat. Journal of Colloid and Interface Science, p.303-309, 2004.

HARTER, R. D.; NAIDU, R.; An assessment of environmental and solution parameter impact on trace-metal sorption by soils. Soil Science Society of America Journal, v.65, n.3, p.597-612, 2001.

HASHIM, M.A.; MUKHOPADHYAY, S.; SAHU, J. N.; SENGUPTA, B.; Remediation technologies for heavy metal contaminated groundwater. Journal of Environmental Management, v.92, n.10, p.2355-2388, 2011.

HASSEN, A.; BELGUITH, K.; JEDIDI, N.; CHERIF, A.; CHERIF, M.; BOUDABOUS, A.; Microbial characterization during composting of municipal solid waste. Bioresource Tecnology, Elsevier, v.80, n.3, p.217-225, 2001.

HENDERSHOT, W. H.; LAVKULICH, L. M.; The Use of Zero Point of Charge (ZPC) to Assess Pedogenic Development. Soil Science Society of America Journal, v.42, n.3, p.468-472, 1978. 
HO, Y. S.; Isotherms for the sorption of lead onto peat: comparison of linear and non-linear methods. Polish Journal of Environmental Studies, v.15, n.1, p.81-86, 2006.

HO, Y. S.; MCKAY, G.; Pseudo-second order model for sorption process. Process Biochemistry, v.34, p.451-465, 1999a.

HO, Y. S.; MCKAY, G.; The sorption of lead (II) ions on peat. Water Research, v.33, n.2, p.578-584, 1999b.

HUAT, B. B. K.; KAZEMIAN, S.; PRASAD, A.; BARGHCHI, M.; State of an art review of peat: General perspective. International Journal of the Physical Sciences, v.6, n.8, p.1988-1996, 2011.

HUAT, B. B. K.; PROSAD, A.; ASADI, A.; KAZEMIAN, S.; Geotechnics of Organic Soils and Peat. CRC Press, 265p. 2014.

HUERTA-PUJOL, O.; GALLART, M.; SOLIVA, M.; MARTÍNEZ-FARRÉ, F. X.; LÓPEZ, M.; Effect of collection system on mineral content of biowaste. Resources, Conservation and Recycling, n.55, p.1095-1099, 2011.

IHSANULLAH; ABBAS, A.; AL-AMER, A. M.; LAOUI, T.; AL-MARRI, M. J.; NASSER, M. S.; KHRAISHEH, M.; ATIEH, M. A.; Heavy metal removal from aqueous solution by advanced carbon nanotubes: Critical review of adsorption applications. Separation and Purification Technology, v.157, p.141-161, 2016.

INSTITUTO DE PESQUISA ECONÔMICA APLICADA - IPEA. Diagnóstico dos resíduos sólidos urbanos - Relatório de pesquisa. Brasília, 2012. 82p. Disponível em: < http://www.ipea.gov.br/agencia/images/stories/PDFs/relatoriopesquisa/121009_relatorio _residuos_solidos_urbanos.pdf $>$. Acesso em 17 de fevereiro de 2016.

INSTITUTO DE PESQUISAS TECNOLÓGICAS DO ESTADO DE SÃO PAULO - IPT; Estudo das possibilidades de aproveitamento de turfa no Estado de São Paulo. Relatório 12.761. São Paulo: IPT, 1979.

INTERNATIONAL PEAT SOCIETY - IPS. Peatlands and Climate Change. 2008. Disponível em: http://www.peatsociety.org/sites/default/files/files/PeatlandsandClimateChange BookIPS2008.pdf>. Acesso em 01 de março de 2016.

INTERSTATE TECHNOLOGY \& REGULATORY COUNCIL - ITRC. Permeable Reactive Barriers: Lessons Learned/New Directions. Washington, D.C. 2005.

INTERSTATE TECHNOLOGY \& REGULATORY COUNCIL - ITRC. Permeable reactive barriers: Technology update. Washington, D.C. 2011.

IQBAL, M.; SAEED, A.; ZAFAR, S. I.; FTIR spectrophotometry, kinetics and adsorption isotherms modeling, ion Exchange, and EDX analysis for understanding the mechanism 
of the $\mathrm{Cd}^{2+}$ and $\mathrm{Pb}^{2+}$ removal by mango peel waste. Journal of Hazardous Materials, v.164, n.1, p.161-171, 2009.

JOOSTEN, H.; CLARKE, D.; Wise Use of Mires and Peatlands - Background and Principles Including a Framework for Decision-Making, International Mire Conservation Group and International Peat Society, Jyväskylä, Finland. 2002. Disponível em:

http://www.imcg.net/media/download_gallery/books/wump_wise_use_of_mires_and_p eatlands_book.pdf $>$. Acesso em 04 de março de 2016.

KABATA-PENDIAS, A.; PENDIAS, H.; Trace elements in soils and plants. $1^{\circ} \mathrm{ed}$, Boca Raton: CRC Press, 1984. 315p.

KADIRVELU, K.; THAMARAISELVI, K.; NAMASIVAYAM, C.; Removal of heavy metals from industrial wastewaters by adsorption onto activated carbon prepared from an agricultural solid waste. Bioresource Technology, v.76, p.63-65, 2001.

KALMYKOVA, Y.; STRÖMVALL, A.-M.; STEENARI, B.-M.; Adsorption of Cd, Cu, Ni, Pb and $\mathrm{Zn}$ on Sphagnum peat from solutions with low metal concentrations. Journal of Hazardous Materials, v.152, p.885-891, 2008.

KASEMODEL, M. C.; LIMA, J. Z.; SAKAMOTO, I. K.; VARESHE, M. B. A.; TROFINO, J. C.; RODRIGUES, V. G. S.; Soil contamination assessment for $\mathrm{Pb}, \mathrm{Zn}$ and $\mathrm{Cd}$ in a slag disposal area using the integration of geochemical and microbiological data. Environmental monitoring and assessment, v.188, n.12, 2016.

KENG, J. C. W.; UEHARA, G.; Chemistry, Mineralogy, and Taxonomy of Oxisols and Ultisols. Soil and Crop Science Society of Florida, v.33, p.119-126, 1973.

KHADIRAN, T.; HUSSEIN, M. Z.; ZAINAL, Z.; RUSLI, R.; Textural and chemical properties of activated carbon prepared from tropical peat soil by chemical activaton method. BioResources, v.10, n.1, p.986-1007, 2015.

KIEHL, E. J.; Fertilizantes orgânicos. Piracicaba: Editora Agronômica “Ceres” Ltda, 1985, $492 p$.

KIEHL, E. J.; Manual de compostagem: maturação e qualidade do composto. 4.ed. Piracicaba, 2004. 173p.

KIEKENS, L.; Zinc; In: ALLOWAY, B. J.; Heavy Metals in Soils. 2nd edition. London: Blackie Academic and Professional, 1995.

KOCASOY, G.; GÜVENER, Z.; Efficiency of compost in the removal of heavy metals from the industrial wastewater. Environmental Geology, v.57, n.2, p.291-296, 2009.

KOIVULA, M.; KUJALA, K.; RÖNKKÖMÄKI, H.; MÄKELÄ, M.; Sorption of Pb(II), $\mathrm{Cr}(\mathrm{III}), \mathrm{Cu}(\mathrm{II}), \mathrm{As}(\mathrm{III})$ to peat, and utilization of the sorption properties in industrial waste 
landfill hydraulic barrier layers. Journal of Hazardous Materials, v.164, n.1, p.345-352, 2009.

KUMMER, L.; Mineralogia e fracionamento de metais pesados em solos de área de mineração e processamento de chumbo, Adrianópolis - PR. Dissertação de Mestrado. Universidade Federal do Paraná (UFPR), 2008. 77p.

LAMIM, A. P. B.; JORDÃO, C. P.; PEREIRA, J. L.; BELLATO, C. R. Caracterização química e física de turfa litorânea e avaliação da adsorção competitiva por cobre e zinco. Química Nova, v.24, n.1, p.18-23, 2001.

LANDGRAF, M. D.; ALVES, M. R.; DA SILVA, S. C.; REZENDE, M. O. O. Caracterização de ácidos húmicos de vermicomposto de esterco bovino compostado durante 3 e 6 meses. Química Nova, v.22, n.4, p.278-283, 1999.

LANGMUIR, D.; Aqueous Environmental Chemistry. Printice Hall, New Jersey. 1997. $600 \mathrm{p}$.

LARGITTE, L.; BRUDEY, Y.; TANT, T.; COUESPEL DUMESNIL, P.; LODEWYCKX, P.; Comparison of the adsorption of lead by activated carbons from three lignocellulosic precursors. Microporous and Mesoporous Materials, v.219, p.265-275, 2016.

LARGITTE, L.; PASQUIER, R.; A review of the kinetics adsorption models and their application to the adsorption of lead by an activated carbon. Chemical Engineering Research and Design, v.109, p.495-504, 2016.

LATTUADA, R. M.; PERALBA, M. C. R.; DOS SANTOS, J. H. Z.; FISCH, A. G.; Peat, Rice Husk and Rice Husk Carbon as Low-Cost Adsorbents for Metals from Acidic Aqueous Solutions. Separation Science and Technology, v.49, p.101-111, 2014.

LEE, S. J.; LEE, M. E.; CHUMG, J. W.; PARK, J. H.; HUH, K. Y.; JUN, G. I.; Immobilization of Lead from Pb-Contaminated Soil Amended with Peat Moss. Journal of Chemistry, v.2013, 6p. 2013.

LEITE, A. L.; Migração de íons inorgânicos em alguns solos tropicais, com ênfase nos processos de sorção e difusão molecular. Tese de Doutorado. Escola de Engenharia de São Carlos, Universidade de São Paulo. 2001. 254p.

LELIS, M. P. N.; PEREIRA NETO, J. T.; Estudo e Avaliação do Balanço de umidade na compostagem. In: $\mathbf{2 0}^{\circ}$ Congresso Brasileiro de Engenharia Sanitária e Ambiental. Rio de Janeiro, p.1699-1708, 1999.

LIMA, J. Z; Avaliação geológica-geoquímica da porção superficial de um solo contaminado por resíduos de mineração. 99p. Monografia de Trabalho de Graduação. Escola de Engenharia de São Carlos, Universidade de São Paulo. São Carlos, 2014. 
LIU, X.; HICHER, P.; MURESAN, B.; SAIYOURI, N.; HICHER, P. Y.; Heavy metal retention properties of kaolin and bentonite in a wide range of concentration and different $\mathrm{pH}$ conditions. Applied Clay Science, v.119, p.365-374, 2016.

LOURIE, E.; GJENGEDAL, E.; Metal sorption by peat and algae treated peat: Kinetics and factors affecting the process, p.759-764, 2011.

MALANDRINO, M.; ABOLlinO, O.; GIACOMINO, A.; ACETO, M.; MENTASTI, E.; Adsorption of heavy metals on vermiculite: Influence of $\mathrm{pH}$ and organic ligands. Journal of Colloid and Interface Science, v.299, p.537-546, 2006.

MASSUKADO, L. M.; Desenvolvimento do processo de compostagem em unidade descentralizada e proposta de software livre para o gerenciamento municipal dos resíduos sólidos domiciliares. 2008. Tese (Doutorado). Escola de Engenharia de São Carlos, Universidade de São Paulo, 2008.

MARQUES, J. P.; Caracterização geológica-geotécnica de solo residual de Eldorado Paulista (SP) para uso como barreira selante. 78p. Monografia (Graduação em Engenharia Ambiental). Escola de Engenharia de São Carlos, Universidade de São Paulo, São Carlos, 2014.

MCBRIDE, M. B.; Environmental chemistry of soils. New York: Oxford University Press, 1994, 406p.

MCKAY, G.; Peat for environmental applications: A review. Developments in Chemical Engineering and Mineral Processing, v.4., n.3-4, p. 127-155, 1996.

MCKAY, G.; PORTER, J. F.; Equilibrium parameters for the sorption of copper, cadmium and zinc ions onto peat. Journal of Chemical Technology and Biotechnology, v.69, n.3, p.309-320, 1997.

MEHTA, C. M.; PALNI, U.; FRANKE-WHITTLE, I. H.; SHARMA, A. K.; Compost: Its role, mechanism and impact on reducing soil-borne plant diseases. Waste Management, v.34, n.3, p.607-622, 2014.

MELO, L. C. A.; SILVA, C. A.; DIAS, B. O.; Caracterização da matriz orgânica de resíduos de origens diversificadas. Revista Brasileira de Ciência do Solo, v.32, n.1, p.101-110, 2008 .

MENDES, L. A.; Estudo para utilização de vermicomposto com vistas à remediação de solos contaminados com cromo, cobre e chumbo. Dissertação de Mestrado. Instituto de Química de São Carlos, Universidade de São Paulo (IQSC - USP), 2012.

MESSIAS, R. A.; Avaliação estrutural de ácidos húmicos de vermicompsoto e turfa por diferentes técnicas de caracterização. Tese (Doutorado). Instituto de Química de São Carlos, Universidade de São Paulo (IQSC - USP), 2004. 
MIMURA, A. M. S.; VIEIRA, T. V. A.; MARTELLI, P. B.; GORGULHO, H. F.; Aplicação da casca de arroz na adsorção dos íons $\mathrm{Cu}^{2+}, \mathrm{Al}^{3+}, \mathrm{Ni}^{2+} \mathrm{E} \mathrm{Zn}^{2+}$. Química Nova, v.33, n.6, p.1279-1284, 2010.

\section{MINISTÉRIO DA AGRICULTURA, PECUÁRIA E ABASTECIMENTO - MAPA. Instrução}

Normativa SDA $\mathbf{n}^{\circ}$ 17. 2007. Disponível em: < http://www.agricultura.gov.br/assuntos/insumos-agropecuarios/insumosagricolas/fertilizantes/legislacao/in-17-de-21-05-2007-aprova-metodo-substrato.pdf>. Acesso em 04 de abril de 2017.

MINISTÉRIO DA AGRICULTURA, PECUÁRIA E ABASTECIMENTO - MAPA. Instrução Normativa SDA $\mathbf{n}^{\circ}$ 27. 2006. Disponível em: < https://www.legisweb.com.br/legislacao/?id=76854>. Acesso em 11 de fevereiro de 2017.

MINISTÉRIO DA AGRICULTURA, PECUÁRIA E ABASTECIMENTO - MAPA. Manual de Métodos Analíticos Oficiais para Fertilizantes e Corretivos. Brasília, 2013. Disponível em: < http://sistemasweb.agricultura.gov.br/arquivosislegis/anexos/arquivos/1204363.PDF>. Acesso em 04 de abril de 2017.

MINISTÉRIO DO MEIO AMBIENTE - MMA. Manual para implantação de compostagem e de coleta seletiva no âmbito de consórcios públicos. Brasília, 2010. Disponível em: $<$ http://www.cidadessustentaveis.org.br/sites/default/files/arquivos/manual_de_compost agem_mma.pdf $>$. Acesso em 02 de fevereiro de 2015.

MOHAN, D.; SINGH, K. P.; Single- and multi-component adsorption of cadmium and zinc using activated carbon derived from bagasse-an agricultural waste. Waste Research, v.36, n.9, p.2304-2318, 2002.

MOREIRA, F. R.; MOREIRA, J. C.; Os efeitos do chumbo sobre o organismo humano e seu significado para a saúde. Rev Panam Salud Publica, v.15, n.2, p.119-129. 2004.

MOREIRA, S. A.; SOUSA, F. W.; OLIVEIRA, A. G.; NASCIMENTO, R. F.; BRITO, E. S.; Remoção de metais de solução aquosa usando bagaço de caju. Química Nova, v.32, n.7, p.1717-1722, 2009.

NAMOR, A. F. D.; GAMOUZ, A. E.; FRANGIE, S.; MARTINEZ, V.; VALIENTE, L.; WEBB, O. A.; Turning the volume down on heavy metals using tuned diatomite. A review of diatomite and modified diatomite for the extraction of heavy metals from water. Journal of Hazardous Materials, v.241-242, p.14-31, 2012.

NASS, D. P.; O conceito de poluição. Revista Eletrônica de Ciências. São Carlos, 2002. Disponível em: < http://www.cdcc.sc.usp.br/ciencia/artigos/art_13/poluicao.html>. Acesso em 15 de fevereiro de 2016. 
NAVARRO, A.; CHIMENOS, J. M.; MUNTANER, D.; FERNANDÉZ, A. I.; Permeable reactive barriers for the removal of heavy metals: Lab-Scale experiments with low-grade magnesium oxide. Ground Water Monitoring \& Remediation, n.4, p.142-152. 2006.

NELSON, D. W.; SOMMERS, L.E.; Total carbon, organic carbon, and organic matter. In: PAGE, A. L.; MILLER, R. H.; KEENEY, D. R.; Methods of Soil Analysis. American Society of Agronomy, Madison, 1982.

NOGUEIRA, J. B.; Mecânica dos solos - Ensaios de laboratório. Apostila do Departamento de Geotecnia da EESC-USP, São Carlos, 1995.

OBIRI-NYARLO F.; GRAJALES-MESA S. J; MALINA G.; An Overview of permeable reactive barrier for in situ sustainable groundwater remediation. Chemosphere, v.111, p.243-259, 2014.

OJEDOKUN, A. T; BELLO, O. S.; Sequestering heavy metals from wastewater using cow dung. Water Resources and Industry, v.13, p.7-13, 2016.

OLIVEIRA, E. C. A.; SARTORI, R. H.; GARCEZ, T. B.; Compostagem. Escola Superior de Agricultura Luiz de Queiroz. Piracicaba, 2008. Disponível em: < https://www.agencia.cnptia.embrapa.br/Repositorio/Compostagem_000fhc8nfqz02wyiv 80efhb2adn37yaw.pdf>. Acesso em 14 de fevereiro de 2015.

OLIVEIRA, W. E.; FRANCA, A. S.; OLIVEIRA, L. S.; ROCHA, S. D.; Untreated coffee husks as biosorbents for the removal of heavy metals from aqueous solutions. Journal of Hazardous Materials, v.152, n.3, p.1073-1081, 2008.

ONG, H. L.; SWANSON, V. E.; Adsorption of copper by peat, lignite, and bituminous coal. Economic Geology, v.61, n.7, p.1214-1231, 1966.

ORGANIZATION FOR ECONOMIC CO-OPERATION AND DEVELOPMENT - OECD; UNITED NATIONS ENVIRONMENTAL PROGRAMME - UNEP; Phasing Lead out of Gasoline: An Examination of Policy Approaches in Different Countries. 1999. Disponível em: < http://www.un.org/esa/gite/iandm/unep-lead.pdf>. Acesso em 21 de março de 2016.

PAOliELlO, M. M. B.; CAPITANI, E. M.; Chumbo. In: AZEVEDO, F. A.; CHASIN, A. A. M.; Metais: Gerenciamento da Toxicidade. São Paulo: Editora Atheneu, 2003.

PARADELO, R.; BARRAL, M. T.; Evaluation of the potential capacity as biosorbents of two MSW composts with different $\mathrm{Cu}, \mathrm{Pb}$ and $\mathrm{Zn}$ concentrations. Bioresources Technology, v.102, p.810-813, 2012.

PARDO, M. T.; Sorption of lead, copper, zinc, and cadmium by soils: effect of nitriloacetic acid on metal retention. Communications in Soil Science and Plant Analysis, v.31, n.1-2, p.31-40, 2000. 
PARKS, G. A.; BRUYN, P. L.; The zero point of charge of oxides. The Journal of Physical Chemistry, v.66, n.6, p.967-973, 1962.

PEJON, O. J.; Mapeamento geotécnico regional da folha de Piracicaba-SP (escala 1:100.000): Estudo de aspectos metodológicos de caracterização e de apresentação de atributos. Tese de Doutorado, Universidade de São Paulo. 2v, 224p.1992.

PEJON, O. J.; RODRIGUES, V. G. S.; ZUQUETTE, L. V.; Impactos ambientais sobre o solo. In: CALIJURI, M. C.; CUNHA, D. G. F.; Engenharia Ambiental: Conceitos, Tecnologia e Gestão. Rio de Janeiro. Elsevier. 2013.

PERH - PLANO ESTADUAL DOS RECURSOS HÍDRICOS 2004 - 2007; Governo do Estado de São Paulo; UGRHI 09 Mogi Guaçu. 2004. Disponível em: < http://www.sigrh.sp.gov.br/arquivos/perh/CRH/1063/ugrhi_06_10.pdf>. Acesso em 29 de maio de 2017.

PETRONI, S. L. G.; Avaliação cinética e de equilíbrio do processo de adsorção dos íons dos metais cádmio, cobre e níquel em turfa. Dissertação de Doutorado. Instituto de Pesquisas Energéticas e Nucleares (IPEN) - Autarquia associada à Universidade de São Paulo. São Paulo, 2004. 134p.

PETRONI, S. L. G.; Estudos de adsorção de zinco e cádmio em turfa. Potencialidade de utilização de um bioadsorvedor natural em sistemas de tratamento de efluentes. Dissertação de Mestrado. Instituto de Pesquisas Energéticas e Nucleares (IPEN) Autarquia associada à Universidade de São Paulo. São Paulo, 1999. 112p.

PETRONI, S. L.; PIRES, M. A. F.; MUNITA, C. S.; Adsorção de zinco e cádmio em colunas de turfa. Química Nova, v.23, n.4, p.477-481, 2000.

PINTO, C. S.; Curso Básico de Mecânica dos Solos em 16 aulas. Oficina de textos, $3^{\mathrm{a} e d,}$ 2002.

POLPRASERT, C.; Organic Waste Recycling. John Wiley \& Sons. 1989. 357p.

PORPHÍRIO, N. H.; BARBOSA, M. I. M.; BERTOLINO, L. C.; Caracterização Mineralógica de Minérios - Parte I. CETEM - Centro de Tecnologia Mineral. Rio de Janeiro. 2010. Disponível em:

http://mineralis.cetem.gov.br/bitstream/handle/cetem/726/CCL00240010.pdf?sequence $=1>$. Acesso em 11 de maio de 2016 .

QI, B. C.; ALDRICH, C.; Biosorption of heavy metals from aqueous solutions with tobacco dust. Bioresource Technology, v.99, p.5595-5601. 2008.

QIN, F.; WEN, B.; SHAN, X. Q.; XIE, Y. N.; LIU, T.; ZHANG, S. Z.; KHAN, S. U.; Mechanisms of competitive adsorption of $\mathrm{Pb}, \mathrm{Cu}$, and $\mathrm{Cd}$ on peat. Environmental Pollution, v.144, n.2, p.669-680, 2006. 
RAIJ, B. V.; Determinação do ponto de carga zero em solos. Revista Científica do Instituto Agronômico do Estado de São Paulo, v.32, n.18, p.337-347, 1973.

RAIMONDI, I. M.; Estudo e caracterização geológica e geotécnica de rejeitos de mineração - Adrianópolis (PR). 2014. 193 p. Dissertação (Mestrado) - Escola de Engenharia de São Carlos, Universidade de São Paulo, São Carlos. 2014.

RASHID, M. A.; Absorption of metals on sedimentary and peat humic acids. Chemical Geology, v.13, p.115-123, 1974.

REDDAD, Z.; GERENTE, C.; ANDRES, Y.; LE CLOIREC, P.; Adsorption of several metal ions onto a low-cost biosorbent: kinetic and equilibrium studies. Environmental Science \& Technology, v.36, n.9, p.2067-2073, 2002.

RICORDEL, S.; TAHA, S.; CISSE, I.; DORANGE, G.; Heavy metals removal by adsorption onto peanut husks carbon: characterization, kinetic study and modeling. Separation and Purification Technology, v.24, p.389-401, 2001.

RODRIGUES, R. F.; TREVENZOLI, R. L.; SANTOS, L. R. G.; LEÃO, V. A.; BOTARO, V. R.; Adsorção de metais pesados em serragem de madeira tratada com ácido cítrico. Engenharia Sanitária e Ambiental, v.11, p.21-26, 2006.

ROWE, R. K.; QUIGLEY, R. M.; BOOKER, J. R.; Clayey barrier systems for waste disposal facilities. 1995.

ROY, W. R.; KRAPAC, I. G.; CHOU, S. F. J.; GRIFFIN, R. A.; Batch type procedures for estimating soil adsorption of chemicals. Technical resource document. EPA/530-SW87-006-F, Cincinnati, EUA. 1992.

RUTHVEN, D. M.; Principles of adsorption e adsorption processes. John Wiley \& Sons, 1984.

RYDIN, H.; JEGLUM, J. K.; The Biology of Peatlands. Oxfors University Press, second edition, 2013.

SAAD, A. R.; ETCHEBEHERE, M. L. C.; PRESSINOTTI, P. C.; SILVA, R. B.; CAMPANHA, V. A.; Potencialidade Mineral do Estado de São Paulo. Série Geociências, 1996.

SAHA, J. K.; PANWAR, N. R.; SINGH, M. V.; Determination of lead and cadmium concentration limits in agricultural soil and municipal solid waste compost through an approach of zero tolerance to food contamination. Environmental monitoring and assessment, v. 168, n. 1-4, p. 397-406, 2010.

SALOMONS, W.; Environmental impact of metals derived from mining actives: processes, predictions, prevention. Journal of Geochimichal Exploration, Elsevier, n.52, p.5-23, 1995. 
SANCHES, S. M.; CAMPOS, S. X.; VIEIRA, E. M.; Caracterização das frações das substâncias húmicas de diferentes tamanhos moleculares. Eclética Química, v.32, n.1, p.49-56, 2007.

SÁNCHEZ, L. E.; O passivo ambiental da desativação de empreendimentos industriais. São Paulo: Editora da Universidade de São Paulo. 2001. 276p.

SÁNCHEZ-MONEDERO, M. A.; ROIG, A.; PAREDES, C.; BERNAL, M. P.; Nitrogen transformation during organic waste composting by the Rutgers system and its effects on $\mathrm{pH}$, Ec and maturity of the composting mixtures. Bioresource Technology, v.78, n.3, p301-308, 2001.

SANTOS JUNIOR, L. F.; Estudo das frações obtidas no processo de extração alcalina de substâncias húmicas da turfa. Dissertação (Mestrado) - Universidade Federal do Rio Grande do Sul. Porto Alegre. 2003. 89p.

SANTOS, C. H.; Estudo da Matéria Orgânica e composição elementar de solos arenosos de regiões próximas a São Gabriel da Cachoeira no Amazonas. Dissertação de Doutorado. Instituto de Química de São Carlos, Universidade de São Paulo. São Carlos, SP. 2014. 173p.

SCHNEIDER, I. A. H.; Biossorção de Metais Pesados com a Biomassa de Macrófitos Aquáticos. Dissertação (Doutorado) - Universidade Federal do Rio Grande do Sul. Porto Alegre. 1995. 157p.

SENG, B.; HIRAYAMA, K.; KATAYAMA-HIRAYAMA, K.; OCHIAI, S.; KANEKO, H.; Scenario analysis of the benefit of municipal organic-waste composting over landfill, Cambodia. Journal of Environmental Management, Elsevier, v.114, p.216-224, 2013.

SHARMA, H. D.; LEWIS, S. P.; Waste Containment Systems, Waste Stabilization, and Landfills: Design and Evaluation. New York, John Wiley \& Sons, 1994.

SHARMA, D. C.; FORSTER, C. F.; Removal of hexavalente chromium using sphagnum moss peat. Water Research, v.27, n.7, p.1201-1208, 1993.

SHEPPARD, J. D.; FORGERON, D.W.; Differential thermogravimetry of peat fractions. Fuel, v.66, n.2, p.232-236. 1987.

SHOTYK, W.; Natural and anthropogenic enrichments of $\mathrm{As}, \mathrm{Cu}, \mathrm{Pb}, \mathrm{Sb}$, and $\mathrm{Zn}$ in ombrotrophic versus minerotrophic peat bog profiles, Jura Mountains, Switzerland. Water, Air, and Soil Pollution, v. 90, n. 3, p. 375-405, 1996.

SILVA, A. C.; HORÁK, I.; CORTIZAS, A. M.; VIDAL-TORRADO, P.; RACEDO, J. R.; GRAZZIOTTI, P. H.; SILVA, E. B.; FERREIRA, C. A.; Turfeiras da Serra do Espinhaço Meridional-MG: I-caracterização e Classificação. Revista Brasileira de Ciência do Solo, v. 33, n. 5, p. 1385-1398, 2009. 
SILVA, B. de C. M.; Estudo da adsorção de chumbo (Pb) por ensaios de equilíbrio em lote em materiais inconsolidados: município de Eldorado Paulista (Vale do Ribeira SP). 210 p. Dissertação (Mestrado) - Escola de Engenharia de São Carlos, Universidade de São Paulo, São Carlos, 2013.

SILVA, E. S.; Zinco. In: AZEVEDO, F. A.; CHASIN, A. A. M.; Metais: Gerenciamento da Toxicidade. São Paulo: Editora Atheneu, 2003.

SILVA, J.; Estudo da eficiência e aplicabilidade de carvão ativado resultante de pirólise de casca de arroz em barreiras reativas na remoção de contaminantes de solos. 204p. Porto Alegre, Brasil. Tese de Doutorado. Escola de Engenharia. Universidade Federal do Rio Grande do Sul. 2009.

SILVA, M. L. N.; CURI, N.; MARQUES, J. J. G. S. M.; GUILHERME, L. R. G.; DE LIMA, J. M.; Ponto de efeito salino nulo e suas relações com propriedades mineralógicas e químicas de latossolos brasileiros. Pesquisa Agropecuária Brasileira, v.31, n.9, p.663671, 1996.

SIMABUCO, S. M.; Emprego da fluorescência de raios-X por dispersão de energia no estudo da dinâmica da vinhaça no solo. Dissertação de Doutorado. IPEN - Instituto de Pesquisas Energéticas e Nucleares. São Paulo. 1993.

SIMANTIRAKI, F.; GIDARAKOS, E.; Comparative assessment of compost and zeolite utilisation for the simultaneous removal of BTEX, Cd and $\mathrm{Zn}$ from the aqueous phase: Batch and continuos flow study. Journal of Environmental Management, v.159, p.218-226, 2015.

SIMANTIRAKI, F.; KOLLIAS, C. G.; MARATOS, D.; HAHLADAKIS, J.; GIDARAKOS, E.; Qualitatite determination and application of sewage sludge and municipal solid waste compost for BTEX removal from groundwater. Journal of Environmental Chemical Engineering, v.1, p.9-17, 2013.

SINGH, U.; UEHARA, G.; Electrochemistry of the Double Layer: Principles and Applications to Soils. In: SPARKS, D. L.; Soil physical chemistry, CRC Press, 1998.

SMIEJA-KRÓL, B.; FIALKIEWICZ-KOZIEL, B.; SIKORSKI, J.; PALOWSKI, B.; Heavy metal behaviour in peat - A mineralogical perspective. Science of the Total Environmental, v.408, p.5924-5931, 2010.

SMITH, E. F.; MACCARTHLY, P.; YU, T. C.; MARK JR, H. B.; Sulfuric acid treatment of peat for cation exchange. Journal Water Pollution Control Federation, v.49, n.4, p.633-638. 1977.

SOARES, M. R.; CASAGRANDE, J. C.; Adsorção e modelos. In: RIBEIRO, M. R.; NASCIMENTO, C. W. A.; RIBEIRO FILHO, M. R.; CANTALICE, J. R. B.; Tópicos em ciência do solo. Sociedade Brasileira de Ciência do Solo. Viçosa, MG, 2000. 
SOIL SURVEY STAFF; Keys to Soil Taxonomy. United States Department of Agriculture (USDA), Natural Resources Conservation Service (NRCS), $12^{\text {th }} \mathrm{ed}$, Washington, DC, 2014.

SOUSA, F. W.; MOREIRA, S. A.; OllVEIRA, A. G.; CAVAlCANTE, R. M.; NASCIMENTO, R. F.; ROSA, M. F.; Uso da casca de coco verde como adsorbente na remoção de metais tóxicos. Química Nova, v.30, n.5, 2007.

SPARKS, D. L.; Environmental Soil Chemistry. Academic Press. 1995a. 267p.

SPARKS, D. L.; Kinetics of metal sorption reactions. In: ALLEN, H. E.; HUANG, C. P.; BAILEY, G. W.; BOWERS, A. R.; Metal Speciation and Contamination of Soil. Lewis Puslishers. 1995b.

SPARKS, D. L.; Kinetics of reactions in pure and in mixed systems. In: SPARKS, D. L.; Soil physical chemistry, CRC Press, 1986.

SPARKS, D. L.; Kinetics of soil chemical processes. New York: Academic Press, 1989.

SPEDDING, P. J.; Peat. Fuel, v.67, p.883-900, 1988.

SPOSITO, G.; The Surface Chemistry of Natural Particles. New York: Oxford University Press. 2004. 242p.

SPOSITO, G.; The Chemistry of Soils. New York: Oxford University Press. 1989. 277p.

STANEK, W.; SILC, T.; Comparisons of four methods for determination of degree of peat humification (decomposition) with emphasis on the von Post method. Canadian Journal of Soil Science, v.57, n.2, p.109-117, 1977.

STEVEnSON, F. J.; Humus Chemistry: Genesis, Composition, Reactions. New York: John Wiley and Sons. 1982. 496p.

STUMM, W.; MORGAN, J. J.; Aquatic Chemistry: Chemical Equilibria and Rates in Natural Waters. John Wiley \& Sons. 1996.

SUN, Q.; YANG, L.; The adsorption of basis dyes from aqueous solution on modified peatresin particle. Water Research, v.31, n.7, p.1535-1544, 2003.

TABOADELA, M. M; FERRANDIS, V. A.; The mica minerals. In: MACKENZIE, R. C.; The differential thermal investigation of clays. Mineralogical Society - Clay Minerals Group. Londres. 1957.

TAHA, S.; RICORDEL, S.; CISSE, I.; Kinetic study and modeling of heavy metals removal by adsorption onto peanut husks incinerated residues. Energy Procedia, p.143-153, 2011. 
THIRUVENKATACHARI, R.; VIGNESWARAN, S.; NAIDU, R.; Permeable reactive barrier for groundwater remediation. Journal of Industrial and Engineering Chemistry, Elsevier, n.14, p.145-156, 2008.

TOMASELLA, R. C.; Avaliação do potencial de compostos naturais (argila, turfa e carvão) na remoção do chumbo $(\mathbf{P b})$ e da toxicidade de um efluente industrial. Dissertação de Mestrado. Universidade Estadual Paulista (UNESP) - Instituto de Geociências e Ciências Exatas, Rio Claro - SP. 2013. 101p.

TUOMELA, M.; VIKMAN, M.; HATAKKA, A.; Biodegradation of lignin in a compost environmental: a review. Bioresource Technology, v.72, n.2, p.169-183, 2000.

URAKI, Y.; TAMAI, Y.; OGAWA, M.; GAMAN, S.; TOKURA, S.; Preparation of activated carbon from peat. BioResources, v.4, n.1, p.205-213, 2009.

VALENTE, B. S.; XAVIER, E. G.; MORSELLI, T. B. G. A.; JAHNKE, D. S.; BRUM JR, B. S.; CABRERA, B. R.; MORAES, P. O.; LOPES, D. C. N.; Fatores que afetam o desenvolvimento da compostagem de resíduos orgânicos. Archivos de Zootecnia, v.58, p.59-85, 2009.

VAZ, C. M. P.; NAIME, J. M.; SILVA, A. M.; MELLO, S.; Análise granulométrica por raios gama. Embrapa Instrumentação Agropecuária. Boletim de Pesquisa, 1997.

VEGA, B. J. J.; Cinética de adsorção de Pb e Cd em solo argiloso laterítico. Dissertação de Mestrado. Departamento de Engenharia de Estruturas e Geotécnica. Escola Politécnica da Universidade de São Paulo, 2016, 123p.

VENEGAS, A.; RIGOL, A.; VIDAL, M.; Viability of organic wastes and biochars as amendments for the remediation of heavy metal-contaminated soils. Chemosphere, v.119, p.190-198, 2015.

WEBER, W. J. Jr; DIGIANO, F. A.; Process dynamics in environmental systems. New York: John Wiley, 1996. 943p.

WEBER, W. J. Jr; Physicochemical processes for water quality control. New York: WileyInterscience. 1972. 640p.

WILlIAMS, R. T.; CRAWFORD, R. L.; Microbial Diversity of Minnesota Peatlands. Microbial Ecology, v.9, n.3, p.201-214, 1983.

WORLD ENERGY RESOURCES - WER. 2013. Disponível em: <https://www.worldenergy.org/wp-content/uploads/2013/09/Complete_WER_2013_ Survey.pdf>. Acesso em 03 de março de 2016.

WORLD HEALTH ORGANIZATION - WHO; Environmental Health Criteria 134 Cadmium; Geneva, 1992. Published under the joint sponsorship of the United Nations Environment Programme, the International Labour Organization, and the World Health 
Organization.

Disponível

em: $<$ http://www.inchem.org/documents/ehc/ehc/ehc134.htm>. Acesso em 22 de março de 2016.

WORLD HEALTH ORGANIZATION - WHO; Environmental Health Criteria 165 Inorganic Lead; Geneva, 1995. Published under the joint sponsorship of the United Nations Environment Programme, the International Labour Organization, and the World Health Organization. Disponível em: <http://www.inchem.org/documents/ehc/ehc/ehc165.htm>. Acesso em 22 de março de 2016.

WORLD HEALTH ORGANIZATION - WHO; Environmental Health Criteria 221 - Zinc; Geneva, 2001. Published under the joint sponsorship of the United Nations Environment Programme, the International Labour Organization, and the World Health Organization, and produced within the framework of the Inter-Organization Programme for the Sound Management of Chemicals. Disponível em: < http://www.who.int/ipcs/publications/ehc/ehc_221/en/ >. Acesso em 22 de março de 2016.

YONG, R. N.; Geoenvironmental engineering - Contaminated soils, pollutant fate, and mitigation. CRC Press. 2001. 307p.

YONG, R. N.; MOHAMED, A. M. O.; WARKENTIN, B. P.; Principles of contaminant transport in soils. Elsevier. 1992.

YONG, R. N.; MUlliGAN, C. N.; Natural Attenuation of Contaminants in Soil. Lewis Publishers. 2004.

ZACHARA, J. M.; WESTALL, J. C; Chemical Modeling of Ions Adsorption in Soils. In: SPARKS, D. L.; Soil physical chemistry, CRC Press, 1998.

ZHANG, C.; SHAN, B.; TANG, W.; ZHU, Y.; Comparison of cadmium and lead sorption by Phyllostachys pubescens biochar produced under a low-oxygen pyrolysis atmosphere. Bioresource Technology, v.238, p.352-360, 2017.

ZHOU, D.; ZHANG, L.; ZHOU, J.; GUO, S.; Cellulose/chitin beads for adsorption of heavy metals in aqueous solution. Water Research, v.38, p.2643-2650, 2004.

ZORZETO, T. Q.; DECHEN, S. C. F.; ABREU, M. F.; FERNANDES JÚNIOR, F.; Caracterização física de substratos para plantas. Bragantia, v.73, n.3, p.3000-311. 2014.

ZUQUETTE, L. V.; SILVA Jr, E. M.; GARCIA, A.; Aspectos de sorção para os materiais inconsolidados da região de São Carlos (SP), Brasil. Revista Escola de Minas, Ouro Preto, v.6, n.2, 2008. 